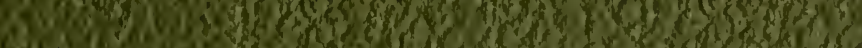

6.8.

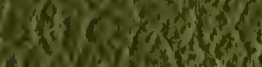

THE BIROS OA YoRk SHIRE

fogus

\title{
- HISTORICA AccoUn on
}

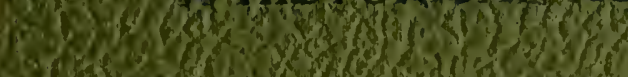

fW ME inging

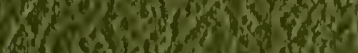

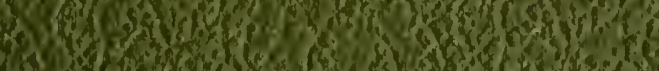

Wh

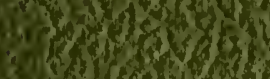

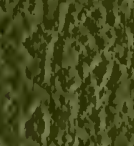

axing

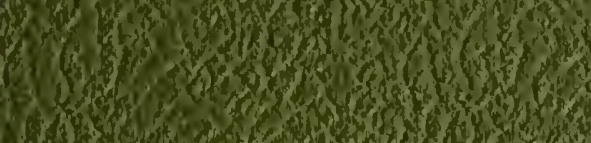

(7.0.

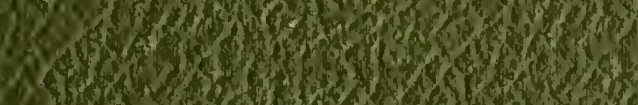

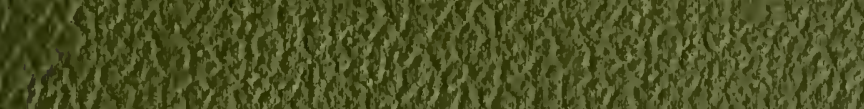

15.

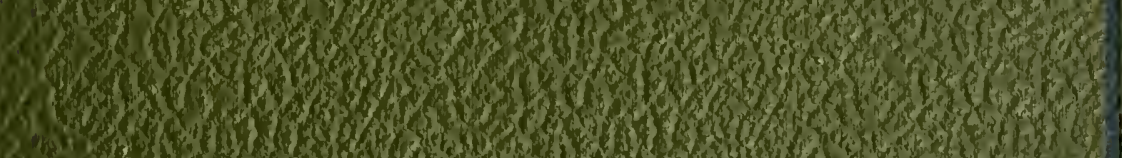

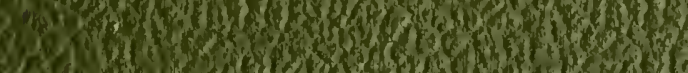

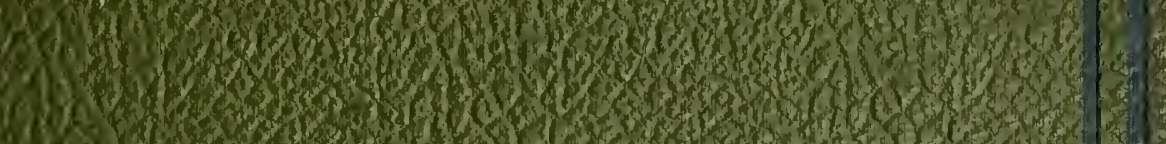

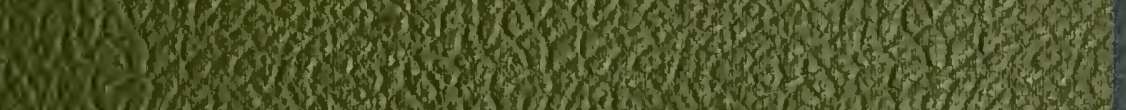

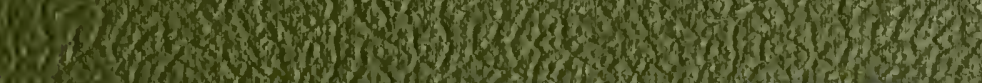

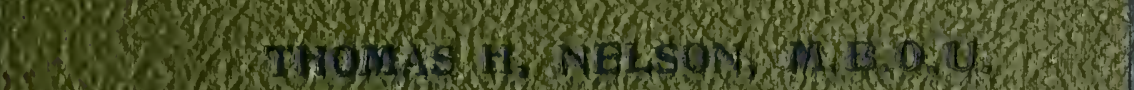

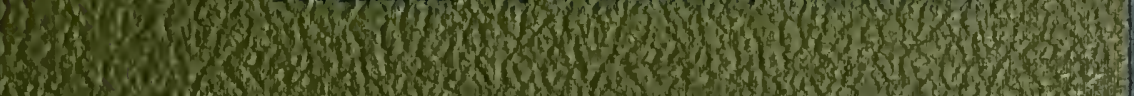

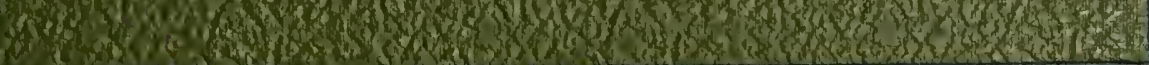



of Nature's Noblemen. Take him all in all, we shall not look upon his like again.

After a few days' illness, he passed away, October 6th, in his 76 th year, and was interred in the Churchyard of St. Bartholomew's, Armley. He was a bachelor. Representatives of the Society attended the funeral, which took place on October IIth, exactly a fortnight after that of his old friend, Mr. Wr. Barraclough, which he had attended. It is now made public that the deceased gentleman, amongst numerous other charitable bequests, has left to his Society the sum of froo.

\section{E.G.B.}

The Birmingham and Midland Institule Scientific Society has issued its annual and valuable 'Records of Meteorological Observations, taken at the Observatory, Edgbaston, I9I 5, by Mr. Alfred Cresswell,' at 2s. In addition it has published Mr. Ernest Crocker's Presidential Address (2 f pages) entitled 'Science as Enemy and Ally.'

The Report of the Natural History Society of Northumberland, Durham and Newcastle-on-Tyne, shows that the work of this excellent Society and its Museum has still further bzen interfered witl, by the fact that the Curator, Mr. E. L. Gill, is in France on ambulance work, and that the caretaker has died. Under the care of the assistant Curator, Mr. H. Fletcher, some progress has bzen made, which is detailed in the Report.

At the Annual Meeting of the Lincolnshire Naturalists' Union, held at Lincoln on November gth, the Rev. F. L. Blathwayt mentioned that in June last he went to see the work of a pair of starlings nesting in a barn at Black. Moor Farm, Doddington. For about a fortnight the birds persevered in pushing hay and straw through a hole in the roof, but there being no support, the stuff all fell through to the ground below, and formed a large pile, four feet six inches high and four feet wide at the base, and weighing, he was told, io lb. The attempt was at last given up. Mr. Griy WV. Mason was elected president for the year, and the Rer. F. I. Blathwayt vice-president. The secretary, treasurer and sectional officers were all re-elected.

'Enquirer' writes as follows:- 'I shonld be much obliged if any of vour readers could tell me what are "Terlalogims." From the facts before me I infer that there are several classes of them, one of which is called " Index Terlalogims," but I do not know the names of the others. They would appear to present great variations, for 2,300 coloured figures can be purchased for $t_{2}$. They have, been studied by an anthor named Wood. This is all the knowledge I have been able to acquire up to the present, but any further information would be gratefully received.'

We must confess that, at first, the enquiry puzzled us, but as we were asked a little while ago to pay a visit to a suburb of London, in order to see a toad's nest in a gooseberry bush, we naturally felt our correspondent was of this harmless variety. It appears, however, that on the cover of a certain well-known natural history journal, a copy of 'Wood's Index rerlalogims 'was offered for sale. We found that the editor of the journal had no control of the advertisements and knew nothing of the matter; but the publishers kindly allowed us to see the MS. for the advertisement, and we must admit that, from a compositor's point of view, the word was clearly 'Terlalogims,' but, as the printer explained, 'naturalists are gene: ally such bad writers' (even in the letter by 'Enquirer ' who is a naturalist. of some standing, the word looks like 'Julalogirus' !). The book offered for sale, of course, should have been Wood's Index Testaceologicus.

1916 Oct. 1. 
404

\section{Fll Inemoriam.}

T. H. NELSON, J.P., M.Sc., M.B.O.L.

IORKSHIRE Ornithology has sustained a heary loss by the death of T. H. Nelson, which occurred at Harrogate on Sunday, November 5th.

Mr. Nelson has for a great number of years occupied a

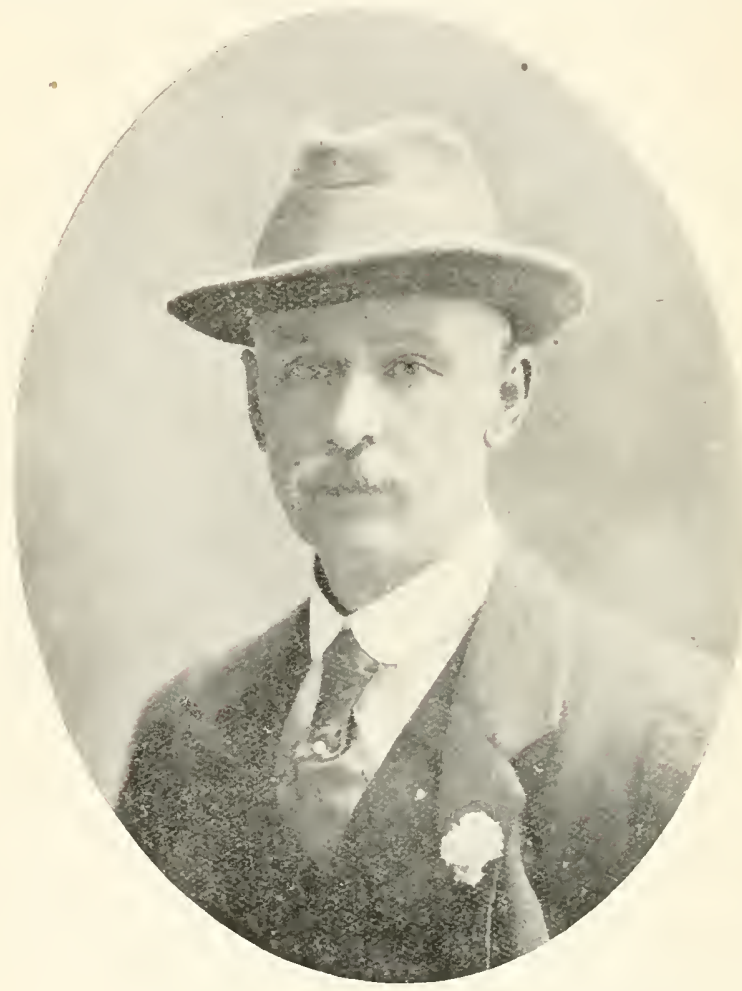

foremost position among the Naturalists of Yorkshire. He was formerly an active member of the Yorkshire Naturalists' Union, but of late, unsatisfactory health has considerably curtailed his field activities. The area of the Tees mouth has always been his happy hunting ground, and his records from this district have been numerous, interesting and valuable. It was on the Durham side of the Tees upon some shooting of his that the Reeve nested successfully a few years ago. He possessed a valuable collection of eggs and birds, most of the latter being obtained in the Tees mouth area. 
Despite his activities, he did not publish any really important work until his "Birds of Yorkshire" appeared. His field notes, scattered in the pages of 'The Ibis,' 'Zoologist,' 'Naturalist,' 'Field,' 'British Birds,' etc., were. however, both numerous and valuable. For a considerable time, he acted as referee for Ornithology for The Naturalist.

When Mr. Eagle Clarke left Yorkshire, a substitute had to be found to undertake the writing of "The Birds of Yorkshire.' The unanimous choice of the Executive Committee of the Lnion fell upon Mr. Nelson, and it would have been impossible to select anyone better fitted for the task. The work was in a true sense 'monumental,' an example of the best kind of county avi-fauna, and one which will stand for all time as a fitting memorial to the author. The present writer was closely associated with Mr. Nelson during the progress of this work, and can bear testimony to the great and unceasing care which was exercised by him to ensure that every statement contained therein was thoroughly reliable. In order that this should be so, the labour entailed was enormous, thousands of references and notes had to be carefully investigated and sifted, some of them time after time, before they were admitted. The results of his labours are universally recognised to be as near perfect as it is possible for works of this kind to be.

When the University of Leeds decided to confer the Honorary Degree of M.Sc. upon a certain number of members of the Yorkshire Naturalists' Union, as an acknowledgement of the great work done in connection with Natural Science by the Union and its individual members, they rightly selected Mr. Nelson to receive the honour on behalf of Yorkshire ornithology. In another direction he was honoured by being placed upon the Commission of Peace for the North Riding, his presence upon the bench being frequent.

Mr. Nelson was of a kindly and somewhat quiet disposition, a good friend, and one who will be missed by a large circle of friends and fellow naturalists, whose sympathies will go out to Mrs. Nelson (who took a keen and active interest in all her lusband's work) in her great trouble--R. F.

In "Nore New Cecidomyid Galls" in The Entomologist's Record for November, Messrs. R. S. Bagnall and J. W. H. Harrison record many northern county species.

To a note on 'Spheriestes (Rabocerus) gabrieli,' by Prof. T. Hudson Beare, in The Entomologist's Monthly Magazine for November, 'G.C.C.' adds a note to the effect that "The insects representing $S$. foveolatus in the collection of the British Coleoptera in the National Nuseum are referable to $S$. gabrieli, as are those (from Scarborough) in my own collection.' 


\section{NEWS FROM THE MAGAZINES, etc.}

The Zoologist for October contains some short notes on Yorkshire birds and insects.

Dr. E. J. Russell writes on ' Chalking: a useful Improvement for Clays: Overlying the Chalk' in The Journal of the Board of Agricultuve for October.

Dr. J. A. Clubb writes on "The Educative Value in Public Mnsenms of Introductory Cases to Animal Groups' in The Museums Joumal for November.

The Animal lforld for November contains the following short papers:- 'Newts,' by Erwward Step; 'Sea-Birds: The Poetry of Flight,' by F. G. Aflalo; and 'Animals that break themselves up,' by C. I'. Jewall.

In The Entomologist for November, Mr. J. WV. H. Harrison writes - Concerning Certain Cynipid Galls in Durham, Northumberland and North Yorkshire,' and Mr. WT. G. Clutten records Evebia blandina and Laventia flavicinctata at Grassington.

A Punch joke:- Private Brown, (inspecting mud on tyre): "You must have had a wonderfully interesting ride. I see you've been in the Lower Silurian, Old Red Sandstone, Crystallite and Netamorphic districts." We presume that 'Crystallite' is the joke?

II'ild. Life for September contains papers on 'The Peregrine Falcon, by Rev. D. A. Scott; 'The Storm Petrel and Manx Shearwater' by 1. Whitaker and T. M. Fowler; 'Some New Facts about the Nightjar,' by A. M. C. Nicholl; 'Sexual Selection in Birds,' by Edmund Selous.

We have received the Annual Report of the Scottish Marine Biological Station for I9I5. It is well written, well printed and well illustrated. It contains 50 pages and is an excellent record of a good year's work at Milport. It would be still more interesting if all the illustrations were described, common objects though some of them are.

In The Journal of Conchology for October, Mr. B. R. Lucas states that a good mixture to prevent the objectionable fungoid growth in improperly cleaned land-shells consists of linseed oil, no per cent. ; benzol, go per cest., and 2 grammes of thymol crystals. The proportion or linseed oil can be reduced for small spinous shells, and increased to give lustre to big shells.

Mr. G. C. Crick has made a critical study of the specimen from Settle, described as Goniatites vesiculifer by Dr. Hind, in the Proceedings of the Iorkshive Geological Society. His paper is printed in Vol. XII., part I, of the Proceedings of the Malacological Society. He concludes that the English fossil is certainly very near to, and probably identical with, De Koenick's species.

The Proceedings of the Coventry Natural History and Scientific Society for the year ending March, I9I6 (30 pages), contains a useful illustrated summary of the field meetings and lectures during the year. It is edited by Mr. H. J. Wheldon, and is sold at the very low price of $6 \mathrm{~d}$. A year earlier, the first part of this Society's publication appeared, containing a record of its work from the Society's inauguration in 1909, to 19I5.

We have received Hull MItseum Publications No. Io6 (Ouarterly Record of Additions, No. LII.), by T. Sheppard, M.Sc., $2+$ pp., illustrated, price one penny (Hull: A. Brown \& Sons, Ltd.). The items include :-Sixteenth Century Powder Horn; Rare Type of Tinder Box; Nusketry Fuse Holder; Iron Nutcrackers; Rare Type of Powder Tester ; Two Hitherto unknown Seventeenth Century Tokens of Halifax; Antarctic Photographs for the Pickering Museum; French and German War Trophies; Recent additions to Collections; Staffordshire Potterr; The Little Walshingam lFont; The Old Hull Whaler 'Truelove'; The Yacht 'Queen of England '; Turner's Pictures of Hull in the W'ilberforce MInseum. The last item is written by Mr. H. E. Wroot. 




THE BIRDS OF YORKSHIRE 


27-109061- ful 28 


\title{
CONTENTS
}

\author{
VOL. II
}

Genus Phalacrocorax (Cormorant, \&c.) - $375-38$

Sula (Gannet) . . . . . . $383_{1-3} 84$

Ardea (Heron, \&c.) . . . . . 384-395

Nycticorax (Night Heron) . . . 395-396

Ardetta (Little Bittern) . . . . 396-398

Botaurus (Common Bittern, \&c.) . . 399-403

CiconiA (Stork, \&c.) . . . . . 403-405

Plegadis (Glossy Ibis) . . . . . 406

Platalea (Spoonbill) . . . . 4 406-408

ANser (Grey Lag Goose, \&c.) . . . 408-422

Chen (Snow Goose) • . . . . 422

Bernicla (Red-Breasted Goose, \&c.). 423-427

Cygnus (Whooper Sivan, \&c.) . . . 428-432

TADORna (Common Sheld-Duck • . 432-434

Anas (Mallard, \&c.) . . . . . 434-437

",$" \cdot{ }^{\circ} \cdot 450-45 \mathrm{I}$

DecoYs . • $437-449$

Gemus Spatula (Shoveller) . . . . $45^{\mathrm{I}-45^{2}}$

Dafila (Pintail) . . . . . . 453-454

Nettion (Common Teal, \&c.) . . . $454-45^{6}$

Querguedula (Garganey) . . . . . $457-45^{8}$

Mareca (Wigeon, Sc.) . . . . $45^{8-462}$

Netta (Red-Crested Pochard) . : . 462

Fuvigula (Common Pochard, \&c.) . . 462-470

Clangula (Golden-Eye, \&c.) • . . 470-472

HARELDA (Long-Tailed Duck) • . . $472-474$

Cosmonetta (Harlequin Duck) . . . 474-475

Somateria (Eider Duck, \&c.) • . . 475-477

CEDemia (Common Scoter, \&c.) . . 477-782 
Genus Mergus (Goosander, \&c.) . PAGE. Columba (Ring-Dove, \&c.) $482-487$ Turtur (Turtle-Dove, \&c.) $487-495$ Syrrhaptes (Pallas's Sandgrouse) Tetrao (Capercaillie, \&r.).

Lagopus (Red Grouse) $495-498$ Phasianus (Pheasant) 498-503 Perdix (Partridge)

Caccabis (Red-Legged Partridge) 503-509

Coturnix (Common Quail) $510-522$ Crex (Corn Crake) Porzana (Spotted Crake, \&c.) .

Rallus (Water Rail)

Gallinula (Moorhen) $523-524$

Fulica (Coot) $524-527$

Grus (Crane)

Otis (Great Bustard, \&c.) CEdicnemus (Stone Curlew)

Glareola (Collared Pratincole). $527-531$ $53 \mathrm{I}-533$ $534-536$ $53^{6-540}$ Cursorius (Cream-coloured Courser) Eudromias (Dotterel) AEgrabitis (Ringed Plover, \&c.) $540-543$ Charadrius (Golden Plover) $544-545$ Squatarola (Grey Plover) 545-547 Vanellus (Lapwing) .

Strepsilas (Turnstone)

Hamatopus (Oyster-Catcher)

Recurvirostris (Avocet) .

Hrmantopus (Black-Winged Stilt)

Phalaropus (Grey Phalarope, \&c.) .

Scolopax (Woodcock, \&c.) $547-548$ $548-560$ $5^{6 r-564}$ 565 $566-567$ - $567-573$ - 573-577 $577-579$ $579-5^{81}$ - $5^{81-585}$ - $585-586$ - $586-5^{88}$ - $5^{88-590}$ - $590-59 r$ - $59^{1-595}$ - 595-60 I

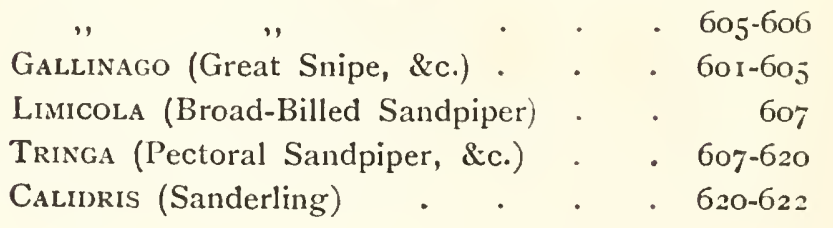


Gemis Machetes (Ruff) . . . . . 622-626

Totanus (Common Sandpiper, \&c.) . 626-638

Macrorhamphus (Red-Breasted Snipe) . 638

Limosa (Bar-Tailed Godwit, \&c.) • . 639-642

Nunenius (Common Curlew, \&c.) . . 643-648

Hydrochelidon (Black Tern, \&c.) . . 648-65

Sterna (Gull-Billed Tern, \&c.) • . . 651-662

Xema (Sabine's Gull). . . . . 662-665

Rhodostethia (Ross's Gull) . . . 665-66

Larus (Little Gull, \&c.) . . . . . 667-688

Rissa (Kittiwake) . . . . . 689-693

Pagophila (Ivory Gull) . . . . 693-694

Megalestris (Great Skua) . . . 697-696

Stercorarius (Pomatorhine Skua, \&c.) · 696-7oS

Alca (Razorbill) . . . . . 708-710

Lomvia (Guillemot) • . . . . 711-724

UrIa (Brunnich's Guillemot, \&c.) • • 724-727

Fratercula (Puffin) . . . . $727-729$

Mergulus (Little Auk) • • • • 730-732

Colymbus (Great Northern Diver, \&c.) · 732-738

Podicipes (Great Crested Grebe, \&c.) • $738-748$

Procellaria (Storm Petrel) . . . $7+8-7+9$

Oceanodroma (Leach's Fork-Tailed Petrel,

\&c.) . . . . . . $750-752$

Puffinus (Great Shearwater, \&c.) . . 75-76́r

Bulweria (Bulwer's Petrel) . . . 762-764

Fulmarus (Fulmar) . . . . . $764-765$

\section{APPENDICES}

Wild Birds' Protection . . . . . 767-753

Extracts from Ancient Records . . . 774-775

Literature Consulted . . . . . $776-777$

INDEX OF BIRDS . . . . . . . 779-803

Index of Persons and Places . . . . $809-8+3$ 



\section{LIST OF ILLUSTRATIONS}

Vol. II

Cliff Climbing at Bempton, on "Old Mosey" Frontispiece TO FACE PAGE

Nesting place of Cormorants, near IVhitby High Lights,

Hawsker . . . . . . . 376

Young Cormorants at Whitby High Lights . • . 378

Nesting site of Cormorants, near Filey . . . 380

Herons' nests at Hornsea Mere • • • . . 388

Humber mud flats, Spurn . . . • . • 426

Faith, the Decoy man, taking Ducks out of the net at

Coatham Decoy . . . . . . . 448

Wild Duck's nest at Harrogate . . . . . $45^{2}$

Nest of Shoveler, near York . . . . . . $45^{2}$

Widgeon's nest, near Scarborough . . . . 454

Nest of Common Teal, Washburn Valley . . • 454

View, near Filey, nesting place of Stonechat, Red-

Legged Partridge, and Teal . . . . . 456

Pochard's nest, Hornsea Mere . . . . . 462

Tufted Duck on nest . . . . . . . 464

Pheasant on nest . . . . . . . . . 464

Nest of Tufted Duck, Nidderdale . . . . . 466

Site of Coatham Decoy, 1887 . . . . . 470

Island in Swinsty Reservoir, where the Golden Eye is

reported to have nested . . . . . 470

Snowden Sleights in his Punt on the Derwent, near the

place where the Hooded Merganser occurred • 486

Ring Dove's nest . . . . . . . . 488

Regular nesting place of Stock Dove . • . . 490

Nesting place of Barn Owl, Jackdaw, and Kestrels 490

Nest of Turtle Dove, at Wykeham . . 496

Nest of Black Grouse, north-west Yorkshire . . 508

Grouse sitting on the roof of a moorland cottage in

Teesdale, as mentioned by Tunstall . . . 510 
flight of Grouse TO FACE PAGR

A flight of Grouse • • • • • • • 518

Nest of Red Grouse . . . . . . . 518

Pheasant's nest with twelve eggs in spruce fir, 22 feet

from ground, near Harrogate, 1906 . $\quad . \quad 524$

Partridge's nest . • . . . . . . 526

Nest of Red-Legged Partridge, near Filey . • . 530

Nest of Land-Rail in the Nidd Valley . • . $\quad 534$

Nest of Water-Rail in the Nidd Valley . • . . 534

Ivy-covered tree in which a Waterhen has had her nest

for many years . • . . . . . 542

Waterhen going on to its nest . . . . $54 t$

Coot's nest with flags interlaced as a bower, Hornsea

Mere . . . . . . . . . 546

Macqueen's Bustard, the first of the two Yorkshire

examples. Shot at Marske-by-the-Sea . . 560

Stone Curlew on nest, near Pickering . . . . $\quad 562$

Stone Curlew's nest . . . . . . . . 562

Stone Curlew's nest from a Wold plantation, under a

small spruce fir with spreading branches • $\quad 564$

Nest of Ringed Plover on edge of sand-hills, Redcar . $57^{2}$

Nest of Ringed Plover on slag-heap at Teesmouth $\quad 572$

Nest of Ringed Plover, Spurn . • • • • 574

Nest of Ringed Plover amongst plants of "sentry,"

Teesmouth . . . . . . . 574

Nest of Golden Plover, north-west Yorkshire . $\quad 578$

Nest and Eggs of Lapwing, Towthorpe, York • . $\quad 5 S_{4}$

A Teesmouth Shore Scene . . . . . . 586

'The first known British example of the Grey Phalarope, shot near Halifax. Described and figured by

George Edwards in Feb., 1757 • . . . 590

Woodcock on nest . . . . . . . . 594

Nest of Woodcock, near Selby . . . . . . . . 596

Nest of Common Snipe . . . . . . 604

Heads and bills of the large and small races of Dunlin.

"The latter is sometimes called the "Drain Dunlin"

in East Yorkshire . . . . . . . . 606

Nest of Dunlin, north-west Yorkshire . . . . . 608

Nest of Dunlin, Teesmouth . . . . . . . . 608 
Nest of Dunlin, Teesmouth .

Nest of Redshank amongst heather, north-west Yorkshire

Nest of Redshank, Teesmouth

- 634

Large flights of Godwits and other shore-birds at the

Teesmouth in September 1895 . . . . 640

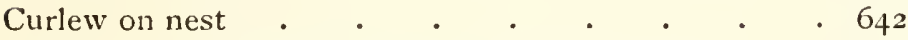

Curlew's nest on Skipwith Common, near York . . 644

Young Curlews just hatching . . . . . 644

Curlew perching on a post, on a moor near Harrogate. 646

Nest of Little Tern at Spurn . . . . . 660

Nest of Black-Headed Gull, north-west Yorkshire . 666

Nest of Black-Headed Gull's eggs destroyed by Crows. 666

Nesting place of Black-Headed Gull, on the moors near

Whitby . . . . . . . . 668

Nest of Black-Headed Gull in North Yorkshire . . 670

Mediterranean Black-Headed Gull . . . . 672

Herring Gull at nest . . . . . . . 674

Herring Gull's nest and eggs, Filey . • • . 676

Herring Gull's nest and young, Hawsker . . . 676

Cliffs near Whitby High Lights, haunt of Herring Gull. 678

Herring Gulls nesting in Captivity at Redcar . . 680

Nest of Herring Gull at Kettleness . . . . 680

Kettleness, the nesting place of Herring and Lesser Black-backed Gulls . . . . . . 682

Kettleness, the nesting place of the Herring and Blackbacked Gulls . . . . . . . . 684

Nest of Lesser Black-backed Gull at Kettleness . . 686

Pomatorhine Skuas, Redcar 1879. . . . . 700

Ringed Guillemot and Razorbill at Staple Neuk • • 7o8

Razorbill newly hatched . . . . . . 708

Young Razorbill . . . . • . . . 708

The Climmer going over the cope of the cliff, and laying

the rope over the pulley. . . . . . 710

A dangerous corner . . . . . . . 712

J. Hodgson seeking Razorbill's eggs . • • . 714

The Climmer at work . . . . . . . 7 . . 
The Climmer ascending.

The Climmer ascending, having taken up the pulley . 720 Cliffs near Hateley Corner . . . . . . 722

J. Hodgson descending the cliff . . . . . 724 The Climmer with his outfit . . . . . . 726

After the ascent . . . . . . . 728

Sharing the spoil . $\cdot$. . . . . $73^{\circ}$

W. Wilkinson on Jubilee Corner . . . . . 732

Guillemots on Hateley Shoot. . . . . . 734

Guillemots newly hatched . . . , . . 736

Young Guillemot with sand-eel . . . . . 736

Guillemots on Staple Neuk . • • • • $\quad .738$

Eggs of Guillemot, Razorbill, and Black Guillemot, showing comparative sizes . . . . 740

Bempton and Speeton Cliffs, looking west . . $\quad 742$

Bempton Cliffs, looking east. . . . . . 744

Puffin newly hatched . . . . . . . 746

Young Puffin. . . . . . . . . 746

Great Northern Diver . . . . . . . 748

Nest of Great Crested Grebe, Hornsea Mere. . 750

Hornsea Mere . . . . . . . . 752

Little Grebe swimming to its nest. . . . . 754

Little Grebe's nest (eggs covered) . $75^{6}$

Little Grebe's nest (eggs uncovered) . . . . $\quad 75^{6}$ 


\section{THE BIRDS OF YORKSHIRE.}

\section{COMMON CORMORANT.}

Phalacrocorax carbo (L.).

Resident, breeding on the cliffs between Whitby and Scarborough, and near Filey; formerly nested in several other localities. The majority retire southward in winter.

The earliest allusion to the Cormorant in Yorkshire was made by Pennant, who, on his journey to Scotland in 1769 , visited Flamborough on July 3rd, and remarked of the birds there:- "Multitudes were swimming about, others swarmed in the air, and almost stunned us with the variety of their croaks and screams; I observed among them Corvorants." (" A Tour in Scotland," I77I, p. I5.)

Thomas Allis, I844, wrote:-

Phalacrocorax carbo.-Common Cormorant-Frequent off Scarborough; a specimen of this bird was taken at Kexby, six miles from York, by a person who was angling for pike; he had left his line for a few minutes fastened to the banks of the Derwent, on his return he saw the bird sitting on the bank, and, on reaching it, found it had dived, swallowed the bait, and was held fast by the line. A. Strickland says that it breeds upon the cliffs at Flamborough, but appears greatly to have diminished of late years.

Although designated as resident in the county, the majority of our Great Cormorants leave the Yorkshire coast and move southward as winter approaches, returning in spring to their nesting quarters. In the north a colony formerly existed on Huntcliffe, near Saltburn, and the late C. C. Oxley informed me that, when he lived at Redcar, he could, in a good light, and by the aid of a powerful telescope, recognise the birds sitting on their nests, although fully five miles

vol. II. 
distant. The formation of the railway, passing near the edge of the cliffs, caused the birds to leave and join another colony between Boulby and Staithes, above a smugglers' cave locally known as "Gin Hole" (a large boulder on the beach below still retains the appellation of "Lintie Cock Stone," from the fact that the Cormorants used it as a favourite perching place); there they bred until 1867 , when some mischievous youths lowered a lighted tar barrel at night on to the nesting ledges, and so terrified the occupants that they forsook that locality, ${ }^{*}$ and established themselves nearer Whitby on Kettleness Point, where I saw about thirty pairs nesting in I880. In May I887, there were upwards of twenty pairs, but again persecution followed, many were shot from the nests, and the opening of the Loftus and Whitby Railway, which runs near the Point, finally banished them from that spot ; in I889 only one pair was seen and they did not nest; a few returned to the Boulby site where odd pairs bred until I900; in Ig0I a nest was reported between Boulby and Hummersea, and on one occasion a young bird was seen with two old ones on the boulders on the beach; in April I902, I saw a Cormorant sitting on "White Stone," a perching boulder, but could not detect any signs of a nest, though during the summer months since the year I904, two pairs of old birds passed Redcar daily, going to and from the Teesmouth, where they obtain food for their young, and I am of opinion that they were nesting at Boulby. The bulk of the Kettleness Cormorants have evidently gone still further south, and about thirty or forty pairs now nest near the Whitby High Lights, two miles from that town. When they bred at Boulby and Kettleness, long strings, sometimes numbering from twenty to thirty individuals, might be observed passing Redcar regularly in the early morning to fish in the Tees estuary, returning to the cliffs in the afternoon, and some-

- At Staithes a humoron story is related that, on the morning following the episode of the tar barrel an old fisherman was on the beach near " Lintie Cock Stone," and heard two Cormorants conversing. One said to his companion. "What's thou think o' that performance last neet?" "Why," replied the other, "Ah'm gaine tae flit fra'e this place I" 


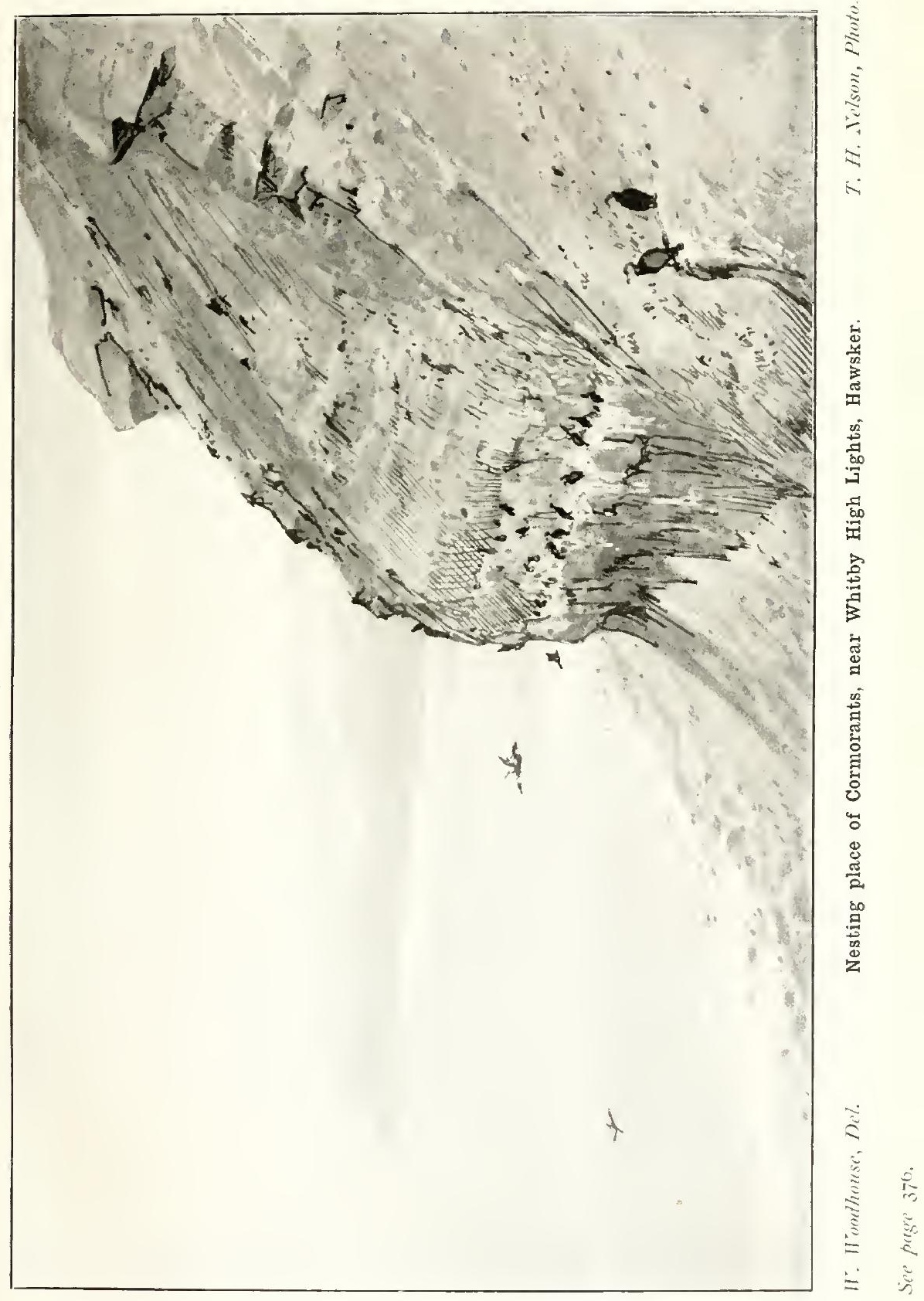




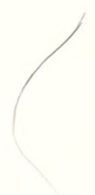


times I have watched these birds taking a "short cut" behind the town.

At Peak, on the north of Scarborough, a colony of some fifty pairs was in existence before the railway was opened, but they decreased in numbers afterwards. Several years ago a Scarborough man shot eighteen out of twenty nesting birds with a rifle; the following year none were noted, but a few pairs have since returned. Between Scarborough and Filey several pairs find nesting places; Mr. Thomas Carter in I 884 observed Cormorants there, and was told by a fisherman that he had seen a nest and three eggs at Scout Nab (Zool. I884, p. 446). I am informed by Mr. J. Fountain of Filey that he had a clutch of five eggs brought to him in the year I902; in I906 there were eight nests.

Concerning its connection with Flamborough, Pennant's remarks are quoted above. The Cormorant used to be a familiar object near the Headland until the "sixties," but there again senseless persecution has banished it as a nesting species. The breeding sites were near the Lighthouse, the Danes' Dyke, on the Bempton range, and also on Raincliffe, where Charles Waterton found it breeding in 1834, and descended to examine the nests. Mr. M. Bailey remarks that one or two pairs returned in 1873 , and in 1880 there were two nests; the Bempton climbers say that some four or five birds frequent a certain portion of the cliffs, but there is no proof of their nesting there now.

The above mentioned constitute all the natural breeding stations of the species, though on the Holderness coast, as Mr. T. Petch and the Rev. A. Donovan inform me, an unusual site has been appropriated on the wreck of a sailing ship, the " Earl of Beaconsfield," that went ashore near Aldborough in $1887 . *$ One of the masts is left standing to warn fishing cobles of the danger to navigation, and on the crosstrees of the main mast several pairs of Cormorants have established themselves; in 1893 it was reported that a pair had nested and brought off young, and since then they have been regularly observed ; sixteen were seen on 3Ist August I900, and nestlings

* See Naturalist, Feb. 1903, p. 42. 
have been recognised. In winter some return to the ship at sunset, but in early autumn they are "at home" after the tide begins to flow, when contests frequently take place for the post of honour.

As previously remarked the majority of the breeding birds retire southward in winter, returning to their nesting resorts early in spring, though some remain in the Teesmouth neighbourhood during the winter months, and the numbers of those wintering appear to have increased of late years. On 26th December I887, one came on board the Tees Light Vessel. At Whitby, Scarborough, Flamborough, and the Humber (at which latter place the late J. Cordeaux considered they were increasing), they are noted in limited numbers, in winter coming at times to fish close inshore and in the harbours. In spring I have seen Cormorants sitting on the rails at the head of Coatham Pier (now demolished), drying their wings, and sometimes they allowed an approach within thirty or forty yards before taking flight; occasionally they alight on Salt Scar at low tide, and in March I899 some used to perch on a portion of a wreck standing out of the water.

The Cormorant has been caught on fishing lines and in nets shot in deep water; two were captured at Bridlington on hooks when five fathoms of line were out, and in the Tees Bay they have at times been entangled in the salmon fishing nets.

This ocean-loving species has been noted at places far removed from salt water and in most parts of the county, an enumeration of which is needless, though one or two instances may be cited : first is that mentioned by Marmaduke Tunstall of Wycliffe-on-Tees, as " shot close to my house (in September 1782 ), though nearly thirty miles from the main sea" (Tunst. MS. p. I00); it is noted in Fothergill's list in Whitaker's "Richmondshire" in I823; Charles Waterton's residence, Walton Hall, was often visited in winter by Cormorants, and, after fishing in the lake, they would preen their feathers on the terrace, within ten yards of the windows. Near York one was taken on a fishing line at Kexby (before I844); at various times individuals have been killed from the turrets and walls of Beverley Minster; at Hudders- 

field an example occurred in November I870, and another was shot whilst sitting on the church top at Mappleton, near Hornsea, as recorded by Mr. Barchard in the Field, 9th August 189o. Formerly small parties occasionally ascended the river Hull for some miles above Beverley, where they are said to have been taken on night lines baited with roach and set for pike, but they have not been noticed of late years; in March I903, Mr. W. Morris saw one on the Lune at Sedbergh.

The nests at Whitby High Lights are much lighter in construction than those I have examined elsewhere, being usually not more massive than Gulls' nests, and in the year I903, amongst the materials used by one pair of birds, was found a child's toy whip.

Variations in plumage are seldom reported, though, in October I879, I obtained an example at Redcar having three of the tail feathers partially white from the tips for a space of about two inches.

The local names are:-Lang Crane at Redcar; Lintie Cock or Liltie Cock at Staithes; and Ralphie or Dykie at Whitby; these last terms from one Tom Langlands who had a couple of tame birds, called by these names, which fished in the harbour, and so the fishermen came to know them thus.

\section{SHAG.}

Phalacrocorax graculus (L.).

Bird of passage on the coast, when on its way to and from its breeding stations. Used formerly to nest at Flamborough.

Pennant was the first to make mention of the Shag in Yorkshire, for we find that he visited Flamborough on his journey to Scotland in 1769 , and thus alluded to the subject under notice :- "Multitudes [of birds] were swimming about, others swarmed in the air, and almost stunned us with the variety of their croaks and screams; I observed among them ... Shags in small flocks." ("A Tour in Scotland," I77r, p. I5.) And in his "British Zoology" (I770, IV. p. 27), 
under the heading of "Shag," he stated that, at Flamborough Head, "this variety with a crest is very rare."

Thomas Allis, in 1844, wrote:-

Phalacrocorax cristatus. - Shag or Green Cormorant-A. Strickland reports that "This bird used, some years ago, to breed in considerable numbers on the rocks off Flamborough, but now seems quite banished from there : I do not believe a single pair is now to be found there."

This bird, sometimes called the Crested Cormorant, is not so abundant as the preceding, and, though it formerly nested on the Yorkshire cliffs, it is now but a periodical visitant on its passage to and from its breeding quarters. The allusion contained in Pennant's "British Zoology," quoted above, shows that the Shag was not unknown to that author in I770. Bewick's figure was drawn from a specimen belonging to Marmaduke Tunstall, who had a Crested Cormorant out of Holderness in I775, which was full of eggs (Fox's "Synopsis," p. I00). Charles Waterton, in his “ Essays on Natural History" (p. 408), stated that it inhabited Raincliffe; Arthur Strickland also referred to it as formerly breeding in considerable numbers at Flamborough, but there is no evidence that it has done so, except in isolated instances, within the memory of living man. Odd pairs visit the cliffs in spring, and would, doubtless, breed if unmolested; their latest appearance at this period was in 1892 when two birds arrived, but they were promptly " acquired" by the fishermen. At Kettleness, in 1878 , J. Kitching saw a pair flying in and out below the Great Cormorants' nesting colony, and lower down than the Herring Gulls' ledges, which points to the possibility of their having nested there.

With reference to its connection with Cleveland, J. Hogg (Zool. I845, p. II8I), mentioned the Shag as "Common on our rocky coast"; though my experience leads me to believe that, generally speaking, the bird is rare on the Yorkshire seaboard. In the Redcar district I have known only four occurrences, viz., in the winter of 1874 ; on I4th February I889; on Ioth January I896, three being seen and two killed near Coatham Pier; and on 4th February 1905, when one was reported from the Teesmouth. At Whitby a specimen is 


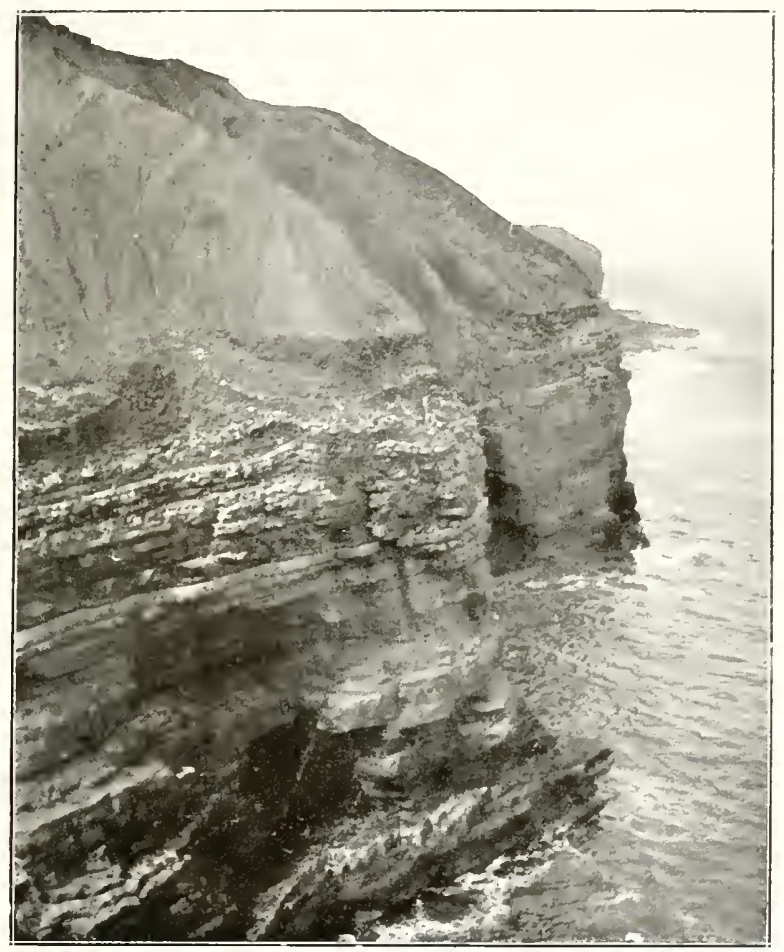

Nesting site of Cormorant, near Filey.

See page 378.

R. Fortune? 

in the Local Museum, and two others are chronicled ,one on 23rd January I894, and the last on Igth May I895. At Scarborough the late Alfred Roberts (op. cit. I855, p. 463I), in recording the occurrence of an adult female, mentioned it as a rare bird there, while Mr. W. J. Clarke expresses a similar opinion when informing me of one being obtained at Scalby Ness, on 24th February I900, and another seen the following day near the Pier.

As mentioned before, it is now but an occasional visitant at Flamborough; several specimens occurred there between 1865 and 1875 , and Mr. Thomas Boynton states (MS. I880), that it was occasionally obtained in Bridlington Bay. One instance only is noted near Spurn, on 22nd November I893, when, as recorded by the late J. Cordeaux (Nat. I894, p. 4I), an example was taken at Kilnsea, which had an eel in its mouth.

This species is less often found on inland waters than its congener, preferring its oceanic habitat, though it was noted by Fothergill of Carr End, Askrigg, as having occurred at Hawes about I820; near Boroughbridge one is mentioned in October I849, by J. C. Garth (Zool. I849, p. 2353); on the Hambleton Hills, according to the late J. Harrison, a specimen was found in a snowstorm in 1853 ; and at Thainston-on-Don one is reported as having been shot in March 1877 (Field, I7th March I877), but it may be well to observe that inland records, as a rule, should be received with caution.

\section{GANNET.}

\section{Sula bassana $(L$.$) .$}

Bird of passage on the coast. Has occasionally occurred inland as a straggler.

The first mention of the Gannet in Yorkshire appears to refer to the specimen taken near Halifax in I83I, and noticed by Thomas Allis in his Report in 1884 , thus :-

Sula bassana.-Gannet-Occurs at Flamborough and Scarborough ; it has been taken at Thorne, also one near Doncaster ; they are picked up on the Wolds and sea borders every now and then when gorged with food; one has been taken near Huddersfield; near Halifax it has 
been taken alive in Booth Deane, October 1831; on Norland Moor, December 6th I844, and a young specimen on Illingworth Moor, September 21st 1836 ; a first year's bird of this species fell exhausted on Staincross Moor, near Barnsley, which passed into the hands of Dr. Farrar, who forwarded it to the aviary at Wentworth House, where it lived many months and at last, as he says, had the supreme pleasure of dying of repletion, the result of an experiment to test its powers in that accomplishment; a few years since a specimen was sent to Henry Chapman of York, which had been picked up dead a few miles from the coast ; in descending on its prey (a garfish), in its accustomed and well-known manner, the sharp upper mandible of the fish passed obliquely through the eye and entered the brain through the optic nerve; the end of the mandible had broken off and caused the death of the bird. A. Strickland says that after the breeding season, and when the herring sprats and other fish are numerous, these birds are generally found on the coast, and occasionally later in the winter.

The Gannet cannot with accuracy be termed a resident, though it is seldom absent from some part of the sea off Yorkshire, and it is perhaps best described as a periodical visitant to the coast on its passage to and from its northern breeding stations, being most abundant in autumn, when old and young birds, the latter predominating, may be seen diligently employed amongst the herrings and other fish. As a rule a few appear soon after the nesting season in early August, whilst in September and October they are often quite numerous in the neighbourhood of the herring shoals, sometimes inshore, and at others several miles away in the offing, especially near Flamborough Head, where large numbers have frequently been noticed, and they were particularly abundant in October I895. In the late autumn it would appear that the Gannets which are then off the coast keep far out at sea, as they are only observed when driven in by gales. During the prevalence of a storm on I2th-I3th November Igor, several adults were found on Redcar beach and in the Tees estuary, and an immature bird was caught asleep during a "north-easter" on 25th November I904. I have rarely noted it in winter; one occurred at Redcar in December I874, and in January I876 three adults were killed, one being stunned with an oar; on 2nd January I894 twenty or thirty were seen flying up and down the Humber side at Spurn. 
In spring the old birds return northward along the coast on their way to their nesting quarters, and come under observation in April and May; a singular and unaccountable return movement was noticed off Redcar on I2th April I887, many pairs being seen flying south. In some seasons mature examples are found washed in by the tide, having apparently died from the effects of a disease, which at this period attacks many pelagic species. In the summer of 1895 seven Gannets were captured in a weak and dying condition, the taxidermist who preserved them discovering the bones to be quite soft and crumbly.

This species is sometimes driven by stormy weather to inland localities, and has been met with in most parts of the county, on reservoirs, lakes, and the most remote fells and moorlands. It would be tedious to recapitulate all these instances, but one may be mentioned, on 22nd April r838, after a two days' hurricane from the north-east, when an adult specimen was picked up on Swainby Moor, in Cleveland, which had evidently been blown in by the gale and flown, blinded, as long as strength lasted. When found it was scarcely stiff, and had about $2 \frac{1}{4} \mathrm{in}$. of the beak of a garfish forced into one eye, leaving only $\frac{1}{2}$ in. visible. It was taken to the Rev. G. J. Marwood of Busby, who had it preserved, and the eye and piece of garfish beak preserved in spirits.* The present keeper at Swainby, Thomas Whitwell, captured a Gannet on the same moor in Igoo.

The method of fishing adopted by the Gannet is too well known to need any description here, though it may be of interest to mention that, in the autumn of 1905 , I was witness of a departure from the bird's ordinary habit. On the Ist September an immature Gannet flew past Redcar Pier head and settled on the water about two hundred yards away; it then dived from the surface in the same manner as a Cormorant or Red-throated Diver. With the aid of powerful binoculars I saw it twice repeat this process, on one occasion bringing up a fish, or food of some kind, which it swallowed; after the

* This is the specimen referred to in Allis's Report. 
lapse of two or three minutes it rose and flew out beyond the rocks, where it continued its fishing as before.

A story is related at Flamborough of a narrow escape the late Thomas Leng, a well-known seabird shooter, had from serious injury, if not death itself. While off at sea he shot a Gannet, and, without lowering his gun, turned to fire the second barrel at another bird. The first one was already falling, and its pointed beak pierced the brim of Leng's "souwester," knocking him down into the bottom of the boat. Leng used to say this was the "closest shave" he ever had.

The local names are Solan Goose, Gant, and Mackerel Gant."

\section{COMMON HERON.}

Ardea cinerea (L.).

Resident; common but local. An influx of migrants from the Continent in autumn and winter.

The earliest allusion to this species in Yorkshire appears to be in the Selby Abbey accounts for $\mathrm{I} 43 \mathrm{I}-32$, where an entry runs to this effect:- " Paid to .... . ; to a certain servant at Fryston bringing two Herons to the lord abbot, 2od. ..." (Morrell's "Selby," r867, p. Ior.)

Thomas Allis, in 1844 , wrote as follows:-

Ardea cinerea.-The Common Heron-Not infrequently seen, wanderers from the Heronries in the county, for a list of which see Yarrell's "British Birds" ; to which list Scarthingwell may be added, on the authority of my friend H. Denny. Arthur Strickland observes "Few countries have undergone greater change in their ornithological features than the East Riding, the drainage of the Carrs in the low grounds and enclosing the Wolds in the chalk districts have of late years made great alterations, and in the low countries the total disuse of decoys, and the Herons no longer resorting to the ancient Heronries, mark this change. The most important and best known Heronry, and the largest resorted to was Scorborough, near Beverley, but that has for many years ceased to be the breeding place of any of them, and I believe no Heronry now exists in the East Riding. Since the disuse of the ancient Heronries a tew pairs have occasionally bred on some trees on one of the islands of Hornsea Mere, but I believe 
Manby, in the north of Lincolnshire, the nearest ancient Heronry that still continues to be resorted to. Mr. Yarrell has stated, in his list of Heronries, Hutton the seat of R. Bethell, Esq. ; but Hutton, or Hutton Cranswick, adjoining the Carrs, never was the property of the Bethells, or as far as I can learn, the seat of a Heronry; but the adjoining parish of Watton or Watton Abbey has long been the property of the Bethells of Rise, but it is not now the site of a Heronry, nor can it have been so for some time, as I can find no one in the parish or country who can remember a Heronry there. At the same time it must be observed that it is a very likely situation to have been one."

The discontinuance of the noble and ancient sport of Falconry has resulted in the dispersal of large Heronries and the establishment of small settlements, the status of the Heron having, in consequence, considerably changed in Yorkshire. Formerly Heronries were maintained and encouraged both for the purposes of sport and also in order that young birds might be taken and used for the table. Thus we find that at the great banquet, given at Cawood in I466, by Earl Warwick "the King Maker," in honour of the enthronement of his brother George Nevell as Archbishop of York, amongst the items of the feast were "Heronshawes, iiiic." Again in the Earl of Northumberland's Household Book, in I5I2, at his castles of Wressill and Lekinfield, near Beverley, the price of "Hearonsewys" was fixed at I2d. ; and in $I_{526}$ and 1530 at the marriage feasts of the daughters of Sir John Neville of Chevet, near Wakefield, "Heronsewes" figured in the list of edibles. We naturally infer from these old statements that extensive colonies were then in existence, but of these no records remain; thus we are dependent upon comparatively recent information respecting the Yorkshire stations. The bird, however, is still resident in fair numbers ; its distribution in the nesting season is very local, though during the rest of the year, and especially in autumn and winter, it is more generally diffused, and it may be well to give in detail the particulars regarding its present status.

Commencing with the West Riding, ancient Heronries were in existence at:-

Hemsworth, near Pontefract. Major Arundel, writing on $4^{\text {th }}$ June I903, informs me that, from investigations he has 
made, it appears the Heron bred at Hagg Wood up to I850, though not after that date.

Kirby Hill, near Boroughbridge, the seat of Mr. R. Thompson. Deserted about I856.

Scarthingwell, near Ferrybridge, a seat of Lord Hawke. (In Denny's Leeds Catalogue (I840), it is stated that there were eighteen or twenty nests, but they were abandoned "two or three years ago.")

Dob Park Wood, Fewston. Owing to the trees being cut down, about I830, the birds left (W. Storey MS.).

Walton Hall, the residence of the celebrated naturalist Charles Waterton. This Heronry was founded in I827, the year after Waterton had completed a wall round his park, built for the purpose of protecting bird-life there. At first there were six nests on Scotch firs, and the new establishment throve until some of the trees were thinned in winter; the following spring the Herons abandoned their former nests and built afresh on oak trees; the colony gradually increased until it numbered thirty-six nests, which continued during Waterton's lifetime; after his death in I865, some of the trees were felled and the birds at once abandoned the place as a breeding station. A pair attempted to nest in 1872 at $\mathrm{Haw}$ Park, near by, but was destroyed.

Wetherby Grange, owned by the late Sir R. Gunter. Long abolished.

Nostell Priory; in 1826 there were five or six nests on a willowed island in the lake. Charles Waterton in his " Essays," remarked that they were reduced to one, or at most two, before the middle of the past century. Soon after the Heronry was deserted.

Azerley Hall, the seat of Mr. R. S. Crompton. There were eight nests in 1844 .

Browsholme, near Clitheroe, Mr. Parker's residence, on the Yorkshire side of the Hodder. There was a large Heronry which was deserted for several years and re-occupied in 1877 ; in 1880 there were fifteen nests, but the birds left about I890, and established a colony at Harrop Hall, near Slaidburn, which, however, was soon abandoned. 
Odd pairs have also at times nested at Wooley Park, Wilstrop, Ripley, Gouthwaite Hall, Bishop Thornton, Goldsborough (near Allerton), Burnsall in Upper Wharfedale, Ingmanthorpe, Bramham, and in Cockett Wood in Upper Ribblesdale.

The existing colonies are at:-

Harewood, the seat of the Earl of Harewood, where there used to be a large Heronry. Mr. Moorsom Maude informed $\mathrm{me}$, in 1902 , that in 1866 there were from twenty to thirty nests in Piper's Wood, and about I 884 a terrific gale blew down many of the trees, thus disturbing the nests. From that date they gradually decreased, and in I902 I. saw only seven, which were in tall fir trees in a different part of the wood to where the old Heronry was situated. In 1903 only five pairs nested, and young were hatched on Good Friday.

Flasby, near Gargrave, on Capt. Preston's estate. There was a Heronry until I865, when, owing to the cutting down of two big oak trees in which some of the nests were built, the birds, intolerant of being disturbed, emigrated to Eshton Hall, Sir M. W. Wilson's property, about a mile distant. In 1881 they numbered twenty pairs, and in the year 1905 seventeen pairs nested.

Gisburn, on Lord Ribblesclale's estate. There is now a colony formed by the Herons from the deserted stations of Browsholme and Harrop Hall. In the present year (rgo6), it consisted of seventeen pairs. Odd pairs also breed in isolated cases in the district.

The East Riding Heronries were stated to be at :-

Hutton Cranswick, Mr. Bethell's; but this is an error, as there is no record of a Heronry at Hutton.

Stork Hill, near Beverley, which ceased to exist about the beginning of last century.

Scorborough, near Beverley, which gradually decreased till about I830, when the birds forsook, partly in consequence of the trees decaying; one or two pairs have bred constantly in a wood called Beswick Rush, two miles from Beverley.

Swanland, near Hull; possibly Herons bred there many years ago, but no information is obtainable.

Hotham. Up to I8rg there was a Heronry in large Scotch 
fir and ash trees. Mr. F. Boyes knew persons who took eggs there.

Sutton-on-Derwent. About a hundred pairs nested up to about I860. Capt. Dunnington Jefferson told me (r903), they bred about twenty years ago, but, owing to persecution, the birds forsook the place.

Holme-on-Spalding-Moor, which ceased about 1865 .

Newton, near Malton, Sir George Cholmley's. There were about twenty to twenty-five nests. This Heronry, which in Sir Geo. Strickland's day contained up to sixty or seventy nests in larch trees, has, within the past twenty years, been forsaken. It was thought to be owing to the Rooks which increased exceedingly, and to the war waged on Herons by Angling Clubs (W. H. St. Quintin MS. r903).

Hornsea. One of the islands possessed a small Heronry, but it is now abandoned, and another colony has been established at the north side of the Mere.

The present Heronries are at:-

Hornsea. On Mr. Strickland Constable's property, established about $\mathrm{x} 880$, and now comprising about eighteen nests in the wood at the Wassand end of the Mere.

Scampston, Mr. W. H. St. Quintin's. About eight nests ; sometimes a few more, built in larches.

Moreby Park, near York, Major Preston's. There were fifty nests in I884 (J. Backhouse MS.), ten to twelve in I8g2, and now about eight or nine.

Isolated nests are found near Winestead, at Everingham, Beswick Rush, and in the Heron Wood at Escrick.

Turning now to the North Riding, breeding places existed at :-

Riccaldale (C. Ward, Helmsley, MS.).

Harmby, near Middleham. From the Heronry formerly existing there the place probably derived its Saxon name, Hernebie (Barker's "Three Days of Wensleydale," I854).

Kildale ("Vertebrate Fauna of Yorkshire"). Concerning the colony here Mr. E. West writes (22nd March I902), that he once knew of a nest at Crag Bank, adjoining the lake, in 1850 , but never a Heronry. Mr. Thomas Stephenson 


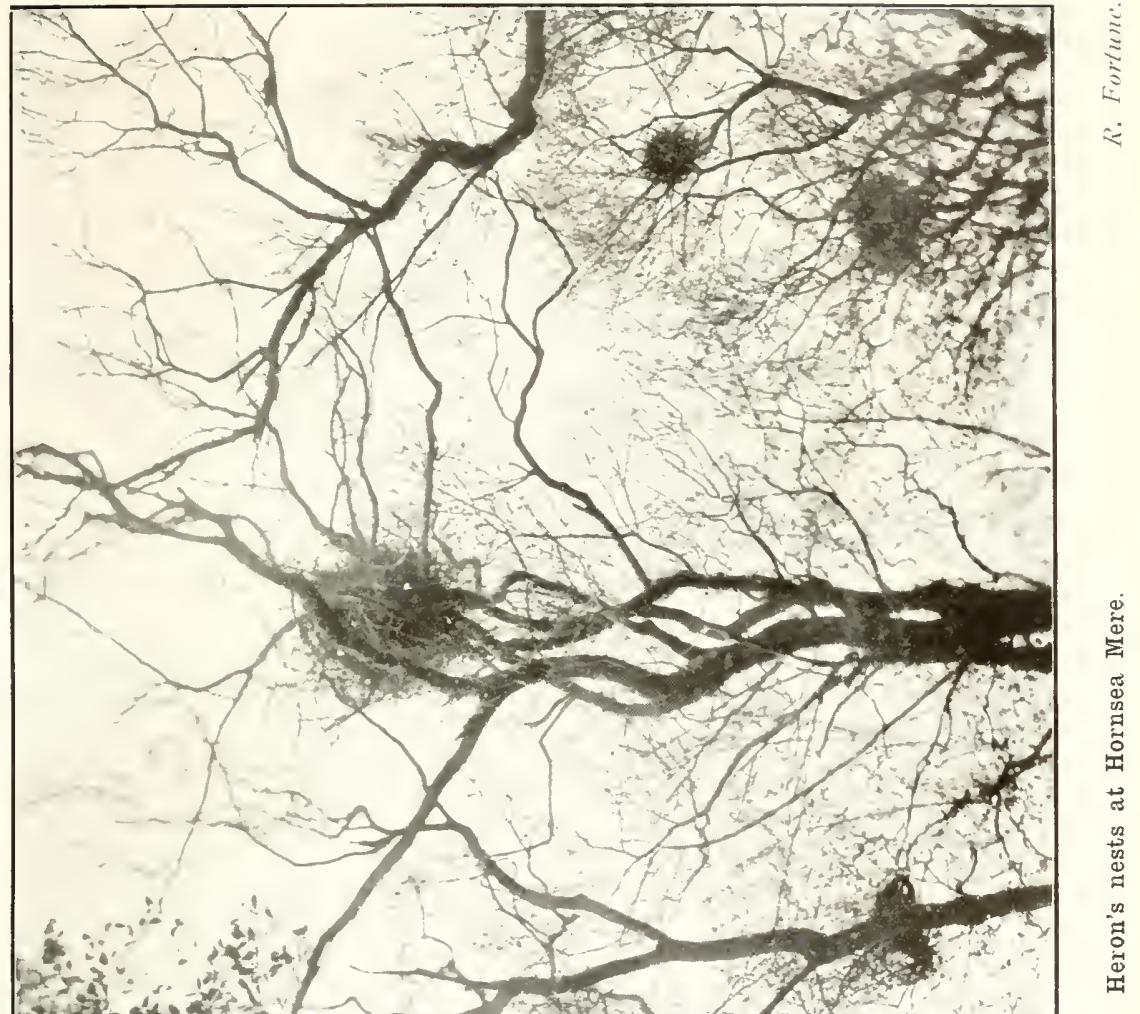



informs me that, in $\mathrm{I} 882$, he received information that several pairs remained all the summer at Randy Mere, Goathland, and in July of that year he saw four birds; but a few years afterwards the trees were cut down, and he concluded the birds left.

Sedbergh. A few pairs used to nest at Ingmire Hall, Mrs. Dormer's, up to I880 (W. Morris MS.).

Swinton Park, Masham, Lord Masham's. Mr. Forbes, forester, informed me that three pairs nested in larch trees in the Druid's Wood in Igoo and Igor, but, for some unexplained cause, they deserted in I902.

According to the information supplied by my correspon. dents there is not at present any Heronry of importance in the North Riding; a small colony consisting of three pairs is established on the late Mr. Rutson's estate at Newby Wiske, and odd pairs nest sparingly in one or two other localities. In 1900 and the two succeeding years a pair bred in the Rookery in Wensleydale, between Carperby and Thornton Rust, but were disturbed by the Rook-shooting and deserted the place. In I903 a brood was reared in the Lord's Wood at Bolton Park. In Arkengarthdale, and at Rutherford Bridge on the Greta, there have also been occasional nests, as well as in Liverton and Grinkle Woods, near Loftus-in-Cleveland, and at Mulgrave, near Whitby.

As migrants from the Continent, Herons are frequently observed in the autumn in the neighbourhood of the coast; I have annually watched the birds crossing the sea from the east, flying high in the air and slowly winging their way landwards. Occasionally they may be noticed sitting on the "Scars" a mile from shore, near Redcar.

Nidification sometimes begins very early. Eggs have been seen in the second week in February, and young were hatched on the 20 th of that month in I 898 .

Charles Waterton recorded the fact of having seen Herons alight in deep water at Walton Park and swim like WaterHens. He also observed them hovering like Terns over shoals of fish.

A curious incident, illustrating the voracity of this bird, 
is told by Mr. F. S. Mitchell (Zool. I88I, p. I86), who says that in the stomach of a young bird was found about half a yard of line with a broken hook at one end, and two lead sinkers attached; no doubt the old Heron had got hold of a fish on a night line, torn it loose, and presented it to its offspring with fatal results to the latter.

An interesting piece of folk-lore is communicated by an old resident in Cleveland, and is to the effect that:- "To look upon black or dark birds (Crows or Rooks especially) when worriting (harassing or pursuing) a 'Sew,' so that it casts up its catch, tells for a certainty that he or she who sets eyes on such a sight will presently suffer through law. Should the pursuing birds be light-coloured (? Peewits), then loss through death will ensue to the beholder."

The vernacular names are really but few in number, apart from the variation in spelling and pronunciation of the principal one, which is rendered Heronshawes by Leland, in describing the Nevell enthronization feast of I466; Heronsewes or Heron-sews at the Neville feasts of I $_{526}$ and I530; Hearonsewys in the Northumberland Household Book of I5I2; Heron-sew, Hearin'-sew, and Herring-sew in the Craven district; Heronseugh, in the East Riding and at Scarborough ; Heronshaw at Doncaster (I849), and at Barnsley; Heronsew or Heron-sue in Teesdale and at Loftus-in-Cleveland, and in the latter district Sew is sometimes used without the prefix; Heronshew in Arkengarthdale, and Heron-sue at Nunnington. Johnson in the Zoologist (I849), rendered it Herring Shrew and Herring-shaw, and Poulson in his "Antiquities of Beverley" (p. 263), quoting the Northumberland Household Book, gave it as Heronsew, Heronseu, Hornsue, and Hernshaw. Long-neck is the appropriate term in use at Sedbergh ; and Yony Crony at Settle and Upper Ribblesdale. 


\section{PURPLE HERON.}

Ardea purpurea (L.).

Accidental visitant from southern Europe and Africa, of extremely rare occurrence.

The Purple Heron breeds in Holland and commonly in south-east Europe, migrating in winter to Africa.

The first known Yorkshire specimen of this bird is that referred to by Thomas Allis in I844:-

Ardea purpurea.-Purple Heron-One shot near Flamborough in 1833, by Mr. Pick of that place, mentioned in F. O. Morris's catalogue of "Yorkshire Birds," now in the collection of A. Strickland, Esq.. is a specimen in young plumage and the only one we have heard of.

This species is an accidental visitant to the British Isles, and has been noted in this county on six different occasions, in spring and summer.

The first, alluded to by Allis in his Report, is now in the York Museum.

At Lowthorpe one occurred at some old fish ponds, in the spring of 1847 , and was mentioned by the Rev. F. O. Morris in the Zoologist (I849, p. 259I); Mr. St. Quintin informs me this bird is in his possession, and is placed at the Lowthorpe Lodge.

Near Leeds a male specimen was procured at Temple Thorpe.

Mr. Thomas Stephenson states that an immature bird was obtained in the summer of I860, by Joshua Barry, at Ruswarp Dam, and was stuffed by J. Kitching. This specimen is now in the Whitby Museum.

A male example, taken in July I862, by W. Wellburn, gamekeeper, at Hornsea Mere, is in the Burton Agnes collection, formed by the late Sir Henry Boynton, where I have had an opportunity of seeing it.

And the latest occurrence was reported in the Naturalist (I888, p. 330), by Mr. W. Eagle Clarke, who says he examined in the flesh a fine mature male, which had been killed on Igth

VOL. II. 
April I888, on the margin of Farnley Pool, near Otley. When first seen the bird was approaching the water from the direction of Harewood. It appeared to have been unsuspicious of danger, and allowed a keeper to approach within gun range, and this in quite an exposed situation, where it was shot for a Common Heron. The specimen is in the possession of the Rev. F. Fawkes of Rothwell.

\section{GREAT WHITE HERON.}

\section{Ardea alba ( $\left.T_{.}.\right)$.}

Accidental visitant from south-eastern Europe and Africa, of extremely rare occurrence.

This bird is an inhabitant of the Lower Danube and Black Sea areas, south-east Europe, north Africa, and India.

A reference to it in Willughby's "Ornithology" may possibly be connected with Yorkshire; that celebrated ornithologist's correspondent, R. Johnson, being quoted as follows :- " For Mr. Johnson [of Brignall, near Greta Bridge], who hath seen the Great White Heron in England, puts it down for a distinct kind in his method of birds communicated to us." (Will. "Orn." I678, pp. 279-8o.)

Thomas Allis, in I844, wrote:-

Ardea alba.-White Heron-F. O. Morris mentions one shot near Beverley a few years ago and now in the possession of Jas. Hall, Esq. of Scorborough, near Beverley; the same specimen is referred to by Hugh Reid. Dr. Farrar says a specimen of this very rare visitant was shot at New Hall by my friend the late John S. Townend, Esq., and by some means got into the possession of Sir Joseph Radclyffe, Bart.; another at Hornsea Mere, in the collection of A. Strickland, Esq., is reported by him, and noticed in Charlesworth's "Magazine of Natural History"; but those who have quoted that paper have mistaken Scorborough for Scarborough, which is forty miles from it.

The Great White Heron is a very rare, accidental visitant, the Yorkshire occurrences, authenticated by the actual capture of the specimens, being but three in number. The first was recorded at the British Association's meeting at 
Newcastle-on-Tyne, in August 1838, by Arthur Strickland, who stated that one was seen for several weeks at Hornsea Mere, and was caught about I825. This example forms part of the Strickland collection, now in the York Museum, and was recorded in the Report of the British Association (I838, p. I06); the "Magazine of Natural History" (I839, p. 2I) ; and Zoologist ( 1856, p. 5035).

The second specimen, which is in full summer plumage, was killed in 1834 by John Norris on the river Hull at Aike, near Beverley, and was sold to the late James Hall of Scorborough. At his decease it was purchased on behalf of the authorities of the York Museum, and is now in the Rudston collection in that institution (see Neville Wood's " Naturalist," November I838; and Yarrell's " Brit. Birds," I843, ii. p. 455).

Near Barnsley, one was obtained at New Hall, in $\mathrm{I} 82 \mathrm{I}$, by the late J. S. Townend, and was formerly in the possession of Sir Joseph Radcliffe, Bart. (Farrar's MS. I844). This specimen is considered doubtful (Harting's "Handbook," and Ed. p. 440).

The above records are all mentioned by Allis in his Report, already quoted.

A later occurrence, reported by Mr. A. S. Hutchinson of Derby, is unquestionably referable to the species under notice. The recorder, a naturalist of great experience, writes in 1902 that, in the summer of I868, he saw a Great White Heron perched on a fir tree at Clay Wheel Dam, near Wadsley Bridge, where he watched it at close quarters for nearly half an hour, and had no doubt whatever as to its identity.

\section{LITTI.E EGRET.}

Ardea garzetta (L.).

Accidental visitant from south-east Europe and Africa, of extremely sare occurrence.

This species breeds in south-east Europe, and is found in the whole of Africa, India, China, and Japan. 
Pennant, in his "British Zoology" (2nd Ed. I768, pp. 492, 495), observed that, in the famous feast of Archbishop Nevell of York, we find no fewer than a thousand Asterides, Egrets, or Egrittes, as it is different spelt. But, as suggested by various authorities, these were, no doubt, Lapwings. (See Yarrell, 4th Ed. Vol. iv. p. I82.)

The Little Egret is an accidental visitant, the Yorkshire occurrences being only two in number.

In the Grosvenor Museum, Chester, is a male example of this graceful bird, the particulars of which have been supplied to me by Mr. Robert Newstead, curator. The specimen was in a case, forming part of an extensive collection of British birds bequeathed by the late Thomas Potts of Chester to the Society of Natural Science in that eity, and the label on the case, which I have inspected, states the bird was "Shot March I826, near Paull, Humberside, Yorkshire." The writing is all in the same hand, and appears to have been written all at one time; "Yorkshire" has not been added, as suggested by Mr. J. H. Gurney (Zool. Igor, p. I07), who considers this specimen may be identical with the one sold at Southampton in 1826 , and probably shot at that place, but I cannot accept Mr. Gurney's theory. The locality indicated on the case in Chester Museum is positive. Mr. Howard Saunders, who remarks that most of the British records are extremely unsatisfactory, has seen the bird in question, and is of opinion that its authenticity is without doubt. Through Mr. Newstead's courtesy I am enabled to produce an illustration of the bird before it was restuffed.

Another Yorkshire example is mentioned by Gould ("Birds of Great Britain," Vol. iv.), the particulars of which were furnished by the late James Hall of Scorborough, near Beverley, as follows :- "The Little Egret in my possession was killed by a labourer with a stick in Ake [Aike] Carr, near Beverley, about I840, and was brought to me tied up in a pockethandkerchief, covered with black wet mud and blood, in which state it was sent to Mr. Reed [Reid] of Doncaster, who restored it in a marvellous manner."

One, recorded by Mr. Harper as having occurred on $4^{\text {th }}$ 
January I8SI, at Hayburn Wyke, near Scarborough, proved to be an imported bird (Zool. I8SI, p. 2I3; and I889, p. I50).

For comments on the authenticity of the British records, see J. H. Gurney (op. cit. I8S8, p. 302).

\section{SQUACCO HERON.}

Ardea ralloides (Scopoli).

Accidental visitant from southern Europe, of extremely rare occurrence.

The Squacco Heron is found in central and southern Europe in spring and autumn, migrating in winter to South Africa.

The first mention of the bird in this county is that contained in the Report of Thomas Allis, in I844, thus :-

Arden ralloides.-Squacco Heron-Arthur Strickland says "A specimen of this bird was killed some years ago in the low grounds below Askern, near Pontefract, and is now in my collection."

There are, so far as is known, but two Yorkshire occurrences of this rare visitant on record.

The individual mentioned by Allis forms part of the Strickland collection, now in the York Museum.

A second Yorkshire example was picked up alive on 26th February I902, by Mr. Thomas Lakin, farmer, Bielby Field, Everingham, in the East Riding, and was preserved by Mr. George Steels of Pocklington, to whom I am indebted for the particulars concerning its capture. The specimen is now in the possession of its captor.

\section{NIGHT HERON. \\ Nycticorax griseus (L.).}

Accidental visitant from southern and eastern Europe and Africa, of very rare occurrence.

The Night Heron nests on the Continent of Europe, and is also found throughout Africa and the south of Asia. 
Thomas Allis, in I844, wrote:-

Nycticorax europaus. -Night Heron-F. O. Morris says he thinks he has seen this bird at the Woodlands, near Doncaster. (We ought to have better evidence.)

There are five authentic instances of the occurrence of this rare wanderer to Yorkshire, the particulars being set forth below :-

An immature male was obtained in I837, on Cottingham Common, by Martin, gamekeeper, and came into the possession of the late W. W. Boulton of Beverley, from whom it was purchased by the late Sir Henry Boynton. This specimen is now in the Burton Agnes Museum, where I have seen it, together with an adult male, which was formerly in the Sunderlandwick collection, procured near the latter place.

On 2Ist May I855, one was killed on a pond at Birdsall, near Malton, by the keeper of Mr. H. Willoughby, in whose collection it now is. The particulars respecting this occurrence were communicated by the late D. Graham of York.

Mr. Thomas Stephenson states that an example, which was captured near Whitby, in the autumn of I86I, is in the possession of Mr. Edward Corner of Esk Hall.

At Kirkby Misperton, near Malton, one was procured in May I870, as communicated by the late Edward Tindall (MS. I880). This specimen is in Mr. Tindall's collection, which was bequeathed to the Scarborough Museum.

\section{LITTLE BITTERN.}

Ardetta minuta ( $($. .).

Casual visitant, of rare occurrence, chiefly in summer.

The Little Bittern is found throughout the southern countries of Europe in summer, migrating in winter to Africa and India.

Probably the earliest allusion to this, as a Yorkshire bird, is in Thomas Allis's Report, I844:-

Botaurus minuta.-Little Bittern-One was shot at Birdsall, nea 
Malton, the estate of Henry Willoughby, Esq., about two years since ; Hugh Reid of Doncaster informs me that one was shot at Thorpe. near Bridlington, and is now in the possession of A. Bosville, Esq. ; another shot near Doncaster is in his own possession.

A rare, casual visitant, the Little Bittern has been chronicled in Yorkshire on fifteen different occasions, all of which are authenticated, while other four instances are reported for which full information is not forthcoming.

The first two mentioned are referred to by Allis, while the late Hugh Reid of Doncaster had a specimen, shot near that town, also prior to 1844 .

On 26th September I 852, one was procured at Redcar, and about the same time a specimen was killed in the neighbourhood of York, and acquired by the late Joseph Duff of Bishop Auckland. This individual is now in my collection.

At the Scarborough Mere one was obtained in August I863, while perched on a tree in a garden at Black House, and came into the possession of Mr. Taylor (A. Roberts MS. ; and Zool. I863, p. 8770).

The late W. W. Boulton of Beverley stated (MS. I880), that an example was killed at Cottingham "several years ago." At Mr. Boulton's death this specimen was purchased by Mr. Thomas Boynton of Bridlington, and is now in his collection.

At Collta, in the Rivelin Valley, one, taken about 1870 , was sent to Webster's to be stuffed. For this information I am indebted to Mr. A. S. Hutchinson of Derby.

On 25th August I872, an individual occurred at Cold Hindley Reservoir, near Wakefield, and is recorded in Talbot's "Birds of Wakefield" as forming part of the collection of that author.

An adult example is recorded by Mr. F. Boyes at Easington on 25th May I874 (Zool. I874, p. 4II8).

In the Whitby Local Museum is a specimen captured in Nay I877, by T. Fletcher, at Ruswarp Dam, near Whitby (T. Stephenson MS.).

At Scalby Beck, near Scarborough, a mature female was procured on 25th February I879, by Mr. Wood of Huddersfield; 
it was afterwards in Mr. E. Thompson's possession, and is now in the collection of Mr. J. Whitaker of Rainworth Lodge.

A paragraph in the Naturalist (I89o, p. 2Io), stating that a Little Bittern from the collection of Mr. J. Whitaker, obtained at Scalby Beck, I6th May I866, was sold at Stevens' rooms on 22nd May I89o, is incorrect. Mr. Whitaker informs me that the individual reported in I879 is the only one he ever possessed.

This is the same as recorded by Mr. E. V. Thompson in "Land and Water," 27th December 1879, "shot off Filey Brigg."

A male specimen, caught alive on the Dutch River bank, near Goole, on 23rd September I88I, was in Mr. W. Eagle Clarke's collection, and was recorded by Mr. Thomas Bunker in the Naturalist (I88I, p. 66).

In Teesdale, Mr. W. Walton informs me of one at Mickleton in 1885 .

In 1892 an example was procured at Sandal, near Wakefield, as reported by Mr. Joseph Morley of Scarborough.

Mr. George Steels of Pocklington states (MS.), that one, killed during very hard weather, within two miles of that town, was brought to him for preservation in $\mathrm{I} 895$.

1 Mr. Gerald Heaton reports (in. litt. I903), that he picked up the remains of a Little Bittern on 7 th January I902, about two miles south of Scarborough. The body had been eaten by vermin, but sufficient remained to enable him to identify the species.

Information concerning the following specimens is incomplete :-

Hunslet, near Leeds, one captured and taken alive to Mr. J. J. Armistead.

Harewood Bridge, one, J. Tennant (MS.); both these were prior to I88I.

Redcar, one from the late C. C. Oxley's collection, probably taken in the locality, now in the possession of Mr. Thomas Watson of Redcar.

One on the river Hull, near Watton Beck, "some years ago" (F. Boyes MS.). 


\section{COMMON BITTERN.}

Botaurus stellaris ( $L$.).

Winter visitant, of uncommon occurrence; sometimes numerous in severe seasons. Probably nested formerly in the Doncaster Carrs and in Holderness.

Historically, the connection of the Bittern with Yorkshire is of great antiquity, for we find allusion to it in the provision made for the great banquet given at Cawood in honour of the enthronization of Geo. Nevell as Archbishop of York in I466, the sixth year of Edward the Fourth's reign. Amongst the delicacies provided were "In Bittors. c.c. iiii." (Leland's "Collectanea.")

We are also told, in the Northumberland Household Book, that the price of "Bytters," for Earl Percy's table at the Castles of Wressill and Lekinfield, in I5I2, was fixed at " $\mathrm{x} 2 \mathrm{~d}$. a pece so they be good"; and the bird figured in the ménus at the marriage feasts of Sir John Neville's daughters

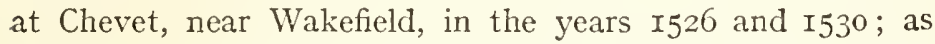

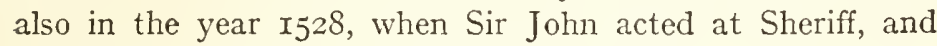
his charges included " Io bytters, I3s. 4d."

Thomas Allis, in his Report, I844, wrote:-

Botaurus stellaris.-Common Bittern-Has been met with a few times near Sheffield; I have no mention of it from near Halifax; very rare near Huddersfield. W. Eddison has only known of two specimens one of which, in his own possession, was shot at Dalton; Dr. Farrar has been unable to obtain a specimen for his own collection, but says several specimens were shot in I830, one at Wortley Park, and several others between that place and Pontefract; it is rare near Leeds, it used to frequent Askham Bogs, near York, but is now scarce though occasionally pretty abundant; in I $837 \mathrm{H}$. Chapman, bird-stuffer of York, had a dozen specimens through his hands; since that time few have been seen, two were killed in the neighbourhood last winter; F. O. Morris says it is not uncommonly met with some winters; in 1831 Mr. Reid of Doncaster had twenty-five specimens brought him: H. Reid himself reports to me that a few years ago not less than fifteen were shot near Doncaster, and that during the same year he observed that many had been killed all over England. Arthur Strickland 
observes "It is probable that before the drainage of the Carrs this bird was common in this district, but at present a single bird only is occasionally found, generally in the autumn or winter; but in January of the winter of 183 I a singular flight visited this country, stated in some of the country newspapers to have arrived from the north of Ireland; at that time from what came under my own observation, what was stated to me by others, and mentioned in the newspapers, I collected a list of upwards of sixty that had been killed in this county. besides many others in different parts of the kingdom."

This interesting species, now, unfortunately, no longer resident in the county, was well known in the early part of the last century; and, as will be seen from the references to the Archbishop of York's feast in Edward the Fourth's reign, and again at the marriage of Elizabeth Neville in I526, the Bittern figured prominently as an article of food, together with many other fowl which are only known to present day naturalists as rare and occasional visitants.

In considering historically the distribution of this bird, we find that accomplished and old-time naturalist, Francis Willughby, in his "Ornithology" ( 1678, p. 25), stated that "Mr. Johnson [of Brignall, near Greta Bridge] has in an evening heard the drumming of the Bittern a mile off. This, I suppose, is the bird which the vulgar call the Night Raven and have great dread of." The celebrated North Riding naturalist, Marmaduke Tunstall, also remarked (Tunst. MS. I784, p. 85), that many were in the neighbourhood of his residence (Wycliffeon-Tees). Another favourite resort of the bird was Askham Bog, near the city of York, where the father of Mr. James Backhouse reported one so recently as the winter of $1874-75$.

In the West Riding, before the drainage of the "Carrs" on the outskirts of the famous level of Hatfield Chase, it was frequently noticed, as also around Doncaster, and in the Western Ainsty.

In "Historical Notices of Doncaster," by Chas. W. Hatfield (I866, p. 22), Mr. Samuel Crawshaw, who died at Bulby in $\mathrm{I} 8 \mathrm{I} 3$, aged 74 , is quoted as follows :- " The Bittern began to desert the Carrs about the year I750. The peculiar sound of the male forms to this day (I866) a topic of conversation of the villagers of Bulby; they were common, and, from the 
beginning of spring to the end of autumn, indications of their presence rent the air-hence the distich :-

$$
\begin{aligned}
& \text { "When on Potteric Carr the Butter Bumps cry. } \\
& \text { The women of Bulby say summer is nigh." }
\end{aligned}
$$

It used to be abundant formerly in the low grounds and marshes of east Yorkshire, and a farmhouse, not far from the site of the old Meaux Decoy, was called " Butter-bump Hall," from the continuous booming of these birds which bred in the adjacent marsh; an old couplet ran :-

\section{"When the Butther-bumps cry, Summer is nigh."}

Mr. F. Boyes has heard old people relate how on still summer evenings it could be heard from close to the town of Beverley as it boomed on the town moor, but drainage and cultivation have banished it from many of its ancient summer haunts; it is, however, not a very rare bird in winter, and in severe weather, when frozen out of its secluded retreats, it is compelled to seek food in more open places where it falls a prey to the gunner; one or more may be found in a certain locality almost any time during the winter months.

A considerable flight of these birds took place in the north of England in the year IS3I, when Strickland and Allis together collected a list of sixty occurrences in Yorkshire ; Hugh Reid of Doncaster had twenty-five brought to him, and many were killed in Wensleydale; again in I837 a dozen came into the hands of a York bird-stuffer (fide Allis's Report).

The instances of its visits in recent years are too numerous for particularization; it has been met with in most parts of the county, even in the remote dales of the north-west, though very irregularly, in severe winter weather, when it is driven out of its otherwise secure haunts in Continental Europe; it was common early in 1875 in England, and the most recent visitations in unusual numbers were in the winters of I899I900 and I904-5, when it was reported in many localities in Yorkshire.

In spring it is now very seldom observed. One occurred at Cold Hiendly Reservoir, near Wakefield, on 25th May I868; 
and in May I 886 two were seen near Gunnergate in Cleveland, and the booming heard.

On the coast line at the migration period it has been noted on several occasions ; one was taken on the rocks at Cattersty, near Saltburn, in November I868; and at Saltwick, near Whitby, a female specimen was captured on the shore in December I89o; while four were seen, on I3th October in the same year, by two Spurn boatmen when off at sea; the birds passed close to the boat, and were described as in flight looking " exactly alike fore and aft; legs straight out behind, and neck and head in front." On 2Ist November I905 a male example was killed by flying against the lighthouse at Spurn.

Concerning the folk-lore and superstitions connected with this bird, Samuel Crawshaw of Bulby (before quoted in Hatfield's "Doncaster"), stated that an opinion was entertained that the Bittern thrust its bill into a reed, that served as a pipe for swelling the note above its natural pitch; while others imagined that it put its head under water and then, by blowing violently, produced the booming; old people in the Doncaster neighbourhood used to recite a doggerel rhyme referring to the weather prognostics from the Bittern's cry, which was not uncommonly heard in their youthful days :-

"There'll either be rain or else summat waur,

When Butter-bumps sing upo' Potteric Carr."

Marmaduke Tunstall asked (MS. I784, p. 85), "Is the old error sufficiently refuted of the Bittern making the bumping or bellowing noise with its bill in a reed? It is probably a cry to love as are most of the unusual cries of birds."

Local names:-Bittor (Nevell's enthronization feast, I466, Leland) ; Bytter or Bitter (Neville's marriage feast, I526); Bittour or Bittor, and Night Raven (Willughby, I678); Bittoun (Dr. Lister of York, I673); Mire Drum (Willughby, I678, Tunstall, I784, and Graves, I808); Butter Bump, Butther Bump, and Bottle Bump (old names used in the neighbourhood of the Carrs); Speckled Heronshew (Loftus-in-Cleveland). 


\section{AMERICAN BITTERN. \\ Botaurus lentiginosus (Montagu).}

Accidental visitant from North America, of extremely rare occurrence.

The North American representative of our Bittern is an extremely rare accidental visitant, two occurrences only being on record for Yorkshire, both of them in localities within a few miles distance of each other in the North Riding.

The first was obtained at Kells Springs, near Slingsby, by Mr. Robert Hicks of York, about I873, being identified by Mr. James Brigham, and afterwards exhibited at a meeting of the York Naturalists' Club. The specimen is now in Sir Vauncey Crewe's collection at Calke Abbey, Derby.

The second example, a female, was killed on 27 th October I8S2, by the Hon. W. Dawnay, at Harlsey Hall, near Northallerton; its gizzard contained the remains of field mice. It was examined by the late John Harrison of Wilstrop, and recorded by Mr. James Backhouse in the Zoologist (I883, pp. I28, I80), and by Mr. W. Eagle Clarke in the Naturalist (IS84, p. I77).

\section{WHITE STORK,}

\section{Ciconia alba (Bechstein).}

Casual visitant from the Continent, of rare occurrence.

The first mention of the White Stork in Yorkshire is contained in Fothergill's "Orn. Brit." (I798), and relates to the occurrence of one at Howden during the severe winter of I798 (C. Fothergill's "Orn. Brit." I798, p. 7).

Thomas Allis, I844, wrote:-

Ciconia alba.-White Stork-Hugh Reid reports that one was killed at Bawtry about nineteen years ago and came into his own possession; F. O. Morris says a flock was seen fourteen years ago 
on the Trent; two supposed to belong to it were shot near Bawtry; Dr. Farrar informs me that, in March $183 \mathrm{I}$, he observed this bird (thongh at the time ignorant of its species from the height of its flight) winging his course from the east in a westerly direction, and next morning the bird was shot at Bretton Park, the residence of T. W. Beaumont, Esq., where it was standing in the shallow bed of the water, looking out for food. Arthnr Strickland says "We have had several instances of this bird straying over from the Continent ; one, formerly in my collection, was killed on the sea shore near Skipsea." In I 830 a small flock appeared on a piece of water at Keelby Common in Lincolnshire.

This species is a rare casual visitant from the European Continent, the instances of its occurrence in Yorkshire, as at present known, being twelve in number.

The first is that mentioned by C. Fothergill in I798 (see above).

At Bawtry one was obtained about 1825 , and was mentioned in Allis's Report, as also was another example in March I83I, at Bretton Park, Barnsley, the residence of Mr. T. W. Beaumont, where it was noticed standing in a shallow bed of the water.

A third instance was reported by the same recorder on the sea shore at Skipsea, the specimen being acquired by $\mathrm{A}$. Strickland.

At Wansford, near Driffield, the Rev. F. O. Morris stated ( $Z$ ool. I 846 , p. I50I), that one was seen in the spring of I 846 by Messrs. Fife and Reynard, who informed him of the circumstance.

A fine male was taken on 18 th May I 848 , on Lord Wenlock's property near Riccal, and came into the hands of D. Graham of York, who preserved it; the occurrence was reported ( $o p$. cit. I848, p. 2I9I), by Sir WV. Milner, whose collection, containing the specimen under notice, is now in the Leeds Museum.

One was killed, about the year 1855 , on a tall fir tree in the village of Great Ayton in Cleveland, and is now in the Museum attached to the Friends' School there.

At Barmston, near Bridlington, Mr. John Harland obtained one on I8th September I856, which is in the collection of the late E. Tindall, now deposited in the Scarborough Museum. On 25th September I869, a White Stork was seen flying 
round Easington Church, where it was shot at and its leg broken. It was afterwards killed near Withernsea by Mr. Crawforth, and preserved by Mr. Philip Loten of Easington. The specimen, which is in mature plumage, is now in the Hull Museum.

In the Burton Agnes collection, formed by the late Sir Hy. Boynton, is a female example, captured at Carnaby, on IIth May I878, by Mr. H. P. Robinson.

One was found floating dead in the sea near Peasholme, Scarborough, on 8 th April I888. It proved to be in mature plumage, but was too far decomposed for preservation (R. P. Harper, op. cit. I888, p. 269; and W. Eagle Clarke, Nat. I888, p. I69). The skull of this specimen is in the Museum of the York Philosophical Society.

Lastly, at Mappleton, near Hornsea, one was shot from a chimney by Mr. T. Ake, and was preserved by Mr. Darley of Hull. Its last meal had been two water voles. This specimen, which became the property of Mr. Haworth-Booth of Rowleston Hall, measured six feet eight inches across the wings and weighed eight pounds.

\section{BLACK STORK.}

Ciconia nigra (L.).

Accidental visitant from Continental Europe, of extremely rare occurrence.

The occurrences of this accidental visitant from the European Continent are but two in number; one in Bretton Park, Huddersfield, in March I836, as noted by Mr. S. L. Mosley in his "List of Huddersfield Birds"; and the other on Market Weighton Common on 29th October 1852 , recorded by B. R. Morris in the Naturalist (1853, p. I9). The last named specimen was purchased by the York Philosophical Society, and is now in their Museum. 


\section{GLOSSY IBIS. \\ Plegadis falcinellus (L.).}

Accidental visitant from central and southern Europe and Africa. of extremely rare occurrence.

There are five instances of the appearance of the Glossy Ibis chronicled in Yorkshire, and, as the bird is an extremely rare and accidental spring and autumn visitant, no apology is needed for setting out at length the particulars regarding theircapture.

The first, as communicated to Mr. W. Eagle Clarke by Mr. Philip Loten, occurred at Easington, near Spurn, in the autumn of 1850 , and passed into the collection of the late Cuthbert Watson.

The late Canon J. C. Atkinson of Danby, writing on 29th May 1880 , remarked that " An Ibis was seen near the Liverton and Moorsholm vicinity, in Cleveland, for some days, about twenty years ago; one day I took my gun, but the bird. flew away."

An immature example, in Admiral Mitford's collection, was captured at Filey in I863, and is noted in Roberts's Scarborough list.

Near Selby, a mature bird was reported at Brayton Bridge, in the last week of May IS74, and is in the possession of Mr. J. Jackson of Cawood (Field, r3th June r874).

And lastly, a male example, for a notice of which I am. indebted to Major Walter Arundel, was obtained on $17^{\text {th }}$. November I902, at Ackworth.

\section{SPOONBILL.}

\section{Platalea leucorodia ( $)$ ).}

Casual visitant from the Continent, of rare occurrence.

Historically considered, the Spoonbill's association with. Yorkshire history is of great antiquity, for we find it mentioned. 
under the old name of "Sholarde" in the Northumberland Household Book, begun in I5I2, at Earl Percy's Castles of Wressill and Lekinfield, where, in the list of birds to be supplied for "my Lordes owne Mees" are "Sholardes," the price fixed to be paid for them being 6d. Again, in the list of expenses returned for the Lammas Assizes, in I528, during the Shrievalty of Sir John Neville of Chevet, near Wakefield, are "I2 Shovelardes, I2s."*

Thomas Allis, in I844, wrote :-

Platalea leucorodia.-The Spoonbill-F. O. Morris records one shot near Masham; Dr. Farrar obtained a fresh killed specimen from Staincross in July 1833, but, from the state of its wings, thinks it must have escaped from confinement.

The Spoonbill is a rare casual visitant from the Continent, generally in spring or summer, the Yorkshire occurrences being so few that full details regarding each instance, so far as they are obtainable, may be set forth :-

One in July I833, at Staincross, was mentioned by Thomas Allis in his Report, and also in Dr. Farrar's MS. (I844), though, from the state of its wings, it was judged the bird might have escaped from confinement.

At Masham, as stated by Allis, one was obtained in I844.

An example recorded by J. Hogg (Zool. I845, p. II72), killed some years previously on the Tees Marshes, may be a Durham specimen, although, in the absence of accurate details, it is permissible to mention the occurrence in the Yorkshire list.

* In connection with this now obsolete name it may be of interest to mention that, some years ago, at my request, Mr. J. E. Harting investigated a case contained in the old Law Reports of Henry the Eighth's reign, with the result that it was found "Shovelards" at that time (1523), bred in company with Herons in the trees of Fulham Palace grounds. It may not be unreasonable, therefore, to suppose the bird may have nested in Yorkshire also at that period (see Harting. Zool. 1886, p. 8I et seq.). Mr. F. Boyes says he has been told by a very old sportsman that Spoonbills formerly bred in Leconfield Park, near Beverley, the ancient seat of the Percy family, but he could get no further information. The district is most suitable, adjoining, as it does, the old Carrs of East Yorkshire, and Herons bred there up to a recent period.

VOL. II. 
The late W. Talbot, in his "Birds of Wakefield" (p. 26), mentioned one procured in I850, by Mr. Firth, at Horbury Mill Dam.

The late Sir Wm. Milner stated (Zool. I85I, p. 3278), that, on 2nd August I85I, an adult female in his collection (now in the Leeds Museum), occurred at Wilberfoss, near York.

The York Museum possesses an adult male from the Rudston collection, killed in $\mathrm{I} 865$, at Hornby Decoy, by Anthony Savage, gamekeeper to the Duke of Leeds.

The late Capt. Clark-Kennedy communicated (op. cit. I868, p. II35), particulars concerning a fine specimen, obtained in one of the early months of I867 by the head keeper of Mr. J. C. D. Charlesworth, at Reeth, near Richmond. It was damaged in the head and too much mutilated for preservation (op. cit. I884, p. I38; and Tinkler, Nat. I892, p. 322).

Admiral Oxley of Ripon possesses a specimen which was talien at Masham in 1877 .

An individual, in Mr. Thomas Boynton's collection at Bridlington, formerly had a place in the Bessingby collection, as the owner informs me, and was captured at Thorpe fishponds, near Bridlington, but no further particulars are obtainable.

[An example of the Flamingo (Phonicopterus roseus, Pallas), killed on the Swale in January 1896 , was, in all probability, an individual escaped from Lord Lilford's aviaries in Northamptonshire.]

\section{GREY LAG GOOSE. \\ Anser cinereus (Meyer).}

Winter visitant, of uncommon occurrence.

The earliest allusion to the Wild Goose in Yorkshire is found in the Cottonian MS., circi I604, and though the writer of that day may rot have been able to discriminate 
between the various species, the legend he mentioned doubtless referred to Wild Geese in general, and may therefore be accepted as the first reference to the bird under notice.

We are told that :-

"Not farre from Whitby is a peice of grounde called Whitby stronde, over when the inhabitantes affyrme that noe wildgoose can flye; yf the reporte be as true as yt is oulde, there must needes be some secret antipathie betwene the ayre of that place and that kinde of fowle; if yt be a tale I wonder much that soe palpable a lye shoulde, from many adges, be nurished by many men of worthe, whom yt ill beseemeth to give vent to such base ware." (Cott. MS. p. 30.)

Camden told of this supposition, the reason for which was ascribed to the great sanctity of St. Hilda, the Patroness of Whitby; hence the rhyme:-

"If the Wild Goose lights in Whitby Strand,

The least bairn that is may take her up in his hand ";

and Sir Walter Scott also took notice of the old fable, thus :-

"Then Whitby's nuns exulting told,

... how sea-fowls' pinions fail,

As over Whitby's towers they sail,

And, sinking down, with fluttering faint,

They do their homage to the saint."

(Marmion, Canto 2, Stanza xiii.)

Thomas Allis, in 1844 , wrote:-

Anser ferus.-Grey-lagged Goose-A specimen was killed last spring near Doncaster and is now in the possession of Hugh Reid; it is obtained about Sheffield; it is rare near York; F. O. Morris says it is common in hard winters; not common about Barnsley ; common, according to H. Denny, at Walton Park. Arthur Strickland says - I have never met with this bird in this county in my life, though it may have been here formerly, or have been overlooked. It is quite a mistake to suppose the name meant Grey Legged Goose, as some have suggested. The fowlers on the Carrs formerly distinguished two kinds of Goose frequenting them, the Grey Lag and the Carr Lag; which the Carr Lag was I cannot now determine."

The Grey Lag Goose, from which our farmyard fowl is descended, was formerly indigenous to Yorkshire, breeding in the "Carrs" and low lying portions of the East and North 
Ridings, and is associated in the minds of Yorkshire ornithologists with the days when the Bittern's "boom" was no uncommon sound, and the Spoonbill and other species (now extinct as nesters), were to be found in the county. The first mention of this species nesting in Yorkshire is found in a communication from the celebrated Dr. Martin Lister of York, a friend and correspondent of John Ray, who described what he supposed to be the Grey Lag, and stated that it was found "nesting in the marshes of the county of York." His account as to its nesting is as follows:-In paludibus agri Eboracensis nidificant: ipsi \& eorum Pulli mense Maio pinguescunt \& in deliciis habentur" ("Syn. Meth. Av." I7I3, p. I38.) (Although there is no doubt it was the Grey Lag which formerly bred in the Carrs, Dr. Lister's description applies to the Pink-footed Goose, which see for further details, p. 4I6.)

In Hatfield's "Historical Notices of Doncaster" (I866, p. 23), it is stated that " the Grey Lag formerly visited the decoy at Potteric Carr in immense multitudes" ; Arthur Strickland (in Allis's Report) also referred to it; and Charles Waterton, in I840, mentioned it as not uncommon at Walton Park; but, owing to improvements in drainage, increase of population, and the advance of civilization, it has long since been banished, and this fine bird is now but a casual visitant to its ancient haunts.

In the autumn and winter long skeins of "Grey Geese" may be seen passing over different parts of the county, but it is impossible to determine the exact species without examination of specimens, and, though it is probable that many of these reported Grey Geese may be veritable Grey Lags, we can only deal with the individuals whose identity has been actually verified.

Its distribution is of a very uncertain character, and the bird now chiefly occurs in the neighbourhood of sheets of water as at Fewston, Malham, on the rivers Nidd and Wharfe, a.t Masham (where the late James Carter shot two several years ago), and similar localities. It is rare in East Yorkshire ; Mr. M. Bailey has informed me that one Good Friday, many 
ycars ago, he saw, in a field near Flamborough, a large flock of Grey Lags, and secured two of them, one of which contained a perfectly formed egg. At Scampston one came to Mr. St. Quintin's semi-wild birds at Christmas 1885 , and remained on the lake for several days. In the North Riding Mr. T. Whitwell, gamekeeper, and his father, each killed a specimen on Lord Faversham's Bransdale estate; a local example is in the Whitby Museum ; and I identified a solitary individual at Redcar on 25th February I89I, when a fisherman caught a wounded bird and brought it ashore in his boat.

The Grey Lag will breed in captivity if suitable surroundings are provided, as is proved in the case of Mr. W. H. St. Quintin's birds at Scampston, where they have repeatedly bred, and have also mated with the White-fronted species (St. Quintin MS. ; and Ficld, rgth July Ig02).

An old superstition connected with Wildgeese may appropriately be referred to here, for the term "Gabriel Hounds " was formerly applied to the flocks of yelping IVildgeese migrating southward in twilight evenings of autumn, their cry being more audible than the assemblage is visible. As they were supposed to be foreboders of evil, betokening death in the house near which the sound was heard, or to some friend or connection, the hearers closed their ears and covered their eyes until the phalanx passed over.

\section{WHITE-FRONTED GOOSE.}

\section{Anser albifrons (Scopoli).}

Winter visitant, of uncommon occurrence.

Thomas Allis has, so far as I can ascertain, the claim to have first mentioned the White-fronted Goose in this county, in his Report of I844, thus :-

Anser albifrons. - White-fronted Goose-Is obtained near Sheffield; also at Doncaster in severe weather; occasionally about Sutton-onDerwent; near York in considerable numbers; though by no means a regular visitant; Dr. Farrar has only met with a single specimen 
near Barnsley; H. Denny says it is not uncommon at Walton Park ; A. Strickland remarks that it is seldom found near Bridlington except in severe weather; a few stray birds or small flocks frequenting the streams and water sides, and not resorting to the open country along with the Bean Goose.

This Goose is but a casual visitant to Yorkshire in the winter, occurring irregularly and in small numbers, being more numerous in severe weather than in mild seasons.

It has been recorded several times from the Humber, where it is considered to be uncommon, though in the winter of I884-85 there were two or three small parties observed. A male specimen in the Burton Agnes collection is from the Beverley neighbourhood.

It has occurred at Flamborough; A. Strickland referred to its appearance at Bridlington (see Allis); it has been noted at Scarborough in December I8go; and J. Hogg, in his "Birds of N. W. Cleveland and S.E. Durham," mentioned it in his time as frequenting the Teesmouth in small flocks (Zool. I845, p. II78), though I have met with it on only one occasion at Redcar; on $27_{\text {th }}$ January 1884 , during a northwest gale with snow, when one was killed from a pond on the sand-hills. At the same time several other Geese were seen, presumably of this species.

The White-fronted Goose has been reported from several inland localities, notably East Cottingworth, where it occurs on the flooded waters of the Derwent; two were shot there in the winter of $1903-04$; it is recorded from the Carrs of Doncaster; at Selby, in I860; near Wakefield, between I847 and I856, and at Ackworth, where in the winter of I880-8I six were seen and one was obtained. At Wilstrop on the Nidd, two or three have been killed; one example is recorded in Wensleydale; whilst in Ribblesdale one was noted in January I8gr.

Mr. W. H. St. Quintin, in a communication to the Field (Igth July I902), reports an interesting instance of the nesting of a pair of these Geese in semi-captivity, which reared young in I900 and I902. Hybrids between this species and the Grey Lag have also been bred at Scampston.

The only name by which it is known, other than its common appellation, is the Laughing Goose. 


\section{LESSER WHITE-FRONTED GOOSE.}

\section{Anser erythropus (L).}

This bird breeds in the northern parts of Scandinavia, and is by some ornithologists admitted to be a separate species, whilst by others it is not considered as specifically distinct from $A$. albifrons.

The only Yorkshire example, of which I have any informa. tion, is a male specimen in the collection formed by the late Sir Henry Boynton at Burton Agnes, and which, according to the catalogue made by the owner, was " taken near York, several years ago."

\section{BEAN GOOSE.}

\section{Anser segetum ( $\mathcal{F} . F$. Gmelin).}

Winter visitant, in small numbers; appears in late September or early October, and departs in April or May.

Thomas Allis, in his oft-mentioned Report, I844, thus alluded to this bird :-

Anser segetum.-Bean Goose-Is met with near Sheffield and York: not uncommon at Killingbeck, near Leeds. Arthur Strickland remarks "This is one of the few species that do not seem to have diminished in numbers of late years, and from the immense flocks that now frequent the Wolds near here we might suppose they have increased of late by the introduction of clover crops which they principally feed upon. This species constantly frequents the open and higher country and never, I believe, resorts to the Carr or fen districts; their movements are very regular, arriving by early dawn of the morning to the open districts of the Wolds, principally to the clover stubble, where they remain till toward dusk in the evening, when they all simultaneously rise and wing their way in long strings to the sand-banks in the Humber, where they securely remain for the night." In one parish on the Wolds a few years ago a person was actually hired to keep the Wild Geese from the clover fields they fed upon.

Strickland's remarks, as quoted by Allis, unquestionably refer to the Pink-footed Goose, and he was also under an erroneous impression when discussing British Wild Geese 
in his Report to the British Association (I858), which is given at length in the article on $A$. brachyrhyncus, pp. 4I5 et seq, and which must be read in conjunction with this species. The confused ideas formerly existing in regard to these two forms of Grey Geese are now dispelled, thanks to the researches of our East Riding ornithologists.

The Bean Goose is a winter visitant, arriving in small numbers in late September and October, and departing in April or May. Compared with its Pink-footed congener it is a scarce bird, generally frequenting the low-lying Carrs and marshy districts of the East Riding, and occasionally the Humber estuary, in contradistinction to the habits of the Pink-foot which resorts to the high Wolds to feed and to the Humber banks to rest at night.

It is stated in Hatfield's " Historical Notices of Doncaster " (I866), to have been common on the Doncaster Carrs; the flooded lands adjoining the Derwent are also amongst its resorts; it is mentioned in Hogg's "Birds of Cleveland" (Zool. I845, p. II78); and in the North Riding generally it is occasionally taken and identified.

In the early part of the year I879 I obtained a male example, from a flock of fifteen flying over the Redcar sand-hills, which weighed eight pounds, and presents the true characteristics of $A$. segetum. Two others, killed in a stubble field at Deighton Manor, near Northallerton, by Mr. C. A. Emerson, are also of this form, and I have examined other specimens in the Cleveland district. It has been observed or reported at Scarborough, Whitby, Loftus, and in the North Riding dales, where large gaggles of "Grey Geese" are frequently seen passing over in autumn, but it is impossible to discriminate between the various species of this family at the distance they usually observe, and the reported occurrences of Grey Lag, Pink-foot, or Bean Geese are not always verified.

In the West Riding this species has been noted in the Western Ainsty, and a few other localities, but is considered of rare occurrence. A pair of semi-domesticated birds, in the possession of Mr. W. H. St. Quintin, nested at Scampston n the year 1885 . 
It is scarcely within the province of this work to enter into the controversy which has recently taken place in reference to the different forms of Bean Goose differentiated by the specific names of $A$. segetum and $A$. arvensis. Yorkshire ornithologists are of opinion that the differences depend greatly on age and sex.* I append measurements and weights of three examples for purposes of comparison, and may remark that Nos. 2 and 3 might be referable to Strickland's A. paludosus, (?) arvensis (Brehm).

No. I. I Shot at Marske-by-the

Weight. Length of bill. Tarsus. Hiddle toe.

Sea, $x 7$ th November 1887 .. $6 \frac{1}{2} 1$ 1bs. $2 \frac{5}{8}$ in. 3 in.

No. 2. $\sigma$ Shot at East Cotting-

with, January I $903 \ldots . .9$ ths. $2 \frac{3}{4}$ in. 4 in. $3 \frac{1}{2}$ in.

No. 3. ? Shot at the same time

and place as No. $2 \ldots \ldots .8$ ths. $2 \frac{1}{2}$ in. $3 \frac{1}{2}$ in. $3 \frac{1}{4}$ in.

The only local name is Gabriel's Hounds ( $N$. \& $Q$. I852, pp. 534, 596), which is of doubtful origin, and might be equally well applied to any other of the British common Wild Geese. See Grey Lag for folk-lore conected with Gabriel's Hounds.

\section{PINK-FOOTED GOOSE.}

\section{Anser brachyrhynchus (Baillon).}

Winter visitant. The common Wild Goose of the county ; abundant in east Yorkshire, where it annually makes its winter home, arriving with great regularity in the last week of September and leaving again about the end of April, the time of departure varying somewhat with the seasons.

The first mention of the Pink-footed Goose appears to have been made by that celebrated naturalist John Ray, who, in his 'Synopsis Methodica Avium,' published in I713, alluded

* Since this was written Mr. H. J. Pearson's work, "Three Summers in Russian Lapland," has appeared, and his remarks on this subject may be of interest as bearing out the above statement. See also Mr. W. Eagle Clarke's note on Strickland's Report (p. 420.) 
to the description of a species of Wild Goose which was reported to him, by the renowned Dr. Martin Lister of York, as nesting in the marshes of the county of York. Ray's account is as follows:- 'Rostrum $\dot{a}$ capite ad mediam fer $\dot{\varepsilon}$ partem nigrum, deinde subpurpureum, ipso etiam apice nigro: in superiore mandibula nonnisi unicus denticulorum ordo, atque idem simplex in inferiore; item huic lingua uno denticulorum ordine armatur. Pedes subpurpurei sive carnei coloris, ungues fere albidi, excepto medii digiti, qui ex majori parte nigricat. Pendet libras $7 \frac{1}{2}$ fere. In paludibus agri Eboracensis nidificant: ipsi \& eorum Pulli mense Maio pinguescunt, \& in deliciis habentur. Hactenus D. Lister, qui tamen hanc speciem ab Ansere fero vulgari nobis descripto diversam esse non fidentur affirmat, quoniam descriptiones in omnibus fere, excepto Rostri \& pedum colore, conveniunt.' ("Syn. Meth. Av." I7I3, p. I38.).*

The species which nested in Yorkshire was, of course, the Grey Lag, though Dr. Lister's description certainly refers to the Pink-footed Goose, and he must have taken it for granted that the specimen he described so well was of the same species as that which bred in the county, about which he possibly had little personal knowledge, and probably never saw an example.

Curiously enough Ray's statement seems to have been entirely overlooked and the vast flocks of migratory Grey Geese, which each winter came to this country with unfailing regularity, and were such a feature in the landscape of certain

* The beak from the top to about the middle part black, thence purplish, the tip (nail) itself also black: in the upper mandible there is but one row of small teeth, and in the lower one the same row is plain (? single); the tongue moreover is armed with one row of small teeth. The feet purplish or flesh-coloured, the claws almost white, except the middle toe, which for the larger part becomes black. It weighs almost $7 \frac{1}{2}$ tbs. They nest in the marshes of the county of York ; they, themselves, in the month of May become fat and are deemed delicacies. Thus far Dr. Lister, who, however, does not confidently state that this species described to us is different from the common Wild Goose, since the descriptions in almost everything, except the colour of the bill and feet, agree. 
districts on our Eastern seaboard, were believed to be Bean Geese (Anser segetum) the species last described, and were stated to be so in all works on ornithology. Such being the case, it may perhaps not be uninteresting to give a short résumé of the past and present status of the species in the county.

On the 8th January I839 the late Mr. Bartlett exhibited several specimens of Wild Geese at the evening meeting of the Zoological Society, which he believed to be new to British ornithology, and which he proposed to call the "Pink-footed Goose" from the colour of its legs and feet. He pointed out the characteristics of the species and where it differed from other members of the genus, and remarked that, although resembling the Bean Goose much in appearance, in the formation of its sternum it was more like the White-fronted Goose.

But although the Pink-footed Goose had been clearly established as a British bird, and specimens had from time to time been procured in various parts of the county, it seems never to have been suspected that the large flocks of Wild Geese frequenting Yorkshire were otherwise than Bean Geese.

Thomas Allis, in I844, reported:-

Anser phanicopus.-Pink-footed Goose-Occurs at Thorne Moor and York in winter. H. Reid has obtained three specimens in Doncaster Market in 1840. A. Strickland says "From information from a sporting friend I have reason to believe that the bird has been killed out of a flock of the Bean Goose, but I never met with it myself."

Then we find, twenty years after Mr. Bartlett's observations, a great authority on Yorkshire birds-the late Arthur Strickland of Bridlington, the friend and correspondent of Thomas Allis-reading a paper on British Wild Geese before the members of the British Association, strongly advocating the opinion that the Yorkshire Wild Geese were Bean Geese. Strickland's report is as follows :-

"Anas ferus or anser, never was a migratory species in this country, but permanently resided and bred in the Carrs of Yorkshire, and probably in the fens of Lincolnshire; but it has long since been banished from these places, but still 
breeds sparingly in the Western Islands of Scotland. This bird displays the same delicate pink colour in its bill when young, as the Bean Goose does in its legs, and which has erroneously been considered a distinct species, under the name of Pink-footed Goose.

"From time immemorial one of the features of the north and east of England has been the regular periodical appearance of countless flocks of Wild Geese which arrive about the end of harvest, and which received the name of Bean Goose as coming in the time of bean harvest, and when the bean stubbles were ready for them. This species is the only one that has any claim to the name of Bean Goose (or segetum), the only migratory species in this country, and the only abundant and common species we have. Unaccountable as the case may appear, this bird is not figured or characterized in any work of Natural History I am acquainted with, and is not mentioned in the works of Mr. Yarrell, Mr. Gould, or Morris, further than ascribing the habits of this bird to one given by these authors under the figure and description of an entirely different species under the erroneous name of segetum, or Bean Goose. Some years ago, Mr. Bartlett, struck with the difference between the geese he met with in the market and the descriptions and drawings given of the Bean Goose, was induced to constitute a new species under the name of Pinkfooted Goose; but this was an erroneous view of the matter, being in fact the young or immature bird of the true Bean Goose. This bird, the true segetum, or Bean Goose, or Shortbilled Goose, is distinguished by its short and strong bill, its depth at the base being nearly two-thirds of its length, and by its migratory habits, differing in that respect from all our other geese, arriving every autumn, spreading during the daytime over the stubbles and clover fields on the Wolds and other open districts, rising like clockwork in the evening, and winging its way in long strings to the sandbanks in the Humber, and other safe retreats for the night, returning as punctually in the morning to its feeding grounds. This bird differs from the Pink-footed Goose in being larger, having a stronger bill and lighter plumage; but these differences are the result of 
age, and not of species, and due examination will confirm this. The next bird to be considered is the Long-billed Goose, figured and described by Mr. Yarrell, Mr. Gould, and Mr. Morris under the name of segetum, or Bean Goose. This is distinguished by having the bill exactly twice the length of the depth at the base, a proportion quite different from the Short-billed Goose. Before the beginning of this century, when the Carrs of Yorkshire were the resort of countless numbers of wild-fowl, it was stated that there were two species of geese frequenting and breeding in the Carrs, known to the fowlers by the name of Carr Lag and Grey Lag. What the Grey Lag was is well known. The Carr Lag is not now easy to identify, but the author thinks it was this Long-billed Goose, a bird that resided and bred in the Carrs along with the Grey Lag, and like that bird is no longer to be found in these districts, and now one of the scarcest British birds, or almost a lost species. This bird is distinguished from the Bean Goose by its long bill, and its entirely different habits.

"The following is a list of the species :-

"Anas albifrons.-White-fronted Goose-Face white, bill flesh-coloured (Gould, No. 349); an occasional winter visitor in this country in small groups.

"Anas ferus, or anser.-Grey Lag Wild Goose-Breeds sparingly in this country, and is not a migratory species. Bill pink, nail white.

"Anas segetum.-Bean Goose-Short-billed or Migratory Goose. Bill short, strong, the depth of the base being nearly two-thirds of that of the length, pale red in the middle, black at the extremities, but varies much in the proportions of these colours. Old birds are as large and pale-coloured as a Grey Lag Goose. Pink-footed Goose, smaller bird, less, and darker ; the young of the last.

"Anas paludosus.-Carr Lag, or Long billed-Goose-Bill long and weak, being exactly twice the length of the depth at the base, being $2 \frac{3}{4} \mathrm{in}$. long and $I \frac{3}{8} \mathrm{in}$. deep at the base. Bill strongly toothed, a groove running the length of the lower mandible; colour same as last. (Gould, plate 348, but not 
the description ; not a migratory species)." (British Association Report, I858, pp. I3I-I32.).*

Notwithstanding that Strickland preferred to call the Wild Geese of Yorkshire 'Bean Geese,' yet he was careful to make it clear that his Bean Goose was not the Bean Goose of Yarrell, Gould, and Morris, and the Bean Goose of to-day. His descriptions and measurements of the beak, etc., show that his bird was in reality the Pink-footed Goose, hence his supposition that the Bean Goose derives its name from 'its coming in the time of bean harvest' rests on no foundation.

The belief in the Bean Goose being the common Wild Goose of the county was still held, and it was not until a quarter of a century after Strickland's paper was printed that the real identity of the bird was established.

In February I883, Mr. J. E. Harting, the editor of the Field newspaper, published an article on Grey Geese, in which it was stated that the Pink-footed Goose was nowhere to be found in any numbers except perhaps in the Hebrides. Mr. F. Boyes questioned this statement, and brought facts from his own observation and experience to prove that the Pinkfooted Goose was the common Wild Goose of the Yorkshire Wolds and the Humber basin. To this Mr. Harting replied "The statement that the Pink-footed Goose is the common Wild Goose of the Yorkshire Wolds is most interesting, and we should be glad if other correspondents would furnish information as to the particular species of Grey Geese which visit their respective districts in winter, etc." Numerous letters followed, and the result of the inquiry conclusively proved that the Pink-footed Goose, and not the Bean Goose, was, and is, the common migratory Grey Goose both of Yorkshire and also of Eastern England.

The distribution of the Pink-footed Goose in Yorkshire is confined almost entirely to the IVold district and the Hum-

* Mr. Eagle Clarke informs me that, according to Alpheraky's Monograph on the "Geese of Europe and Asia" (1905), Strickland's A. paludosus is probably the Yellow-billed Bean Goose, the Anser arvensis of Brehm, which is said to be a commoner visitor to Britain than the true Bean Goose, A. segetum. 
ber basin, though odd examples have occurred from time to time in various parts of the North and West Ridings; these instances, however, are far too numerous for mention in detail.

The Pink-footed Goose is readily distinguished from the Bean Goose by the colour of its legs, which in the latter are yellow, and also by its shorter beak, as well as by the lighter colour of the wing shoulders, they being blue as in the case of the Grey Lag Goose; but no mistake can be made in differentiating these two, the Grey Lag having a white nail at the tip of the beak, which in the Pink-foot is black. The pink colour of the legs varies in intensity in different individuals according to age, being often very light in the young birds, and dark in the old ones. There is also considerable difference in the weight of old and immature examples, the former occasionally scaling 8lbs., whilst the young ones sometimes do not weigh more than four.

The voice of the Pink-footed Goose is a single note "Ky-ack" "Ky-ack" often repeated, and it is the repetition of this note by so many voices which makes the gabble or gaggle of a flock of Wild Geese as they wing their figured flight across the sky.

The habits of this species have not changed since Strickland's day, and now, just as then, they may be seen each morning shortly after daybreak, in large and small flocks, skeins, and strings, winging their way to the high Wolds to feed on the scattered grain and young clover, while at dusk they rise with unfailing regularity and bend their course back again to the islands in the Humber, there to remain until the breaking of another day sets them in flight again to their accustomed feeding grounds inland. This habit of feeding by day and returning to the Humber to spend the night is as old as the hills, and has been noticed from time immemorial, while so regular is their first appearance on the Wolds that the old men have for generations fixed the date as the 25th September-"Weeton Fair Day"-i.e. Market Weighton.

Wild Geese are not now so numerous as in the old days before the caclosure of the Wolds, for then they were quite 
unapproachable except by the aid of a stalking horse; now they are subject to much persecution both by night and day; not that they have lost any of their wary nature, but advantage is taken of foggy weather, at which time they are not able to see their enemy hiding behind the fences on their feeding grounds on the Wolds, and they are shot in great numbers with large punt-guns on the Humber at night, Wild Geese not having good sight after dark.

Wild Geese, like most other birds, are subject to temporary alteration both of habits and location-a heavy fall of snow driving them completely off the Wolds by cutting off their food supplies, they then are compelled to stay in the Humber and paddle about the slob for a precarious living, when the puntgunners, seeing their chance, take heavy toll of their ranks. In hard frosts they sometimes come inland to tidal rivers, or other open water, and then usually fall victims to the gun.

A variety of the Pink-footed Goose in the Hull Museum is much darker in colour than the typical form, and has a black tail instead of a white one.

\section{SNOW GOOSE.}

\section{Chen hyperboreus (Pallas).}

Casual visitant from North America in winter, of extremely rare occurrence.

The only claim of this North American species to be admitted to the county list is on the strength of the reported occurrence of three examples seen near Beverley on I6th January I8gr, by Mr. Henry Sharp, a practical wildfowler. In recording the facts in the Field (24 January I89I), Mr. Sharp states that the birds were only about two hundred yards distant; and, on the editor of the paper in question suggesting that the observer might have mistaken Gannets for Snow Geese, he reiterated (Field, 7 th February), his opinion as to the identity of the species. 


\section{RED-BREASTED GOOSE.}

\section{Bernicla ruficollis (Pallas).}

Accidental visitant from northern Asia, of extremely rare occurrence.

Writing of this handsome Goose, Marmaduke Tunstall of Wycliffe-on-Tees observed: "Have a beautiful specimen of this scarce species . . . Shot in the severe frost in 1776 , near London. . . . Never heard, I think, but of two more seen in England. One was taken alive in this neighbourhood [Wycliffe], and is still living.-(P.S.-Was the property of a lady lately deceased.)-It is kept in a pond with some ducks of the wild breed, with which it is very sociable, but never produces any breed together, though there is one it particularly associates with and seems to be partial to. It is very tame and familiar." (Tunst. MS. I784, pp. 96, 97.) George Allan, later (Fox's "Synopsis," p. 2I2), referring to this specimen, quoted Latham's account in which there is an error as to the date of its capture, I766, instead of I776, and this error was repeated in 1844 by Thomas Allis, who wrote:-

Anser ruficollis,-Red-breasted Goose-W. Yarrell in his "British Birds" reports that one was captured alive in Yorkshire about I766. soon became tame, and was kept with some ducks in a pond; this is the only specimen I have noticed.

J. Hogg, in his "Catalogue of Birds of S.E. Durham and N.W. Cleveland" (Zool. I845, p. II78), stated that two of these birds were seen "of late years by the Tees." One was afterwards shot by Mr. J. Hikeley. I understand, however, that this record referred to the Durham side of the estuary.

\section{BERNACLE GOOSE.}

\section{Bernicla leucopsis (Bechstein).}

Winter visitant, of irregular occurrence on the coast; has occasionally been observed inland.

The earliest known reference to this Goose as a Yorkshire bird occurs in Willughby's " Ornithology" (I678, pp. 359, 360),

VOL. II. 
where it is stated that Mr. Jessop sent a specimen " out of Yorkshire." In Ray's correspondence is the letter accompanying the bird:- "Broomhall, 25th November x668. Mr. Jessop to Mr. Ray. Sir . . . I I have procured the skin of a great bird, which he that gave it me called a Scarfe; but I believe it will prove a Bernicle. The description of it I sent to Mr. Willughby. ... I am, etc., Fra Jessop." ("Ray's Corresp.," Ed. Lank. x848, p. 33.)

Thomas Allis, I844, wrote:-

Anser leucopsis.-Bernicle Goose-R. Leyland reports two being killed on Midgley Moor, 2nd September 1836; H. Reid says it is frequently shot near Doncaster in severe weather; taken occasionally near Huddersfield on the Marsden, Slaithwaite, Meltham, and Holmfirth Moors; occasionally met with near York; H. Denny reports it as rare near Leeds, but one was shot at Rigton in 1837 . A. Strickiand reports that it may at times be found on the sea shore during severe winter weather, on the extensive flats of the Humber during low tides.

The Bernacle is of rare and irregular occurrence in winter on the coast; it is met with occasionally on the Humber, where three were shot on Christmas Day 1875 , and in $\mathrm{r} 8 \mathrm{gr}$ Mr. L. West saw one at Brough in the higher portion of the estuary. It has also been obtained at long intervals in the neighbourhood of Bridlington and Flamborough; at the latter place Mr. M. Bailey told me he had only had two or three specimens to preserve. It has occurred at Filey; Scarborough, where it is described as rare; Robin Hood's Bay, and Loftus.

In Cleveland J. Hogg (Zool. I845, p. II78), mentioned it as " occasionally killed on the Tees, but a rare bird," and Morris recorded one procured from a flock of nine on Coatham Marsh on ist October I853. Geo. Mussell, however, informs me that fifty years ago it was by no means uncommon; about the year 1857 fourteen were killed at one shot at the Teesmouth, and the professional fowlers frequently obtained from four to ten birds in a day. It is now very rare, and I have noted it in two instances only:-on 28th September I883, I saw a flock of eleven which passed me on Coatham sands, and on xst October following I purchased a winged female from a fisherman who had caught it on the Tees sands, and which 
may have been one of the members of the flock I had previously observed.

The Bernacle has been found in inland localities, some of which are mentioned by Allis; it is noted in Fothergill's list ("Richmondshire," I823) ; Mr. E. R. Waite records it in the Western Ainsty (Nat. I89I, p. IOI); and it has been noticed also at Ackworth, Staveley, East Cottingworth, near York (where Snowdon Sleights, the veteran wild fowler, informs me he has procured several on the Derwent in different years), Slingsby, and Thirsk.

The individual mentioned as purchased by me in 1883 , was kept alive in a walled-in garden where it lived for nineteen years; during the early portion of its captivity it formed an attachment for a Sheld-Duck, and, in its latter years, had for its master a tame Raven, which kept it in complete subjection. This Goose fed readily on grass, but was very partial to corn steeped in water.

\section{BRENT GOOSE.}

\section{Bernicla brenta (Pallas).}

Winter visitant to the coast, common in some seasons. Occasionally occurs inland.

The earliest known British information with regard to the Brent Goose is found in Willughby's "Ornithology" (I678), under the head of "Rat or Road Goose-Brentus fortasse," where it is stated that:- "Mr. Johnson, who showed us this bird at Brignall, in Yorkshire, thus describes it [Here follows an accurate description of the Brent]. It is a very heedless fowl (contrary to the nature of other Geese), so that if a pack of them come into Tees, it is seldom one escapes away, for though they be often shot at, yet they only fly a little, and suffer the Gunner to come openly upon them." (Will. "Orn." I678, p. 36r.)

Thomas Allis, in I844, wrote :-

Anser brenta.-Brent Goose-Is met with at Sheffeld; is shot in 
hard winters near Doncaster; it is obtained occasionally near York, and occurs in the same localities as the preceding near Huddersfield, and is rare in the vicinity of Leeds. A. Strickland says this is not uncommonly met with in winter both at the sea side and inland, but never abundantly now in this country.

This, the smallest of the British Geese, is a winter visitant to the coast line, and was formerly very common in the estuaries of the Humber and Tees, where large quantities were killed by the professional fowlers. In Willughby's time we are told that the Tees gunners exacted heavy toll from their ranks, and from the diary of an old wildfowler, whom I have often seen at work, I find that in the season of I869 his bag of "Rhode Geese" amounted to sixty-five. At the present time it is not met with in the immense flocks which might have been seen in the first half of last century, though in some seasons it is fairly abundant if severe weather prevails about Christmastide. In January and February I879 it was very numerous at the Teesmouth, as also in February and March I886, and in the winter of I890-9I it was abundant in the Humber. Odd stragglers occasionally appear in September; I saw one as early as the I4th of that month in 1879 , and in 1877 one was observed on the 22nd, but, as a rule, the main body does not arrive till after Christmas. The flocks remain off the coast until March and then depart on their journey northward, some lingering until May or even as late as June, and in the first week of that month in I900 a flock of seventeen was noticed at the Teesmouth. During the prevalence of a severe northerly gale on 22nd December I894, large numbers of Brent, unable to remain at sea, were driven ashore and took refuge on Coatham sands. At most of the Yorkshire coast stations this species occurs sparingly, generally in severe weather.

Though essentially a bird of the tidal waters, the Brent is sometimes found inland; it is mentioned in Fothergill's list in Whitaker's "Richmondshire" (I823), and has been reported from the neighbourhood of Sheffield, Huddersfield, Wakefield, Leeds, the Wharfe and Nidd Valleys, and Fewston Reservoir, in the West Riding, while the late Hugh Reid 


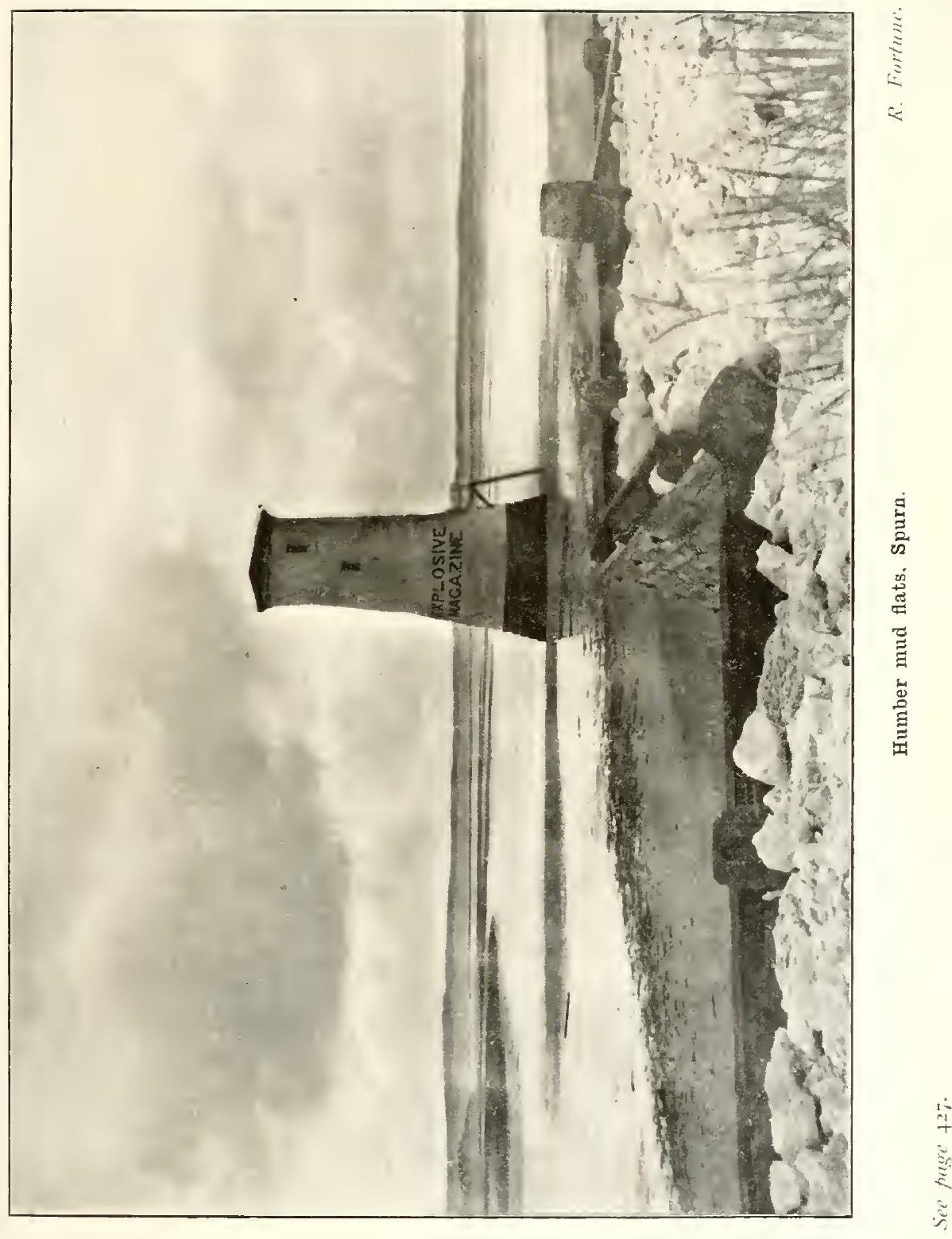



referred to it as a winter visitant to the Doncaster "Carrs." It has also occurred at Beverley, Thicket Priory, Strensall Common, near York (where a flock of twenty-eight was seen on I7th March I88I), Thirsk, Wensleydale, near Northallerton, and other places which it would be tedious to particularize.

Important and interesting evidence of the existence of the Brent in this county in pre-historic times is afforded by the discovery of fossil remains in Kirkdale Cave, the particulars of which are furnished by Mr. Lydekker in the Ibis (I89I, p. 390).

Both the white and dark-bellied forms occur in Yorkshire, the former variety being abundant in the Humber in the winter of I880-8I; I obtained a pair belonging to this form at the Teesmouth in 1879 ; an example of the small race, having very dark under parts, which I have seen, was taken at Deighton, near Northallerton, and is now in the possession of Mr. E. B. Emerson of Tollesby.

Mr. J. E. Harting informs me, on the authority of the late Dr. Gwyn Jeffreys, the eminent conchologist, that, in the stomach of a Brent Goose, shot on the Yorkshire coast, were found specimens of a mollusc (Crenella faber), the only known locality for which is the Sea of Ochotsk; thus proving that wild-fowl will travél enormous distances in a short time.

The local names are:-Black Goose in general use; Scotch Goose at Flamborough; Rock Goose on the Humber; and Road or Rhode Goose at the Teesmouth; the latter terms are given by Swainson in the variant forms Rat or Rott Goose, and Road or Rood Goose, and in "Notes and Queries," I5th December I855, the term "Gabriel Hounds" is applied to this species. (For folk-lore of Gabriel's Hounds, see Grey Lag.)

[The Canada Goose (Bernicla canadensis, L.) and the Egyptian Goose (Chenalopex agyptiaca, Gm.) have occurred in Yorkshire, but, as these species have been introduced, and are semi-domesticated, it is impossible to discriminate between "escapes" and feral birds.] 


\section{8 \\ WHOOPER SWAN. \\ Cygnus musicus (Bechstein).}

Winter visitant, irregular in numbers, which vary with the season. In severe weather large flocks occur.

Probably the earliest Yorkshire mention of the Whooper is in Fothergill's "British Ornithology" (I799, p. I0), where it is stated that "one or two were shot in the winter of 1798 near York."

Thomas Allis, in I844, wrote:-

Cygnus ferus. - Wild Swan-Shot near Doncaster in hard winters : rare near Sheffield; Dr. Farrar obtained one specimen in the severe winter of 1829 , at Storrs Mill, near Barnsley; several others were seen but escaped; occasionally met with about Leeds, also on the moors near Huddersfield; about Sutton-on-Derwent they are, in severe winters, occasionally abundant. I have heard of a flock of fifty being seen there; I have had a dozen through my hands in a single season, and have known upwards of twenty in a week exposed for sale in York.

This royal fowl is never altogether absent in any winter, though its numbers vary considerably in different years; it usually makes its appearance in severe weather, more frequently in January and February than at any other period, when frost and snow drive it from its resorts on the European Continent. The earliest date on which I have noted it at the Teesmouth is roth October 1876 , when a small flock of six was seen, from which one was obtained.

In some winters it is very numerous, such being the case in 1829 ; in 1838 ; in 1865 , on the Humber (when as many as a hundred were offered for sale one market day in York); in $187 \mathrm{I}$ in East Yorkshire; and in I894-95, when several were captured in a starved condition. In the winter of 1880 an immense herd passed the Teesmouth flying in a northwesterly direction; when the leading birds arrived on the Greatham shore, the rearmost portion of the herd was still at the Yorkshire side of the estuary, and it was computed at a rough calculation that the flight must have consisted of at least a thousand birds. 
The Whooper frequently occurs on inland waters; in February I86I, a party of six settled on the river Ure in Wensleydale; and one locality greatly favoured by its visits is the neighbourhood of Sutton-on-Derwent, especially when the low-lying lands around are flooded, while it is a frequent visitor to the river Hull, sometimes in large flocks in severe weather. In January I89I, ten Swans came to the lake at Scampston and remained for a few hours; then a day or two later two adults and one in grey plumage came into an inclosure, where grain was scattered for food, but they ignored it and tore up the grass edgings of the walks and swallowed the roots and blades. They left after four days, but returned three weeks later; the cygnet began to eat grain and became so tame that it was eventually snared with a salmon line; it was sent to Scotland, moulted a pure white, and apparently paired with another Whooper on the same water; they built several nests but no eggs were laid (St. Quintin MS.). At Harewood Park, the residence of Lord Harewood, the Whooper has several times bred in a semi-domesticated state during the past few years.

In addition to the names of Hooper and Whooper, this bird is occasionally called the Whistling Swan, and it is well known in East Yorkshire as "Elk."

\section{BEWICK'S SWAN.}

\section{Cygnus bewicki (Yarrell).}

Winter visitant, less frequent than the Whooper, though not uncommon in severe weather.

The first Yorkshire reference to this Swan appears to be made by Thomas Allis, in I844, thus:-

Cygnus bewicki.-Bewick's Swan-F. O. Morris reports one shot near Bawtry some years ago; it is occasionally obtained near York; a skeleton of a young bird is in the Museum at York; A. Strickland says "I have known several instances of its being killed in this neighbourhood [Bridlington] in severe weather, one of these is in my collection.' 
Though not so abundant as the preceding species, Bewick's Swan is met with in most seasons as a winter visitant, and under circumstances similar to those connected, or associated with the visits of its congener. It appears in some years in small numbers in the Tees and Humber estuaries, and in $\mathbf{I 8 6}$, in the latter locality, several small flocks were observed. In the winter of I870-7I two flocks, containing nine and twenty-two birds respectively, were seen on the river Hull, one specimen being examined by Mr. F. Boyes (Zool. I87 I, p. 2644). At the Teesmouth, in the winter of 1876 , an example, in my possession, was killed by a wildfowler in ambush, from a herd of about a dozen individuals which flew close over the shooter's head. Mr. Claude Pease obtained one on the sands at Marske, during a fog, in the winter of 1897 , and at other coast stations it occasionally occurs, but is, generally speaking, considered rare.

It is also met with on fresh water in various inland districts, as Sheffield, Skipton-on-Swale, Masham, and Beverley. A specimen in the York Museum was shot on Strensall Common in February 1879, from a herd of eleven, by Col. Hill ; in the neighbourhood of East Cottingwith this species has been recorded on several occasions since I849; Mr. F. W. Horsfall procured two there in December I902, and another was taken at the same place in the following March.

\section{MUTE SWAN. \\ Cygnus olor ( $\mathcal{F}, F$. Gmelin).}

A domesticated species, but wild individuals may occasionally occur on migration from Continental Europe.

Historically speaking, the Mute Swan is of great antiquity as a Yorkshire bird, for we find in the Selby Abbey accounts in $\mathrm{I} 43 \mathrm{I}-32$ it was mentioned; also at the marriage feast of the daughter of Sir John Neville of Chevet, near Wakefield, in 1526 , Swans were included in the good things provided; 
and in 1652 , in the household accounts of the Cliffords, is an entry of a Swanherd with his coat and badge; the cost of the same being returned as 23s. rod. (Whitaker's "Craven," 2nd Ed. I8I2, p. 32r.)

Thomas Allis, r844, wrote:-

Cygnus mansuetus.-Mute Swan-I have obtained a specimen of this bird from near Sutton-on-Derwent, the favourite locality of Ferus, it was nevertheless most probably an escaped bird from some gentleman's enclosure, or may have been the next species, of the existence of which I was not then aware.

Although this Swan is domesticated in the country, yet there are now many existing in a wild state on the European Continent, and it is quite possible some of those which are seen at large, especially in the neighbourhood of the coast, may be ferce nature. Examples of this species have occurred at various times and places, but in the majority of cases it is not possible to discriminate between "escapes" and wild birds.

[Polish Swan (Cygnus immutabilis, Yarrell).

Thomas Allis, r844, observed of this bird, which has no claim to specific rank:-

Cygnus immutabilis.-Polish Swan-Arthur Strickland writes "I have no doubt this bird has frequently been seen on this coast but has not been discriminated from the other species, most probably taken for the domestic Swan. On the I 3 th of this month (1844) a flock of pure white Swans was seen on the sea not far from the Pier at Bridlington; the circumstance of finding a flock of white Swans at this season immediately attracted my attention, as it was obvious they must be all old birds (a very unlikely circumstance), or they must be a family group of the changeless Swan; fortunately one was procured, and upon examination I have no doubt of the species; it had every appearance of a young bird, but if so could only be of this species, but it must be observed that without knowing the particulars of their plumage, it would have been at once considered the domestic Swan with the knob on the bill partly developed; the breast bone and windpipe were like that of the domestic Swan, not that of the Wild or the Bewick species."

In addition to the instance of this doubtful species referred to by Allis, one was reported by the late J. Harrison of 
Wilstrop, killed from a party of two or three in late autumn, about $I 860$; and five others are said to have been obtained at Scarborough in October 1890.

In the so-called Polish Swan, the young birds are white, but it is now considered by ornithologists to be a mere variety of $C$. olor as regards the plumage of the immature bird.

(See Saunders' “ Manual, 2nd Ed. p. 4I8; and the letters of Messrs. Saunders, Macpherson, Bartlett, and Southwell, Field, 25th August and Ist September I894.)]

\section{COMMON SHELD-DUCK.}

\section{Tadorna cornuta (S. G. Gmelin).}

Resident in limited numbers, its breeding quarters being confined to the Humber and Teesmouth districts. Large flocks of migrants observed in spring and autumn. Occasionally occurs inland.

The Rev. John Graves appears to have first mentioned the Sheld-Duck in connection with this county, in his "History of Cleveland" (I808), where it is enumerated amongst the resident birds.

Thomas Allis, in I844, wrote :-

Tadorna vulpanser.-Common Shieldrake-Has been shot near Doncaster, and is of rare occurrence near York, though small flocks occasionally appear about Sutton-on-Derwent ; I at one time obtained about half-a-dozen from that locality; W. Eddison remarks that the Shieldrake, Scaup, Shoveler, Wigeon, Pochard, Pintail, Golden-eye, Tufted Duck, Garganey, and Teal are all birds of passage, and are frequently shot as they rest on the large reservoirs on the wild moors near Huddersfield, particularly after stormy weather and adverse winds, or during long frosts, when keepers frequently shoot numbers of them, many of them rare and often beautiful specimens. A. Strickland says this bird used to, and still occasionally does, breed in rabbit burrows a little north of the banks of the Humber, to which place they take their young as soon as they are able to travel; a pair of young birds have been shot within the present month near Driffield; it is occasionally shot near Thirsk.

It is with great satisfaction that I am able to claim this handsome Duck as still resident in the county, though in but 
limited numbers, and confined to the Humber and Tees estuaries. A few years ago it was subject to much persecution at Spurn, and also suffered through being sometimes unintentionally caught in traps set in the rabbit burrows, the result being that it was almost banished as a nester from the district, but, owing to increased protection, it has now become re-established; it also breeds in the higher reaches of the Humber, and is said to have nested near the junction of the Trent and Ouse in 1900.

Formerly it used to make use of burrows on the sand-hills between Redcar and the Teesmouth, on what is now the Cleveland Golf Club course, and one or two pairs occasionally breed in the reclamation walls by the side of the estuary, where they find a secure home amongst the slag with which the walls are constructed, the nest being most difficult to discover; one was located in an iron water pipe fixed in a slag wall, and I knew of one in the year I883 with fifteen eggs, eleven of which were successfully hatched.

In addition to the Tees estuary, a pair sometimes resort to the sandhills between Redcar and Marske, the latest instance of which I am aware being in I902; the old Duck brought her young brood down to the sea when they were a few days old, and five of them were captured on the rocks near Redcar. A pair has been observed in the breeding season on the seabanks at Cattersty, near Skinningrove, where there is every reason to believe a nest was established.

A considerable accession to the numbers of the resident birds takes place in autumn, being composed of immigrants from more northern latitudes, many of which remain in the Tees estuary throughout the winter; at this period the bird occurs sparingly at most of the Yorkshire coast stations, and also in localities remote from the seaboard, being found on the rivers of the West Riding and the sheets of water on the high moorlands; it has also been noted in Wensleydale, Teesdale, and Ryedale; not infrequently near Sutton-onDerwent and East Cottingwith, Beverley, and other portions of the East and North Ridings.

In early spring a migration northward is observed, large 
flocks being then seen on the coast and in the estuaries; in the Fourth Migration Report is an entry to the effect that, on I3th January I882, a flock of three hundred was reported from the Tees Light Vessel, and I have frequently noticed parties of from thirty to upwards of a hundred individuals at the Teesmouth, which arrive in April, remain for several weeks, and then leave for their northern breeding quarters. The Sheld-Duck is included in the list of victims killed by flying against the Lighthouse at Spurn.

Of local names, Shell, Skell or Skell-Duck are in general use; and Sly or Burrough (? Burrow)-Duck were used by Tunstall (p. 99).

[Ruddy Sheld-Duck (Tadorna casarca, L.). The only instance of the occurrence in Yorkshire of this southern species is that mentioned in the "Handbook of Vertebrate Fauna of Yorkshire," p. 55, as " killed at Cottingham some years ago, and seen by Mr. H. B. Hewetson"; but the circumstances connected with this record are of so dubious a nature, that no reliance is to be placed on them.]

\section{MALLARD.}

\section{Anas boscas ( $L$.).}

Resident, local, abundant. Immense flights of migrants arrive in autumn, and become distributed over the county.

Historically, the connection of this bird with Yorkshire is of great antiquity, for we find that, in the ordinances issued by Royal proclamation as to the price of food in the City of York in the year I393, I6th Richard II, the Wild Duck was put down at $4 \mathrm{~d}$. ; the same sum was fixed as the value of a "Mallerde" at Hull in I560; at the great banquet at Cawood, in I466, four thousand Mallards and Teal were provided; it figures in the Northumberland Household Book (I5I2), the price being placed at $2 \mathrm{~d}$. ; and again at the marriage feast 
of Sir John Neville's daughter at Chevet, near Wakefield, in 1526 , when thirty dozen Mallards and Teal were priced at $£ 3$ IIs. 8d. ; while of its former abundance on the Carrs of Doncaster we find evidence in Hatfield's " Historical Notices of Doncaster," where we are informed that, in the winter of r692-93, no fewer than thirty-two pairs of Duck and Teal were killed on Hatfield Levels, in a single shot, by a fowler named Hill.

\section{Thomas Allis, in 1844, wrote:-}

Anas boschus.-The Wild Duck-Of rare occurrence near Halifax and Hebden Bridge; not uncommon about Barnsley; frequent in the vicinity of Sheffield and Doncaster ; it occurs near Huddersfield; is occasionally seen about Leeds ; it is common about York and breeds in several localities in the neighbourhood; it is met with at Pilmoor, near Thirsk. A. Strickland writes "In the year 1800 the Act for the Beverley and Barmston drainage was passed; in this Act compensation for the destruction of the two principal decoys in this country was provided for, and which necessarily took place soon after the drainage of the country: these were the decoys of Watton and Scorborough; two other decoys, those of Holme and Meaux, probably ceased to be used about this time also. I am informed that at the decoy of Watton only, which had a range of upwards of a thousand acres of water, nearly four hundred ducks have been known to have been taken in one day; we may imagine the change in these matters in a country where now only a few chance birds fall by the gun in the course of a winter."

The present status of the Mallard is that of a well-known, though local, resident, breeding in those parts of the county where marshes, moorlands, and rush-covered margins of streams, lakes, or reservoirs afford the necessary protection and seclusion for its nest. Many birds are also kept in a semi-domesticated state on ornamental waters of private estates, and "escapes" are frequently met with nesting in unusual situations, of which two only need be here referred to:--one, at Castle Howard, was found in a tree twenty-five feet above the ground, and the Rev. F. O. Morris recorded another on top of a stack at Nunburnholme. Some fifteen years ago a true wild bird nested and brought off her brood in a small patch of corn between the Cleveland Golf Links and the high road leading from Redcar, where hundreds of people passed daily within a few yards, and 
within half a mile of the old Coatham Decoy. It used to breed plentifully at Hornsea Mere, where as many as sixty drakes have been flushed in May, when the ducks were engaged either sitting or attending to their young; latterly the disturbance by boat-sailing reduced the numbers, though some still nest there and are now strictly protected.

In the autumn large quantities of foreign fowl arrive on the coast, and the species then becomes more generally diffused. As early as the third week of August I have observed flocks of Grey Duck, as they are locally termed, passing along shore, and, on the I7th of that month in the year I88I, several flights were noticed, of from two hundred to five hundred in each, off the Cleveland coast. They are also occasionally seen in September, though there is a possibility of these early birds being of local origin, for the main body does not, as a rule, put in an appearance until October or November. In some seasons the migration continues for days together, but it would be tedious to recapitulate all the "great rushes" of such a regular visitant. If the weather is fine when migration is progressing, the route taken lies a considerable distance out at sea, but in storms with on-shore gales, the flocks are compelled to hug the coast and so are brought under observation. On 3oth October I90o, during an easterly gale, the heaviest migration known for many years took place; and in the winter of I903-04 Mallard were exceptionally numerous about Christmas, as, owing to the disastrous effects of the wet autumn, the corn and bean crops were scattered on the ground, and great numbers of Duck resorted to the stubbles to feed, where they supplied excellent sport for flight-shooters. This bird figures in the list of "casualities" at the lanterns of our coast beacons.

A very remarkable incident occurred at Redcar in the winter of 1879 ; the sea, rising suddenly in the night, surprised a flock of Mallard resting on the water near the shore, when a heavy wave fell amongst them, stunning and washing ashore several birds, which were picked up in a dazed condition on the sands next morning. About the year I850, as I have been told by an old fisherman, a similar event happened, 
but on a much larger scale, nearly a hundred ducks being then captured.

The Wild Duck is subject to much variation in plumage, Yorkshire examples being not uncommonly reported. Snowden Sleights, the veteran wildfowler of East Cottingwith, told me he had shot two pure white birds; a specimen, nearly all white, with yellow bill, feet, and legs, was obtained from a flock of seven ordinary Duck at Stainsacre, near Whitby, on IIth February I897; various other instances are communicated of pied or parti-coloured individuals, and an example with yellow neck and breast was shot, during the evening flight, at Redcar, on I7th January I905. A duck assuming drake's plumage was recorded by Mr. F. Boyes in 1878 . Hybrids between this species and other ducks are also met with. A cross between the Mallard and Pintail was recorded at Moreby, near York, and exhibited before the York Naturalists' Club on 5th December I849, while a similar hybrid, believed to be a true feral bird, was killed by Mr. W. H. St. Quintin from some wild Mallard (Field, I7th November I900).

As to local names:-Grey Drake or Grey Duck is the common term amongst coast-shooters.

\section{DECOYS \\ Past and Present.}

In former years most of the "Carrs" and levels of Holderness and the south-eastern portion of Yorkshire, before their drainage and reclamation from a state of nature, were frequented by enormous numbers of fowl which not only bred there annually, but these fastnesses afforded a suitable home for vast hordes of Duck from northern Europe. The introduction of duck decoying into this country was intimately associated with the drainage and reclamation of these fenlands, and the first in England to receive practical attention at the hands of the reclaimer were those of south-eastern Yorkshire, 
known as Hatfield Chase. This work was undertaken in the year 1626 by Cornelius Vermuyden, a Dutch engineer, who employed almost exclusively Dutch workmen. On the completion of the work Sir Cornelius, for he received the honour of knighthood, was rewarded, along with his partners in the undertaking, which cost them, it is said, $£ 400,000$, a grant of 25,000 acres of the reclaimed land. Here he settled down, along with a numerous following of his countrymen, and thus a very considerable Dutch element was imported into, and colonised, this part of Yorkshire. Here in all likelihood they constructed the earliest British Decoys. Indeed, the most ancient decoy, of which any reliable information has been preserved, is that erected at Doncaster in the year 1657 , made, no doubt, in imitation of those which probably then existed on the neighbouring levels of Hatfield.

Regarding the suitability of the district for the successful working of the old Doncaster Decoy, it may be remarked that on the southern confines of this ancient borough there existed, up to the closing years of the eighteenth century, a compact and unbroken expanse of carr land, covering no less an area than 4,000 acres, and known as Potterick Carr. Fortunately there is handed down an excellent-perhaps a historicdescription of the Carr in its primordial state, made in July I762, by so distinguished a Yorkshireman as John Smeaton, the celebrated civil engineer, whose name will ever live in connection with the Eddystone Lighthouse. In his report to the Doncaster Corporation in that year Smeaton thus describes the place:- "Potterick Carr is a fenny piece of ground, containing, as appears by an old survey of Saxton's, about 2,300 acres. In its present state no brook or spring of any account discharges itself thereupon, so that it is affected only by the downfall waters which fall immediately thereon and from the higher grounds which border upon the same. These downfall waters, however, on account of the natural flatness of its surface, the imperfection of its present drains, and the want of a sufficient outfall to discharge them, generally overflow the whole, or greater part thereof, during the winter season, which waters are partly discharged by drains, and 
partly evaporated by the sun, so as in dry summers to be tolerably dry, as was the case when the present view thereof was taken."

Such a fen, it is manifest, must have been eminently suited for the successful practice of the decoymen's art. That vast numbers of various kinds of ducks bred there, and that still greater numbers sought its genial fastnesses in winter, is certain.

The decoy was situated in the centre of the Carr, and about a couple of miles from the town. It was approached, in its latter days at all events, by a specially constructed embankment, over three-quarters of a mile in length, known to this day as the "Decoy Bank." It embraced an extensive sheet of water, from which radiated six pipes, and was suitably planted. Circular in shape, it covered an area of 6a. 3r. 27p., and, in addition to being surrounded by a high embankment, it had an outer and wider encircling ditch.

With reference to the progress of this Decoy; all that is now to be learned concerning it is contained in the "Courtiers" of the Corporation, and from these the following facts may be gleaned :-

On 6th September I662, the Decoy was leased for twentyone years to Mr. Benjamin Marshall of Doncaster, at the annual rent of $£$ I5. The occupier evidently did not deliver up the Decoy in a satisfactory state, hence the following minute:- "June 20th I683, It was agreed by the Mayor, Aldermen, and Common Council, at a meeting, that $\mathrm{Mr}$. Marshall shall pay unto the Corporation towards the repairs of the Decoy thirty pounds. Mr. John Maddox, a member of the Corporation, was the next occupier of the Decoy from the 3oth of May I684, for seven years, at a rent of $f_{\mathrm{I} 2}$, and on condition that he furnish the several Mayors, during their term of office, with twelve couple of ducks annually when demanded. On July 3Ist I695, it was ordered that the Decoy, now to let, shall be let to any freeman of the body of the Corporation, forty shillings a year thereupon than to any other person. It was agreed that every person shall stand to the rent he shall bid for the Decoy, or he shall forfeit three 
pounds for the use of the Corporation. And further agreed that whosoever shall farm the said Decoy shall take no part nor accept a Corporation man or a freeman."

The results of these regulations do not appear in the data at disposal; but, on Ist July I707, the Decoy was entered upon by Mr. Roger Gough, at a rental of $£ 3$, and under covenant to leave the Decoy in working condition for taking fowl, and to grind his corn at the Doncaster Mills. On 28th May I7I4, Mr. Gough was required to "make the Decoy good and justified by the Corporation."

At the end of Mr. Gough's tenure the following entry appears:- "November 27th I727. Ordered that the Decoy and the bank leading thereto be let by the Corporation for the term of thirty-one years to such person or persons as will take the same, and make the said Decoy a good and perfect Decoy for the taking of fowl, and to leave the same, with all the nets and other things the same to belonging, paying the rent of ten shillings."

"January Ioth I728. Ordered that a lease be drawn from the Corporation to Mr. Recorder (George Bagshaw, Esq.), and several other gentlemen, of the Decoy and the bank leading thereunto, according to an order of the Corporation, made the 27th of November last, to commence from Lady Day next."

Lord Galway must have been one of the other gentlemen alluded to in the above resolution, for soon after the Decoy was let to the first Lord Viscount Galway, a local magnate, residing at Hodroyd, and a relative of the Marquess of Granby, who also resided in the neighbourhood-hence the following minute :-

" $25^{\text {th }}$ September I729. The lease from the Corporation to the Lord Viscount Galway and others of the Decoy having been engrossed and this day read, was by the order of the Corporation sealed with their common seal."

Lord Galway died in $175 \mathrm{I}$.

Finally, in I772, during the Nayoralty of Mr. Richard Kent, it is noted that "the Decoy was repaired and the walks improved."

The date was now rapidly approaching that was to terminate 
the career of this interesting place by drainage and its inevitable concomitants. As long ago as 1616 , a decade before Vermuyden entered upon his agreement to reclaim the adjoining levels of Hatfield, the Doncaster Corporation was anxious to improve the Carrs adjacent to the town. It would appear that nothing material was done towards the attainment of the ends indicated for many years. In I762, however, Mr. John Smeaton was consulted as to the feasibility of carrying out this drainage. He inspected the Carrs, and reported hopefully to the Corporation in July 1762 , and an application was successfully made to Parliament in 1764 for their drainage and enclosure.

The drainage of the Carrs seems to have been regarded as a death-blow to the success of the Decoy; but the district must have abounded in wild-fowl for many years after the initial stages of reclamation had been commenced. The end, however, was foreshadowed as early as I765, when $\mathrm{Mr}$. Robert Hudson was requested by the Corporation to view and value the wood in the Decoy; and Hatfield (" Historical Notices of Doncaster"), tells us that the last decoyman was one William Fenton, who died in the year I794, and that all the pipes were in existence in 1778 . The occupation of the Decoy having evidently long since passed away, the site was planted in the year I805. In I830 the wood was valued at $£ 27$ per acre, and the land at $£ 22$, making a total of $£ 392$, so that it is due to the investors - the Corporation-to assume that the poor of Doncaster fared not amiss from this unique speculation in the annals of investments. But the site of the Doncaster Decoy was yet to witness a more important event in the record of the nation's progress than that already experienced from the comparative antiquated art of drainage. In the year 1849 the main line of the Great Northern Railway pierced almost the centre of this once zealously guarded sanctuary, occupying about two acres of its area. Thus to-day the traveller by this favourite route between the metropolis and the north is carried unconsciously through what were once the scared precincts of a classical, because the most time-honoured, British wild-fowl Decoy. 
An interesting entry in the diary of the Rev. Abraham De La Pryme supplies evidence as to the abundance of fowl in this neighbourhood in the seventeenth century; it is dated 20th November I697, and runs as follows:- "This day I have heard for a certain truth, and there are many that will give their oaths upon it, that Tho. Hill, fowler for Mr. Ramsden, did shoot thirty-two pair of duck and teal at one shot in the Levels (Hatfield) in I692-3" (Surtees Society Publications, Vol. liv. I869, p. I65).

Ancient Decoys existed at:-

$\begin{array}{ll}\text { Meaux, } & \text { Thorne (2), } \\ \text { Watton, } & \text { Goole (2), } \\ \text { Scorborough, } & \text { Escrick (2), } \\ \text { Holme-on-Spalding Moor, } & \text { Osgodby, } \\ \text { Sunk Island, } & \text { Birdsall, } \\ \text { Coatham, near Redcar.* }\end{array}$

Decoys now in use are two in number, at Hornby Castle and Thirkleby Park.

Of the ancient Decoys four ceased to exist between the years 1762 and 1800 . These were Meaux, Holme, Watton, and Scorborough. No records of their age are forthcoming, nor of the exact date when they were discontinued.

Neaux.-This Decoy stands at the edge of a large extent of low-lying land, and must in past days have been almost surrounded by marsh and water; it lies two and a half miles due east of Beverley, a mile and a half on the east side of the river Hull, and a mile north-west of the once famous abbey of Melsa or Meaux, so closely associated with Beverley Minster. It is also a mile west of the village of Meaux, and a mile and a half east north-east of Weel. Its decay as a successful Decoy would date from I763, for in that year (4th Geo. III) an Act was passed for draining the marshes in Holderness that surrounded Meaux, and several more recent Acts, such as the Beverley and Barmston Drainage Act of I798, still further

* The particulars relating to Meaux, Watton, Scorborough, and Holme are supplied by Mr. F. Boyes of Beverley, and those of the remainder are extracted from Sir R. Payne-Gallwey's excellent work on Duck Decoys, published by Van Voorst, I 886. 
destroyed the avocation of this and other Decoys by reclaiming from the wild fowl their old feeding grounds. The marshes or Carrs extended from Beverley to near Barmston and Bridlington, and comprised II,000 acres. The outline of the Meaux Decoy and its pipes was plainly visible some fifteen years ago. A plan of this Decoy shews a peculiarity in the west pipes, which turn towards each other like the arms of a pair of calipers. Another interesting feature consists in

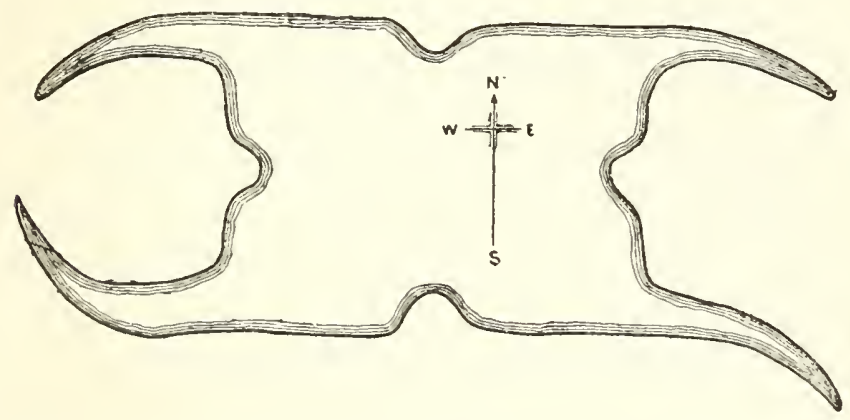

the small promontories in the centre of each side; their use is not quite clear, but they may have been const ucted to give the decoyman some slight advantage in driving the ducks nearer to the mouth of the pipes.*

Watton.-This Decoy was alluded to by A. Strickland, who remarked that it had an area of I,000 acres of marsh and water round it, and was very productive, yielding as many as four hundred ducks daily before drainage sealed its fate.

It is situate seven miles north of Beverley, between the high road from Beverley to Driffield and the river Hull, and, like Scorborough Decoy, from which it is distant four miles in a northerly direction, it also lies in the valley of the Hull river.

Scorborough.-This, like the Watton Decoy, was once very noted. It is situate two and a half miles N.N.E. of Beverley, on the west bank of the river Hull, and in the low-lying land between the river and the high road from

* See " Old Wild Duck Decoys of Lincolnshire and the East Riding of Yorkshire," by T. Audas. Trans. Hull Sci. and Field Nat. Club, vol. i. No. 3, I900, pp. 91-97 (with illustrations). 
Beverley to Driffield. The pool and pipes were visible about fifteen years ago, and the site was well chosen, for even now, when there is an overflow from the river (fo:merly an annual, now an occasional, occurrence), the duck resort to its vicinity in considerable numbers.

Holme Decoy was contemporary in its decay with those of Meaux, Watton, and Scorborough, and was placed on Spalding Moor, five or six miles S.W. by W. of Market Weighton. This district formerly comprised a large extent of wet moor and fen-land, and there are now several large ponds where wildfowl still assemble in severe weather; Allen, in his "History of Yorkshire" (I829), alluding to Spalding Moor, remarked that " People then living could recollect when this moor and its neighbourhood was one great morass, extending from Holme to Howden on the river Ouse, ten miles distant."

Sunk Island.-A Decoy was constructed here about the close of the seventeenth century, but, owing to its exposed position, neither trees nor underwood could be induced to grow round it for shelter, and consequently it was abandoned soon after it was completed (Allen's "Yorkshire," I829). This Decoy is referred to in Leland's "Itinerary" in a letter from the Rev. Francis Brokesly, according to whom "in I667 ... a Decoy was made upon the Island, which is plentifully stored with wildfowl, especially Ducks and Teal, but it turns to little account for want of trees, which will not grow well here, as the ground is too salt."

This Decoy was admirably placed, as the neighbouring estuary of the Humber was, and still is, the resort of immense congregations of fowl in hard weather. There is now no trace of the Decoy, though on some maps " Decoy Creek" is marked. Sunk Island is on the north bank of the Humber, twelve miles S.E. by E. from Hull. It was gradually reclaimed from the sea, and is now joined to the mainland, and comprises 7,000 acres of Crown land in a high state of cultivation.

Thorne WASte is four miles south of Goole, in the West Riding. There existed a productive Decoy here, north of the Keadby Canal on the moor some two miles west of Crowle which is just over the Lincolnshire border. There are no 
records of this Decoy, but in 1836 it was in full work; it ceased to be used about the year 1840 , as by that time a great portion of the moor had been drained. The Decoy was an acre in extent, and had three pipes as well as a Decoyman's hut close by. Its site is now almost indistinguishable, and is covered by small beech trees, but Mr. Henry Ellis of the Manor House, Crowle, informed Sir R. Payne-Gallwey in I885 that, knowing its exact position, and having seen it in opera. tion, he had no difficulty in finding it.

In the "History and Topography of the Isle of Axholme," by the Rev. W. B. Stonehouse (I839), the author remarked :"A small decoy yet lingers on part of the common, where wildfowl are occasionally taken, just sufficient to remind the modern sportsman what a diversion the ancient fowler found in these extreme and wild resorts of the feathered race."

NEw ZEALAND.--In I880 the late Mr. Durham, who owned a large part of Thorne Waste, partly constructed a small Decoy on a portion of the moor known as "New Zealand," near Thorne. It was never properly worked, and soon became out of order.

Goole Old Decoy.-A Decoy, that has not been worked since the early years of the past century, existed near the south bank of the Dutch River, near its junction with the Humber at Goole, six miles N.N.E. of Thorne, on a large extent of marsh, in those days known as Greenland. A farm, called the Decoy Farm, still marks its position, and a house close by the latter, at one time an inn, had for its sign "The Dog and Duck"-a name possibly suggested by the vicinity of the Decoy. Some few years back the shape of this Decoy was easily to be traced, but it is now grown up and lost to view.

Goole New Decoy.-Another Decoy, four miles west of the latter, is shewn on some maps, also on the south bank of the Dutch River. Being marked "New Decoy" it is probable it was started either in rivalry of the last mentioned, or else to take its place on Goole, soon after the commencement of the past century, increasing in size from a hamlet to a busy town.

ESCRICK PARK.-Seven miles south of York, the seat of Lord Wenlock. There were formerly two decoys here, one 
of which, made by old George Skelton, about I830, with four pipes, was used until the year I860. The formation of an island in the pool operated prejudicially, for fewer fowl were subsequently taken, and it was eventually abandoned. Of the other Decoy, situated in the Park, some two hundred yards only from the mansion, nothing now remains but a stagnant pool overgrown with rushes, no trace of the pipes being observable. Tradition, however, states that when in working order about 2,000 fowl were taken there in a season.

The more recent Decoy is to be easily traced, its form being compact, well-shaped, and planted. It is, however, though in the Park, within one hundred paces of a high road. The Decoy was made for the late Lord Wenlock, and the present owner of Escrick recollects seeing Ducks caught in it when a boy.

OsgodBy.-Three miles east of Selby, formerly the property of Mr. G. P. Dawson, but now belonging to Mr. Riley Briggs, possessed a Decoy which was last worked in 1877 . Situated at the north side of the Park, in the centre of the estate, it had four pipes, and some years ago answered very well, an average season producing 1,600 to 2,000 fowl. Mr. Briggs informed Sir Payne-Gallwey he had occasionally seen as many as I,500 birds on the pool at one time.

When in working order it was found that there were more Teal taken in the eastern pipe, and more Duck and Mallard in the south pipe, than in any other. In the best season of which any record has been preserved there were captured I,800 Duck and Mallard, besides 500 Teal and Wigeon; the last named began to discontinue their visits about 1867 . As many as eighty Duck have been taken in one pipe of this Decoy at a single drive.

Birdsall.-The site of a Decoy is shewn on old maps at Birdsall, near North Grimston, six miles S.S.E. of Malton. This was not a pipe Decoy. It was near Birdsall House, the seat of Lord Middleton, to whom the estate belongs, and who informed Sir R. Payne-Gallwey it was a trap or cage Decoy, and that it has long since been discontinued, and is now silted up.

CoATham, NEAR Redcar.-On the Kirkleatham estate, now owned by Mr. G. H. T. Newcomen, a Decoy was constructed 
on Coatham Marshes in I840, by the then owner, Mr. H. Vansittart. The area of ground enclosed was about three acres, with a pool of two acres, through which a "stell" or "fleet" runs, carrying surface water to the Teesmouth, being occasionally increased when the Marsh was flooded. The position of the Decoy is on the south of the railway near Tod Point, about 300 yards distant from, and opposite to, the Marsh Farm at the west end of the village of Warrenby. There were originally four pipes, which, however, were reduced to three, but only two were in regular use, each about fifty

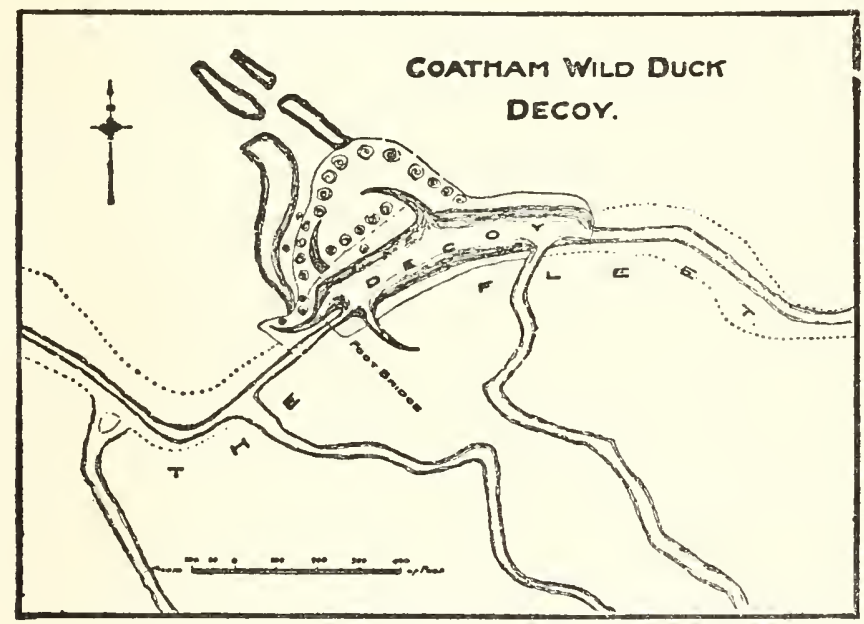

yards in length; that on the north side was the largest and best. For twenty-five years the Decoy was very productive, and many kinds of fowl were captured, including Sheld-Duck, Shoveler, Pintail, Mallard, Wigeon, Teal, Pochard, occasionally a Scaup, and once, in 1850 , a Ferruginous Duck. On the occasion nearly five hundred Ducks were enclosed in the net, which broke with their weight and all escaped but a hundred birds.*

* The information concerning this Decoy is compiled from recollections of old residents of Coatham, who assisted the Decoyman, Faith ; for the particulars of plans and measurements I am indebted to the late R. Lofthouse of Middlesbrough, who surveyed the site in 1887 . 
The Redcar fishermen and professional fowlers at that period were in the habit of stationing themselves on the sand-hills between the marshes and the sea to await the Ducks as they flew to and from the Decoy at evening and morning flight, and in stormy weather, when the birds were reluctant to leave the sanctuary of the pool, one of the gunners fired a marble into the Decoy in order to flush the birds and induce them to fly. The shooters in the other parts of the Tees estuary adopted the plan of concealing themselves in tubs sunk in the "slems," from which points of vantage they could carry on warfare against the wily fowl.

An illustration is here given, reproduced from a watercolour drawing painted by order of Mr. Vansittart in I850, shewing the Decoyman, Faith, in the act of taking the Ducks out of the tunnel net. In the year 1872 the erection of blast furnaces within a few hundred yards of the pool effectually destroyed the utility of the Coatham Decoy, which from that time fell into disuse. I have frequently visited the site when all that remained to indicate the previous condition were a few stunted trees and bushes, the relics of the shrubbery that sheltered the pool from the north, and stumps of posts to which the hoops spanning the pipes had been fixed. Even these have now disappeared and the pipes are scarcely discernible.

On the summit of Yearby Bank, four miles south of Redcar, and one mile from Kirkleatham, also on Mr. Newcomen's estate, is a marshy pond, almost grown up with vegetation, and surrounded by trees, called the Old Decoy, but no records exist as to its origin, or whether it was ever in actual operation.

Of the two Decoys now in use one is at Hornby Castle, and the other at Thirkleby Park.

Hornby.- In the park at Hornby Castle, five miles north-west of Bedale, are two Decoy Ponds, one disused, and the other, until I885, the only example of a Decoy in use in the county. The original Decoy was constructed for the seventh Duke of Leeds, in I854. It is seven acres in extent, and has the remains of four pipes. In I882, the present Duke moved the materials of the pipes from the old Decoy 


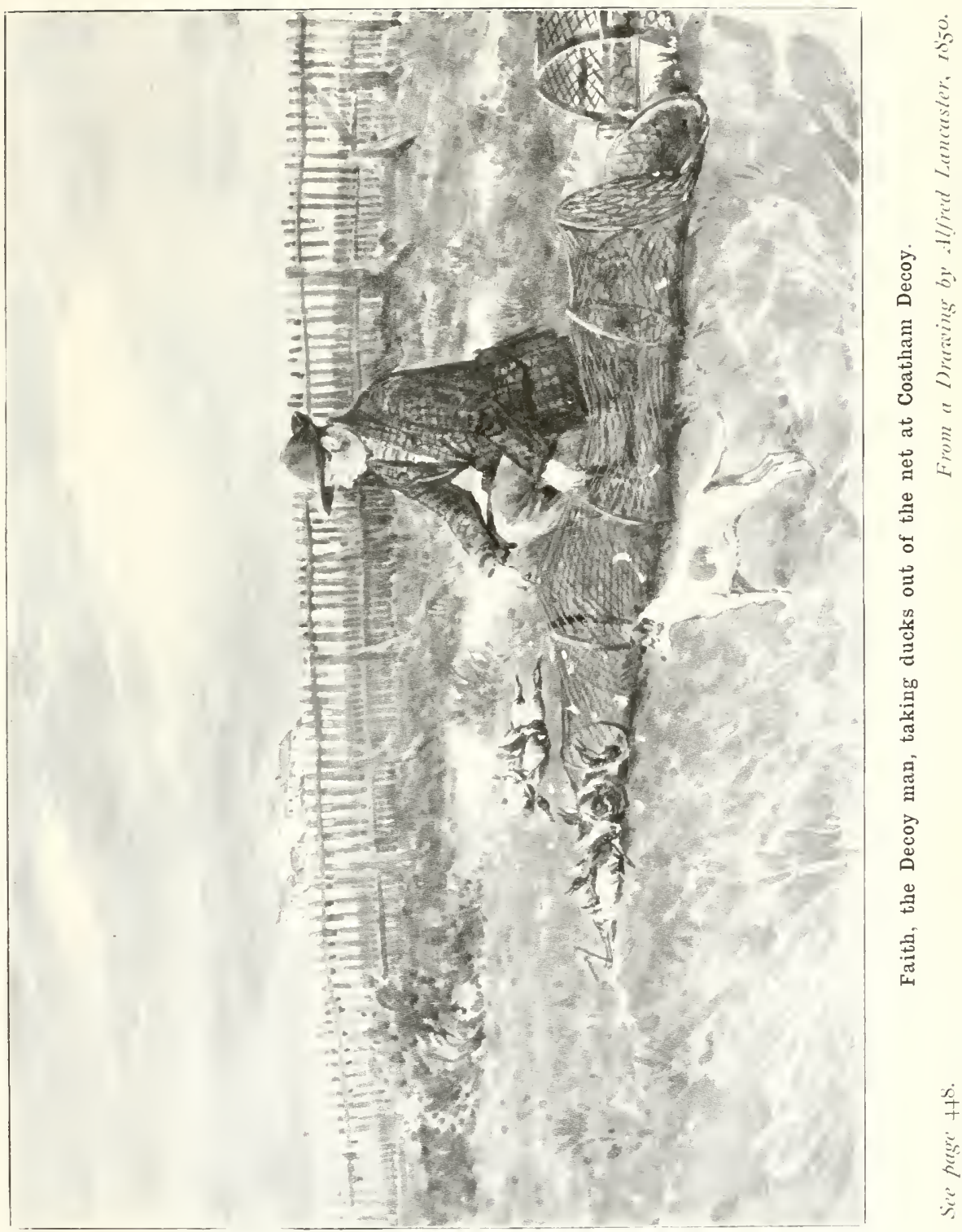



to their new position. The original Decoy is situated south of the Castle, between the Stone Pond and the present Decoy, which is now in the Blessington plantation close by.

The new pipes were excavated under the direction of Lord Fitzhardinge's Decoyman, from Berkeley Castle. The new pool is about sixty yards square, and the pipes are at the corners. The old Decoy was found to be too large, the fowl keeping out of reach of the pipes and of the Decoyman. The new Decoy, being much smaller, is more easily managed. The first pipe made at Hornby on the old Decoy was made by Harrison, Captain Healey's Decoyman at Ashby in Lincolnshire. Soon after T. Gilbert Skelton made another at the north-west angle of the lake, and lastly old George Skelton (junior) and the Rev. M. Fountaine added a third and fourth in I856. Finally, in I882 as stated, the present Duke of Leeds removed the netting, screens, and hoops to the new Decoy hard by, and completed it with four pipes.

This Decoy averages from 300 to 400 Ducks per season, chiefly Mallard and Teal. On one occasion only has I,00o birds been exceeded, in that instance some $\mathrm{I}, 500$ were taken by the Decoyman, Barrett. Once 250 fowl were captured in a morning, and several times fifty to sixty Duck and Teal have been taken at a drive.

The Hornby Decoy, like the one at Osgodby, was constructed owing to the successes reported at Mr. Healey's Ashby Decoy, in Lincolnshire.

THIRkLeBY.-At Thirkleby Park, the residence of Sir Ralph Payne-Gallwey, Bart., three miles south of Thirsk, a Decoy was constructed in I885. It consists of an acre of water and has three pipes. 


\section{GADWALL.}

Anas strepera (L.).

Winter visitant, of rare occurrence.

This species nests in northern and central Europe, migrating in winter to Asia and Africa.

The first mention of it in Yorkshire is in Denny's Leeds Catalogue, I840, where it is stated that one occurred at Swillington, near Leeds.

Thomas Allis, I844, wrote:-

Tadorna strepera.-Gadwall-Often bought, according to F. O. Morris, in Doncaster Market ; query are they Yorkshire birds ? Hugh Reid of Doncaster says a pair were shot near there in the spring of this year, and are now in his possession; this does not appear like its being common there; it is quite a rare bird near York, but it is sometimes met with; has been obtained at Swillington, near Leeds, but is rare in that part. Arthur Strickland says "Notwithstanding the close attention to the Duck tribe, I have never met with an instance of this species being killed in this county."

The Gadwall is but a casual visitant in winter, having occurred on the following occasions :-

At Swillington, prior to $\mathrm{I} 840$, as mentioned above.

Mr. W. Backhouse had a specimen, on I8th February I843, from the Teesmouth (Zool. I846, p. I263).

In the spring of 1844 a pair was obtained at Doncaster (see Allis, above).

On the Humber, a pair was killed on Ioth March I85I (Morris, "Brit. Birds").

In the winter of $1856-57$, an example was captured on the Hornby Castle Decoy.

In Matthewman's Selby List (I858), one is mentioned.

Mr. Fred Boyes, writing to the Zoologist (I871, p. 2525), says a fine drake was shot on 3Ist January I87I, at Skerne, near Driffield, and passed into the possession of Mr. F. Hoare of Tranby Park.

At Helpholme, in Holderness, a male was reported in 1876 . A party of four females was seen near York, one being 
killed on I5th December I880, as recorded by Mr. T. M. Lambert in the Field (I5th January I88r).

Near Beverley, a pair, the female containing eggs the size of peas, occurred on the river Hull (N. F. Dobree, Nat. I882, p. I85).

A male and female in the Hull Museum are believed to be of local origin-the former from the Scorborough collection, while the latter was killed on the Humber in December I885.

At Lowthorpe, one was taken in the winter of I899.

A female example, in the York Museum, was killed at East Cottingwith in February $I 892$ ( $\mathrm{J}$. Backhouse, op. cit. I892, p, II6).

And lastly, in October 1896 , three were obtained by a punt-shooter at the Teesmouth; all of which I afterwards saw in the hands of Geo. Mussell of Middlesbrough.

At Thirkleby Park, the residence of Sir Ralph PayneGallwey, several young birds have been hatched, from eggs sent by Lord Walsingham, and kept in a semi-wild state.

\section{SHOVELER. \\ Spatula clypeata $(L)$.}

Spring and autumn migrant, and occasionally a winter visitant, but not numerous. Nests in one or two localities.

Perhaps the earliest reference to the Shoveler as a county species is in Fothergill's Wensleydale list, published in Whitaker's "Richmondshire" (I823), where it is enumerated amongst the birds noted in that district.

As a breeding species this bird is very locally distributed, but few places being at present known where it nests annually. Hornsea Mere was, on the authority of Mr. Henry Milner, mentioned by Hewitson in his "Eggs of British Birds " (I856, Vol. ii. p. 400), as being a breeding resort, and one of the keepers told Mr. F Boyes that he once found a nest prior to I88I. Since that date occasional pairs have nested on the mere, and it has frequently been observed there in the 
summer. In the North Riding, a nest was found in I866 at Marfield Pond, near Masham; in May I880, Messrs. Talbot, Ianson and Marsden recorded a nest with four eggs on Thorne Waste, in the extreme south of the county, close to the boundary at Crowle (Zool. I882, p. I75); at Kiveton Park it has bred and possibly does so annually; and at Temple Newsam the nest was reported in I897. In I896 a pair nested at a disused brickpond at Skipwith, but the young were, with the exception of three, taken by a pike. More recent information respecting its breeding shews that, on 2nd May I900, a nest with twelve eggs was discovered on Skipwith Common; and at Scampston a duck, captured in the winter of 1902 , has become naturalized and breeds there.

Generally speaking, the Shoveler is best known as a more or less rare visitor on the spring and autumn migrations and also in winter, occurring on reservoirs, large ponds, and slow flowing streams which suit the habits of this fresh water Duck. At the Tees estuary it is of fairly frequent occurrence in spring and autumn, mainly owing to the presence of a well protected breeding place in south-east Durham, the specimens met with in August and September being, without doubt, birds from the above locality. In September I877, I obtained one from a flock of nine on the Tees sands, and examples have at intervals been killed there and on the Coatham Marshes.

It appears to be on the increase in the East Riding, where it is a spring and autumn migrant in small numbers, and the neighbourhood of Beverley seems to be favoured by its occurrence, as the numerous records testify, while the individuals which have been reported in late April and May suggest a possibility of their breeding in the locality had they been unmolested. On the Derwent at East Cottingwith it is occasionally killed in winter.

It has occurred at various places in the North and West Ridings, other than those already mentioned, which it would be tedious to particularize. It is regularly taken in Hornby Castle Decoy.

The only local vernacular name by which it is known is Spoonbill, which is applied to it in the East and North Ridings. 


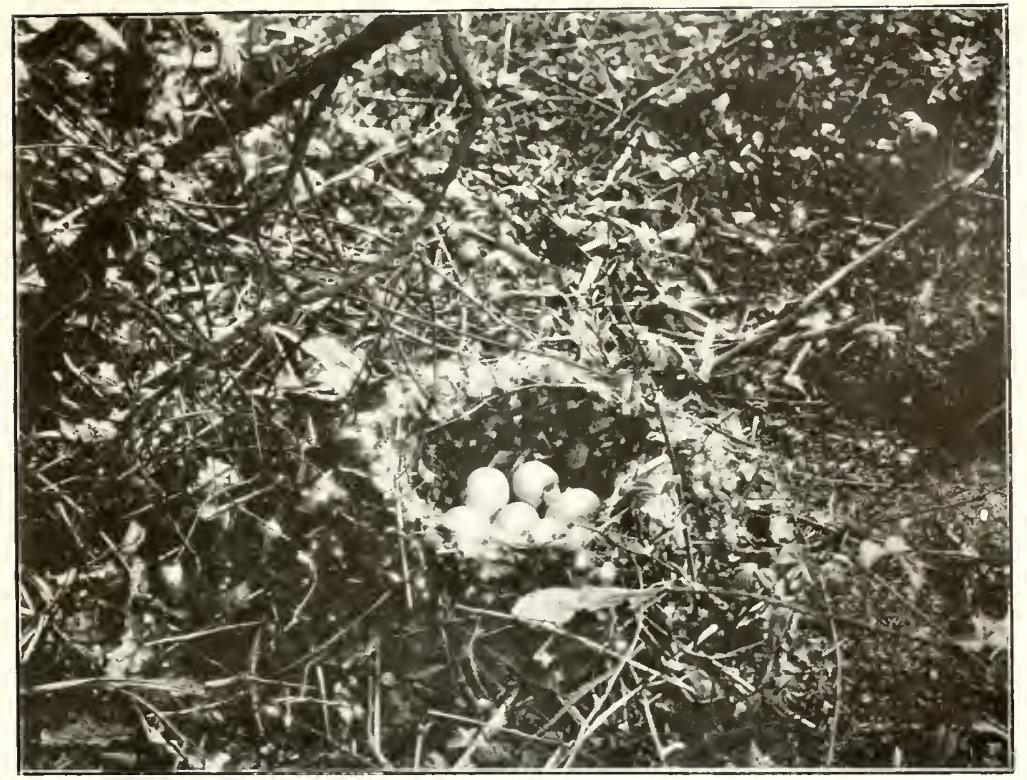

Wild Duck's nest, Harrogate.

R. Fortune.

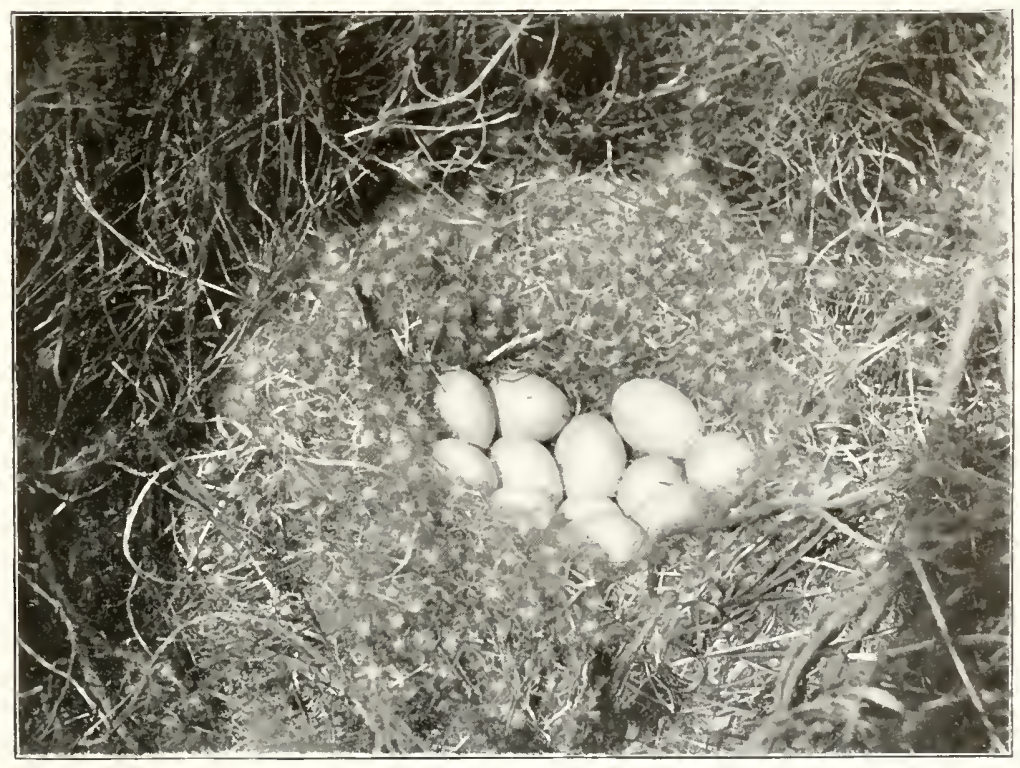

Nest of Shoveler, near York.

E. (i. Potter.

See page +52 . 
. 


\section{PINTAIL.}

\section{Dafila acuta $(L)$.}

Winter and spring visitant, not numerous. Rare inland.

The first notice of this duck in reference to Yorkshire appears to be made in Denny's Leeds Catalogue (I840), where it is stated to be rare.

Thomas Allis, in I844, wrote:-

Anas actuta.-Pintail Duck-H. Denny reports it as having been met with at Walton and Scarthingwell; it is sometimes obtained near York. A. Strickland says "This bird appears never to have been so abundant in this country in proportion to the rest of the tribe as it appears to be in the south of England, but it is occasionally met with in the winter.'

Half a century ago, the Pintail was a numerous species in the Tees, where, as Geo. Mussell tells me, it was greatly sought after by the professional gunners, who would not trouble with other fowl if they could get the Pintail, and, as it was most plentiful in May, and no restrictions were at that time placed upon shooting, great numbers of this delicious duck were procured and brought into market.

It is now, however, by no means abundant, occurring as a visitant, sparingly on the coast, from October onwards to spring. Two pairs remained on the warren pond at Kilnsea until 4th May in I88I, and an example in immature plumage was captured at Spurn on the I2th of the same month in I888. It is occasionally obtained in the Humber and at other coast stations, as Flamborough, Scarborough, Whitby, and the Teesmouth, and has been met with at various inland localities in addition to those referred to by Allis. It is perhaps needless to give these in detail, and it may suffice to mention a few of the reported instances of its occurrence. It is enumerated amongst the birds visiting Doncaster Carrs in Hugh Reid's time, and has been taken at Escrick and Hornby Decoys. It used to occur on the river Hull near Beverley pretty regularly in the late spring months, but is now seldom met with; it has been obtained at East Cotting- 
with, Pocklington, Moreby, Thornton near York, Malton, the Nidd Valley at Wilstrop and Newton Kyme, also at Allerton Park, near Halifax, and in Upper Ribblesdale.

Mr. W. H. St. Quintin informs me he shot a hybrid Pintail and Mallard some years ago, at Lowthorpe, from amongst Wild Ducks.

The only local names of which I am aware are Sea Pheasant, used in the East and North Ridings, and Pheasant Duck, which is sometimes applied to it in the Beverley neighbourhood.

\section{COMMON TEAL.}

Nettion crecca $(L$.$) .$

Resident, local. Also common winter visitant, the first arrivals taking place in August.

As a Yorkshire bird, the Teal can boast of remote ancestry, for we find, in the ordinances as to the price of victuals at York in I393, in the xvi. year of Richard II., the value of a Teal was placed at Id.

Thomas Allis, in I844, wrote:-

Anas crecca.-The Teal-Common near Doncaster, Sheffield, York, and Leeds; not uncommon near Barnsley during the winter months; occasionally they are found located with Wigeons on the Canal, and still more frequently on the open brooks with the Mallards. It is occasionally seen near Halifax in winter, as well as about Huddersfield ; it breeds on Strensall Common, near York, as I am informed by my friends Jas. and Wm. Tuke; it is met with very rarely near Hebden Bridge.

This pretty little duck may be described as a local resident, being recorded as breeding in limited numbers in several moorland or other secluded localities, amongst which may be enumerated Goole Moor and Thorne Waste (I889), Hemsworth Dam (I902), Riccal and Skipwith Commons (I88I), Strensall Common (I883), Pilmoor, Danby, and several other places in the Whitby and Cleveland districts, Allerton Park, Malham Tarn (commonly), Bashall Hall, Sedbergh 

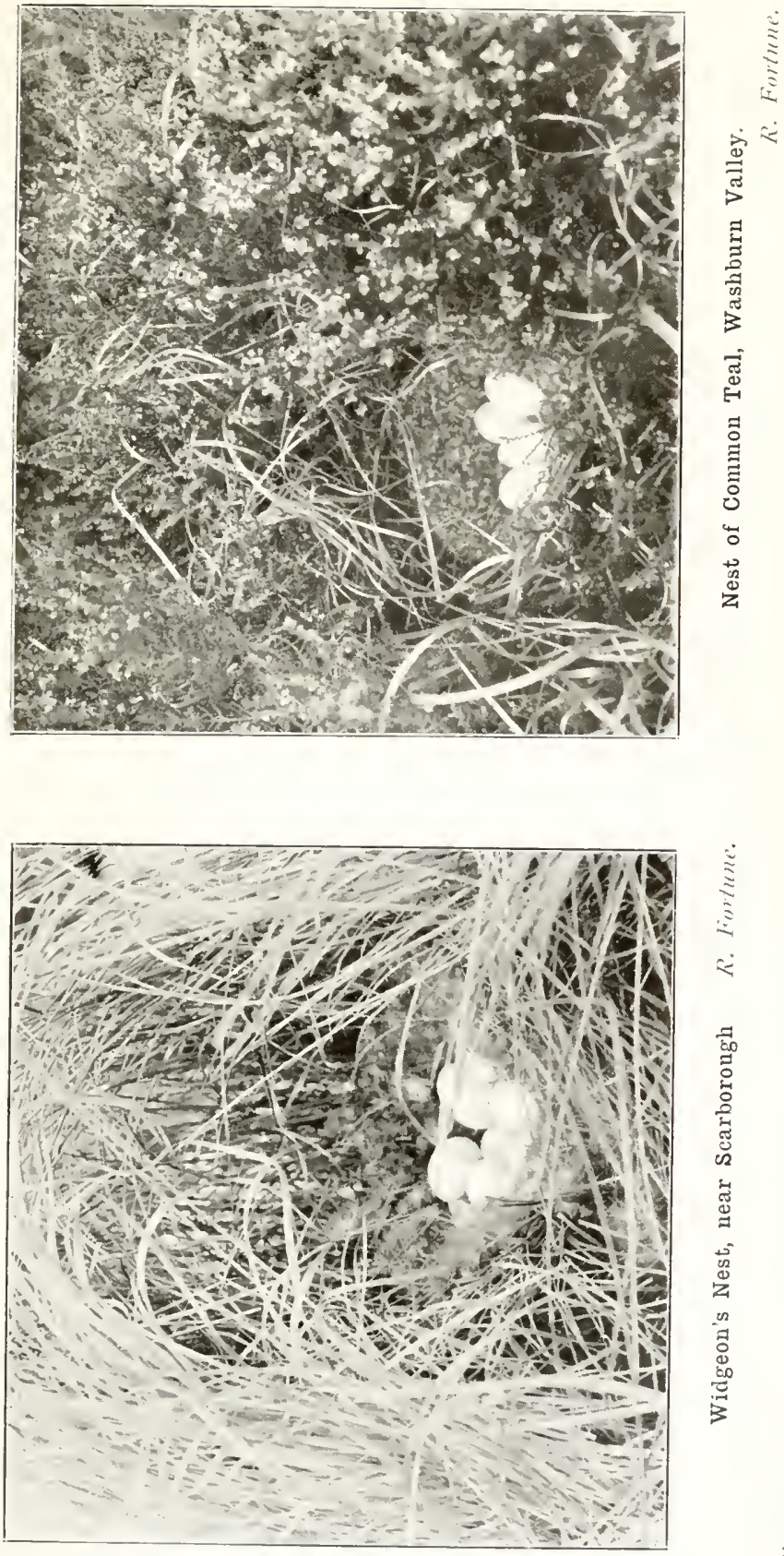

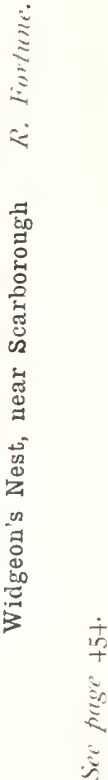



(rarely), Locker Tarn in Wensleydale (I893), Masham (occasionally), Swaledale, as high as Keld (I9OI), Arkengarthdale (in these two latter dales several pairs nest, and it is described as a more abundant resident than the Mallard); in Upper Teesdale it nests occasionally, and is recorded from Adel Moor, near Leeds, in 1876 (Leeds Nat. Club, July I876). In the Holderness district it is not considered as a frequent or regular nesting species.

Amongst the migratory waterfowl the Teal is the earliest in arrival, and is well known along the coast line as a common autumn and winter visitant, large flocks coming from oversea as early as August; I have noticed them at Redcar on the I6th of that month. Great flights occur in September and October, passing with other migrant fowl, which in winter become diffused over the country, being then found on most of the marshes, rivers, and sheets of fresh water. There is a return migration in March and April, and individuals have been seen as late as the 22nd of the latter month at the Teesmouth, though it is possible they may have been intending nesters on the marshes of the Durham side of the estuary. This duck has occasionally been killed by striking against the lanterns of our sea-beacons; Mr. M. Bailey shewed me a specimen in October I903, which was picked up under the Lighthouse on Flamborough Head.

Though it is to be feared that, both as a resident and also as an immigrant, this species is decreasing in numbers, there can be no doubt it was extremely numerous in former times, as may be gathered from the evidence contained in ancient documents; thus we find that, at the great banquet given at Cawood in I466, in honour of the Archbishop of York, amongst the provision made were 4,000 "Mallardes and Teales" ; in the Northumberland Household Book, begun in I5I2, at Earl Percy's Castles of Wressill and Lekinfield there appears "Item, it is thought good that no Teylles be bought bot if so be that other Wyldefowl cannot be gotten and to be at jd. a pece." Again, at the marriage feast of Sir John Neville's daughter at Chevet, near Wakefield, in I526, thirty dozen Mallards and Teals were priced at $£ 3$ IIs. 8d. In the

VOL. 11 . 
fourteenth century the value of wildfowl at York was fixed by law, the price of a "Teall" being $\mathrm{Id}$.; two centuries later at Hull, in I560, it was placed at 2d. (" Land and Water," I7th January I89I); while of the bird's abundance on the Doncaster Carrs we have authority in Hatfield's " Historical Notices of Doncaster" (I866), where we are told that thirtytwo pairs of Duck and Teal were killed at one shot, by a fowler named Hill, at Hatfield Levels, in the winter of I692-93. At Hornby Decoy, between I 856 and I864, two hundred and eleven Teal were taken in the nets; and from the diary of an old puntsman at the Teesmouth I have extracted some totals of his " bag," the greatest number of Teal killed on one day being twenty-three, in September 1863 .

\section{GREEN WINGED TEAL.}

Nettion carolinense ( $\mathcal{F} . F$. Gmelin).

Accidental visitant from North America, of extremely rare occurrence.

The only claim of this American species to be included in the Yorkshire list is on the strength of an example recorded by Mr. (afterwards Colonel) John Evans, in the Zoologist (1852, p. 3472), thus:- "I received a few weeks since from Scarborough, a specimen of the American Teal, in good plumage, which was killed near that place last November. I mention it because it is a bird of only recent occurrence in this country, not being mentioned in Yarrell's birds. . . . . John Evans, Darley Abbey, near Derby, April r852."

The specimen in question passed into the collection of the late Lord Hill, and further information respecting it is not now available. It may, however, be stated that other examples have occurred in England (cf. Saunders' "Manual," and Ed. p. 433). 


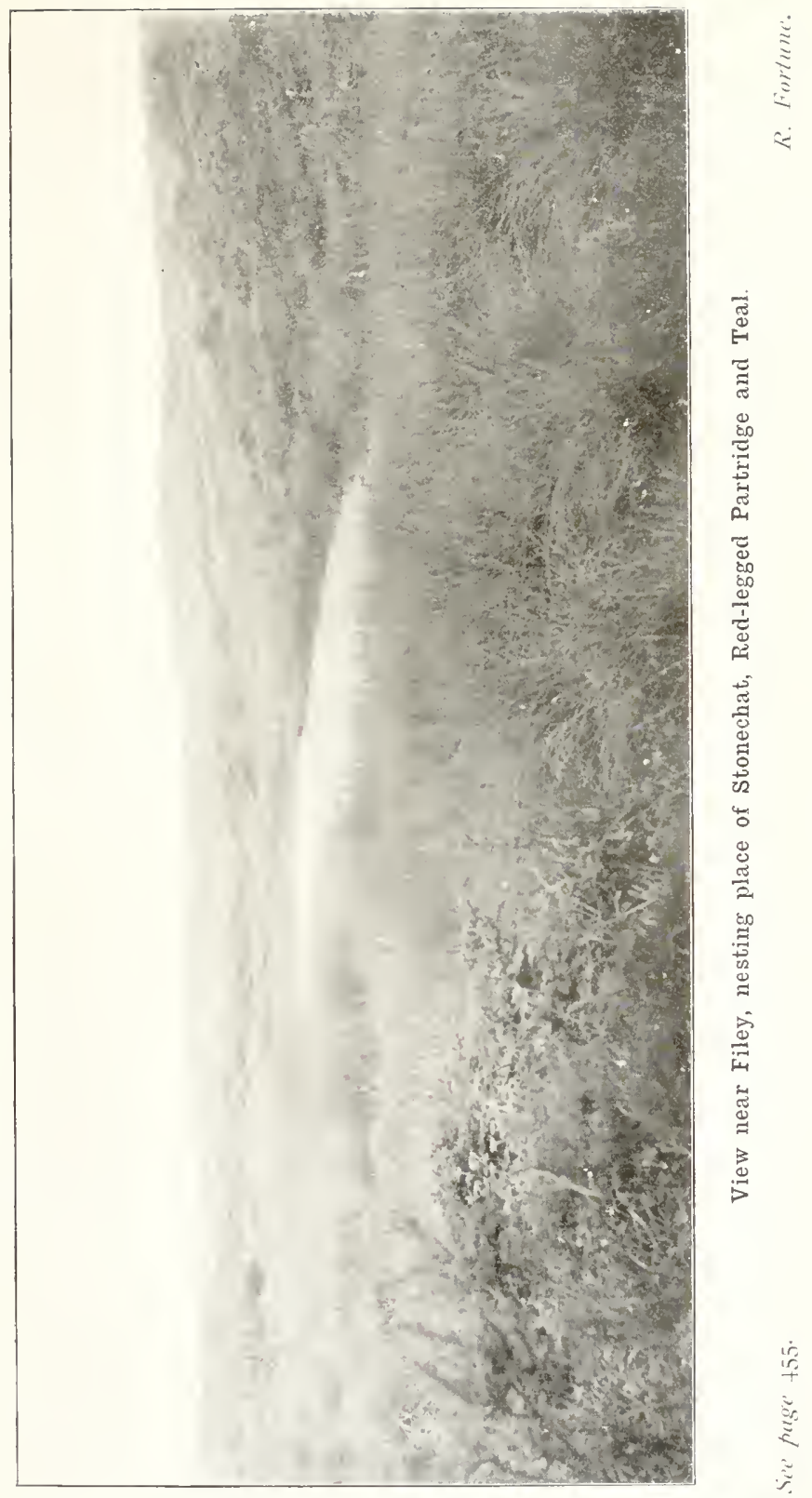





\section{GARGANEY. \\ Querquedula circia $(L)$.}

Bird of passage in spring and autumn. Has nested in east York shire.

The earliest published reference to this bird is found under the heading of "Summer Teal " in Willughby's " Ornithology" (1676, p. 378), where there is a description of the plumage, followed by the remark :- "This is the least of the Ducks. In its stomach dissected I found nothing but grass and stones. This description we owe to Mr. Johnson" [of Brignall, near Greta Bridge].

Thomas Allis, I844, wrote:-

Anas quevquedula.-The Garganey. Frequently shot near Doncaster in the spring; Dr. Farrar has met with but one specimen near Barnsley, which was shot in the low grounds at Bolton-upon-Dearne in $1828 ; R$. Leyland mentions a beautiful pair killed on the river near Elland many years ago ; it is rare near Leeds, but was obtained from the River Calder, near Copley Mill, in 1816; very rarely met with near York; A. Strickland says it is occasionally met with in winter, but is one of our rarest species.

The Garganey is a bird of passage in the spring and autumn, of rather rare occurrence, and has been known to nest in east Yorkshire in I882, where Mr. F. Boyes, in company with the late $J$. Swailes of Beverley, discovered the nest containing eight eggs, from which the female rose a few feet off. There is no doubt this species had bred on this ground for some years, as the young had several times been procured there in the early autumn, and adult birds, in full breeding plumage, had been shot on the river close by for a period extending over ten years. Mr. Richardson of Beverley has had many adult birds from the river Hull in the month of April, and a male, killed at Wilfholme, on the Ioth of that month in I882, is in the Hull Museum.

It also bred between I 880 and I 887 on the north side of the Teesmouth, which, though in Durham, is only separated from Yorkshire by the river, and stragglers from the Durham 
Marshes have, from time to time, occurred in this county; two specimens in my collection were killed in August I885.

The Garganey is of most frequent occurrence in east Yorkshire; Mr. M. Bailey informs me he has three records at Flamborough; two specimens in Mr. J. H. Gurney's collection were obtained at Bridlington on Ist and 2nd June I868, and in the Holderness district it has been met with on many occasions, more especially in spring, though a young male was taken at Easington on I9th September I892 (Nat. I893, p. 8).

At inland localities, in addition to those mentioned by Allis, it has been reported from Wensleydale (1823), Bedale (1870), Ilkley (I878), and Pontefract. A male in the Ripon Museum was obtained near that place, and Captain Dunnington Jefferson, of Thicket Priory, has an example killed on the Derwent near East Cottingwith.

\section{WIGEON. \\ Mareca penelope $(L)$.}

Winter visitant, common.

The Wigeon's comnection with Yorkshire history dates back to the sixteenth century, when it figured in the Northumberland Household Book, begun in I5I2, at Earl Percy's Castles of Wressill and Lekinfield; amongst the birds to be provided for " my lordes own mees" were "Wegions," the price being fixed at "Id. ob. (I $\frac{1}{2} d$.) the pece except my Lordes comaundment be otherwyze."

Thomas Allis, I844, wrote:-

Anas penelope.-Wigeon. Common near Doncaster and York: rather common about Sheffield; not uncommon near Leeds; it is rare about Hebden Bridge ; Dr. Farrar says 'So long as the Canals remain unfrozen this species is commonly to be met with near Barnsley, but the adjoining brooks seldom seem to offer much attraction for its resort: I have occasionally seen it in considerable flocks.' A. Strickland says that 'The Teal and Wigeon are comparatively two of 
the commonest species, but do not now, I believe, breed in the district, though it is probable that they did so formerly.'

One of the most abundant and best known of the "game ducks" is the Wigeon, which is an exceedingly common autumn or winter visitant, the first comers, generally young birds, arriving in August and September. The earliest date of which I am aware at Redcar is IIth August I883, when one was shot on Coatham Marsh; at Spurn, the earliest record is the 26 th of the same month, 1892 . Later in the season, in October and November, flights of both old and young join the ranks of the first arrivals, and congregate in large numbers in the Tees and Humber estuaries, or on the sea adjacent ; the majority of these are young males and females or adult males, the old females being considered very scarce.

Off the Cleveland coast, the Wigeon is very frequently observed passing along shore, to the north-west, on migration, and at times comes within range of the fowlers stationed on the "scars" or sand-hills, who take toll of their numbers. In some seasons, when favourable winds from the east or north-east prevail at the time of full moon, immense flights are seen ; I have noticed them passing incessantly, from early morn till noon, in flocks numbering several hundred birds; such was the case in the first week of November I878, on Ist October I887, the I3th and I4th October I894, and the 29th and 3oth October IgoI; it was very abundant also in the Tees and Humber in the winter of I864-65; in January of that winter a Teesmouth punt-shooter, whose game-book I have been privileged to examine, killed twenty-three "Whews" at one discharge of his big gun.

The Wigeon leaves for its northern nesting quarters in March or April, though I once saw an assemblage of fine males and females, in full summer plumage, sunning themselves on the sides of one of the "stells" on the Tees Marshes as late as 4th May I899, and on the I5th of May, in the year I902, I noted two pairs flying about the reclaimed land at the estuary.

The standard authorities on British Birds state that this duck has not been known to breed in a wild state in England, 
and, though it may be a difficult task to disprove this statement, I propose to lay before my readers the evidence supplied in support of the assumption that Yorkshire can claim the Wigeon as a nesting species.

Allis's friend, Arthur Strickland, gave no confirmation of his belief that it formerly bred in his district, Bridlington, (see the Report), and the first instance which I need mention is vouched for by Mr. Thomas Stephenson, who informed Mr. W. Eagle Clarke in I88I that it nested regularly in Fen Bog, near Whitby; the nest had repeatedly been seen by J. Kitching, who had that year found one containing eleven eggs, and handled the female which had been shot off the nest; the residents in the neighbourhood had several times taken eggs and set them under domesticated ducks, but never reared any young ones. Kitching was quite firm in his assertion as to its identity, as he knew the bird well. Mr. Stephenson has personally corroborated this statement to me, but it is to be feared there is now no possibility of obtaining absolute proof, as Kitching is dead, and the birds have not been seen at the nesting place for several years past.

The following circumstantial, but somewhat doubtful, account is communicated by Mr. Thomas Raine who, in a letter dated 25th February I902, says that on Ist May I897, he saw a Wigeon fly from a patch of heather on Skipwith Common, and discovered the nest with twelve eggs. A third occurrence was at Malham Tarn, where, as Mr. A. Ward informs me, a pair bred in the year Igor ; my informant saw both old and young birds on the lake.

In a semi-domesticated state, the Wigeon has frequently nested on Sir Ralph Payne-Gallwey's estate at Thirkleby Park; in I886 there were four pairs nesting there. On Mr. W. H. St. Quintin's property at Scampston, also, it has bred under similar conditions, and outlying nests belonging to birds from that locality have been found at a few miles' distance.

In east Yorkshire, whenever the Carrs become flooded by continuous heavy rains, the Wigeon leave the Humber and come inland in flocks, and in former days they were frequently captured in the Decoys; in the North Riding, 
at Hornby Castle, where is one of the two surviving Yorkshire Decoys, one hundred and one birds were taken between the years $r 856$ and $r 864$; and it was from this place that, in I860, the late John Hancock had sent to him a pair of hybrids between the male Wigeon and female Mallard, and another pair between the male Wigeon and female Call Duck. One of the females laid eleven eggs and sat them, but produced no young; one of the male birds was alive in 1874 (see " Birds of Northd. and Dm." p. 153). A female, assuming drake's plumage, was obtained at the Teesmouth in the year 1865 (Nat. I865, p. 38).

The local vernacular names are Whewer or Whew Duck; Whew is a common name amongst coast fowlers at the Teesmouth; the drake is called Pendle Whew, and the female Grass Whew.

\section{AMERICAN WIGEON. \\ Mareca americana ( $\mathcal{F} . F$. Gmelin).}

Accidental visitant from North America, of extremely rare occurence.

Concerning this American representative of our Wigeon, Sir Ralph Payne-Gallwey of Thirkleby Park, Thirsk, writing to the Field (9th March I895), states:-

"On 26th February, Mr. R. Lee, taxidermist, of Thirsk, obtained in Leeds an adult female American Wigeon. It was hanging up for sale with several common Wigeon in the shop of Mr. Murray, gamedealer, Leeds, who had just received it with other birds from the coast. I saw this bird when quite fresh, and it had pellets of shot in it with which it had been lately killed. It proved, on dissection, to be a female, though it has the green eyestripe and speckled neck and forehead of the male, but the crown is dark, and there is a good deal of chestnut on the flanks, and a little on the breast. The only British killed specimen of this bird, so far as I know, is one 
in the collection of Mr. J. H. Gurney, bought in London in the winter of $1837-8$. The one now recorded I have secured for my own collection."

This specimen, which is probably a young male, was exhibited at the Zoological Society's Meeting on 2nd April I895 (P.Z.S. I895, p. 273), and is figured in Lord Lilford's work on British Birds (Vol. 7, pl. 42).

\section{RED-CRESTED POCHARD.}

Netta rufina (Pallas).

Accidental visitant from south and east Europe and north Africa, of extremely rare occurrence.

This duck nests in the southe $\mathrm{n}$ and eastern portions of Continental Europe and north Africa, migrating in winter to India and China.

Its claim to rank as a Yorkshire bird rests on the occurrence of one example only, a male in good plumage, which was killed off a pond on Coatham Marshes on 20th January I900.

I saw the specimen soon after it was procured and purchased it from the shooter (Zool. I90o, p. 483; and Nat. I900, pp. $304,322)$.

Mr. T. Stephenson states (MS. I880), that "J. Kitching [of Whitby] says this has been shot at Redcar" ; but I am unable to trace any record previous to that mentioned above.

\section{COMMON POCHARD.}

Fuligula ferina $(L)$.

Resident; extremely local; breeds at several places. Also winter visitant, not very abundant.

The earliest reference to this bird in Yorkshire appears to be in connection with the working of Doncaster Decoy in $1707-27$, where mention is made of a contrivance used 


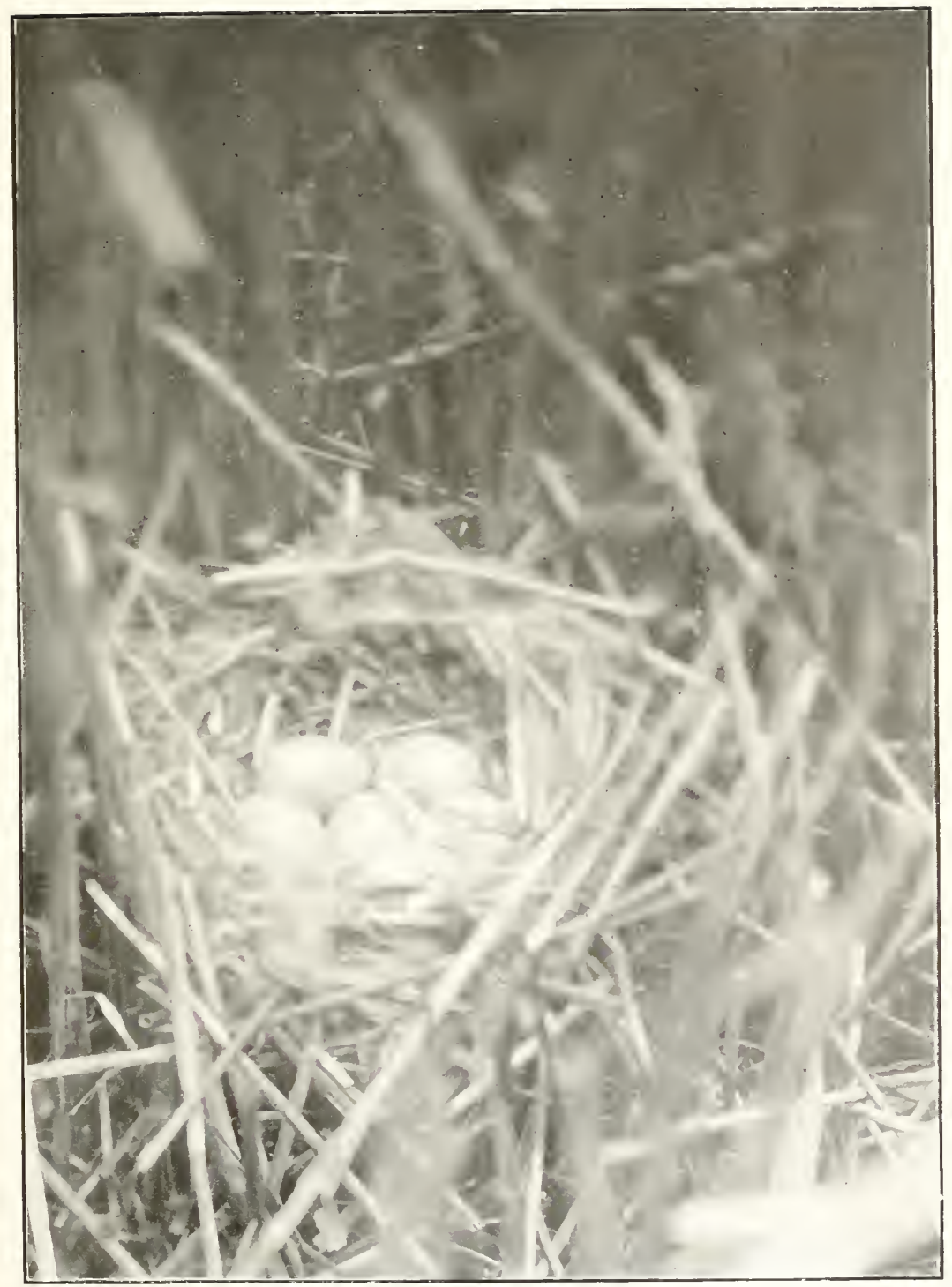

Pochard's nest, Hornsea Mere.

R. Fortune.

See page +63 . 

for capturing Pochards by means of a net at dusk. (Hatfield's "Historical Notices of Doncaster," I866.)

Thomas Allis, I844, wrote:-

Fuligula ferina.-The Pochard-Common near Doncaster; not infrequent about York; rare near Sheffield and Hebden Bridge; met with in a large pond at Hemmingfield, near Barnsley, generally in company with the Scaup, Golden-eye, and Tufted Ducks; Dr. Farrar remarks that a friend of his who lived close by, and waited on them very attentively with his gun, assured him that the only attraction to that spot appeared to be a species of duckweed which grew there abundantly, and which they devoured with avidity; on the moors near Huddersfield it is occasionally obtained, also in the vicinity of Leeds; rare about Hebden Bridge; A. Strickland says 'though it is to a considerable degree a maritime bird, it is not often killed near Bridlington, except in severe weather, but it is often found in our shops in winter.'

As a resident species the Pochard is extremely local, its breeding places being now restricted to very few localities. One of these formerly existed at Scarborough Mere, where, in June 1844 , the late Mr. Bean of Scarborough shot a female from the nest (Hancock, "Birds of Northd. and Dm." p. I56), and Hewitson ("Eggs of British Birds," 3rd Ed. I 856, pp. 423-4), described a visit paid by J. H. Tuke to the same place, which is now practically destroyed by the railway. The late Alfred Roberts noted the birds there almost every spring, and the late Mr. Champley of Scarborough had eggs which had been taken there. The most recent occurrence of which I am aware was in the summer of 1903, when Mr. Morley noticed a duck on the Mere.

In the year I854 the late Sir W. Milner mentioned the fact of the Pochard nesting at Hornsea Mere in considerable numbers. Mr. Henry Strickland Constable of Wassand informed Mr. G. D. Rowley that, in I874, the ducks laid at the usual time in the reeds, but the rain fell so continuously that all the eggs were destroyed by the rising waters of the Mere ("Orn. Mis." Vol. 3, p. 23I) ; in $\mathrm{r} 88 \mathrm{I}$ as many as fifty pairs were observed, whilst a well-known and protected colony still exists there; the egg figured by Hewitson from Sir W. Milner's collection had probably been taken at that 
place (Zool. I854, p. 444I). This species has also nested at Cold Hiendly Reservoir, near Wakefield, where, in June I86r, a male bird was procured and four eggs were taken, two of which were sent to Mr. J. E. Harting; it was stated by A. G. More (Ibis. I865), to have been found "quite recently" breeding in the Craven district, and it now nests there annually; also near Shipley, where eggs were found in 1893 ; in 1898 it nested at Ackworth, while at Scampston and Thirkleby it breeds in a semi-feral state.

In addition to being a resident, the Pochard occurs as a winter visitant, being met with both on the coast and on inland waters. It used to be not uncommon in the Tees in the first half of the past century, and in the Humber it was formerly observed in hard weather; several flocks were noticed there in the early weeks of 1895 , and it is reported from time to time at the various coast towns.

We are told in Hatfield's " Historical Notices of Doncaster" (I866), that this duck was a difficult bird to take in the decoy on account of its facility in diving, which enabled it to get back under water in the pipe, but still many were caught every season. Mr. Roger Gough, who rented the decoy from 1707 to 1727 , made use of a clever arrangement by means of which many were captured in nets at dusk; twenty dozen are said to have been taken at one catch. It also figures in the list of ducks "captured at Hornby Decoy, and is enumerated amongst the birds in Fothergill's Wensleydale list (I823), repeated in Barker's “Three Days of Wensleydale" (I854). It has occurred on most of the reservoirs and sheets of fresh water in the West and North Ridings, and occasionally in Teesdale, Swaledale, Wensleydale, and Ryedale; near Masham it has been seen several times in spring ( $N$ at. I886, p. 233); and in May I878 one was obtained at Glasshome Reservoir, near Pateley Bridge. It is also noted from the valleys of the Nidd, Wharfe, Ribble, Calder, and Hodder; on Malham Tarn and Semerwater, besides other localities which it would be tedious to recapitulate.

In the neighbourhood of Cottingwith and Thicket Priory 


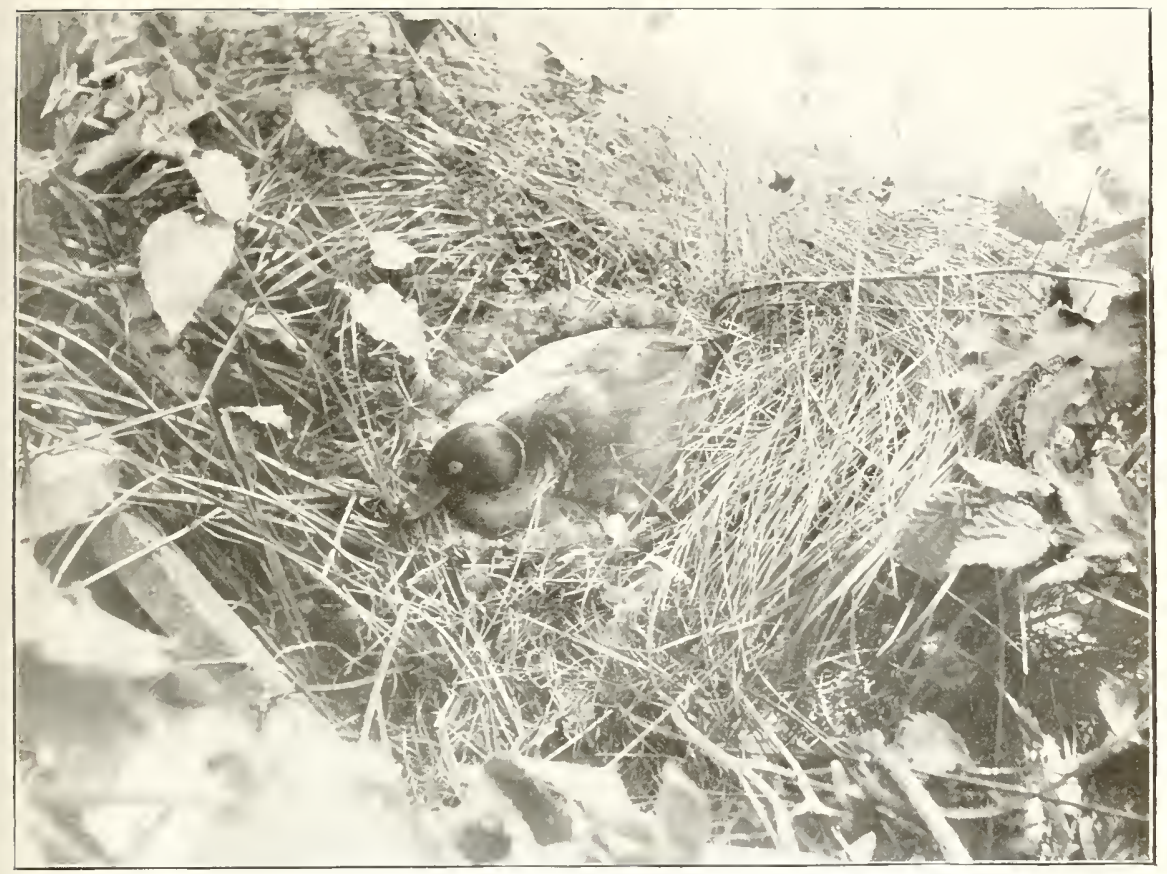

Tufted Duck on Nest.

S. Simith.

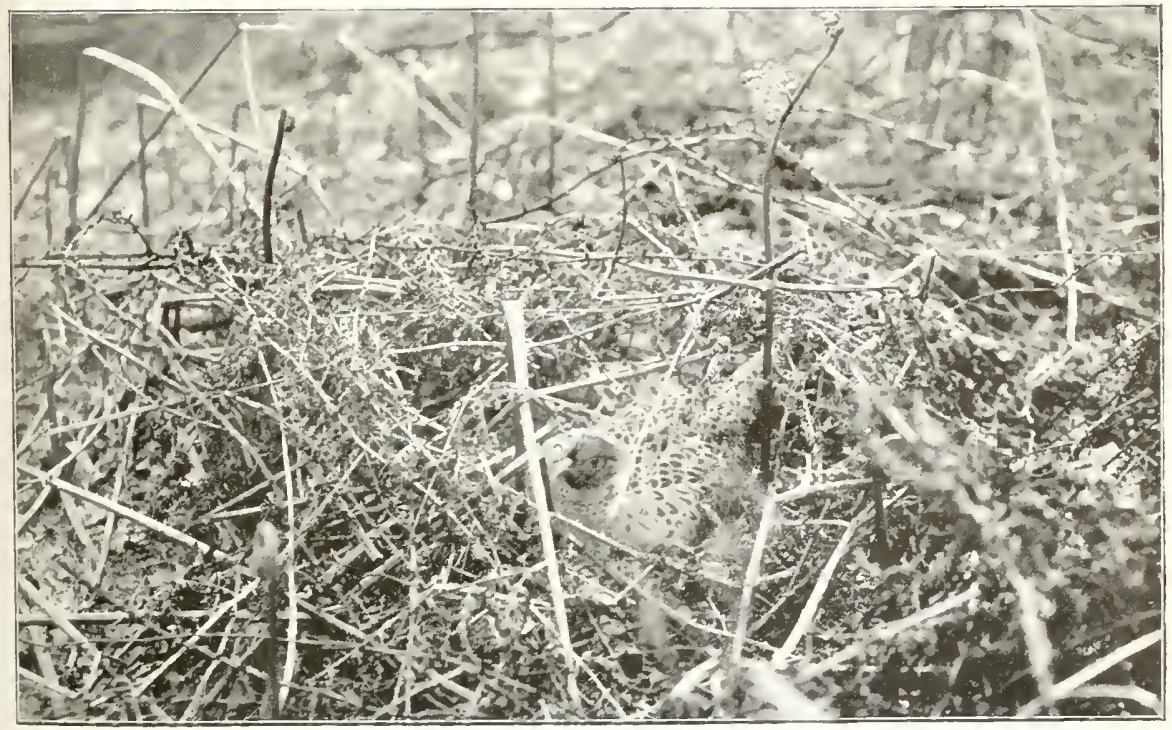

Pheasant on Nest. 

it has been killed on the flooded waters of the Derwent, while near Beverley the late W. W. Boulton recorded it as abundant in the winter of $1864-65$; indeed, it is one of the commonest ducks on the river Hull in severe weather. The Pochard is not a common species in the Teesmouth district, though I have noted it at intervals in winter, and have seen a specimen on the Coatham Marshes; it is also recorded from the Esk Valley, near Whitby.

As regards local names, Dunbird, Red Head, and Poker appear to be used indifferently; and Pokker, Dunpocker, and Bighead are additional names by which it is known on the river Hull.

[The so-called "American Scaup " reported at Scarborough (Zool. I855, pp. 463I, 4947) proved, on examination by the late J. Hancock, to be a female Pochard.]

\section{FERRUGINOUS DUCK.}

Fuligula nyroca (Guldenstadt).

Casual visitant, of very rare occurrence.

This small duck is resident in southern Europe, and migrates in winter to northern and central Africa.

It is but a rare casual visitant to this county, having been noted on six occasions only.

The first was taken in Coatham Decoy on $x 7^{\text {th }}$ January r850, and recorded by T. S. Rudd in the Zoologist (I850, p. 2773).

Near Huddersfield a specimen was shot at Dalton, in December 1858 (Hobkirk's "Huddersfield," Ist Ed. 1859, p. I45).

A pair in the collection of Mr. Thomas Boynton of Bridlington, was, as that gentleman informs me, formerly in the late W. W. Boulton's collection at Beverley, and is probably of local origin.

On 23rd December I876, I saw one exposed for sale in a 
fish shop at Redcar, and was told it had been killed near the Teesmouth.

Two were seen, and one was shot, on 3 rd October 1878 , by the late Rev. H. Smith, on Coatham Marsh (Zool. I879, p. 2II; and Field, I5th February I879).

And Major W. B. Arundel of Ackworth, writing on 2oth April I903, says "A pair of adults in excellent plumage was secured lately near here. The irides of the female were slatey brown." In a later communication my correspondent writes that two pairs were noticed, one of which remained all the summer and the following winter (See also Zool. I904, p. 33).

\section{TUFTED DUCK.}

Fuligula cristata (Leach).

Winter visitant; not uncommon on the coast in some severe seasons. Occasionally occurs inland, and nests in one or two localities.

The first reference to this species in Yorkshire is, apparently, that in Fothergill's Wensleydale list (I823), where it is enumerated amongst the birds of that district.

Thomas Allis, I844, wrote:-

Fuligula cristata.-Tufted Duck-Frequent near Doncaster; is met with near Barnsley, Huddersfield, and Leeds; it is scarce near Halifax, but a male was shot in January 1832 , and a male and female on the roth March 1836 ; at times abundant near York. Arthur Strickland remarks that the Tufted Duck, Scaup Duck, and Goldeneye, though comparatively scarce to what they used to be, are not uncommonly met with in winter.

The Tufted Duck occurs as a winter visitant, arriving late in October in small parties, and is more numerous in severe winters than in mild seasons. It is found sparingly distributed on the coast, in the harbours, and the Tees and Humber estuaries, but is never very numerous, associating sometimes with Scaups and Golden-eyes. Females and immature males are well known on the river Hull near Beverley, where, in the winter of $1864-65$, the species was more than 


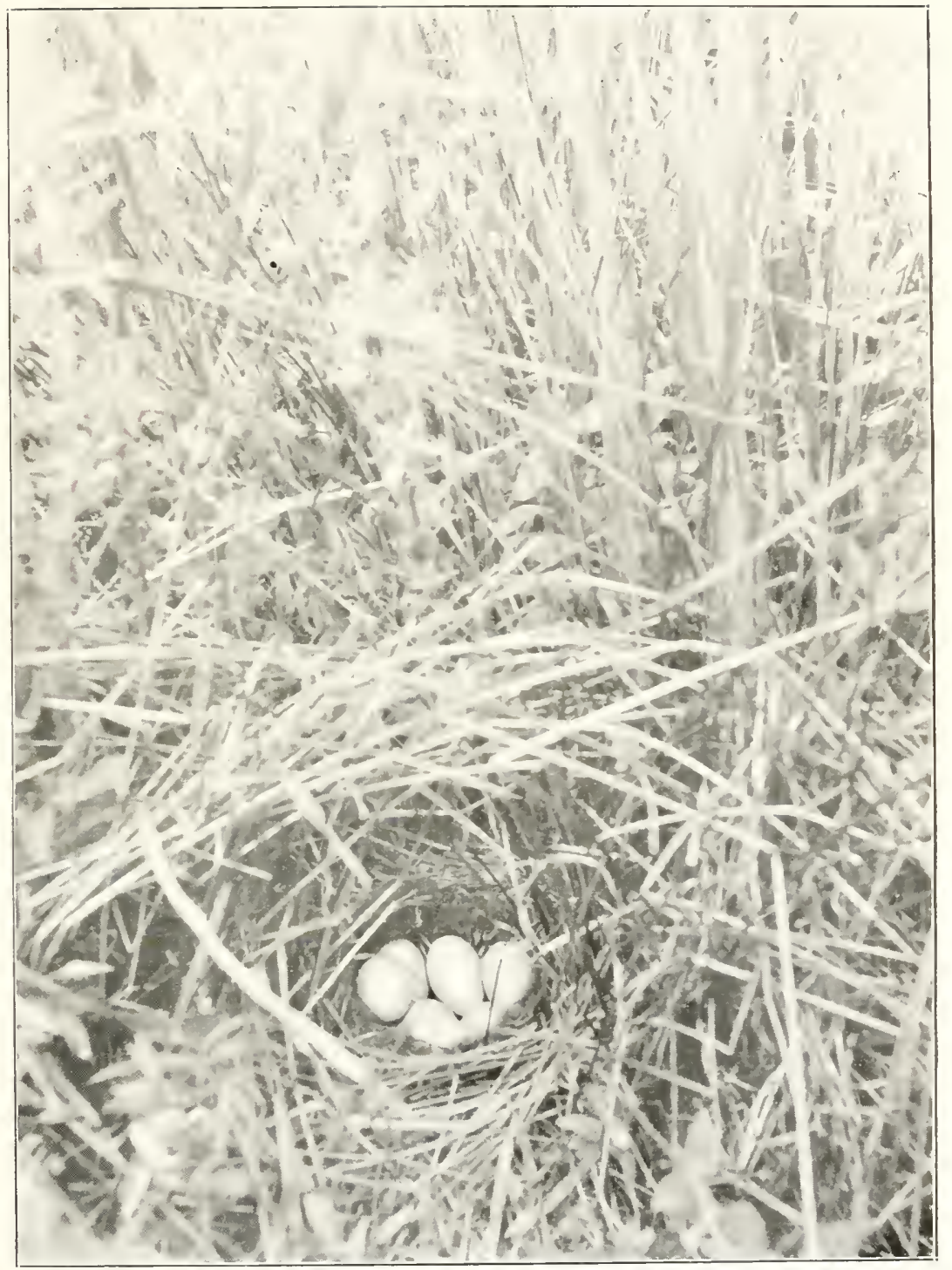

Nest of Tufted Duck, Nidderdale.

R. Fortune. 

usually abundant, but the adult is extremely rare. In the Tees district it is not by any means plentiful ; I have known a few specimens procured at sea, and I obtained a drake, in November I900, on a small pond on Coatham Marsh, where a few other examples have been noted.

It occurs with tolerable frequency on inland rivers and lakes; a flock of eighteen was seen at Masham in October I884, and a party of six was observed on Eccup Reservoir in December $\mathrm{x} 886$. It was enumerated as a visitor to Doncaster Decoy and the Carrs, it is noted in Wensleydale, and has been met with near Sutton-on-Derwent, and on the rivers Wharfe and Nidd, and various streams and reservoirs of the West and North Ridings.

As a nesting species, the Tufted Duck is increasing in numbers; in 1849 it was mentioned by the Rev. R. B. Cooke as breeding to 1300 feet elevation at Malham Tarn (Zoob. I850, p. 2879); subsequent to that period, I have notice of a brood being observed in I895, and in 1903 three nests were found. Several pairs have nested during the past two years on a protected lake in Nidderdale, and also in the Washburn Valley and on the lake at Castle Howard. On Hornsea Mere the nest was reported in 1856 , when the late Sir W. Milner noticed sereral birds in company with the Pochards (op. cit. I854, p. 444I); it still occasionally remains during the breeding season, and of late years one or two pairs have been seen there in early summer. It is noted almost annually at Worsborough Reservoir, near Barnsley, while Major Arundel informs me that a drake, which visited a sheet of water in that neighbourhood in the spring of Igor, was incapacitated from leaving, and its mate remained with it, bringing off a brood of seven young (op. cit. I904, p. 33).

This duck has bred in a semi-domesticated state, at Thirkleby Park, where in I887 I had the pleasure of seeing the young; at Wentworth Park it has been introduced by Earl Fitzwilliam, and it nested on an island in the lake.

The only vernacular names known to me are Black Pocker, in the Beverley neighbourhood, and occasionally Blacktoppin Duck. 


\section{8 \\ SCAUP.}

\section{Fuligula marila (L.).}

Winter visitant, irregular in numbers; very abundant in some severe seasons; occasionally occurs on inland waters.

The earliest mention of the Scaup in connection with Yorkshire is contained in Willughby's "Ornithology" (I678), thus :-

"It is called Scaup Duck from its feeding upon Scaup, i.e., broken Shellfish; varies infinitely in colour, especially in Head and Neck, so that among a pack of forty or fifty you shall not find two exactly alike. A thing not usual in this kind. We owe this description and history of it to Mr. Johnson" [of Brignall, near Greta Bridge]. (Will. "Orn." I678, pp. 28, 365.)

Thomas Allis, I844, wrote:-

Fuligula marila.-Scaup-Has been shot near Doncaster; is rare near Sheffield; obtained near Barnsley and Huddersfield, and not infrequently met with near Sutton-on-Derwent in the neighbourhood of York.

One of the latest of our winter visitors, the Scaup does not appear until towards the end of October, at the time when we may expect Scoters, Longtails, and other " Norroway Ducks," as the Yorkshire fishermen call them; the earliest date of which I have had personal experience was on the Igth of that month, in the year I886, when one was obtained near Redcar Pier. The numbers vary greatly in different years, and are few or many according to the mildness or severity of the season.

In the Teesmouth district, before the advent of steamships, and when the population was, comparatively speaking, small, the Scaup was one of the commonest of the " sea-ducks." Sir Cuthbert Sharp tells us in his "List of Birds of Hartlepool" that, in the winter of $1788-89$, they were in such quantities that above a thousand were caught in a week and sold for I/- per dozen. I have been assured by an old Redcar fisherman, now (Ig06), living at the age of ninety-one, that when 
he was a young man, about the "thirties " or "forties," the fowlers of those days did not as a rule trouble with Scaup, confining their shooting to the "game ducks"; he, however, used to shoot them and sell them for $2 \frac{1}{2} \mathrm{~d}$. each to a carrier, who took them to Stockton market. One stormy day at the Teesmouth my informant crept close up to a pack of fully five hundred of these ducks, but his old flint lock " snapped."

In the winter of $1864-65$, when wildfowl were abundant in the Humber, this species also occurred in immense flocks; it is a regular and numerous visitor there, and may be found all through the winter months, being especially numerous in severe seasons. Mr. Francis Hoare states in a letter, dated 9th January I880, that, after strong north-east gales, he has known them to come up to Paull bight below Hull, when he has killed great numbers; sometimes the flocks remained there all the season. In the winter of I890-9I, and in the severe weather of the early months of I895, it was unusually abundant in the Tees Bay, several large flocks, composed entirely of adult birds, frequenting the Teesmouth and the immediate vicinity of Redcar, when I shot some fine specimens from the deck of Coatham Pier.

At other stations on the coast this duck is observed more or less commonly, and, as at the Tees and Humber, is occasionally very numerous in hard winters off Whitby, Scarborough, Filey, and Bridlington.

On inland waters it is frequently found in the immature plumage, but old males are scarce. Chas. Hatfield in "Historical Notices of Doncaster" (I866), stated that it came to the Decoy throughout the winter months; Allis recorded it in several instances; on Walton Lake it was noted in some numbers in I882; it often occurs on the river Hull near Beverley; and it has also been reported from Hiendley Reservoir, near Wakefield; Nostell, Ackworth, Fewston, Allerton, Pateley Bridge, Bedale, Malton, and other places which need not be particularized.

It departs in spring, having been observed off the coast a) late as May.

As to vernacular names, it is known as Black Scaup 
and Black Poker Duck on the Humber; Mussel Duck and Bell Wigeon about the Teesmouth; and Golden-eye and Silver Pochard at East Cottingwith, near York.

[The supposed example of the American Scaup, reported in January I855, at Scarborough (Zool. I855, p. 463I ; and Yarrell, iii. p. 349), was examined by the late J. Hancock, and found to be a female Pochard.]

\section{GOLDEN-EYE.}

Clangula glaucion (L.).

Winter visitant, immature birds not uncommon in some seasons adult males rare. Occurs on inland waters in considerable flocks.

The first mention of the Golden-eye in connection with Yorkshire was made by Fothergill, who stated, in I799, that one shot near Helmsley was in his possession ("Orn. Brit." p. Io).

Thomas Allis, in I844, wrote :-

Clangula vulgaris.-Golden-eye-Not uncommon near Doncaster ; is obtained at Hebden Bridge, also near Barnsley, Leeds, and Huddersfield; it is very abundant in the neighbourhood of York, especially in immature plumage.

The Golden-eye is a late autumn or winter visitant, never, as a rule, arriving before October; the individuals then seen are generally in immature plumage, the adult bird being rare, and the drake especially so.

This duck is found on the coast singly or in small parties, and in the estuaries of the Tees and Humber it was fairly numerous before the growth of steam traffic; it is now more abundant on fresh water lakes and rivers, while they remain unfrozen, than on the tide, though in hard frosts it is driven to the salt water and its numbers are augmented in severe winters by fresh comers. In the winter of $1864-65$ it was numerous on the river Hull, and in immature plumage is 


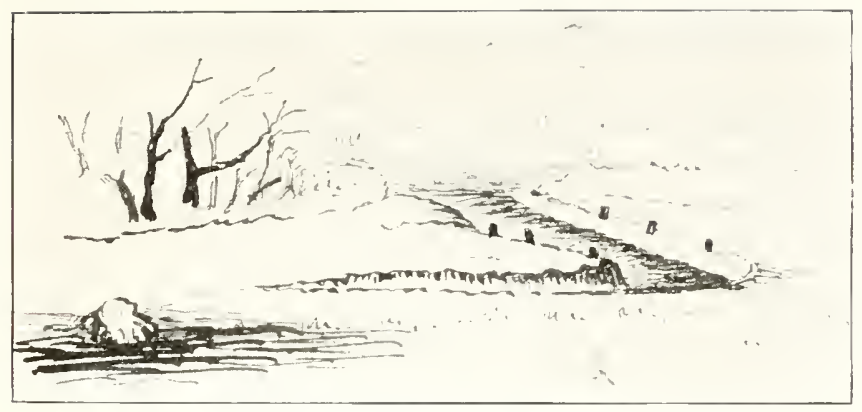

Site of Coatham Decoy, 1887. R. Lofthouse.

See fage tti

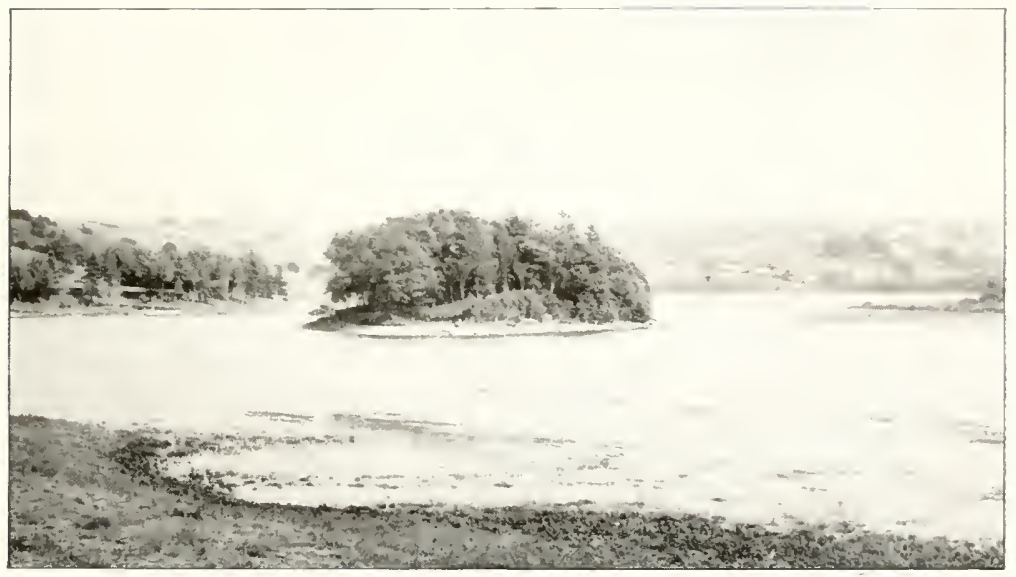

Island in Swinsty Reservoir, where the Golden Eye is reported to have nested.

R. Fortune'

Set page tir. 

common above Beverley in most seasons ; several flocks were observed in the Humber in January and February I895, and in the spell of Arctic weather in February I897 no fewer than six adult males were procured; it is also occasionally seen on Hornsea Mere.

The Golden-eye is enumerated amongst the birds taken at Doncaster Decoy; it has occurred frequently on the Derwent near Thicket Priory, and an adult male in the York Museum was taken at Newton-on-Derwent in February I900; it has been observed on the Yore near Masham in hard winters; it occurs annually, but in limited numbers, on Hiendley Reservoir (where, according to $\mathrm{W}$. Talbot, it was abundant in I876), on Nalham Tarn, Fewston Reservoir, and other sheets of fresh water; and has been noted from most places where the inland waters are sufficiently quiet for it to remain in security.

On Fewston Reservoir, in January I884, Mr. W. Eagle Clarke noted a small party consisting of several adult birds, and Mr. W. Storey reported that a pair bred on Swinsty Reservoir, in I89I, one of the young being captured, and the old drake afterwards secured and placed in the collection of the Leeds Naturalists' Club (Zool. I895, p. 449).

\section{BUFFEL-HEADED DUCK.}

Clangula albeola $(L$.$) .$

Accidental visitant from Northern America, of extremely rare occurrence.

This duck is a native of North America, and a rare accidental straggler to this country in winter.

The only Yorkshire record is of an adult male in very fine plumage, shot in the winter of I864-65 by Richard Morris, on the Bessingby Beck, near Bridlington, and preserved by

VOL. II. 
Mr. Machen of that town. The occurrence was chronicled by the late J. Cordeaux in the Zoologist (1865, p. 9659), and "Birds of the Humber District" (I879, p. I76).

The specimen is now in the collection of Mr. J. Whitaker of Rainworth Lodge.

\section{LONG-TAILED DUCK.}

Harelda glacialis (L.).

Winter visitant; sometimes not uncommon in immature plumage off the coast ; rare in the adult stage. Occasionally occurs as a straggler to inland waters.

The earliest British information concerning this species is afforded in Willughby's "Ornithology" (I678), by Ralph Johnson of Brignall, near Greta Bridge, the friend and correspondent of John Ray, who sent a description of a bird called the "Swallow-tail'd Sheldrake,' which answers accurately to the Long-tailed Drake. Mr. Johnson's communication is as follows :-

"I should have taken this to be the Male, and that described by Wormius the Female Harelda in respect of some common notes in Tail and Neb, but that the Female was with this of mine (as may be presumed, a pair only, feeding together, several days in Tees river, below Barnard Castle), and did not much differ in colour." Thus far Mr. Johnson: "I am almost persuaded that it is specifically the same with Wormius his Harelda, differing only in Age or Sex, or perhaps both." (Will. "Orn." I678, p. 364.)

Thomas Allis, 1844 , reported :-

Clangula glacialis.-Long-tailed Duck-Not very uncommon about Doncaster; it is met with but rarely near York. A. Strickland observes "This is truly a Northern species, but is occasionally met with in this country in winter, but is not common now." 
It is somewhat remarkable that the earliest British information concerning this northern ocean-loving duck should be from the fresh waters of the Tees near Barnard Castle, as related by that famous old-time ornithologist Francis Willughby, whose oft-quoted correspondent, Ralph Johnson of Brignall, sent him the description of what is termed the "Swallow-tail'd Sheldrake." After the days of Willughby it was referred to by George Allan (I79I) as " only visiting our coast in the severest winters, but never in numbers " (Fox's "Synopsis of the Tunstall Museum," p. 99).

The status of the Longtail, as defined by modern Yorkshiremen, is that of a rather rare winter visitant, the immature bird being more common than the adult, and as such it is known on the greater portion of the coast. It arrives in small parties during the October gales, and is considered rare in the Humber and Spurn district; at Flamborough Mr. M. Bailey tells me he has only shot one; at Filey it is uncommon, but is met with occasionally, and the same remark applies to Scarborough and Whitby. In the Redcar and Teesmouth neighbourhood it is a regular winter visitant in varying numbers, making its appearance at the same time as the Scoters, with which species it often consorts, haunting the vicinity of the rocks, and feeding on the small marine life of the scars. In some years it is uncommon, and in other seasons it is of frequent occurrence, as, for example, in the winter of $\mathbf{8} 857-88$, when it was very abundant, and at least forty were procured, to my knowledge, between October and February (Zool. I888, p. I37; and Nat. I889, p. 84).

The adult male is rare, the mature female still more so; Mir. W. J. Clarke of Scarborough had one of the latter sent to preserve in November 1897 , it being only the second example he had known; but of the former I have observed, and secured, some very good specimens, and in February I892 I watched, through the lifeboat telescope, two perfectly adult drakes disporting on the water about a mile off shore.

Though essentially a marine duck, the Longtail has been occasionally obtained on inland waters, the first notice being by Willughby; whilst Allis referred to its occurrence at 
Doncaster and near York. One was reported at Nun Appleton in December $\mathrm{r} 869$; at Riccal, Driffield, and Cawood it is noted, also on the Derwent at East Cottingwith and Thicket Priory; Mr. A. Crabtree records one at Sowerby Bridge in I886; it has been taken at Wilstrop by the late John Harrison; Mr. R. Foster saw two at Killinghall in December I883; it has occurred two or three times on Hornsea Mere; Scampston and Bessingby are localities where it is recorded, and, in October 1882 , on a flooded meadow at Kilnsea, the late J. Cordeaux shot one which had been feeding on small red worms.

The local names are Swallow-tail'd Sheldrake (Willughby, I678) ; in the East Riding it is sometimes called Sea Phcasant, while it is known as Go-West at Redcar.

\section{HARLEQUIN DUCK.}

\section{Cosmonetta histrionica (L.).}

Accidental visitant from Northern Europe, Asia, and America, of extremely rare occurrence.

The Harlequin Duck, which is a circumpolar species, is only an accidental visitant to this country.

Thomas Allis, I844, wrote :-

Clangula histrionica.-Harlequin Duck.-Hugh Reid says "A female of this species was shot in the river Don a little above Doncaster, by the late Mr. Cartmell, and was sold by me to Mr. N. E. Strickland." A. Strickland has never met with it in this country.

The first Yorkshire specimen is that mentioned by Al'is, though Mr. J. H. Gurney ("Rambles of a Naturalist," p. 263), considers it of doubtful authenticity.

A young male, now in the collection of Mr. J. Whitaker of Rainworth Lodge, was purchased by him from the late Alfred Roberts of Scarborough, who procured it about IS62, at Filey, from some fishermen who informed him they had found it washed up on the beach (Zool. I878, p. I35). 
The Hornby Decoy example, alleged to have been captured about I860 ("Handbook of Vertebrate Fauna of Yorkshire," p. 58), proved, on investigation by Mr. W. Eagle Clarke, to be an imported specimen.

\section{EIDER DUCK. Somateria mollissima (L.).}

Winter visitant, not common.

The first reference to the Eider in Yorkshire, though of a rather dubious character, may be said to be the quotation from Strickland in Allis's Report :-

Anas mollzssima.-Eider-A. Strickland says that "Though this bird is abundant in parts in the north, it seems very seldom to stray much to the south, I have seldom known it killed on this coast" (Thomas Allis, 1844).

This handsome and conspicuous duck is a casual visitant in winter, generally in immature plumage, though, now that its numbers have so greatly increased at the Farne Isles, there seems every probability that its occurrence may be looked for with greater frequency on the Yorkshire coast.

Arthur Strickland (in Allis's Report), though mentioning it as "seldom killed on this coast," did not give any specific instance within his knowledge.

It has been met with at sea off Spurn in full plumage, an adult male be ng picked up on the beach in January 1893 (Nat. I893, p. I04); and a young male, shot there, is in the Hull Museum.

Mr. T. Boynton has an example taken at Flamborough in 1868 , and at Filey it is recorded on four occasions; the first in November I864, the latest in the winter of I902-03.

At Scarborough, one, out of four seen, was obtained in December I89I; at Whitby, three have been procured between I888 and I897; and in the Redcar district I have notes of its appearance in $I S 79, I 888$, and I89I; in addition to these occurrences, on 26th February I894, I watched, through a powerful telescope, a very fine old drake sitting on Salt Scar, 
a reef of half-tide rocks about a mile off the shore; I afterwards put off in a boat, but the bird escaped into broken water, swam through an opening in the rocks and so got out to sea. In the winter of I902-03 one occurred in the Tees Bay; while, finally, on 2nd February I905, a flock of about twenty was seen near the Tees Breakwater, and an aduit male specimen was secured.

The only inland locality this species is recorded from is Tong Park Reservoir, near Shipley, about the year I895; the specimen is now in the possession of Mr. John Reed, Thackley, near Bradford.

\section{KING EIDER.}

\section{Somateria spectabilis (L.).}

Accidental visitant from Northern Europe, Asia, and America, of extremely rare occurrence.

The King Eider, whose habitat is the Arctic regions, has occurred in Yorkshire on one occasion only, at Bridlington Quay, in 1846. This occurrence was chronicled by misprint for Bedlington (Northumberland), by the late Joseph Duff (Zool. I85I, p. 3036), and corrected by J. Hancock (" Birds of Northd. and Dm." p. I59), on the authority of a letter from Mr. Duff, who informed me many years afterwards of the circumstances of its capture at Bridlington.

\section{STELLER'S EIDER.}

Somateria stelleri (Pallas).

Accidental visitant from Northern Europe and Asia, of extremely rare occurrence.

Like the King Eider, this bird is an inhabitant of the Arctic regions and only an accidental visitant to this country. Its claim to rank as a Yorkshire bird rests on the 
strength of one occurrence at Filey (misprinted "Filby"), a male, assuming winter plumage, shot on I5th August I845, by Mr. Curzon, and submitted to Yarrel for inspection (R. J. Bell, Zool. I846, p. I249; and Yarrell's "British Birds"). The specimen is now in the collection of Lord Scarsdale of Kedleston.

\section{COMMON SCOTER.}

\section{Edemia nigra (L.).}

Winter visitant, common on the coast; very numerous in some seasons; a few remain during summer. Observed on inland waters ocasionally.

The first allusion to the Common Scoter, as a Yorkshire bird, is found in Willughby's "Ornithology," under the heading of :-

"The Black Diver or Scoter-Anas niger minor. Its case stuft was sent us first by Mr. Fr. Jessop out of Yorkshire : Next we got it at Chester (in I67I) as we have said: Then Sir Thomas Brown sent us a picture of it from Norwich; and lastly Mr. Johnson [of Brignall, near Greta Bridge] sent a description of it in his method of Birds, in which description are some particulars not observed by us, viz:- that the Male hath on the upper side some tincture of shining green, and that in the Hen the Neck and Head on both sides, as far as the Eyes, is white." (Will. "Orn." I678, pp. 366-7.)

Thomas Allis, in I844, wrote:-

Edemia nigra.-Common Scoter-Shot near Doncaster in severe winters, and at York occasionally; my friend J. Heppenstall says - A specimen of this marine species was found quite fresh in one of the streets of Sheffield; it appeared to have died from exhaustion as it was very poor.' It is met with on the moors about Huddersfield ; has been taken near Selby. Dr. Farrar says the Scoter was irregular in its appearance, both in numbers and season; in July 1834 a very large flock visited the extensive sheets of water in Bretton Park, and great numbers of them were shot. A. Strickland remarks that this is much more frequent than the Velvet Scoter, and seldom a winter passes but some are killed. 
The Common Scoter, or Black Duck as it is usually known to fowlers, is the commonest of our marine anatidæ, and is a winter visitant to the coast, where immense flocks may be seen in the autumn and winter months; it is found in varying numbers at most of the coast stations between the Tees and Humber, Bridlington Bay being a favourite locality. In the Humber it is reported to arrive in September; I have noticed considerable numbers passing Redcar as early as I7th August, and in some seasons small flocks occur in September, but, as a rule, the main body does not put in an appearance until mid-October, and if severe north-east gales then prevail, and continue for several days, the flocks become " haunted to the Scars," as the local term expresses it, remaining in the vicinity during the whole winter, but in mild seasons they do not appear in such large numbers, or, alternatively, frequent the neighbourhood of the Teesmouth or Huntcliffe Foot. In the winter of 1876 the species was exceptionally abundant, and again in I887, also in $I 900$ and rgor. It takes its departure late in spring, in April or May; I have observed considerable quantities as late as the 25 th of the latter month, and in most years a few non-breeding birds remain throughout the summer off the Cleveland coast and also in the Humber. I procured a very fine drake on IIth August I877, and another on the 22nd of August in 1888 .

This species is occasionally found on fresh water, the recorded and communicated instances of which are too voluminous for particularization. It has been met with on most of the large tarns, lakes, and reservoirs, and on many of the rivers, particularly in the West Riding. At Masham one was obtained on 23rd August I883, and two remained on Fewston Reservoir in the summer of I902, one being captured and set at liberty again.

A very unusual circumstance is mentioned in Allis's Report of a flock appearing in July I834, at Bretton Park, while, singular to relate, in I879 Mr. W. Eagle Clarke recorded a most extraordinary migration of Scoters at Skipton-in-Craven. On 24th April in the year named, shortly after dusk, birds 
were heard passing overhead and continued most of the night, many being bewildered and flying against chimney pots and houses. At the Railway Station they were immolated against the telegraph wires and several were picked up on the following morning, one porter securing as many as seventeen. It was calculated that, in all, one hundred and fifty had been taken, the majority of which were males. The migration continued on the $25^{\text {th }}$, and on the 26 th the fowl were heard passing over for two hours between eight and ten o'clock (Zool. I880, p. 355).

As an article of food the Scoter is not held in high esteem, being decidedly rank and fishy in taste unless properly cooked; George Allan remarked (Allan MS. I79I ; Fox's "Synopsis," p. 98), that "The Catholics are allowed to eat them in Lent." As a sporting bird, when in large packs, it affords excellent practice, comparable even to grouse-driving, with the additional difficulty of a rocking boat to take into consideration. I have at times enjoyed capital shooting amongst the Black Ducks over the Redcar Scars by putting out decoy birds to attract the wild ones within range. As is well known, the Scoter can carry off a heavy charge of shot, and, even when knocked down and apparently helpless, a wounded bird has an annoying trick of diving if a spark of life remains, and so often baffles the shooter, for it is practically useless to pursue one under these conditions, while if hard pressed it will even cling to the rocks or seaweed and commit suicide by drowning. On several occasions, after a day's shooting over the rocks, dead birds have been found at low tide with wings firmly clasped round a stone, or holding on by the bill to a piece of seaweed.

The local vernacular names are Black Duck or Black Scoter, in general use ; and Mussel Duck in the Humber. 


\section{VELVET SCOTER.}

\section{Edemia fusca ( $L$.).}

Winter visitant in small numbers. Has occurred inland.

The first British information containing the Velvet Scoter appears in Willughby's "Ornithology," where there is a description given which leaves no doubt as to the identity of the bird. It is under the heading of :-

"Aldrovandus his Black Duck. The description of this bird we owe to Mr. Johnson [of Brignall, near Greta Bridge] with whom also we saw its case stuft." (Will. "Orn." I678, p. 363.)

Thomas Allis, in his Report, I844, wrote :-

Edemia fusca.-Velvet Scoter-F. O. Morris and H. Reid report one shot at Bentley by the gamekeeper of Sir W. B. Cooke, which is in the possession of that gentleman; it is obtained occasionally at the reservoirs on the moors near Huddersfield; A. Strickland says "Though this is a marine bird it is one of our scarcer species and seldom killed near Bridlington."

Essentially an oceanic species, this fine duck is almost entirely restricted to the seaboard, where it arrives in small flocks during the first October gales; the earliest date of its appearance of which I am aware is 2Ist September I89I, when one was captured after a strong on-shore wind; on IIth August I877 four flew past me while at sea, but these were in all probability individuals which had remained throughout the summer, as the preceding species often does.

The Velvet Scoter is not common anywhere in Yorkshire; at Bridlington a small flock is usually to be seen in the Bay, consorting with Common Scoters; it is rare at Flamborough, Scarborough, and Whitby; and is perhaps most numerous in the neighbourhood of Redcar and the Teesmouth, where it is a regular visitant in limited numbers, sometimes associating with the huge packs of its more common congener, but generally keeping apart from them. Its large size and the conspicuous white alar patch render it easily distinguish- 
able while flying, and in some seasons it is fairly abundant near the "scars," or at the Teesmouth; the largest number seen at one time was a flock of some thirty birds, at Christmas I895, inside Redcar rocks.

At high tide it feeds upon the small mussels on the rocks, departing to the open water with the ebb, and here I must traverse the late J. Cordeaux's statement in his "List of Birds of the Humber District" (p. 25), where he stated "it does not approach the shore so closely as the Common Scoter." My experience differs from his, and tends to prove that it is frequently found much closer inshore than the other; so recently as November I903, I observed three fly along behind the breakers and settle almost within stone's throw of the beach, where I afterwards procured two of them; whilst twice I have seen individuals actually shot on the sands. Several times I have rowed within range of small parties of these ducks on the open sea, and on one occasion four were killed out of a flock of about thirty, which allowed a quite near approach; nor is this so unusual as appears to be the opinion of some authors of ornithological works.

The adult drake of this species is very rare; only three examples have come under my notice at Redcar, two of them being found dead on the beach in March ISS8, while the third was reported in October I896. The late A. Roberts of Scarborough had four brought to him in the winter of I854-55; one was recorded at Spurn in October 1876 , and another, in the York Museum, was obtained at Goole in January I893.

The Velvet Scoter seldom occurs on inland waters; Hugh Reid stated that it visited the Doncaster Carrs; it is enumerated in Fothergill's Wensleydale list of 1823 , and Barker's "Three Days of Wensleydale" (I854); one was taken at Clapham in I84I ; Allis mentioned it in his Report ; Waterton recorded it from Walton Park; T. Lister reported it from Barnsley in December I872; W. Talbot ("Birds of Wakefield," I876), noted it on Hiendley Reservoir ; and Mr. J. H. Gurney examined a specimen killed on the Tees at Cotherstone "forty years ago" ("Upper Teesdale," I896). 
With regard to this bird's imperviousness to shot, the remarks applied to the common species are equally applicable.

The only vernacular names by which it is known are Velvet Duck, and Big Black and White Duck.

[Mr. A. S. Bell reported the occurrence of a Surf Scoter, Edemia perspicillata (L.) at Gristhorpe, near Scarborough, shot by him on 25th November I860 (Zool. I860, p. 7274, I86I, p. 7385). On investigation, however, it proved to be a mistake, the bird being a Velvet Scoter (Harting's "Handbook," and Ed. p. 463)].

\section{GOOSANDER.}

\section{Mergus merganser (L.).}

Winter visitant, the numbers depending on the rigour of the season. In mild winters young males and females are chiefly found; in hard weather adult males in beautiful plnmage are not uncommon on the inland waters.

The first Yorkshire allusion to the Goosander may be found in the Allan MS. (I79I), and refers to a river Tees specimen in the Tunstall Museum, thus:-

"These birds frequent our rivers and other fresh waters, especially in hard winters. This specimen is the male bird, and was shot in the river Tees, near Wycliffe, in January I789." (Fox's "Synopsis," p. 95.)

Thomas Allis, I844, wrote:-

Mergus merganser. - The Goosander-Occasionally got near Leeds and Huddersfield; it is shot near Doncaster in hard winters; it is very rare about Hebden Bridge; a fine male was shot in January 1842 ; it is occasionally met with at Gormire near Thirsk; the female and immature young are frequently met with in winter near York, and I have myself procured four or five full plumaged males in beautiful condition at one time.

This handsome bird is an irregular winter visitant to the coast line, estuaries, and inland waters, the first arrivals in October and November being, as a rule, females or birds 
in immature plumage; later in the season adult examples are occasionally met with.

It is not uncommon in the Humber; it occurs also at Flamborough, Bridlington, Scarborough, and other coast stations, but cannot be termed an abundant species. In the Teesmouth area it is occasionally killed from the "scars," or on the sands at Redcar, during the prevalence of on-shore gales, and was formerly not infrequent in the Tees estuary, but is now considered as being of rather rare and irregular occurrence.

In some seasons of exceptional severity its numbers are augmented by later comers from far northern latitudes, and at these periods some very fine adult birds of both sexes have been procured, though the old males are considered rare in mild seasons.

The Goosander is more of a fresh water species than its congener, $M$. serrator, and often follows the course of the various rivers and their affluents, being seen in localities far distant from the coast. The late Rev. J. W. Chaloner of Newton Kyme stated that, on 6th March I884, he noticed nine Goosanders in magnificent plumage on the river Wharfe, behind his house, an extraordinary number to be seen at that place. On the river Hull at Beverley it is fairly common; several flocks were observed in the winter of I $864-65$ and I870-7I, twelve specimens being procured in the latter year, and many superb old male examples have occurred there. In the winter of I886-87 it was more than usually numerous in the Humber.

It has also been obtained on most of the fresh water lakes and reservoirs in the North and West Riding dales. It is noted at Malham Tarn, and is reported as a rare visitor from the upper reaches of the Ribble, Wharfe, Yore, Tees, and indeed almost every part of the county where pure and fresh flowing streams are found. One was shot by Mr. (now Sir) Alfred Pease, in $\mathrm{I} 883$, in a small beck near Guisborough, and three years later another was seen in exactly the same place. An example captured in Lower Wharfedale, in March I886, disgorged a trout ten inches in length, while the Rev. F. O. Morris stated ("British Birds"), that in the gizzard of one 
shot in the Tees near Stockton, in March I853, was found part of a gold ear-ring.

The usual name used by coast shooters is Sawbill or Jacksaw, and Dun Diver is a term applied to the immature birds; it is known to the old shooters on the river Hull, in Holderness, as Horner ; Sparling Fowl (Fox's "Synopsis," p. 95), is a name used by old writers, though I have heard this given by river Tees shooters to the Red-throated Diver.

\section{RED-BREASTED MERGANSER.}

\section{Mergus serrator (L.).}

Winter visitant, not common. Occasionally occurs on inland waters.

The first Yorkshire reference to the Red-breasted Merganser is, apparently, that in Allis's Report (I844), thus :-

Mergus serrator.-Red-breasted Merganser-This bird is rare about Hebden Bridge; it is shot near Doncaster in hard winters, one specimen in 1837 ; it is met with about Huddersfield ; rare near Leeds, one was shot at Swillington, January $24^{\text {th, }} 183^{8}$, in the mature male plumage ; it is rare about York, but I have frequently seen specimens of the female and immature male. A. Strickland has only met with it in the mature plumage in the winter of I 830 , when several were procured.

In the middle of the past century the Red-breasted Merganser was, as I am informed by George Mussell, the Middlesbrough taxidermist, frequently found in winter and spring in the Tees estuary; it is now classed, on the coast generally, as an uncommon winter visitant, occurring singly or in small parties of three or four, being more frequently observed in severe weather than in mild seasons. The earliest date for its appearance, of which I have note, is 22nd September I903, when one was obtained at the Teesmouth. It has been reported in spring as late as $4^{\text {th }}$ May, off Flamborough Head, while a party of five remained in the Tees Bay until IIth May in $I 898$.

It is recorded from most of the coast stations, and is more 
of a marine species than the preceding, but it has been found in several inland localities in addition to those mentioned by Allis, viz.:-Richmond, Ilkley, the flooded waters of the Derwent at East Cottingwith, Masham, Malton, Kirkburton, and on some of the large West Riding reservoirs.

The name by which this bird is known to coast gunners and wildfowlers is Sawbill or Sawbill Duck, and sometimes Dun Diver, terms which are also applied to the Goosander.

\section{SMEW. \\ Mergus albellus (L.).}

Winter visitant, of uncommon occurence. Is reported both on the coast and on inland waters, chiefly in immature plumage, the adult being extremely rare.

Willughby's "Ornithology" contains the earliest known Yorkshire reference to the Smew, where it is alluded to as "The White Nun.-Albellus alter. Aldrov." "The female of this is also mistaken for a different kind, and called Mergus glacialis, which Mr. Johnson [of Brignall, near Greta Bridge] Englishes the Lough Diver." (Will. "Orn." I678, p. 27.)

Thomas Allis, I844, wrote:-

Mergus albellus. - Smew-Several have been shot near Doncaster in hard winters; it is rare near Leeds, but has been procured at Swillington in 1838 , and also at Gledhow; occasionally obtained near York, but the female and immutare male are much more frequent than the full plumaged male.

The Smew is not an abundant species; as a winter visitant it is met with sparingly at the coast and on inland waters, females or males in immature plumage being more often reported than old birds, though during severe winters and in stormy weather adults of both sexes are occasionally captured.

This bird is, perhaps, more frequently noted on fresh water than on the tidal portions; the river Hull in the neighbourhood of Beverley, and the Derwent near Cottingwith, Escrick, 
and Sutton, being favoured by its visits, which, as a rule, take place late in the season, in December, January, and February ; Mr. F. Boyes procured an adult female near Beverley, and he has seen four mature males killed near that place. It occurs rarely in the estuary of the Humber, and has been noted at Bridlington, Filey, Scarborough, and Whitby. At the Teesmouth it was frequent about forty or fifty years ago, but there are only three or four instances of its occurrence in Cleveland communicated during the past twenty years, one being a mature male taken on a pond at Skelton in the winter of Igoo.

Like its congeners, the Goosander and Merganser, it follows the course of the large rivers, and several have been killed on the Tees in the vicinity of Yarm, while on other streams and sheets of fresh water odd examples are reported from time to time. The late Rev. J. W. Chaloner shot a male and female on the Wharfe at Newton Kyme, on Igth January I892, at the same place where he had killed a male exactly sixty years before; on the river Nidd at Ribston three were seen and one obtained, in January I893; while it has been observed near Doncaster, Barnsley, Wakefield, Halifax, Leeds, York, Malton, and other places in this county, the particulars of which it is not necessary to recapitulate.

The Smew is not now sufficiently common to be known by any vernacular names, but it was called White Nun by Willughby, and Lough Diver by Ralph Johnson of Brignall, in 1678 .

\section{HOODED MERGANSER. \\ Mergus cucullatus (L.).}

Accidental visitant from North America, of extremely rare occurrence.

The true home of this Merganser is in northern America, whence, at rare intervals, stragglers have wandered to this country. Its occurrence in Yorkshire was chronicled by 


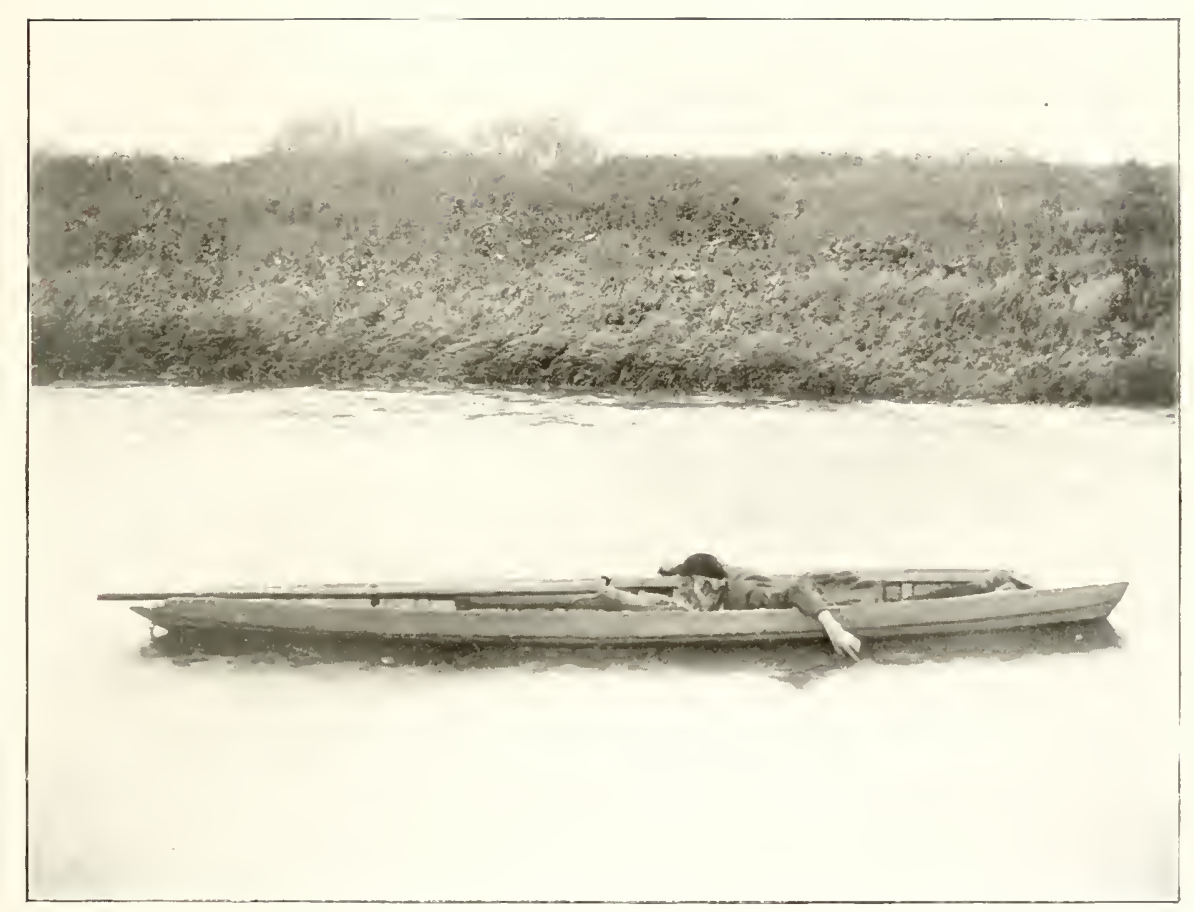

Snowden Sleights in his punt on the Derwent, near the place where the Hooded Merganser occurred.

S. H. Simith.

See page +87 . 

Gould in his "Birds of Great Britain " in the following words : "Mr. W. Christy Horsfall, of Horsforth Low Hall, informs me that he has a pair in his collection which were killed in the neighbourhood of Leeds."

In connection with this statement Mr. W. Eagle Clarke, when engaged in writing the bird portion of the "Handbook of the Vertebrate Fauna of Yorkshire," was unable to trace these specimens; my more recent efforts in that direction have resulted in obtaining the information that the British Museum (Natural History) at Cromwell Road, South Kensington, contains a mounted specimen of this bird in the British series, which bears the following particulars:- "Colder [? Calder] river, Yorkshire, I843. Mr. Parke. Presented by Mr. J. Baker." It is possible that this may be one of the examples referred to, as the river Calder flows into the Aire not far distant from Leeds.

I have, however, examined a male example, in the collection of Capt. Dunnington-Jefferson of Thicket Priory, which was procured in that neighbourhood by the well-known veteran wildfowler, Snowdon Sleights. Unfortunately, neither the present owner of the specimen nor its shooter kept a record of the date, and all the information the old fowler is able to give is that it was shot in the "North Ings," when the Derwent was in flood, and much of the surrounding country was covered with water.

\section{RING-DOVE.}

\section{Columba palumbus (L.).}

Resident, generally distributed, abundant. An influx of immigrants takes place in autumn, in varying numbers, depending upon the rigour of the season.

The earliest mention of the Ring-Dove in Yorkshire is probably found in the writings of the celebrated Marmaduke Tunstall, F.R.S., who lived at Wycliffe-on-Tees, thus :-

"Ring Pigeon. Have many here, and what is singular, VOL. 11 . 
more in the winter than in summer, even in the severest weather. Are very mischievous in gardens, destroying all sorts of grains, cabbages, etc. ... They usually begin cooing in March, though I have heard them in January, in mild, warm weather." (Tunst. MS. I784, p. 77.)

Thomas Allis, in I844, wrote:-

Columba palumbus.-Ring Dove-Also becoming rare near Halifax ; plentiful in other districts; although I have succeeded in breeding this bird in confinement, I never could domesticate it ; though hatched and bred in the Aviary, as soon as ever it had an opportunity, it would fly off to a distance and never return. The Stock Dove, on the contrary, bred, though not hatched, in confinement, has felt attached to its companions and its adopted home, and has returned and re-entered the cage after escape.

As an abundant and widely distributed species the RingDove, or Wood-Pigeon, requires but little notice here; it is resident, and breeds commonly and increasingly throughout the county wherever suitable woods and plantations are found, including the Wold districts of the East Riding being absent only on the moorlands of the north and southwest. In autumn and winter large flocks assemble, and, leaving their nesting localities, forage far afield for food in the stubbles or amongst the green crops of the lowlands, their ranks being frequently augmented by arrivals from more northern parts of the kingdom, or from the European Continent, the numbers of these foreigners depending upon the severity or mildness of the season, and the consequent scarcity or abundance of food. In October and November I884, an enormous influx took place on the north-east coast, continuing from 2oth October to the end of November (Sixth Migration Report, p. 59), and was observed in its full strength at Redcar, where one gunner on the sands shot fifty in three days, all birds coming in from the sea.

These migrations were very pronounced in I88I, I884, I889, I894, I898, I899, and I90I: in the last named year I saw great flights come in at Redcar on I6th November. During the severe weather of December I878, many of these birds perished of starvation, and were found dead on the beach at Flamborough. 


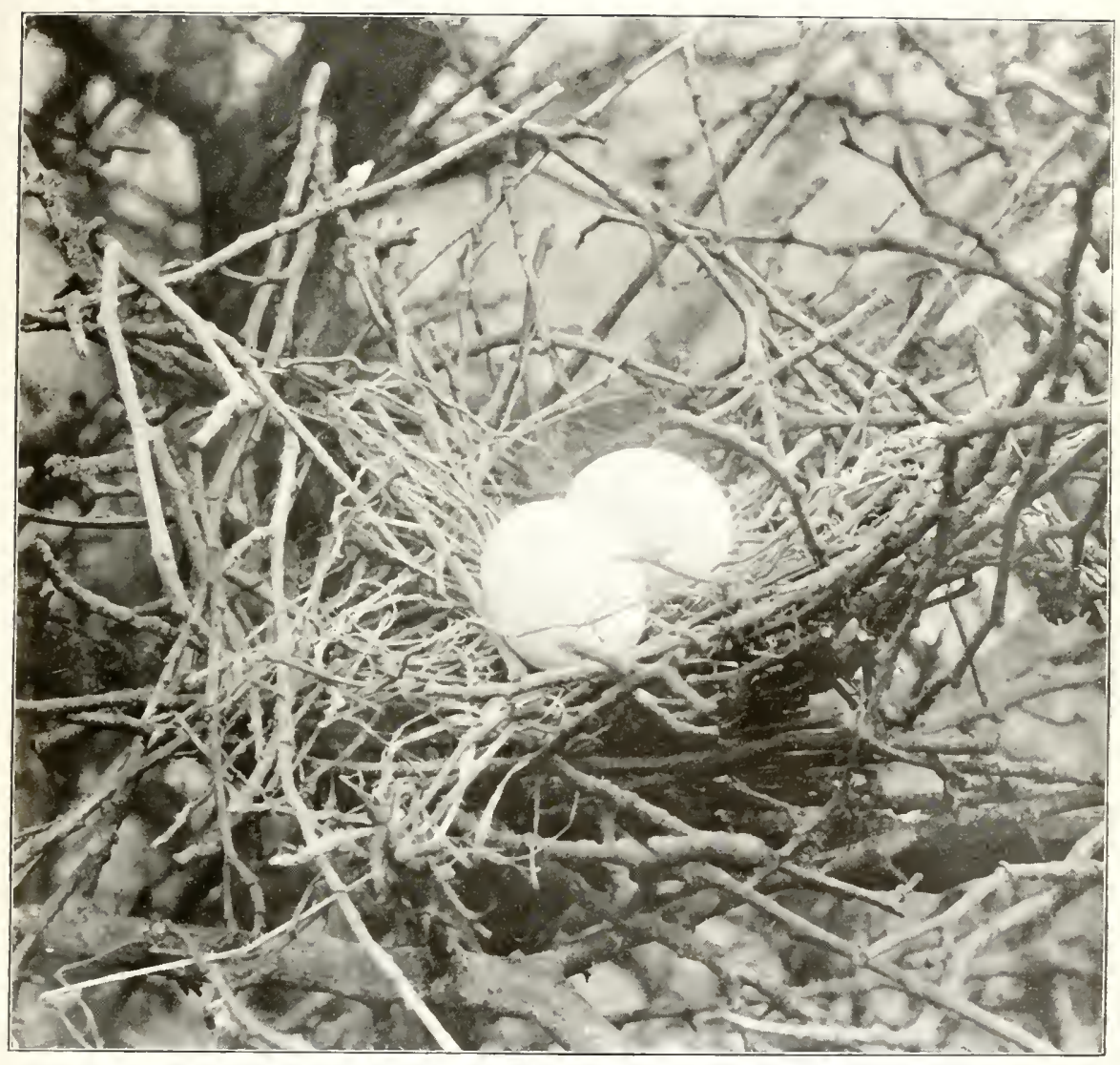

Ring Dove's nest.

R. Fortunt

See pare tion. 

In some instances the species has been observed at the Lighthouses on the coast, as reported to the British Association Migration Committee, and mentioned in the Reports issued by that body.

The voracious appetite of the Wood-Pigeon is commented upon so long ago as Tunstall's time, and as much as half a pint of wheat has been taken from the crop of an individual near York (Zool. r866, p. 456). As illustrating the damage done by this bird, the following saying, in vogue amongst Cleveland agriculturists when sowing beans, may be quoted :-

"Sow four beans in a row,

One to rot, one to grow,

One for the Pigeon, and one for the Crow."

Another item of folk-lore in the North Riding is to the effect that the common people believe that at some remote period the "Cushat" laicl its eggs on the ground, while the Peewit made its nest on high. An amicable exchange took place between the two birds, and at the present day they respectively sing out their feelings on the subject; according to the local rhyme the Peewit says-

$$
\begin{aligned}
& \text { "Peewit, Peewit, } \\
& \text { I coup'd my nest and I've it." }
\end{aligned}
$$

The Cushat's note implies-

$$
\begin{aligned}
& \text { "Coo, coo, come now, } \\
& \text { Little lad, with thy gad, } \\
& \text { Come not now." }
\end{aligned}
$$

Though not, as a rule, amenable to domestication, this species has been bred in confinement in the City of York, as mentioned in Allis's Report, and strangely enough a pair used to breed annually in the elms near the Boys' School at Bootham in that City. Late nesting is not uncommon, and, of Yorkshire examples, Mr. F. Boyes reports one of a nestling found on and November in the year I872.

Of variations in plumage may be mentioned a specimen with grey back, at Huddersfield (Zool. I888, p. 352); a pure white example, seen at Ingleby by Lord de L'Isle and Dudley, in the summer of IgOI; one of a pale red colour in Mr. F. 
Boyes's collection, and an albino specimen, procured near Scarborough, on 4th August I905.

Local vernacular names:-Cushat, in general use, altered to Cooshat at Fewston; Cushard in Teesdale; Cowscot in the North Riding, and Cooshout in Craven (A.S. Cusceate, Eng. Coo-shout); Wild Pigeon at Wilsden; Ring Pigeon (Tunst. MS. I7S4); Woodie in Cleveland; Clatter Dove at Staithes and Loftus; Stog Dove in the East Riding, and Stoggie or Stock Dore, occasionally applied in the East Riding, Scarborough, and Doncaster.

\section{STOCK-DOVE.}

Columba œnas $(L$.$) .$

Resident, local, common in most places where it occurs. Increasing in numbers, and in its area of distribution.

The first notice of this bird in Yorkshire appears to be that of Thomas Allis, who, in his Report on the Birds of Yorkshire, read before the British Association at York, in I844, remarked :-

Columba cunas.-Stock Dove-The only Yorkshire specimen I have seen is that in the Museum of the Yorkshire Philosophical Society, which I obtained in our market, where it was exposed for sale with a number of the preceding species [the Ring Dove], which had been shot by a neighbouring farmer. H. Chapman of York informs me that he, last winter, saw two or three other birds in our market with Ring-Doves, but that they were too much injured for stuffing. J. Heppenstall says they are not infrequent near Sheffeld along with palumbus. I have no other notice of their occurrence in Yorkshire.

The remarkable increase of the Stock-Dove since the date of Allis's Report is one of the most interesting events in connection with Yorkshire ornitholgy, and for much important and valuable information concerning its former existence on the East Riding Wolds, and the reasons for its diffusion, naturalists are indebted to the researches of $\mathrm{Mr}$. 


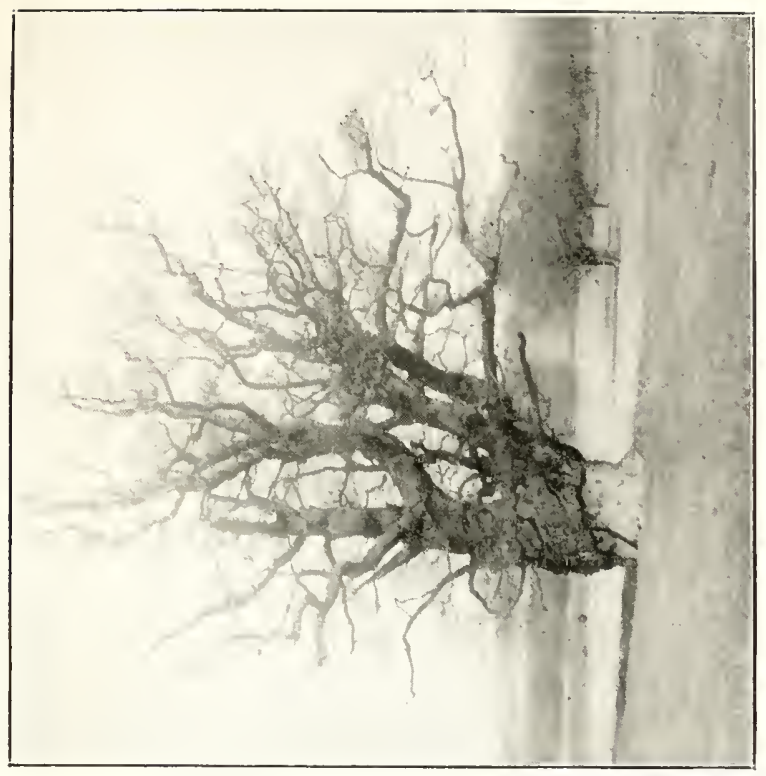

吾

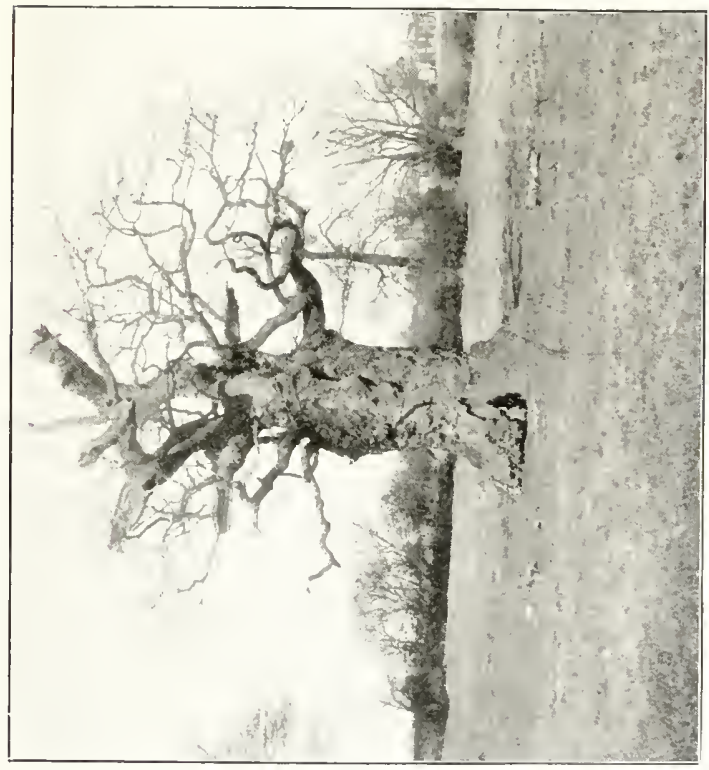

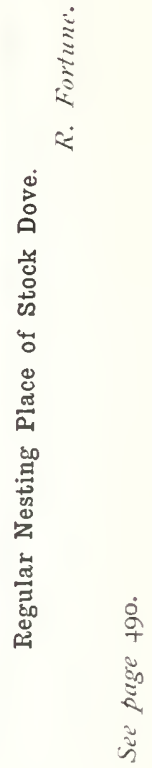



F. Boyes, who states that the bird has no doubt increased and spread over all parts of the county within recent years, but it existed on the extreme unenclosed tracts of the East Riding long previously.

Prior to 1864 it was numerous in all the old warren grounds, more so than at any subsequent period; for about that time the reclamation and bringing under cultivation of the warrens was commenced, and, with high farming and breaking up of the soil, the Stock-Doves were dispersed and driven out to find other haunts. At first, being loth to leave, they nested on the outskirts of the warrens under furze-bushes, amongst roots in old pits, or in holes about the roots of trees, and this habit of adapting itself to its surroundings, and finding a nesting site almost anywhere, is the cause of its wide distribution in the breeding season. Old warreners were still alive when this subject was investigated, and their evidence, extending to so far back as I820, was to the effect that the "Blue Rock," as they termed the bird, was very numerous then, breeding in the rabbit burrows, and they always claimed the young ones as their perquisites. Thus it is clearly shewn that our old writers, Allis and Strickland, had no knowledge of these warren birds. It is reasonable to presume that most parts of the county have been populated by these evicted tenants of the warrens, and it is highly interesting to know that, at a period when the bird was almost, if not quite, unknown in every other portion of Yorkshire, it should be so common on the Wolds, and that, with the gradual enclosure of these waste tracts, there was a simultaneous spread of the bird over the county.

A correspondent of the Field of I2th May I877, called attention to the sudden increase of the Stock-Dove near York; in $I 865$ it is described as rarely visiting the foot of the southern Wolds, and it only established itself in the Malton, Lowthorpe, and Flamborough districts about the same time. The late Canon Atkinson ("Moorland Parish," p. 347) recorded it as very rare at Danby in $1846-47$, when he noticed the first example there, whilst lower down the Esk Valley, and at Whitby, it did not appear until the "fifties." 
In the west of the county it was reported about 1875 ; in Masham neighbourhood it was first observed about 1842 , and numerous correspondents furnish information as to the extreme rarity of the bird until the latter quarter of the past century. It is now found breeding more or less abundantly in most districts, and in localities where it was unknown until within comparatively recent years, being reported even in the high dales to upwards of Iooo feet elevation; indeed, it may be described as being generally diffusec, excepting on the moorlands, and in manufacturing districts, where the conditions are unsuitable to its existence.

In severe winters it congregates in considerable flocks, associating with its larger relative, the Ring-Dove, in search of food. Several perished at Flamborough in the hard winter of $1878-79$, and near Redcar, in February I888, no fewer than fourteen of these birds were killed at a single shot, whilst feeding on cabbages in a field adjacent to the coast. It is common in winter at Lowthorpe, where, on 22nd January I897, out of sixty pigeons obtained, twenty were of this species. Though it is possible these assemblies are attributable to the gathering together of birds from various parts of this and neighbouring counties, and not to Continental immigrants, there nevertheless is sometimes an oversea migration.

It is mentioned in the Fifth Migration Report (p. 50) "25th October, at Kilnsea, one seen coming in from sea, and observed to pitch in a field near." At the Teesmouth a flight was noticed coming from seaward on 5th October Igor, and, in the following year, many were reported coming in at Flamborough in November.

The Stock-Dove now breeds commonly in the Beverley district; Mr. Boyes has several pairs inhabiting boxes in his garden, and a few have nested in the Minster and the Parish Church. In addition to its usual nesting sites in rabbit burrows and holes of trees, it is found in quarries, on the rocky ledges of inland "scars," such as those on the Hambleton Hills, in ivy-clad ruins, and occasionally in deserted nests of other birds, and on the wall-plates of field sheds. I have frequently seen it on the sea-cliffs which 
extend from Saltburn to Flamborough, and at Kettleness I shot one as it darted from a hole in some ivy. On the coast, as elsewhere, it is no doubt confused with the true Rock-Dove, which it far outnumbers, while it is probable that the so-called "Blue Rocks" reported as seen nesting on inland cliffs are referable to the present species.

Nidification commences early; Mr. E. R. Waite found eggs partly incubated near Headingly on $5^{\text {th }}$ March I877, and young have been seen near Beverley so late as October. An unusual instance of Stock-Doves and Starlings nesting in company near York is reported in the Zoologist (r88r, p. 65).

Variation of plumage in this bird is not common; Mr. John Morley of Scarborough had a pied example in August I905, and, near Malton, in August I903, he procured a curious specimen, which has dun or fawn coloured wings; the head, breast, neck, and under parts are lighter coloured than in the ordinary type, but the soft parts are of the normal colour. Another variety, with white and cream-coloured plumage, is recorded (Field, Igth August I896) as having occurred at Beckwithshaw, near Harrogate.

Local names:-Stockie or Stoggie in the East Riding, at Scarborough, and Doncaster (so called from nesting in stocks or trunks of trees). Rock-Dove-Beverley, Flamborough, Bempton, Western Ainsty, Ackworth, Thirsk, Hambleton, Swaledale, Arkengarthdale, Settle, Ribblesdale, and Whitby. Blue Rock-Eastern Wolds, Beverley, Teesdale, Ackworth, Fewston, Swaledale, Arkengarthdale, Nidderdale, Thirsk, Hambleton, and Whitby. Rock Pigeon-Western Ainsty. Wood Pigeon or Ring-Dove-Nidderdale and Ryedale. Burrow Pigeon-Sedbergh. Rocket-Dove-Gunnergate-in-Cleveland (from the rocket-like flight as it leaves the ivy-clad trees). 


\section{ROCK DOVE.}

\section{Columba livia (Bonnat.).}

Resident, local; breeds on the sea-cliffs.

The first allusion to this bird is, probably, that contained in Willughby's "Ornithology," where it is stated that it was described to that famous naturalist by Ralph Johnson [of Brignall, near Greta Bridge]. (Will. "Orn." I678, pp. 23, I86.)

Thomas Allis, in 1844 , wrote:-

Columba livia.-Rock Dove-Breeds abundantly on the rocks about Flamborough.

This bird is a very local resident, breeding in the caves of the Flamborough and Bempton range, and thence northward to the Cleveland coast, but in less numbers than the preceding species, though still in considerable quantities. Old George Londesborough, or Lowney, and Henry Marr, the cliff-climbers, once tried an experiment by which they hoped to make a good haul of these birds to supply a pigeon-shooting match. Selecting a suitable night for the occasion, as Marr has informed me, they let down a net over Bempton "PigeonCote," one of the large caverns where these birds breed abundantly; it was soon full of Pigeons, and they made sure of getting a good quantity ; they found, however, it was not possible to catch them alive, but they killed fifteen with a stick.

The Rock-Dove is also reported as nesting in some of the dales of the West and North Ridings ; there can be no question, however, that this bird is confused with the Stock-Dove, and my requests for proof of identity have failed to produce satisfactory replies.

The Flamborough Rock-Doves resort to the "Carrs" and Wold farms in winter to feed, when they associate with domestic pigeons, sometimes being trapped in the cotes with them, and, as the latter frequently escape to the cliffs, and interbreed with the birds established there, the task of 
discriminating between those which are ferce nature and the individuals which have reverted to a feral state is rendered very difficult.

The extraordinary capacity of Wild-Pigeons' crops has frequently been commented on; as an instance of this bird's voracious appetite it may be mentioned that an example was obtained at Fryup, near Whitby, in February I87I, whose crop contained seeds of the wild rape; these were counted, and totalled 7,424 , besides which there were 65 seeds of corn and barley, making altogether 7,489.

The vernacular name is Blue-Rock or Cliff Pigeon in ordinary use; at Flamborough and Bempton it is known to the fishermen and cliff-climbers as Rock Pigeon, in contradistinction to the Stock-Dove, whose cognomen is Rock-Dove.

\section{TURTLE-DOVE.}

Turtur communis (Selby).

Summer visitant; extremely local, but is increasing ; breeds in several districts, and is extending its range northward. Observed on the coast on both the vernal and autumnal migrations. Of rare occurrence in the west of the county.

The earliest notice of this, as a Yorkshire bird, is contained in the Report of Thomas Allis, written in I844, thus:-

Columba turtur.-The Turtle Dove-R. Leyland reports a single specimen shot some years ago near Halifax; Dr. Farrar has seen but one specimen which was shot near Rotherham about $1824 ; \mathrm{H}$. Chapman mentions it as having occurred to him; it is mentioned by W. Yarrell as having been taken near Scarborough; and I had one specimen which was shot at High Catton, near York; a single bird only has been seen by Arthur Strickland in the vicinity of Bridlington.

Popularly supposed to be a south-country bird, the Turtle-Dove has of late years, like some other species, been extending its range northward. In the middle of the past century, Thomas Allis, in his "Report on the Birds of 
Yorkshire," informed the naturalists of his day that there were but some half-dozen examples known in the county (a specimen shot at the Teesmouth in I837, now in Mr. Turton's possession at Upsall, appears to have been unknown to him); in I866 the late W. W. Boulton, writing from Beverley, mentioned that it occurred there sparingly, and that he had only had four or five specimens in the course of five years (Zool. I867, p. 543), and Mr. Howard Saunders, in the 4th Edition of Yarrell (I885, Vol. iii. p. 23), and also in his "Manual" (2nd Ed. I899), describes it as only a straggler on migration north of Sheffield. The evidence supplied, however, tends to prove that it is now a regular summer visitant, nesting in some localities where it was previously unknown, and annually in several districts in the eastern half of the county, while in all probability it is gradually becoming more widely diffused. At the present time its nesting area may be defined as being on the eastern side of a line passing through the centre of the county by Ripon, Harrogate, Leeds, and Wakefield, to Sheffield.

It now remains to discuss the distribution of the bird within this area, commencing at the southern limit of its Yorkshire range. For several years past it has nested in the neighbourhood of Sheffield, and, according to my correspondents in that district, does so still; the late W. Talbot, in his "Birds of Wakefield " (I876), did not mention it, though Mr. G. Parkin states that it now occurs in the nesting season. Near Doncaster its nest has been found in Wheatley Wood, and it breeds sparingly, but increasingly, in the Ackworth neighbourhood, while at Skipwith and at Pocklington it was reported to me as nesting in I894. It has for some years bred annually at Kipling Cotes, South Dalton Park (the seat of Lord Hotham), and Market Weighton, and is increasing. Mr. W. H. St. Quintin, writing in I902, says the TurtleDove was unknown to him in his nesting days, being first heard at Scampston about I885, later still at Lowthorpe, and now each year it is found at both places. At the end of May 1900, he saw five together in a field at Scampston, and in 1897 knew of six pairs in the plantations there. A 


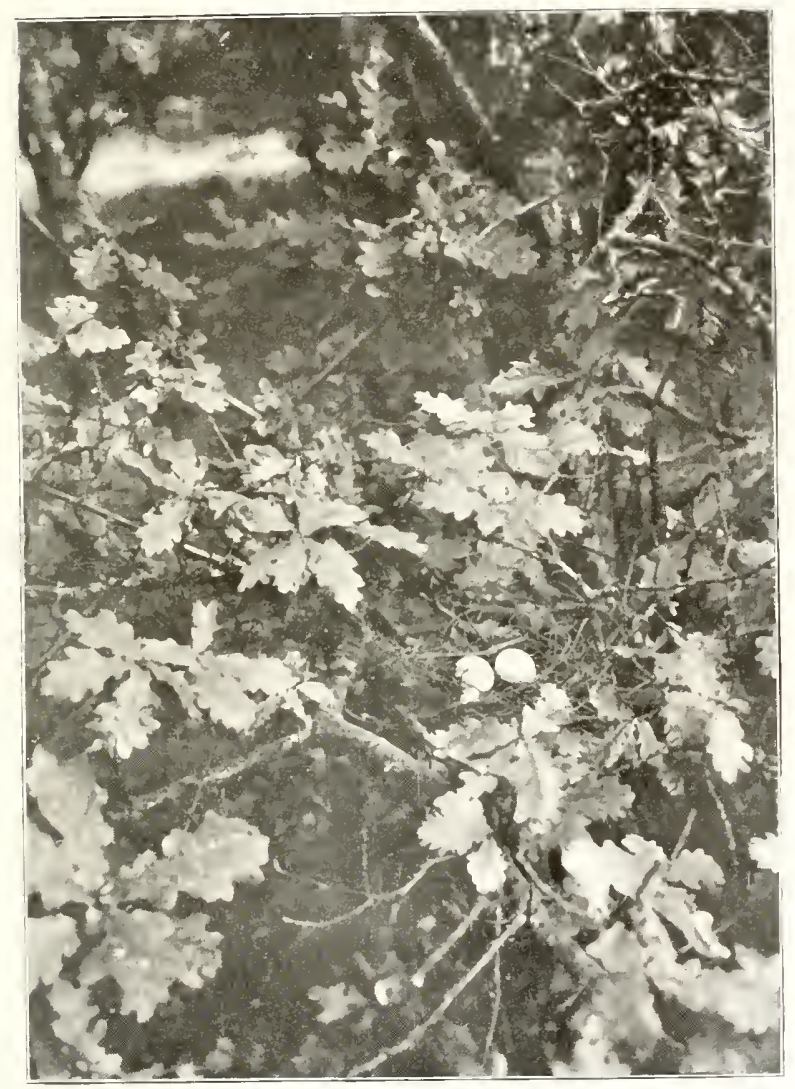

Nest of Turtle Dove, at Wykeham.

R. Fortune.

See pagt +97 . 

pair was reported near Masham in June I880 (Carter MS.). In the Central Plain, near the City of York, four nests of this bird were found in $\mathrm{r} 880$ (Zool. I88o, p. 405); further to the westward it is reported to have bred near Harrogate; and, since 1898 , at Woodhall Bridge, on the Wharfe, where there were three pairs in Igor; while at Scarborough it reaches the most northerly point at which the nest has been known with absolute certainty; there the eggs were found in June I900, and in I905 Mr. R. Fortune discovered a nest at Wykeham. It is not improbable, however, that the Turtle-Dove may have nested still further north, for, in the first week of June I902, two birds were seen for several days in a plantation near Marton-in-Cleveland, although a diligent search failed to reveal the nest.

As a migrant the species has been noticed both in spring and autumn at the coast stations, particularly at Spurn and Flamborough; at the latter place a flock of fifteen was seen in April I878, while the earliest date on which the bird has been observed is $I 7$ th April I896, when several arrived in an exhausted state at the Headland. In June $188_{3}$, I saw a pair on the Tees Breakwater, and in the autumn of I886 a small flock of seven alighted on Coatham sandhills, where one was afterwards killed. In various other localities, within the breeding area, it appears almost annually, but is of very exceptional occurrence in western Yorkshire; one was reported at Wilsden in 1876 , another at Halifax in I885, and it has been noticed at Skipton-in-Craven in July and August I880.

The latest date on which it has been chronicled is given by the late W. W. Boulton (op. cit. I866, p. 96), who noted one at Beverley on I8th November I865. 


\section{8 \\ RUFOUS TURTLE-DOVE.}

Turtur orientalis (Latham).

Accidental straggler from Asia, of extremely rare occurrence.

The first British example of this Asiatic Dove was made known through the instrumentality of Mr. James Backhouse, who procured it from Mr. Head, a naturalist of Scarborough, near which town it had been captured on 23rd October I 889 . The bird was forwarded to the late $\mathrm{H}$. Seebohm, who declared it to be Turtur orientalis, in first plumage, probably a wild bird, and a most interesting addition to the list of accidental visitors to England.

The specimen in question has been presented by Mr. Backhouse to the collection of birds in the York Museum (Nat. I890, p. 258; P.Z.S. I890 ; Saunders' "Manual," 2nd Ed. p. 487).

[An example of the American Passenger Pigeon (Ectopistes migratorius, L.), killed at Mulgrave, near Whitby, on I2th October I876 ("Birds of Nd. and Dm." p. 337, and Zool. I877, p. ISo), proved to be an escaped bird.]

\section{PALLAS'S SAND GROUSE.}

Syrrhaptes paradoxus (Pall).

Accidental visitant from the Asiatic Steppes, of extremely rare and irregular occurrence.

This singular looking bird, which is a resident of Chinese Tartary, is an accidental wanderer to the British Isles, its first appearance in Yorkshire taking place during the year I863, when a remarkable visitation was recorded. The facts, so far as they concern this county, are to be found in the Zoologist for I863 (pp. 8688-89, 8722-24, and I865, p. 9563), and a careful computation of the records made by Mr. W. Eagle Clarke resulted in his being able to state (" Hand- 
book of Yorkshire Vertebrata," p. 6I), that at least eighty birds had been seen, and twenty-four procured. Since the publication of the "Handbook," however, four other examples of the 1863 visitation have been discovered: one by Mr. P. Loten of Easington, who remembers having it to preserve, but cannot give any further particulars; and three specimens in the York Blue Coat Boys' School (J. Backhouse, Nat. I886, p. 308), two of which were obtained at Stockton-on-theForest, and one near Keighley, thus bringing the number of Yorkshire examples, taken in 1863 , up to twenty-eight.

Since that date there is no evidence of any other occurrence of the species in this county until 1876 , in which year several parties were noted on the Continent, and, at the latter end of August, I saw three on the sands near the Teesmouth. They were very wild, not permitting an approach nearer than a hundred yards, at which distance I distinctly identified them through a telescope. A shooter in the locality informed me he had followed the same three birds for a whole day, but in vain.

Exactly a quarter of a century after the first great incursion of Sand Grouse, i.e., in May I888, there occurred another, but on a much more extensive scale, assuming the proportions of an "irruption," which excited the greatest interest in ornithological circles. The arrival of the vanguard of this great host appears to have taken place simultaneously on the whole length of the Yorkshire seaboard, though, so far as I can ascertain, the first example was obtained in the north. The earliest comers, a party of six, were noticed at the Teesmouth about the middle of May,* and these, probably, all perished, as several were shortly afterwards found dead on the neighbouring salt marshes; a tail and foot of one were brought to me on I2th June. On 22nd May a female specimen, water-sodden, but otherwise in good condition, was picked up on the sands, and about the same date another

* I was absent from home in May, and on my return at the end of the month, was informed of the advent of these birds "early in May," but subsequent information fixes the date about the I5th or 16th of the month. 
was washed up by the tide. On 7 th June five (one male and four females) were shot near Marske, in mistake for Golden Plover, from a flock of thirty or forty; these I purchased shortly afterwards. At intervals during the summer months small flights were seen, some of which came off the sea, and on I3th November a pair was killed at Kirkleatham. At Ormesby a flock of twenty was seen on Ioth June; at the end of May one was found under the telegraph wires at Battersby; near Guisborough Mr. (now Sir) A. E. Pease caught one in a ditch, on 23rd October; at Allerton, near Pickering, ten or twelve were noted early in June, and near Misham two flocks, of seven and fourteen respectively, were reported by the late $\mathrm{J}$. Carter. In the Whitby district a male and female were obtained from a flock of twenty at Carr Hill, on 28th May, and six others were procured from a large flight in June, whilst at Kettleness a female was picked up below the telegraph wires. At, or near, Scarborough, on I6th May, a flock of twenty-five was reported, out of which a pair was shot; a male and female were killed from a flock of forty at Burniston on the 24th; two flocks, comprising eight and twenty individuals respectively, were seen on 28 th May, and near Slingsby six were noted on $9^{\text {th }}$ June.

In the East Riding Mr. D. Brown of Filey had thirty-two specimens sent for preservation, all of which were killed in that neighbourhood. At Flamborough the first comer was reported on I8th May, fifty or sixty more on the $24^{\text {th, and }}$ several other flocks of smaller numbers were observed or recorded by Mr. MI. Bailey, who states that an individual was found dead on the beach, and another in a field, whilst up to IIth October many were taken to him to be preserved. At Mappleton, near Hornsea, on 20th May, three were killed from a flock of sixteen; on June 7 th a party of fifty was noted ; on the 8th one of twenty-three, with others later, and between 28 th June and 5 th July fresh arrivals, coming from seaward, took place. At Withernsea a small flock was seen, and a female example secured, and on Igth November two males were killed at Hollym from a flock of about forty in number. The famous promontory of Spurn, as might be expected, 
was not neglected : on I8th May Mr. P. Loten and his father noticed four birds coming in from the direction of the sea, five more being observed by the light-keeper on the same date; twenty others were noted at Welwick, and various small flights occurred in different parts of the promontory from then until the 3 Ist May, when the late J. Cordeaux estimated the numbers seen at seventy; seven others were shot and one "telegraphed." On Ist June four more were killed, others being recorded from time to time until the end of the month.

In the Beverley district fourteen were brought in by a farmer and eight by another man; at least fifty pairs were in the neighbourhood in July, and a large flock was noted between that place and Driffield in June.

Near Market Weighton two were obtained from a party of thirty in June; the Rev. E. Maule Cole reported two at Wetwang on 6th September, and a pair in the Hull Museum was killed on 29th May, near Etton. On the open land between Kilham and Burton Agnes a large number was observed by Mr. W. H. St. Quintin for some weeks; he gave strict orders for their protection, but early in August they were reduced from forty-two to twenty-two birds, being then in heavy moult. Several other smaller parties were noticed flying about the district, but nothing had been seen of them at Lowthorpe since August, and it was presumed they had departed.

In West Yorkshire Mr. W. Eagle Clarke received the earliest notice of the Sand Grouse on I7th May, when one was brought to him which had been captured the previous day in Dewsbury Road, near Leeds; two days later a party of twenty was seen near Ardsley Reservoir; on the 24th a specimen was "telegraphed" at Newton-le-Clay, and eight others noted at the same place. Mr. Riley Fortune saw four at Beaver Dam on the 26th; near Goldsborough a flock of fifteen was noted on the 3oth; two were procured, from a party of five, at Darley in Upper Nidderdale, by Mr. Smorfitt, and others were reported in several localities in the Western Ainsty. The Rev. E. P. Knubley recorded a flight of twenty at 
Staveley; two were killed at Staveley Bridge; one was noted near Huddersfield, and a pair in the Settle district. On I4th February in the following year (I889), a female example was shot, from a flock of seven, by a fisherman at the South Gare Breakwater ; the next day another was killed at the same place, and a male bird was picked up dead, whilst in January a female was found dead near York.

It is an ascertained fact that some of these interesting birds nested in East Yorkshire, two clutches, consisting of two eggs each, being reported near Beverley. The first was discovered on I5th June I888, on Newbald Lodge Farm, by Joseph Long, rabbiter, whilst the other was found by the late Johnson Swailes, laid on the bare ground at High Gardham, on 5 th July in the same year. These specimens are now in the possession of Mr. T. Audas.*

The individuals examined in winter or in the year following their arrival were much darker in plumage than those first obtained ; two males killed on 2Ist December I888, at Hollym, in Holderness, scaled eleven and twelve ounces respectively. The heaviest specimen I weighed was ten ounces.

The crops of those killed generally contained seeds of weeds, although two specimens, taken near Redcar in winter, had been feeding on wheat and buckwheat, as also had some other examples that were killed near Spurn, where a grainladen vessel had been wrecked.

It is quite possible, indeed almost certain, that many of the flights were recorded more than once, by different observers, but again there can be no doubt that fresh arrivals continued to cross the sea, and this renders the task of estimating the numbers chronicled extremely difficult. I have, however, after making due allowances for the circumstances mentioned, arrived at the following figures, which are taken to be the lowest possible estimate of the numbers seen and obtained in the three Ridings, according to the information available.

* A beautiful coloured plate of these specimens, with a brief description by Mr. T. Sheppard, appears in the Transactions of the Hull Scientific and Field Naturalists' Club, Vol. III. pt. 4, for 1906.-ED. 


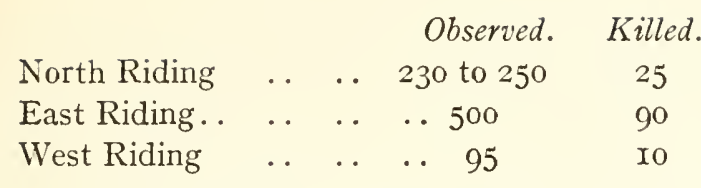

The authorities consulted in reference to the irruption of I888 are numerous notes in the Naturalist, the Zoologist, and the Field for 1888 and I889.

Subsequent to the I 888 invasion of this species, the following occurrences are reported :-

On 24th May I890 six were seen, coming in from the eastward, by two boatmen while about half a mile at sea off the Spurn light; the birds passed within thirty yards, and were afterwards seen to alight on the sandhills (Nat. I890, p. 202). In May I89I, the late Col. Haworth-Booth saw six on the cliff tops at Roulston; a pair procured soon afterwards was in his possession (op. cit. IS95, p. 327). On x $3^{\text {th }}$ May $x \$ 99$, a small flight at Easington was seen by Mr. P. Loten (op. cit. IS99, p. I75), and the latest occurrence is reported to me by Mr. T. Wellburn, keeper, of Millington, East Yorks., who writes that, in the second week of February I904, he observed a flock of eighteen, travelling northward; they passed him within a few yards, and, having seen many in 1888 , when he had five specimens through his hands, he easily recognised them by their flight, long pointed wings and tail feathers, and also by their call note. A neighbouring keeper saw a small flock about the same time.

\section{CAPERCAILLIE.}

Tetrao urugallus $(L$.$) .$

Formerly resident in the forests of north-west Yorkshire; now extinct.

Evidence is afforded of the former existence of the Capercaillie in the discovery of bones amongst the remains in VOL. II. 
the Victoria Cave, near Settle. In one of the caves of Upper Teesdale, also, at an elevation of 1600 feet, numerous bones of this bird were found by Mr. James Backhouse, who tells me that the cave is situate in Durham County, about two miles from the nearest point of Yorkshire, but it is hardly conceivable that such a bird would adhere to one side of the vale, and not occasionally visit the other. Amongst these bones is one nearly perfect humerus, belonging to a male bird of full size; others, less perfect, to the female of ordinary size; whilst others, again, are smaller than those of the type. Some appear to indicate a hybrid between this species and the Red Grouse. From the abundance of the remains, there can be no doubt that the Capercaillie was, in past ages, a common inhabitant of the forests of the north of England, and was taken into the caves as food, either by cave men or cave animals.

The only instance of its occurrence in the county, within historic times, was in the woods near Clapham, where a male example was procured by the late Mr. Foster, whose son, Mr. Wm. Foster of Stoke House, Tenbury, writing on 2oth February I904, informs me that, so far as he can ascertain, the bird was killed about the year I830, and was preserved, but my informant does not remember what became of it. $\mathrm{He}$ is of opinion that it was not a bird which had been turned out in the neighbourhood of Clapham, and he adds that his father and the late James Farrar of Ingleborough were the only persons who shot in that part of the county at the period named (cf. Rev. E. Peake, Nat. I896, p. 45).

In connection with this note it is well to remember that the date is somewhat extraordinary, as this bird became extinct, even in Scotland, in the latter half of the eighteenth century, and was only re-introduced there in 1837 . 


\section{BLACK GROUSE.}

Tetrao tetrix (L.).

Resident, local, occurring chiefly on the western borders of the county. Has been introduced in several districts.

In view of the general interest attached to this noble game-bird, it is desirable to give at some length the details concerning its past history and present distribution in the county. There is proof that it was an indigenous, and possibly abundant, species in prehistoric times, in the discovery, made by Mr. James Backhouse, of remains of this bird in the Teesdale caves, though the earliest dated allusion to it, so far as can be ascertained, is in the list of Wildfowl supplied to Skipton Castle in the seventeenth century, I606I639 (Whitaker's "Craven," 2nd Ed. p. 3ro) ; it is referred to by Fr. Jessop, one of John Ray's correspondents, who, writing from Broomhall, Sheffield, on 25th November I668 said : "I have stuffed the skin of a Moor Cock and Moor Hen" ("Correspondence of John Ray," I848, p. 33). Another renowned Yorkshire ornithologist, Marmaduke Tunstall, F.R.S., of Wycliffe-on-Tees, also mentioned it, and his quaint comments are quoted in extenso, conveying, as they do, his opinions on the decrease of the bird in the north of England. His remarks are as follows :-

"(Tetrao tetrix, Lin. \& Gm.). Grown very scarce all over the North of England . . . . for which many probable reasons are given : the principal seem to be the great improvement of late years in the art of shooting flying; moors and commons taken up; the hurt sustained by burning the ling in the moors to make the herbage grow, which it is very difficult to prevent, being commonly done by stealth in the night; when once fired will reach miles: this done in the spring destroys many eggs, and the old ones upon them . . . lastly, the facility of carrying them to London and the great trading towns; and the great demand there for them by flys and machines, and various other causes.

The whiteness of part of the breast so singularly contrasted 
by the surrounding black flesh, seems rather a singular circumstance. Commonly called in the north the White Muscle. This is not found in the congenerous species of the Cock of the Wood, or Red Grouse. The Black Cock is a very rare bird in Yorkshire at present. Was assured by an elderly gentleman, that he remembered them on our neighbouring moors; now a Phœnix or a Parrot might as well be seen ; in short, except in a very few places, where they are diligently guarded, they are rarely to be found in this or any of the Northern Counties. ... Sometimes a few are found in wild boggy moors, where none can come at them. (Tunst. MS. I784, pp. 78-9.)"

The Rev, Geo, Graves, the author of " British Ornithology " (I8I3), noted the fact that " poachers take considerable numbers of Blackcocks by imitating the call of the hen-bird, as many as fifty males being lured by this means in the course of two days." R. Leyland, in I829, remarked it was pretty common near Sheffield, but odd individuals occasionally strayed, and he had known examples killed in Wombwell Wood and vicinity in 1829 ; and Dr. Farrar. in I844, stated it was naturalized on Bradfield Mloors. Thomas Allis, in his Report, also written in I844, observed :--

Tetrao tetrix.-Black Grouse-J. Heppenstall says they are pretty abundant in some woods near Sheffield, and that a female was taken one evening last winter, about ten $a^{\prime}$ clock, in a street of the town; R. Leyland says two instances have come to his knowledge of the female of this species having rambled so far from its native locality as the neighbourhood of Heptonstall and Lightcliffe; it is sometimes. met with near Hebden Bridge; S. Gibson has a fine male shot there, May I 842 .

The present status of the species is that of a resident, limited in numbers, and very local in its distribution, being restricted chiefly to the southern, western, and north-western parts of the county, and, generally speaking, stationary or decreasing in numbers. It still breeds in one or two localities in the neighbourhood of Sheffield; in the Holmfirth and Penistone districts it has been introduced by Mr. Spencer Stanhope, and a few pairs breed annually. In the Hebden 
Valley several attempts have been made to acclimatise it; eggs were set under domestic hens and chicks were reared, but they gradually died off or disappeared; similar results attended efforts in the same direction at Whitewell in Bowland, the last specimen obtained there being a Grey-hen, shot on Holden Clough in I885; nor has any greater success been achieved at Arncliffe in Wharfedale. Near Huddersfield it has been naturalized at Meltham, where a few pairs still breed, and some are killed annually on the moors. On the Bluberhouse estate in Washburndale it was formerly not uncommon, as is shown by the following extract from Sir Thomas Frankland's gamebook for I798:- " Pullan, keeper, says that when a boy he shot nine Blackgrouse one morning on these moors, and that his mother made them into a pie for the haymakers." It had evidently greatly decreased after that period, for some were turned down by Mr. J. Yorke of Pateley Bridge, but soon disappeared. The present owner, Lord Walsingham, writing to Mr. W. Eagle Clarke on I4th September I886, says "I have killed two, and seen one other since this moor has been mine; the last killed was in 1875 , the last seen in $1877 . "$ A more recent instance of its occurrence is mentioned by Mr. William Storey of Fewston, who saw a male and two females in a plantation in February I895. In Arkengarthdale and Swaledale the Black Grouse is found at Kexwith in the New Forest, where it breeds in small numbers, and is slightly increasing ( Nat. I892, p. 323); it is fairly numerous on Col. Wade Dalton's Barden and Hauxwell moor, between Leyburn and Richmond, and also on a small moor about three miles north-west of the latter town; a few brace occur on Stainton moor, and an occasional brace on Carperby moor. In Wensleydale it breeds annually on Bellerby Moor ; odd birds are found on Lord Bolton's moors, and it has also been seen on the East Witton moors, near Colsterdale, but the numbers do not appear to increase.

In the extreme north-west corner of the county near Sedbergh, a few, probably wanderers from Westmorland, occasionally nest in Garsdale. In Upper Teesdale district 
three or four plantations are specially devoted to this bird, where it is probably increasing; this appears to be the case also at Lartington, where it has been introduced, and is fairly common in the fir woods, whence stragglers find their way on to the adjoining moors; Mr. E. B. Emerson shot several examples on Bowes moor in the "seventies."

In the Cleveland area Mr. Thomas Stephenson of Whitby was told by Mr. W. H. Raw that Blackgame bred yearly in Commondale until I847; a specimen obtained there is in his possession, but, about the date mentioned, a pine plantation, where they nested, was cut down and the birds disappeared; a few were turned down at Kildale in I840, by the late R. Livesey, and were occasionally found in the neighbouring woods (Zool. I845, p. III2); I have been informed by Mr. W. Cook, late keeper of Grinkle, that some were introduced into East Cleveland about the same year; they bred along the moor edges, and were from time to time killed in the fir plantations around Gerrick until I86o. The late Canon J. C. Atkinson reported a brood of nine on Danby low moor in I846, which died out, although, to his knowledge, none were shot ("Moorland Parish," p. 309). Odd birds were met with in Glaisdale until I840, and in Fryup until I865. In I872 Blackgame were re-introduced on Lord Downe's Danby estate, but no evidence is forthcoming as to their breeding there, though odd individuals occasionally occurred in the neighbourhood. In the winter of 1864 a Black-cock took up his quarters in a rabbit warren on the cliffs near Loftus, where it remained till spring. Sir A. E. Pease remarks that an old gamekeeper, named Pearey, formerly in his employ, could remember Blackgame being common at Hutton in the early part of the past century; the last indigenous nest was seen about 1852 . Several pairs of birds were turned out at Birk Brow, near Guisborough, in 1860 , and there was a brood that year at Waupley. Within the past few years I have had intelligence of a few examples seen on the Cleveland Moors, and so recently as I903 Lord de L'Isle and Dudley, writing on I6th December, says a Black-cock was observed on the moors near Guisborough in 


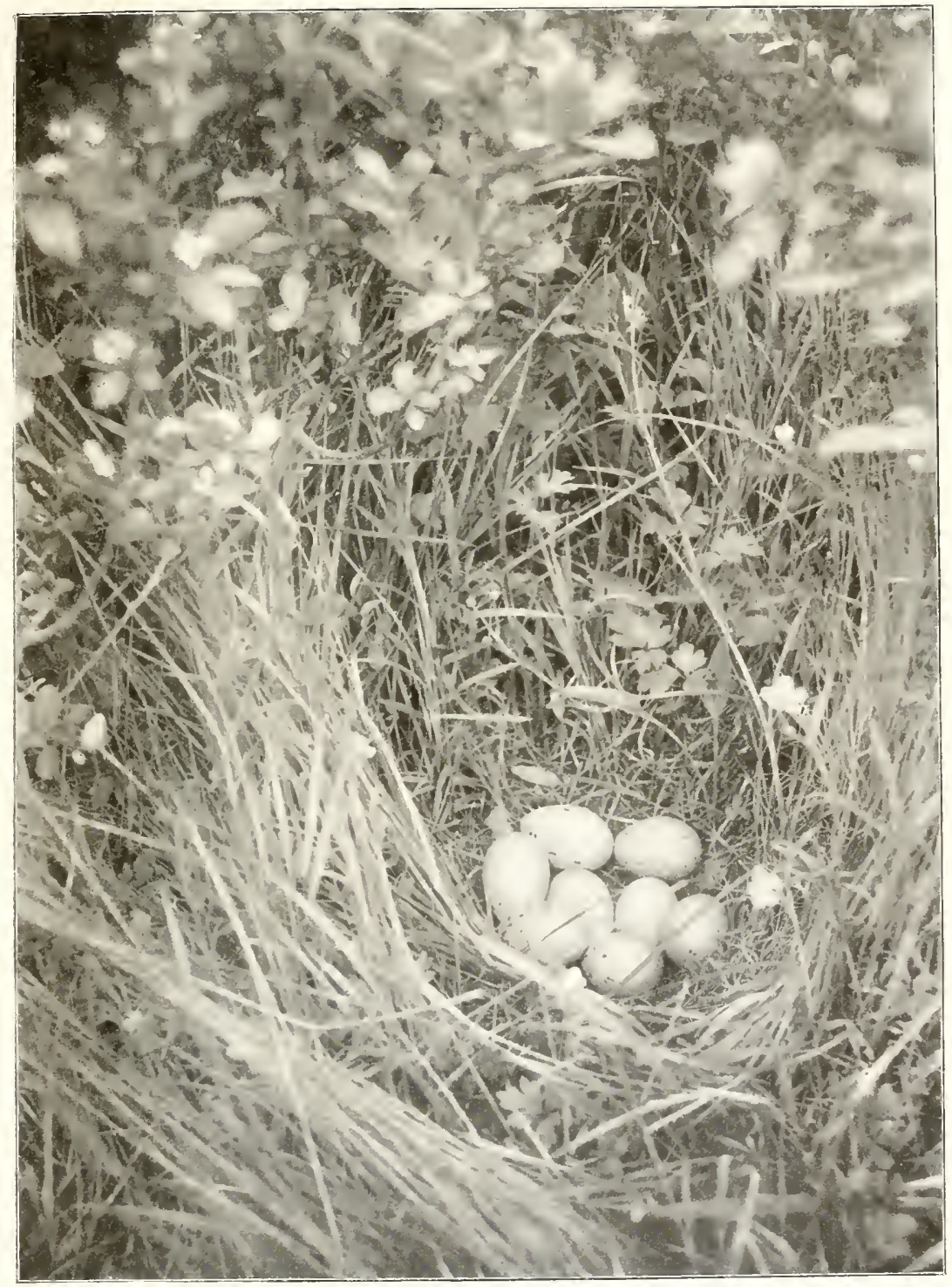

Nest of Black Grouse, north-west Yorkshire.

R. Fortune.

Se' puge' 5os. 

October; one was procured in Bransdale in the year I890, and in Bilsdale, south of the Cleveland area, they were introduced by setting eggs, about I896, but do not appear to have become acclimatized.

In the south-east of the county an attempt was made to introduce this species on Thorne Waste; a few birds have been observed at long intervals; a nest was found in the year I880, while Mr. Leonard West of Brough killed a male bird in October 1896 , near the Vermuyden River.

The causes which have led to the general decrease of Blackgame in Yorkshire are, probably, the increase of Pheasant rearing and the consequent multiplication of those birds, the cocks battling with the Black-cocks for possession of the woods, and so driving them away. In various other parts of the county than those indicated stragglers have occurred, travelling birds, doubtless, from one or other of the above mentioned centres of introduction; one instance only need be cited as an example, namely: two Grey-hens seen on Strensall Common in 1892 .

Cases of hybridity between the Black Grouse and Pheasant are not infrequent, and of these Yorkshire can claim two examples; one was shot on 3oth October I894, on a moor near Loftus-in-Cleveland, which, through the kindness of Mr. F. Wilson Horsfall, came into my possession; it exhibits the characteristics of both parents, but the Pheasant predominates, and it is of the same type as that figured in Vol. iii.

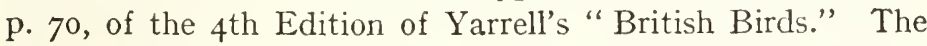
other, which is similar to the first, was taken near Whitby, being acquired by Mr. W. Pyman, and described by Mr. W. B. Tegetmeir (Field, 23rd January, I897); it is a somewhat strange coincidence that both these birds should have been obtained within a short distance of each other, and points to a similarity of origin.

Local names:-Black-cock (male), Grey-hen (female), Heath Cock, Blackgame. 


\section{RED GROUSE.}

\section{Lagopus scoticus (Iatham).}

Resident, abundant on all the high moors, and in severe winters occurs as a straggler in lowland localities.

Although mentioned in Whitaker's "Craven" (I8I2), as occurring in the Skipton Castle accounts (I604-I639) of Lord Clifford, last Earl of Cumberland, the first published reference to this bird in Yorkshire was, so far as is ascertained, made by Willughby, who alluded to it as "Red Game, called in some places the Gorcock and Moorcock. It is frequent in the high mountains of Derbyshire, Yorkshire," etc. (Will. "Orn." I678, p. 177).

Another early allusion to the species is in a letter dated I2th September I724, written by Sir Hans Sloane to Dr. Richardson of North Bierley, and thanking him for his "present of potted Moorfowl." ("Dr. Richardson's Correspondence," p. 2I2.)

Marmaduke Tunstall also, in 1784 , gave a long dissertation on the Grouse in the Teesdale district, under the name of "Red Cock." He stated that "This singular species of moor game appears to me to be confined to the British Isles. . . . . This fine species, like the Black, has been much diminished these late years to my knowledge ; have a pretty large tract of moor myself of some miles extent, where I have known 25 or 30 brace killed of a day, but are now miserably fallen off, tho' carefully watched; and in the same state are most of the moors in the North, owing to the same causes as the destruction of the Black Cock. Some even say, the Act of Parliament, postponing the time for the commencement of shooting, has done more harm than good, as, when the young ones were killed so early, the old birds frequently had a second brood, which escaped, yet this appears to me rather problematical. When the early shooting was not forbid, they began in June, when many broods were very small, and as many were worried by dogs as killed by the gun. One great cause of their decrease, as well as the Black Game, is the 


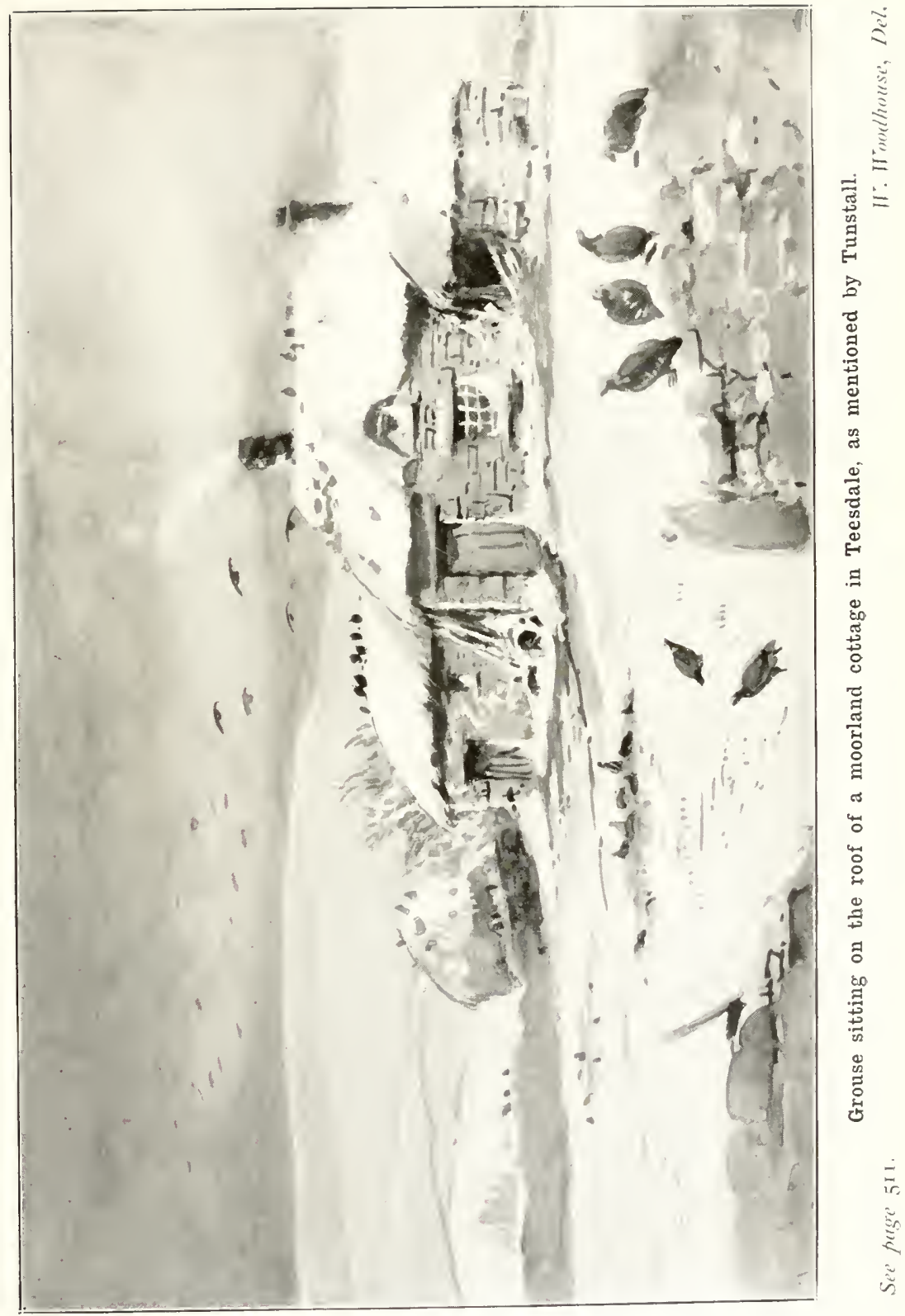



population and enclosing of wild lands and moors. ... I have been told, (and this from good authority), even his Majesty had not tasted any till about ten years since, which, I believe, came from my moors. I sent a fine pair, well set up, to Linnæus, in the year I773, which he admired much, and acknowledged in a very polite letter. .... One, of a much superior size than usual, was killed near Richmond, in Yorkshire, in Oct. I877, which weighed 25 ounces. Tho' very shy in mild winters, yet in severe weather they will come down to the vales in the neighbourhood of the moors, and feed with the common fowls, and sit on the ling coverings of the poor cottages, sometimes in great numbers, the poor peasants not regarding them, or meddling with them. Was told by a neighbouring apothecary, who goes into the fells to visit his poor patients in this weather, that he has seen the whole roof of the house covered with moor game, sitting so quiet that they appeared at first like domestic poultry. ... Excuse this digression, as I am in the country of this fine bird, the species of which I see daily expiring under my eyes, to my great regret, even in my own property, notwithstanding what care I can take of them." (Fox's " Synopsis," p. 79-8o.)

Thomas Allis, in I844, wrote:-

Lagopus scoticus. - Red Grouse-Common on all the high moors.

The Grouse may be termed the typical bird of Yorkshire, as in no other English County is it so widely distributed or so abundant; it is found without exception throughout the broad belt of moorland extending from the Derbyshire border in the south to the extreme north, including Teesdale, and the moors between the Cleveland and Hambleton Hills and the coast line as far south as Scarborough; nor is it confined to the high moors, as on the low ground where heather is common it is also to be met with in abundance; in fact, wherever there is a wide expanse of heather these birds will be found more or less numerous. Mr. F. Boyes observes that within his recollection heather was abundant in the Market Weighton, Cliffe, and Holme-on-Spalding-Moor districts of the East Riding, now under cultivation, and he can remember the last Grouse being shot there. He is of opinion that they 
were introduced with the idea that they would thrive, but the experiment had proved to be a failure.

It is doubtful if Grouse migrate far from their own ground for any lengthened period; the Rev. H. H. Slater informed Mr. Eagle Clarke, on the authority of his uncle, Mr. T. Horrocks of Eden Brows, Carlisle, that towards the end of October every year there is a migration of packs of Grouse from the Duke of Cleveland's moors in Teesdale to Mr. Horrocks's moors at Alston in Cumberland, a distance of twenty miles, where they remain till the end of the season, and then return to their own country. A large proportion of these emigrants are hens, and are different in size and plumage, and readily discriminated from the Alston birds, being only two-thirds their size and weight, and the plumage more speckled and yellow (cf. Zool. I895, p. I07). Grouse have been seen at Strensall, where a covey of eight or nine was flushed on I3th August I88I. They also occasionally migrate from their own ground to the neighbouring moors for food, but this chiefly occurs during the afternoon, as they seldom move about much during the day unless disturbed, and feed only once a day, viz., towards evening.

In severe winters, when there is a great depth of snow, birds are driven down to the cultivated valleys literally by the thousand, the moors being utterly deserted by them. So long as the snow is soft at the top they are able to form tunnels several feet in depth to get to their food; when, however, a thaw is followed by rain and succeeded by a frost, the surface of the snow becomes glazed with ice, and they are unable to make a way through owing to the formation of their claws, which, admirably suited as they are for walking on soft snow, are not adapted for burrowing through its surface when frozen; the result is that, forced by want of food, they leave the moor in immense packs and travel down to the low country where, as in I886 and r 895 , they feed on corn and turnip leaves in the fields, on shoots of the blackthorn, haws, and buds in the hedgerows, and wherever food of any description is to be found. In weather like this they may be seen perched in hundreds in the hedgerows and on 
the lower branches of trees. Large numbers have been observed on the sea beach in the Cleveland district, and on one occasion during a lengthened snowstorm a pack of several hundred birds passed over ; these, however, were only present when the tide was down, and as the water flowed they returned to the moors.

It is often found that in very mild, as well as in severe, winters a partial and temporary migration takes place, as the lower moors are sometimes full of birds that, it is known, do not belong to the ground, and that shift their quarters again later on; frequently too a sheltered moor will attract a big stock of birds in wild rough weather, but the stay is only of a temporary nature. Birds also shift from the low grounds to the tops in fine weather, returning again if a change for the worse occurs. In the winter of 1878 several were obtained at Redcar, and in December of that year I passed within five yards of a hen Grouse feeding on a hawthorn bush behind the sand-hills; in the severe winter of I879-80 Grouse were seen at Oswaldkirk, near York, and at Bridlington. In the storm of $\mathbf{1 8 8 6}$, when heavy snow on 24th January was succeeded by a partial thaw, accompanied by rain, and then followed by frost, large packs of birds came down into the lowlands, and were noticed in lower Swaledale and Wensleydale, Arthington, Weeton, Leeds, and other places remote from their usual haunts, as many as five hundred being seen in one day; numbers were killed by flying against the telegraph wires, others were shot by pot-hunters, or died of starvation, and many, doubtless, never returned to the moors.

In 1895 a state of weather similar to that in I 886 prevailed, and many Grouse appeared in the vicinity of Harrogate and lower Nidderdale.

On the breaking up of the storm birds gradually work back to their original quarters, although many seek fresh ground, thereby providing a much needed change of blood, to the ultimate advantage of the supply on the moors. It has often followed that, despite the immense losses incurred during a severe storm, when dead Grouse may be picked up 
by the dozen in a short walk, the succeeding season has been fully up to, or above, the average, especially on the lower moors. It might reasonably be expected that, after a severe winter, the birds would be left in a weakly state, and the clutches of eggs would be smaller and the young broods weaker, but this is not the case; possibly the whole of the weakly and diseased individuals, being unable to withstand the weather, succumb, thereby leaving a stronger and more vigorous breeding stock.

Grouse are seldom observed in the cultivated lowlands in mild winters, although during the season I903-4 they were seen in scores on oat stubbles adjoining the moors in Wensleydale, an event of rare occurrence; probably the exceeding late harvest had something to do with this. It was most interesting to watch them feeding on the stooks, where they appeared to adopt the same method of stripping up the ears as they do in dealing with the young shoots of heather; evidently they are exceedingly fond of corn, as they persistently frequented these oat stubbles when shooting was going on a few hundred yards away.

The habits of Grouse are even yet imperfectly known, but, thanks to the keener observations of some of the more intelligent moorland keepers, fresh traits are constantly being discovered; as is well known, they are very fond of grit, which is in fact a necessity to them, and until recently it was not generally known that they ate peat, but in north Yorkshire they have been observed to do so. In the mornings they eject a pasty mass of indigestible matter; this was very conspicuous on the snow in the winter of I895, and Mr. J. Ingleby of Eavestone kindly forwarded me samples, which were examined by Mr. Percy Grimshaw of the Royal Scottish Museum, who pronounced them to consist of pieces of grit and vegetable matter, leaves of plants and ling, formed into a pulp. Partridges eject substances of a similar nature. Grouse will freely perch on the stunted trees at the fringe of the moor, and they have constantly been observed late in the autumn and early winter perched in thorn bushes on a lowland moor in Wensleydale. In frosty weather they are 
often seen on the wall tops, and will remain there until an intruder gets quite close to them if driving, as they take but little notice of a passing cart; yet a man walking across the moor will flush every bird within hundreds of yards. Tunstall refers to the habit of these birds perching on roofs of cottages; in the great storms of I886 and I895 they were seen on the hawthorn hedges, and in January of the latter year Mr. M. A. Horsfall of Hornby Grange, Northallerton, shot a cock Grouse from the top of an oak tree. Many in the Bowes district were also observed sitting in trees.

Grouse are comparatively easy to rear by hand; Mr. John Thwaite, Moorland Cottage, Hawes, informs me that in 1865 he had seventeen birds so tame that they would feed out of his hand and follow him wherever he went on the moors, walking as long as they could, then rising and flying to overtake him. He reared Grouse more or less every year from I860 to I870. One peculiarity of these birds is the extreme pugnacity of the cocks, which appear to be absolutely without fear, and will attack both dogs and men with the greatest impetuosity.

In Yorkshire the coveys are found packed by the first week in August, and it is now the universal custom to drive early in the season on all the principal moors. It is still an unsettled question when shooting birds on the wing was first practised in England. In the time of James I. it was the custom to take game either by nets or with Hawks; and in a memorandum made by Wilson of Broomhead, the antiquary of Broadfield, it is stated that the first person who shot Grouse on the wing on these moors was a member of his own family, who died in I687, at the age of sixty-one (Hunter's " Hallamshire, S. Yorkshire," Vol. ii. p. I83). Yarrell (" British Birds," I843, Vol. ii. p. 318) mentioned that Lord Strathmore's keeper on the Teesdale moors was matched to shoot forty brace on I2th August, and performed this feat with great ease, bagging forty-three brace by two o'clock. At eight o'clock in the morning, owing to fog, he had only killed three birds.

The following letter addressed to $\mathrm{Wm}$. Lipscombe, Esq., of Beech Lawn, near Wakefield, gives probably the best account 
of the origin of Grouse driving. It is dated Cannon Hall, Barnsley, 28th November I885, and is as follows:-

"Grouse driving first commenced on the low moor at Rayner Stones (now cultivated) about I805. There were regular drives in I84I, but no butts. Three brace per gun for a drive was considered a good bag, and a bag of fifty brace in 1843 was considered a great day. Holes were dug on Ryshworth and Edwarde's moors in I847. In August I849, 448 Grouse were shot, which was considered the highest score up to that date. W. Spencer Stanhope."

The late Henry Savile's keeper, George Sykes, has generally been credited with the first application of the system of Grouse driving; he laid out the ground on several moors, High Force amongst them. There is no doubt that the system of driving and the great care and attention paid to preservation have enormously increased the stock of birds on the Yorkshire moors, and more are now bagged in one day than were previously killed during the whole season when shooting over dogs was in vogue. At High Force, in General Hall's time (I886), eight guns killed from I3th to I7th August $2,6 \mathrm{I} 6$ brace. In $\mathrm{x} 8 \mathrm{72}$, which was the record year for Yorkshire, some very heavy bags were made, and on 6th September, on Mr. R. H. Rimington-Wilson's moor at Broomhead, $\mathrm{I}, 3 \mathrm{I}_{3}$ brace were killed in one day by eleven guns driving, which was the largest number recorded that season; in the same year $\mathrm{x}, 040$ brace were stated to have been bagged by seven guns. Wemmergill was exceedingly prolific in game that season; in six days a party averaging six guns killed $3,983 \frac{1}{2}$ brace, and during the season 17,074 birds, of which Sir Frederick Milbank claimed 5,668; the average total bag on this moor for twelve seasons was 4, I33 brace, whilst the largest collective bag was made on 2oth August I872-I,035 brace to six guns, of which Sir Frederick shot 96 brace in one drive lasting twenty-three minutes, his total bag for that day amounting to 728 birds. A granite monument erected on Wemmergill moor commemorates this feat in Grouse shooting.

Lord Walsingham, on Bluberhouse, on 28th August I872, 
had 842 birds, shooting in two batteries for twelve hours; twenty drivers were employed, in two parties of ten each, for sixteen drives, the guns used being a pair of breechloaders and a pair of muzzle loaders; on the same moor in 1864 the largest bag was 85 birds over dogs. On 3oth August I888, his lordship killed $\mathrm{I}, 070$ birds in twenty drives, using four breech loaders, and having two men loading.* On Mr. R.

* First drive commenced at 5-12 a.m.

No. of Birds to each Drive. No. of Minutes in each Drive.

\begin{tabular}{|c|c|c|c|c|c|c|c|c|}
\hline & 49 & $\cdots$ & $\cdots$ & $\cdots$ & $\cdots$ & $\cdots$ & $\cdots$ & . 33 \\
\hline & 64 & . & . & . & . & . & . & . $3^{8}$ \\
\hline & 59 & . & . & . & . & . & . & $\ldots 16$ \\
\hline & 79 & .. & . & . & .. & . & . & .. 18 \\
\hline & 71 & . & . & . & . & . & . & . 24 \\
\hline & 58 & . & . & . & . & . & . & . 18 \\
\hline & 56 & . & . & .. & . & . & $\ldots$ & .. 19 \\
\hline & 53 & . & $\ldots$ & . & $\cdots$ & . & $\cdots$ & .. 20 \\
\hline & 42 & $\cdots$ & . & . & .. & .. & . & .. 20 \\
\hline & $6 \mathrm{I}$ & . & . & . & $\ldots$ & . & $\cdots$ & $\ldots 16$ \\
\hline & 16 & . & $\ldots$ & $\ldots$ & $\ldots$ & $\ldots$ & $\cdots$ & $\ldots 17$ \\
\hline & $2 \mathrm{I}$ & . & . & . & . & . & $\cdots$ & . 30 \\
\hline & 32 & . & . & . & . & $\ldots$ & $\cdots$ & $\ldots 25$ \\
\hline & $9 \mathrm{I}$ & . & . & . & . & $\cdots$ & $\cdots$ & $\ldots 2 \mathrm{I}$ \\
\hline & 39 & . & . & $\cdots$ & $\ldots$ & . & . & .. 28 \\
\hline & 93 & . & . & $\cdots$ & . & . & $\cdots$ & $\ldots 21$ \\
\hline & 52 & . & . & $\cdots$ & $\cdots$ & $\cdots$ & $\cdots$ & $\ldots 20$ \\
\hline & 33 & . & . & . & . & . & . & .. 24 \\
\hline & 23 & . & $\cdots$ & . & $\cdots$ & $\cdots$ & $\cdots$ & $\ldots 2 I$ \\
\hline & 30 & $\cdots$ & . & $\cdots$ & $\cdots$ & $\cdots$ & $\cdots$ & .. 20 \\
\hline Walking home & $\begin{array}{r}\ldots \quad 14 \\
\end{array}$ & & ncluc & ling & $7-30$ & p.m. & & \\
\hline
\end{tabular}

Picked up ... . 22

12

1070

From first shot to last, $14 \mathrm{hrs}$. $18 \mathrm{~min}$. No. of cartridges fired, about 1,550 , including 40 signal shots.

Deducting the 14 killed walking home, and adding $22+\mathrm{I} 2$ picked up, the result is 1,056 killed in 449 minutes, or $2 \frac{1}{3}$ per minute in the actual time occupied in shooting in the 20 drives. Once three birds were killed at one shot, the only three in sight at the time, and thrice two birds were killed at one shot, each time intentionally. 
H. Rimington-Wilson's moor, in the year I904, a party of nine guns made a record bag of I,374 brace on 24th August. On the Marquis of Ripon's moors near Studley Royal, Lord de Grey has killed 575 birds in one day, as one of a party of seven guns. In Igor, a Richmond game dealer sent away, during one week in August, I7,352 Grouse, the price ranging as low as $2 /$ - per brace.

Grouse pair in January or even earlier, generally commencing to nest in March or April ; the old cocks are most pugnacious, driving away the younger birds during the breeding season, and the old hen birds also drive off the younger hens from their vicinity, with the result that the nests suffer. Young vigorous Grouse usually have clutches of from seven to nine, whilst the older birds seldom lay more than five to seven eggs; occasionally, but very rarely, nests are found to contain more than ten, although an instance is on record of one at Routh Head, Arkengarthdale, in I885, with seventeen eggs, but in this case probably two birds used the same nest. On Lord Walsingham's moors a nest of fourteen eggs was found, all of which were hatched.

In severe weather nests have been noticed with the contents carefully covered with moss or heather, thus affording protection trom late spring frosts; as eggs are generally found to be uncovered in normal conditions, it would appear that the birds have some instinctive foreboding of the approach of bad weather. When the moors are covered with snow, as occasionally happens during the nesting period, many nests must of necessity be lost and the eggs destroyed through being hidden from view by the covering of snow. In these circumstances the birds, being unable to find their nests, drop their eggs at odd places on the open moorland; many were thus found in I903.

There is no doubt that fewer eggs are destroyed by the action of frost than is generally thought to be the case, as the surrounding heather affords a certain amount of protection. In the exceptionally good grouse year of 1872 snow was lying on the higher hills in North Yorkshire for a period of three days during the nesting time, yet the season was a record one. 


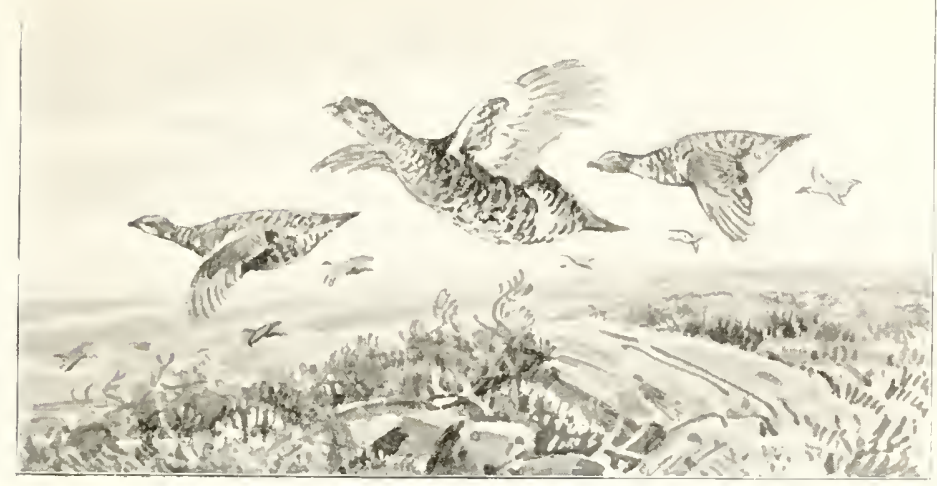
A Flight of Grouse.
II. IVodherese
$D e \%$

Se'r pases 508 .

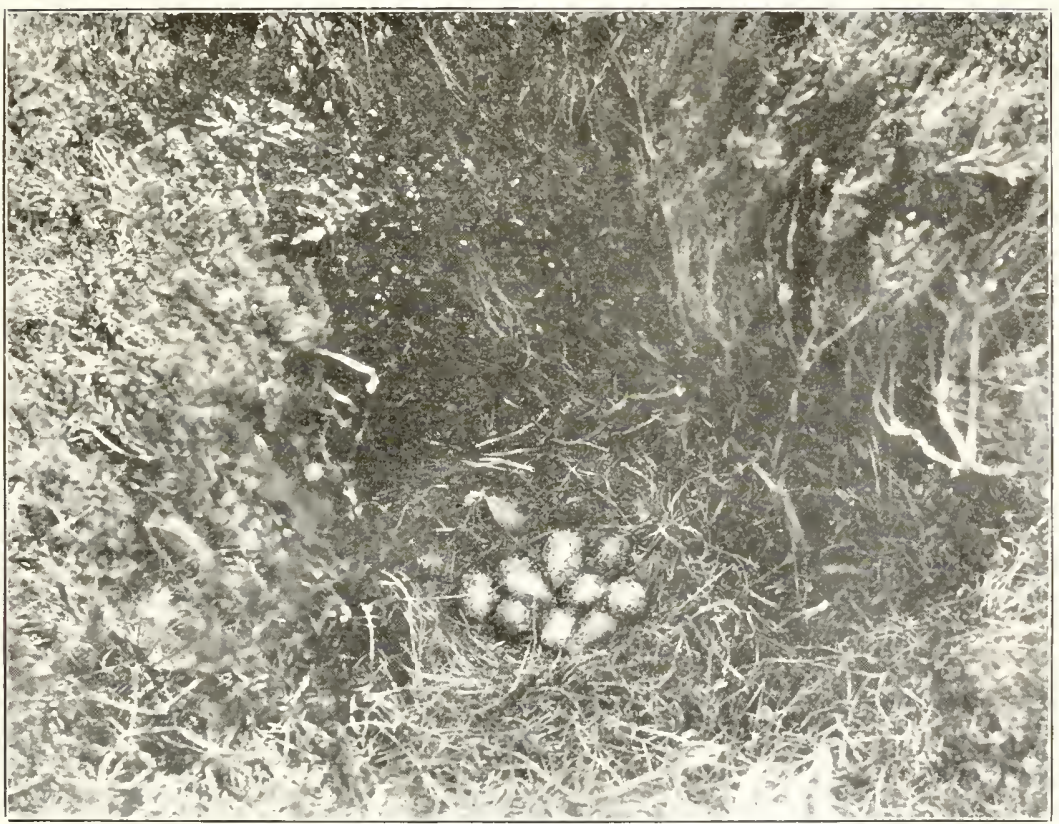

Nest of Red Grouse.

R. Fortune. 

In the year I903, when the late spring frosts took place, and the hills were covered with snow at the time the birds were busy nesting, it was feared that numbers of eggs would be spoilt by the frost, and on at least one large moor in North Yorkshire the keepers were instructed to destroy all the eggs found (under the mistaken impression that these would be frozen), with disastrous results, as the second clutches were small, and the birds late and not fit to shoot at the commencement of the season.

Young Grouse have been seen early in April; Yarrell mentions that a brood able to fly a little were seen on $5^{\text {th }}$ March I794, on Pendle Hill, on Lord Ribblesdale's moors ("British Birds," I843, Vol. ii. p. 3I7 ; and 4th Ed. Vol. iii. p. 75). When the early nests have been destroyed late broods are the result, and an instance is given of a hen being found sitting on a nest of six eggs on Bingley Moor on I2th August. There is a considerable variation in the size and colour of the eggs, the ground colour normally being pale olive, with dark brown, almost red, blotches all over them, some being quite light in shade, whilst others are much darker. An egg little larger than a Robin's was found in 1877 on Sykes Moor, Bowland, and a clutch very dull in colour and quite abnormal, except in size and shape, was found near Ripon.

Grouse vary greatly in plumage, some varieties being much lighter than others and more speckled; in some districts the hens are not only considerably smaller but are of a more golden hue, resembling to a great extent the colouring of the Golden Plover, and in Cleveland these birds are locally termed "Moss Hens" or "Lancashire Duns"; this peculiarity has been noticed in Coverdale, Wensleydale, and in Upper Teesdale, whilst on a moor near Harrogate packs of birds are annually seen late in October which can be distinguished from residents by their smaller size and more golden colouring. Other variations from the normal plumage occur: birds partially white were seen one season near Pateley Bridge, and others similarly marked, some of which were shot, at Whernside, whilst a pure white specimen was shot on Lady Chaytor's moors at Caldbergh. A brood of cream coloured 
birds were on Crimwith moors, near Pateley Bridge, and of these three were procured; two are in the possession of Mr. Newbould, Grouse Inn, Pateley Bridge, and one is owned by Mr. Hutchinson (Nat. I886, p. 48). A curious specimen reported at Bolterstone, near Sheffield, was pale on the upper parts and had the breast suffused with black (op. cit. I887, p. 374); another variety occurred near Middleham, the belly being entirely white, eyes and legs pink, and the rest of the body a delicate fawn colour (op. cit. IS9I, p. II5). Whernside moors were at one time noted for silver varieties; Mr. R. H. Rimington-Wilson informs me that he has a nearly white specimen, killed on Broomhead moor, another slate coloured, and a bird which in appearance resembles a hybrid between the Grouse and the Partridge ; and Mr. E. B. Emerson has a hen bird, shot by himself on his Swainby moor, about the year I89o, that is of a uniform black plumage, speckled with grey or yellowish grey, and a few greyish brown marks on the breast.

In the Field of I3th January I866, reference is made to a Grouse in Wensleydale which had a third foot protruding from under the right wing. Hybrids are not unknown, and a cross between this species and the Partridge was recorded from Bluberhouse by Lord Walsingham (Nat. I896, p. I59; and Yarrell's "British Birds," 4th Ed. Vol. iii. p. II4). In the Field of 2nd June Igoo, Mr. John Foster of Hortonin-Ribblesdale, near Settle, states that he flushed a bird from a nest containing seven Grouse and five Partridge eggs.

Grouse vary considerably in weight, the cocks being much heavier than the hens ; Daniel, in his "Rural Sports," recorded one at Richmond of twenty-five ounces; Pennant one of twenty-nine ounces (Yarrell, I843, ii. p. 3I9); a bird weighing thirty-two ounces was killed by Mr. Newbould, at Pateley Bridge, on I7th August I872, whilst one of thirtyfour ounces was recorded in the Field of I6th November I90I. Tunstall mentioned twenty-five ounces as being an exceptionally heavy weight, but birds up to twenty-eight ounces have been reported, and Mr. A. W. Chaytor of Scrafton Lodge, Coverdale, has killed one of this weight. The average 
weight in the Wensleydale district is about twenty-four ounces for cocks and twenty ounces for hens.

The dreaded Grouse disease has at times greatly reduced the stock of birds on some moors, but it does not appear to have attracted any attention until the year I847, although the remarks made by Tunstall, previously quoted, as to the great decrease of the birds in his time, would lead one to infer that it was then prevalent. For a long period after I 847 the outbreaks of the disease were sporadic, occurring every seven years, but this may have been merely a coincidence, yet many keepers still believe that a recurrence will take place at these periods. Dr. Klein made a thorough investigation into the causes of the epidemic, but it is problematical if the true reasons have as yet been ascertained. Overstocking, with the consequent scarcity of food, stagnant water, and the attendant indigestible character of the food when the young shoots of heather are nipped by late spring frosts, are all prejudicial to a healthy stock. Various theories have been from time to time advanced by close observers, men who have spent all their time in a moorland district, and one of these, the late Dr. Cockroft of Middleham, was strongly of opinion that the epidemic resembled most closely typhoid fever in the human subject, and there is great reason to believe that his diagnosis was correct.*

There is an Act still in force for regulating the seasons when heather shall be burnt, but its provisions are not strictly enforced in Yorkshire. In past times heather burning, except during the legal periods, was looked upon as a serious offence, and in the "Charge to the Jury," found in the old minute book of Harmby township, in the North Riding, dated in I825, the following statement occurs under the head of "Ling " :-

"And if any person shall burn any Ling, Heath, Furze, \&c., between the 22nd February and the 24th June (old style) he shall be sent to the House of Correction for any time not exceeding a month, there to be whipt and kept to hard labour."

*cf. J. E. Harting on "Grou se Disease," Field, 25th June 1904. 
This extract shows that it was a risky proceeding to burn heather during the nesting period, although it is improbable that the enactment was made in the interest of the Grouse.

I have been favoured by Lord de L'Isle and Dudley with a copy of a "Bill of Particulars," of a sale of the Ancient Baronry, Manor, or Lordship of Stokesley, in March I779; from which it appears that amongst the lands offered for sale were "Two very extensive moors or commons called Stokesley Moor and Basedale Moor, containing together 3,129 acres, represented to afford the finest and most abundant Grouse shooting in the North of England. This privilege was formerly let to a gentleman at $f_{5} 6$ a year."

The rights of shooting on the famous moor of Bowes, now at a very high rent, were in the "fifties" let by ticket at $£ 5$ per gun. Year by year the rents of Grouse moors in Yorkshire are increasing, and, owing to the improved value of the shooting rights, and the greater attention paid to the management of the vast expanses of breezy moorland, the Grouse is far more numerous than of yore, and there is no likelihood of it losing its position as the typical bird of Yorkshire.

Considering the wide distribution of this bird in the county, the folk-lore is very meagre. In the Craven dialect the crowing of the Moor Cock is termed "Bragging"; and Gormire on the Hambleton Hills is supposed to derive its etymology from the Gor or Moor Cock.

The local names are:-Red-game, Gor-cock, Moorcock (Will. "Orn." I678), whilst Tunstall termed it the Red Cock (MS. I780). It is generally called Moor-game or Moor-bird, and in one case where there is a variation in the colour and size of the hens these are locally termed Moss Hens. Moor-poot or Moor-pout is also applied to the young bird, and in the Craven district this term is metaphorically an "ignorant clown " or " one bred at Moorside." 


\section{PHEASANT.}

\section{Phasianus colchicus (L.).}

Resident; semi-domesticated, common, generally distributed.

The first Yorkshire mention of the Pheasant is found in the account of the great banquet at Cawood, in I466, given in honour of the enthronement of Archbishop Nevell. Included in the provision made were: "Fessauntes, 200." (Leland's "Collectanea.") In the Northumberland Household Book, begun in I5I2, at Earl Percy's Yorkshire castles, "Fesauntes" were priced at "I2d." "for my Lordes owne Mees." The bird is also mentioned at the marriage feast of Sir John Neville's daughter at Chevet, near Wakefield, in I526, and

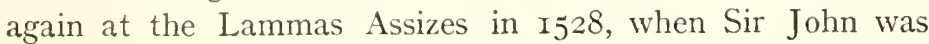
High Sheriff; his expenses including "I2 ffesants $£$ I"

Thomas Allis, I844, wrote:-

Phasianus colchicus.-Common Pheasant-As common as shooters and poachers will allow them to be.

Allis's pithy remarks as to the status of this well-known game-bird are as true at the present day as they were in $\mathrm{I} 844$, and it requires but little further notice here; it is common where preserved, and generally distributed, except in the highest portions of the West and North Riding dales, and on the moorlands, though not altogether absent even in those places.

The ring-necked variety ( $P$. torquatus) has been so largely introduced of late years that the old-fashioned race ( $P$. colchicus) is now seldom found pure, the majority of the birds exhibiting more or less signs of hybridity with the former species.

The late John Cordeaux stated ("Birds of Humber District," p. 79), that he had known several instances of Pheasants flying across the estuary, four miles, on to the Lincolnshire coast, though observers in Spurn neighbourhood are sceptical on this point, and some ornithologists are doubtful whether this bird can fly such a distance. At Redcar 
Pheasants occasionally come down to the sands, and so recently as October I90I, a hen bird flew over my head down to low water mark and along the beach.

Many curious nesting sites and incidents connected with nidification might be mentioned, but one or two will suffice. A deserted nest of a Ring-Dove was selected by a Pheasant in which to lay fifteen eggs at North Stainley, near Ripon (Nat. I894, p. I74) ; and I am enabled to give an illustration of a nest in a squirrel's drey, 22 feet from the ground, at Plumpton. An instance of a Tawny Owl and a Pheasant occupying the same nest, at the foot of a spruce fir tree at Hambleton, is recorded in the Field, 2Ist. May I898 : in the same journal for IIth October I902, is an account of a hen Pheasant being flushed by Partridge shooters in September from a nest of nine eggs at Mulgrave; and on the adjoining estate of Grinkle, Mr. W. Cook, keeper, told me he had seen a cock Pheasant brooding ten eggs.

White and pied varieties are common; rufous, cream or fawn-coloured, and mottled specimens have occurred; whilst an example of a hen assuming the plumage of the male, obtained in North Yorkshire, is in the possession of Mr. George Parkin of Wakefield (Nat. I887, p. 45), and others have come under the observation of Mr. F. Boyes.

Two instances of hybridity between Black-game and Pheasant are dealt with under the former species, p. 509.

\section{PARTRIDGE. \\ Perdix cinerea (Latham).}

Resident, generally distributed, abundant.

The Partridge may claim ancestry of great antiquity in this county, for we find, in the ordinances respecting the price of victuals in the City of York, issued by Royal proclamation, dated I393, the value of a Partridge was placed at $2 \mathrm{~d}$. In the Selby Abbey Accounts for the years I4I3-I4 is an 

item, "paid for catching ... Partridges at Crowle, 2s." It appears in Leland's description of the Cawood feast, at the enthronization of Archbishop Nevell, in I466, when 500 "Partriges" were included in the provision made; and in the oft-quoted Northumberland Household Book, in I5I2, where the price of "Pertryges" was fixed at "ijd. a pece yff they be goode" for Earl Percy's table at "Wressill and Lekinfield." The bird is also mentioned in connection with the marriage feast of Sir John Neville's daughter at Chevet, near Wakefield, in I526, "forty Partridges" being priced at 6s. 8d. ; and two years later, when Sir John was High Sheriff, amongst his expenses were eighty Partridges at $£$ I $6 \mathrm{~s} .8 \mathrm{~d}$.

Thomas Allis, in 1844 , wrote:-

Perdix cinerea.-Common Partridge-Common in most parts; scarce about Halifax and Hebden Bridge.

The life history of the Partridge has been so ably written by authors of works dealing exclusively with sporting-birds, that little remains to be related here on this well-known indigenous species. It is generally distributed and abundant, excepting in the Halifax and Skipton districts, and on the highest mountains, where it is reported to be scarce. On the lower slopes of the north-western fells, and on the borders of the moorlands, there is a rather smaller race than the lowland bird, and, probably from the nature of its food and surroundings, it appears somewhat darker in colour, whilst the flesh partakes slightly of the Grouse flavour. In some localities this is referred to as the "little moor Partridge."

Yorkshire can claim its quota of curious incidents connected with the Partridge; several cases are reported of the eggs of common farmyard fowls being hatched, and the chickens adopted, with the bird's own proper family (Zool. I865, p. 9793 ; and Saunders and West, Field, 7 th July I900, and 27th September I902). In the autumn of the year I884 I was witness of a remarkable incident of the tameness to which these wild creatures may be brought with care and patience ; the birds, two in number, were hatched from eggs set under a bantam, and were reared by Mr. J. J. Emerson's gardener at Easby Hall in Cleveland. For several weeks they lived 
in a walled enclosure, following the gardener about while he attended to his duties, and became so tame as to permit visitors to approach within a yard of them; they were fed regularly by the hand, and even took corn from a lady who was a stranger to them. They shewed no desire to leave their home until they were frightened by a cat, and from that time they flew out into the park to roost, returning at daylight to receive their breakfast (Zool. I885, p. 29). I have twice seen a covey fly out to sea at Redcar, and on one occasion, at high tide, observed seven or eight birds settle on the water near the pier, where they remained for a little time and then rose and flew inland. In January Igor a Partridge was picked up about a mile off at sea, where it had alighted near a boat.

Of curious nesting situations may be mentioned one in a farmyard at Laughton-en-le-Morthen, in I85I, and another on the top of a stack, about twelve feet from the ground, at Brompton, near Northallerton, in May I886. The nest has occasionally been found at the extreme point of the Spurn promontory, and amongst the bents on the Breakwater at the Teesmouth, where there was one in April I900, containing seventeen eggs, all of which were hatched.

Nidification has been recorded as early as Igth February, and an early brood was found at Bolton-on-Dearne on 27th May I872; whilst in the other extreme a hen bird was noted sitting on nine eggs as late as I4th October, at Cherry Burton (Field, Ist November I884). On 2Ist March I883, an unbroken covey was noticed at Masham.

Although the immense bags of Partridges made in more favoured counties are not equalled in Yorkshire, yet there are some on record which are noticeable. At Hornby Castle, in I859-60, no fewer than 5,359 birds were killed, and Earl de Grey shot 303 birds near Ripon, to his own gun or guns, on 23rd September I884.

Many examples of white and parti-coloured specimens are chronicled; in the "Gentlemen's Magazine" (I797), is an account of four birds of a delicate milk white, which were taken in a net in September, and kept in confinement 


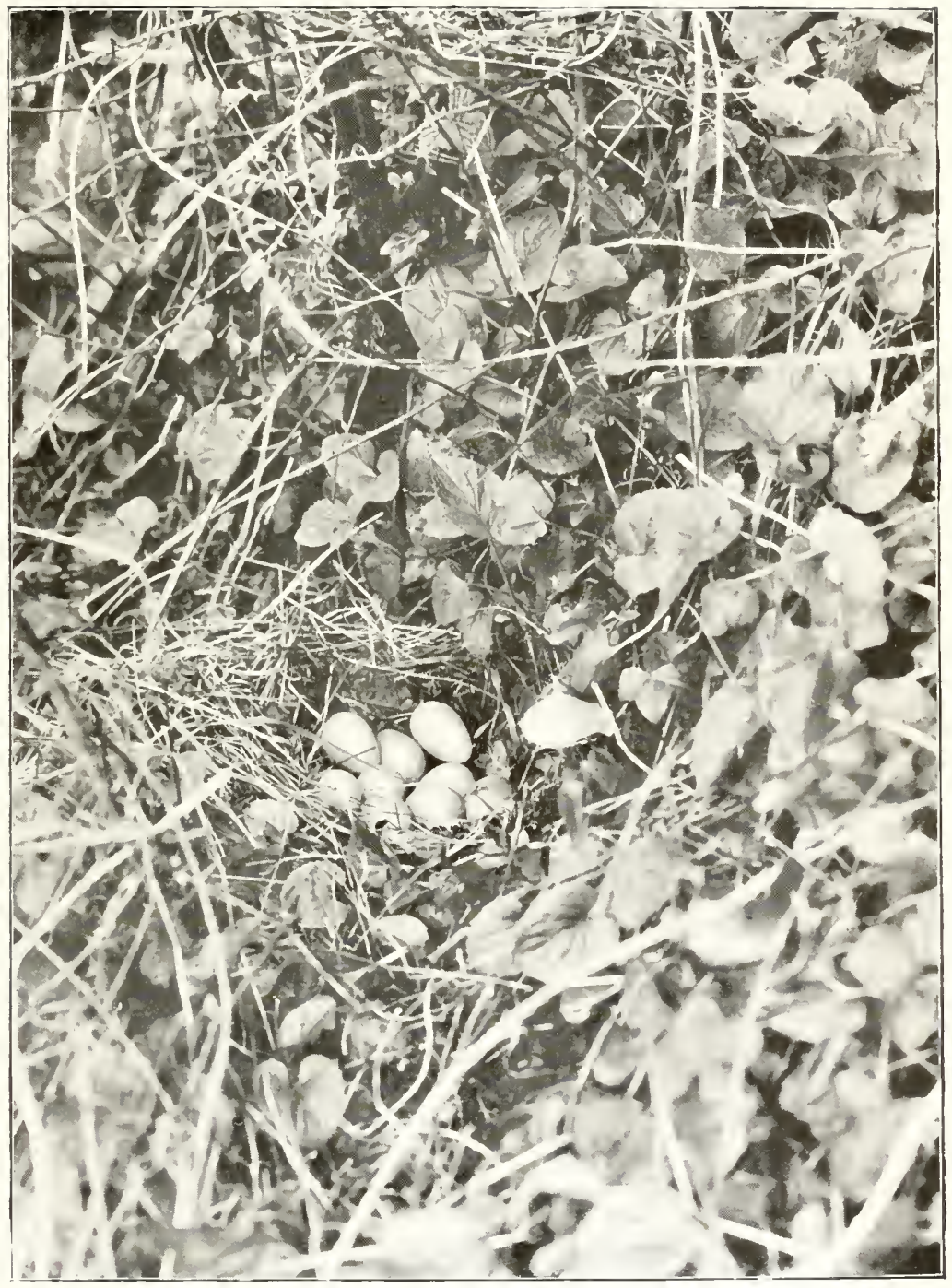

Partridge's nest.

i. Fortune, 

at Mr. Barnard's, South Cave; four pure white examples were killed from a brood near Scarborough in October 1869 (Zool. I869, p. I954), and five more, in a covey of eleven at Doncaster, are recorded in the Field (28th November I885); in a brood of twelve near Northallerton, about I860, three had white wings, whilst I have seen and examined pied and buff or cream-coloured specimens, several of which are reported in various parts of the county. A local variety has the horseshoe white instead of chestnut hued; this is not uncommon in the East Riding, and near York; it occurs near Whitby, and I have seen and shot specimens in the Vale of Mowbray; the white horse-shoe is more frequently found in immature birds than in adults, though Mr. R. Lee of Thirsk has a very fine mature example, and one in my own collection was obtained by Col. I'Anson of Howe. Lord de L'Isle and Dudley, when shooting in Baisdale in November I903, killed two birds, both immature, whose horse-shoes were the colour of a Grouse, nearly black, all the rest of the covey being of the ordinary type.

An example of what is considered to be a Partridge-Grouse hybrid, procured by Lord Walsingham at Bluberhouse, in August I866, was in the collection of the late F. Bond ( Nat. I896, p. I59; Yarrell's "British Birds," 4th Ed. Vol. iii. p. II4).

The only vernacular name appears to be a corruption of the ordinary one, Partrick, or Partrig, which is used in the north-west and in Cleveland.

\section{RED-LEGGED PARTRIDGE.}

\section{Caccabis rufa (L.).}

Resident in limited numbers, very local, though it appears to be extending its range. Originally an introduced species.

Like the Pheasant, this handsome bird is not an indigenous species in Yorkshire, the earliest allusion to it in 
connection with the county being, apparently, in Thomas Allis's Report, written in I844, thus :-

Perdix rufus.-Red-legged Partridge-Several have been killed near Doncaster.

The next reference of any importance was made by $\mathrm{A}$. G. More, who stated that "A few breed very rarely in West Yorkshire (Ibis, I865, p. 438). These, as Mr. Harting remarks, may have strayed across the borders from Westmorland.*

At the present day the status of the bird may be best defined as that of a resident, very local in its distribution, and not abundant in any part, whilst it appears to be gradually extending its range coastwise and inland.

On the southern fringe of the Wolds it is rare in Beverley district, and is occasionally observed on the sandy tract of country between North Cave and Howden. It nested at Ousefleet, on the borders of Lincolnshire, in I880, and Mr. L. West of Brough informs me he has shot examples in that vicinity, where it is becoming more common, probably crossing the narrow part of the Humber near the junction of the Ouse and Trent.

On the north Wolds it is spreading, being most plentiful about Foxholes, Filey, and Hunmanby; several were seen at the latter place by Mr. Pease in 1880 , one occurred at Flamborough in I888, and it nests in the neighbourhood of the Headland and the Speeton Cliffs; I have information of some having been turned down between Scarborough and Filey about I892; in March 1898 four were seen at Scampston, flying over the lawn, going east, but were not observed again; in the same year two coveys were at Barmston, and in December I90 four birds were seen and three killed at Wintringham. Mr. D. Young, keeper, of Irton, near Seamer, informs me two were shot whilst driving in I903, and odd birds are met with from time to time. At Cropton, six miles north of Pickering, a covey, supposed to have been reared on the estate, appeared

* An interesting article, by this well-known ornithologist, on the local distribution of the Red-legged Partridge appeared in the Field of $27^{\text {th }}$ January 1883. 
in 1898 , but the birds were dispersed in the course of two or three years. There are but four records of its occurrence at Scarborough since I8go; one was observed on 4th April I890, to come in from the sea and fall exhausted on Filey Road ; on the same date in 1896 another was seen to alight near the Harbour, and was captured on the Pier ; a third also came from seaward on 22nd March I897, and dropped in the water off Hayburn Wyke, where it was picked up. At Whitby two were taken alive in one of the streets of the town, and I have examined a pair obtained near Kettleness in I897, and preserved by Mr. F. Calvert, who mentioned that several had been turned down by the Maharajah Dhuleep Singh at Mulgrave some years previously. At Loftus it has been occasionally noted in September and October.

Judging from the foregoing particulars most of these birds are presumed to be wanderers from other districts, most probably Lincolnshire; the late J. Cordeaux stated that they have been observed coming in from the sea at Spurn in spring, and are occasionally captured alive in an exhausted condition, thus pointing to the possibility of their being travellers.

In the central area of the East Riding several pairs were turned down at Warter Priory about I892; it has nested and reared its young near Beverley, and there can be no doubt that individuals have strayed from there and been shot in other localities, as Pocklington, Youlton, and Church Fenton, at which latter place it was numerous in October of the year Igoo.

The Red-legged Partridge is recorded as nesting in the West Riding at Bramham and Wighill Park, and has been introduced near Huddersfield, but does not stay; examples have from time to time occurred in various other districts in this Riding: as at Hatfield, Ingmanthorpe, Ackworth, Sheffield, Wakefield, Wilsden, Otley, Bishop Thornton, and Staveley, their origin being traceable in some cases to introduced stock, others probably having strayed from the adjoining county. 
In the North Riding, at Hornby Castle, near Bedale, and at Swinton Park, near Masham, some were turned out about I846-47, but were afterwards killed off, though on the latter estate a brace appeared so recently as I89o. In Cleveland, as mentioned by me in the Field (I4th March and 4th April I88I), this bird was first made known about I860 by the late Lord de L'Isle and Dudley, who liberated some fifty pairs at Ingleby Manor. None of these were killed there, but they strayed away and a few brace were, at intervals, obtained in the surrounding districts, at Deighton, Ormesby, and Bonny Grove; they were fairly numerous in I875 at Gunnergate, and several coveys were at Newham about that period; in 1883 two were killed by flying against a wire fence, and one was procured at Bonny Grove, while two more were shot there in I887. A pair that nested at Otterington in I879, and examples that were met with at Thirsk and Hovingham, may have sprung from the Ingleby birds, all of which appear to have died out; but the sudden reappearance of the species in north-west Cleveland in 1890 , when three were shot by Mr. E. B. Emerson at Bonny Grove, and one by Mr. Mills at Newham, induced me to institute inquiries, with the result that I learnt from Mr. (now Sir) A. E. Pease that he had turned down several pairs at Pinchinthorpe, and about the same time some were introduced by Sir I. L. Bell at Rounton Grange. It is evident, however, that the country is not suited to the birds' requirements, for they have not become acclimatized, and only two odd examples have been reported within the past fourteen years, viz., one at West Coatham in January I899, and another which was caught in a yard in the heart of Middlesbrough in March I903. During the past spring (I906), some twenty to thirty pairs were turned out in north-east Cleveland, where they nested.

The only noteworthy incident connected with nidification is that of the discovery of a nest at Boston Spa containing fourteen eggs of the common Partridge, one of a Pheasant, and two belonging to the species under notice.

Besides its ordinary name of Red-legged Partridge, this bird is known to sportsmen as French Partridge, or Frenchman. 


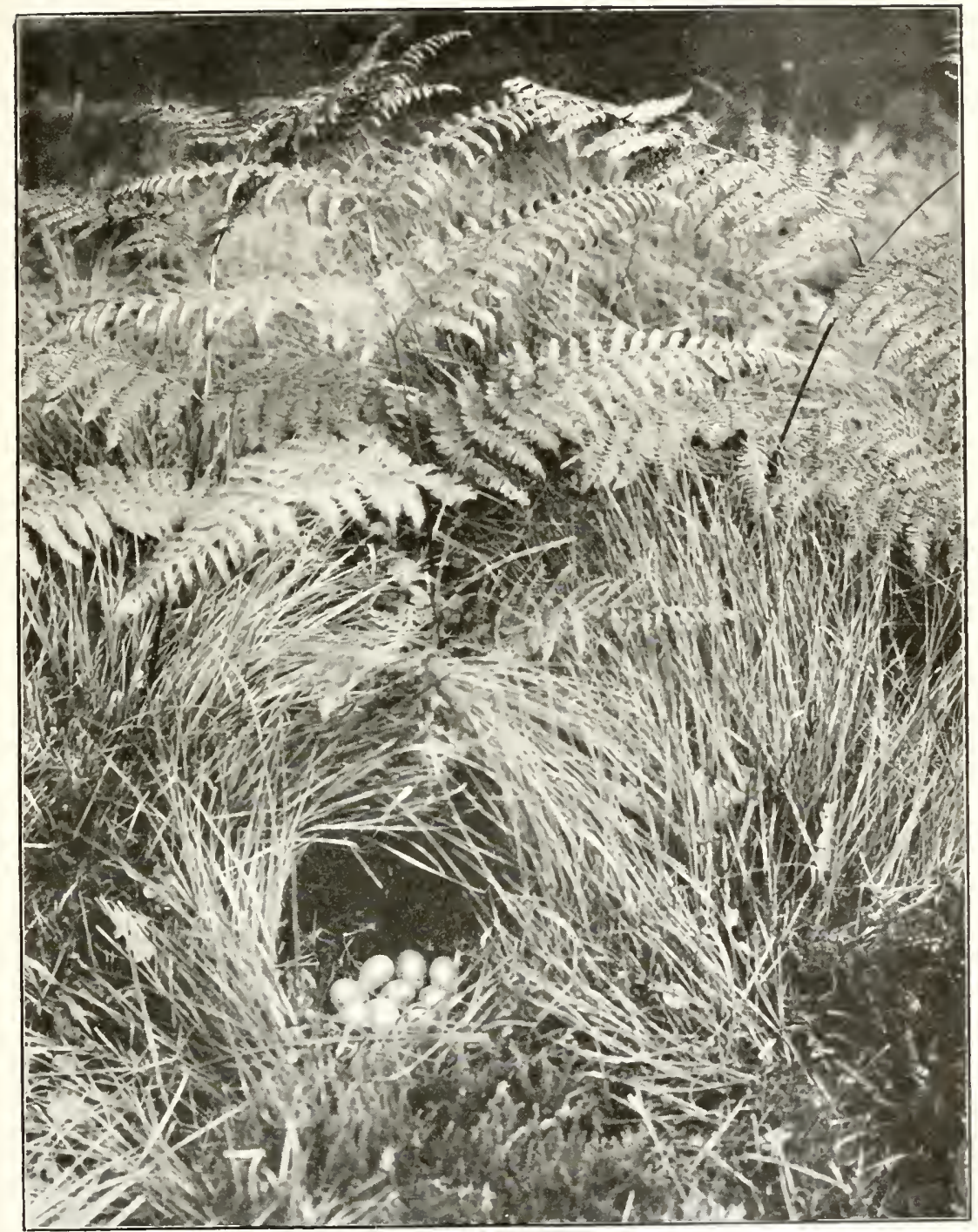

Nest of Red-legged Partridge, near Filey.

R. Fortune.

See page 530. 

[An example of the Barbary PARTridge (Caccabis petrosa, Gm.) is recorded in the "Handbook of Vertebrate Fauna of Yorkshire," as having been procured near Beverley about I869, but further investigation proves that it was an escaped pinioned bird.]

\section{COMMON QUAIL.}

\section{Coturnix communis (Bonnat.).}

Summer visitant, breeding in limited numbers in Holderness and in the Western Ainsty. Has been met with occasionally in winter. Less abundant than formerly.

The first mention of the Quail is in the provision at the great Cawood banquet in I466, given in honour of Archbishop Nevell, thus :- "Quayles a hundred dozen " (Leland's Collectanea). It also figures in the Northumberland Household Book in I5I2, at Earl Percy's castles of IVressill and Lekinfield, "Quayles" being amongst the birds to be provided "for my Lordes owne Mees at Pryncipall Feestes and at rjd. a pece at moste."

Thomas Allis, in 1844, wrote:-

Coturnix dactylisonans.-The Quail-Is occasionally heard about Sheffield; formerly it bred in the vicinity of Halifax, and occasionally does near York, though much less common than formerly; rare near Leeds, but occasionally met with at Scarcroft, Killingbeck, and Churwell. W. Eddison says "On some occasions I have shot a number of them in the cornfields, near Huddersfield, discerning them by their peculiar call in the springtime, about when the rye begins to shoot." Dr. Farrar observes "This species was very uncertain in its appearance, but far more abundant in 1832 than, to my observation. either at an earlier or later period." A. Strickland remarks "From accounts I have heard we might suppose Quails used to be numerous in this district, as I have been told they used to be taken in nets here formerly, but they are now seldom met with; a few may be heard at times among the corn in summer, or met with in turnips in winter.

The Quail is a summer visitant, arriving in May with the latest of the spring migrants, and was formerly a fairly abundant species; Arthur Strickland informed the naturalists 
of his day that it used to be taken in nets near Bridlington (cf. Allis's Report), and in other parts of the East Riding it was considered not uncommon. It still nests irregularly and in limited numbers in several localities, in some years being common, noticeably so in I 832 and 1870 , while in other seasons it is scarce, though, compared with its former status, it is gradually decreasing, due in part to high cultivation and the discontinuance of rye growing. Mr. F. Boyes flushed a bird, at two or three feet distance, from a nest containing eleven eggs, in July I870, on a railway embankment in East Yorkshire; the nest was in a slight hollow and composed of a few dead grasses, with the eggs laid slovenly, some on top of others. George Petch, late keeper to Mr. St. Quintin of Scampston, used constantly to hear Quails calling, and they still occasionally nest near there, and are heard in the young corn. The late E. Tindall of Knapton also reported it as nesting in 1876 .

In the West Riding it has bred in several districts of the Western Ainsty, and did so regularly at Newton Kyme up to I830, and at Boston Spa until I88I. Near Brimham Rocks two nests were taken in July I865 and I87o (Field, 2Ist August I880; and Zool. I88o, p. 356). Mr. Leonard Gaunt has an egg found on Brayshaw Hill, and has seen several nests at various times in Leeds neighbourhood; the species also breeds occasionally in Sheffield district. Other localities from which the nest has been reported are Ackworth, in I89I and I893; Balne Moor, near Snaith, in I880; Selby; Holdsworth in Ovenden (nest and fourteen eggs); Keighley in I879 (an egg being now in the Museum of that town, W. Eagle Clarke, Field, 2Ist August I880); and Halifax, in I878.

In the North Riding Marmaduke Tunstall, in I784, wrote of it as being found at Wycliffe-on-Tees, but not frequent (Tunst. MS. p. 82); the late Canon Atkinson recorded two broods at Moorsholm-in-Cleveland in I859; several nests have been found near Loftus-in-Cleveland between 1875 and 1890 ; the late Afred Roberts stated that he had had young from near Scarborough, whilst Canon Atkinson used repeatedly to hear the birds calling at Danby, where 
a pair once came into the Vicarage garden ("Moorland Parish," p. 327). Mr. J. Braim had eggs in his collection, taken near Whitby in the "fifties," and the bird has been known to breed near there on several occasions since then, the last instance of which I am aware being in 1896 ; an egg in my possession was one of a deserted clutch of eleven found at Glaisdale in August of that year. At Easbyin-Cleveland I heard birds calling in June I895; a young one was seen at Kirkleatham in I896, and at Carperby, in Wensleydale, a nest containing ten eggs was discovered in I884.

On both the spring and autumn passage the Quail has occurred at various coast stations, while during Partridge shooting in September it has been met with repeatedly, the reported and communicated instances of which are too numerous for recapitulation.

It has also occasionally been killed in mid-winter; one at Nafferton, in December I85I, is mentioned by the Rev. F. O. Morris; Mr. F. Boyes had one brought to him on 28 th December 1878 ; and on 20th February I866, one was obtained near Beverley (Zool. I867, p. 540).

As on various occasions Quails have been turned down for experimental purposes by estate owners in Yorkshire, it is possible some of the records may be attributable to imported birds.

[A Virginian Colin (Ortyx virginianus, L.), killed at Cottingham (" Birds of Humber District," I872, p. 83), was, doubtless, an imported specimen, as was also an Andalusian Hemipode (Turnix sylvatica, Desf.) obtained near Huddersfield, 7 th April I865 (Gould, P.Z.S. I866, p. 210).] 


\section{CORN CRAKE OR LAND RAIL. \\ Crex pratensis (Bechstein).}

Summer visitant, generally distributed; common, except in manufacturing districts.

The first published reference to the Corn Crake appears to be in Graves's "History of Cleveland" (1808), where it is enumerated amongst the migratory birds.

Thomas Allis, in I844, wrote:-

Crex pratensis.-Corn Crake-R. Leyland says "The peculiar note of the Land Rail is now seldom heard with us ; incessant persecution of bird-stuffers and others having nearly exterminated them." The bird is not named in my accounts from Barnsley, Huddersfield, and Hebden Bridge ; near York it is certainly less abundant than formerly ; it is frequently met with near Leeds, Sheffield, and Doncaster.

Although probably less abundant than formerly, the Land Rail, or Corn Crake as it is more frequently termed, is not the "rara avis" that Allis's remarks would lead us to infer. A summer migrant, it arrives about the end of April or early in May; the earliest reported date of which I am cognizant is I5th April I869, the recorder being the late Thomas Lister of Barnsley.

Its departure usually takes place in September or early October, though numerous instances are chronicled of individuals being noticed in November, and even in December; one was announced to have occurred on the 24 th of the latter month at Healaugh, near Tadcaster (Nat. I885, p. I49). This bird has been recorded amongst the casualities at the Spurn Lighthouse; individuals have been killed during both the spring and autumn migrations, and one was shot on the Redcar "scars" in the first week of November 1906.

The Corn Crake is fairly generally distributed in the agricultural districts, resorting chiefly to meadows, clover fields, and young corn, being numerous in some seasons and unaccountably scarce in others. J. J. Briggs, writing to the Zoologist (1845, p. 820), stated that six or seven might 


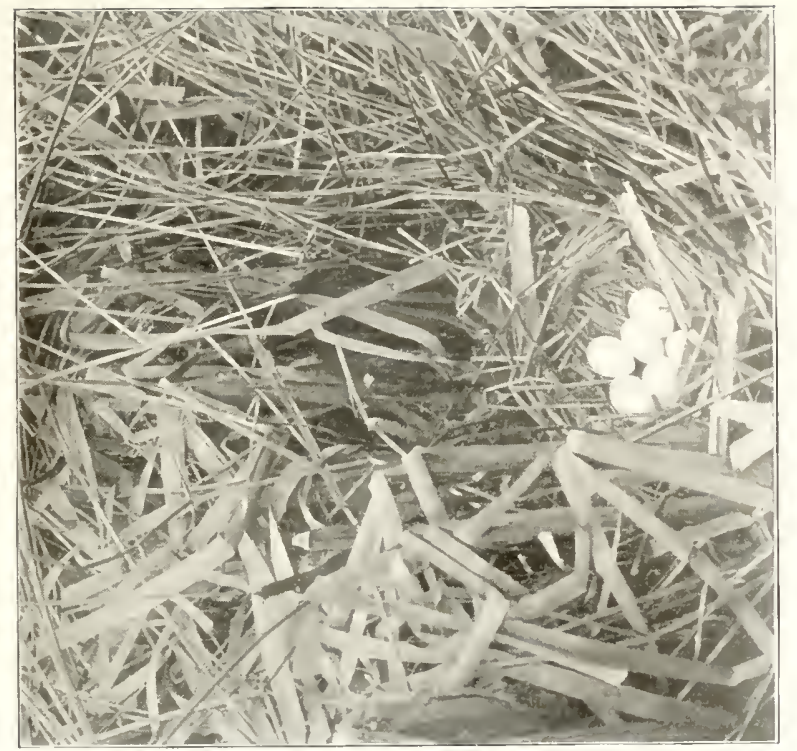

咅

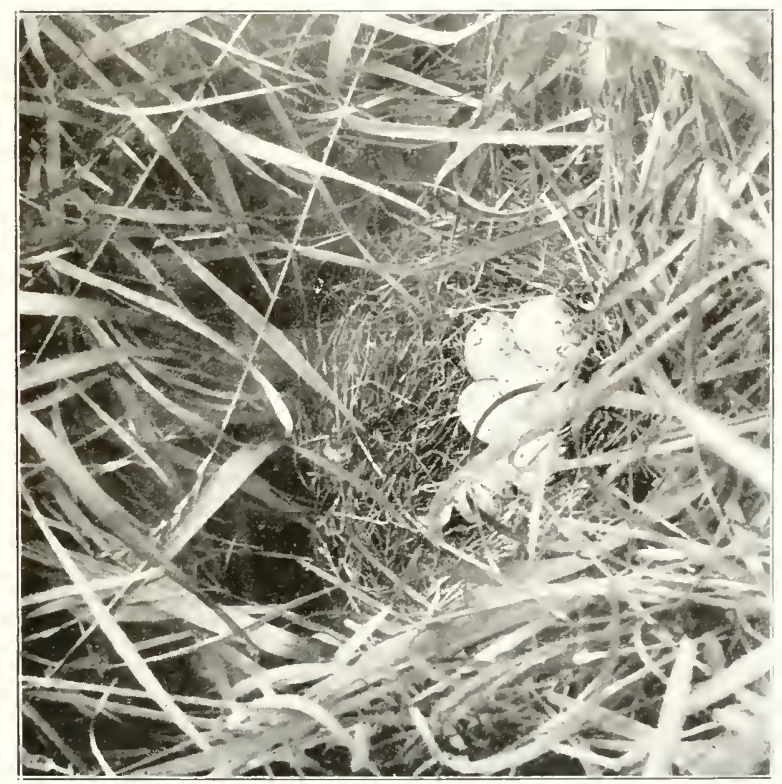

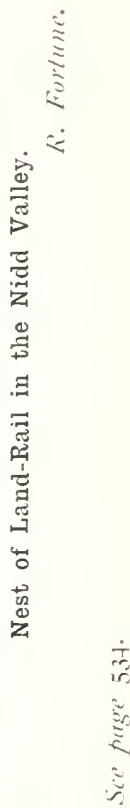



at that time have been killed on their arrival at Spurn, and the late W. Talbot, author of the " Birds of Wakefield " (I876), remarked that he had seen forty-one sent to one man in a season; per contra, in I868 it was very scarce in the Western Ainsty; in I877 in Wharfedale, in the Hawes district in I884, and generally throughout Yorkshire in 1906. Although more frequently observed in the low-lying portions of the county, it is not altogether absent from the higher parts of the dales, and has nested to I,000 feet elevation in Teesdale, and to an altitude of $I, 400$ feet in Nidderdale.

Mr. F. Boyes asks the question (Zool. I87I, p. 2869), "Is the Corn Crake polygamous ?" thinking that it might be so, from the fact that he found three nests in one field. As illustrating the tenacity with which this bird clings to its nest, Mr. C. Blenkhorn of Knaresborough writes (in litt. 2Ist June I880), that, on cutting the grass round a haystack close to a road, the mower exposed a Corn Crake's nest containing twelve eggs; several stackpins were then arranged to form a roof over the sitting bird, so as to screen her from observation, and she successfully brought off her young. At Redcar I have seen young birds which were hatched on 2nd July in a nest that had contained thirteen eggs.

The Rev. R. A. Summerfield of North Stainley watched a Corn Crake uttering its cry, and observed that it turned its head round over its back, opening its mandibles widely, in this position giving forth its craking note.

As regards country superstitions, the children in Skipton district are forbidden by their parents to search for this bird, being warned that death is certain to follow within a year if they see one. In some districts the frequent calling of the Corn Crake is said to be an indication of rain.

Local names:-Corn Crake, Land Rail, Daker Hen, and Meadow Drake are in general use; Drake Hen, at Linton-onOuse; Draker Hen, in Teesdale; Corn Drake, in Ryedale at Nunnington, and in the North Riding generally; Corn Rake, in the Hawes district; Grass or Gress Drake in the West Riding, at Huddersfield, Wilsden, Liversedge, and Ackworth; Land Drake, Grass Crake, and Hay Crake, at 
Ackworth; Dress Drake, at Skelmanthorpe; Grass Quake, at Barnsley; and Gurs or Gors Duck, near Huddersfield (Zool. 1848, p. 2290); while Creek, Crake, or Cracker are mentioned by Swainson.

\section{SPOTTED CRAKE.}

Porzana maruetta (Leach).

Resident; very local and limited as to numbers. A spring and autumn migrant; in some years not uncommon during the latter period.

The first mention of the Spotted Crake for Yorkshire is found in the Tunstall MS. (I784, p. 9I), under the title of Spotted Gallinule, "Not unfrequently shot here [Wycliffe-onTees], and as late as October."

Thomas Allis, in 1844 , wrote :-

Crex porzana.-Spotted Crake-H. Reid says it is common near Doncaster ; it is not frequent near York, though it breeds most years close to the City. I had two young birds from that locality in $184 \mathrm{I}$; the one flew across a river and entered a cottage, the other was caught by a boy.

This bird is a resident, very local and limited in numbers, and owing to its peculiar skulking habits is, perhaps, the most difficult of all birds to discern in the dense aquatic vegetation which it frequents. There can be little doubt that it is, for this reason, frequently overlooked during the breeding season.

Thomas Allis, in his Report (1844), mentioned it, on the zuthority of Hugh Reid, as frequenting the "Carrs" of Doncaster, and stated that it was found breeding in most years near York, from which locality he had two young birds, able to fly, in I84I. Mr. F. Boyes is of opinion that it used to breed annually in Holderness, where he found the nest and eggs in a patch of dense sedges, near the banks of the river Hull, on 2Ist May x882. Near Ackworth a pair bred at Hemsworth Dam in 1899 , as Major Arundel informs me (in litt. March I903), and it has occurred on the Harrogate Irrigation Farm in the nesting season. 
In addition to its nesting, the Spotted Crake is a spring and autumn migrant; at the former season individuals are not uncommonly found killed under the telegraph wires, and were it not for the unfortunate propensity of the bird thus immolating itself, its appearance at this period would be seldom noted.

In autumn there is a considerable accession to its numbers from August to November; it is then occasionally observed on the coast line; my spaniel flushed one amongst the rough benty grass on the Tees Breakwater in September Igoo, and it also occurs in similar situations at Spurn. In October I89o, one was obtained in a clover field at Easby-in-Cleveland. Later in autumn wildfowlers meet with it while shooting in reed beds and rough marshes, and it is sometimes found even in the remote dales of the north-west. In the Beverley district it was fairly common in some years; in the winter of I863-64 thirty-two were killed, some being quite young birds, which had doubtless bred there; again in the summer and autumn of 1865 several were procured in various stages of plumage, the first being killed on 3oth August; in the Spurn neighbourhood it was abundant in the autumn of $I 88 \mathrm{~g}$, and continued to be plentiful in Holderness every autumn up to the last few years, but has since been annually shot out, and is now scarce.

Formerly the Tees marshes were favourite resorts of this bird, and certain spots in its haunts appear to have special attractions, for, if one is killed, its place is soon occupied by another. In connection with this trait in the bird's habits, a rather curious coincidence is communicated to me by $\mathrm{Mr}$. T. T. S. Metcalfe of Roche Court, Salisbury, who says that, while Snipe shooting at Appersett Bottoms, near Hawes, on 5th October I870, he shot a Spotted Crake, and in the following year he killed another on the 7 th of the same month, within twenty yards of where the first fell.

The only vernacular name is Spotted Rail; it received the book-name of Spotted Gallinule in the Tunst. MS. (I784); and Small Spotted Water Hen is another term given to it in Fothergill's "Richmondshire" (I823). 


\section{LITTLE CRAKE.}

Porzana parva (Ścopoli).

Accidental visitant, of extremely rare occurrence.

This bird nests on the Continent of Europe, and migrates in winter to mid-Africa and Asia.

The earliest notice of the Little Crake in Yorkshire is apparently in a communication from W. Fothergill of Carr End, near Askrigg, where it is stated that "The Rallus pusillus of Gmelin (Gallinula minuta of Montagu, and Gallinula pusilla of Temminck), was shot on 6th May ISo7, by Mr. John Humphrey of Wensley, on the banks of the Yore, near that place. It was alone, and suffered itself to be approached very near without betraying any sense of danger. It ran with great rapidity, carrying its tail erect." (Tr. Limn. Socy. xiv. p. 583 ; Fothergill's List in Whitaker's "Richmondshire," I823, i. p. 4I6 ; and Yarrell's " British Birds," I843, iii. p. I6.)

Thomas Allis's Report, in I844, runs thus :-

Crex pusilla.-Little Crake-H. Reid tells me that a specimen of this rare bird was taken alive at Cantley; it ran into a tuft of grass and was captured by a boy, and came into his possession about eighteen years ago. The only other instance that has come to my knowledge is the one shot on the banks of the Yore, and recorded in Yarrell's "British Birds."

The Little Crake is a rare casual visitant to Yorkshire, and has been recorded on five occasions only, the particulars being as follows :-

The first is that referred to (ante) by IV. Fothergill, in 1807 .

On the authority of $\mathrm{H}$. Reid of Doncaster, it is stated to have been a migratory visitor to the "Carrs" near that place, and Allis mentioned a specimen at Cantley about I826, which came into Reid's possession.

In the year I 836 one was captured near Scarborough, and was recorded by the late Prof. W. C. Williamson in the P.Z.S. I836, iv. p. 77 .

The fourth example was caught alive on a canal boat 
on 6th May I862, at Aldwarke Bridge, near York; it formed part of the collection of Mr. Johnson of Masham, being afterwards acquired by the late J. C. Garth of Knaresborough, in whose collection I have had an opportunity of inspecting it. At the dispersal of Mr. Garth's effects in December Igo4, the specimen under notice was purchased by Mr. Riley Fortune of Harrogate.

The fifth, and latest, occurrence was on I7th October I892, when one was taken alive at Green Hammerton, its identity being placed beyond doubt by Lord Lilford, to whom it was sent for inspection; the particulars of this capture were chronicled in the Field of 2 Ist and 28 th January I893.

The Little Crake is also known as the Little Gallinule, which appellation is bestowed upon it in Hatfield's " Historical Notices of Doncaster" (I866); Olivaceous Gallinule is a term used by other writers.

\section{BAILLON'S CRAKE.}

\section{Porzana bailloni (Vieillot).}

Accidental visitant, of extremely rare occurrence.

Baillon's Crake nests on the European Continent, migrating in winter to Africa and Asia.

The instances of its occurrence in Yorkshire are extremely few, there being, so far as can be ascertained, only three authentic examples placed on record.

The first was killed by Mr. George Challand on 29th May I874, at Hors Dam, Kirkheaton, and was mentioned by Mr. J. E. Palmer in the Zoologist (I874, p. 4I59). This specimen passed into the collection of Mr. S. L. Mosley of Huddersfield.

One at Holmpton, Holderness, was reported in I880, and is now in the collection of the Rev. H. H. Slater (op. cit. I884, p. I79, and Slater MS.).

The third, and most recent, occurrence was at Whitsuntide I892, when an adult male was killed by flying against the telegraph wires between Pocklington and Wilberfoss, 
in the East Riding. It was afterwards placed in the York Museum, as announced by Mr. J. Backhouse in the Naturalist (I8g2, p. 308).

A specimen in my possession was obtained while I was shooting with the late R. F. Chilton, at the Teesmouth, though on the Durham side of the river, on September I6th I882; at the same time and place we also procured two Spotted Crakes.

The alleged example of this species, recorded as being obtained at Goole ("Vertebrate Fauna of Yorkshire," p. 64), proved to be an immature Spotted Crake.

\section{WATER RAIL.}

Rallus aquaticus (L.).

Resident in very limited numbers, and local. Also a winter migrant, being then more numerous.

The first Yorkshire reference to the Water Rail, so far as is known, is contained in the Allan MS. in connection with the Tunstall Museum (I79I), thus :- "Water Rail, Bilcock, or Brook Ousel. Common in this kingdom in the North, where it is seen in winter." (Fox's "Synopsis," p. 9o.)

Thomas Allis, in I844, wrote:-

Rallus aquaticus.-Water Rail-Common near Doncaster; very scarce near Sheffield; rare near Hebden Bridge; also at Halifax; one specimen in immature plumage was shot at Salterhebble in that neighbourhood; common near Leeds; not uncommon about Bridlington and York; it is occasionally met with near Barnsley.

A resident in limited numbers, and very local, the Water Rail, owing to its solitary and skulking habits and the nature of its haunts, often escapes observation. The nest has rarely been found in Yorkshire, but young birds are occasionally captured, and it may be desirable to give a detailed account of the bird's status as a breeding species. In the south of the county, according to Hatfield's " Historical Notices of 
Doncaster" (I866), it bred in that district in olden times, before the drainage and reclamation of the "Carrs"; $\mathrm{Mr}$. Thos. Bunker reports, in I88o, a nest at Airmyn, near Goole; Thomas Allis mentioned the capture of a young bird at Salterhebble, near Halifax, before I844; near Wakefield a nest is said, on the authority of Mr. J. Emmet, to have been found on the banks of a canal; the species used to breed in the valley between Thornton and Bradford, and may still do so, but is very scarce now; in Ribblesdale it has bred on Austwick moors, as mentioned by the Rev. E. Peake in the Naturalist (I896, p. 45); in Wharfedale the nest was found at Boston Spa in I884 and I885, according to Mr. J. Emmet (op. cit. I885, p. 299); it has also been discovered near Low Mills, while at Fewston and in the Nidd Valley the bird has bred sparingly.

In the Beverley and Hornsea districts of the East Riding the Water Rail breeds annually, and, notwithstanding the density of the herbage and the aquatic vegetation forming its surroundings, the nest and eggs have been found several times, while at Scampston, Mr. W. H. St. Quintin, although not having had ocular proof of nidification, has no doubt of its occurrence. Near Scarborough, the late A. Roberts stated (MS. I880), that he had eggs taken from the Mere " a few years ago"; further north and still on the coast line, the young have been caught in a field near Whitby, the old ones being also seen at the time by J. Kitching, who communicated the fact to Mr. Thomas Stephenson in I880; a nest was found at Newby Wiske, near Northallerton, in I88o or I88I, and at Bedale the call note has been heard, and the birds observed, in summer.

In the Cleveland division it was found breeding about I870 in Westerdale, by Mr. Husband, who informed Mr. Thomas Stephenson of Whitby that he and a companion saw the female bird come off the nest, which contained two eggs. At the Teesmouth I have positive evidence of the occurrence of the bird in the breeding season so far back as I882, and down to the present year, but the nest has not as yet been reported, though I found one on the Durham side of the river 
in June 1883 , and it is quite probable that it may be met with on the south side.

As an autumn or winter migrant the Water Rail is of more general, though still local occurrence, usually arriving in late September, October, and early November. The late J. Cordeaux observed that its immigration appears as well marked nearly as that of the Woodcock, while the Reports of the British Association Migration Committee contain a reference to its arrival at Spurn on Ist November I886 (Eighth Report, p. 42), and one came on board a fishing smack some miles off the coast in the winter of $1878-79$. I have twice known examples immolated during the night by flying against the telegraph wires near Redcar, the latest instance being on 29th September I9or. An individual, caught on Coatham Marsh in November Igoo, had but one wing, the other having in all probability been torn off in contact with the wires, although the wound had completely healed; and I have had brought to me several live specimens which had been captured in the autumn.

In most of the low-lying and marshy districts the bird may at this season be found, though it is far from common, and is probably decreasing in numbers, owing to the curtailment of its habitat, but, as remarked above, in dealing with its status as a resident, its shy retiring habits render it a difficult bird to flush, and it may really be commoner than is supposed to be the case. In the winter of I903-04 it was more than usually numerous, being reported from several localities where it is considered rare.

It was very abundant in the Beverley neighbourhood in the winters of $I 864, I 865,1866$, and I878-79. It is common on the sedgy margins of the river Hull, which extend for miles beyond Beverley, frequenting the densest covert, from which it is driven only by the aid of a good dog, and it will double and redouble, using every artifice before being finally compelled to take wing. As illustrating its reluctance to resort to flight, I may state that, while I was shooting in the winter of IgOI-02, my spaniel flushed a Water Rail which rose within a foot of the dog's nose, and at the same time I saw another 


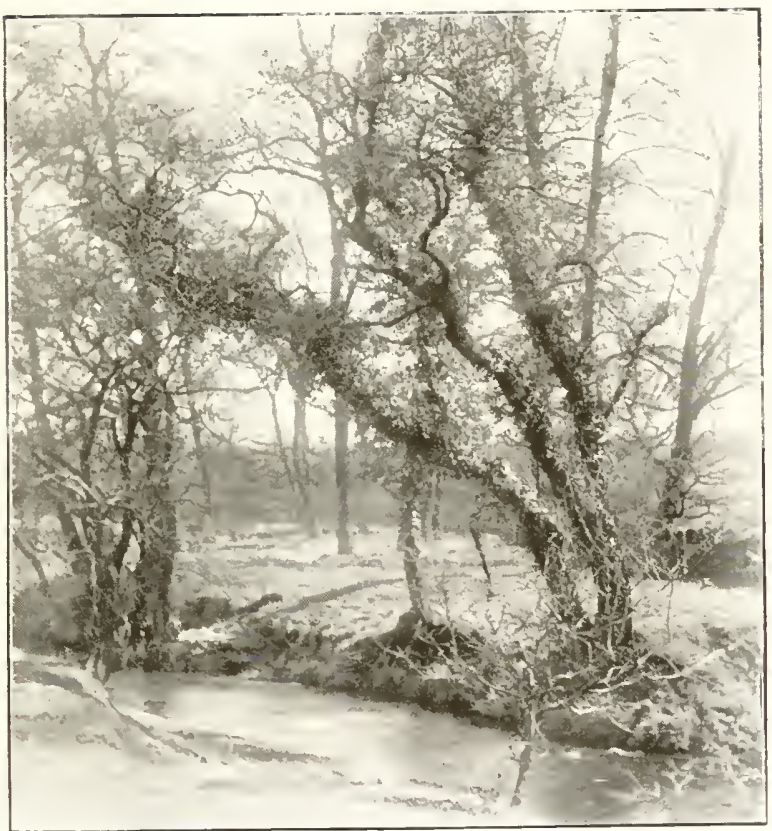

Ivy covered tree in which a Waterhen has had her vest for many years.

R. Fortune.

Sie prege $5+5$. 

running like a rat between the reed stems, but the united efforts of the dog and myself failed to force it to rise. It is occasionally found in the remote dales, and has been reported from Malham Tarn on the north-western fells. In severe winters it is driven out of its marshy retreats, being then compelled to resort to more open districts, and is met with by the sides of streams and ditches where there is running water. It appears to resemble the Woodcock in its partiality for certain localities, and may be found season after season in the same place; there used to be, until quite recently, a little marshy strip of ground near Redcar which never failed to produce a Water Rail as autumn came round, and, though one bird might have been killed, another could be flushed there the next season.

A return migration takes place in spring, but of this movement little appears to be known; a specimen was taken against the Spurn lantern in April I899; another was found below the Flamborough Lighthouse in I904; at the Teesmouth one was picked up under the telegraph wires on I3th April I898, while my personal experience is limited to one instance only, which, strangely enough, occurred in the town of Redcar, and within a few yards of my house. On I3th April I902, I was called to see a " strange bird " in a cottage yard, where fowls are kept, and discovered it to be a Water Rail perched on the top of some wood placed against a wall; I approached to within five yards, when it flew over the wall and disappeared; the wind, which had been easterly for several days previously, had probably brought it in.

Of local names, Bilcock seems to be general; Brook-runner and Brook-ouzel are mentioned by Swainson, while Rat Bird, Rat Hen, and Runner are terms applied to it at Sedbergh. 


\section{MOORHEN.}

\section{Gallinula chloropus (L.).}

Resident, generally distributed, common.

The earliest note of the Waterhen as a Yorkshire bird, so far as is ascertained, is in the Rev. J. Graves's "History of Cleveland" (I808), where it is enumerated amongst the resident birds.

Thomas Allis, IS44, wrote:-

Gallinula chloropus. - The Moor Hen-Not uncommon about Halifax and Hebden Bridge. Common in most other districts.

As a common and generally distributed inhabitant of marshy districts, reedy ponds, and banks of slow running streams, the Moorhen, or Waterhen as it is indisciminately termed, is well known in Yorkshire, and occurs in most parts of the county, except in manufacturing districts and on the highest fells. Where the conditions are suitable it appears to be on the increase.

In some localities, and especially in the Beverley district, it is to a certain extent migratory, and leaves its nesting quarters as winter approaches, returning again in spring. There is in some seasons a decided increase in the numbers, but whether this is to be attributed entirely to immigration, or partly to merely local movements influenced by the state of the weather, which in severe floods and frosts drives them from their haunts, is not yet determined. I may, however, state that $I$ have seen a specimen that was killed by striking against Flamborough Lighthouse, and occasionally examples are picked up in the streets of sea-coast towns in the autumn, which points to the probability of these being oversea immigrants.

Mr. F. Boyes (Zool. I87x, p. 2522), notes an instance of a Moorhen submerging itself, and describes the operation, of which he was an eye-witness. The species under notice figures in the list of birds captured in the nets of Hornby Castle Decoy. 


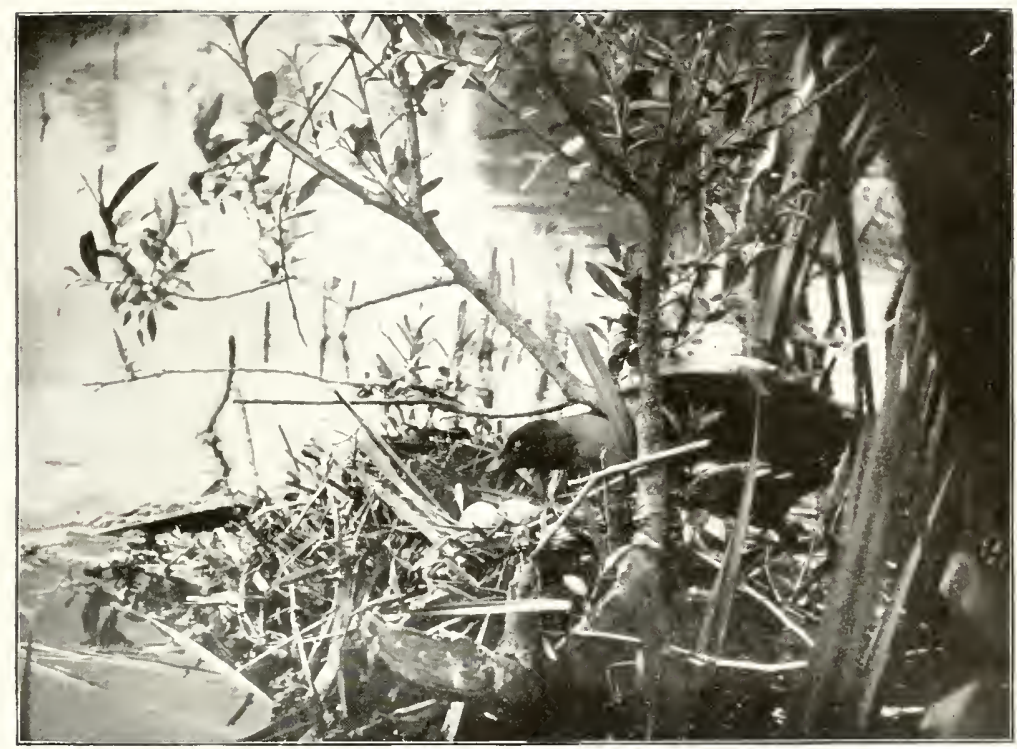

Water-hen going on to its nest. T. At. Metcalte. See page $5+5$. 

The nidification habits of this bird have frequently been commented upon, strange nesting sites being occasionally placed on record, of which Yorkshire can claim its share; there are numerous instances of nests being found in bushes and on the branches of high trees, but perhaps a more curious situation is reported from Masham, where, in I885, a bird was discovered incubating an egg in a hole of a tree eight feet above the ground. A case of dual occupation came under notice at Strensall Common in I882, the partners in the nest being a Moorhen and a Coot; and in the same locality, in I880, a nest contained twenty-six eggs, of three distinct types, doubtless the produce of three different females; eggs streaked like a Bunting's have also been observed.

Of variations in plumage, the only example which has come under my observation is a buff-coloured specimen, in the collection at Thicket Priory, taken on the Derwent near that place.

The local names are not many: Water Hen is used generally by country people, and Bilcock and Biltor are north country terms.

[Examples of the PURPLe Gallinule (Poryphyrio coruleus), have been reported at Easington, near Spurn, in September I897, and at Bedale in the autumn of I903; but, as this species is frequently kept in semi-captivity, these individuals are probably escaped birds.]

\section{COOT.}

Fulica atra $(L$.$) .$

Resident, generally distributed, and common, except in manufacturing districts and the western fells, where it is not numerous.

The earliest reference to the Coot in Yorkshire is, so far as is known, that in Graves's “ History of Cleveland" (I808), where it is enumerated in the list of resident birds. 
Thomas Allis, in 1844 , wrote:-

Fulica atra.-Common Coot-Nearly extinct about Huddersfield; not abundant near Sheffield; occasionally seen near Leeds, at Killing• beck and Walton; common about Barnsley, Doncaster, and York.

The Coot is resident throughout most parts of the county, excepting in the manufacturing districts and on the high moorlands, though even on some of the latter it is not altogether absent. It breeds commonly on the lakes, rivers, and meres in the low-lying parts of the East Riding, being particularly numerous on Hornsea Mere in Holderness.

In the West Riding it is more local, and scarce in the neighbourhood of the large manufacturing towns, yet Talbot mentioned it as an abundant nester on the reservoirs near Wakefield, and he noted large numbers in February $\mathbf{I} 872$ on that at Hiendley. It is described as resident, but not common, on the "Carrs" of Doncaster; in the Central Plain it nests sparingly on the rivers Nidd and Wharfe, and is fairly common on the lakes at Harewood and AllertonMauleverer. It is rather scarce on Fewston Reservoir, but on Malham Tarn is abundant and nests freely, also in Bowland district. Mr. J. Backhouse informs me that, in May I895, he found a nest containing three eggs, at an altitude of $I, 500$ feet, at the back of Mickle Fell, in Lunedale.

In the North Riding it occurs on most of the large ponds and lakes, as at Gormire, Strensall, Pilmoor, Castle Howard, Newburgh Priory, Bedale, and Scarborough, as also in isolated cases on some of the slow running streams. In Wensleydale it breeds on Locker Tarn, at I,o Io feet eleration, and is a rare resident in Teesdale and at Sedbergh.

In winter, especially during severe weather, when the fresh water is ice-bound, the Coot leaves its accustomed haunts and often appears in most unlikely places; it is then frequently met with on tidal waters, particularly in the estuaries of the large rivers, and, though not usually classed as a migrant, has even been immolated by flying against the lanterns of the Light-stations on the coast. In the winter of I90I-02 several specimens, killed on the brackish "fleets" during the frost, were brought in to the Redcar taxidermists; 


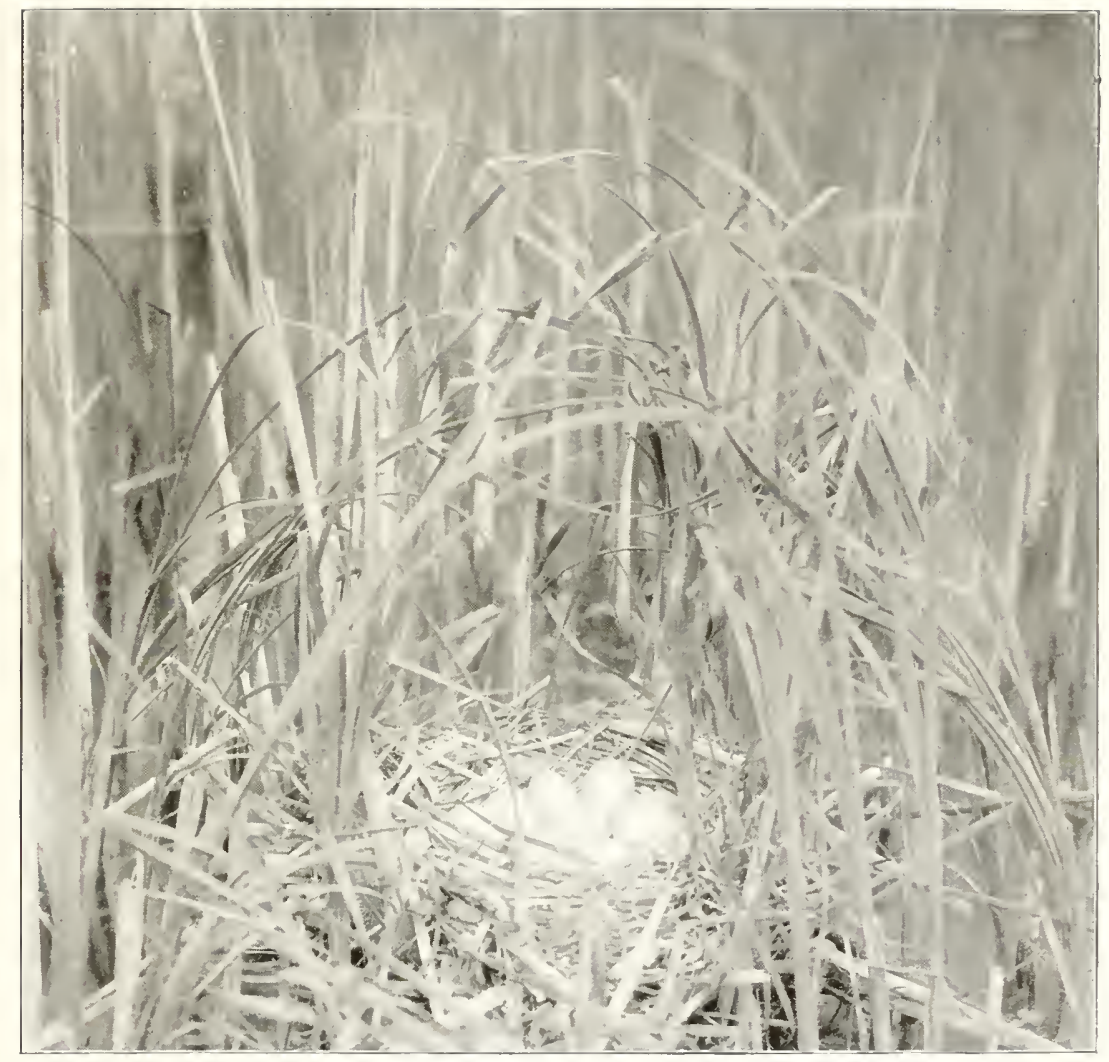

Coot's nest with flags interlaced as a bower, Hornsea Mere.

R. Fortune.

Sce page $5+6$. 

and two or three examples have been shot on the open sea.

Nidification commences in May, on the $4^{\text {th }}$ of which month I have seen a clutch of seven eggs, and have observed young on the $23 \mathrm{rd}$. As many as ten to twelve eggs are occasionally found. Varieties in this species are not often met with, the only record being a white one, mentioned by F. O. Morris as occurring at Bawtry.

In addition to its ordinary name, the bird is known as the Bald Coot, and Bald-headed Coot.

\section{COMMON CRANE.}

Grus communis (Bechstein).

Accidental visitant from northern Europe, of extremely rare occurrence.

The former existence of this magnificent bird in the county of York is evidenced by items in the Bill of Fare at the great banquet given at Cawood in $\mathbf{4}$ 66, in honour of the Archbishop of York, where it is stated that there were "In Cranes, c.c. iiii." [204]. In the fifth Earl of Northumberland's Household Book, begun in I5I2, the following entry occurs: "It is thought that Cranys muste be hadde at Crystynmas and other principall feestes for my Lordes owne Mees, so they be bought at xvjd. a pece," (equivalent to about eight shillings of the present currency), and at Chevet, near Wakefield, on the marriage of Elizabeth, daughter of Sir John Neville, High Sheriff of Yorkshire, on I4th January I526, in the Igth year of Henry VIII., it is set forth :-

$$
\text { "Second course, }
$$

and For a Standart.

Cranes, two of a dish ... The expense of the week ... Nine Cranes If Ios. ..."

In more modern times there is a record in Fothergill's " Orn. Brit." (I799, p. 7), of an example shot near York in 
I797; whilst the only other county specimen was noted by the late J. Cordeaux in the Naturalist (I893, p. 203). where the recorder stated that he saw, at the house of a Flamborough fisherman, a Crane obtained by John Huddleston, farmer, Flamborough, from a field near his house, in the last week of February I892. It had been set up by Jones of Bridlington, and was a young bird of the previous year; it had feathers but no red patch on the crown, and the hind plumes were short.

In the second edition of Mitchell's " Birds of Lancashire" (p. 206), Mr. R. J. Howard of Blackburn mentions the occurrence of two birds of this species seen with the naked eye, and also through a glass, by Mr. R. Milne Redhead, F.L.S., of Bolton-by-Bowland, at 4 p.m. on 25th August I884. They were flying in the direction of the Lancashire border, their course being WNW. to SSE. Mr. Milne Redhead is perfectly familiar with the appearance of the bird, having often seen it in Germany and other places on the Continent. (cf. Zool. I884, p. 470.)

An example in the York Museum is labelled "Adult, Strickland Collection, probably local," but no further information concerning its origin is now obtainable.

The place-name Cranswick (Craneswick), near Driffield, probably had its origin in its associations with the Crane, the neighbourhood in former days being eminently suited to this bird's habits.

\section{GREAT BUSTARD.}

\section{Otis tarda $(L$.$) .$}

Accidental visitant from Continental Europe, of extremely rare occurrence; formerly resident in great numbers on the Wolds of eastern Yorkshire, when in their virgin state as undulating barren sheepwalks.

The only reference of early date to this bird is in the Earl of Northumberland's regulations, in I5I2, for his "Castles 
of Wressill and Lekinfield in Yorkshire" ; included among the articles for principal feasts we find the following :“Item, Bustardes for my Lordes owne Mees at Pryncipall Feestes Ande noon outher tyme Except my Lordes comaundment be otherwyse" ; but no price is attached, as in the case of other birds mentioned.

It is much to be regretted that almost all the records of the existence in Yorkshire of so fine and conspicuous a bird should date subsequently to its extinction, the precise period of which is uncertain; although there is reason to believe that the last bird was seen at Foxholes, near Scarborough, about the year I835, and it is somewhat remarkable that there should be only two published contemporary allusions to its presence in the county in the eighteenth century. These were by Marmaduke Tunstall, and a writer in the "Sporting Magazine" ; probably this want of record may be explained by the very abundance of the species. Even the records that exist are derived from memory, or based upon hearsay statements.

The materials available for treating of the past history of Yorkshire Bustards consist of Marmaduke Tunstall's MS., dated $\mathrm{I}_{784}$, contained in Fox's "Synopsis," p. 82 ; a paragraph, dated October I792, in the "Sporting Magazine"; Arthur Strickland's account given in Allis's Report on the Birds of Yorkshire, in I844; notes by Henry Woodall of North Dalton, and E. H. Hebden of Scarborough, contributed to Morris's "British Birds" in I854; articles in the Zoologist for I870 (pp. 2063, 2I02, 2I03); a letter from Sir Charles Anderson of Lea, to the late John Cordeaux, dated I4th December I874; letters to Mr. W. Eagle Clarke from Mr. Thomas Boynton, late of Ulrome, now of Bridlington, Sir C. W. Strickland of Hildenley, Professor Newton, and Mr. J. W. Woodall of Scarborough; letters from Mr. W. H. St. Quintin of Scampston, and the Rev. G. D. Armitage, written in March 1902, and articles in the Field of 6th and 27th March I897, by Mr. J. E. Harting and Mr. St. Quintin. From such of these materials as have been published, the numerous statements given in books have been compiled. Of the early 
writers mentioned, the first to comment on the great Bustard is the celebrated Yorkshire ornithologist, Marmaduke Tunstall, F.R.S., of Wycliffe-on-Tees, who remarked: "Some still remain on our Yorkshire Wolds. An acquaintance of mine pursued for three days the last summer, without effect, a brood [sic] of seven; and one of twelve, at least, he had heard of."

The only other eighteenth century record is contained in the "Sporting Magazine," under date October I792, thus :"Within these few days a Bustard was killed at Rudstone-onthe-IVolds, by a gamekeeper belonging to Sir Griffith Boynton. The width of the wings was seven feet over."

Mr. W. H. St. Quintin also communicates an interesting item of information, taken from an old estate book in his possession, concerning the price paid by his ancestor, Sir William St. Quintin of Wansford, in the year 1760 , to his gamekeeper, Wm. Wiley, for Bustards; these birds being valued at two shillings.

At the northern extremity of the Wolds, the chief and last haunt of the Great Bustard seems to have been about Flixton, Hunmanby, and Reighton. It was here-as she informed Mr. Boynton-that the late Miss Charlotte Rickaby of Bridlington Quay, when a girl, counted fifteen Great Bustards in a field, while riding with her father from Bridlington Quay to Flamborough, early in the last century; and Sir C. W. Strickland wrote that his grandfather, Sir William Strickland, used to say he could remember a flock of about five and twenty of them on the Wolds between Reighton and Bridlington, and that the last of them was eaten at Boynton. A farmer living at Reighton in I830 told Sir Charles Anderson that when he was a boy flocks of eight and ten together were found all over the district. Mr. W. H. St Quintin, writing on 4th March I902, says:- "In the churchyard at Lowthorpe is buried —-Agars, for some time keeper in our family. Lord Lilford had a manuscript, from which he has quoted to me, to the effect that Agars once killed eleven Great Bustards at a shot .... this happened on the Wolds."

This is the same incident as is referred to by Mr. J. E. 
Harting, in an article on "The former occurrence of the Bustard in Yorkshire," in the Field, 6th March I897. Mr. Harting states that the precise details have only recently come to light in a letter written by the grandson of the keeper who shot the birds. For this information we are indebted to Lieut. Gen. A. C. Cooke, who writes as follows :-

" On looking over some old documents belonging to a deceased relative, I came across the following letter, which may, I think, be of interest to sportsmen and naturalists. It gives an account of eleven Great Bustards killed at one shot on the Wolds of Yorkshire, near Sledmere, in I8o8, by one Agars, gamekeeper to Mr. St. Quintin of that day. The writer of the letter was Agar's grandson, whom I knew very well, as he was watcher to the Foston Trout Club, in whose water I used to fish. The father of the writer (and son of the shooter) I also knew well. He had been gamekeeper to Col. St. Quintin, and was a fine specimen of the old English keeper, of good presence and courteous manners. The account now transcribed, and given below, was written by his son at his dictation in I864, and, as he states that he was twelve or thirteen years old when the occurrence in question took place (I808), he must have been then sixty-eight or sixty-nine. Col. St. Quintin's property adjoins the Foston Club water. When the occurrence took place the Wolds had not been ploughed up, and consisted of uninclosed rolling downs, the natural haunt of Bustards, which bred there, and of which some were doubtless killed every year, for it seems that the equipment of a Wolds keeper included a stalking horse, a coat made of horse hide with the hair outside, and a blunderbuss. This particular occurrence had evidently impressed itself on the old man's mind, on account of the unusual number of Bustards killed in one day; and the fact of his remembering the subsequent destination of the dead birds shows that his memory was tolerably accurate. Of his reliability I have no doubt. Possibly some old members of the Foston Club will remember him; Mr. Woodhall, who was for many years secretary, may possibly do so. The following is his letter :- 
"Foston, Cross Keys, March I9, I864.

"Rev. Sir,-Father wishes me to give you all the particulars in his power respecting the number of Bustards killed by my grandfather at one shot. It being so long a time since, he is not able to give you a correct account of all the particulars you name in your letter; he is not positive (in) what year (it happened), but he thinks it was in 1808 , and that it was in the month of March. He cannot remember how many Bustards there were at the time grandfather fired; he thinks seven fell to the gun and four (were) got afterwards which were wounded. He does not know the weight of the gun (used), but it was more than the strongest man could hold without a rest. He cannot say how much powder or shot was used in the charge, neither the size of the shot, but grandfather generally used No. 3. He does not know the distance he was from the birds, but thinks about thirty yards. The horse was a big bay coaching mare properly trained as a stalking horse; his (own) coat was generally made of a bay horse-skin tanned with the hair on. It was near Borrow where they were killed, between Langtoft and Sledmere; it was before the Wolds was enclosed, and before it was plowed out. Grandfather lived with Wm. Thos. St. Quintin, Esq., at the time. He believes six Bustards were given away in the neighbourhood and the rest sent to Mrs. St. Quintin, then in London. It being so long a time since, and father being only twelve or thirteen years old, he is not able to give you a correcter account. I am, Rev. Sir, your obedient humble servant, Robert Agars.

"To the Rev. R. B. Cooke."

Following upon this interesting information, which was not in the possession of Mr. W. Eagle Clarke when writing the bird portion of his and Mr. Roebuck's "Handbook of Yorkshire Vertebrata," is a short communication from Mr. St. Quintin (Field, 27th March I897), as follows :-

"May I correct a trifing inaccuracy which has crept into Mr. Harting's letter in the Field of the 6th inst, on the subject of a remarkable shot at Bustards in East Yorkshire about 
the year ISoS? The ground upon which the incident in question occurred, though only some six miles distant, never belonged to my family, but at the date named was part of the Sledmere estate, and is now the property of Sir Tatton Sykes. It is high wold land, and, no doubt, at the time was open sheep walk. Agars, the keeper who fired the shot, and more than one other of the same family, was (as Mr. Harting has stated) in the employ of my grandfather; but it seems that in those days, when game was not plentiful on the Wolds, or held in much account, considerable liberty was allowed to those who cared to go even beyond the boundaries of their own manors in search of such precarious or arduous sport as the pursuit of Wild Geese, Dotterel, and, as in this case, Great Bustards."

Mr. Hebden's information was to the effect that to the best of his recollection it would be about the year I8II that he first saw the five large Bustards on Flixton Wold, that number continuing there at least two years, when two were killed; the remaining three still continued on the same Wold for at least one year, when two disappeared, leaving the solitary bird, which, after a length of time, was severely wounded by Sir William Strickland's keeper, and found some days afterwards in a turnip field near Hunmanby, by the huntsman of the Scarborough Harriers, and secured. Mr. A. S. Bell adds that this bird was brought to Scarborough and cooked at a supper given by the hunt (Zool. I87o, p. 2063).

Professor Newton of Magdalene College, Cambridge, kindly communicates the following additional evidence:" Rather more than a year ago the Master of Trinity College, Dr. W. H. Thompson, told me that when he was about six or seven years old he was living at York with his grandfather, to whom a Bustard was sent as a present. Dr. Thompson remembered going into the servants' hall or the kitchen to look at it, and some one was holding it up by the legs. $\mathrm{He}$ thought it weighed about eight or nine pounds, and it would therefore be a hen bird. He supposed it had been procured on the Yorkshire Wolds where he had heard Bustards once existed, and that it was eaten in the house, but he had no 
recollection of having tasted it, or indeed, anything more about it. Dr. Thompson graduated B.A. in I832, and, supposing him to have been then twenty-two years of age, the event must have happened about I8I6 or I8I7." Mr. J. W. Woodall states that about I825 a Bustard was run over and killed between Folkton and Hunmanby. Sir Charles Anderson has a stuffed specimen, taken in I825 at Hunmanby, and in I828, while shooting on Mr. Osbaldeston's property at that place, he saw a fine cock. This would, no doubt, be the identical bird seen in Grindale Field by Mr. John Milner of Middledale, Kilham, he thinks, about the year I828, for-as he informed Mr. Boynton-it was some time after he left school in I825, and at the time he was riding with his father, who died in I830. Mr. Boynton was also told by the late Mrs. Metcalfe of Bridlington Quay that she and her husband (who was Vicar of Reighton, and died in I834), were invited to dine at Boynton Hall with Sir Wm. Strickland, the principal dish being a Great Bustard, which Sir William, in his note of invitation, described as probably " the last of his race."

Sir Charles Anderson believes the existence of the Great Bustard in Yorkshire ceased in I832 or I833, when the last hen bird was trapped on Sir Wm. Strickland's estate at Boynton, near Bridlington. This, however, was not the case, as Professor Newton, in I88I, gives particulars of a conversation he had many years before on this subject, to the following effect :-

"In October I854, Mr. Barnard Henry Foord of Foxholes, near Scarborough, aged then twenty-five, told me he remembered having seen Bustards-the last was at Foxholes about nineteen years before (i.e., I835). His father once saw eleven together. He had heard his uncle speak of running Bustards with greyhounds, as if he had been present at the time. This Mr. Foord is, I believe, now dead. I was very much struck at the time by the nature of his evidence, for I had believed that the bird was extinct in Yorkshire before I835, and I remember pressing him particularly with questions on this point; but he persisted in the truth of his statement. 
I confess I was not, nor am I now, satisfied with it, though I am unable to suggest any explanation of the difficultyfor, even if he had been a year or two older than he said (and he could not have been more) it would still remain."

Thomas Allis, in his oft-quoted Report, in I844, wrote:-

Otis tarda.-The Great Bustard-F. O. Morris and Hugh Reid refer to a specimen killed at North Dalton, and now in the possession of James Hall, Esq., of Scorborough, near Beverley. See also Yarrell's "British Birds," where several instances are mentioned, but it is now nearly if not quite extinct. Arthur Strickland says: "This splendid bird used to be a constant resident on the extensive Wolds in this Riding, but the extension of tillage and the numerous enclosures which have taken place within this half century, and the introduction of artificial crops, particularly saintfoin and clover, which from being early cut often led to their destruction, they rapidly decreased, and have for some years been quite extinct. About thirty years ago [i.e., I814] when I first knew this country, the flock frequenting this part of the Wolds was reduced to five or six, and appeared to remain at that standing for some time, and I not infrequently met with it when riding about; it however soon became reduced, and it is about fifteen years since [i.e., I 829] the last was lilled at Reighton, since which [time] none have been seen in this neighbourhood. I believe those frequenting the Wolds south of Driffield remained in existence some years longer, but are now totally exterminated."

In this last and somewhat offhand statement I am of opinion that Strickland was mistaken, for, judging from the evidence which I am able to quote, the birds on the north Wolds certainly existed a few years later than those in the south.

The last Bustards which frequented the southern portion of the Wolds were in the vicinity of North and South Dalton. There is an egg-the only Yorkshire one known to existin the Scarborough Museum, the note attached to which states it was found by James Dowker of North Dalton, in the East Riding, in I8Io. This was presented to the Museum in March I840, by Dr. John Bury (H. W. Fielden, Zool. I870, p. 2063). John Wolley, the eminent oologist, who saw the egg in 1843 and in 1850 , noted in his egg book that it had been boiled with the notion of preserving it, and was of bad colour (tom. cit. p. 2IO2). H. Woodall informed F. O. Morris that in 1816 or 1817 James Dowker killed two Bustards 
near North Dalton, with a right and left shot, and saw a third, Mr. Woodall believed, at the same time; a nest that had been forsaken was also found, with one egg in it, which is now in the Scarborough Museum.*

One of the birds shot was presented to George IV., then Prince Regent. A. S. Bell (tom. cit. p. 2ro3), added that the other was cooked by Mr. Dowker, and that in the previous year-which he stated as I809-five Bustards were seen on the same moor, but were very wild, and none killed. These dates disagree, but it is more than probable that that of the label on the egg is the correct one, especially as the Rev. G. D. Armitage informs me (in litt. I902), that a Great Bustard was obtained by W. Armitage at North Dalton in I8I6. Sir Charles Anderson also states that the Bustard bred at Haywold [evidently the Hawold of the Ordnance Map, situate above North Dalton] about I8Io.

It is by no means unlikely that a pair or two of Bustards may have lingered much longer in some districts than in others, as the Enclosures Act, which gave them 'notice to quit,' was not a general Act, but each parish obtained its extension at different times, hence some years elapsed between its operation in various districts, and the birds would linger the longest where the Act came into operation the latest.

In I865 the late W. W. Boulton saw at Scorborough, the seat of Mr. James Hall, two specimens which had been captured in the East Riding-one, a female, was evidently a bird of the year; it was taken alive in the neighbourhood of Scorborough, about forty years before (about I825), and Mr. Hall had had it tethered on his lawn; the other, an old male, Mr. Hall had forgotten the history of, but thought it was taken not far from Doncaster, and certainly in Yorkshire (op. cit. I865, p. 9446). After Mr. Hall's death, his collection was sold, the male Bustard passing into the possession of Mr. Thomas Boynton, and the female into that of Mr. John Stephenson of Beverley.

A pair-male and female-are preserved in the Blackmore

* As bearing on this point it may be of interest to mention that a farm at Hutton Cranswick is still called "The Bustard's Nest." 
Museum, at Salisbury, which were killed near Malton in I825 (Thomas Norwood of Salisbury, " Country," IIth January I877, viii. p. 39).

The fine pair in the Scarborough Museum were purchased from Hugh Reid of Doncaster, and presented by Dr. Murray, many years ago.

Since the date of its final extinction as a resident, the Great Bustard, now become an accidental visitant, has twice occurred in Yorkshire. A female example was shot on Rufforth Moor, near York, on 22nd February I86I (T. Allis, Zool. I86I, p. 7507), and is now in the York Museum; and another female, just dead but still warm, was picked up in the sea near Bridlington Quay on IIth November I864 (W. W. Boulton, op. cit. I865, p. 9442). This specimen is now in the collection of Mr. Thomas Boynton at Bridlington, where I have had the privilege of examining it, as also the male individual purchased from the Scorborough collection.

\section{LITTLE BUSTARD.}

Otis tetrax (L.).

Accidental visitant from the European Continent, Asia, and north Africa.

The true home of this handsome bird is in the deserts of Asia and north-west Africa, though it also nests in the east of Europe, whence rare stragglers on migration in winter wander to our shores.

The first recorded Yorkshire specimens of this bird are those referred to as seen at Flamborough, in I8I4-I5, and mentioned by Arthur Strickland in the Report of Thomas Allis, who, in I844, wrote:-

Otis tetrax.-The Lesser Bustard-Dr. Farrar informs me that a specimen of this beautiful species was shot in Bolton Wood, near Bradford, about five years ago by the keeper of Francis Simes, Esq., in whose possession it now remains; F. O. Morris reports another specimen shot near Beverley, and now in the possession of James Hall, 
Esq. Another was killed at Boythorpe, Sledmere Wolds, near Scorborough, see Yarrell's "British Birds." Arthur Strickland remarks "It is possible that this species was a native of, or regular visitor to, the Wolds of this county in former times, but of late it has been of the rarest occurrence. One in my collection was killed there some years ago, but the exact date I do not know. In the winter of I8I4-15 two of these birds were seen at Flamborough; one of them was killed, which I believe was still in preservation. These are the only instances that have come to my knowledge."

Yorkshire appears to have been favoured by the visits of this species more frequently than any other county excepting Norfolk, the instances of its occurrence, so far as is ascertained, being as follows :-

In addition to those mentioned by Strickland, Thomas Allis referred to three individuals before 1844 .

At Goodmanham, near Market Weighton, a female was procured on I9th January I854, by the Rev. W. Blow, and was presented by him to the Rudston collection, now in the York Museum (T. Allis, Zool. 1854, p. 4254).

Another female, a mature bird, was killed at Leven, near Beverley, on 3Ist January I862, by the keeper of Canon Wray, and was in the possession of Mrs. Wray (W. W. Boulton, op. cit. 1862, p. 7938).

In October I886, a pair occurred at Allerston Marishes, near Pickering.

A specimen in the possession of Mr. P. Hawkridge was taken near Scarborough "a few years ago" (A. Roberts MS. I88I).

At North Burton one was killed in I868, by a boy, and is in the possession of Mr. Appleby of North Burton ( $\mathrm{T}$. Boynton MS.).

The late Col. B. B. Haworth-Booth informed me that a female in splendid condition was obtained by Mr. B. Holmes during the last week in December I895, in a turnip field at Burton Pidsea, Holderness.

And on 5th December 1902, Mr. G. E. Clubley of Kilnsea shot one at dusk near Spurn; the body was not recovered until next day, when it was found to have been partly eaten by a cat (P. Loten and Clubley MS.; and Nat. Igo3, p. 6I). 
I saw the preserved remains of this specimen at Easington in the October following.

Six specimens of the Little Bustard are in the York Museum, and formed part of the Strickland and Rudston collections. One of these is the Goodmanham bird (I854), and probably some others may be the examples mentioned in Allis's Report.

\section{MACQUEEN'S BUSTARD.}

Otis macqueeni ( $\mathcal{~ E . ~ E . ~ G r a y ) . ~}$

Accidental visitant from Asia, of extremely rare occurrence.

This handsome Bustard, known also as the Asiatic Houbara, and Ruffed Bustard, is resident in the Aralo-Caspian region, and winters in north-western India. It is a very rare accidental straggler to this country, only four instances being recorded, two of which belong to Yorkshire.

The second British, and first Yorkshire, occurrence refers to a male example obtained at Marske-by-the-Sea, within sight of the room where these lines are being written. It was first observed on 5 th October I892, by some boys, in a field at Windy Hill Farm, near the coast, and was so fearless that it took little notice of several stones thrown at it. Information was then sent to a man named Richardson, who brought a gun, and, as the bird rose, killed it at close range, damaging it badly on one side. It was taken to Pearce Coupe, taxidermist, of Marske, for identification, and he at once communicated with the authorities of Newcastle Museum, by whom it was eventually purchased. I had an opportunity of examining it before it was forwarded to Newcastle, and have since been favoured by the late curator, Mr. House, with particulars and dimensions of the specimen. It had apparently been feeding, a few grass seeds being found in its crop and also in the throat and beak.

The illustration of this bird is taken from a water colour drawing (after a photograph of the stuffed specimen) by Mr. 
Woodhouse. (cf. Zool. I893, p. 21 ; Nat. I892, p. 373; and Field, I7th December I892.)

The second Yorkshire specimen, a young male, was seen at Kilnsea, near Spurn, on I7th October I896, and was fired at by Col. White but, apparently, not injured. On the following day it was observed by Messrs. W. Eagle Clarke and H. F. Witherby, who watched it for some time through powerful binoculars at a distance of a hundred and fifty yardis. On the wing it looked like a large Owl, and was mobbed by small birds; when it alighted behind a high bank the Grey Crows hovered about it and so revealed the place where it was; it flew low, and slowly, skimming the ground. In walking it carried the head and neck like a feeding Pheasant, and appeared to spend its time in feeding, washing, and preening itself. It walked in a stately fashion, but not with head upright, though when alarmed it stood with head and neck erect and on the alert, the long black feathers on each side of the neck being very conspicuous. It was fired at several times, and on being flushed never flew to a great distance, going about a hundred yards and then alighting, being eventually killed by G. E. Clubley. The bird weighed 3tbs. IIOz.; its stomach was filled with vegetable matter, chiefly heads of ragwort, and fragments of beetles.

A peculiarity of the plumage was that the base of the feathers on the back and breast was, for about a fourth of their length, salmon pink, as also was the down.

Mr. W. Eagle Clarke and the late J. Cordeaux dined off the body, and found the flesh dark and tender, in taste like a Wild Goose, with a savour of Grouse.

This specimen is now in the possession of Col. White of Hedon (Zool. I896, p. 433 ; and Nat. I896, p. 323).

It will be remarked that both these Houbraas were so tame, or unsophisticated, as to allow a shooter to approach within range. 


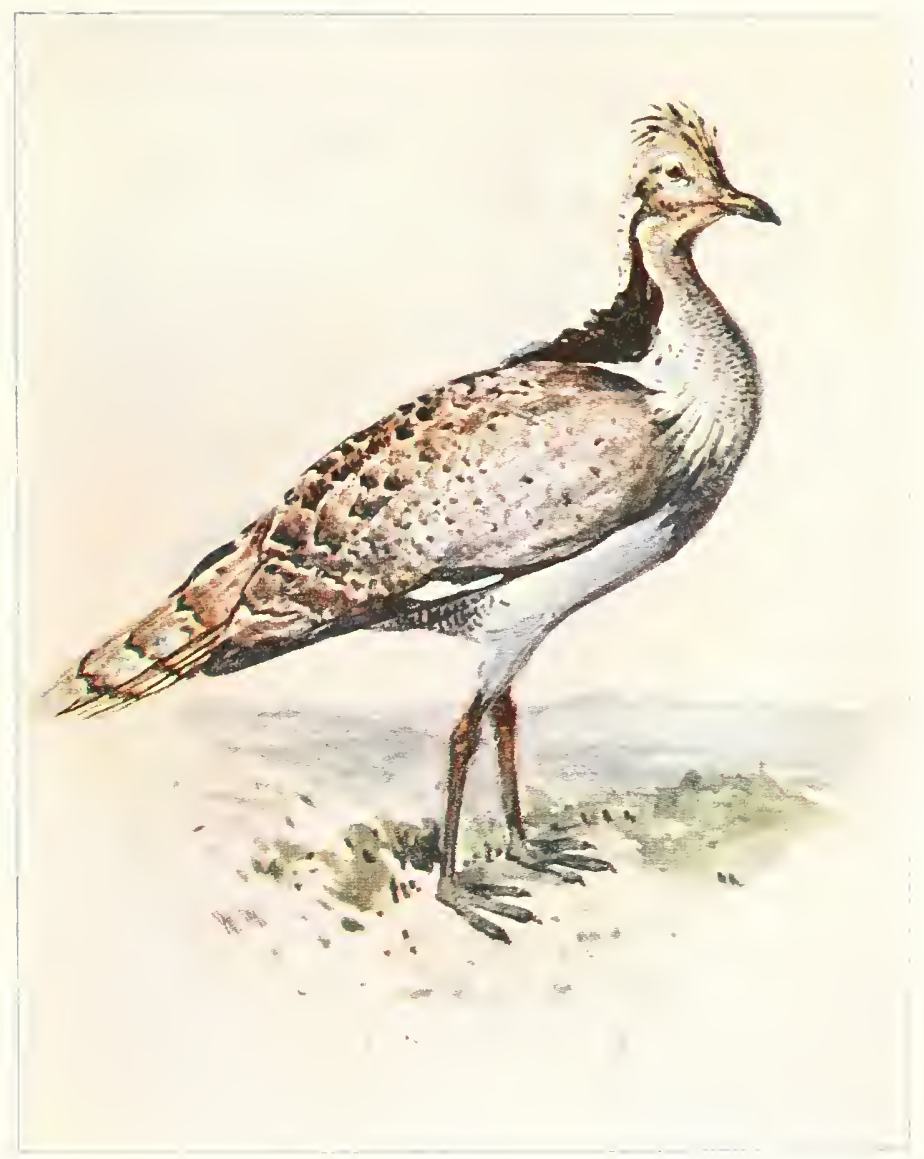

From a Itatir-Colour Drawing by II. Hhothouse.

Macqueen's Bustard, the first of the two Yorkshire examples. Shot at Marske-by-the-Sea.

See puge 560 . 



\section{1 \\ STONE CURLEW. \\ Edicnemus scolopax (Gmelin).}

Summer visitant, chiefly to the East and North Ridings; very local, and decreasing in numbers; still breeds in a few secluded districts. A rare straggler to west Yorkshire. Has been observed in winter on several occasions.

An early allusion, probably the earliest, to the Stone Curlew, is found in the MS. of Marmaduke Tunstall, F.R.S., who lived at Wycliffe-on-Tees, thus :-

"The Thick-kneed Bustard, or Stone Curlew. Very rare in these parts, yet one was taken in this neighbourhood in August 1782, probably blown out of its customary haunts by storms, many of which felt about that time. It was extremely lean and pined." (Tunst. IS. I784, p. 83.)

Thomas Allis, in I844, wrote :-

Cdicnemus crepitans. - The Great Plover-Breeds at Rossington and other places near Doncaster; very rare near Leeds ; it also breeds in the vicinity of Scarborough, see Yarrell's "British Birds." A. Strickland says: "This bird used regularly to breed on the Wolds, but never abundantly since my knowledge, and I have known both the egg and young bird found, but they are now seldom met with; they are very clamorous in the evening."

The Stone Curlew, Norfolk Plover, or Thick-knee, as it is variously called, is a summer visitor, usually arriving in April; an exceptionally early date is March I897, when Mr. E. B. Emerson and his gamekeeper saw a pair on the moor at Swainby-in-Cleveland. It is of very local distribution, being almost restricted to the eastern half of the county, and is, unfortunately, not only limited, but decreasing, in numbers. It was formerly not uncommon on the Wolds and the rough unenclosed tracts of heath and warren, where it bred in several districts until the middle of the past century. Marmaduke Tunstall referred to it in north Yorkshire at the close of the eighteenth century; Allis and Strickland mentioned. it as breeding near Doncaster, and regularly on the Wolds 
before I844, although these old writers do not appear to have been aware that it was an abundant species in the warrens of the East Riding; in the neighbourhood of Scarborough, also, it was reported by the late Prof. Williamson as nesting on the fallows (P.Z.S. 1836, Vol. iv. p. 77). In the centre of the East Riding, R. Mortimer of Fimber, writing in I886, stated that he had seen old and young birds, and also eggs, for the previous four years, while old men of the village had told him it was very common on the Wolds half a century previously, before the enclosures, and when many rabbit warrens existed; Mr. N. F. Dobree of Beverley observed that, up to I870, the Stone Curlew was well known to him as a nesting species, and he possessed a fine series of eggs taken on the waste lands between Market Weighton and Selby. An interesting selection from the north Wolds, taken in the "fifties" and "sixties," has been obligingly presented to me by Mr. J. Braim, late of Pickering. The late W. W. Boulton possessed examples of the bird from Holme-onSpalding-Moor in I864 and I865, where several pairs were nesting. Another well-known ornithologist, Mr. W. H. St. Quintin, writes as follows:-

\section{"Scampston Hall, 2Ist May I8go.}

"My father used to see them (Stone Curlews), and shot one at Lowthorpe. About twelve years ago I saw a pair running in a furrow of a fallow field as I was driving between Weaverthorpe and Langtoft in early summer."

The foregoing evidence, respecting the former status of the species in the Wold district, is confirmed by the following summary, which sets forth the reasons of its gradual decrease, and its present position amongst the nesting birds of the county.

Before the enclosure of the Yorkshire Wolds, the Stone Curlew was, no doubt, pretty generally distributed, and nested in considerable numbers all over the then sheep-walks and rabbit warrens which formerly extended over an enormous area, and were the home at that time of the Great Bustard. As the Wolds became gradually enclosed these two species, 


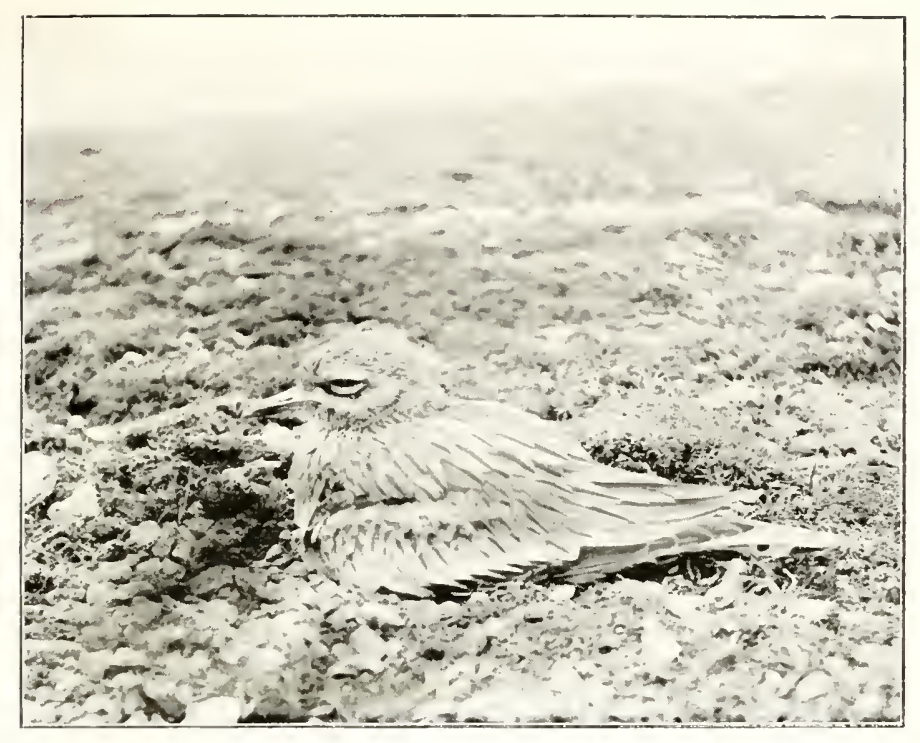

Stone Curlew on nest, near Pickering.

T. A. Metcalfe.

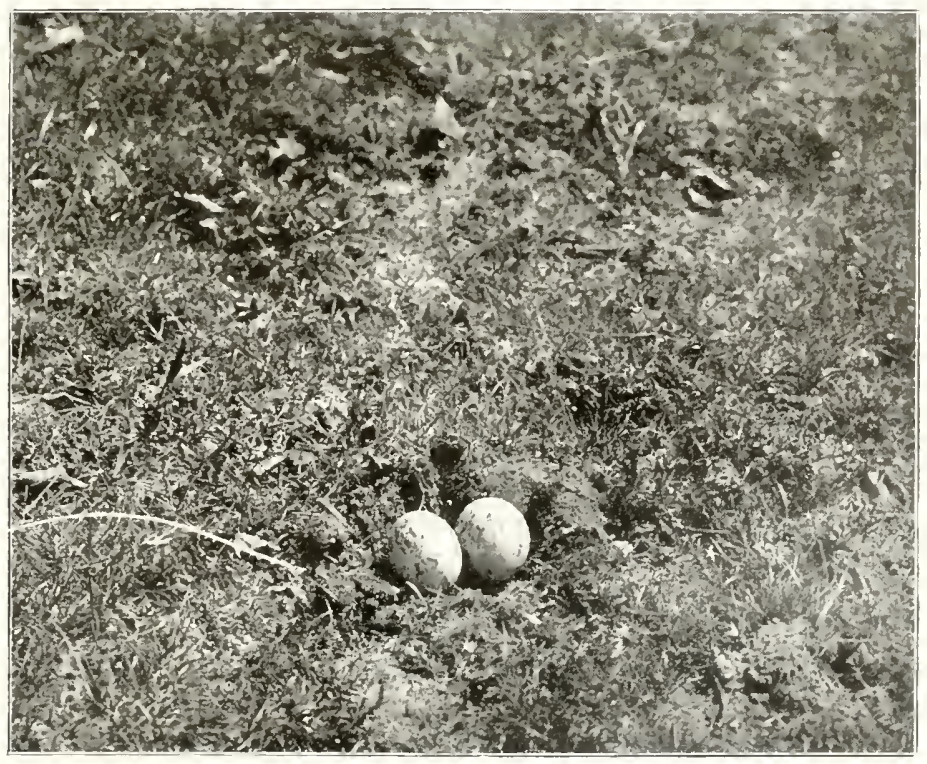

Stone Curlew's nest.

R. Fortune.

See page 563 . 

lovers of the lonely sheep-walks, were restricted to the remnants of these once famous downs, and as these became more and more circumscribed they were banished altogether, and what were once the uncultivated uplands are now waving cornfields. There were, however, still some portions, here and there, which were used as rabbit warrens, and in these the Stone Curlew continued to breed up to about I874, when it finally ceased to do so, and it is now almost extinct in its old haunts.

The Stone Curlew at one time bred on the Hambleton Hills in North Yorkshire, though its present breeding grounds are confined to one or two localities in the East Riding and one in the North, the latter being the northerly limit of its nesting range in the British Isles, and the exact whereabouts of which are, in the interests of the birds themselves, not specifically pointed out further than by indicating that the boundaries of the two Ridings named include the breeding area as at present known.

A recent instance of its nesting in south-east Yorkshire has been communicated to me by Mr. J. H. Gurney, who, writing on $5_{5}$ th May I902, says, "You may be interested to know that on roth May Mr. Hugh Buxton found a nest and two eggs of the Norfolk Plover. He first saw a fox, which put the bird up, and that led to the discovery of the eggs."

In several other parts of north and east Yorkshire it has been observed at intervals when on passage to and from its nesting quarters; so long ago as I845 J. Hogg recorded one between Saltburn and Brotten, and it has been once observed at both the Tees and Humber estuaries. In the west of the county it is a rare straggler; a pair in the collection of the Rev. G. D. Armitage was inadvertantly killed in the summer of I865, on Crossland moor, near Huddersfield; one was taken on Coniston moor, in Craven, in August r866, another at Bilton, near Harrogate, about I865, and one was seen on Malham Ings about the end of April, I895.

The Stone Curlew takes its departure in September or October ; on the $9^{\text {th }}$ of the latter month, in 1874 , a flock of about forty was seen on rough grass land at Ganton, evi- 
dently assembling for migration. Occasionally cases are noted of individuals being met with in winter, these are probably late hatched birds unable to migrate at the usual time; one occurred at Toothill in January I862; another, obtained near Filey, was preserved by Mr. Stuart of Beverley; there are several instances known of winter occurrences in Holderness; Capt. Dunnington-Jefferson of Thicket Priory saw one on 24th December I888; I examined a specimen in the possession of Mr. T. Machen of Bridlington, which had been killed at Sewerby on Sth January I899; in the following month another was reported at Reighton ; and, finally, on I6th December, in the same year, a female example was caught by a dog, during a snowstorm, on the Redcar sand-hills, and brought alive to me; it was, however, suffering from a shot wound, and only lived till the following day.

Nidification commences early in May, and eggs have been found on the first of that month. As exemplifying the pertinacity with which this species clings to its old haunts, it may be mentioned that, quite recently, Mr. T. Audas found a nest, in the East Riding, in the middle of a fairly large plantation of trees from twelve to fourteen feet high; evidently an old nesting site, and resorted to prior to the planting of the trees. In the breeding season the Stone Curlew utters a note somewhat like " Kiddy, kiddy, kiddyKiddy, kiddy, kiddy. Kiddy, kiddy, kiddy, kiddy ": this is when a bird has lost its companions. In the evening they leave the dry, sandy rabbit-warrens, and seek their food in the cultivated fields, when they become very noisy, and their wild whistling cries may be heard in many places where the birds are not to be found in the day-time.

Besides the names of Stone Curlew, Norfolk Plover, and Thick-knee, this bird sometimes receives the cognomen of Great or Whistling Plover; Tunstall terms it Thick-kneed Bustard; while Kelne was the name given by all the old warreners in east Yorkshire. 


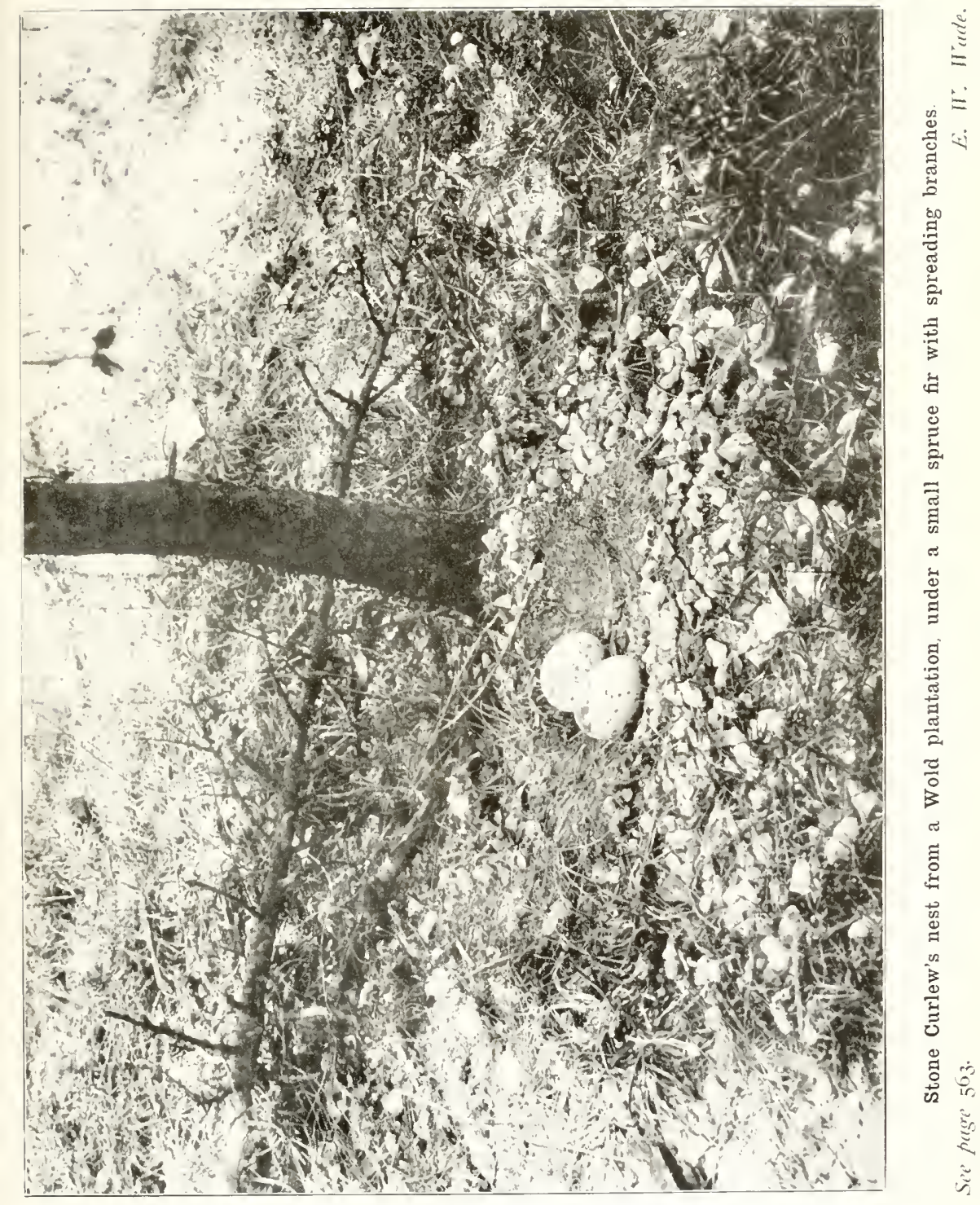





\section{5 \\ COLLARED PRATINCOLE.}

.Glareola pratincola $(L$.$) .$

Accidental visitant from southern Europe, Africa, and Asia, of extremely rare occurrence.

This peculiar and interesting bird is an accidental wanderer from the south of Europe, Africa, and Asia, occurring very rarely in these islands. It has been chronicled on three different occasions in Yorkshire, the first being noted by the late Sir Wm. Milner, who stated that a fine specimen was killed when in company with a flock of Dotterels, in May I844, on Staxton Wold, five miles from Scarborough, and passed into the possession of Mr. Peter Hawksworth (Zool. I848, p. 2023).

The second example was recorded by the late Joseph Duff of Bishop Auckland, as being just (9th February I850) received by him from "Bedlington in Northumberland" (op. cit I850, p. 277I), but, in a subsequent letter to the late John Hancock, he informed him that the locality mentioned was a misprint, and that the bird had been taken at "Bridlington in Yorkshire" (" Birds of Northd. and Dm." p. 96, footnote). Mr. Duff, in conversation with me, confirmed this statement, and added that he disposed of the specimen to Mr. J. H. Gurney.

The third Yorkshire bird was obtained between Ruswarp and Whitby, by Wm. Wilson. It was a male, and the stomach contained ants and a few feathers. This specimen is now in the Whitby Museum; but the date on the label, "September I87I," should be, as Mr. Thomas Stephenson tells me, " Igth October I87x." 


\section{CREAM COLOURED COURSER.}

Cursorius gallicus (Gmelin).

Accidental visitant from northern Africa and Asia, of extremely rare occurrence.

It is difficult to understand the causes which impel this beautiful bird to wander from the deserts of Africa and Asia to these inhospitable shores. The first reference to its occurrence in Yorkshire appears in Atkinson's "Compendium of British Ornithology," where one is recorded as having been killed near Wetherby, in April I8I6, but unfortunately so much injured by the shot, and so ill preserved, that it fell a prey to insects. It was seen alone, frequenting a dry piece of fallow ground, over which it ran with great swiftness, making frequent short flights, and was approached without difficulty. The haunts and habits of this bird, as described by Latham, exactly agree with the foregoing, and in no respect do they differ in plumage except that in the specimen under notice the black patch behind the eyes was undivided by any pale streak, and the crown of the head was ash-coloured. A correct drawing of this bird was made when in its most perfect state (Atkinson's "Compendium," I820, p. I65).

This is the same example as is referred to by Thomas Allis, in his Report on the Birds of Yorkshire, I844, thus :-

Cursorius isabellinus.-Cream-coloured Courser-Formerly the only Yorkshire specimen was the one recorded by my friend $H$. Denny, in his Catalogue of Leeds Birds ; in the "Annals of Natural History," Vol. vii., he says a specimen was shot in April 18 I6, in a fallow field near Wetherby, by Mr. Rhodes of that place. It came into the possession of Mr. J. Walker of Killingbeck Lodge, near Leeds; he observes "I did not see the specimen myself, but I have seen a most accurate and highly finished drawing taken from the bird, which was in such a mutilated state when it came into the possession of my friend Mr. J. Walker, as to render its preservation impossible, having been killed several days; but from his sound practical knowledge as a naturalist and his abilities as an artist, which are well known in this neighbourhood, there cannot remain the least doubt as to the authenticity of the species; I may add that its peculiar habit of running and then 
taking short flights struck the person who shot it (who, however, was no ornithologist) as something new, and the beak again being different from the Plovers, for which he at first mistook it, and which caused him to keep it." Arthur Strickland informs me that another specimen of this rare bird was killed in 1825 , by the keeper of the Earl of Harewood, and another in 1828 by the keeper of the Hon. Chas. Stourton of Holme [on Spalding Moor], near Market Weighton.

It will be observed that Allis, on the authority of his friend and correspondent, Arthur Strickland, mentioned the occurrence of two specimens of the Courser, in addition to that first reported. One in 1825 , killed by the Earl of Harewood's keeper (see also Gould, " Birds of Great Britain "); and another in I828, shot by the keeper of the Hon. Chas. Stourton, at Holme-on-Spalding-Moor, near Market Weighton. The foregoing furnishes all the information available with regard to the visits of the species to the county. There is no record of its appearance since the year when Allis wrote.

\section{DOTTEREL.}

\section{Eudromias morinellus (L.).}

Bird of passage in spring and autumn; very local and not common. Most frequent in spring on the coast, where it arrives in May, remaining for two or three weeks; also observed on the high lands at the same period; less abundant in autumn.

The earliest mention of the Dotterel in Britain is contained in the Percy's "Northumberland Household Book," begun in I5I2, at the Castles of "Wressill and Lekinfield," where this entry occurs :- "Dottrells to be bought for my Lorde when they are in Season and to be at jd. a pece."

Thomas Allis, in I844, wrote:-

Charadrius morinellus.-The Dotterel-Rare near Sheffield; occasionally met with on the moors:about Halifax in spring and early summer. Wm. Eddison says it occasionally comes to breed on the Marsden and Slaithwaite Moors; very rare near Leeds; Arthur Strickland says "The Wolds near here [Bridlington] seem to be the ancient resort of this species previous to their retiring to the mountains in the west to VOL. II. 
breed. They appear in flocks in the spring and remain two or three weeks, and resort principally to the fallows and open districts ; formerly considerable numbers were killed at these times, but of late'their numbers have been so much reduced that but few are now met with, and that only by ranging the country on horseback very early in the morning before the ploughman is abroad." It is very rare near Barnsley, Dr. Farrar saying that he never obtained but one specimen, which was shot at Staincross in 1830 .

Naturalists cannot but regret the great diminution in the numbers of Dotterel during the last half century, and although it was never an abundant nesting species with us, being, as it still is, chiefly known as a passing visitor in spring and autumn, it has a peculiar attraction to the ornithologist, who usually has to content himself with observing the " trips" on passage, and imagining the nesting economy. An early reference to this bird in Yorkshire is contained in the Allan MS. in connection with the Tunstall Museum, written in the year I79I, as follows :- " They are stupid birds, easily enticed into a net. A dull person is proverbially called a Dotterel " (Fox's "Synopsis," p. 90).

As is generally known, the breast feathers of this bird were formerly, and are still, in great request by fly fishers, and such was the demand for them in comparatively recent times that, from the Holderness coast right up to the high grounds about Bempton and Specton, the shooting of Dotterel was a regular occupation in spring: for some coast gunners and old shooters boast that in former days-fifty years agothey have taken as many as fifty couple in a season. The destruction was carried on with equally disastrous effects on the Wolds, moors, and commons inland, where the ranks of the "foolish birds" were decimated to such an extent that as many as forty-two couple were secured in a single day on the Wolds of Ganton, Sherburn, and Knapton. J. H. Anderson of Kilham, in the East Riding, stated (Rennie's " Field Naturalist," January I834), "The Dotterel visit our large open fields every spring and autumn, and dire is the slaughter committed amongst them." It seems also, from St ickland's communication to Allis, that considerable numbers were killed, but they had then (I844) been so much reduced 
that but few were met with. On the moors in the route travelled by the birds on their way to the north-west heavy toll was exacted; Mr. J. H. Phillips remarked (Nat. I890, p. I5), that about the middle of the past century numerous flocks were found on the Hambleton Hills; between Dialstone Inn and South Woods he had put up hundreds on the moors; on the Wensleydale moors it used to be sought regularly every year for feathers for anglers (op. cit. I886, p. I86). Additional evidence of its former abundance (if such is required), on the spring passage over the Wolds and along the coast line in the district mentioned by Strickland, is afforded by the house named "Dotterel Inn" at Reighton, which was built by one of the Strickland family, and the sign painted by Mrs. Strickland. It is said in that district that the Inn was designed for the accommodation of gamekeepers, who came from all parts to the neighbourhood of Reighton and Hunmanby for the purpose of shooting Dotterel in the spring.

At the present time the bird is a fairly regular visitor, in limited numbers, to its old haunts, while on passage to and from its breeding places on the mountains of the north. On the vernal migration the earliest recorded date for its appearance is I8th February rgor, two being seen on that day at Kilnsea by the late G. IV. Jalland, who informed me of the fact shortly afterwards. The usual time, however, is about the end of April or early in May, and at this season it is met with in small " trips " of from two to fifty in number; the largest flock I have known at the Teesmouth was in May I903, and comprised fully thirty birds, but on 6th May I897, fifty were observed near the "Dotterel" Inn at Reighton. They return year by year to certain old-time haunts; there is a field at Easington, near Spurn, where they have occurred from time immemorial, and fall an easy prey if a gunner appears; they also visit the Wolds regularly, and well-known localities in the Reighton and Hunmanby districts, while at the Teesmouth a certain strip of short grass land is annually visited in May and September; several other similar instances might be cited if necessary.

The proverbial tameness of the Dotterel in spring is by 
no means invariable, for I have known a flock to be almost unapproachable at this season; and it may not be out of place to observe here that most of the "full plumaged " specimens observed in May lack the black crown and nape which is characteristic of the nuptial dress.

The return passage southward takes place in August and September ; in the East Riding an adult female was killed at Kiplingcotes on the 2oth of the latter month, I869; the latest date of which I am aware is 29th November I90o, on which day an example occurred on Coatham Marshes during a strong south-east gale.

The numbers noted in autumn are much fewer than during the vernal passage, and are usually immature, though adults in the dull brown plumage are sometimes erroneously named young birds. The route pursued on the autumnal migration is similar to that followed in spring-either along the coast or across the moors; in August I893, while Grouse-driving on Swainby moor, I shot one of two Dotterel which were passing over the butts and whistling as they flew, whilst other examples have been noted on the Whitby moors. In addition to the places named, it is met with occasionally on migration on Penyghent, Pateley moor, near Huddersfield, Sheffield, Wilsden, Wakefield, Keighley, Halifax, Ripon, and other localities which are too numerous to mention in detail.

As a breeding species it is extremely rare and local, and in view of the interest attached to this bird in Yorkshire, I propose to quote from an article by the late Rev. H. A. Macpherson (Nat. I89o, p. 95), on the former nesting of the Dotterel, which may not be accessible to all my readers.

Mr. Macpherson prefaced his remarks by stating that, although the late Dr. Heysham of Carlisle examined eggs taken in the north-west of England in I784, it fell to the lot of the late T. C. Heysham to investigate the question of whether the species really bred south of the Scottish border. He then gave at length two letters relating to Dotterel in Yorkshire, and, as it is upwards of seventy years since they were penned, they are quoted here in extenso :-

The first letter is that of a John Brown, written in 
answer to Heysham's inquiries, and dated from Marble Mills, Stone House, Dent, I 5 th July I83I, which runs thus :-

" Sir,-I am sorry to say, in reply to your favour of the I2th inst, that your application for eggs of the Dotterel is at least one month too late. The birds have nearly all left the hills. But have you not made a mistake? I think it possible that in the hurry of writing you have said eggs instead of skins. Great numbers of these are preserved and sold to anglers, but I am told the eggs are seldom taken. If you wish to have a few skins, pray inform me, and I will send you some. Late in the season as it is for these birds to be on the hills, and it is unusual for them to remain so long, I believe I can yet procure two or three fresh ones."

The following year Heysham applied to John Robinson of Stone House, Dent, on I6th May, but the letter was delayed in transit.

Robinson replied :- "I am afraid it will be out of my power to procure you a nest with eggs. There is some dispute whether they breed or not. Some are of opinion they do, others the contrary. I have never yet met with anybody who had found a nest. I called a few days ago on a man who partly makes it his business to look after them. He informed me that lately he shot a bird Dotterel (sic) which on opening he found contained an egg, which puts the matter out of dispute. He informs me that for the last four years the bird has become more plentiful, which is to be wondered at, considering that immediately upon its being ascertained that they have arrived everyone that can raise a gun is after them. . . . About the I5th or I6th of last month (? May I832) a flock of nine or ten arrived. One of our men shot two of them."

Robinson appears to have taken an active interest in assisting Heysham, for on 29th August in the same year (I832), Heysham received a couple of Dotterel shot on Woofell, with a note, in which the following passage occurs:-

"I have been repeatedly on the mountains during the summer, but could never meet with any (Dotterel). I think there is little doubt they leave us in the spring and return again in September and remain a little while with us, prior 
to leaving our island for the winter. I would suppose that they (the birds despatched with the letter) are male and female or a young and an old bird. I am sorry one of them is hurt in the plumage round the neck. You will see, by the map of Yorkshire, that Woofell is very high land."

It thus appears, from the foregoing, that, at the period named, the fact of the Dotterel breeding in the north-west of the county was not clearly established, although one of Thomas Allis's correspondents, W. Eddison (cf. Allis's Report), stated it formerly bred on the Marsden and Slaithwaite moors. Important additional evidence relating to its nesting in Yorkshire is contained in the private correspondence of the late John Hancock of Newcastle, which I have been permitted to inspect, and is communicated by Mr. J. E. Anderson who, writing from Holy Island in April I875, observes that the Dotterel builds on another Fell Top [in Yorkshire] a few miles south from Crossfell, but he had forgotten the local name. This might possibly have been Mickle Fell. We next find (Nat. I886, p. I86), that it was said to breed in Wensleydale up to about 1866 at High Stake, and one Arthur Sayer, who was shepherd for seventeen years on these moors, was in the habit of searching for the eggs with the keepers; though the author of this statement, the late E. Chapman, was careful to observe that he had never seen the eggs himself, and there appears to be considerable doubt as to the reliability of the record. Mr. Tinkler (op. cit. 1892, p. 324), remarks that on the fells at the head of Swaledale and Arkengarthdale it bred up to about $\mathrm{x} 860$; and in Ribblesdale it is reported as nesting within the past twenty years. My information as to its status at the present time, however, leaves room for doubt as to whether the bird is to be considered as a constant nesting species in the county; the localities where it may possibly nidificate are restricted to one or two of the mountains of the north-west, and on one of these hill-tops Mr. R. Fortune has seen a pair of adult birds in the breeding season, but has not been able to locate the nest; probably not more than two or three pairs attempt to breed, though the young birds were observed in the summers of I895, I902, and I904. I 


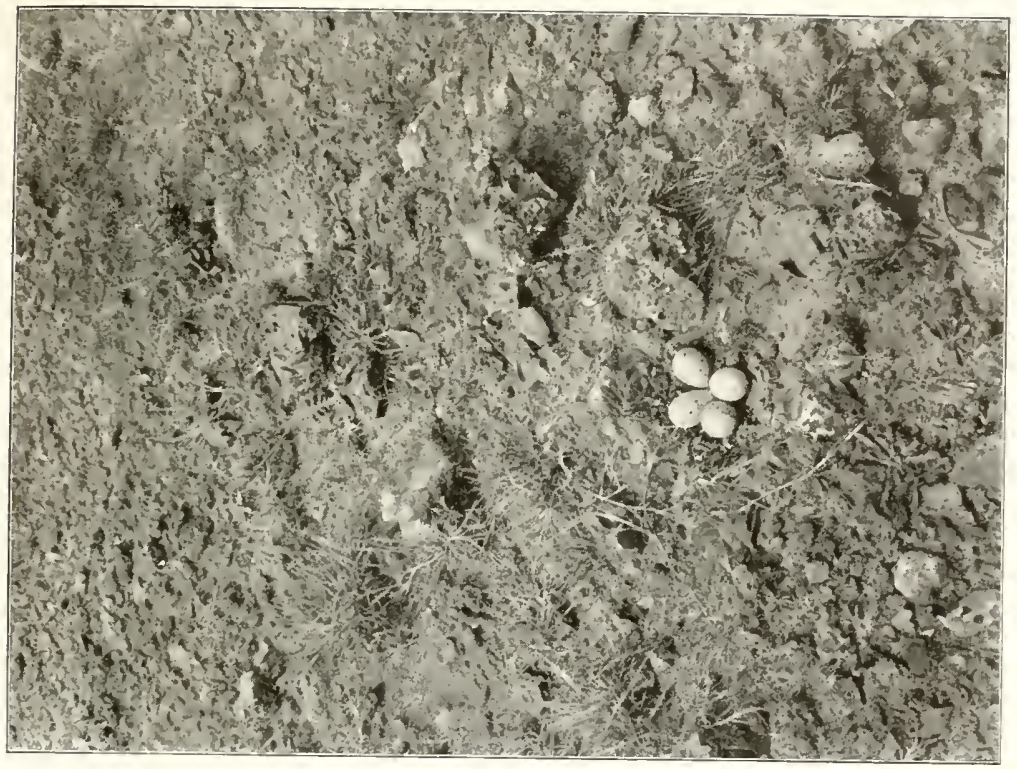

要

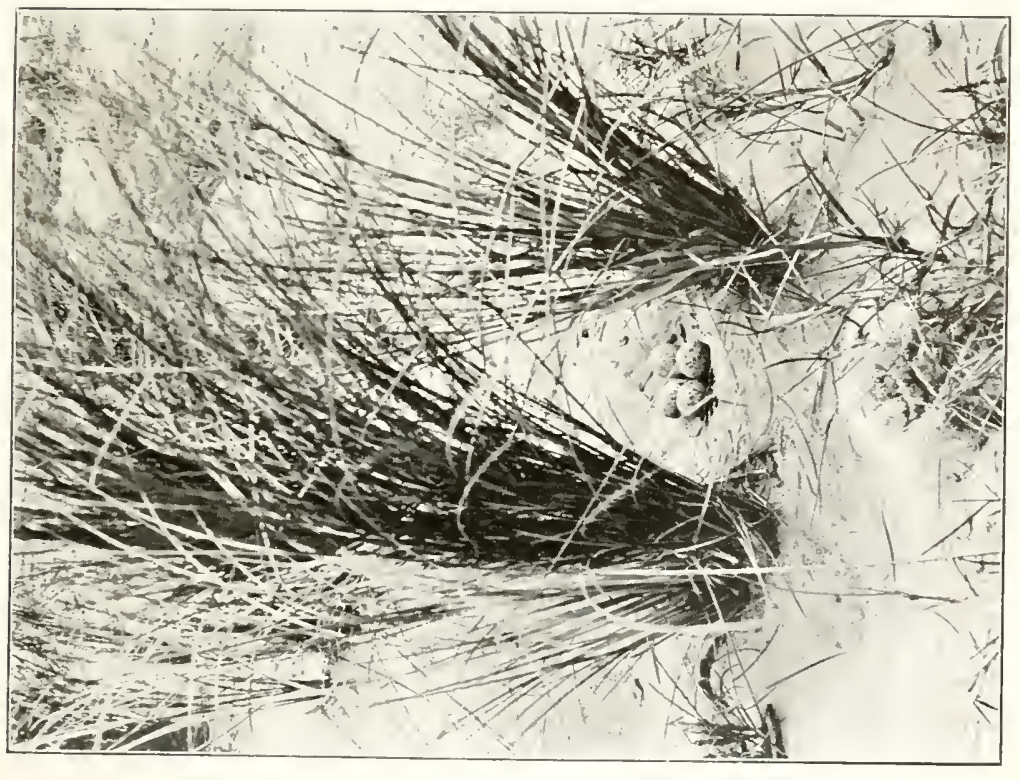

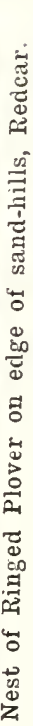



have purposely refrained from supplying more precise details in the interests of the birds themselves, but fear their existence is a precarious one, for on one of the high fells, where a pair was observed for several days in June Igo2, it disappeared about the middle of the month, but in its stead were found two empty cartridge cases !

The local names are: Land Dotterel and Spring Dotterel, used at Spurn, while at Whitby it is called Moor Dotterel.

\section{RINGED PLOVER.}

\section{AEgialitis hiaticula (L.).}

Resident, very local ; is common, and nests in the Tees and Humber districts. Also spring and autumn migrant. Of occasional occurrence inland.

The first mention of this species in Yorkshire is probably found in the Allan MS. in connection with the Tunstall Museum (I79r), thus :- "Sea-Lark-Frequent our shores in summer, but are not numerous. Lays four eggs, of a dull white colour, sparingly sprinkled with black. Disappear on the approach of winter. There is a light-coloured variety in this Museum." (Fox's "Synopsis," p. 90.)

Thomas Allis, in I844, wrote:-

Charadrits hiaticula.-Ringed Plover-Rare near Halifax, also at Sheffield, where only two or three specimens have been obtained. A. Strickland says "A few of these birds may generally be met with on the sands in autumn or winter, generally in pairs, or small numbers, and never in large flocks ; they do not breed here [Bridlington]."

Essentially a bird of the shingly beach and mud-flats of our tidal estuaries, the Ringed Plover is naturally most abundant on the Tees and Humber shores, and the low-lying coast line adjacent, and in these particular localities only can it be termed resident and common. On the rest of the coast, namely from Saltburn to Bridlington, it is best known as a frequent visitor on the spring and autumn migrations, 
although at Flamborough one or two pairs are stated to be resident, and it nested north of Scalby in I88r.

Inland it occurs almost every year, on the large reservoirs and river banks, during the vernal and autumnal passages, being reported from Slingsby, Malton, Goole, Ingbirchworth, Swinsty and Fewston Reservoirs, Pateley, the Lower Wharfe, the Nidd Valley, Ackworth, Wakefield, Sheffield, and other places more or less frequently.

From the middle of July until October migratory Ringed Plovers are numerous at the Tees and Humber estuaries, while even during the winter the species is one of the commonest of our waders; it also figures not infrequently in the list of casualities at the Lighthouses on the coast, the victims being birds on passage attracted by the fatal beams from the lanterns. During the winter months the major portion of our nesting birds retire further southward, and are absent between October and January; in the latter month they usually begin to reassemble on the beach at the Teesmouth, and I have heard their pairing notes as early as the 27 th, but, generally speaking, not until mid-February, and they return to the nesting grounds a little later. From March onwards to about the middle of May a more pronounced migration, probably of individuals which have wintered much further south, takes place, the small brighter-coloured race being frequently met with in May; these birds linger in the estuaries for several days before resuming their journey to more northerly stations.

Nidification commences about the first week in April, although "scratchings" may be seen in March, and the first full clutches are generally noted by the middle of April ; a nest with four eggs, and several others with incomplete sets, were seen on the Ioth of that month, in the year I903. These early breeding birds, if undisturbed, have a second clutch in June, and I have known two broods to be reared from one nest in a season. The later breeders, which do not nest until May, only rear one brood, but as many eggs are destroyed by birds'-nesting boys, and devoured by predaceous Rooks and Crows, nesting is sometimes prolonged as late as 


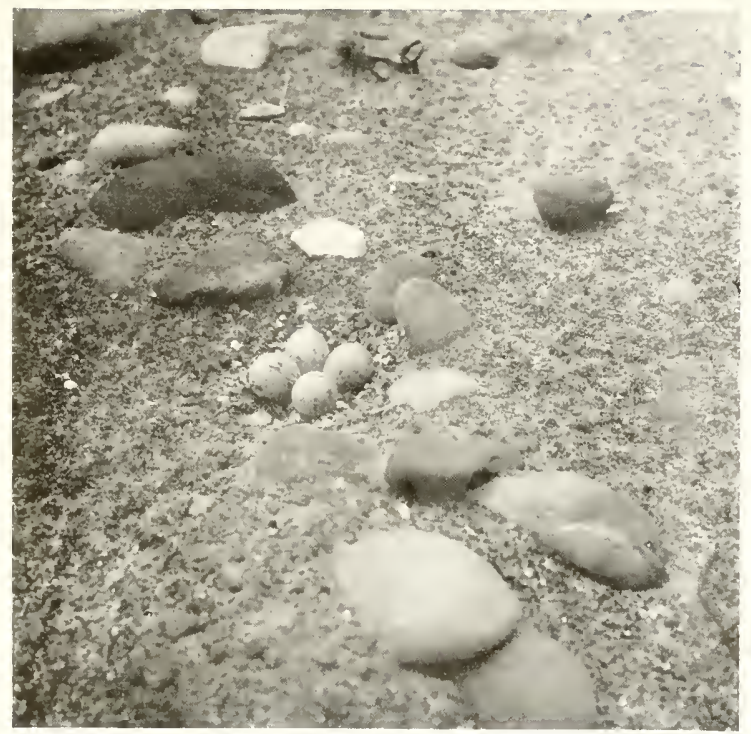

Nest of Ringed Plover, Spurn. K'. Fortune.

Sere puge 575

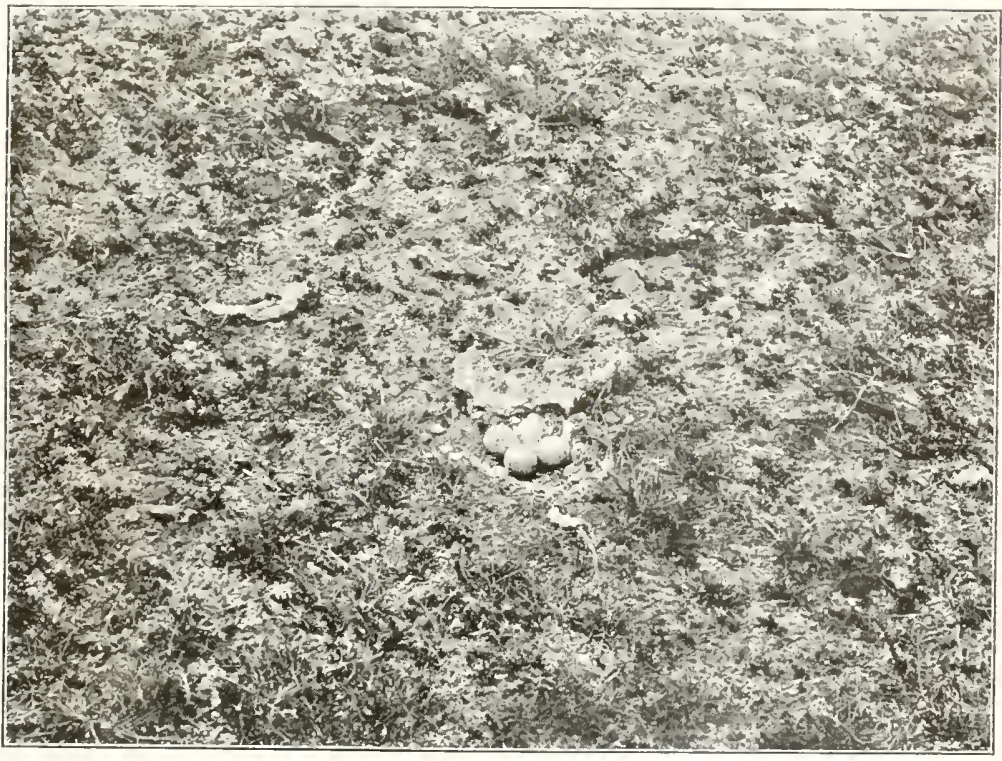

Nest of Ringed Plover amongst plants of "sentry," Teesmouth.

See page 57 .

T. H. Nelson. 

August. Very often several "mock" nests are formed, and on one small patch of shingle, within a space of twenty square yards, at the Teesmouth, I counted no fewer than six of these, in addition to the true nest. Owing to the persecution to which the birds have been subjected in past years they have had recourse to strange nesting situations in the Tees district, and have resorted to the heaps of slag near the Breakwater, and to the sand-hills forming the Cleveland Golf Club course. Of other curious sites may be mentioned the top of a low wall; a hollow in a slag ball; a space between the metals of a railway running along the Breakwater; another within two or three yards of the firing point of the Rifle Club; while the centre of a heap of dried cow dung has also been utilized for nesting purposes, and the prettiest and best protected nest I have seen was amongst a clump of daisies. In unexpected positions such as these the birds frequently succeed in hatching their eggs.

A few pairs only nest on the Spurn promontory, and also at one or two spots higher up the Humber estuary. As yet a clutch of five is unreported from the Tees area, though one was discovered at Spurn in June I880 (W. Eagle Clarke, Zool. I880, p. 356).

A variety of this bird, having the mantle of a stone buff colour, is recorded by Mr. J. Whitaker (op. cit. I882, p. 79), as having been obtained at Scarborough in I882, and a similar specimen in the Tunstall Museum was probably of local origin (Fox's "Synopsis," p. 90).

Local vernacular names in use are:-Ring or Ringed Dotterel on the Humber and Tees; Ring-Neck on the Tees; Sand Runner and Sand Dotterel at the Humber; Sand Lark, and Sea Lark in the Allan MS. (I79I) and Graves's "Cleveland" (I808).

[Lesser Ringed Plover (Egialitis curonica, Gmelin). An example of this small Plover was recorded by the late J. C. Garth of Knaresborough as taken at Whixley on 3oth July I850 (Zool. I85o, p. 2953), but an examination of the specimen in Mr. Garth's collection led me to believe that it is merely 
a small example of the common species ( $E$. hiaticula), in which opinion I am confirmed by Messrs. J. Backhouse and Riley Fortune.

In I85I, three were said to have been killed on the Calder (Talbot's "Birds of Wakefield," p. 25), and in the Field of I5th October I86I, the late W. W. Boulton announced the occurrence of one at Spurn on the 5th of the same month, but it is highly probable that these also were referable to the large race.]

\section{KENTISH PLOVER. Agialitis cantiana (Lath.).}

Casual visitant, of extremely rare occurrence.

This small Plover nests on the south coast of England" and is but a rare and casual visitant during its migratory movements in spring and autumn.*

Of our seven county occurrences it will be observed that five have been recorded from the vicinity of Bridlington. The first example came into the possession of Mr. Matthew Bailey of Flamborough in 1857 .

Two, a male and female, were obtained on 25th and 28th May, respectively, in the year I869, on the sands at Ulrome, by Mr. Thomas Boynton, and are now in his collection at Bridlington (Zool. I869, pp. I843-44).

Another example was procured by Mr. Boynton in 1875 , at the same place where those previously mentioned were obtained, and is now in the collection at Burton Agnes, formed by the late Sir Henry Boynton.

Mr. Forster of Bridlington is in the possession of a specimen, taken near Flamborough in August I88I.

* Until the year I904 Yorkshire could lay claim to being the most northerly county from which it has been reported, but on the 2oth May in that year the late C. Braithwaite of Seaton Carew picked up a female specimen at the north side of the Teesmouth. 
I have had opportunities of examining the last four mentioned examples in the collections of their respective owners.

The latest occurrences took place on I2th September I $89 \mathrm{I}$, when two in immature plumage were killed at Cayton Bay, near Scarborough, as I am informed by Mr. W. J. Clarke of that town.

\section{GOLDEN PLOVER.}

Charadrius pluvialis $(L$.$) .$

Resident, breeds on the fells of the west and north-west, also sparingly in the south-west, and commonly on the Cleveland moors. A great influx of migrants takes place in autumn and winter, when the species is more generally distributed. A few remain on the coast until late in May.

The first mention of this, as a Yorkshire bird, is in the ordinances as to the price of victuals in the city of York in the year I393, I6th Richard II., when, by a Royal proclamation, the value of a Plover was fixed at Id. Another early allusion to it is at the feast given to Archbishop Nevell in I466, when the provision included "Plovers IIII. C." It is also referred to in a quaintly worded entry in the Northumberland Household Book, in the year $\mathrm{I}_{5} \mathrm{I} 2$, in connection with Earl Percy's regulations at his Yorkshire Castles, which informs us that it was "thought good that no pluvers be bought at noo Season bot oonely at Chrystynmas and Princypall Feestes and my Lorde to be servyde therewith and his Boordend and non other and to be boght at jd. a pece or jd. ob (I $\frac{1}{2} d$.) at moste." And in the list of expenses of Sir John Neville High Sheriff of Yorkshire in $\mathrm{I}_{52} 6$ and $\mathrm{I}_{528}$, Plovers are referred to; as also in the prices of provisions at Hull in 1560 , where we find "Plover, rjd."

Thomas Allis, I844, wrote of it as follows:-

Charadrits pluvialis.-Golden Plover-Occasionally seen at Whin Moor, near Leeds ; in the neighbourhood of Halifax it breeds sparingly on the High Moors; common about Sheffield; common on the moors about Malham where it breeds, and remains the year round; also 
common on the moorlands near Barnsley; and is frequently to be obtained in the markets at York; it is met with at Hambleton. A. Strickland remarks that considerable flocks of this bird and the Grey Plover* are occasionally met with on the Wolds in autumn in immature plumage, and at times in small numbers on the sea shore in winter, but he has never met with it in mature plumage in this country.

As a resident in Yorkshire the Golden Plover is local and restricted to the fells and moorlands of the south, west, and north-west, including also the Cleveland Hills and the range of moors extending thence to Scarborough. The area of ground thus comprising its summer habitat being of great extent, the numbers of nesting birds may appear to be fewer than is really the case; it is sparingly distributed in the south and west, and is perhaps more abundant in the north-west of the North Riding than in other places. It arrives at its breeding quarters in March or April, and departs thence in August, soon after the commencement of Grouse shooting. The earliest immigrants which appear on the coast are a few old birds in faded plumage late in July or early in August, and these are followed in September by other flocks of young and old, which continue to increase as the season advances, the main migration usually taking place in November. In the low grounds and Carrs of East Yorkshire they are to be seen in large numbers : should wet weather supervene, and the Carrs become flooded, these vast flocks join together into enormous congregations, and acres of ground are covered with them. They frequent the low ground by day, but in the dusk betake themselves to the high Wolds for the night, returning again shortly after daybreak.

Towards the end of the year, especially if severe frost and snow prevail, immense numbers of these birds congregate, together with Lapwings, in the fields and marshes near the coast, but, with a long continuance of hard weather, they are driven southward; on I2th December 1878 , during a winter of Arctic severity, the sands and muds at the Teesmouth were absolutely covered with Plovers at low tide;

* See remarks on Grey Plover under the heading of that species. 


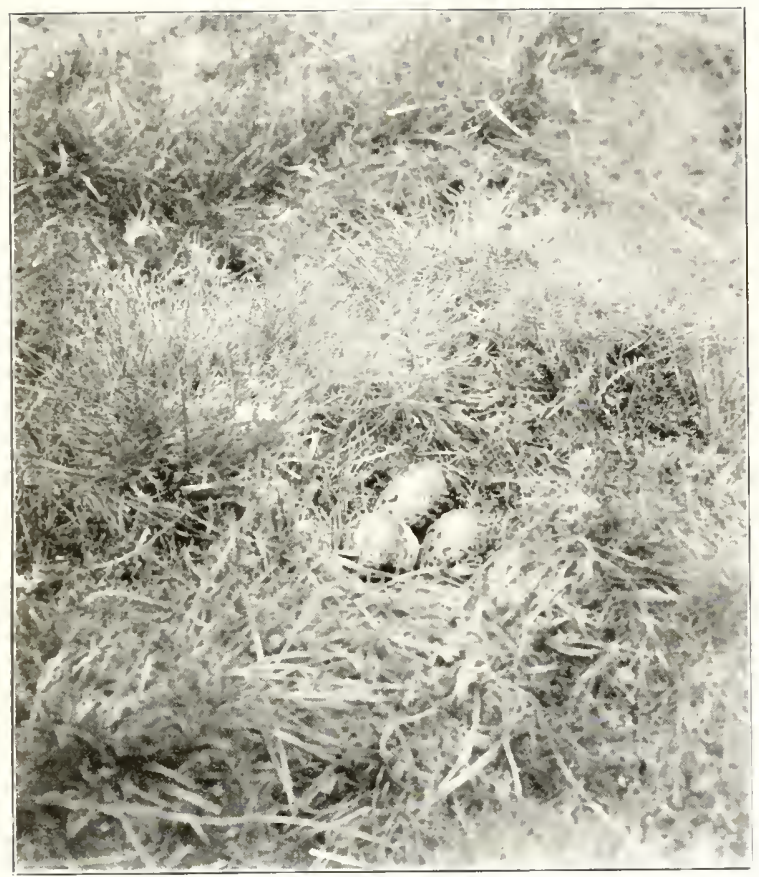

Nest of Golden Plover, north-west Yorkshire.

R. Fortune.

See page 5is. 

as the water flowed the noise made by the masses of birds, forced by the rising waters to the circumscribed space of dry sand, was marvellous, and finally the host rose like an immense cloud; but next day they had all disappeared. In seasons when the weather remains mild and open in the early months of the year, the lowlands are frequented until late in March by hosts of Plovers, a few occasionally lingering till the middle of May.

As stated above, our local breeding birds resort to the moors in March or April, and at the end of the latter month, or in May, the foreigners move northward ; in May rgo4, I noticed a very large assemblage of unpaired birds on a moor near Harrogate.

The Golden Plover is frequently immolated against the lanterns of our coast beacons; many were thus killed at Spurn Lighthouse on I6th November I898; and in the very severe winter of $1878-79$ numbers were starved to death in the neighbourhood of Flamborough. In autumn and winter the species is generally distributed in the agricultural districts of the county, in large or small numbers, varying with the severity or mildness of the season.

Nidification, as a rule, begins in late April or early May.

Variations of plumage are seldom met with; Mr. F. Boyes has obtained two specimens with white wings, and a beautiful white and buff-coloured example was killed at Wycliffe-onTees in February 1900.

\section{GREY PLOVER.}

\section{Squatarola helvetica $(L$.$) .$}

Winter visitant, abundant on the coast, and observed both on its autumnal and vernal passage, less frequently at the latter period. Arrives in August, September, and late in October, many passing southward for winter. Is noticed in May, in summer plumage, both on the coast and inland on the moors.

Probably the first notice of the Grey Plover in Yorkshire is found in the Allan MS., in connection with the Tunstall 
Museum (I79I), where it is stated to be "now and then seen in small flocks in winter." (Fox's "Synopsis," p. 89.)

Thomas Allis, in I844, wrote:-

Squatarola cinevea.-Grey Plover-F. O. Morris reports it common on the coast; it is rare near Sheffield; Wm. Eddison remarks that this species is not so common as the Golden Plover, but is occasionally seen in the same localities; J. and W. Tuke inform me that they saw a pair on Hambleton in June, which no doubt had eggs or young ones, as they would not leave the place, although watched for several hours. It is met with on the Wolds* in autumn, and on the coast in winter.

The Grey Plover is a winter visitant, common on the coast in some seasons; small parties of old birds in partial summer dress occur at both the Tees and Humber estuaries in late July and August, and in some years at the former, these companies consist of as many as a hundred individuals, the young following in September, but not in such large flights as the Golden Plover. Individuals retaining the summer plumage have been noted as late as September, and, in one case, in October, though such instances are very uncommon. During September and October both young and old birds continue to arrive and frequent the tidal portions of the estuaries, consorting with Knots, Dunlin, and other shore birds, in some years assembling in large flocks in the Tees area; the bulk of these retire further south as the season advances, although many remain throughout winter, and I observed considerable numbers at the Teesmouth in quite Arctic weather, in December 1878 , and, under similar conditions, in February 1895 and I90I. It appears to be more abundant in that district than elsewhere in the county, but is much scarcer now than was the case several years ago. On the spring migration small parties of from ten to fifty are seen at Spurn in April and May, in all phases of plumage, leaving towards the end of the latter month. The late $\mathrm{J}$. Cordeaux was of opinion that this species, like the Bar-tailed Godwit and Knot, does not proceed along the Yorkshire coast north of Spurn on the vernal passage, but crosses the

* Mr. F. Boyes states that he is not aware of any instance of the Grey Plover occurring on the Wolds. 
North Sea from the Humber; I must, however, differ from this view, for all three of these waders are met with at the Teesmouth in the month of May, and sometimes later; on $9^{\text {th }} \mathrm{June}$ in the year I887, a large mixed flock of Grey Plovers, Knots, and other shore birds was observed on the sands near Redcar at 3 a.m.

The Grey Plover has been reported on the Hambleton Hills in June, as mentioned by Thomas Allis, and was supposed to have a nest near; in this connection it is worthy of note that it has, to my knowledge, occurred regularly in spring on the moors near Helmsley, from which locality I have seen birds in full summer garb.

On the coast between the Tees and Humber this is not a very plentiful species, being chiefly observed on the autumn passage, and at this period immature examples are occasionally reported from inland districts far removed from its accustomed haunts; on Thornton moor, in Wensleydale, two adults were observed in August I894, one with a black breast being obtained, while a female in summer dress was killed on Midgeley moor on 9th August I899; it has also occurred at Ackworth.

The Grey Plover figures in the list of casualties at the Lighthouses on dark or foggy nights.

The local vernacular names are:-Sand Plover, Pigeon Plover, and Sea Pigeon in the Humber district. At the Teesmouth it is known as Silver Plover, and to the Redcar fishermen it is the young Golden Plover.

\section{LAPWING.}

\section{Vanellus vulgaris (Bechst.).}

Resident, generally distributed, common. In autumn and winter it congregates in the lowlands and on the coast, when its numbers are greatly augmented by an influx of immigrants from the Continent.

Historically considered, the Lapwing in Yorkshire may claim ancestry of great antiquity; Selby was of opinion that 
the "Egrittes," to the number of I,000, served at the celebrated banquet to Archbishop Nevell in I466, are referable to this species; under the synonym of "Wype" it was mentioned in the Northumberland Household Book, I5I2, where in the list of birds to be bought for " my Lordes owne mees" the price of "Wypes" was fixed at Id., "so they be good and in season" ; while under the name of Bastard Plover it figured in "Wildfowl at Hull" in 1560 , the price being stated at three-halfpence each.

Thomas Allis, in I844, wrote:-

Vanellus cristatus.-Common Lapwing-Common in most districts.

In addition to being a well-known and abundant resident, the Lapwing is a common migrant in autumn, when enormous flights arrive on the coast during October and November, these migrations sometimes continuing for several days in succession, and extending to as late as the last week of December, whilst on one or two occasions I have noticed large flocks crossing late in January. Great "rushes" occurred in ISSI in the month of November; in I887 there was a constant migration from mid-October to mid-November; also in October I89o, in November I899, and in Igor. On some days the passage continues from daylight to 3 p.m., the birds crossing incessantly in immense bodies; a rough estimate of the numbers contained in one of these " rushes," in October I899, was computed to be at the rate of I0,000 in a quarter of an hour. On arrival many of these new-comers settle on the lowlands near the coast, while others disperse inland, and in IgoI they were more numerous in the pastures and marshes near the seaboard than I have ever known them to be. Should mild weather prevail they continue to haunt these localities throughout winter, but depart southward if frost and snow ensue, and during conditions of this nature there was a decided southerly movement in February and early March I904. The bulk of the winter visitants depart in late March or April on their return migration; on $23 \mathrm{rd}$ and 24th March I895 I observed a passage of oversea migrants, and these would, doubtless, be birds returning northward. In this connection an interesting entry is found in the " Annual 
Register" for I799, where it is stated that, on the $4^{\text {th }}$ of April in that year, hundreds of Plovers and Lapwings were cast on shore on the Holderness coast in a dreadful storm.

When crossing against a west or south-west gale these migrant Lapwings fly low, hugging the surface of the water in a compact body, but as they approach the land they gradually rise high in the air and assume an open and scattered formation, in this manner passing over the "danger zone" commanded by coast gunners and wildfowlers. On dark and foggy nights numbers of these birds fall victims to the attractions of the coast beacons.*

As a nesting species the Lapwing is generally and widely diffused, being found in all suitable localities from the marshes and coast lands up to the highest elevation on the fells and moorlands of Cleveland and the north-west of the county. It was very abundant in the Doncaster Carrs until the middle of the past century, but has been driven away from its haunts in that district by drainage and high cultivation, while it is to be feared that the practice of collecting the eggs for sale is rapidly reducing the numbers of our native stock.

The resident birds usually repair to their nesting haunts towards the close of February or March, and at the end of the latter month, in mild seasons, eggs are sometimes met with; but, as a general rule, they are not found before April; in the first week of that month I have seen full clutches at the Teesmouth, though they are a week or two later on the high fells, where, in late seasons, they are occasionally covered with snow; in a severe storm in May I89I, near Harrogate, the Lapwings flew high above the snow-clouds; when the fall ceased they returned to their breeding quarters, but were unable, on the snow-covered ground, to find their nests (Nat. I89I, pp. I65, 214).

Variations of plumage are not unknown; one at Oswaldkirk had the wings and upper part of the back light brown

* It may be mentioned here that an interesting and concise history of the migration of this species is published by Mr. W. Eagle Clarke in the Report of the British Association for 1902.

vOL. II. 
or fawn, with the back of the head and lower breast creamcoloured (Field, Ist March I884); a cinnamon-hued specimen was obtained at Redcar in December I892; and in the year I903 a white example occurred on the moors near Fewston Reservoir, Washburndale. A considerable diversity as regards colour and form exists in the eggs, some being occasionally found of a white or pale green or blue ground colour, profusely dotted with small black, purple, or grey spots; and I have seen numerous examples of dwarf and deformed eggs, some no larger than a Lark's, while others are elongated or stunted in form. A clutch of four, found at the Teesmouth in I902, consisted of :-

One the size of a common Sparrow's.

One the shape of a Common Gull's.

One of normal type, and

One long and narrow, with heavy blotches.

Very rarely a clutch of five is met with, though no fewer than three containing that number were recorded from Masham in 1883 and $r 884$.

It may be worthy of mention that Mr. Palmer in the Zoologist (I884, p. 69), notes the fact of a Lapwing perching on a stone wall in Wharfedale in July 1875 .

Concerning Yorkshire folk-lore there is a belief in the West Riding that at one period the Peewit made its nest in trees and that the Cushat built on the ground; an amicable exchange took place between the birds, and now they respectively sing out their feelings on the subject. According to a local rhyme the Peewit says,

"Peewit, Peewit,

I coup'd my nest, and I've it."

(See Ring-Dove.)

Local vernacular names :-Lapwing, Peewit, Green Plover are in general use. Tewhit, Tewit, Tewet, Tuit, Tuet, and similar variants are commonly used in the West and North Ridings. (The Tewit Well, on the Upper Stray at Harrogate, is so called on account of its connection with these birds, whose large numbers are said to have attracted the attention of Sir William Slingsby, and so led to the discovery of the 


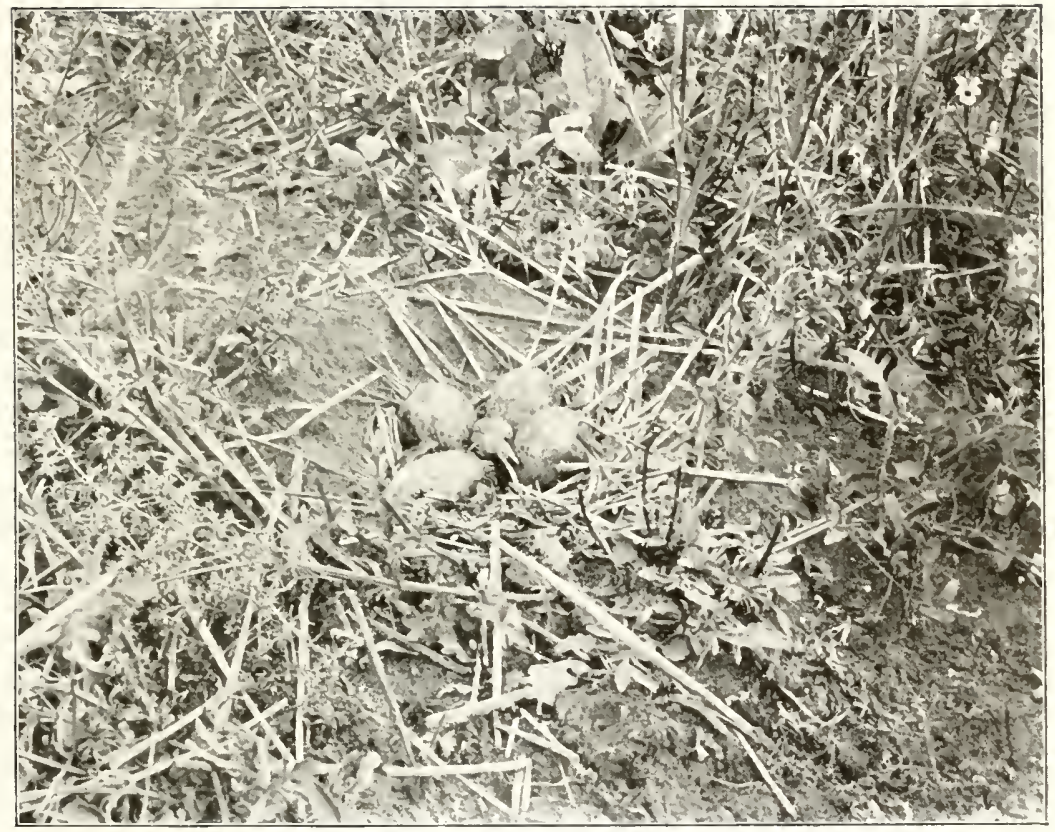

Nest and Eggs of Lapwing, Towthorpe, York.

H. Lazenbu.

See page $58+$ 

well, in the year $157 \mathrm{r}$.) Teewit is in use in Central Ryedale, Doncaster, and Skelmanthorpe; Tewfit is common in the East Riding, in Swaledale, and Arkengarthdale; and Teäfit is a term freely used in the North Riding and Cleveland, and equally so in the East Riding; Wype, an obsolete name for this bird, was referred to in the Northumberland Household Book ( $\left.\mathrm{r}_{5} \mathrm{r} 2\right)$; and Bastard Plover was applied to it in the ordinance as to the price of provisions at Hull, in $\mathbf{I} 560$.

\section{TURNSTONE. \\ Strepsilas interpres (L.).}

Winter visitant on the coast, arriving in August and September, retiring further south as winter approaches. A return passage occurs in spring; a few remain during summer.

The earliest reference to this, as a Yorkshire species, appears to be that of Thomas Allis, in his oft-mentioned Report on Yorkshire Birds, written in I844, thus :-

Strepsilas collaris.-Turnstone-Met with on the coast, frequenting rocky shore; not infrequently seen at Filey. "A. Strickland."

This handsome bird is an autumn or winter visitant on the coast, not uncommon on passage, and particularly abundant in the Tees and Humber districts. Towards the end of July the immature birds commence to arrive from the nesting grounds, the 26th being the earliest date of which I have any record, but the great majority do not appear until August and early September; I have at these times frequently recognized their calls when the birds were passing overhead on still, dark nights. As stated, most of these are immature, yet a few adults in faded summer plumage are occasionally found with them. Very few Turnstones remain on the Yorkshire coast after the middle of autumn; I once procured an old bird on the 8 th of October, and saw an immature example as late as the 2Ist of that month, while at Spurn it was numerous on 24 th November I888, an unusually late date. 
On the return passage in spring small parties, from five to twenty in number, are observed going north; I have noted them at the Teesmouth as early as 8th May in the year I9OI; and a very large flock of shore birds, consisting of Turnstones, Knots, and Grey Plovers, was on the sands at Redcar on 9 th June 1887 , at 3 a.m. At both the Tees and the Humber a few, probably non-breeding birds, though in full plumage, remain throughout the summer.

This species is essentially a shore-bird, frequenting the harder and stony portions of the flats, and at the Teesmouth it is often found on the slag heaps which are left bare at half tide; small parties, when on migration, occasionally rest on the "scars," reefs of low-lying rocks, some of them a mile distant from the shore, and uncovered at low tide.

The Turnstone is seldom found far away from salt water, though it has been reported from one or two inland localities; one was shot from a flock of pigeons at Boroughbridge in October I849; others occurred at Cold Hiendley Reservoir in September I868, and at Harrogate in I896, whilst in I883 one was killed from a flock of seven on Eldrick moor.

Of local names, there are but two known to me in Yorkshire: it is called Dotterel in the Humber district, and at the Teesmouth is known as Turnstone Plover.

\section{OYSTER - CA T CHER.}

Hæmatopus ostralegus.( L. .).

Winter visitant on the coast, local, common in some places. Appears sometimes in July, remaining until spring. Occasionally seen inland. One or two pairs nest at Spurn.

In the Northumberland Household Book, begun in I5I2, at the Earl Percy's Castles of Wressill and Lekinfield, is found the first mention in Yorkshire of what is evidently this species, which figures in the list of birds to be provided for " my Lordes owne mees," but no price is allotted, thus :- 


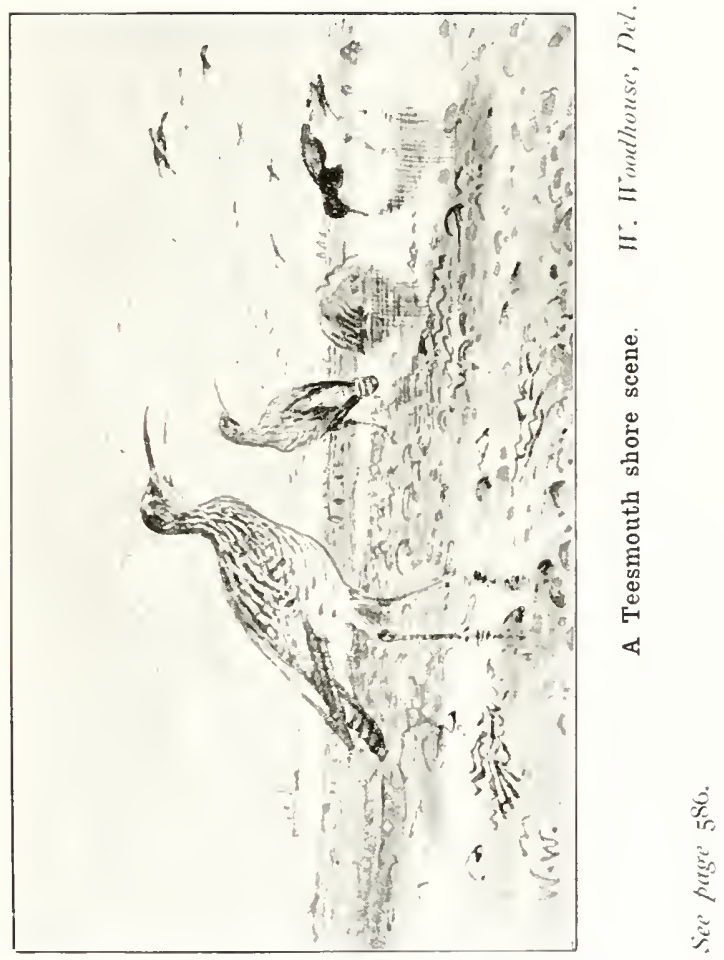



"Item, See-Pyes for my Lorde at Princypall Feestes and non other tyme."

Thomas Allis, in I844, wrote:-

Hematopus ostralegus.-The Oyster-Catcher-F. O. Morris reports it frequent on the coast; W. Eddison remarks that it is rarely met with near Huddersfield; he has two specimens shot on Slaithwaite and Marsden Moors in winter, near the Reservoirs.

Although this conspicuous bird may be found on some parts of the coast at all seasons of the year, it can strictly only be termed a winter visitant, very local, and common in some places, particularly at the Tees estuary. After the nesting season small flocks begin to appear on their journey from more northerly or Continental breeding places, occurring as early as the I3th of July; many more arrive in August, whilst in September large migratory flights, sometimes numbering three or four hundred individuals, are noticed on passage, or frequenting the "slems" and sands of the Teesmouth; these migrants continue to arrive until as late as the middle of November, and on the I6th of that month, in the year I898, several struck the Spurn Lighthouse. On the Humber flats a few occasionally remain during the winter and until late in spring, but in the Tees area it is quite a rare bird between October and the early months of the year following, when small numbers put in an appearance, and many may be seen going northward in April and May; on 27 th February I884 one of the largest flights I have ever known was observed at the Teesmouth.

The Oyster-Catcher was not known as a nesting species at Spurn until the year I888; it may, however, now be claimed as a resident there, though in very limited numbers. In the year named three nests with eggs were discovered, and since that date one or two nests have been noted; in I903 two pairs nested on the shingle banks, but it is to be regretted that the birds did not succeed in hatching eggs in the year following.

As regards the Teesmouth, it is not at all improbable that this species was included in the "Sea-fowl which laye their egges here and there scatteringlye," as mentioned in 
the Cottonian MS., about I604; the locality would be eminently suitable for them, but I have not been able to ascertain that even the proverbial "oldest inhabitant" ever recollected it nesting there. On those portions of the coast outside the areas named it occurs sparingly, and generally when on migration.

It is also reported from many inland places in the dales, far removed from its accustomed haunts, where it generally frequents reservoirs or follows the course of rivers, the enumeration of which would prove tedious, and is unnecessary. Lord Walsingham informed Mr. W. Eagle Clarke, in August I883, that he shot a mature bird on Thackerey Beck, Bluberhouse, the only one ever known there; and from most of the reservoirs on the West Riding moors it has been recorded at various times.

Although the Oyster-Catcher is not usually held in high esteem as a table delicacy, I can testify that the young birds are excellent eating in early autumn, though later in the year they become rank and fishy, as may be understood from the last meal of an individual killed near Whitby, which consisted of no fewer than seventy-seven limpets, or "flithers " as they are locally called, extracted from the shells.

The vernacular names are:-Sea Pie, or Sea Nanpie, in general use, and Mussell Cracker is a term applied to the bird in the Teesmouth district.

\section{AVOCET.}

Recurvirostris avocetta (L.).

Accidental visitant from the European Continent, of extremely rare occurrence.

The first reliable mention of the Avocet, as a Yorkshire species, is apparently that referred to in Thomas Allis's Report, thus :- 
Recurvirostra avosetta.-The Avoset.-H. Chapman had two, killed on Skipwith Common, near Selby, about twenty years since, one of which is now in the Museum of the Yorkshire Philosophical Society ; F. O. Morris says several have been shot on the Humber and on other parts of the coast. A. Strickland has known several near the Spurn Lighthouse in spring some years ago, but he has heard of no recent instance.

This singular looking bird was formerly not uncommon in Yorkshire, when the mud banks of the Humber and the adjacent marshes and Carrs of the East Riding afforded a congenial environment to birds of this class; the same causes, however, which conduced to the extirpation of other rare species have driven it from its former haunts, and it is now but an accidental straggler from Continental Europe.

The latest known instance of the Avocet nesting in Britain was at the mouth of the Trent, about the year 1837. Hugh Reid of Doncaster informed A. G. More, in a letter dated Ist June I86I, that eggs were taken on a sand island at the mouth of the river Trent about twenty-four years before. There was at the time a spring tide, which nearly covered the island, and the eggs were floating on the water. The man who took them shot one of the parent birds at the same time and brought the eggs to Mr. Reid. The island had patches of grass growing on it, and there was always mud and warp about it-a likely place for the bird to feed on.

The county boundary being at this place drawn in the centre of the River Trent, Yorkshire will share with Lincolnshire the honour of possessing the last British breeding station of the Avocet.

The recorded and communicated notices of its occurrence during the past century are as follows :-

Two on Skipwith Common, about I824 (Allis).

At Spurn Point several were obtained before I844, according to Allis's friend and correspondent, Arthur Strickland.

In I827-28 one, as recorded by J. Hogg (Zool. I845, p. II72), at the Teesmouth; a locality whence Mr. J. H. Gurney reported it (op. cit. I876, p. 4765) as having occurred two or three times, one of which was probably referable to an individual from the Teesmouth in the spring of 1849 , formerly 
in the collection of the late J. Duff of Bishop Auckland, and recorded by him (op. cit. I849, p. 259I). This specimen was sold at the dispersal of Mr. Duff's effects in Igor, but was in such a moth-eaten state as to be useless.

Another example, which may have been in Mr. Gurney's list, was killed by a Stockton gunner, in the Tees, about I870, but was rendered worthless for preservation.

An adult specimen, taken about I865, at Scarborough, is now in the York Museum.

Another adult, a male, was purchased at the sale of $\mathrm{Mr}$. Hall's Scorborough collection, and is supposed to be a local specimen. It is now in the Hull Museum.

And the most recent record of its appearance was near the Flamborough Lighthouse, where two were seen for several days in April I893; one was procured by Mr. Coates of the Lighthouse Farm, and was stuffed for him by Mr. M. Bailey; the other, which is in the collection of Mr. Forster of Bridlington, was killed on I6th April, at Marton Lodge, near the latter town. I have had an opportunity of examining both these specimens in the possession of their respective owners. (cf. Nat. I893, p. I7I.)

\section{BLACK-WINGED STILT. \\ Himantopus candidus (Bonnat.).}

Accidental visitant from southern and south-eastern Europe, and Africa, of extremely rare occurrence.

The claim of this rare and accidental straggler to rank as a Yorkshire species rests on the occurrence of an adult, and an immature specimen, obtained in Aike Carr, near Beverley; and a third individual, stated to have occurred near Spurn. The Beverley examples were formerly in the possession of of the late James Hall of Scorborough, and were purchased at the sale of his collection, in 1878 , by Mr. John Stephenson 


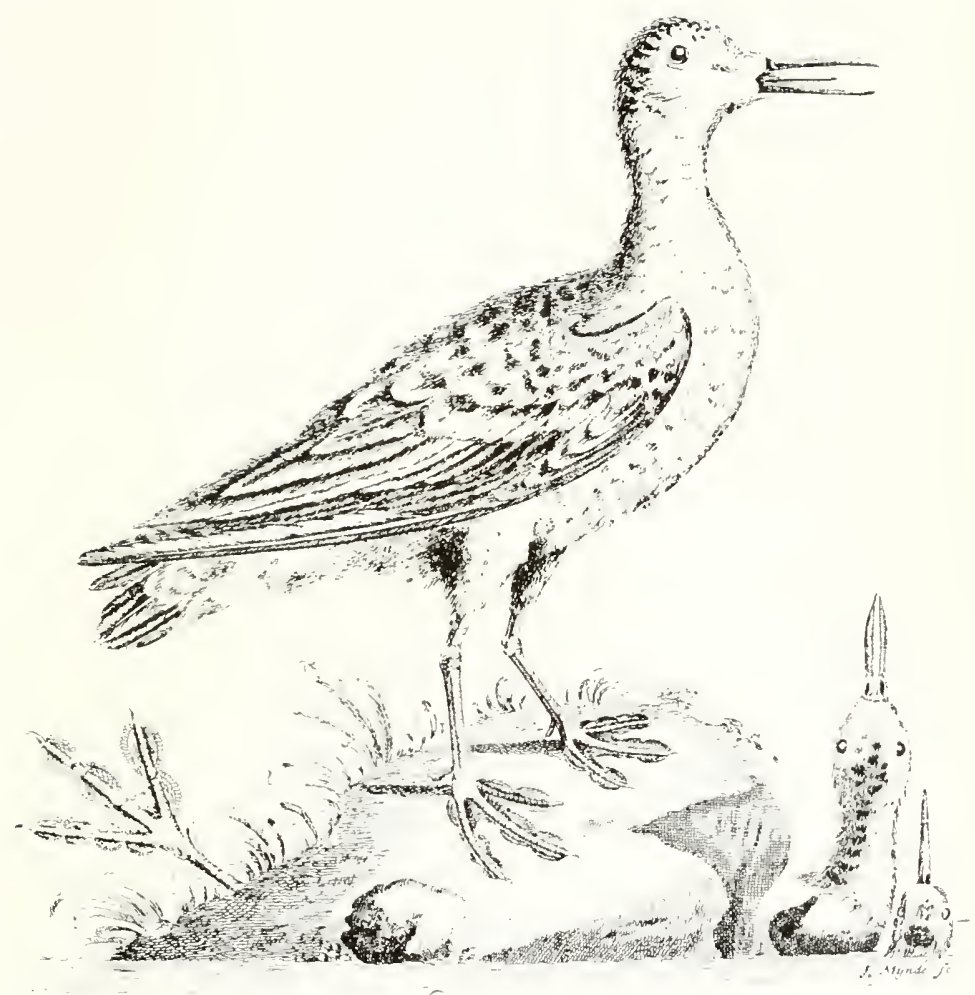

The first known British example of the Grey Phalarope, shot near Halifax. Described and figured by George Edwards in February 1757.

See page 591 . 

of Beverley, who was informed by Miss Hall, in a letter dated 25th July I88I, that they were shot by Lord Hotham's keeper " about thirty years ago." Mr. Stephenson knew a woman who lived at Aike, and who remembered the birds being killed and shewn to her on account of their long legs.

The third specimen was procured at Kilnsea, near Spurn, many years ago, by the late John Clubley, who described the bird to Mr. F. Boyes so accurately as to leave no doubt as to its identity. He did not know the date, but it was in late spring.

\section{GREY PHALAROPE.}

\section{Phalaropus fulicarius (L.).}

Occasional visitant in autumn and winter, of rare and uncertain occurrence.

This interesting species was first made known as a British bird from an example which was killed at Warley Clough, near Halifax, by Thomas Bolton, and sent to George Edwards, who described it in the "Philosophical Transactions," and afterwards figured it in his "Gleanings of Natural History" (I743-76, pl. ii. p. 206, iii. pl. 308), with the following observations:-

" This Tringa I believe had not been figured or described before it appeared in the 'Philosophical Transactions,' vol. i. pl. i. p. 255, for the year 1757 . [The species is minutely described in the work referred to.] ..... It was procured for me by my obliging friend, Mr. Thomas Bolton, florist, of Warley Clough in Yorkshire, near which place it was shot in January I757. . . . Mr. Bolton says in his letter, that when newly killed, it weighed one ounce."

Thomas Allis, I844, wrote:-

Phalaropus lobatus.-Grey Phalarope-F. O. Morris reports them as shot near Brignal, Scarborough, and Crimpsall not rarely; $H$. Reid informs me that a specimen was shot near Rossington Bridge in the 
year 1836 , in the summer plumage, in a drain, and in September of the same year another was shot, in the winter plumage, in a pond near Doncaster ; Dr. Farrar says of this rare and beautiful species "I have obtained three specimens; the first was caught alive, apparently uninjured, in the low marshy grounds of Bolton-upon-Dearne, by a party of poachers; the second was shot on the margin of a small pond adjoining a few cottages at Hound Hill, near Barnsley, in 1835." A fine specimen that was taken up alive in a ditch a short distance from York, came into my own possession a few years ago.

The Grey Phalarope is an uncertain and irregular visitant in autumn and winter, in some years being altogether absent, in others odd specimens are recorded, and at rare intervals it has appeared in considerable numbers, as in 1854 , when the late Rev. Henry Smith shot four at Redcar,* and the late A. Roberts of Scarborough had fourteen brought to him for preservation. The year 1866 also was unusually prolific in birds of this species throughout the kingdom, the visitation extending to this county, as recorded by the late W. W. Boulton, who obtained two examples in East Yorkshire (Zool. 1867, p. 540). It has been only once reported in summer plumage, viz., in Allis's oft-quoted Report, the individuals met with being usually in immature or winter garb. It is most frequently brought under observation on the coast during the prevalence of strong gales, and, as it is of a remarkably tame and confiding nature, it falls a victim to the first gunner who notices it. My earliest acquaintance with this bird was in October I874, when I saw one swimming amongst the breakers near East Scar, where it was eventually shot by a fisherman.

The Grey Phalarope has occurred with more or less frequency at most of the coast stations, after heavy weather. The inland localities from which it has been recorded, in addition to those mentioned by Edwards and Allis, are :Kirkthorpe, near Wakefield, in September I86r, and two at Horbury; Denby, near Huddersfield, November I873; Hambleton; Birchworth Reservoir, December I876; Wetherby

* Mr. Smith informed Mr. W. Eagle Clarke that these were Rednecked Phalaropes, and as such they were recorded in the "Vertebrate Fauna of Yorkshire." 
December I88I ; Tadcaster, two shot (Nat. I89I, p. I07); near York, October I877; Brigham, near Leeds, October I89I ; near Harrogate, October I89I ; and Ackworth, October I892.

The only name, other than its usual one, by which it is known is Phalaroe, sometimes used by fishermen, and merely a corruption of Phalarope.

\section{RED-NECKED PHALAROPE.}

\section{Phalaropus hyperboreus (L.).}

Accidental visitant, in autumn and winter, of rare occurrence.

Is is a curious coincidence that the first British information respecting both the Phalaropes should have been derived from Yorkshire specimens. This species was described in 1676 by Willughby from an example supplied by Ralph Johnson of Brignall, near Greta Bridge, and, following the account of its appearance and plumage, are the following quaint remarks, under the title of "Mr. Johnson's small cloven footed Gull " :"When I first saw the skin of it stuft at Mr. Johnson's at Brignal in Yorkshire, from the make of its feet I judged it to be of the Coot kind. But afterwards being informed by Mr. Johnson that it is much upon the wing, hath sharp Wings, and cries like a small Gull, differs also in the fashion of the Bill, I changed my opinion, and think that it ought rather to be referred to the Gulls, to which I have subjoined it." (Will. "Orn." I676, p. 355.)

Thomas Allis, in I844, wrote :-

Phalaropus hyperboreus.-Red Pharalope-A. Strickland says both this and the former species are occasionally met with on the Bridlington coast in autumn or winter, in grey plumage, but never in summer attire. I believe that both species in winter plumage are often confounded under the name of Grey Phalarope, but may easily be distinguished by the bill.

Allis's suggestion that the two species of Phalarope, when in winter dress, are liable to be confused does not accord with 
present day experience. The bird under notice is of much less frequency than its larger and more robust looking congener, and may be defined as a rare and casual visitant from northern latitudes in autumn and winter.

It has twice been obtained in summer plumage, but the instances of its visits are so few that it may be advisable to detail the occurrences so far as they are known :-

The first is that referred to by Willughby.

In the autumn of $\mathrm{I} 8 \mathrm{I} 2$, one was taken at Swinton Lake.

The Rev. F. O. Morris reported one at Redcar on 22nd November I85I.

At Scarborough the late A. Roberts recorded an example in November 1854, and another mature specimen in December of the same year, as announced by him in the Zoologist (I854, p. 433I ; and I855, p. 4558).

Sir Wm. Milner's collection, in the Leeds Museum, contains an individual in summer plumage, shot in May I854, at Wilberfoss, near York; it was swimming in a pond in company with some ducks (Milner, op. cit. I854, p. 444I ; and Morris, "Brit. Birds").

A specimen was reported by J. Harrison (MS.) " in spring I854, in the neighbourhood of Hambleton."

An example in summer plumage was presented to me in I904, by Mr. J. Braim, late of Pickering, who supplied the information that it was obtained while swimming on a pond at Scampston "about forty years previously," i.e., in the "sixties."

About the year I860 Geo. Mussell of Middlesbrough had two specimens brought to preserve.

The late J. C. Garth's collection at Knaresborough contained one, labelled "Arkendale, 7 th October I87I."

At Bridlington a male occurred on I4th October I872, and was recorded by Mr. F. Boyes (Zool. I873, p. 337I).

In the Burton Agnes collection is a male from Fraisthorpe in 1876 .

On $9^{\text {th }}$ October I88I, an example was shot at Spurn, and on the same date another at Withernsea, as recorded in the Third Migration Report, p. 32. 


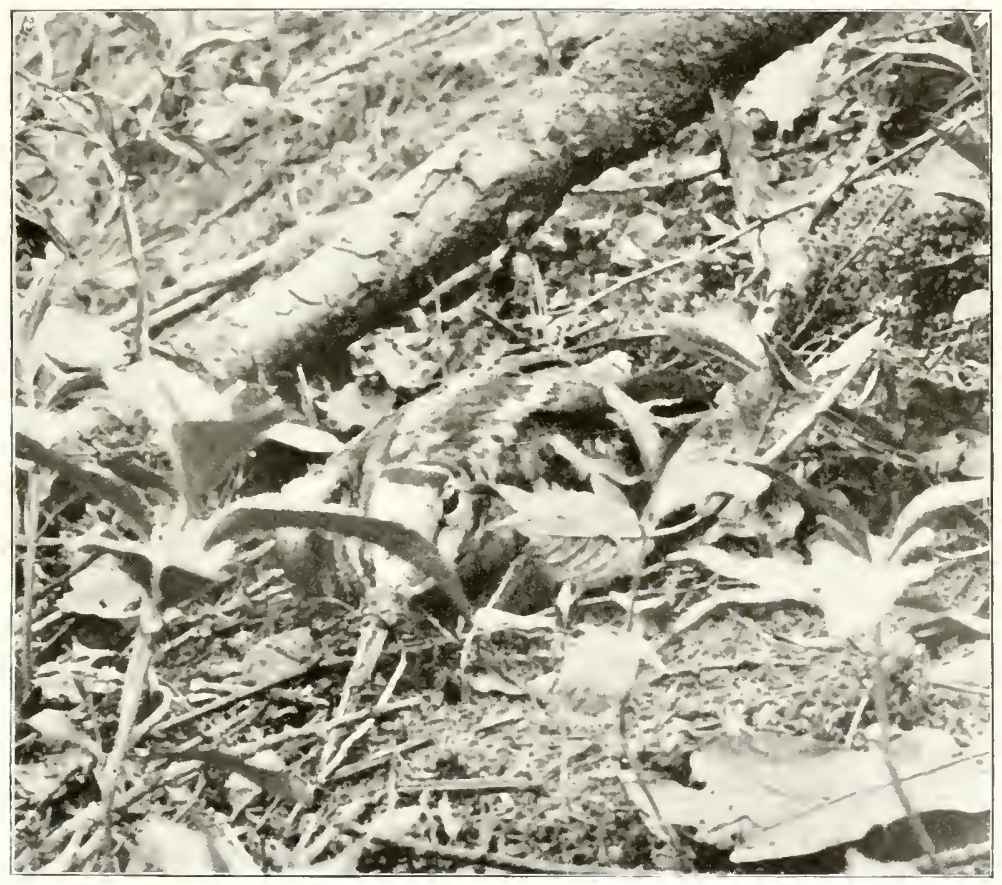

Woodcock on nest.

H. Lasenbu.

See page 597. 

The late G. W. Jalland of Hull procured one at Spurn, on 8 th November I889, and another in I890. These specimens were in his collection, where I examined them.

One in my collection was picked up dead at the Teesmouth, on 23 rd October I89I.

At Scarborough one was reported by Mr. W. J. Clarke in the winter of 1892 .

An immature male was taken at Spurn on Ioth September I894 (J. Cordeaux MS.).

And a specimen in Mr. T. Machen's possession at Bridlington, was procured at that place in 1898 .

The late Rev. H. Smith of Redcar informed Mr. W. Eagle Clarke that four Phalaropes, shot by him in I854, were of this species, and as such they were recorded in the "Vertebrate Fauna of Yorkshire"; they proved, however, to be $P$. fulicarius.

\section{WOODCOCK.}

\section{Scolopax rusticola (L.).}

Resident, in limited numbers. Best known as a winter immigrant. arriving in October and November, sometimes in large flights. Appears on the coast in March and April preparatory to returning to its northern haunts.

Historically speaking, the Woodcock's association with Yorkshire dates back to remote times, for it is mentioned in the ordinances issued by Royal proclamation as to the prices o victuals in the City of York, in the year I393, I6th Richard II. as follows :- "For a Woodcock Id." It next appears in connection with the great banquet, given in $\mathrm{I}_{4} 66$ at Cawood, by Earl Warwick, the "King Maker," in honour of the enthronization of his brother, George Nevell, as Archbishop o York, when in the goodly provision made were "Woodcockes, 400" (Leland's "Coliectanea"); it also figures in the No thumberland Househo'd Book, in I5I2, thus : "Item it is thought good that Woodcokes be hade for my 
Lordes owne mees and non other and to be at jd. a pece, or jd. ob. ( $I \frac{1}{2} \mathrm{~d}$.) at the moste." In the "Correspondence of Dr. Richardson " of North Bierley (p. 226), is an interesting reference to this species, contained in a letter, dated North Bierley, I3th November I725, and addressed to Sir Hans Sloane in London, thus:- "On Wednesday last I sent you a pott of Woodcocks by .... a Kendall carrier, who inns at the Bell, in Wood Street."

\section{Thomas Allis, in 1844, wrote:-}

Scopolax rustrcola.-The Woodcock-Common in most parts; W. Eddison says it is often numerous; it comes about the 5 th November, and departs about the 17 th March. Seldom seen in summer, though he is of opinion it does occasionally remain the year round, and breed in the Storrs Hall and Farnley Woods; F. O. Morris states that several instances have occurred of their breeding in Yorkshire. J. Heppenstall says it breeds occasionally near Sheffield, and has done so this year in Wharncliffe Wood. Dr. Farrar has seen this bird late in summer, and is satisfied of its breeding here. Arthur Strickland observes that the promontory of Flamborough Head, being the first land that birds from the Continent approach, has been long celebrated for flights of these birds, which are occasionally found there on their first arrival, but these arrivals are much less certain and numerous than they used to be, and the birds soon disperse westwards.

The earliest authentic account of the Woodcock's nesting in England is, probably, that by Willughby, who stated in his "Ornithology" (I678, pp. 289, 290), that "Mr. Jessop [of Broomhall] saw young Woodcock to be sold at Sheffield." J. Heppenstall of that town also mentioned the fact of young birds being observed (Zool. I843, p. I5; and I844, p. 667), and according to Seebohm ("British Birds," vol. iii. p. 234), it still breeds in the Sheffield district, where that author saw a nest in April I870. It was not unknown as a breeding species to Allis and, doubtless owing to the greater interest now taken in ornithology, and to the operation of the Wild Birds Protection Acts, the discovery of the Woodcock's nest is no uncommon occurrence. In addition to the localities referred to, it is reported from near Doncaster in I834, Stainborough Woods, near Barnsley, in I8 $3 \mathrm{I}$ and 1876 , in the secluded woods of Airedale, Ribblesdale, the Forest of Bowland, Nidderdale, Wharfedale, Craven, the Washburn Valley (where I 


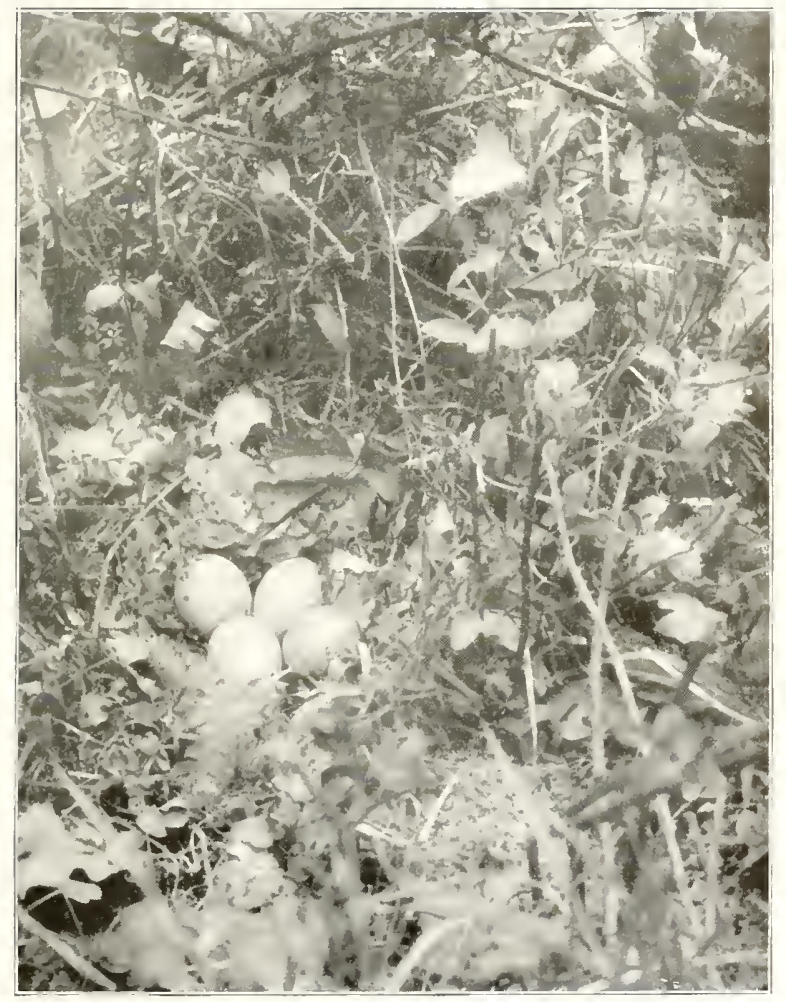

Nest of Woodcock, near Selby.

R. Fortune.

Se'e page 597. 
saw eggs in I903), near Ripon, and other suitable parts of West Yorkshire. In the North Riding it breeds with greater regularity and frequency than is generally supposed to be the case; the late J. Carter of Masham has known of six nests in one season in Lower Wensleydale; it is probably of annual occurrence near York, in Swaledale, and near Sedbergh; on the southern slopes of the Hambleton Hills several pairs breed near Sessay and Coxwold, also near Helmsley, in Ryedale, and in Bilsdale, where I saw three old birds in June I883. In the Cleveland area it nests regularly in the woods of Wilton, Arncliffe, Swainby, Ingleby, and Kildale, as well as lower down the Esk Valley, and in the Mulgrave and Grinkle woods near the coast.

In East Yorkshire the nest has been occasionally known on the Wolds, and in 1875 one was found at Knapton. The home-bred birds leave their nesting quarters as winter approaches, and, presumably, migrate further southward.*

This sporting bird is, however, best known as an autumn and winter immigrant, coming, as a rule, in two great flights. Its arrival on the coast can be predicted with great certainty, viz. :-during the first N.E., E. or S.E. wind after or about the middle of October; if no such wind occurs there is not a great arrival of 'Cock in that month, but if the period of full moon synchronizes with the other favourable conditions the flight is more pronounced; a supplementary flight takes place in November, and very often a small one in September, on the r6th of which month, in I890, I saw a single bird fly up the sands at Redcar. The earliest arrivals I am aware of were in the last week of August I883, when one was shot on the sand-hills and two or three others were seen near the Tees Breakwater. The numbers vary greatly in different years, depending mainly on the force and direction of the wind and the state of the weather. On dark and foggy nights

* Marked birds bred in Alnwick Park, Northumberland, have been shot in places as widely apart as the south-west of England, mid-Scotland and Ireland, whilst some have been killed near the nesting localities, showing that the young do not always follow the usual rule in migration. (ct. Field, 23rd April 1904.) 
they strike the lanterns of our sea beacons, many being thus immolated at Spurn and Flamborough; at the latter station in October I864, a Woodcock dashed through the quarter-inch glass, and was picked up dead and mutilated amongst the lamps. A south-east to north-east wind is most favourable for coast observation, as the birds on arrival are exhausted and ready to drop anywhere, and under these conditions, with the addition of a foggy or drizzly atmosphere, the coast gunners are always on the alert for the "Cocks" advent to take advantage of the opportunity to make a good bag.

A quaint reference to the migration of this bird is made in a communication from Ralph Johnson of Brignall, to the renowned John Ray, thus:- “ Brignall, 7th May I686. Sir .... and Woodcockes from Norway come often so tired to us." ("Correspondence of John Ray," p. I83.)

At Flamborough, on arriving, they frequently drop at the foot of the cliffs, being sometimes found amongst the boulders on the shore, or seek shelter in the little ravines running up from the beach; several occurred there in October I903, and it is quite a mistaken idea to imagine they are lean or in poor condition on first landing, for of their estimable qualities I have personal experience. At Redcar they commonly find refuge in the benty grass on the sand-hills and the Tees Breakwater, and occur in most unlikely situations: in the streets, in doorways and on window-sills, in yards, gardens (I flushed one, on 2Ist November I902, in the garden behind my house), on the sands, and amongst the fishing cobles. Although generally observed singly on migration, they do occasionally cross the sea in company; I have on three separate occasions seen two together, and, in November I877, when they were very abundant in Cleveland, a small party of nine was noticed coming in from seaward.

According to the information supplied to the British Association Migration Committee, and detailed in their Reports, it is found that great arrivals of Woodcock took place as follows :I88I. Igth to 2oth October. Upwards of a hundred shot at Spurn. 
I882. Second week in October.

I883. Fourth week in October.

I884. Throughout October and up to mid-November.

1885. 22nd to 24th October. N.E. gale. At Spurn seventy-nine were secured by one party on the $24^{\text {th }}$. Small red form.

I886. Third week in October.

Subsequently to the Migration Reports there were large flights in I888, in the first week of November; in I889, in the second week of November; and in I89o, on 20th to 22nd October, when forty were killed at Flamborough.

The general character of the migratory movements of this; interesting species in Yorkshire is here briefly outlined: a few odd stragglers keep dropping in throughout October, and until the November flight, after which we may conclude the main body will be established in their winter haunts, though occasionally in very severe weather, when birds are "frozen out," local migrations may be observed.

The vernal migration of the Woodcock is, probably, more noticeable inland than on the coast; at that period, March and April, they may often be flushed in woods and spinneys, especially if their departure be delayed by continuous easterly winds. The late Prof. W. C. Williamson stated that at Scarborough they used to be shot in March, when prevented from continuing their over-sea journey (P.Z.S. I836, Vol. iv. p. 77), and it is stated in the Annual Register for the year I799, that "Many Woodcock, with Plovers and Crows, were cast ashore in Holderness, during a great snowstorm on the 4 th of April." At Redcar I have noticed them in mid-April, and in $I 89$ I they remained for several days in the vicinity of the coast during stormy weather while, doubtless, awaiting a favourable opportunity for continuing their journey and crossing the North Sea. At Flamborough and Spurn, also, they have been noted on the vernal passage.

A species of such general distribution needs but little further notice in that respect; as is well known to most naturalists and sportsmen, on its first arrival it may be flushed in almost any place : hedgerows, on moors, amongst bracken,

vol. II. 
and other unlikely situations, but, after settling down, it becomes "haunted," as the Cleveland saying goes, and year after year may be found in the same spot, whilst, if killed, its place is soon taken by another.

Heavy toll of their ranks is often exacted by coast shooters, yet large bags are made on favoured estates in various parts of the county. Lord de L'Isle and Dudley told me that the largest number killed at Ingleby in one season was seventythree, in the year I864; and W. Cook, formerly head keeper at Grinkle, a very favourite haunt of 'Cock, bagged twentyfour in one day. There had been a heavy snowstorm, and he tried all the known resorts of the bird; twice he killed a right and left, and once two at a shot, thus emulating Chantrey's famous achievemnet immortalised in "Winged Words."

So much has already been written, in works specially devoted to game-birds, on the habits of the Woodcock, that it would be superfluous to occupy the space in a county history for this purpose ; it may not be out of place, however, to state that the old birds have been seen carrying the young, which they held pressed under their bodies, but not in their claws; and, as early as Ist April I894, Lord de L'Isle and Dudley discovered a nest with the parent bird sitting on four eggs.

A singular instance of tameness in this species is related by the late Hon. H. Sidney, who says (Field, 3rd April r886) that, during the snowstorm of that winter, the occupants of a house in the village of Ingleby threw out food for small birds, and were surprised one day to see a Woodcock come in quest of a meal; it continued to put in an appearance every day till the thaw came, and if the food was not ready at the same time each day it sat waiting for its arrival.

The average weight of this bird is I20z. The late J. Gould remarked, in reference to a Woodcock shot near Halifax in I86r, and said to have weighed $20 \mathrm{oz}$., "A bird of this weight I have never seen," an assertion which will be confirmed by every other ornithologist. The heaviest of which I have personal knowledge weighed $\mathrm{I} 7 \mathrm{oz}$, and was killed at Hutton, near Guisborough, while the lightest healthy bird was one of $7 \frac{1}{2} \mathrm{oz}$., obtained by Mr. E. B. Emerson at Easby-in-Cleveland. 
Of Yorkshire varieties, Tunstall recorded one sent to him in 1766 , shot in Winston lordship, near York, which had all the large feathers perfectly white. The late IV. Talbot of Wakefield had one in his collection, taken on 2rst September I85I, of a uniform rufous or light brown shade ; a white specimen was killed on Strensall Common in October I875; and an example, almost white in plumage but with faint yellow markings, was reported at Ormesby-in-Cleveland in the first week of November I904.

\section{GREAT SNIPE.}

Gallinago major (Gmelin).

Bird of passage, of uncommon occurrence.

In all probability the earliest reference to this bird in Yorkshire is that reported by R. Leyland, as shot in $\mathrm{r} 836$, and which is mentioned in Thomas Allis's Report of I844, thus :-

Scolopax major.-Great Snipe-F. O. Morris reports two shot near Doncaster; R. Leyland one from Sowerby Moor, shot 27 th September I 836 , and now in the Halifax Literary and Philosophical Society's Nuseum. W. Eddison says a few specimens have been shot, but the bird is very rare ; those found were shot near Deane Head ; H. Chapman has also had the bird; A. Strickland has one specimen killed at Flamborough.

The Great, or Solitary, Snipe is a bird of passage in autumn or winter, of rare occurrence. Instances are reported of individuals being killed on IIth August I899, at Townhead, near Sheffield; on 23rd August rgor, at Cherry Cob Sands, near Spurn; and in the last week of the same month in 1877 and 1887 , near Beverley; but, generally speaking, it does not arrive until September.

The average weight of this species is $7 \frac{1}{2} \mathrm{Oz}$. to Soz., and an example weighing I0 $\frac{1}{2} \mathrm{Oz}$., which occurred near Pickering, and was recorded in the Field (5th October 1895), calls forth 
an editorial comment in that journal on the unusual weight. In the York Museum is a specimen shot at Hayton, in September I878, said to have scaled the extraordinary weight of $140 z$.

The late W. W. Boulton of Beverley mentioned that the gizzard of one, obtained in October I863, contained a few seeds and vegetable matter, foreign to the bird's usual food (Zool. 1864, p. 8890).

The communicated and recorded occurrences number upwards of sixty, and are too voluminous for particularization. It may, perhaps, suffice to state that eighteen have been shot in the North Riding, seventeen in the East Riding, and in the West Riding twenty-nine.

\section{COMMON SNIPE.}

Gallinago cœlestis (Frenzel).

Resident, local, breeds in most suitable districts. A great influx of immigrants takes places in autumn. During winter it is more generally distributed.

The earliest mention of the Snipe in Yorkshire is, probably, to be found in the Northumberland Household Book, in $\mathrm{I}_{5} \mathrm{I} 2$, in which the price to be paid for birds for "my Lordes owne Mees" is fixed, and "Snypes after 3 for Id." is given as applicable to the species under notice. Another early allusion is in the value of "Wildfowl at Hull" in I560, that of a Snipe being Id.

Thomas Allis, in I844, wrote:-

Scolopax gallinago.-Common Snipe-Common in most parts; it breeds occasionally near Sheffield, Doncaster, and York; and on the moors near Halifax sparingly.

The Snipe is a local resident in Yorkshire, breeding not uncommonly from the marshy lands bordering the coast up to the high fells of the west and north-west and on the Cleveland Hills. In the dales of the West and North Ridings it nests in most of the rough sedgey pastures and boggy 
lands, and, although drainage and reclamation of waste spaces have conduced to its decrease as a nesting species, it still occurs in all suitable localities removed from the vicinity of manufacturing centres.

In autumn large numbers of immigrants arrive on our shores; the first comers about the third week in September, and the main flights in October and November with the Woodcock, when they are not infrequently immolated against the lanterns of our coast beacons. I have seen Snipe crossing from seaward so early as 2Ist September, and in October I 890 I shot one of two, which were flying over the Redcar " scars," coming direct from the sea.

On first arrival many remain in the coast marshes, others are flushed by Partridge shooters in the stubbles and root crops, but the majority gradually disperse over the country, when they are much more generally distributed than in the nesting season. Their movements vary greatly, and are regulated by the condition of the weather; should intense frost and snow occur they betake themselves to open streams and running ditches, in which situations in Cleveland they were very plentiful in mid-December I899; and in severe winters they desert even the streams, and resort to the tidal portion of the Tees estuary, leaving the district altogether if unpropitious weather continues for long, while only a few return with milder conditions. In I879 large numbers arrived in Holderness from the middle to the end of November, preceding an outbreak of frost and snow in December, and all left again before the middle of that month.

In some seasons on the Tees marshes they are very numerous, and I have flushed a large "wisp," which might almost have been called a flock, of fully a hundred, evidently newly arrived. On a fine warm day in the autumn of $I 890$, a large assemblage of Snipe was seen sunning themselves on a small grassy spot in a marsh near the Teesmouth, where they were observed by a gunner, who fired into the " brown," and told me afterwards he picked up seventeen-fourteen Common and three Jacks. The Common Snipe was in great abundance near Beverley in the same year. 
The return migration of the winter visitants usually takes place about the end of March and in April.

Nidification commences in April; I have found young in June which were well on the wing in July. A clutch of five eggs, reported by Mr. R. Fortune, in Ripon Park on Ist June I89o (Nat. I89o, p. 210), must be considered as unusual.

The late Canon Atkinson related ("Moorland Parish," p. 325) an incident of a couple of Snipe coming regularly two or three times a day for eight or nine days to feed on bread soaked in milk provided as a meal for hungry birds, and placed on the lawn of Danby parsonage. It is known to most ornithologists that wading birds are at times in the habit of perching, and as regards the Snipe there is evidence of this habit from the fact that it has been captured in that deadly instrument the "pole-trap." I have also had ocular proof of the same fact in Ryedale, in June I883, when I saw a Snipe fly on to the topmost twig of a dead ash tree and perch there for a minute (Zool. r884, p. 28).

There is still considerable diversity of opinion as to the method by which the humming or bleating sound is produced by the Snipe when descending in its spiral flight; some observers say it is caused by both wings and tail, while others assert that the wings alone are used.

The late J. Carter of Masham stated that an instance of maternal devotion in this species came under his notice in the spring of 1880 . A drain was being made through a field, in which a Snipe had built, and would of course have destroyed the nest, but the workmen made a circuit, enclosing the piece of ground containing the nest, which formed a kind of bracket to the edge of the drain, and the bird, notwithstanding the presence of the men, continued-its duties and hatched off the eggs.

The number of tail feathers in the Common Snipe does not appear to be constant; I have seen and examined specimens which had, some fifteen, and some sixteen feathers.

Of the so-called Sabine's Snipe, now generally admitted to be merely a dark form of the common species, Thomas Allis's Report, I844, contains the following observation :- 


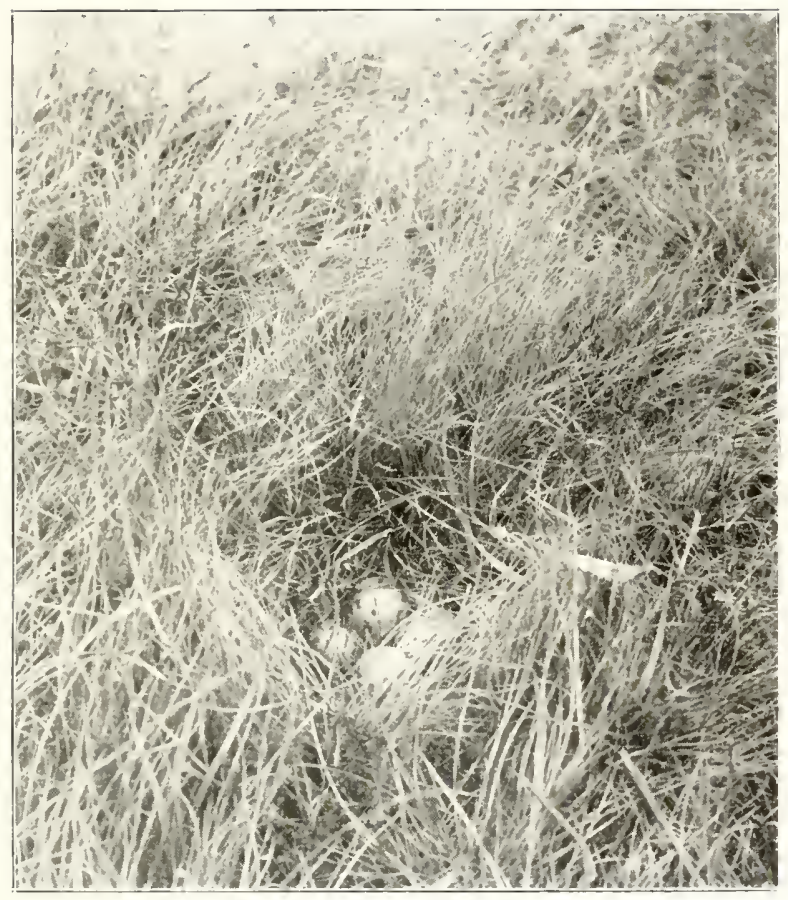

Nest of Common Snipe. R. Fortune.

See pager bot. 

Scolopax sabini.-Sabine's Snipe-Arthur Strickland says he has reason to believe, from description, that one was killed in his neighbourhood a few years ago.

Local names:-Long Neb is used in the East and North Ridings; Full Snipe at Scarborough; and Heather Bleater is mentioned by Captain Turton as in use at Upsall.

\section{JACK SNIPE.}

\section{Scolopax gallinula (L.).}

Winter visitant; generally distributed in suitable situations. Arrives in October, and departs in April.

The first mention of this as a Yorkshire species occurs in Willughby's "Ornithology," under the title of "The Gid, or Jack-Snipe or Judcock:-I, sometimes, following the vulgar error, thought it not to differ from the Snipe in kind, but only in sex, taking it to be the Cock-Snipe. But afterwards being advised by Mr. M. Lister [of York], I found it to differ specifically. For, dissecting several of these small ones, some proved to be males, some females." (Will. “Orn." I678, p. 29г.)

Thomas Allis, r844, wrote :-

Scolopax gallinula.-Jack Snipe-Is common in most parts; it breeds in the neighbourhood of Huddersfield, at Slaithwaite, and .... it breeds occasionally near Doncaster and Halifax.

Needless to remark, there is not the slightest evidence in support of Allis's statement respecting the nesting of this bird in Yorkshire, which error is also repeated by Yarrell ("British Birds," I843, Ir. p.6I4), by Mr. C. C. Hanson (Nat. I88I), and by more than one of my numerous correspondents ; it is quite evident, on investigation of the circumstances, that the Dunlin has, in all these cases, been mistaken for the species under notice.

This diminutive Snipe is a winter visitant, generally arriving in October, varying in numbers in different seasons, 
and less abundant than the foregoing species. An unusually early appearance was on I8th August I863, near Beverley, where one was shot by the late T. E. Buckley. On IIth September I886, Lord Walsingham killed an example on Bluberhouse moor, and forwarded the specimen to Mr. W. Eagle Clarke, with the observation that it was the first he had known there; the earliest of which I have had personal knowledge was on Ist October Igor, at the Teesmouth.

It is fairly generally distributed in suitable localities, and resembles the Woodcock in its partiality for certain haunts, but in many districts it is decreasing in numbers. It is usually found singly, though I have occasionally flushed several, probably new arrivals, in close proximity to each other. It was very numerous in the winter of $1864-65$ near Beverley, and in the Tees marshes in the autumn of 1883 ; on 23rd October Igoo I bagged four out of six which rose from a small marshy tract at the same place where fourteen Common Snipe and three Jacks were killed at one shot (see Common Snipe, p. 603). In the winter of I897 Mr. E. B. Emerson shot eighteen Jacks, in a small bog on Swainby moor, nearly all of which were males.

The return migration takes place in April, odd individuals sometimes lingering until the first week in May; one was seen in Cleveland as late as the 3 rd of that month. The Jack Snipe sometimes strikes the lanterns of our coast beacons on dark and foggy nights when on migration, and at this period often occurs in very unlikely situations; in October I88I one was caught asleep on the beach at Redcar, having evidently dropped exhausted after its flight across the sea, and I have frequently flushed single birds from a small patch of grass near the Tees Breakwater. The late Canon Atkinson of Danby related (Zool. I853, p. 4656) an instance of this bird's habit of "lying close" for purposes of concealment, and mentioned the fact of this usually silent species uttering a slight note, a fact which is corroborated by Mr. F. Boyes from his personal observation. 

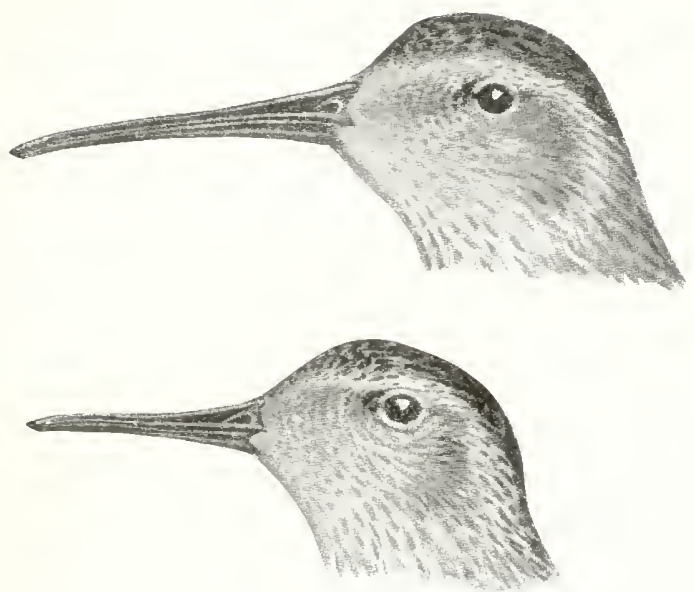

Heads and bills of the large and small races of Dunlin-the latter is sometimes called the "Drain Dunin" in East Yorkshire.

J. Buckhouse, Zorhl., Ig,oI.

See page 611. 



\section{BROAD-BILLED SANDPIPER.}

\section{Limicola platyrhyncha $(T \mathrm{em})$.}

Accidental visitant from northern Europe, of extremely rare occurrence.

This Sandpiper has its habitat in northern Europe and Siberia, migrating in winter as far south as India and China.

Its claim to be considered a Yorkshire bird rests on the occurrence of a single male example, procured by Thomas Ellotson, in April I863, from a large flock of Dunlins, at Hornsea Mere in Holderness.

This specimen is now in the collection formed by the late Sir Henry Boynton at Burton Agnes, where I have had the pleasure of seeing it.

\section{PECTORAL SANDPIPER. Tringa maculata (Vieillot).}

Accidental visitant from North America, of extremely rare occurrence.

It is somewhat strange that, since the early records of this North American species in Yorkshire in the years 1853 and 1854 , there should have been no notice of its visit to the county until I888, when the late J. Cordeaux announced its reappearance at the Humber mouth; though there is a probability that it may escape observation when consorting with other small waders, and may really be of more frequent occurrence than the few records lead us to infer. As, however, there are but five communicated instances of its capture, it is desirable to give the particulars of each.

T. S. Rudd mentioned two as having been shot near Redcar-one at the Teesmouth on 3oth August 1853 , and the other in a field near Coatham on $I 7$ th October of the same year (Nat. I853, p. 275). 
One at Filey is recorded by the Rev. F. O. Morris ("British Birds," I854, iv. p. 3I6).

On 2nd October I888, Mr. T. W. Pool of Hull procured one of two, supposed to be of the same species, on the coast near Kilnsea, and left it with Mr. P. Loten of Easington to be preserved. The skin was forwarded to the late J. Cordeaux for identification, with the information that it was a male (Nat. I888, p. 354 ; and Zool. r89r, p. 366). This specimen is now in the possession of Mr. Riley Fortune, and was figured by the late Lord Lilford in his magnificent work on British Birds (Vol. v. Pl. 3I).

At Bridlington one was shot on 15 th August I89I, and has been submitted to me for examination by its owner, Mr. S. Smith of York.

Lastly, a very fine adult male example, in summer plumage, was obtained by Dr. Steward of Harrogate, on 28th September I897, at Easington, near Spurn, and was seen shortly afterwards by Messrs. H. Saunders, W. Eagle Clarke, and J. Cordeaux. The irides were dark coloured, and the legs and feet ochreous yellow. This individual is now in the Royal Scottish Museum.

\section{DUNLIN.}

Tringa alpina (L.).

Resident, breeding in limited numbers, and irregularly, on the fells of the west and north-west, and sparingly on the Tees marshes. Very abundant as a winter visitant to the coast, particularly at the Tees and Humber estuaries, arriving in August and September, and departing in April and May. A few non-breeding birds remain throughout the summer.

The earliest allusion to this in Yorkshire is in the Northumberland Household Book, begun in I5I2. In the list of birds to be provided for "my Lordes owne Mees" is found "Styntes so they be after 6 a Id." ; and later, amongst the provisions at the marriage feast of Sir John Neville's 


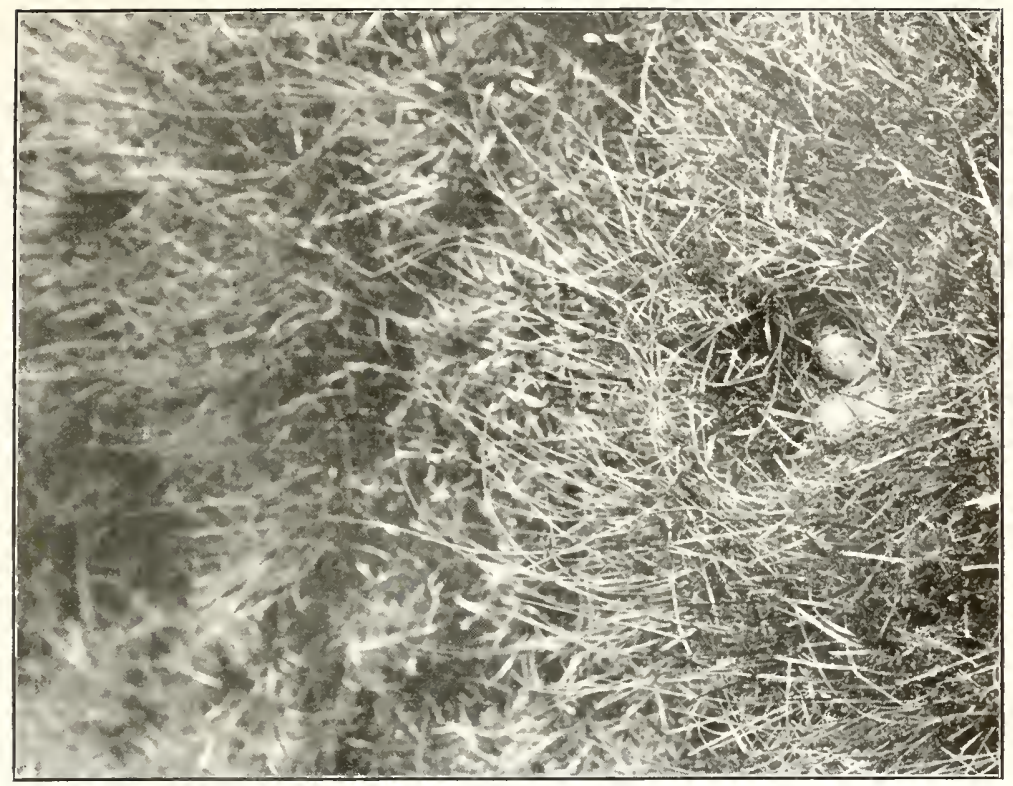

تే

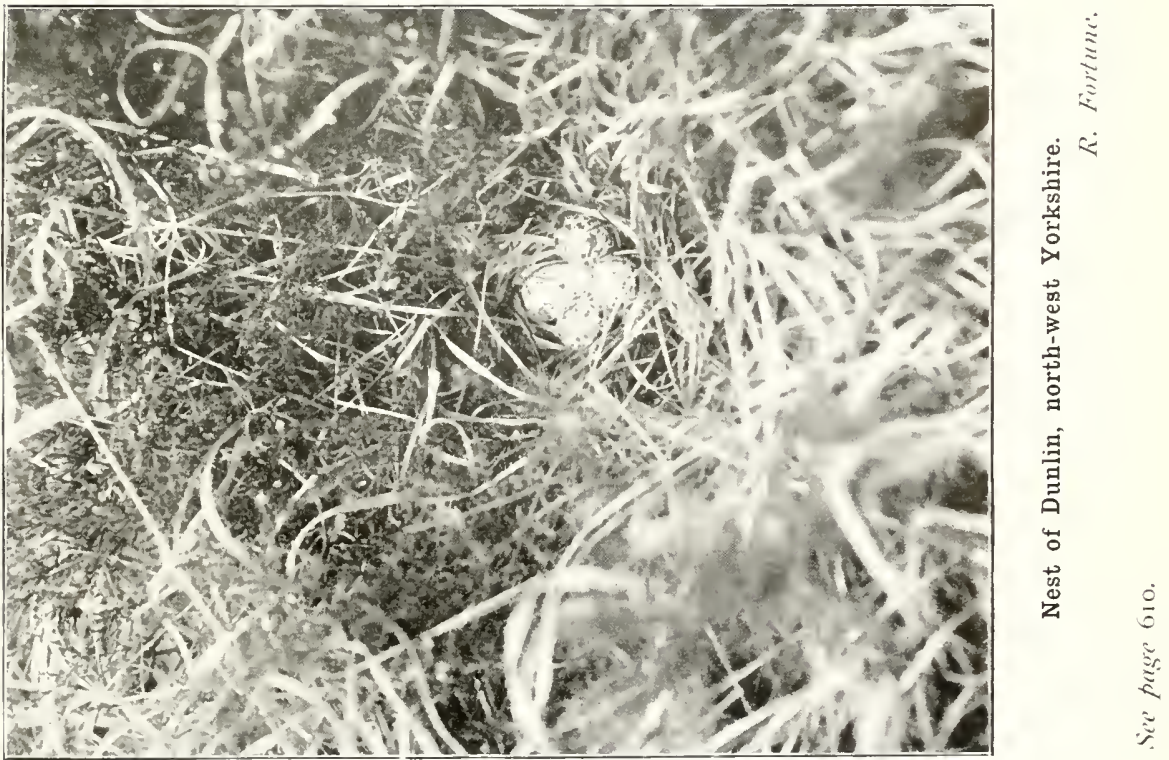


daughter, in I526, at Chevet, near Wakefield, are " five dozen Stints, 9d." George Allan referred to these birds as being "formerly a great dish at our tables" (Fox's "Synopsis of the Tunstall Museum," I79I, p. 86), which is quite apparent from the price of "Wildfowl at Hull" in $\mathrm{I}_{560}$, when "Stintes" are quoted at $4 \mathrm{~d}$. a dozen.

The first British description of the bird occurs in a communication from Ralph Johnson of Brignall, near Greta Bridge, to Willughby, thus :-

"It is about the bigness of the Jack Snipe or Judcock, hath a straight, channell'd, black Bill, a little broader at the end, oblong nostrils; a blackish tongue. The Throat and Breast white, spotted with black. The middle of the Belly is blackish, varied with white lines. The Lower Belly, and feathers under the Tail white. All the upper side is red, everywhere spotted with pretty great black spots with a little white. Yet the wings from a grey incline to a brown or dusky colour. The Legs and Feet are of a competent length and black. The back-toe the shortest. The Tail consists of twelve feathers of which the two middlemost are dusky [" brown "] with one or two red spots. The rest from brown incline to white. It gets its food out of the mud." (Will. "Orn." I678, p. 305.)

Thomas Allis, I844, wrote:-

Tringa variabilis.-The Dunlin-J. Heppenstall informs me it is found on Thorne Moor in summer; R. Leyland says it breeds on the High Moors, round Halifax; H. Reid reports it as very rare near Doncaster, and that one specimen was killed at Bradsworth in the spring of this year; it is common at Hebden Bridge, and not infrequently to be seen in considerable numbers during winter in the shops in York. A. Strickland says considerable flocks, in various stages of plumage, are frequently met with on the sea shore about Bridlington in the autumn and winter, and that it is about the most abundant species on the shore; he says they must breed in considerable numbers in some part of the county, but he does not know where, and that a few pair used to breed, many years ago, in Stockton Forest, near York, where he has taken both their eggs and young.

In addition to being the most numerous and familiar of our Sandpipers, the Dunlin is known in some parts of Yorkshire 
as a nesting species and, whilst endeavouring to define its distribution, it may perhaps be advisable to exercise a certain amount of discretion in regard to its breeding areas, for reasons which will be apparent to most ornithologists.

According to Allis's correspondents (quoted above), it formerly bred on the low-lying tract of Thorne moor, and may possibly still do so, as one or two pairs have been noted in summer within recent years; on the authority of Leyland and Strickland it is mentioned as nesting near Halifax and York; Mr. S. L. Mosley informs me that his father took the young at Booth Deane, above Sowerby Bridge; he himself found newly hatched young at Muker, Swaledale, in IS7I, and saw a pair of old birds on Standedge in the summer of the year following. Another low-lying district where it has nested, to my certain knowledge, for many years past, is the marshland near the Teesmouth, though the breeding birds are limited to a few pairs. I am not aware of any other nesting locality in Cleveland, but on the fells of Upper Teesdale the Dunlin breeds sparingly on the grassy. slopes of the hills, where I saw six pairs in June I900, and in I 902 a clutch of eggs was taken.

In the higher reaches of Swaledale, Wensleydale, Yoredale, Arkengarthdale, and Lunedale in the North Riding, and the range of hills bordering on Westmorland and Lancashire, including Ribblesdale and Wharfedale, Nidderdale, and southward to the moors in the Sheffield neighbourhood, it nests irregularly and sparingly, and in some parts to upwards of 2,200 feet elevation. On these extensive fells and moors there may be more breeding birds than the casual observer imagines, for the nest is difficult to locate on such tracts of wild and desolate country; in one or two places it is in considerable numbers, and my reticence respecting the precise localities where the nest may be found will be understood and appreciated, when it is stated that reliable information has been supplied to the effect that unscrupulous persons take advantage of the birds' confiding nature in the breeding season to drive them into nets set for the purpose.

The Dunlin, however, is best known as a shore bird, and 


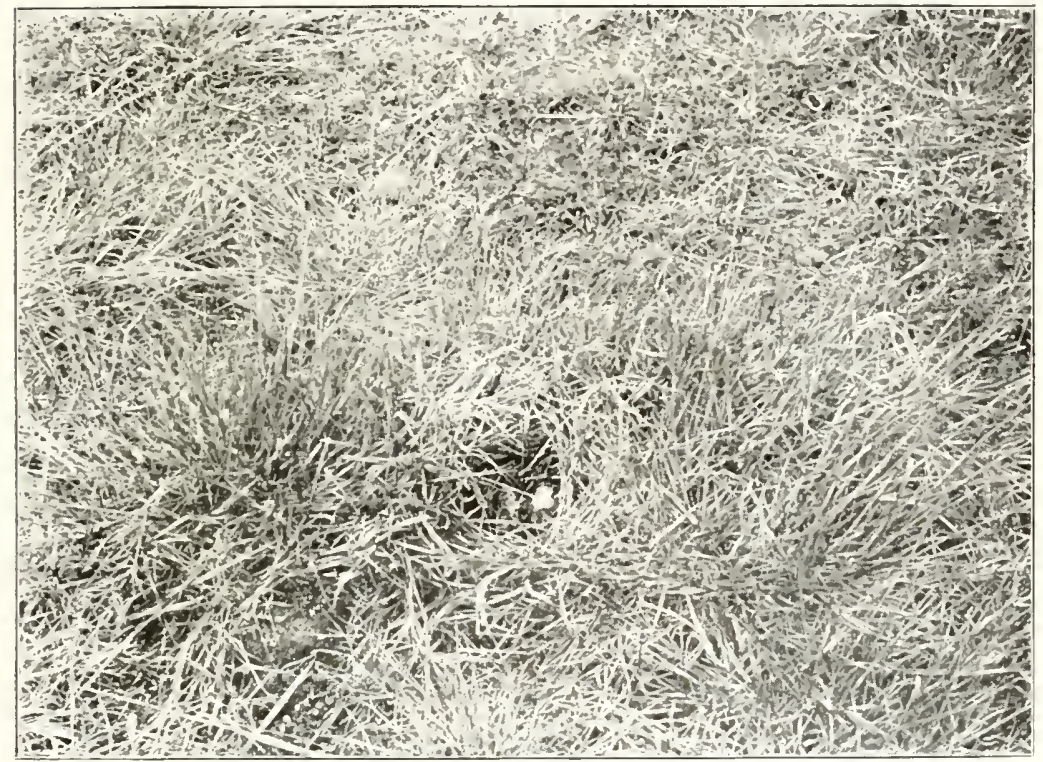

Nest of Dunlin, Teesmouth.

TH. Nelson.

Sé puge 6ro. 

on the mud flats of the Tees and Humber estuaries a great influx of immigrants takes place in mid-August, frequently continuing to arrive throughout October. In very severe weather many of these leave for more southern quarters, though vast numbers make Yorkshire their winter home, and may be seen on the "slems" and sands, or performing their aërial evolutions at high tide.

A return movement takes place in April and May, often in company with Ringed Plovers and other northward travelling waders; some linger at the estuaries as late as June, and a few non-breeding birds in partial summer plumage remain during the summer; on 2 Ist June I899, a pair was observed at Hornsea Mere in Holderness.

The Dunlin is frequently found amongst the victims lured to their destruction by the rays of our sea-beacons, and on calm evenings in autumn I have many times listened to the calls of birds passing overhead on migration.

A divergence of opinion exists in reference to the question of the different races of this species, and I may state that my experience on this point shows that our nesting birds invariably belong to the small bright-coloured form; both the large and small varieties appear on the spring and autumn passages; I have shot examples of each kind from the same flock in September, and am strongly of opinion there are two races, but doubt whether the differences in size are sufficient to constitute specific distinctions; they are more likely attributable to the influences of climate and food. Measurements of the two forms, taken from Yorkshire specimens, are set forth by Mr. J. Backhouse, in the Zoologist (I90I, pp. 9I, et seq.).

On all the sandy beaches between the Tees and Humber the Dunlin occurs more or less frequently, generally whilst on its migrations, at these periods being also observed in small parties at localities far distant from the coast.

Nidification commences early in May on the low grounds, being a week or two later in the fell districts. Though most authors agree that the nest is very difficult to discover, it may be worth mentioning that one, found at the Teesmouth in 
May 1898 , was quite exposed to view under a tussock of grass in a wet spot, and visible at fully twenty yards' distance.

A curious accident to one of these birds is reported by Sir Ralph Payne Gallwey, who found it starved to death, a cockle shell having closed upon the bill so tightly as to muzzle it completely and prevent its feeding, whilst in the winter of r890-9I Mr. F. Boyes saw one at Spurn which was disabled owing to having a cockle attached to its leg (Field, I5th March I884, and 3 Ist January I890).

Varieties of plumage are very uncommon; the only instance of which I have had personal knowledge was one of a nesting pair at the Teesmouth, several years ago, which had a large white patch on one wing.

Of local names, Stint is the universally accepted term, and by which it has been known for centuries. It is called Purre in the Tunstall MS., and in Wensleydale, according to Barker (1854); Tommy Stint is in use at Spurn; Jack Plover, in the North Riding dales; and Judcock and Little Snipe, in Swaledale and Arkengarthdale.

\section{LITTLE STINT.}

Tringa minuta (Leisler).

Bird of passage on the coast on the spring and autumn migrations, chiefly at the latter period. Very rare inland.

Possibly the earliest reference to this, as a Yorkshire bird, is made in Thomas Allis's Report of I844, when he wrote :-

Tringa minuta.-Little Sandpiper-F. O. Morris reports six being killed near Redcar on the River Tees. S. Gibson says it is rare near Hebden Bridge, he has a single specimen shot there a few years since; it has been shot in the neighbourhood of York.

This diminutive Sandpiper is a bird of passage on the coast line, chiefly during the autumn migration, being most frequently found at the Tees and Humber estuaries; in some 
years it is rare or altogether absent, whilst in exceptional seasons it has occurred in great abundance. These erratic visitations are evidently due to the fact that the Yorkshire coast lies to the westward of its chief line of flight, and it is only under extraordinary circumstances that large numbers are met with.

The earliest date of which I have note of its arrival in autumn is I2th August Igoo, when one was obtained near Redcar; it was especially numerous in the years I88I, I887, I889, I892, I894, and I903; in the latter season in flocks of forty to fifty in number, at the Teesmouth. In 1887 , both at the last named locality and at Spurn, it was exceptionally plentiful from the 25th of August to the end of September, fresh comers arriving almost daily up to the 6th of the latter month, when there was a great "rush" of small waders; that season has since been distinguished as a remarkable "Little Stint and Curlew Sandpiper year."

On first arrival the Little Stint does not, as a rule, associate with other shore birds, and occurs in small parties of half-adozen up to forty and fifty, or even more, but later in the season it is seen consorting with the Dunlin and Curlew Sandpiper, the latter of which is generally associated with it on migration. Although often found on the sands and muds this species appears to prefer the salt marshes and reclaimed land adjacent to the estuary, where large flocks have been observed feeding on the margins of the brackish pools, whence they fly only a short distance if disturbed. Early in October the southward flight is resumed; one was reported at Spurn on 8th October I88I, and the latest lingerer I have noted at the Teesmouth was on I4th November I903.

On the spring passage northward it is extremely rare; a male in full summer plumage was procured at Kilnsea on 7 th May 1877 ; one in the Hull Museum was obtained near Beverley in June I885; and occasionally it occurs in the Tees area in May and June, generally singly, and never in flocks as in autumn.

On other portions of the coast it ranks as a casual visitant 
only, and as such it may be classed in localities away from the seaboard, a list of which is here appended:-

Mentioned in Allis's Report.

Two were seen, and one shot, near Killerby, in August I843, as recorded by Mark Booth (Zool. I844, p. 444).

At Yeadon Moor Reservoir, near Leeds, one was obtained in September I864 (op. cit. I864, p. 9289).

Near Barnsley it occurred in 1869 .

In 1875 one was recorded near York.

The late Wm. Talbot ("Birds of Wakefield," I877, p. 27) mentioned two killed from a flock at Cold Hiendley, and three at Horbury Reservoir.

In Wensleydale it has been noted at Thornton Rust by E. Chapman.

And at Haxby, near York, one was reported in July I9oo.

\section{TEMMINCK'S STINT.}

Tringa temmincki (Leisler).

Accidental visitant, of extremely rare occurrence.

Thomas Allis, in I844, observed :-

Tringa temmincki.-Little Temminck's Stint-H. Denny writes me, "I have heard of Temminck's Stint being shot on the York Road [Leeds] last year, but I have not seen it." A. Strickland says he has met with minuta or temmincki, or both, but cannot exactly decide which.

The evidence adduced by Allis's correspondents in support of their records of this, the least of the British Sandpipers, is not of a nature to warrant their inclusion in the history of Yorkshire birds, and the earliest reliable mention of it may be found in the late Prof. W. C. Williamson's Scarborough List (P.Z.S. I836, p. 77), where it is stated that one was obtained at Scarborough.

Temminck's Stint is a rare accidental visitant on migration southward from its breeding grounds in northern Europe, 
but it is quite probable it may occasionally be overlooked amongst the flocks of Little Stints which visit us periodically.

In addition to the example recorded from Scarborough, it has been reported from near Hull (Yarrell, I843, ii. p. 648).

The late W. W. Boulton examined a specimen obtained at Bridlington in I864 ("Birds of Humber District," I872, p. I37).

One in the possession of Mr. S. L. Mosley of Huddersfield was, as I am informed, taken in that district.

Mr. F. Boyes states that in August I887 one occurred on the river Ouse, and is now in the Hull Museum.

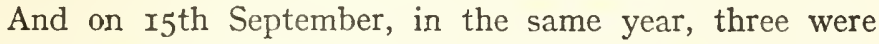
seen, and one killed, at Spurn (Ninth Migration Report, p. 32).

\section{UIR!LEW SANDPIPER. \\ Tringa subarquata (Guldenstadt).}

Bird of passage on the coast; not uncommon in some years. A rare straggler inland.

Probably the earliest notice of the Curlew Sandpiper in Yorkshire is in Leyland's Halifax Catalogue (I828), where it is stated to be "very rare near Halifax."

Thomas Allis, in I844, wrote:-

Tringa subarquata.-Pigmy Curlew-F. O. Morris says this bird was killed in great numbers by G. Rudd, Esq., and several were killed near Hull. H. Denny reports it as very rare near Leeds; it has been met with occasionally near York, though by no means frequent. Dr. Farrar informs me that he has occasionally had a few scattered specimens, they were invariably with the Common Sandpiper on banks and sides of the fresh water reservoirs. Arthur Strickland has known it killed near Bridlington, but it is of rare occurrence.

The Curlew Sandpiper, or Pigmy Curlew as it is sometimes called, is a bird of double passage, occurring rarely in spring on its journey northward to its breeding quarters, and in greatly varying numbers on the southward migration in autumn; in some years it is scarce or altogether absent,

VOL. II. 
whilst in others it is met with in large flights, these occurrences being coincident with the appearance of the Little Stint, with which it is usually associated on migration, and like that species it is both a coast-marsh, and a shore, bird. It is most numerous in the Tees and Humber districts, but is also met with on other parts of the coast, particularly where sandy beaches are found. The earliest date on which it has been noticed on the autumnal passage is 4th July 1855, when an adult example, now in the collection of Mr. Thomas Boynton of Bridlington, was taken on the East Riding Wolds; on the 2 Ist of the same month, in the year I88I, the late J. Cordeaux obtained two at Spurn. At the Teesmouth the earliest I have had personal knowledge of was on 27th July I894, when I saw two with deep chestnut coloured breasts by the margin of a brackish pool on the salt marshes.

The principal arrivals take place from mid-August to midSeptember, and generally consist of " youngsters," with buff breasts, although occasionally a few adults in faded summer plumage accompany them; by the end of September the bulk have passed on in their southward journey; the Ist of October is the latest date or. which $I$ have seen it at the Teesmouth, but the late T. E. Buckley procured one at Spurn on the $9^{\text {th }}$ of that month in 1869 .

There was an extensive migration of this bird in 1873 ; in I88I it was very abundant both at the Tees and Humber, as also in 1887 ( $N a t$. I889, p. 83, and Ninth Migration Report, p. 57); in the autumn of ISgo I have notes of upwards of a hundred, obtained at the Tees; and in I892 many were killed at Spurn, several with red breasts, the richest coloured being found to be females.

Inland this Sandpiper has occurred as a rare straggler, and, in addition to those mentioned by Allis, it is reported from Huddersfield in 1837 ; on the river Colne in 1843 ; Wakefield (Talbot, " Birds of Wakefield," I877, p. 27), and occasionally on flooded land at Scampston, Beverley, and one or two other localities on the East Riding Wolds. 


\section{PURPLE SANDPIPER.}

Tringa striata (L.).

Winter visitant to the coast, not uncommon in some seasons. The young arrive in September, the adults in October. Remains as late as April.

Apparently the first notice of the Purple Sandpiper in this county is in Leyland's Halifax Catalogue (I828), where one is recorded as shot on Ovenden Moor in December 1827 .

In I844, Thomas Allis wrote :-

Tringa maritima.-Purple Sandpiper-A specimen was shot on Sowerby Moor in the winter of 1832 , and one on Ovenden Moor in 1827. A. Strickland observes that this bird generally confines itself to rocky or stony parts of the sliore, and is seldom found on the sand, and is to be met with at Filey and other parts of the coast.

This species is a winter visitant to the coast, and of rather uncertain or irregular appearance, being scarce in some years, while in others it is not uncommon. First to arrive are the young birds in August and September; one was seen at Spurn on I 7 th August I 880 by Mr. P. Loten, but the 2oth of September is the earliest date on which I have noticed it on the Cleveland coast; mature birds put in an appearance in October and November. The immature examples arrive in small flocks, the adults generally in pairs, and they are occasionally observed on the sands and muds. At Flamborough, Filey, Scarborough, and Whitby it is reported as occurring irregularly on the rocky portions of the shores.

Its favourite resorts at Redcar are the reefs of rocks, or "scars," running out from the shore, which are covered at high tide ; in November I876 I saw a flock of about a dozen on Salt Scar, and on I3th November I893 a large flock of forty or fifty on West Scar, from which I secured six with ore barrel. At the Tees estuary the species fiequents the slag and blocks of concrete forming the sides and ends of the South Gare Breakwater.

It takes its departure northward in spring, the latest date. of its stay being 25th April, when a flock of seven was noted. 
at Flamborough in I865. It is enumerated in the list of victims killed by striking against the Lighthouse at Spurn.

Although essentially a coast bird, the Purple Sandpiper has been observed in Ribblesdale on Cam Fell (Nat. I896, p. 46), and at Penistone in November I89I (W. E. L. Wattam, MS.).

\section{KNOT.}

Tringa canutus (L.).

Winter visitant, abundant on the coast, especially in the Tees and Humber estuaries. The majority retire further south as winter approaches; a return passage observed in April and May; occasionally occurs inland.

This bird was evidently appreciated as a table delicacy by the Percys, as the first reference to it occurs in the Northumberland Household Book, begun in I5I2: amongst the birds to be provided for " my Lordes owne Mees " appear "Knottes at Id."

Thomas Allis, in IS44, wrote:-

Tringa canutus. -The Knot-Has been met with near Hebden Bridge, but is rare; it is rare near Leeds; $H$. Denny mentions a pair shot at Killingbeck in 1839 ; A. Strickland says it is met with in small flocks on most of our coasts in autumn and winter, in grey plumage, and occasionally in spring assuming the red dress of breeding but never in full dress.

Needless to remark, Strickland was wrongly informed when he made the foregoing statement that the Knot is never found in this county in full dress; it regularly occurs in that plumage in May and June, when on passage from its more southerly winter quarters to the nesting grounds within the Arctic Circle, and at Spurn it is quite common at this period, though the late $\mathrm{J}$. Cordeaux was in error in supposing that that district is its northern limit in Yorkshire on the spring migration. (See also Bar-tailed Godwit.) I have for many years known it at Redcar, where migratory flocks may be observed resting on the tidal rocks, and an old fisherman 
tells me that, in the middle of last century, these birds often used to alight on Salt Scar in the spring of the year when going north. A large mixed flock of Knots and other shore birds appeared on the sands at 3 a.m. on 9 th June 1887 ; at Spurn they have been seen coming from the south as late as I $3^{\text {th }}$ June in 1883 ; whilst small parties of non-breeding birds, in various states of plumage, have occasionally remained throughout the summer.

The Knot is, however, best known as an autumn or winter visitant on the southward journey from its breeding quarters, when a few old red-breasted individuals appear in July and August, sometimes as early as the first or second week of the former month, though the earliest date of which I have personal knowledge is the 23rd of July in the year I884. Late in August, and during September, flights of young bird; occur, accompanied by an occasional adult; one in partial summer plumage was picked up at Spurn as late as

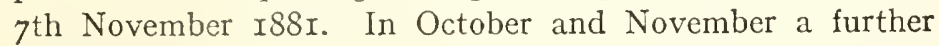
migration takes place, and in some seasons enormous flights are met with at the Tees and Humber estuaries; at the last named place the late $J$. Cordeaux graphically described the movements and evolutions of these enormous congregations ("Birds of Humber District," p. I32). As the season advances they become wild and difficult of approach, whilst, if an outbreak of very severe weather should occur, many retire further south.

From the information supplied to the compilers of the British Association Migration Reports we learn that this bird frequently falls a victim to the attractions of the Lighthouse rays on dark and foggy nights, and on the Cleveland coast it is no uncommon thing to hear the notes of migrating flocks on still autumn evenings.

At the majority of the seaboard stations between the Tees and the Humber the Knot is a more or less abundant visitant in spring and autumn, and also at various inland localities; in addition to those mentioned by Allis, it has been recorded from Halifax, Cold Hiendley Reservoir, and East Cottingwith. 
The causes which govern the abundance or scarcity of shore-birds visiting our islands are not within the knowledge of naturalists in this country, but it may be of interest to state that years of "great plenty" were I872, I88I, I883, I887, I892, and 1895 . In the days before the invention of the breech-loader, when the mud-flats of our estuaries were less frequented by gunners than at present is the case, large bags of Knots were secured by fishermen and professional fowlers. I have often heard old sportsmen relate their experiences of these times " afore t' licenses cam oot," when they sometimes bagged more Knots and Godwits than they could conveniently carry, and, as birds of this class are gregarious and pack into close bodies, it follows that a " shot into the brown" is attended with disastrous effects; I have myself, in recent years, gathered thirty-two Knots killed with a "right and left" from a I2-bore, though the bird does not now occur in anything like the same numbers as formerly.

Its vernacular name in the Spurn district is Plover Knot. In the Tees it is known to the professionals as Dunlin; Redcar fishermen call it Grey Plover; and Red Sandpiper is an old term, now obsolete, used in Fothergill's list (Whitaker's "Richmondshire," I823).

\section{SANDERLING.}

Calidris arenaria (L.).

Spring and autumn migrant to the coast line, very abundant; a few remaining during winter. Occasionally occurs inland.

Probably the first reference to this, as a county species, is to be found in Williamson's Scarborough List (P.Z.S. I836, part iv. p. 77), where it is stated that it "visits the shore in May and September."

Thomas Allis, in I844, wrote:-

Calidris arenaria.-Sanderling-S. Gibson reports this species as rare near Hebden Bridge; it is met with on the coast. A. Strickland 
says "It frequents sandy shores, and is occasionally met with at Bridlington, generally in autumn."

Although this nimble little wader is to be met with in every month of the year on the sandy beaches and tidal estuaries, it is by far best known as a common bird of double passage, and during its migration down the coast in autumn it is at times quite as numerous as the Dunlin and Ringed Plover in the Tees district, which is its chief Yorkshire haunt. Small parties on return migration appear about mid-July; the I 7 th, 20th, I4th, I 7 th, and I6th respectively being the earliest dates for the years rgor to I905. These first arrivals are wholly composed of old birds in summer plumage, and at the end of the month they are found in flocks from about ten to a hundred strong; birds of the year are seldom noted before the first week of the succeeding month, and by the middle of August large flights of guileless youngsters, together with mature birds fast losing the mottled throats, swarm on the beach by the tide-line. In September the immature birds outnumber the old, and at times large bags may be made by those gunners who are desirous of shooting such "small deer."

In October the Sanderling becomes less common; the few that remain associate with the huge congregations of waders which spend the winter in comparative safety, their extreme wildness rendering them unapproachable within gunshot, and at this period odd birds may be seen in the beautiful perfect grey plumage; it was very abundant in February I870, in the neighbourhood of Bridlington, as many as fifty individuals being in some of the flocks. Late in spring the northward migration commences, the first comers I have noted being on $4^{\text {th }}$ May in 1897 , when several individuals were on the mud-flats at the Teesmouth; it collects in considerable numbers until early June, and so late as the Irth of the month, in the year rgo3, I watched six small companies on the sands near Redcar; but this movement is not so pronounced as that in autumn. At Spurn the Sanderling arrives on the return journey from its nesting grounds late in July, August, and through September; in May it occurs in small 
numbers in summer plumage, though I have observed that very few of those seen in spring in the Tees area are in full breeding dress, the majority retain more or less traces of the winter plumage, and only about one in twenty has assumed its nuptial garb.

In habits this bird is very conservative, seldom being found at any distance away from the tide proper; the late J. Cordeaux remarked ("Birds of Humber District," p. 98), that he had occasionally seen it on the fallows near the coast, but its occurrence in inland localities is of more exceptional occurrence than is the case with other shore-bird. ; in Neville Wood's "Naturalist" it is said to have been observed in February 1838, at Doncaster; two were obtained at Waplington in the East Riding; and one, which I examined in the possession of Mr. W. Walton of Middleton-in-Teesdale, was procured on the Yorkshire side of the river in the autumn of 1902 .

Local names:- at the Humber mouth it is the Sandrunner or Stint; at the Teesmouth it is called by the general name of Stint, and Redcar fishermen distinguish it as the White Stint.

\section{RUFF.}

Machetes pugnax (L.).

Bird of passage in spring and autumn; very limited in numbers, and chiefly observed on the coast. A rare straggler inland.

The earliest reference to this species, in connection with Yorkshire, may be found in the account of the great banquet at Cawood in I466, and it is evident these birds were held in high esteem as delicacies, as it is stated that "of the fowles called Rees there were supplied 200 dozen " (Leland's "Collectanea"). It also appears in the Northumberland Household Book, in I5I2, where, amongst the birds to be provided " for my Lordes owne Mees," are " Reys," the price allotted being $2 \mathrm{~d}$. each. 
Thomas Allis, I844, wrote:-

Machetes pugnax.-The Ruff-Used to be common, according to F. O. Morris, on Hatfield Moor twenty years ago ; are still occasionally met with on Skipwith Common not far from Selby. I have one specimen in winter plumage shot near York in February, and have seen one or two others in the same plumage shot about the same time. A. Strickland says before the drainage of the Carrs they used to be taken in considerable numbers in the breeding season, but he should doubt if any had bred in this county within the last half century; he never met with any except young birds of the year that occasionally stray and join flocks of other species of Sandpipers.

This singular and interesting species, in the latter part of the eighteenth and early part of the last century, bred commonly in suitable marshy districts, but owing to drainage and cultivation of its haunts, and to the practice, which at that period was in vogue, of capturing the birds in the breeding season to fatten them for the table, it is now only known as a bird of passage during migration in spring and autumn. Under these circumstances a short review of its former status in the county is desirable.

In Pennant's "British Zoology" (I766, ii. p. 363), we are told that "These birds are found ... in the East Riding of Yorkshire where they are taken in nets, and fattened for the table, with bread and milk, hempseed, and sometimes with boiled wheat; but if expedition is required, sugar is added, which will make them in a fortnight's time a lump of fat: they will then sell for $2 /-$ or $2 / 6$ a piece. Judgment is required for taking the proper time for killing them, when they are in the highest pitch of fatness, for if that is neglected the birds are apt to fall away. [Here follow method of killing, dressing, habits as to fighting, and intimation that the females or Reeves are not taken.] They lay four eggs in a tuft of grass, beginning to lay the first week in May, and sit about a month ; the eggs are whitish, thinly marked with deep ferruginous spots. They are birds of passage, coming into the fens the latter end of April, and disappearing about Michaelmas. These birds are taken by the fen fowlers in nets that are about 40 yards long, and 7 or 8 feet high. These are supported by sticks at an angle of near forty-five degrees, and 
placed either on dry ground, or in very shallow water, not remote from the reeds, among which the fowler conceals himself, till the birds, enticed by a 'stale' or stuffed bird, come under the nets; he then, by pulling a string, lets them fall."

The Rev. F. O. Morris stated ("British Birds"), that it was common on Hatfield Moor, near Thorne, and on Skipwith Common, near Selby, about I824 (see Allis). According to Hatfield's "Historical Notices of Doncaster" (x866, p. 24), "The Ruff once bred near the Decoy (Potteric Carr) and the Moor Buzzard has been known to build among the ling, a fact often observed by Mr. Reid." This statement receives important confirmation from A. G. More, of the Science and Art Museum, Dublin, who, writing under date of $x 6$ th June I88I, says : "In his list, Mr. H. Reid remarks of the Ruff, 'None left, once plentiful, I have taken numbers of them.' This was probably near Hatfield Moor, where the Black-tailed Godwit used to breed, but Mr. Reid did not give me any locality; I think he was in communication with the Rev. F. O. Morris, who gives Hatfield as a locality." Another breeding ground of this bird, until the early part of last century, was Riccal Common, near Selby, and I have seen several adult examples, in Capt. Dunnington-Jefferson's collection at Thicket Priory, which were taken in that neighbourhood.

In the Western Ainsty it was formerly common at Wighill Ings, and bred at Newton Kyme ; the latest instance of its appearance in that area was in September 1905, when one was reported near Harrogate.

The Holderness district was eminently suitable for the requirements of the Ruff before drainage and high cultivation banished it, and other marsh-loving birds, from the fastnesses they frequented; up to about a hundred years ago it bred near the sites of Meaux, Watton, and Scorborough Decoys, and on the Carrs through which the river Hull runs. Birds of this species are still often observed there, which suggests they are guided by the old instinct and would probably breed again if the conditions were favourable. In the Zoologist for 1864 (p. 9362), the late W. W. Boulton mentioned facts 
suggestive of their having nested in the locality during the summer of that year.*

At the present day it occurs on the spring migration from mid-April to late in May, very sparingly, and is much more numerous during the autumnal passage southward in August and September, when immigrants from the Continent are frequently noted on the coast, especially at the Tees and Humber estuaries. A detailed list of these occurrences would be tedious to particularize; it is met with in more or less numbers every autumn, and during September I876 a flock of fourteen, three of which were killed, was seen near Redcar. It was fairly common at Spurn in I89I, whilst ten were noticed at the Teesmouth in August and September Igo3.

Inland it is much rarer than on the coast, though it has been reported from Wensleydale in I873; in Upper Teesdale it is occasionally killed by Grouse shooters; at Pilmoor, near Thirsk, one was procured in October I879, and three at the same time near Northallerton; a pair was shot in September I902, at Deighton, near Welbury; at Beverley it is a fairly regular visitor in spring and autumn, and is occasionally obtained at East Cottingwith and Scampston. In the West Riding it is reported from Wighill Ings, Newton Kyme, Bilton, Harrogate, Wakefield, and Barnsley.

In the York Museum is a large case of Ruffs and Reeves, in the full glory of their nuptial dress, from the Strickland collection, and two pairs of each sex in similar plumage, also obtained in Yorkshire, are in the Chester Museum.

The wintering of the Ruff was recorded by the late J. Cordeaux (Nat. I889, pp. 44-I29), specimens being shot on the 7 th and 2oth January in that year at Sunk Island and Hollym, near Withernsea; the observer being under the impression that these were the first instances of such an occurrence in Great Britain. The late Rev. H. A. Macpherson (tom. cit. p. 79), drew attention to the fact that so early as 1876 it had been recorded in winter, and in the same journal

* In the years 1901, 'O2, 'O3 the Ruff nested on a marsh at the north side of the Teesmouth (cf. "Ibis," Igo6, p. 735). 
it was reported that one was exposed for sale in Leeds market in January I877. These, however, are not the earliest records, for Thomas Allis, in his Report written in I844, stated that he had one specimen in winter plumage, from near York, in February, and had seen one or two others in the same plumage taken about the same time.

In autumn this species frequently associates with other shore birds; I saw one in August ISSS flying in company with a flock of Sanderlings, alld have known it consort with Knots, Golden Plover, Redshank, and even Teal.

\section{COMMON SANDPIPER.}

\section{Totanus hypoleucus (L.).}

Summer visitant, local, breeds more or less abundantly in the west, north-west, and north-east of the county. Arrives in mid-April, departs in August or September.

Perhaps the first mention of this as a Yorkshire bird occurs in Hill's "History of Animals" (I752, pp. 475-6), thus :-

"The Lesser Tringa... The Grey Tringa, spotted with black, with a smooth beak, and a white belly..... Aldrovand calls it Gallinula hypoleucos; Willughby and Ray Tringa minor;.... and our people in Yorkshire and some other places, the Sandpiper."

Thomas Allis, in I844, wrote :-

Totanus hypoleucus.-Common Sandpiper-Not so frequent as formerly in the neighbourhood of Sheffield; rare at Hebden Bridge; F. O. Morris reports it as common; it breeds sparingly about Halifax; Dr. Farrar says this species is not uncommon near Barnsley on the edges of fresh water during the summer months, where they nidify, and very much ornament the scene by their notes and activity; not uncommon near Leeds; common near Huddersfield; used to breed near the King's Mills and Dalton Lees; becoming more scarce as population increases; it is met with near Bridlington in the same localities as ochropus. 
This bright and cheerful little bird is a summer visitant, generally arriving about the third week in April, and from then to May; the earliest date of its spring appearance of which we have note was at Settle on 9th April IS94 (Nat. I896, p. 47); a late migration took place at Spurn in I88I, when from I4th to 20th May small flocks were observed passing along the coast to the northward. It occasionally visits the Tees marshes at this season, soon, however, making its way to its breeding haunts by the sides of the lakes, reservoirs, rivers, and tributary streams in the dales of the west and north-west of the county; at this period, as also in autumn, it may be noted in many unusual localities while on passage. It is enumerated amongst the list of casualties at the coast beacons, and a female specimen, killed at Spurn Lighthouse in May I899, is in the Yorkshire Philosophical Society's Museum at York.

This Sandpiper is a characteristic and familiar bird of our sub-alpine streams, local in its distribution, and occurs more frequently in the higher reaches of the valleys running towards the west and north-west than elsewhere, though it breeds not uncommonly in the lower portions of the North and West Riding dales, including those of Cleveland, where I have found it very abundant on the moorland reservoirs; it also nests in the neighbourhood of Whitby and Scarborough.

At Flamborough it is frequently seen both in spring and autumn, while in East Yorkshire generally it is a regular visitor at these periods, frequenting the margins of the river Hull and its tributaries, and may be met with on all the drains and running streams with low shelving shores where it can run and wade at leisure.

After the breeding season the Common Sandpiper departs in July or August, a few lingering on the coast marshes and on the shore until September; I have observed it at the Teesmouth as late as the $23 \mathrm{rd}$; on Swinsty Reservoir one was seen on the 27 th of that month; and it has been noted as late as 4 th October, in I892, near Beverley.

In Yoredale the nest has been found in the woods near Masham, at two hundred yards' distance from a stream, 
and the brooding bird has been noticed uttering a peculiar, low note, resembling that of a Stock-Dove, but more subdued. The late James Carter told me he had seen this Sandpiper perch on a tree thirty feet above the ground.

The only Yorkshire variety of which I have information is an example with white wings, the rest of the plumage being of the ordinary colour, in the possession of Mr. J. Whitaker of Rainworth Lodge (Zool. I884, p. 72).

Local names:-in addition to the term Summer Snipe in general use, and the West Riding appellation of Sand-Snipe, the only local name we have on record is Tillie-Littie, used in Ribblesdale (Nat. I896, p. 47).

\section{SPOTTED SANDPIPER.}

Totanus macularius (L.).

Accidental visitant from North America, of extremely rare occurrence.

The claim of this North American Sandpiper to be admitted to the Yorkshire list rests on the authority of Sir Wm. Milner, who stated that a beautiful adult female was killed just to the north of the pier at Whitby, on 29th March I849, by a sailor on the beach. It came the next day to Graham, the bird-stuffer of York, who set it up for Sir Wm. Milner's collection (Milner, Zool. I849, p. 2455). E. T. Higgins of York saw the specimen in the flesh, but the sex could not be determined. The bird was said to have been very tame, and when shot was in company with a flock of Dunlins (Higgins, tom. cit. p. 2456).

A specimen recorded "on the Tees" by John Grey (Hogg, op. cit. I 845, p. II73), proved to be a Green Sandpiper (cf. Gurney, "Rambles of a Naturalist," p. 255); whilst one at Bridlington (Higgins, Zool. I848, p. 2I47), is considered doubtful; as also is another, reported by the late Col. HaworthBooth as obtained in October I892, at Rowlstone in Holderness (Nat. I895, pp. 3II, 327; and I896, p. 24). 


\section{WOOD SANDPIPER.}

Totanus glareola (L.).

Bird of passage in autumn; of rare occurrence in spring.

The first mention of the Wood Sandpiper in this county is contained in the Report of Thomas Allis, in I844, thus :-

Totanus glareola.-Wood Sandpiper-A specimen was shot at Campsall, near Doncaster, and is now in the possession of $\mathrm{H}$. Reid of that place; another specimen is reported by F. O. Morris as being shot on the borders of Lincolnshire.

The Wood Sandpiper is a rare visitant on passage, and, like many others of its class, is more frequently met with on its southward journey in autumn than during the spring migration to its breeding quarters in north Europe. The instances of its appearance at the latter season are very few, only three being known to me. Mr. F. Boyes possesses one obtained near Beverley in the spring of I882; a male in the Hull Museum was taken on the river Hull, near Pulfin, in April I886; and a third was reported by Mr. P. Loten, at Easington, on 5th May I889.

In autumn it has, as stated above, occurred more frequently, and for purposes of reference it may be well to give the data in each case.

Two examples are mentioned by Allis.

The late A. Roberts of Scarborough stated that he stuffed an immature specimen in 1856 .

A male and female in the Burton Agnes collection were procured at Staithes in I860.

Mr. Thomas Boynton has an example which was formerly in the Bessingby collection.

At Knapton one was killed in October 1863, by a lad with a pistol (E. Tindall, MS.).

Mr. F. Boyes noted three on the river Hull on $4^{\text {th }}$ August I878, and secured two of them, the other being afterwards procured by another person. 
An immature male, captured at Kilnsea on 7 th September I878, was recorded by Mr. W. Eagle Clarke in the Naturalist (I879, p. I79), with the remark that another was seen by him the same day.

On Coatham Marshes on 6th August I88r, Mr. E. B. Emerson killed an adult example, but the sex was not ascertained (Zool. I882, p. 9I).

In the same journal for I884 (p. I79), Mr. W. Eagle Clarke mentions seeing a specimen in the possession of Mr. Jones of Bridlington, taken on the south sands in mid-August I883; and in September of the same year three were brought to Mr. P. Loten of Easington (tom. cit. p. I85).

At Spurn on 2Ist August 1884, a female example was obtained; and another specimen in September I887 (Ninth Migration Report, p. 32).

On 6th August I888, Mr. P. Loten reported the occurrence of one "last week."

The late J. Cordeaux, writing to the Naturalist (I889, p. 9I), recorded four in the Spurn neighbourhood during autumn, one being a female, and probably mature.

About the year I89o one occurred at Hornby Castle, the seat of the Duke of Leeds, as I am informed by Mr. J. Morley.

In October I899 a female specimen, obtained near Beverley, was taken to Mrr. Stuart of that place, who kindly gave me an opportunity of examining it. Another example in Mr. Stuart's possession was picked up at Dalton Holme on IIth August I904.

Mr. F. Boyes remarks that this bird was formerly probably a nesting species in the neighbourhood of Beverley; in its habits it differs from those of its congener, the Green Sandpiper (with which it may sometimes be confounded by incompetent ornithologists), in that it resorts more to swampy ground than to the shallow streams beloved by the latter bird; he has roticed it on several occasions wading about on the floating weeds in the river Hull, and in spring several years ago he saw a male bird toying about in the air, in a similar manner to Redshanks when on their breeding grounds ; 
while in the autumn of that year two or three young birds occurred on the river, which it was believed were bred on a swampy piece of ground where Redshanks and Snipe annually nested.

\section{GREEN SANDPIPER.}

Totanus ochropus (L.).

Bird of passage, and occasional winter resident.

In Yorkshire the earliest allusion to this bird, of which I am aware, is in Fothergill's Richmondshire list (I823), where it is enumerated amongst the birds of that district.

Thomas Allis, I844, wrote :-

Totanus ochropus.-Green Sandpiper-F. O. Morris reports it as not uncommon; it is scarce at Hebden Bridge; is occasionally obtained in the neighbourhood of York; one was shot at Low Moor in 1830; Dr. Farrar has obtained but two specimens; one in 1835, from the Worsborough Reservoir; it was associated with the Common Sandpiper, and was only detected after being shot; the other was a solitary one from the Barnsley canal bank, and shot in July 1835 ; rare near Leeds; one shot at Temple Thorp, October 28th 1839; another at Birstal, in I 840 ; rare near Huddersfield; occasionally found at the streams or lakes about Bridlington, but not known to breed there.

The faunistic status of the Green Sandpiper may be defined as that of a bird of passage, very local in its distribution, sometimes arriving as early as July, a few remaining in some localities over winter and departing again in spring.

In the Holderness district it is more or less frequent on the shallow drains from the beginning of August to the following spring, being most numerous in early autumn, and becoming scarcer as winter approaches, though individuals have been observed throughout winter, even in severe frosts, on the quick-flowing streams of the East Riding Carrs, and it is probable that there is a late migration.

The Green Sandpiper is continually observed in winter in the neighbourhood of Scampston, and it is also fairly 
common in South Holderness near the Spurn promontory, where five were seen together in the autumn of I884, and where it was unusually abundant in the season of I903. It has also been known at the period of migration on the shore below the cliffs of Flamborough.

When departing it has occurred near Spurn in April, as many as five or six being seen together there on the I 7 th of that month in I88I; as a rule, however, it leaves in May.

In the North Riding it is by no means common, though recorded as at one time regularly visiting the neighbourhood of Killerby, near Northallerton (Zool. I844, p. 444), and it is generally met with in the dales or by the sides of moorland ponds. It has been noted at Masham several times in August; in the Cleveland district I have observed it very rarely near the Teesmouth; occasionally in the marshes in September, and once on 27th July, when I flushed two by the side of a brackish pool on the reclaimed land.

In the West Riding it is described as a rare visitant in spring and autumn, but several have been reported in Lower Wharfedale, where the late Rev. J. W. Chaloner saw four on 28th June 1883 ; and an instance of one wintering near Settle is chronicled by the Rev. E. Peake (Nat. I893, p. I7I).

With regard to the alleged nesting of this bird in Yorkshire, the late Alfred Roberts of the Scarborough Museum, reported to Mr. W. Eagle Clarke (MS., 25th January I88I), that a gamekeeper named Roberts at Hunmanby told him he had shot a specimen when it was leaving an old nest in a tree; and that he (A. Roberts) had stuffed the bird for the shooter.

Examples have been seen near Beverley in June, and the species has once been noted at Lowthorpe in summer.

The only vernacular names are those in use in the East Riding, where at Spurn it is known as the Drain Swallow and Wheat Bird; and in one locality in South Holderness, at Cherry Cob Sands, it receives the cognomen of White Rump.

[An example of the Yelrowshank (Totanus flavipes, Gmelin), an American species, is mentioned in the " Handbook of the Vertebrate Fauna of Yorkshire" (p. 77), as having 
occurred at Tadcaster in October 1858 , the authorities quoted being Sir WW. Milner (Zool. I858, p. 5958), and Graham (Nat. I858, p. 9I). On examining these references, I find that Sir IV. Milner stated the bird was obtained at Misson in Yorkshire. This place is in reality in Nottinghamshire, so that the spacies must be removed from the Yorkshire list. (See also Waite, Nat. I89r, p. I07.)

The figure and description given in Yarrell's "British Birds" were taken from this specimen, which is now in the Leeds Museum.

With regard to Giaham's note, Mr. Howard Saunders, in the fourth edition of Yarrell's "British Birds" (p. 48I) remarks, "Another example was stated by Graham of York [reference quoted], without a particle of substantiating evidence, to have been obtained near Tadcaster."]

\section{REDSHANK.}

\section{Totanus calidris (L.).}

Resident, local, increasing in numbers; also a common autumn migrant, many remaining throughout winter.

Historically considered, the Redshank can claim ancestry of great antiquity in Yorkshire, for it is mentioned in the Northumberland Household Book, commenced in I5I2, at Earl Percy's Yorkshire Castles, where, amongst the birds to be bought for "my Lordes owne Mees," it appears as "Redeshankes after Id. ob. (I $\frac{1}{2} \mathrm{~d}$.) the pece."

Thomas Allis wrote in 1844 :-

Totanus calidris.-Common Redshank-Breeds near Doncaster, also at Strensall Common, near York; rare at Sheffield, but common on Thorne Moor; rare near Leeds; rare near Huddersfield; $\mathbf{A}$. Strickland says that some years ago it used to breed near the stream 3 at Driffield, but has not done so of late years.

It is satisfactory to find that within the past few years the Redshank has prospered in Yorkshire, having established itself 
in places where hitherto its querulous call note was almost unknown, and at the present time colonies of these interesting birds-the majority small ones, it is true-are to be found in the breeding season, from Thorne Waste to the fells of Upper Teesdale, in variously situated tracts of marsh and moorland. In the West Riding it nests at Thorne Waste, near Ackworth, Doncaster, Sheffield, Barnsley, Wakefield, Wilstrop, Appletrewick, Harrogate, Ripon, Ilkley, Fewstor, and Swinsty, Malham Tarn, Winterburn, and in Igor a pair bred in the Forest of Bowland. In the East Riding, Riccall and Skipwith Commons, the neighbourhood of Beverley, Scampston and South Holderness, provide suitable breeding localities; while in the North Riding the elevated districts of Sedbergh and Upper Teesdale have their colonies of these birds; and Nalton, Pilmoor near Thirsk, Masham, Locker Tarn, Northallerton, Scarborough, and the Teesmouth marshes are other haunts.

The Redshank can only be considered as a coast resident, for inland it is reported as appearing about the middle of March, leaving again in September after the young are well on the wing. At the Teesmouth the breeding birds are certainly summer visitors only, the first arrivals being announced with unfailing regularity during the latter half of February. Pairing takes place about the middle of Narch, and nidification commences early in April; the first full sets of eggs are usually found in the middle of the month, and the majority in the first week of May; in I903 a full clutch was discovered on the roth of April, the last being noted on the 28th of June. One pair of Teesmouth birds, at least, produce clutches of five eggs, which are invariably of the same type, and have been tound annually for several years in succession. Nests are occasionally found in quite open positions, like Peewits'.

As a rule one brood only is reared in a season, but, owing to disturbance by cattle, and harrying by predatory Rooks and Crows, a second set of eggs is very frequently laid. By the end of July the birds, old and young, are gathered together in flocks, and towards the end of August have left 


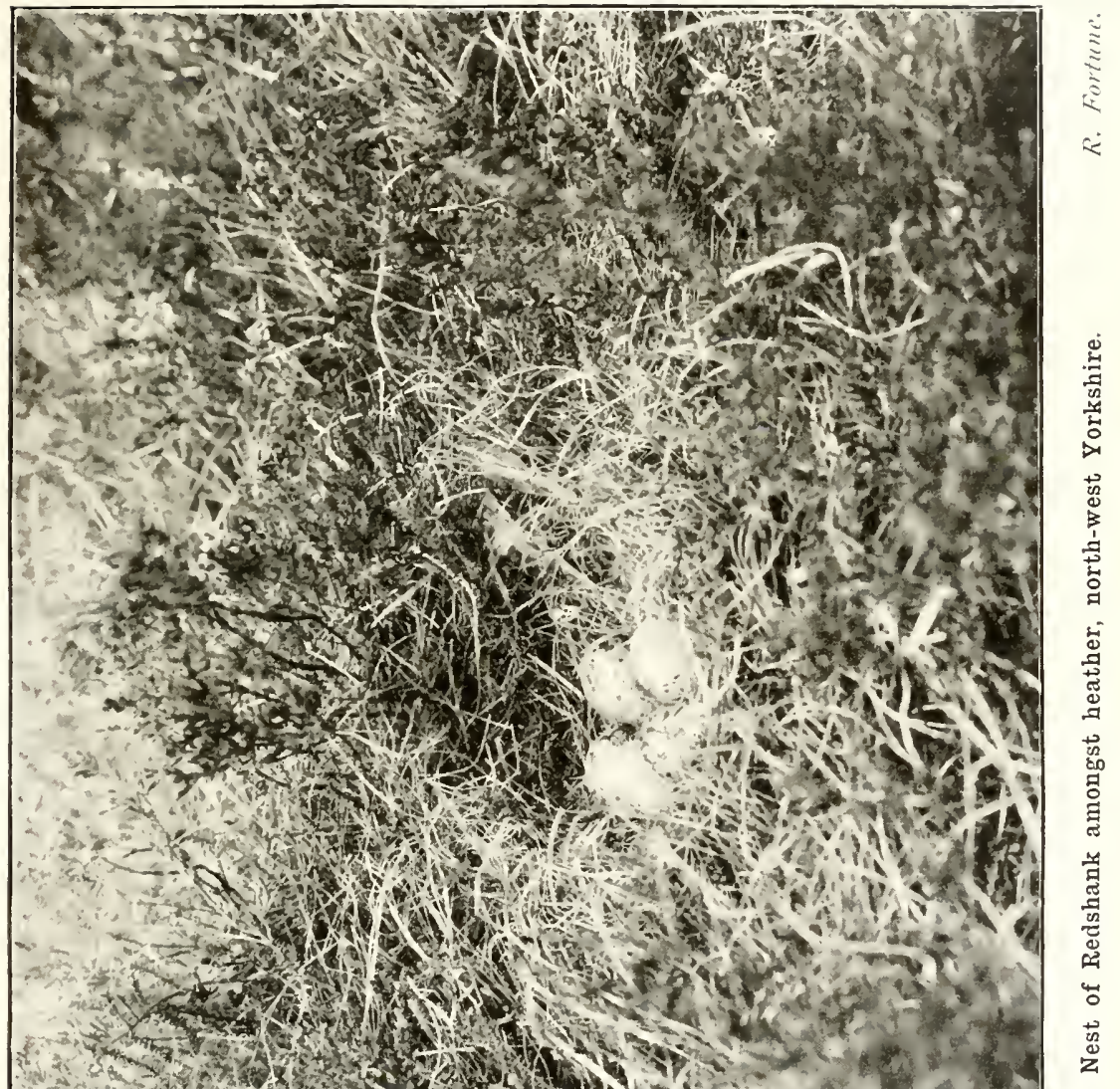



the vicinity of their nesting quarters, the species being then represented on the coast by immigrants from more northerly latitudes.

At Spurn large migratory flocks, often consisting of hindreds of birds, arrive in September, while both there and at the Teesmouth considerable numbers remain throughout the winter; I have known as many as thirteen killed at one shot on the Tees Marshes in December. The return migration takıs place early in April.

At various other places, both on the coast and inland, too numerous to particularize, the Redshank occurs on migration to and from its nesting grounds.

The vernacular names are as follows:- Pool Snipe (Will. " Orn." I678, p. 299) ; Reddy and Swat (Teesmouth) ; Redlegs (Sedbergh, and formerly in East Yorkshire); and Thrattle is another name which I have heard applied to it by old decoymen in the Tees area.

\section{SPOTTED REDSHANK.}

Totanus fuscus $(L$.$) .$

Bird of passage, of rare occurrence, chiefly at the Tees and Humber estuaries.

Thomas Allis's Report on the Birds of Yorkshire (I844) contains what is probably the first reference to this as a county species, thus :-

Totanus fuscus.-Spotted Snipe-H. Reid informs me that sixteen years ago one was killed at Braithwell Grange by Mr. Toone, and came into his possession. Rarely met with at Hebden Bridge; has been killed on the moors about Whitby.

Though generally speaking the Spotted, or Dusky, Redshank is of rare occurrence, and only on the autumn passage southward, it is considered to be a fairly regular visitant at that period to the Humber, usually singly or in pairs, 
and chiefly in immature plumage. One or two examples are reported from that neighbourhood almost annually, the greatest number being in November I89I, when a flock of twelve was seen. At the Teesmouth it is decidedly rare and has, so far as I can ascertain, been noted on six or seven occasions only, but it is quite possible that this species may be of more frequent occurrence than the few records imply, as it is liable to be overlooked or mistaken for its commoner relative. It may be useful, for purposes of reference, to detail the recorded or communicated instances of its occurrence. which, in addition to those mentioned by Allis, are :-

One from the Teesmouth, in the collection of Mr. W. Backhouse (Zool. I846, p. I26I).

At Hornby, near Catterick, one killed in August 1864 (Aspden, Nat. I865).

An immature male example, in August i869, at Kilnsea, near Spurn (Field, 3oth October I869).

An immature female at Spurn, in September I876 (J. Cordeaux MS.).

One in the same year at the Teesmouth.

At the same place one, on I5th September I88I, reported as mature (Zool. I882, p. 93), but proved, on examination, to be a young bird.

A flock of twelve seen, and five procured, at Sunk Island, in November I8gI, by Mr. H. Sharp of Beverley (Field, 28th November r89I).

At East Cottingwith, one obtained in August I896, by Snowden Sleights; and on 2nd September, in the same year, I recorded a specimen killed on the beach at Redcar, by a fisherman, who was intending to dispose of it as a Common Redshank.

Another at the Teesmouth on 2Ist September I899.

At Seamer, near Stokesley, in I902, one was shot on 27th August, and another at the Teesmouth in September.

The following records are without dates:-

A male and female taken near Beverley, formerly in the Sunderlandwick collection, now in the Museum at Burton Agnes. 


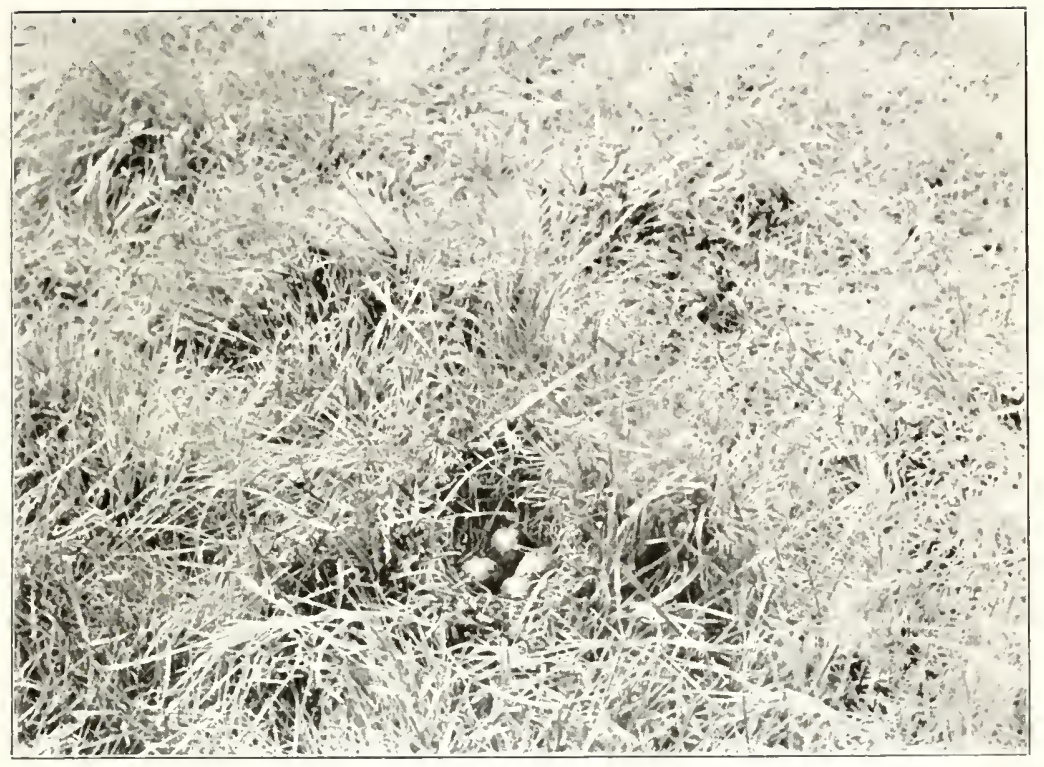

Nest of Redshank, Teesmouth.

T. HI. Nelson.

See parge 63t. 

One, formerly in the collection of the late W. W. Boulton now in the possession of Mr. Thomas Boynton.

One in Thicket Priory collection, killed near that place.

One obtained at Spurn by the late G. W. Jalland, "several years ago."

\section{GREENSHANK. \\ Totanus canescens (Gmelin).}

Bird of passage in spring and autumn; most numerous on the coast at the latter season. Occasionally remains during winter.

Probably the earliest allusion to this, as a county bird, is in the Allan MS. of the Tunstall Museum (I79I), where it is stated it "appears on our coasts and wet grounds in winter, in small flocks, but not very common." (Fox's "Synopsis," p. II5).

Thomas Allis, in I844, wrote:-

Totanus glottis.-The Greenshank-F. O. Morris reports two killed near Doncaster, and that it has been met with elsewhere.

The Greenshank is a bird of passage in spring and autumn, and is observed chiefly at the latter season on the coast; it is perhaps most numerous on the Humber flats, where it was fairly common in 1892 , and as many as twelve have been seen together on 16th October I88r. At other seaboard stations north of Spurn it is a rare visitant on passage, and in Cleveland a few are generally met with in August and September at the Teesmouth or on the neighbouring marshes. According to Mark Booth (Zool. I844, p. 444) it was formerly a regular visitor at the end of July to Killerby, near Northallerton, and an example is reported in that month, from East Cottingwith, in I882. After the end of October the majority move south, though there are exceptional instances of individuals having remained over winter.

Mr. W. Eagle Clarke is of opinion that it occurs on migration in suitable inland localities; he saw five on 26 th and $27^{\text {th }}$ September I886, and at the same date in the previous year, 
on the margin of Fewston Reservoir, where he had an opportunity of watching their movements at close quarters. It is mentioned in Fothergill's list ("Richmondshire," I823), and has also been noted in the Western Ainsty; at Thirsk, Hovingham, Ackworth, Wilsden, Halifax, and Wakefield; in the Beverley district it is rare, but occasionally occurs in autumn.

On the vernal passage to its northern breeding stations it is seldom reported, and only at Spurn, on the river Hull, and at the Teesmouth.

\section{RED-BREASTED SNIPE. \\ Macrorhamphus griseus (Gmelin),}

Accidental wanderer from North America and Siberia, of extremely rare occurrence.

The claim of this bird to be admitted to the Yorkshire list rests on the occurrence of one example only, for particulars of which I am indebted to Mr. A. Crabtree, of Halifax, who obligingly forwarded the specimen to be examined by Mr. W. Eagle Clarke and myself. It is an adult changing to winter plumage, but still retaining portions of the summer dress, and forms part of the collection owned by the late James Cunningham, now in the Halifax Museum.

The label on the case is as follows :-

"Brown Snipe. Shot on Norland Moor. September I864. Shot and cased by James Cunningham."

The information concerning this specimen was not in Mr. W. Eagle Clarke's possession when writing the bird portion of the "Vertebrate Fauna of Yorkshire," and it affords us much pleasure to be able now to make this addition to the avi-fauna of the county. 


\section{BAR-TAILED GODWIT.}

Limosa lapponica (L.).

Autumn or winter visitant to the coast, arriving in great numbers in August and September; many remain throughout winter. Occurs regularly on the spring passage northward in May. Is occasionally observed inland.

Pennant made the earliest allusion to this species in Yorkshire, under the title of "Scolopax lapponica-The Red Godwit. We have known it to have been shot near Hull." (Pennant's "British Zoology," I766, Vol. ii. p. 353.)

Thomas Allis, I844, wrote:-

Limosa rufa.-Bar-tailed Godwit-F. O. Morris mentions one shot near Doncaster; Dr. Farrar mentions one shot at Haw Park, Walton, in March 1833, and another at Hawksworth Hall, near Otley, in May 1839; H. Chapman has had it from the neighbourhood of York; A. Strickland says it is not uncommon on the sands in winter, in brown plumage, and is in spring at times shot, assuming the red plumage, but they go inland to breed.*

Until within comparatively recent years the Bar-tailed Godwit was considered by the chief authors on works on British ornithology to be a bird of double passage only, continuing its southward journey with the approach of winter, but for many years I have known it as one of the species which, like the Knot and Sanderling, remain on the coast throughout the drear months.

It is certainly a spring and autumn migrant, very abundant in some seasons at the latter period; the advance guards of the migratory flocks are old birds in the red plumage of summer, and odd individuals have occurred as early as I2th July; while on Ist August I879 I saw two, and secured one in perfect summer dress.

Early in August the young birds appear in flocks, with a few adults, and continue to arrive from then up to the

- Strickland probably did not intend it to be inferred that this species bred in this country, though at one time the Black-tailed Godwit was a nesting bird jn Yorkshire. 
middle or third week of September; their numbers vary in different years, in some seasons being few, whilst in others they are amongst the most abundant of the waders found in the Humber and Tees estuaries, where immense assemblies are met with, and, being unsuspicious of danger and very easily "called," their ranks are speedily decimated by the shore shooters. I have heard the old professional wildfowlers of the Tees relate wonderful stories of the bags they made in years gone by, when the "slems" were tenanted by hundreds of birds where now few are seen. On one occasion at the end of August two fishermen killed upwards of one hundred Godwits and Knots with old single-barrelled muzzle-loaders; and when shooting at the Teesmouth I have frequently walked within a few yards' distance of flocks busily feeding and quite oblivious of danger. Seasons of great plenty were September I876; I88I ; September I887; I89o; I892; and in September 1895 there occurred one of the greatest "rushes" I ever witnessed. On the $7^{\text {th }}$ an immense flocl, consisting of fully four hundred birds, alighted on the sand, in front of Redcar, being soon driven off by boys throwing stones at them; they then fled towards the Teesmouth, where they allowed a gunner to walk within easy shot, and not until he had fired the third time did they take alarm and fly out of sight. On the same day I saw other flights at the Tees estuary, where large numbers were bagged by various shore shooters.

As autumn advances the Godwit consorts with Curlew and Grey Plover, becoming unapproachable, so that although huge parties are to be seen at high spring tides in the estuaries, very few are shot. In severe winters the species appears more in evidence than in mild seasons, and it seems probable that there may be a late migration of birds from more northerly or Continental resorts. On I2th February I895, when a long continuance of frost and snow rendered the Teesmouth like an Arctic scene, large congregations of Godwits were noticeable, those which were procured being all in the grey plumage, with plain ash-coloured tails; again from I8th to 25th March I899, during severe gales and snowstorms, I noticed con- 


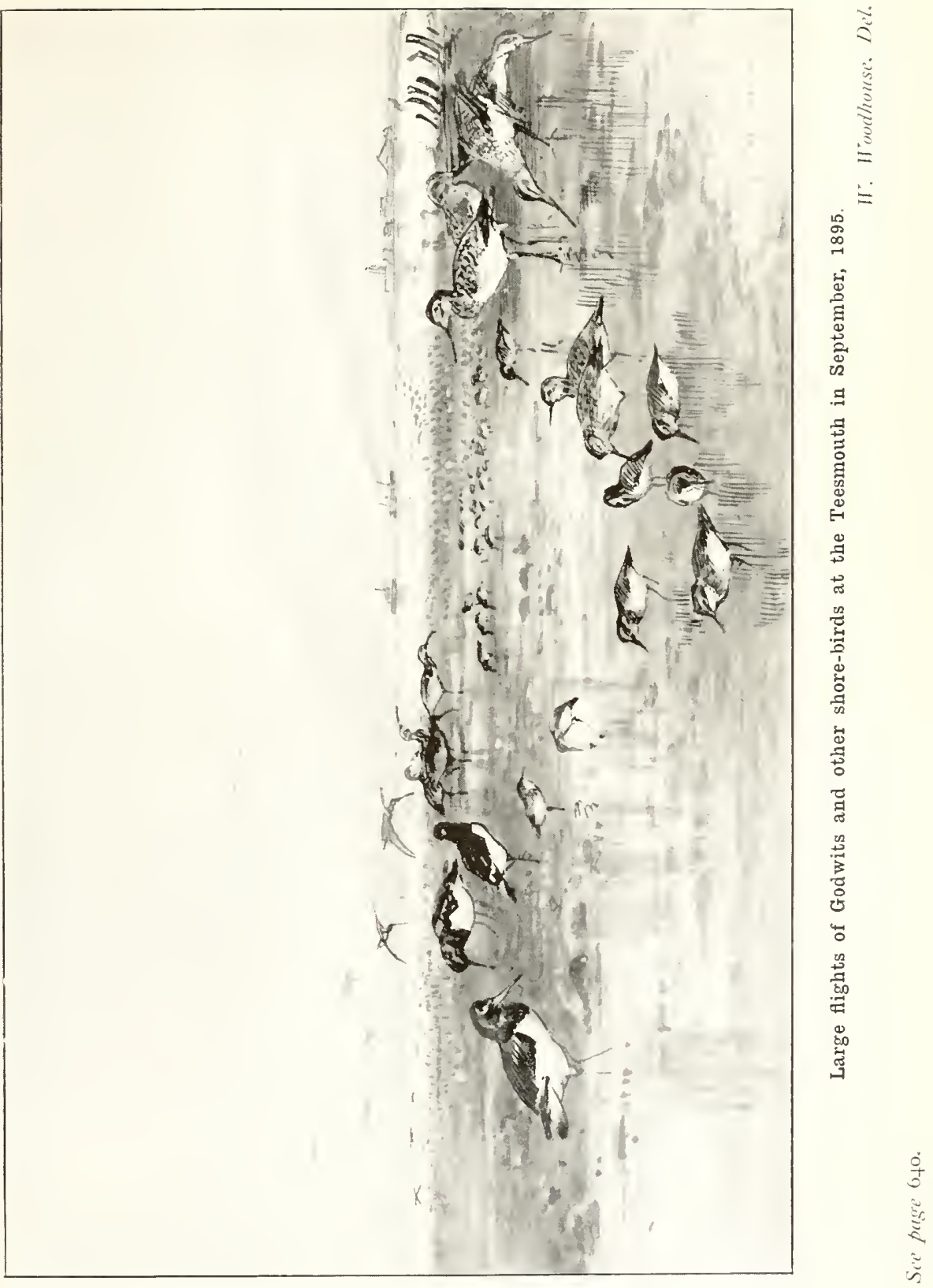



siderable flocks on the Tees "slems." At Spurn it was abundant in the winter of I890-9I, and also in January and February 1897 .

On the return passage in spring it appears at Spurn about the middle of May, but only as an occasional visitor, and not with the regularity of many other species. In the Tees area I have noticed small flocks going northward on the 6 th of May, and from that date up to the first half of June. On the main portion of the coast, between Saltburn and the Humber, the Bar-tailed Godwit occurs only as a migrant on passage, and has also been observed on several occasions in inland localities. It is stated, on the authority of Hugh Reid, to have been a migratory visitant to the Doncaster Carrs; it is mentioned in Fothergill's list in Whitaker's "Richmondshire" (I823), and in Allis's Report; one in red plumage was obtained at Littlethorpe about I850; in Wensleydale three were killed from a flock on Scarrow Fell moor in I872; two were reported at Bagby, near Thirsk, and one in Ribblesdale in August I892.

The weights of three birds procured in autumn at Redcar were twelve, ten, and eight ounces respectively.

The local names are not many: Godwin, or Goodwin, is used by Redcar fishermen; Set Hammer is a term applied to it by the Teesmouth fowlers; and Curlew-Whelp is stated to be its name on the Humber foreshores.

\section{BLACK-TAILED GODWIT.}

Limosa ægocephala (L.). Bird of passage, of rare occurrence. Formerly nested in the
county.
The earliest known reference to this, as a ccunty bird, is
probably that in Thomas Allis's Report on the Birds of
Yorkshire, written in I844, thus:- 
Limosa melamura.-Black-tailed Godwit-According to F. O. Morris, breeds on the edge of Hatfield Moor.

The Black-tailed Godwit was formerly classed as resident in Yorkshire, and, according to the late Hugh Reid of Doncaster used, within his recollection, to nest on Hatfield Moor, in which locality he once found the young birds himself (cf. A. G. More, Ibis. I865), and, doubtless, it also bred in the Carrs of the East Riding. The advance of civilization, with its accompaniments of drainage, high farming, and the increase of population have long ago driven it from these haunts, and it is now known only as a bird of passage, but, unlike the preceding species, never in large numbers; indeed, it may be considered as a rare bird.

It has occurred more frequently at Spurn of late years than elsewhere, usually in August or September, singly or in small parties, and very rarely in winter, though one was killed there as late as 9 th December in I875. In Cleveland it was, early in the last century, not uncommon at the Teesmouth, whence an old bird-stuffer of my acquaintance, who died in I880, aged 75 , used often to have specimens sent. My own experience of the bird is very limited; I saw one on 3oth August 1883, which allowed an approach within easy gunshot; another in my collection was obtained near Redcar Pier in September I892; and I have seen three or four others, all in immature plumage, killed in the district.

On the passage northward in spring it is of extremely rare occurrence.

This species has been reported from inland localities more frequently than its congener; one in summer plumage, which I have seen in the collection of Mr. Forster of Bridlington, was procured at Littlethorpe in I850 ; another example, also in breeding plumage, was in the late C. C. Oxley's collection at Redcar; while it has also been noticed at Beverley, Goole, Wakefield, Ackworth, and Arthington. 


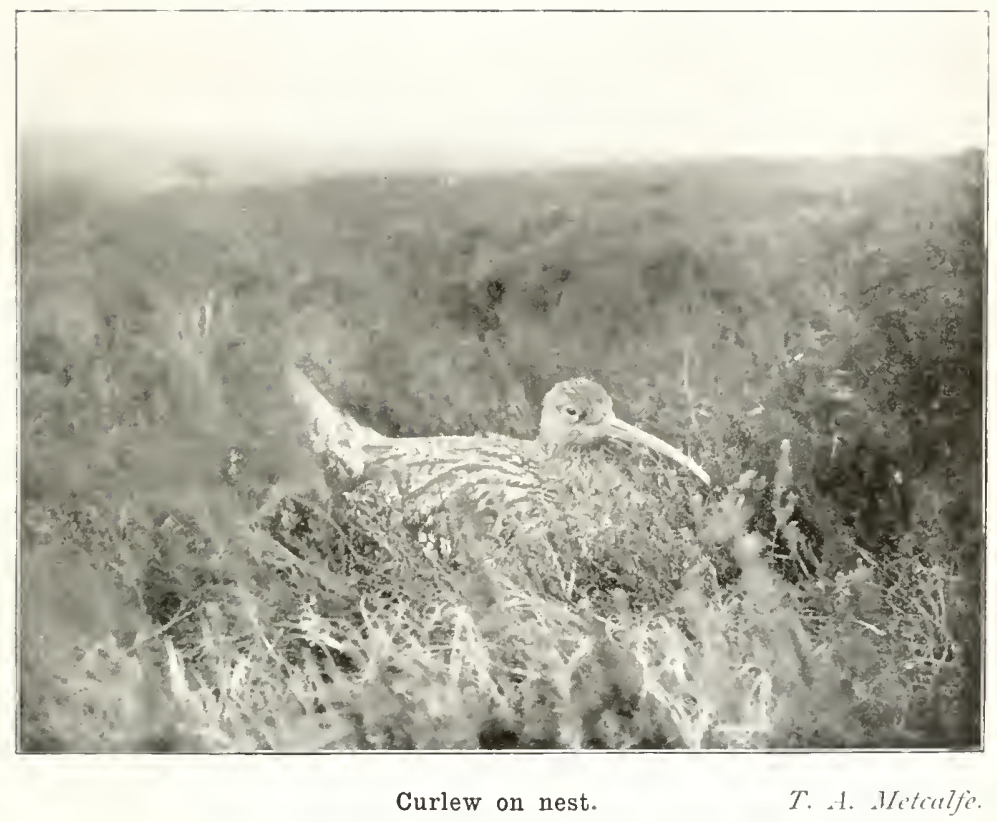

Se' page 6+3. 



\section{COMMON CURLEW.}

Numenius arquata (L.).

Resident : local, breeds on most of the moors in the West and North Ridings, least numerous in the south. Leaves the breeding haunts in July or August for the coast, where it remains during the winter, returning to the moors in March or April. A great influx of immigrants in autumn.

The Curlew's ancestry in Yorkshire is of great antiquity, for it is mentioned in connection with the Nevell banquet at Cawood in $\mathrm{r} 466$, the items at the feast including " Curlewes, Ioo" (Leland's "Collectanea"). It figured in the Northumberland Household Book, in I5I2; amongst the birds to be provided " for my Lordes owne Mees" being "Kyrlewes," with the price fixed at $\mathrm{I} 2 \mathrm{~d}$. each. Again, at the marriage feast of the daughter of Sir John Neville, at Chevet, near Wakefield, in I526, "Eighteen Curlews" were enumerated in the bill of fare; and during Sir John's Shrievalty, the expenses, returned at the Lammas Assizes, included "Twenty Curlews, £I 6s. 8d."

Thomas Allis, writing in 1844 , reported :-

Numenius arquata.-Common Curlew-Sometimes seen on the moors in the neighbourhood of Halifax and Huddersfield; rare at Leeds and Hebden Bridge : occasionally seen near York, and common near Sheffield and Doncaster, and is rare about Huddersfield. In the Museum of the Yorkshire Philosophical Society there is a skeleton of this bird, which had its knee dislocated, the femur had passed behind the tibia, so that the weight of the body was supported wholly on that leg by the tendons ; the action of the end of the femur on the posterior portion of the tibia had caused such a secretion of bone that a socket was formed in which the end of the femur worked, and which again gave it an osseous support. Arthur Strickland reports that a few frequent the sea shore and adjoining grounds every autumn, but do not remain long.

In addition to being a well-known summer resident on the moors and fells of Yorkshire, the Curlew is an autumn or winter migrant to the coast, and one of the most ardently desired spoils of the shore shooter; in the Tees and Humber 
it is never altogether absent at any season of the year, a few, probably non-breeding birds, remaining during the summer months; then, in the middle or latter part of July, small parties of youngsters may be observed frequenting the borders of the estuaries; the earliest date of this arrival, of which I have note, is I3th July I9oo. As soon as the moors are disturbed by Grouse shooting operations great additions of both adults and young are made to the ranks of the birds already on the coast; these arrivals, together with foreigners from more northerly latitudes, continue throughout August, in which month they are frequently heard at night passing overhead and coming from eastward. The influx of foreign immigrants is kept up during September and October and as late as mid-November, whilst the information supplied to the British Association Migration Committee testifies to the extent and continuity of this movement; a perusal of the Reports issued shows also the frequency with which this bird is known to strike the lanterns of our sea-marks, both on the autumnal passage and also on the return journey in the spring.

As a breeding species the Curlew occurs more or less abundantly on most of the moorlands and fells of the West and North Ridings, from the southern portions of the county, where it is least numerous, northward to Sedbergh and Teesdale, including also Cleveland and the Whitby and Scarborough districts. Although the situation chosen for the nest is generally on the highest parts of the moors, where it has been found to 2,I50 feet elevation, yet in some cases the lower slopes of the hills are selected, and this is particularly noticeable near Sedbergh. In the neighbourhood of Harrogate it is commonly met with on the low moors to the westward, and in a few instances the nest has been found in grass fields within half a mile of the borough boundaries; several pairs of birds have bred in this locality during the past few years. The Curlew has also bred on Thorne Waste in the south-east, where Mr. W. Eagle Clarke discovered eggs in I88I, and noted birds there in May and June of the following year. The only East Riding locality where its nest is reported 


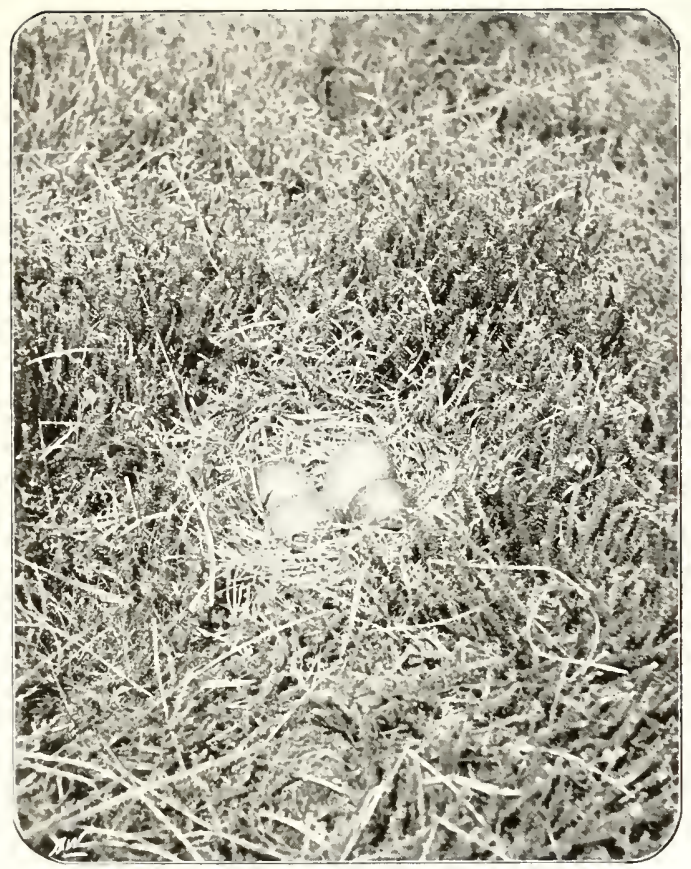

Curlew's Nest on Skipwith Common, near York

II. Lasenb:

Se' forge $6+4$.

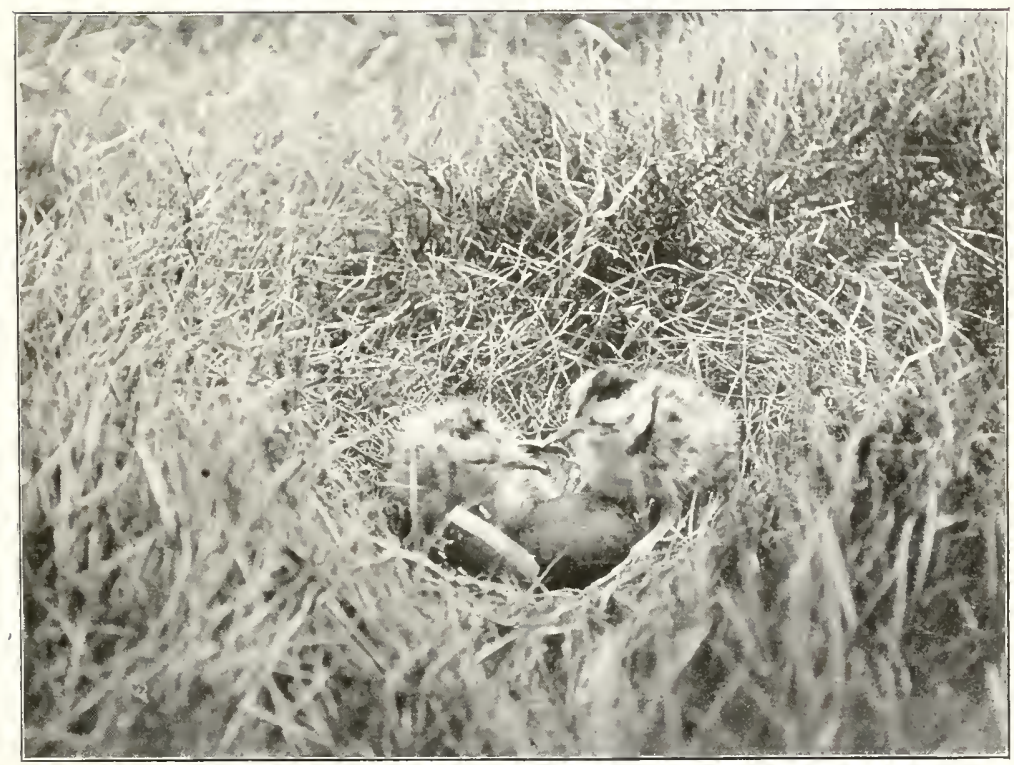



from is Skipwith Common, where eggs were found on 8th May Igor, and a pair of birds was observed in the spring of 1902 .

In March the coast Curlews begin to leave their winter resorts and repair to the nesting grounds; by the middle or latter end of April nidification commences, eggs being found from that time onward till the end of May. A clutch containing the unusual complement of five was taken near Sedbergh, and I have seen one other of that number also taken in northwest Yorkshire. The earliest date of which I have note of young being observed is 7 th May, in the year I903.

Though not classed amongst perching birds, the Curlew, like several other waders, is occasionally known to depart from its ordinary habits; in April I904 I saw one alight on a stone wall bordering a moor near Harrogate, where it remained for some minutes whilst I was in the vicinity; and a few days afterwards, on the same moor, my wife saw one perch on a post and stand preening its feathers for some considerable time.

The celebrated Yorkshire ornithologist, Marmaduke Tunstall, in 1784 refers to the old proverb as to the value of this bird :-

"A Curlew, be she white, be she black,

She carries twelve pence on her back."

and it is somewhat remarkable that this price should have been paid for "Kyrlewes" so long ago as the year I5I2, as noted in the Northumberland Household Book, while other birds, esteemed by us as delicacies, are put at a much lower figure, as for instance, Woodcocks being Id., and Mallards and Partridges $2 \mathrm{~d}$., though in the year 1560 , in the value of "Wildfowl at Hull," the price is fixed for a "Courlewe $6 \mathrm{~d} . "$

The only local vernacular name by which it is known is Whaup 


\section{6 \\ WHIMBREL. \\ Numenius phæopus $(L$.$) .$}

Bird of passage in spring and autumn; common. Leaves for its breeding haunts in May, returning in July and August. Odd individuals have remained at Spurn throughout the summer. Sometimes occurs inland.

The earliest known allusion to this, as a Yorkshire bird, is containcd in the accounts of the expenses incurred by Sir John Neville of Chevet, near Wakefield, during his term of office as High Sheriff in 1528. At the Lammas Assizes in that year there appears the item "Curlew Knaves, 32, EI I2s." In the same century, and the year 1560 , the value of "Wildfowl at Hull" was fixed by proclamation, the price of a "Curlew Knave" being placed at $4 \mathrm{~d}$.

Of peculiar interest to Yorkshiremen is the description, the first British, given by that old Yorkshire ornithologist, Ralph Johnson of Brignall, near Greta Bridge, and contained in a communication to Francis Willughby, who, in his "Ornithology," wrote:- "The Whimbrel-Arquata minor. Mr. Johnson, in his papers communicated to us, describes this Bird by the name of a Whimbrel, thus : 'It is less by half than a Curlew, hath a crooked bill, but shorter by an inch or more; The Crown deep brown without speckles. The Back under the Wings white, which the Curlew hath not. Besides the colour of the whole body is more duskish or dull. It is found upon the sands in the Teezmouth.' " (Will. " Orn." I678, p. 294.)

Thomas Allis, I844, wrote:-

Numenius phoopus.-The Whimbrel-Rare at Hebden Bridge. very rarely met with about Halifax or Huddersfield; occasionally obtained at York, and not uncommon on the moors in the vicinity of Sheffield, and in the neighbourhood of Doncaster. Arthur Strickland never met with it himself in this county, although he has been told it is sometimes met with; he thinks the young Curlews may at times be mistaken for it.

It seems passing strange that Strickland, who resided at 


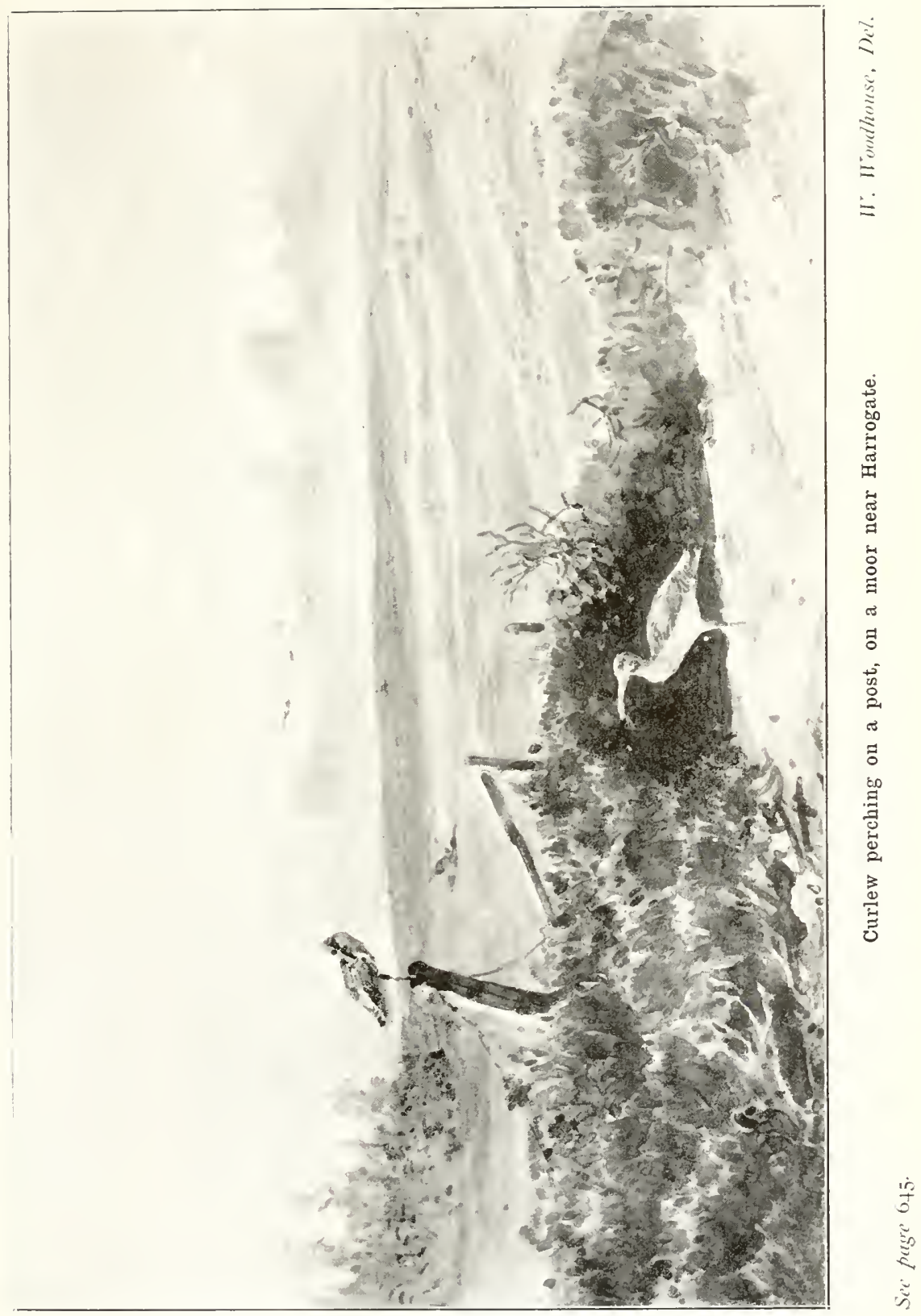


Bridlington was personally unacquainted with the Whimbrel, whose rippling notes are familiar sounds to the ornithologist on the coast, where the bird is very regular in its appearance in spring, remaining for a few days before proceeding to its nesting grounds, and again on the return passage south in autumn. During the vernal migration its arrival may be looked for in May with unfailing regularity, and a few instances are known of its occurrence in the latter part of April; the 2Ist of that month, in the year I90I, being the earliest date of which I have note. At times large numbers are observed on the sands above high water mark, diligently feeding on sand-hoppers, when they allow a very near approach without taking flight; this movement continues throughout May and occasionally into June; at Filey some were heard going northward on 8th June I896, while on the Igth of the same month in I886, I recognised the whistle of birds passing overhead; in 1873 and 1896 a few remained on the Humber foreshore all the summer, and odd individuals occasionally stay in the Teesmouth district; I heard and saw one on 26th June in the year I904.

The return migration commences early in July; in I880 a large flock was noticed at the Teesmouth on the 4 th, and in 1884 a few passed from the Ist to the 15 th ; in Igoo several were at the estuary on Ist July. These first comers are generally old birds, which are followed in August by small parties of young ones; in some seasons they are very common, and considerable quantities were at the Teesmouth on 6th September I887. They remain on the coast until the end of September, then leaving for their winter quarters in the south. I am not aware of any instance of the Whimbrel remaining on the Yorkshire coast during winter.

The Whimbrel frequently alights on the "scars " off Redcar at low tide, and I have many times seen parties coming directly off the sea, and have called them over within range; on $7^{\text {th }}$ September I89I I shot a migrating bird, which fell on the water, and so fat was its condition that its breast split open with the contact; on another occasion, on the Ist of September, I killed two, whose feet and tails were stained with purple juice,

vol. II. 
which also exuded from their bills, thus proving their direct flight from the Scandinavian fjelds where they had been feeding on berries.

As a rule this species migrates by day; on the Cleveland coast, and also at Spurn, the majority alight to rest for a few days, while others pass on without alighting; and at this period individuals are occasionally reported from inland localities. Like many other shore birds, it figures amongst the casualties at the coast beacons on dark nights, but not so frequently as the Curlew.

There is no satisfactory evidence of the Whimbrel having nested in Yorkshire, although mentioned by A. G. More (Ibis. I865, p. 434), on the authority of Mr. Thomas Gough of Kendal, as having been found on the moors adjoining Westmorland; one or two instances of the alleged discovery of the eggs have been reported to me, but these specimens appear to be merely small examples of the Curlew's. (cf. Field, I2th May 1877.)

The local vernacular names are :-Curlew Jack, and Half Curlew; whilst Curlew Knave is an obsolete name used in olden times (cf. Barker's "The Three Days of Wensleydale") and first mention of this bird.

\section{BLACK TERN.}

\section{Hydrochelidon nigra (L.).}

Bird of passage, chiefly on the coast and estuaries, in spring and autumn; not uncommon. Also occurs inland.

The first British information concerning this Tern was given by Willughby, thus :- "The Scare Crow-Larus niger, Gesneri. This is (I suppose) the same with that which Mr. Johnson [of Brignall, near Greta Bridge] saith, they in the North call the Scare Crow, and thus briefly describes. It cannot abide the presence of men. Its Head, Neck, and Belly 
are black; its wings ash-coloured; its tail a little forked; its feet small and red." (Will. "Orn." I678, p. 354.)

Thomas Allis, I844, wrote:-

Sterna nigra.-Black Tern-A specimen was shot at Kirkstall, near Leeds, in 1842 ; it is occasionally obtained about Sheffield, J. Heppenstall has a specimen shot in the centre of the town; it occurs near Barnsley, Hebden Bridge, and Huddersfield; a pair was shot at the Foss Islands, close by York, in I84I; A. Strickland remarks that it used to breed near some of the streams at Driffield, but has not done so now for some years.

The Black Tern, according to Allis's friend and corres* pondent, Arthur Strickland, used to breed in the East Riding near Driffeld, but is now only a visitant in spring and autumn ; on the coast it is observed passing north in May at Spurn and Flamborough; off Redcar two were seen four miles out at sea on 23 rd May I882, in company with a flock of the common kind, and individuals occasionally linger on the Tees marshes until late in May; several were noted at Spurn on the $25^{\text {th }}$ of that month, and in mid-June, I88 r, whilst one was seen on Hornsea Mere on I2th June I882, but there is no evidence that it now nests in the county. The return migration takes place in late summer; five were flying with the Little Terns at Spurn on 26th July I887, and in August small numbers, chiefly consisting of immature birds, are observed at sea, associating with their larger relatives, where they remain until late in September; a late record being 3oth September I892, when one was obtained off Redcar.

The Black Tern also occurs regularly in spring and autumn on the river Hull near Beverley; on the Driffield streams it has been observed in early summer in full breeding plumage ; and it has been reported from Walton Park and other inland places, as mentioned by Allis.

A remarkable spring migration has been noticed at the end of April or early in May at Hemsworth Dam, near Ackworth, by Mr. Leonard Gill, now of the Newcastle Museum, who states (in litt.) that he first saw them in I 893 , when nearly a thousand passed from west to east.* They were subsequently

* Mr. J. H. Gurney observed them in Norfolk a day later. 
noticed annually up to the year I898, though in smaller numbers.

The only local name is Frenchman, in use at Bridlington ; though, as remarked above, it was stated by Willughby to have been called Scare Crow.

\section{WHITE-WINGED BLACK TERN. Hydrochelidon leucoptera (Schinz).}

Casual visitant from southern Europe, of extremely rare occurrence.

This species breeds in central and south-east Europe, northern Africa, Abyssinia, and Asia, and in winter is fourcl in eastern Asia and north Australia.

Yorkshire can claim three examples of this rare and elegant bird :-

The first was obtained in 1860 , near Scalby Mills, Scarborough (Tindall MS.), and formed part of the collection of the late Ed. Tindall, which is now in the Scarborough Philosophical Society's Museum.

At Flamborough, one, a mature bird, was seen for some days in the spring of 1867 , but was not procured ( $\mathrm{J}$. Cordeaux, Zool. I867, p. IoII ; “Birds of Humber District," p. I97).

At Scarborough a specimen was shot on 26 th September r896 (W. J. Clarke, Zool. r896, p. 387).*

* The example, now in the Newcastle Museum, which was purchased at Mr. Oxley's sale at Redcar in $187 \mathrm{I}$ (Nat. I887, p. 77), was killed ly G. Mussell in the marsh at Port Clarence, on the north side of the Tees, on I 5 th May I 869 (cf. Hancock's " Birds of Northd. and Dm." p. I43). 


\section{$65 I$ \\ WHISKERED TERN.}

Hydrochelidon hybrida (Pallas).

Accidental visitant from central Europe and northern Africa, of extremely rare occurrence.

The Whiskered Tern breeds on the Spanish marshes, the banks of the Danube, in south Russia and northern Africa, and is found as far south as the Cape of Good Hope, and eastward in Mongolia.

The only notice of its occurrence in this county is reported from Hornby Castle, the residence of the Duke of Leeds, where one was shot on the river Swale by one of the keepers, in I842 (T. Southwell, Nat. I885, p. 393).

\section{GULL-BILLED TERN.}

Sterna anglica (Montagu).

Accidental visitant from southern Europe and northern Africa, of extremely rare occurrence.

This Tern nests on the west coast of Denmark; at the mouth of the Rhone; and on the north and east shores of the Mediterranean, and the Black and Caspian Seas; it migrates to India, China, and the Eastern Archipelago.

The only Yorkshire example is that mentioned in the "Ann. and Mag. N. H." (I\$43, p. 297), and also referred to in Allis's Report, which had been wounded, and was brought alive to $\mathrm{H}$. Denny in the last week of July I 843 .

Thomas Allis's Report of 1844 contains the following :-

Sterna anglica.-The Gull-billed Tern-H. Denny informs me that a bird of this species was taken alive in a reservoir belonging to a mill on the York Road, near Leeds, and was brought to him in July 1843 . 


\section{CASPIAN TERN.}

Sterna caspia (Pallas).

Accidental visitant from the shores of Continental Europe and Africa, of extremely rare occurrence.

This handsome bird, the largest of the British Terns, is an inhabitant of the Mediterranean coasts, and nests by the Black and Caspian Seas, while colonies exist on the coasts of Sweden and Denmark. I found it fairly plentiful in the spring of I889 on Menzaleh Lake, Upper Egypt, flying in small flocks, and also feeding near the edge of the lake; both adult and immature birds of the previous year were fishing in company.

Its claim to rank as a Yorkshire species rests on the occurrence of one example at Filey, which was recorded by the possessor of the specimen, in the Field (I5th November I879), as follows :-

"The Caspian Tern ... . was shot at Filey by a friend early in September I874, and was sent by him to Baker of Cambridge, to mount for me. Although I have seen the bird there, I have not yet obtained possession of it, but it was, I believe, seen by Professor Newton at Baker's, so that there can be no doubt as to its identity." (R. A. Willis, Franklands, Addleston.)*

\section{SANDIVICH TERN. \\ Sterna cantiaca (Gmelin).}

Bird of passage in spring and autumn. Very rare inland.

The first mention of this bird's occurrence is in Allis's Report, I844, as follows :-

* See Mr. J. H. Gurney's article on British examples of this Tern (Zool. I887, p. 458). 
Sterna cantiaca. - The Sandwich Tern-Is met with near Huddersfield. W. Eddison says : "In the commencement of severe winters it is common for us to be visited by small flocks of Gulls, Terns, and other sea-fowl, driven so far inland by rough weather. Terns of nearly all the British kinds have frequently been shot."

This noble Tern, the Sea-Swallow of the east coast, is a visitant on its way to and from its breeding places to the northward, the nearest of which is at the Farne Islands, where a large and increasing colony exists. It occurs more frequently in spring than most of the other Terns, and has been noted at Spurn and Flamborough, while every year, early in May, a few are to be seen off Redcar and at the Teesmouth. The earliest date on which I have observed it is 3rd May I894, when several passed at sea; I also heard one on I2th June I886, and an adult male was picked up on Ist July I 888 . During the whole of the summers of I904, I905, and I906 two pairs remained in the vicinity of Redcar, where I frequently saw them throughout June and July, fishing near the rocks opposite my house.

In August the Sandwich Tern begins to move southward, accompanied by the young birds, the main body passing on without lingering, though a few remain off the coast and in the estuary, small parties being reported late in September and occasionally in October, the peculiarly harsh, grating call at once giving notice of their approach, though the birds themselves may be undiscernible, and probably a mile distant. It was more numerous than usual in I902, and remained until 27 th September. The latest record for the Redcar district is 7 th October I88I, when I saw one at the Teesmouth, though a later date for the county is given in I875, one being obtained on I5th December, at Filey (Zool. r876, p. 4804). On the autumn passage this species has been met with at most of the coast stations between Teesmouth and Spurn, at the latter place consorting with the Arctic and Common Terns.

It is very rare inland, though it has been recorded from Huddersfield ("Hobkirk," 2nd Ed. I868); Wakefield (G. Roberts, September I868), and on Ioth October I88I, Mr. 
E. B. Emerson saw two at Deighton Manor, near Northallerton, flying southward.

The alleged breeding of the Sandwich Tern at Spurn was disproved many years ago (Zool. I869-70-7I).

Local name :-Big Sea-Swallow.

\section{ROSEATE TERN.}

Sterna dougalli (Montagu).

Casual visitant on its way to or from its nesting grounds; of rare oscurrence.

To Thomas Allis belongs the honour of first noticing this species as a Yorkshire bird, in his Report of 1844 , as follows :-

Sterna dougalli.-The Roseate Tern-Has been met with near Hebden Bridge; it has been shot near Scarborough and Hornsea by H. Reid of Doncaster. A. Strickland says: 'In the autumn we have at times great abundance of Terns upon the coast, but a large portion of them are young immature birds, of which it is very difficult to discriminate the species; both the Sandwich and Roseate Terns breed to the north of us, and are occasionally found here.

This delicately shaped and lovely bird, the greyhound amongst the Terns, as it has been very aptly termed, has been but seldom chronicled from this county; Mr. W. Backhouse, writing in 1846, stated that it "occurs in the Tees Bay, but rare" (Zool. I846, p. I262); Allis also mentioned its appearance on several occasions; one is reported from Spurn on 9th September I893 (Nat. I893, p. 359), and another at Whitby on I7th September I894 (T. Stephenson, in litt. I902), but I regard these two last as doubtful; whilst five, stated to have been obtained in Tees Bay (Field, 13th January 1877 , and "Vertebrate Fauna of Yorkshire," p. 79), proved to be Common Terns. There is not an authentic instance of its capture on record within recent years, although, since it has become re-established on the Farne Islands, there 
is every reason to presume that it passes along the coast in spring and autumn, like others of the genus which nest on the east coast of Britain, but, as it is the earliest to leave on its southward migration, it escapes detection before the shooting season commences. Its note is easily recognisable, even when mingling with those of its congeners, and exactly resembles the latter half of the Corn Crake's call.

Tho Roseate Tern nests in limited numbers on the Farne Islands; off the east of Scotland; and on two or three islands on the west coast of Britain, at one of which a colony of considerable size exists ; there is strong presumptive evidence, also, that it breeds on some of the small rocky islets off the west coast of Scotland. The eggs of this bird have a characteristic individuality, being quite distinct from those of the Common and Arctic species; a clutch of a rather peculiar variety, in my collection, has the ground colour of a yellowish stone tint, heavily blotched with dark reddish brown and violet under-markings.

[The Sooty Tern (S. fuliginosa, J. F. Gmelin), recorded as shot in I863, at Scalby, near Scarborough, which passed into the collection of the late Ed. Tindall ("Vertebrate Fauna of Yorkshire," and Tindall MS.), proved to be a Black Tern. As yet neither this bird nor the NODdy TERN (Anous stolidus) has occurred in Yorkshire.]

\section{COMMON TERN. \\ Sterna hirundo (Naumann).}

Bird of passage in spring and autumn. Occasionally occurs inland.

Though sea-fowl are not valued as table delicacies at the present day, the first allusion to the Tern, as a Yorkshire bird, appears in the Northumberland Household Book (I5I2). Amongst the birds for "My Lordes own Mees," are included "Ternes after iiij. a jd."

Another early mention of the species is contained in the 
Cottonian MS., which is also referred to in the Introduction, thus:- "Neere unto Dobhoome (the porte in the mouth of Tease so named) .... an infinite number of sea-fowle laye their egges heere and there scatteringlie in such sorte that in tyme of breedinge one can hardly sett his foote soe warelye that he spoyle not many of their nestes" (Cott. MS. I604). The shores of the Tees estuary at that time would afford very suitable nesting ground for birds of this family; old inhabitants of the district are still living (I906), who can recollect the time when Terns nested in great quantity, and the Common Tern would, doubtless, be one, if not the most numerous of the fowl resorting there in summer.

Willughby's allusion to the Brown Tern may be referable to the young of this bird :- "The Brown Tern-Larus cinereus minor (Aldrov). This is also the brown Tern of Mr. Johnson [of Brignall, near Greta Bridge] (if I be not mistaken) whose underside is all white, the upper brown; the Wings partly brown, partly ash-coloured; the Head black; the Tail not forked. The Birds of this kind are gregarious, flying in companies." (Will. "Orn." I678, p. 352.)

Thomas Allis, in 1844 , reported as follows:-

Sterna hirundo.-Common Tern-Common on the coast; seen near Leeds rarely; about Huddersfield occasionally; Hebden Bridge rarely; not infrequent near Barnsley, where they frequent the fresh water reservoirs and the course of the canals.

The Common Tern is a visitant in spring and autumn, when on its way to and from its nesting quarters, the nearest of which, where it breeds in any abundance, consorting with the Arctic Tern, being at the Farne Islands. The first passers-by are noticed early in May; in I883 on the $4^{\text {th }}$ of that month they were observed at Spurn all day going north (Fifth Migration Report). At Redcar and the Teesmouth it occurs in spring, though not so frequently as in the autumn when on the return passage south, and accompanied by the young birds. In August it congregates in large flocks, which remain on the coast, in the estuary of the Tees, and sometimes, in rough weather, in the Humber, following and feeding on the young herrings until nearly mid-autumn. It was more 
numerous off Redcar on 26th and 27 th September I883, than during the whole of the year; a few linger into mid-October, and odd birds even later ; on 9th November I 892 an immature example was procured at Redcar, while during a heavy storm on Igth November I893, many Terns were observed at Flamborough. This is by far the commonest of the family in the Teesmouth area, though at Flamborough and Spurn it is not so abundant as the Arctic Tern. The two species frequently intermix when following the herring "sile," and are difficult to discriminate when in large flocks and at a distance, but as a rule $S$. hirundo outnumbers macrura as ten to one on the Cleveland coast.

Inland it is occasionally found on rivers and the reservoirs which supply the large West Riding towns with water, where it alights in passing on migration, or is driven out of its course by stormy weather.

The Migration Reports contain but few references to its occurrence at the Light stations; one was killed against Spurn lantern in September 1896 .

As stated above, this bird probably bred at the Teesmouth in the seventeenth century, and another colony is supposed to have existed at that period at Hornsea Mere, although it is not unlikely the so-called "Terns " were Blackheaded Gulls, which used to nest there in great numbers. A reference to this breeding place is contained in a letter to Abraham de la Pryme, dated "Hornsey, 21st December I693," which runs as follows :- " Sir, I received yours of the $5^{\text {th }}$ inst. (then follows a description of the mere or 'marr,' as it is termed). I had almost forgot to add that there are three hills (islands we call them) in the marr, two of them at the season of the year are so full of tern eggs and birds as can be imagined. A man must be very careful it he tread not on them! Your very humble Servant, W. Lambert." (From the "Diary of Abraham de la Pryme," pp. 272-73. Surtees Socy. liv.)

The only vernacular name that can, with strict accuracy, be applied to this bird, is that used generally for the family, viz., Sea Swallow. 


\section{ARCTIC TERN. \\ Sterna macrura (Naumann).}

Bird of passage in spring and autumn. Rare inland.

The first British information concerning this bird is contained in Willughby's "Ornithology," under the heading of "The Lesser Sea-Swallow." Mr. Johnson [of Brignall, near Greta Bridge] thus briefly describes it:- "It hath the Wings, Tail and swiftness of a Swallow; a red Bill; a black crown; brown legs; a forked Tail six inches long." In the colour of the legs he agrees with Gesner [Bill and Feet of a pale dusky colour] but perchance the colour may vary with age, or differ in the Sexes." (Will. "Orn." I678, p. 353.)*

Thomas Allis, I844, wrote:-

Sterna arctica.-Arctic Tern-On the coast; not uncommon in the spring near Sheffield, as I am informed by my friend J. Heppenstall ; A. Strickland remarks, speaking of the Common and Arctic Terns, " As far as I have observed, the latter of these is by far the most common on this coast, at least in mature plumage, but the Common Tern is occasionally found here, and at times proceeds inland, which I never found the other to do."

The present species, like the preceding one, is a visitant in spring and autumn on its passage to and from its breeding grounds, the most southerly of which on the east coast is at the Farne Islands; it is not very often observed at the former period owing to its route lying some distance from shore; a few were seen off Redcar on Igth April I879, and small numbers occasionally occur at the Teesmouth early in May; on the return passage in autumn, however, when in company with the young, it remains off the coast, feeding on sprats, and consorting with the Common Tern, a few sometimes lingering until October; in I879 a large flock was at the Teesmouth on the $I 7^{\text {th }}$ of that month, and two on the $24^{\text {th }}$ (Zool. I879, p. 490); on 23rd October I892, I walked near to

* Willughby and Ray do not appear to have seen this bird. 
one sitting on the sands at Redcar, though the latest record is 2nd December 1905, when an immature example was obtained at the Teesmouth. At Flamborough and Spurr, according to the late $\mathrm{J}$. Cordeaux, it is the most numerous of the Terns, but on the Cleveland coast, although very abundant in some years, yet in others, one of which was 1885 , without any apparent reason, it is remarkably scarce. (See Common Tern.)

Inland it is very rare, but is recorded from Barnsley, Wakefield, Gormire, Knaresborough, Fewston, Bluberhouse moor (where one in first plumage was noted by Lord Walsingham on $7^{\text {th }}$ September I883), and at several other places.

An uncommon and interesting state of plumage is that of the second year, which was formerly attributed to a separate species known as $S$. portlandica (Ridgway). An example in this condition was procured at Spurn in July I884, and sent by Mr. W. Eagle Clarke to Mr. Howard Saunders, who states that it is evidently a bird hatched in the summer of I883. The forehead is white, the crown streaked with black, and the nape almost entirely black. The upper parts are grey as in the adult, except for a dark mottled line, indicative of immaturity, along the lesser wing coverts, and the darker tints of the tail feathers, especially on the outer webs; the entire under parts are white. In their dried condition the bill, legs, and feet are nearly black (the webs of the latter livid.)* Mr. Saunders remarks that he has only seen five or six specimens of this intermediate phase of plumage (Nat. I887, p. 353).

The only vernacular name is that used generally for the family, viz., Sea Swallow.

* I had two specimens in this stage in I901, and in their fresh condition the bills were red, legs and feet light orange red. 


\section{LITTLE TERN.}

Sterna minuta (L.).

Summer visitant; breeds at Spurn; very rare inland.

Perhaps the earliest Yorkshire reference to this species is that made by Tunstall, thus :- " The Lesser Tern-Sterna minuta (Linn and Gm.). Common, and frequents sea-coasts. unable to bear the inclemency of winter on our coasts, but returns in spring." (Tunst. MS, I784, p. 94.)

Thomas Allis, I844, wrote:-

Sterna minuta.-Lesser Tern-Is met with near Huddersfield; near Sheffield two individuals have been shot in Ecclesfield Dam; not infrequently obtained near Barnsley. A. Strickland says, "Though this breeds to the north of us it is certainly one of the least frequent about here, though I have known it killed."

This graceful little bird, the smallest of the Terns, is a summer visitant to the south-eastern extremity of the county, Spurn Point, where a considerable nesting colony has been in existence for many years. The main body generally arrives in May, although individuals are sometimes seen earlier, as on $5^{\text {th }}$ April I886 (Eighth Migration Report), 15th April I885, and I4th April I893. An account of a visit to Spurn during the last week of May I86I, states that the nesting site was on the seaward side of the sandy neck of land that connects Spurn Lighthouse with the coast, and about half a mile from the point. From forty to fifty pairs of birds were noticed, and the nests were, as in other colonies, in close proximity and within a few yards of high water mark. They never breed on the Humber side of the neck, although the distance across is only about a hundred yards (Dobree, Zool. I86I, p. 7648). The colony afterwards extended its limits, and now includes nearly the whole of the strip of shingle from the point mentioned by Mr. Dobree to opposite the warren. The nests were mercilessly plundered by egg collectors and excursionists, but in the year I895 an effort was made by the County Council, under the powers of the 


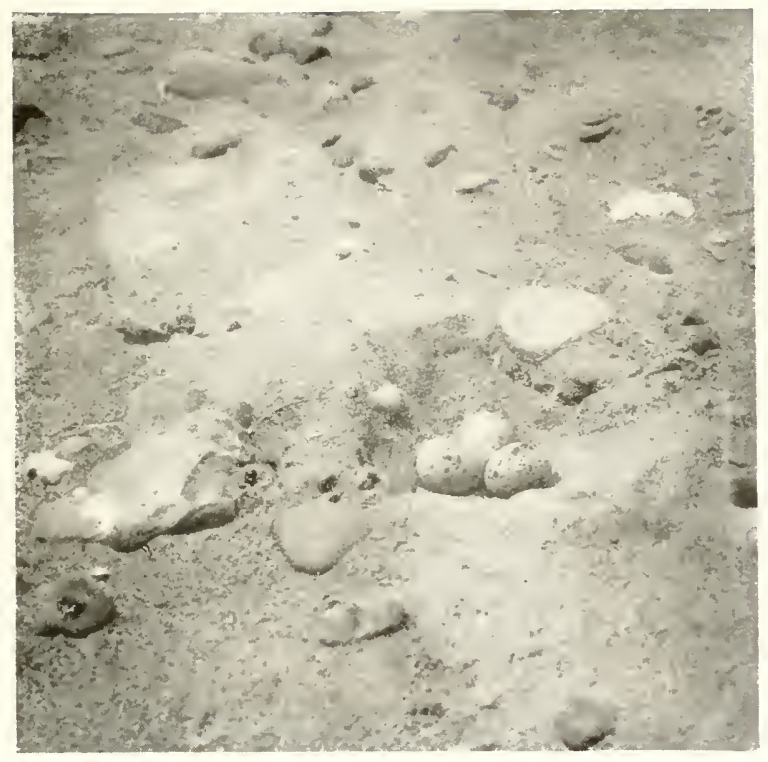

Nest of Little Tern at Spurn.

R. Fortune.

Se page 661. 
. 
Wild Birds Protection Act of IS94, to save the birds from molestation. Spurn was declared a protected area, a watcher was appointed, and although a certain amount of "egging" cannot altogether be prevented, it is satisfactory to know that the only Yorkshire colony of Terns is now increasing in numbers (in I 900 about a hundred pairs of young were hatched), and the protection is continued (see Cordeaux and Boyes, op. cit. 1868, '69, '70, '7I; Field, 6th April I895; and Nat. I900, p. 32I). Writing in the Zoologist (I845, p. II87), J. Hogg referred to the Lesser Tern as "inhabiting in summer the sandy beach near the Teesmouth," but whether it is to be inferred from this that it nested there is not clear.

On the coast north of Spurn the Little Tern occasionally occurs in spring and autumn at Flamborough, Scarborough, Whitby, and Staithes; and both adult and young birds annually visit the estuary of the Tees late in summer and autumn. It usually appears in August, although on 29th July I878, I saw ten, three of which were procured; in I884 two were obtained on I2th July; and on 30 th July I905 a large flock, comprising two or three hundred individuals, was reported at the Teesmouth. The majority leave early in September, stragglers occasionally remaining later; three immature birds were observed on 25th September I90I, and two on the I 7 th of the same month in the year following. It has been noted at Spurn as late as the second week in October, whilst at Flamborough I examined a specimen on I5th October I903. The only spring occurrence at Redcar was in I882, when an individual was picked up on the sands on I8th May.

The Little Tern is a very scarce species inland, but has been recorded from Sheffield and Huddersfield; it occurs regularly on the reservoirs near Wakefield in spring and autumn; one was taken at Selby about I862; another at Blackley in I875; it was noted for Wensleydale by Barker; and at Acaster one was shot in 1869 , and exhibited at a meeting of the York Naturalists' Club.

A rather peculiar variation from the ordinary type of egg was found at Spurn in I894; it was one of a clutch of 
three, the ground colour of pale stone or light brown, with a blotch of reddish purple forming a zone round the broad end (E. G. Potter, Nat. I895, p. I50). Mr. Potter also mentions a clutch of four found in one nest, but probably these were the produce of two females.

\section{SABINE'S GULL. \\ Xema sabinii (Sabine).}

Bird of passage in autumn from Arctic Asia and America; generally in immature plumage, adult birds being very rare.

This small Gull nests in the Arctic regions and in eastern Siberia, while in winter it is found as far as Texas, the Bermudas in the Atlantic, and in the Pacific down to $12^{\circ}$ south.

It is now ascertained to be a fairly regular visitant in autumn to this county, and has occurred most frequently off the famous headland of Flamborough and in the adjoining bay of Bridlington, where upwards of forty examples have been obtained; three others are noted from Scarborough; two from Filey; and one from the Tees Bay near Redcar. Most of these were in the immature garb of autumn, but at least ten adults in summer plumage have been chronicled, while four additional specimens are known to me, the particulars of which have not hitherto been made public. It will be observed that all the recorded occurrences are between the months of August and November, and it may be well, for convenience of reference, to give a list of these in chronological sequence :-

The first mention of the species in Yorkshire refers to an adult female at Bridlington on 5th September I866, as mentioned by the late W. W. Boulton (Zool. I867, p. 543, and MS.). This specimen is now in Mr. Thomas Boynton's collection, where I have had an opportunity of seeing it.

The next is also an adult, in full summer plumage, obtained at Bridlington, Ioth August I872 (J. H. Gurney, op. cit. I872, 
p. 33I6). This is the first recorded male example in the adult summer dress.

Flamborough, one immature, I5th October I873 (Gurney, in. litt. and op. cit. 1873, p. 3802$)$. This specimen is in Mr. Gurney's collection.

Bridlington, one immature, I4th October I875 (J. Whitaker in litt.), also recorded by Mr. Gurney (op. cit. I876, p. 4883), with the adjoinder that it was the fourth example he had known near Bridlington. This bird is in Mr. Whitaker's collection at Rainworth Lodge, Mansfield.

Scarborough, one immature, 7 th November I 878 (op. cit. I878, p. 455).

Same place, one immature, November I879 (Tindall MS.). This specimen formed part of the collection owned by the late $\mathrm{E}$. Tindall of Knapton, which has now been transferred to the Scarborough Philosophical Society's Museum.

Flamborough, one adult, procured in $\mathrm{I} 877$ by Thomas Leng, and now in the possession of his son-in-law Wm. Major of Flamborough, who allowed me to examine the specimen.

Same place, one immature, 6th September I887 (Field, Ist October I 887 ; possibly the same as recorded by M. Bailey, Nat. I888, p. I5).

Bridlington, an adult in full plumage, first week in August I889 (Field, 3Ist August I889, where the plumage is described).

Flamborough, one immature, October I889 (Nat. I889, p. 333).

Redcar, one immature, obtained in the Tees Bay, 6th October I889 (op. cit. I89o, p. I00). This example is in my collection.

Flamborough, one immature male, August I890; now in the collection at Burton Agnes formed by the late Sir Henry Boynton.*

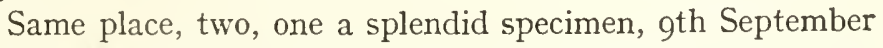
I890. (Mr. Bailey has subsequently informed me that this

* Possibly the Burton Agnes specimen, which I have seen, may be one of those first mentioned by Mr. Bailey.

VOL. 1 . 
bird was in adult plumage.) Two at the same place, on the I5th of the same month, and two others on the 2oth (tom. cit. p. 3I8); one, 7 th October I89o, south of the Headland; and another on I3th October, north of the Headland (tom. cit. p. 354).

Bridlington, one immature, October I89o; now in $\mathrm{Mr}$. Riley Fortune's possession.

Flamborough, one, November I89I (op. cit. x892, p. 372).

Bridlington, one immature, October I829.

Flamborough, one, 2oth September I893 (op. cit. I893, p. 323).

Bridlington, one immature, 24th September I893.

Same place, an adult male, 9th September $x$ 895. I have examined this specimen, which is in the mature garb of summer.

Flamborough, two, south of the Headland, mid-October I895 (op. cit. I895, p. 312.)

Bridlington, one immature, second week in November (I895 op. cit. I896, p. I00).

Yorkshire coast, possibly Flamborough, an adult in full plumage, 5 th September I 898 .

Flamborough, one adult, 29th September I899 (Field, 2Ist October I899).

Yorkshire coast, possibly Flamborough, one immature, autumn I899.

Bridlington, three immature, 24th September I900; and two, also immature, 3rd October I900. (I saw and examined these specimens.)

Flamborough, one adult, Igor, obtained by George Emmerson, and now in the Hon. Walter Rothschild's collection (G. Emmerson, oral communication).

Bridlington, one immature, r2th October Igor (Moiser, in litt.). Now in the possession of Mr. Cyril Moiser of York.

Filey, one immature, in the collection of Mr. H. E. Rawson of Fallbarrow, Windermere, where I have examined it.

In addition to those chronicled, adult examples are in the collections of Mr. Thomas Boynton of Bridlington, and Mr. Walter Pyman of Raithwaite Hall, Whitby, both of which 
I have seen, and which were procured in the neighbourhood of Bridlington about the year I890.

Bridlington, two adult and one immature, September and October I903; the latter and one of the adult specimens are in the collection of the Rev. J. G. Tuck of Tostock Rectory, Bury St. Edmunds (Zool. I903, pp. 353, 394, 436).

Scarborough, an adult female, in winter plumage, 5th September rgo3 (W. J. Clarke MS., and tom. cit. p. 394). This specimen is in the York Museum.

Filey, one adult, 2Ist September I903; purchased by Mr. IVilliams of Dublin (tom. cit. p. 394).

Flamborough, two immature, one of which I examined on $25^{\text {th }}$ September I904.

Same place, one in the autumn of 1905 .

The figure of the immature example in Lord Lilford's work on "British Birds" was taken from a specimen shot at Bridlington in September Igoo.

\section{ROSS'S GULL.}

\section{Rhodostethia rosea (Macgillivray).}

Accidental visitant from the Arctic regions, of extremely rare occurrence.

This circumpolar species, also called the Cuneate or Wedgetailed, and the Rosy Gull, is an inhabitant of the far north, where Nansen observed it, during his famous voyage, in the neighbourhood of Hirtenland Islands, on which it was probably breeding.

The only example known to have occurred in the British Islands was shot near Tadcaster, purchased by Sir IVm. Nilner of Nun Appleton, and recorded by him as "killed on 22nd December I846, by Mr. Thomas Robinson of Saxton, near Aberford, in this county, and discovered by Mr. Graham, bird-preserver, York, who brought it to me" (Zool. I847, 
p. I694). In a later communication from Mr. Henry Milner (Nun Appleton) it is stated that :- “ Ross's Gull was killed by Horner, Lord Howden's head-keeper, in February last (I847), in a ploughed field, near the hamlet of Milford-cumKirby, in the parish of Kirby" (tom. cit. p. x784; and Charlesworth, "Proc. Yorks. Phil. Socy." I847, p. 33).

Considerable scepticism has since prevailed with regard to the reliability of Graham's assertion that the bird was obtained in Yorkshire, and it has been surmised that Sir W. Milner was imposed upon by the professional bird-stuffer; but the fact that the specimen was in winter plumage is proof of the reliability of his statement, as at the time of its. occurrence that phase of plumage was unknown. Important evidence bearing upon the authenticity of the record is, however, brought to light in the Field: on 7 th November r885, an editorial note is appended to an account of Ross's Gull in Greenland, to the effect that "No faith is to be placed in the oft-quoted statement that one was obtained in Yorkshire.". A fortnight afterwards a letter appeared as follows :-

“ In your notice about Ross's Gull you mention its occurrence in Yorkshire as being unauthenticated. I perfectly recollect the bird having been killed at Tadcaster. I believe the late Mr. Graham of York had it in the flesh, and sent it to my relative, the late Sir W. Milner of Nun Appleton, whose collection is now at Leeds, having been lent to the town by the present Baronet." (F. J. Saville Foljambe, Osberton, Worksop, I4th November.)

(" It is precisely because the bird was obtained of a dealer that its alleged history has been doubted. If we mistake not, two contradictory stories were published about it, and it is a significant fact that the species has not been heard of in this country before or since.-Ed.") (Field, 2Ist November I885.)

Mr. Foljambe then rejoined:- "The following extract from Gould's 'Birds of Great Britain,' I think, ought to be sufficient evidence as to the specimen being what it professes to be. 'Ross's Gull was killed by Horner, Lord Howden's 


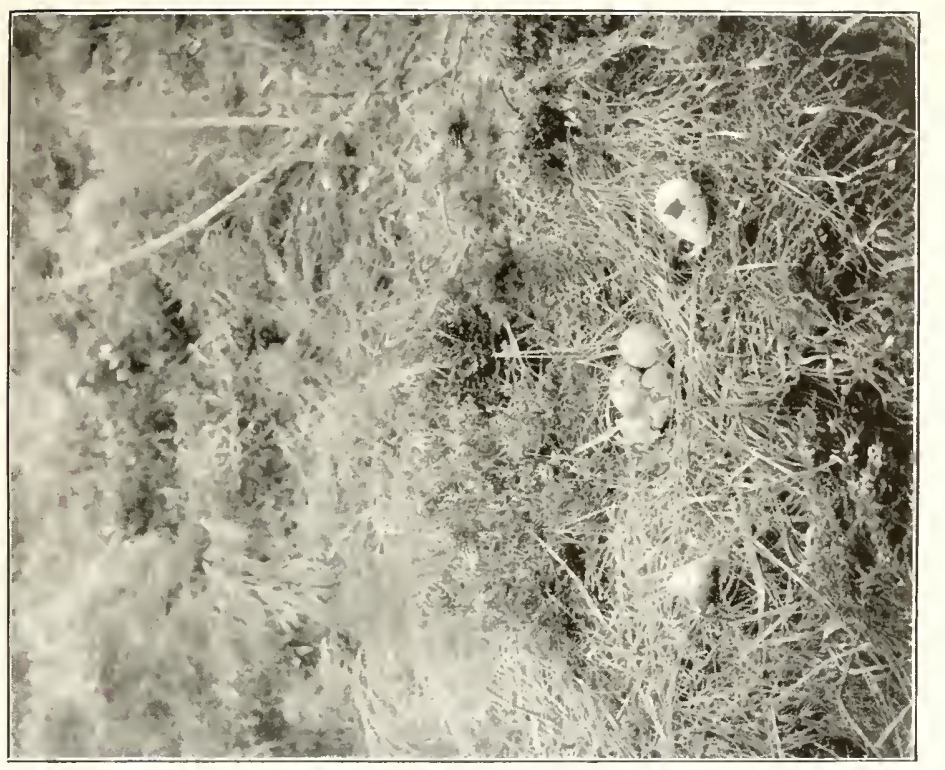

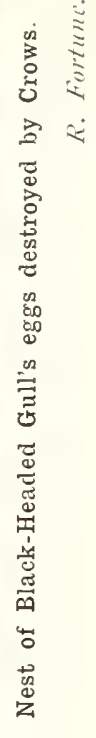

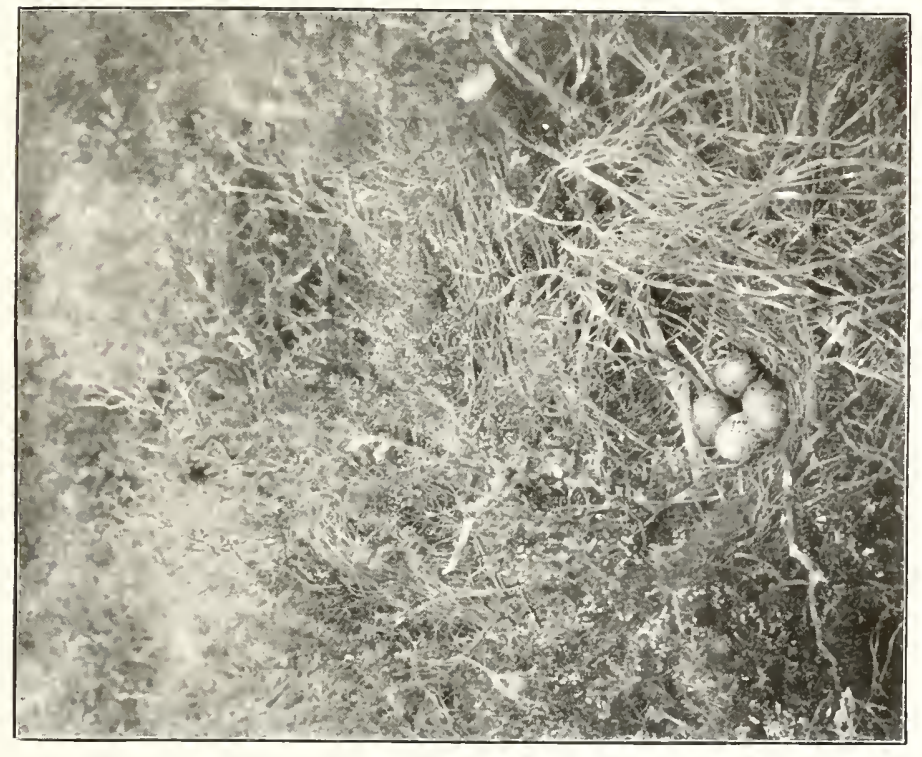

严

굴

त

章

$\Xi$

号

is 

head-keeper, in February I847, in a ploughed field near the hamlet of Milford-cum-Kirby, in the parish of Kirby.' My impression is that it was brought in the flesh to Sir Wm. Milner."-F. H. Foljambe. To this letter the Editor quoted Sir W. Milner's account (Zool. I847, p. I694) as to the bird being killed on 22nd December 1846 (Field, 28th November I885).

In the following week another important communication was published :-

"Referring to Mr. Foljambe's letter ... concerning the specimen said to have been obtained in Yorkshire, I may state that my brother (Rev. W. Garwood of Staveley, Yorks.) writes me that he remembers, in his egg collecting days, seeing this identical bird in the flesh at Mr. Graham's shop when it was in Spurriergate, York." (C.R.G[arwood], Acomb, York. Field, 5th December I885.)

The discrepancy (as regards locality) in the account given by Sir W. Milner and that by Mr. Hy. Milner, quoted above, is not so great as may appear, the actual place, Milford, being "near Tadcaster." and, as Messrs. Foljambe and Garwood are both of opinion that the bird was seen in the flesh, the evidence in favour of its being a Yorkshire species seems to be conclusive.

Mr. Howard Saunders, who has seen the specimen, pronounced it to be in the winter plumage (Field, February I875, p. I96).

\section{LITTLE GULL.}

Larus minutus (Pallas).

Autumn and winter visitant, irregular in numbers.

This bird nests on the swamps and lakes of Russia, and migrates in winter to the coasts of the Mediterranean and the shores of north Africa.

The first known allusion to it in Yorkshire is, probably, 
in Williamson's Scarborough Catalogue, where it is stated that "The Little Gull is obtained generally during the prevalence of strong north-easterly winds" (P.Z.S. I836, iv., p. 77).

Thomas Allis, I844, wrote:-

Larus minutus. - Little Gull-F. O. Morris says it has been shot near Scarborough. I believe this is confirmed in Yarrell's "Birds," on the testimony of Patrick Hawkridge, an industrious and persevering naturalist. Another specimen was killed about a fortnight ago at Bridlington, which was sent to Hugh Reid of Doncaster to stuff. A. Strickland has known several of these birds killed near Bridlington, but thinks he never knew above one killed during a winter ; the breeding haunts of this bird do not seem to be known, and are probably distant. as I never met with it in full plumage.

The Little Gull is an autumn and winter visitant to this county, irregular, and varying in numbers, though it appears in most seasons, and has occurred more frequently on this coast than in any other part of the United Kingdom, being therefore of more than passing interest to Yorkshire ornithologists.

As a rule it is observed in September and October, though in February of the year 1870 it was very abundant during stormy weather; and the vicinity of Flamborough and Bridlington is most favoured by its presence, the host of Kittiwakes and other Gulls feeding around the Headland attracting it to the fishing grounds; while, judging from the reports received relating to this part of the coast, no fewer than one hundred and fifty of these beautiful little Gulls have been obtained there, though perhaps some of the records may have been duplicated, as in the years of plenty there would, doubtless, be notices sent from both Flamborough and Bridlington referring to the same specimens. Mr. T. Boynton of the latter place procured thirty, most of which he shot himself, between the years I868 and I872, several being adult birds, whilst Mr. M. Bailey, the veteran taxidermist of Flamborough, up to the year I88I, had had forty through his hands. In the course of conversation with him he informed me that he once observed a flock of about twelve of these birds, and he, perhaps, has done more than any one to make it known 


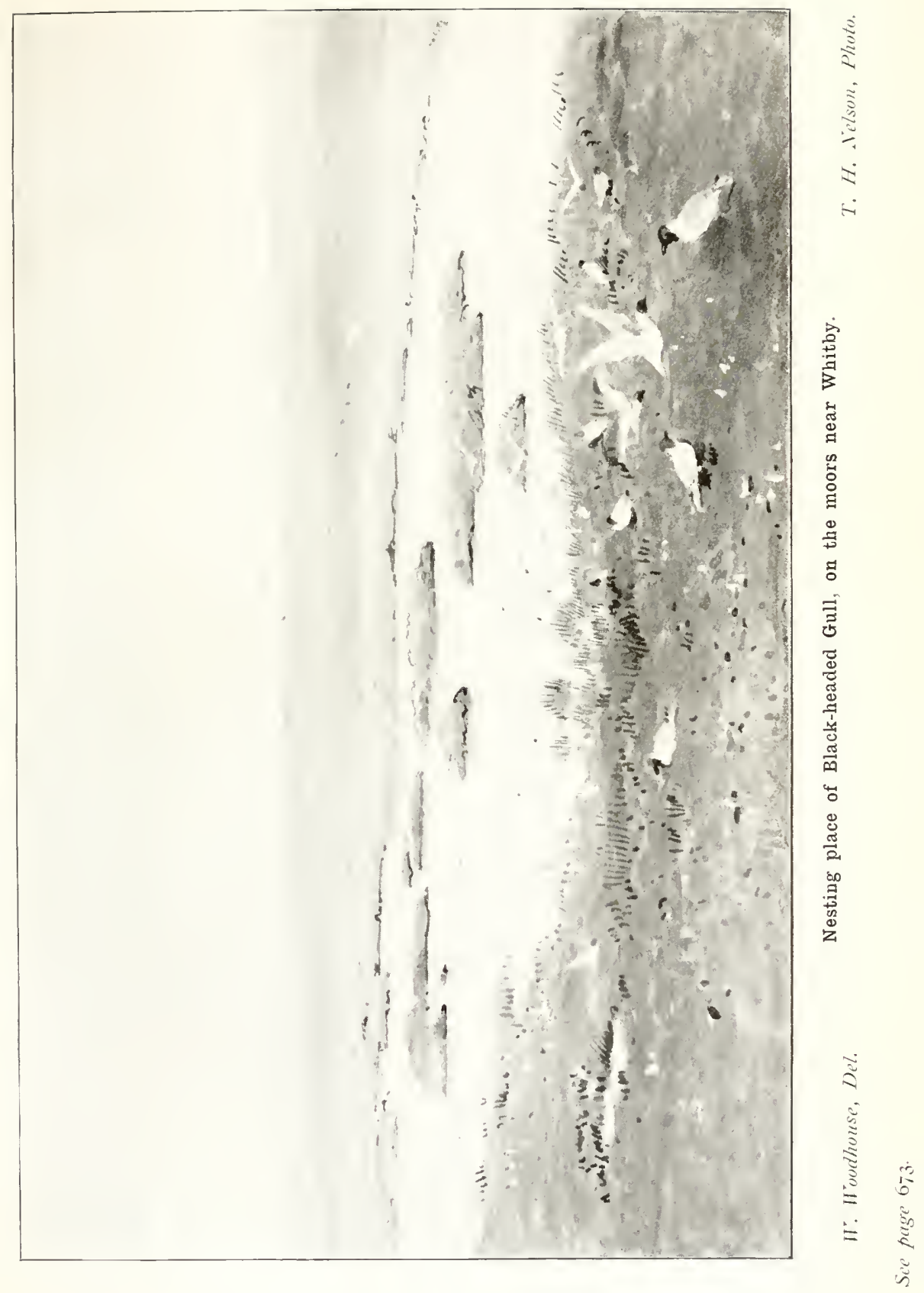



as a Yorkshire species. The most prolific seasons were I866, I868, in which latter year Mr. J. H. Gurney had thirteen specimens sent to him; I869; and I2th-I4th February I870, when thirty were obtained in Bridlington Bay during a fearful easterly gale, nineteen of them being old birds; two adults, male and female, were reported at the same place in September r88r. Scarborough ranks next to Flamborough as to numbers noted; three adult examples were procured in 1870 , and about twenty adult and immature have been taken there between I836 and I902. Redcar and Teesmouth district can claim fifteen specimens between I849 and I902; two occurred at Spurn on 26th October I88I ; one at Withernsea about 1897 ; an adult example at Skipsea in February I87I; one at Filey in I868; one in I863 at Whitby, where several individuals have since occasionally been seen in the harbour; and one at Runswick Bay in r89o.

The only inland localities where it has been noted are Skipwith Common, two being shot there on Ist September I856 ; and near Ackworth, where a specimen was killed in the winter of I880-8I.

The Little Gull sometimes associates with Terns when off this coast; one in immature plumage, which I saw on $9^{\text {th }}$ September 1885 , was with a large flock of Sterna macrura; and Mr. Bailey has also noticed these two species fishing in company off Flamborough Headland. The majority of those obtained are immature, but occasionally old birds in winter plumage are met with, and, as stated above, nineteen were killed in I870; an adult in full summer garb, procured on I2th July r868, and another taken on 5 th August I886, off Flamborough, are in Mr. Gurney's collection (Zool. I868, p. I379; and Nat. I887, p. 22) ; Mr. Boynton of Bridlington and Mr. W. Pyman of Whitby also each possess a specimen in similar plumage, which I have examined; and an adult in winter dress, which occurred in October I886, is in the York Museum.

A white variety from Flamborough, on 29th October I889, was in the collection of the late Mr. Marshall of Taunton. It is not an albino, as the terminal bar on the tail is visible, 
the occiput and ear-coverts are faintly mottled, and the hue of the mantle is just perceptible (Nat. I890, p. 38 ; and Zool. I890, p. I9).

Other references to L. minutus are :-Zool. I864, p. 9365; I866, p. 30 ; I867, p. IOI8; I868, pp. I379-I482; I870, pp. 208I-2I07; I875, p. 22 ; I884, p. 6I; Nat. I887, p. 22 ; Field, 26th November I887, and 6th March I897.

The only local name, of which I am aware, is Dwarf Gull, used at Bridlington.

\section{BLACK-HEADED GULL.}

Larus ridibundus (L.).

Resident; very local in the nesting season. Common on the coast in early spring, late summer and autumn; less plentiful in winter.

Probably the first Yorkshire reference to this Gull is found in the Diaries of Bishop Nicholson of Carlisle, which contains an account of his Lordship's journey from Carlisle to York; it certainly is interesting as shewing that a large nesting colony was then in existence in the North Riding. The extract reads thus :-

"I702. 22 May.... That night to Greta Bridge. .... 23. Baited at Butcher Houses ye property of Sr. Chrisr. Wanesford. The sign, Lion Rampant, his Arms.About a mile and half short of Thornton Bridge thousands of the Blackcap Mews breeding in a moss." (Extract from Bishop Nicholson's Diaries, Part ii., by the Bishop of Barrowin-Furness. Trans. Cumb. and Westm. Antiq. and Archæol. Society, Vol. ii., New Series, p. I656.)

Thomas Allis, I844, wrote :-

Larus ridibundus.-Black-headed Gull-Common on the coast; John Heppenstall informs me that this bird was formerly very abundant on Thorne Moor, but has now very nearly disappeared; it has been shot at New Miller Dam, near Wakefield ; it is met with near Huddersfield. A. Strickland says this bird breeds in great abundance on one of the islands in the middle of Hornsea Mere, but it is not often found 


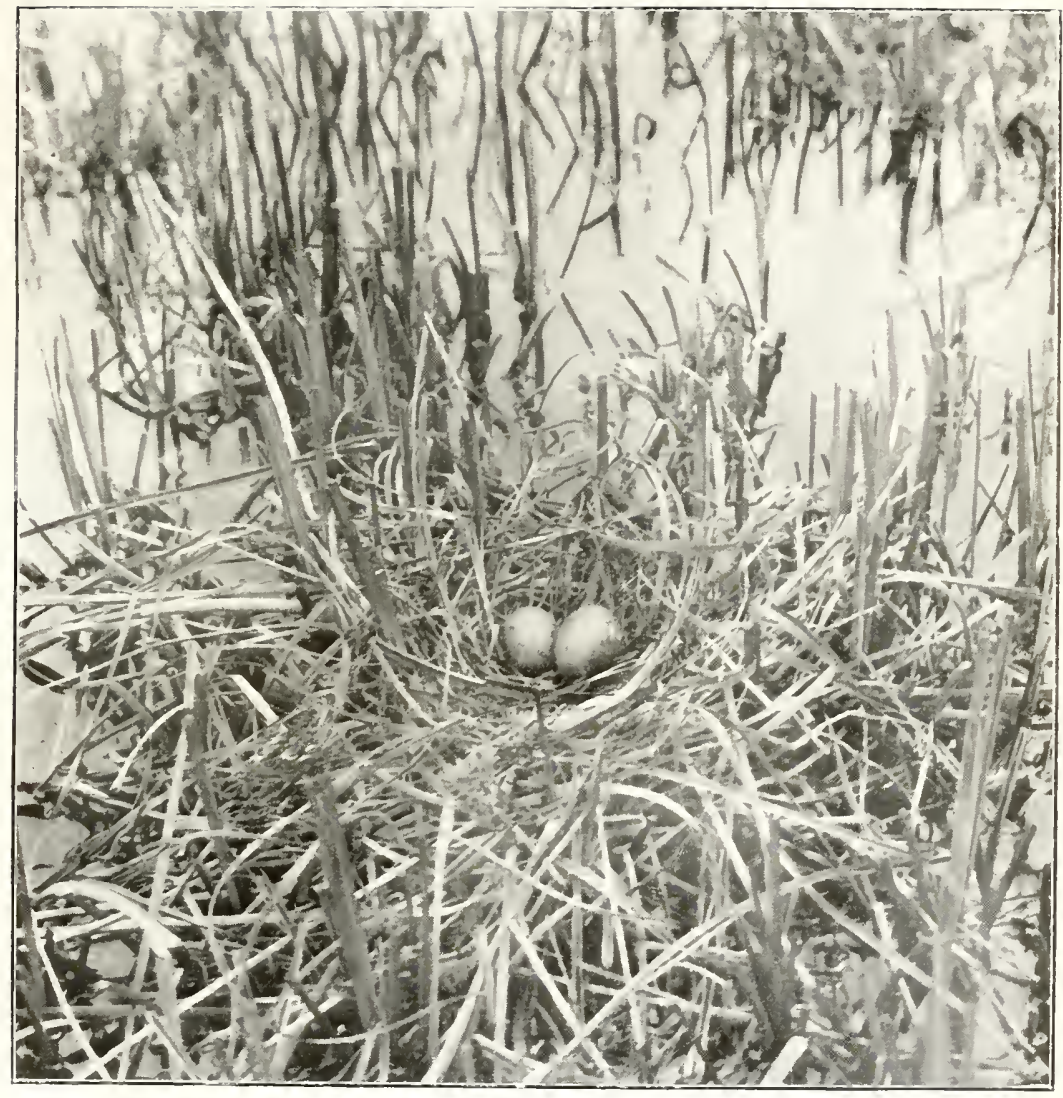

Nest of Black-headed Gull in North Yorkshire. R. Fortune. 

in Bridlington till after that time, when out of mature plumage; it is common on the shore.

This familiar species, sometimes called the Brown-headed Gull, is resident in Yorkshire, where at one time several extensive breeding stations existed; the most important of these have been destroyed by draining and other agricultural im. provements, and there now remain but a few small colonies and scattered, or isolated, nesting sites. The earliest known Gullery is that already referred to, which was visited by Bishop Nicholson in his journeying to York in 1702 , when it would appear that a vast colony, of which no trace now remains, was in existence at Thornton Bridge, near Bedale. At Hornsea Mere, in Holderness, large numbers of Gulls bred on an island,* which was in occupation until about twenty years ago, when they were scared away by the planting of the ground with potatoes. Possibly a stray pair of birds from this place tried to nest at Spurn, where an egg was found in a hollow scratching above high water mark, on 27 th July I883, and forwarded by Mr. P. Loten to Mr. W. Eagle Clarke for identification. Another Gullery was on Strensall Common, near York, which decreased rapidly in the last quarter of the past century, being almost deserted before $I 880$; in that year a few pairs attempted to re-establish themselves; nests were built and eggs were laid annually until $I 884$, when about thirty pairs nested, although, owing to the robbery of the eggs, no young were hatched; the year following drainage operations were commenced, and, partly from this cause, together with its proximity to the City, and the additional fact that the ground has been utilised by the Government for military purposes, the colony has been destroyed, and, although for two or three years afterwards a few pairs visited the place, no more attempts were made at nesting. Riccal and Skipwith Commons, about ten miles south of York, formed other interesting breeding resorts of this bird; some years ago the nests were near the high road leading from Selby to North Duffield; afterwards the birds changed their quarters to nearer the

* See Common Tern. 
centre of the Common; in I880 they were fairly abundant, but in I88I extensive improvements were carried out, which broke up the land, although the nesting pond was not directly affected; in that year about twenty nests were built and some young were reared, though the birds seemed to resent the interference with their solitude, and in the following year only three or four pairs appeared. Since then they have nested irregularly; in 1898 they did not lay eggs, and in one or two seasons only five or six pairs succeeded in building. They are, however, protected by Lord Wenlock's keepers, and in Igoo about fifty pairs brought off their young; in I90I, strange to relate, only very few appeared, yet in I902 some twenty-five pairs nested. This species, according to Allis, bred on Goole and Thorne moor before I844, and continued to do so in different parts of that district until I895; here, again, interference with its nesting haunts has caused the desertion of the place; Mr. T. Bunker says eighty eggs were taken by one person in I880. There is no doubt there were colonies of these Gulls in the "Carrs" of east Yorkshire before they were drained; every spring a few birds revisit the scene of their former homes, and often remain until the nesting season.

In the north-west of the county, near the Lancashire border, an attempt was made, about the year I860, to form a Gullery ; several birds built on the edge of a tarn on Newton fell, their efforts, however, were frustrated by robbery of the eggs by farm-hands, and the birds left. Other attempts at nesting, made in I88I-2 in the Aire Valley outside Leeds, were rendered futile by the eggs being stolen as soon as they were laid; these birds have lately become very numerous in the upper reaches of the Aire since the formation of so many sewage farms between Skipton and Bingley. Between I893 and I903 a considerable number bred on Keighley Moor Dam; on one occasion twenty-three nests were counted, but the eggs were all taken and the birds abandoned the place. A statement recording the discovery of an unfledged young one,

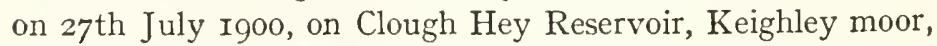
appears in the Naturalist (I900, p. 304), and in the year I904 


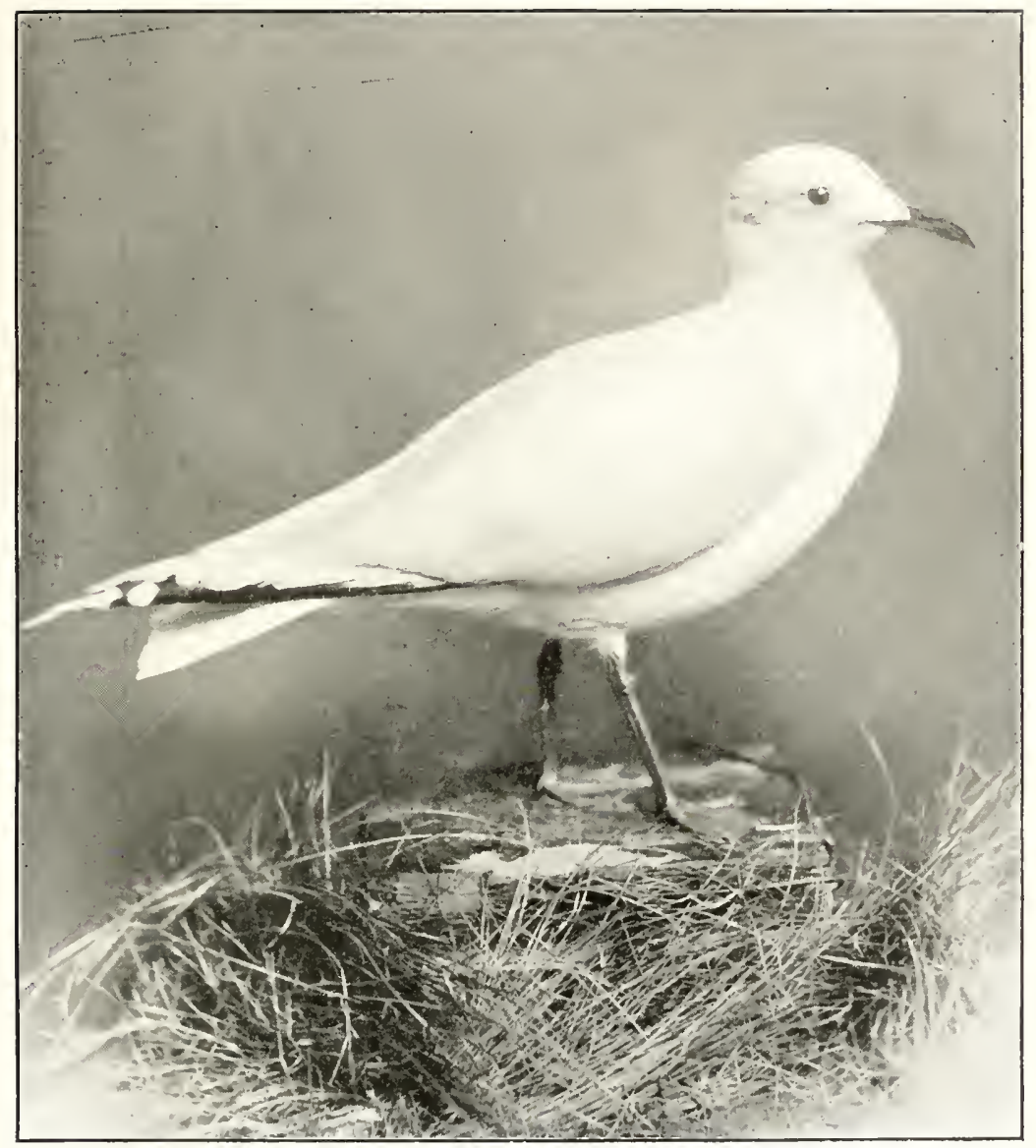

Mediterranean Black-headed Gull.

See page 675. 

a large colony of between twenty and thirty pairs was in existence in a locality protected from molestation.

In Swaledale a small community, composed of four nesting pairs, was in existence at Summer Lodge Tarn until I865, and a few pairs also bred at Punchard Head in Arkengarthdale ; this latter station is probably the one referred to in the Zoologist (1884, p. r39), under the impression that the birds were Common Gulls, and corrected in the same volume (p. I96), the recorder stating that the birds were doubtless Blackheaded Gulls. Another small colony of about a dozen pairs was on Semer Water in Yoredale until about 1897, though, unless protection is afforded them, it is probable that repeated robbery will cause the birds to abandon it as a nesting resort.

Of Yorkshire Gulleries now in occupation, besides that on Skipwith Common, there is one at Locker Tarn in Wensleydale, which was founded about I888, when a single pair of birds nested, and the colony has increased, until in I902 it was composed of about forty or fifty pairs. Another Gullery is situated on the moors between Whitby and Scarborough; it originated about the year I893; in 1902 there were some twenty pairs nesting, but the eggs are constantly robbed, and it is to be feared that the birds will be driven away if persecution does not cease. I am enabled to give an illustration of this place. On the fells of the north-west odd pairs occasionally nest irregularly on the edges of the tarns, the most populous station being on Browsholme Tarn, near Bashall Hall, where several pairs are established; a number breed near Grassington, Skipton, and Oxenhope, and Mr. R. Fortune discovered a new colony in the year Ig04 on a lonely mountain in one of the wildest parts of the fell district.

The Black-headed Gull is an abundant species on the coast in spring, and again in autumn after the young are fledged, when both adult and immature birds resort to the shores of the estuaries; the bulk appear to move southward as winter comes on, returning in the early part of the year. In some severe winters it is extremely numerous on the coast, as in February I888, and December I8go, when, during the prevalence of a hard frost, hundreds frequented the 
beach between Teesmouth and Saltburn, feeding on the edge of the tide amongst crustaceans which were washed ashore in myriads. A few non-breeding birds remain on the coast throughout the summer.

Being an inland nester this Gull is observed away from the tide more frequently than any other of the Laridæ, and has occurred in most parts of the county, generally in the neighbourhood of lakes, reservoirs, or streams; it also associates with Rooks in following the husbandman in ploughing time.

Occasionally odd examples assume the dark hood very early ; one with the black head has been reported in November, two years in succession, in Whitby harbour; whilst at the same place an instance, if it may be so termed, of birds adapting themselves to the advantages of civilization was noticed in January 1903, when a number of these Gulls was observed as late as half-past ten p.m., feeding by the light of the electric lamps opposite the Museum.

The specimen from which Bewick made his figure of the "Red-legged Gull" is this species in winter plumage, and was in the Tunstall or Allan Museum (cf. Fox's "Synopsis," p. 94).

The local vernacular names are many and varied. It was termed Black Cap by Tunstall (1784); Black Cap Mew by Bishop Nicholson (I702); Sea Crow by Tunstall, and also in the Western Ainsty; Pigeon Gull at Spurn and Scarborough; Peewit Gull by Tunstall (I784), Graves (I808), at Spurn and in the East Riding ; Land Maul and Carr Swallow in east Yorkshire ; Black Cap Gull in Wensleydale ; Sharpie, at Bridlington; Tumbler or Tumbling Gull at Redcar (so called from its habit of turning in the air like a Tumbler Pigeon), and Tunney at Whitby.

[The LAUghing Gull (Larus atricilla, L.) is reported to have been obtained near Filey (Tuck, Zool. I876, p. 4960), but this species is not recognised as a British bird. Cf. Yarrell,

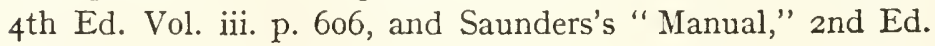
p. 662.] 


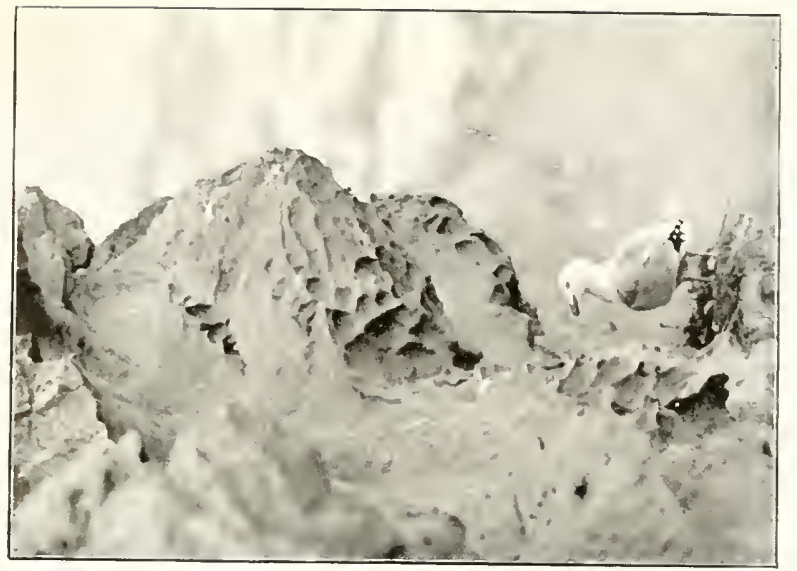

$\vdots$
$\vdots$
$\vdots$

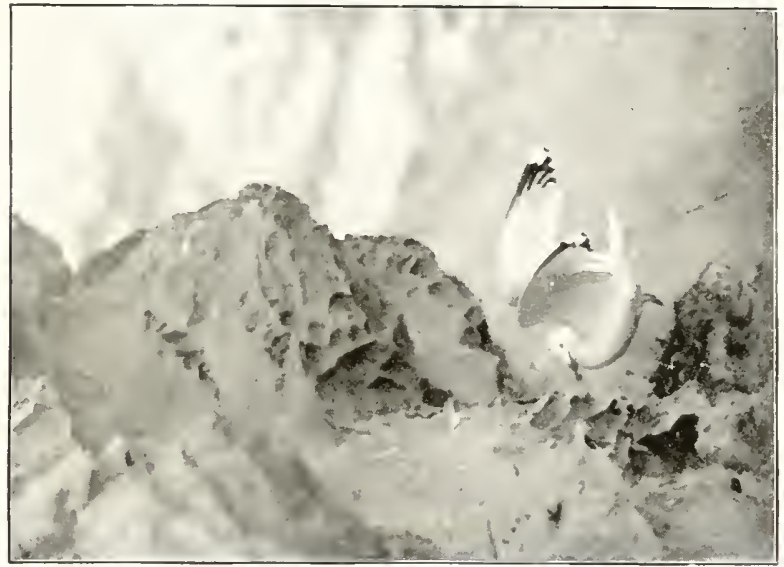

雚

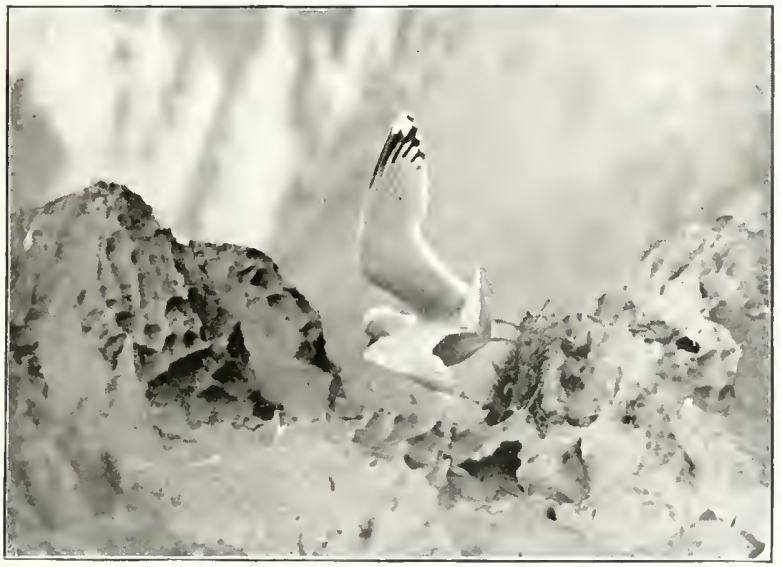

is 



\section{MEDITERRANEAN BLACK-HEADED GULL.}

\section{Larus melanocephalus (Natterer).}

This Gull is resident on the shores of the Mediterranean, and, according to Mr. Howard Saunders's "Manual" (2nd Ed. I899, p. 667), there are only two instances on record of its occurrence in Britain, and indeed one of these is open to doubt.

This species may, however, now be added to the county list, for an adult example, in winter plumage, was obtained on the Yorkshire coast in November 1895, and a figure of the bird is here given.

I have further information regarding this individual, but, unfortunately, have failed to obtain permission from the owner of the specimen to make it public.

\section{COMMON GULL.}

\section{Larus canus $(L$.$) .$}

Winter visitant, fairly abundant; a few immature birds remain in the estuaries of the Tees and Humber during summer.

The earliest known reference to this bird in Yorkshire is in the Rev. J. Graves's "History of Cleveland" (I808), where it is enumerated in the list of birds.

Thomas Allis, I844, wrote:-

Larus canus.-Common Gull-Common on the coast; it is seen rarely near Sheffield; Dr. Farrar remarks that "Near Barnsley the Gulls were occasional visitants, they sometimes remained a day or two, but were generally in transition apparently between the east and west seas, and, as far as my observation extended, invariably from the former to the latter. The Common Gull, Wagel, and Herring Gull were by far the most numerous in these migrations." It is seen occasionally near Leeds, at Hebden Bridge, and York; it also occurs near Huddersfield. A. Strickland says that it is common on the east shore, except at the breeding time, and does not breed on any part of the coast. 
Though its trivial name seems to indicate that it is common, this Gull is not so abundant as some others of the genus, and the statement made in Allis's day holds good at the present time. On the coast it is fairly plentiful in autumn and winter, both adult and immature birds being met with, and in some seasons it is very numerous, especially in stormy weather, and notably so in I877; I883, (in both the Spurn and Redcar districts;) I888, and I892. During the prevalence of strong north or north-east gales, from October to January, immense numbers pass along shore on the Cleveland coast, flying head to wind, or with the wind " on the beam," and going in a north-westerly direction; this passage sometimes continues for three or four days, and in that time many thousands of birds go by. The reasons for these movements of Gulls are not thoroughly understood; they are not merely local, and it seems probable that they are migrations on a large scale. With an easterly gale a movement to the southward is observed, but the numbers travelling in that direction are comparatively few, and these may be local birds changing their quarters.

In the spring the Common Gull leaves the Yorkshire coast for its nesting stations, a few immature birds only remaining during the summer in the river estuaries. The sole instance of the occurrence of an adult example at that period which has come to my notice, was at Redcar on Igth July I903, when I found one washed ashore on the beach. A statement by Mr. Tinkler, that this species bred in Arkengarthdale is not correct, the bird referred to being the Blackheaded Gull (cf. Zool. I884, pp. I39, I96).

In the Wold district this Gull is frequently seen on the ploughed land, where it follows the husbandman in his farming operations, returning to the coast at nightfall in regular formation like a flock of Geese ; every spring, until the breeding season arrives, adult birds congregate on the public common at Beverley. It also occasionally occurs at a distance from tidal waters, generally on inland lakes or reservoirs; Mr. IV. Eagle Clarke reported two at Fewston in June I884; the individuals thus observed are immature birds, and, 


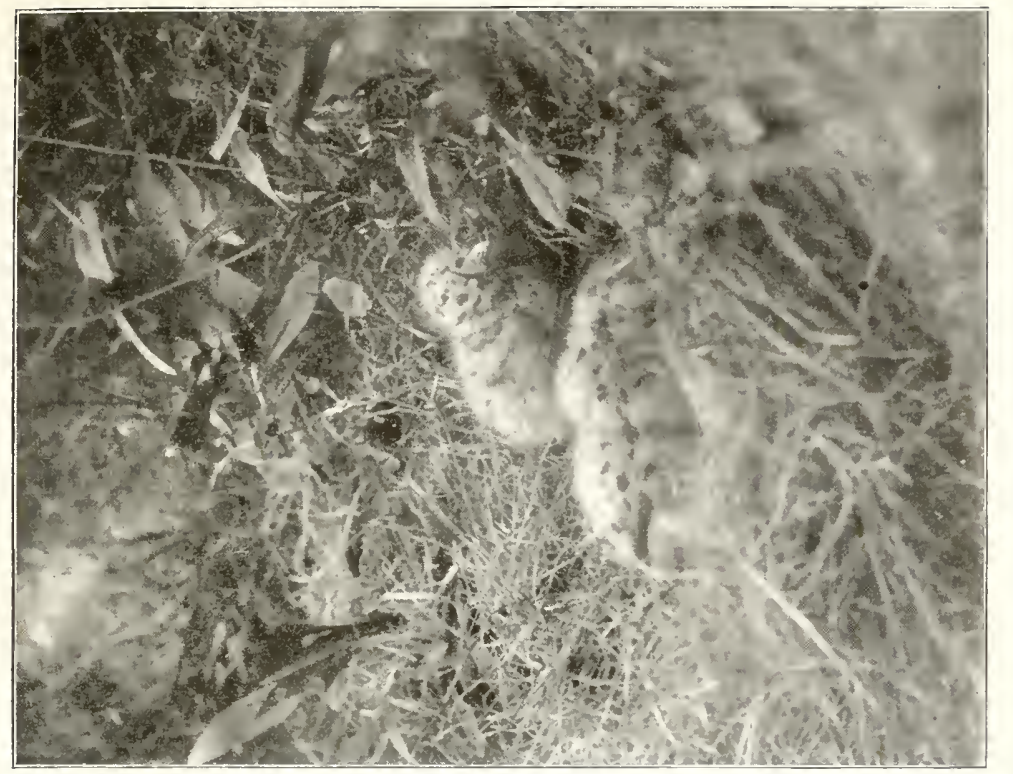

吾

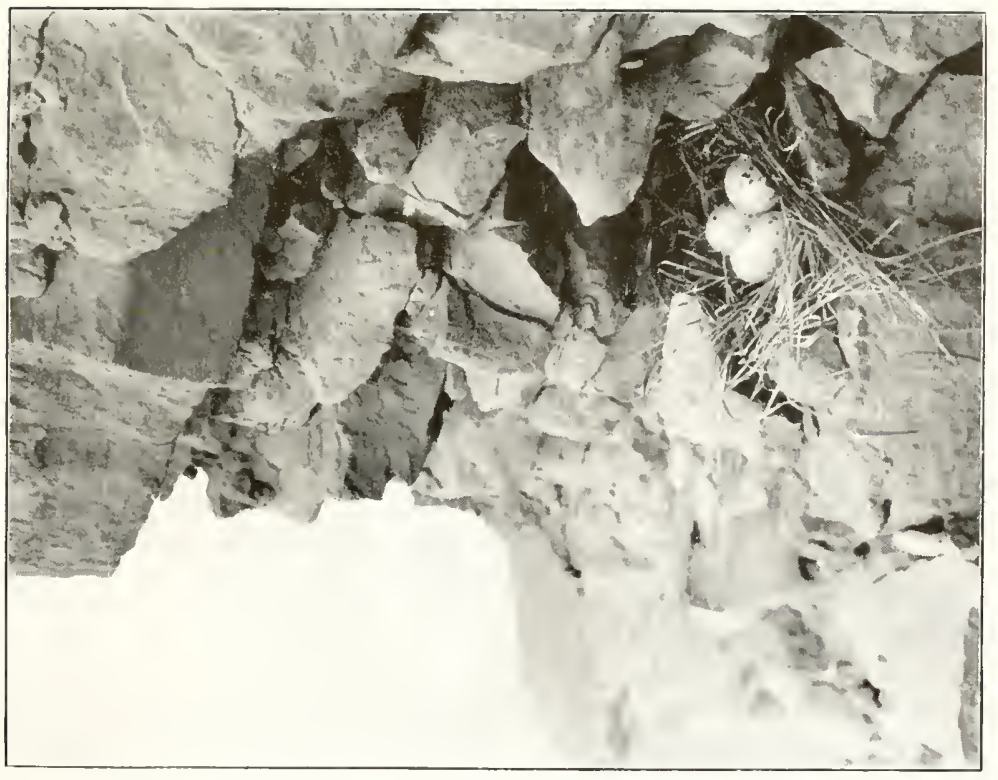

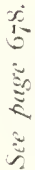



in all probability, are passing from the east to the west coast.

At Masham, on 26th August I889, a curious incident took place, resulting in the capture of one of these birds, which swooped down on a minnow used as a bait by a fisherman, who successfully played and landed it (Field, 3Ist August I889).

The local names are:-Sea Mew, Sea Crow (Western Ainsty), and Pet Maw (Redcar).

\section{HERRING GULL.}

Larus argentatus (Gmelin).

Resident, common; nests on the sea-cliffs from Saltburn to Bempton.

The Cottonian MS. contains a quaint reference to "Huntley Nabbe " [Huntcliffe, near Saltburn], "where the coaste beginnes to rise Highe, full of craggs and steepe Rockes, wherein Meawes, pidgeons, and Sea-fowle breede plentifullye" (Cott. MS. about I604, pp. 20-2I). The Meawes, doubtless, were Herring Gulls, which still have a fairly large colony there, and the quotation given may be taken as the first mention of this as a Yorkshire bird. When Pennant visited Flamborough on 3rd July I 769 , he observed Herring Gulls amongst the multitudes of birds there ("A Tour in Scotland," I77I, p. I5).

Thomas Allis, in I844, wrote :-

Larus argentatus.-Herring Gull-Common on the coast ; obtained about Barnsley; rarely seen near Hebden Bridge; the young frequently met with about Sheffield. A. Strickland remarks that, "Though the scientific names of the Lesser Black-backed and Herring Gulls have till lately been in great confusion and uncertainty, the English names have been perfectly explicit and correctly applied ever since they were accurately defined; but Mr. G. R. Gray of the British Museum has lately done what is likely to revive all the confusion that formerly existed about them by naming the specimens of the Lesser Black-backed Gull 
as the Herring Gull and the Herring Gull as the Silvery Gull, a name not known for it in any part of the country. In applying to Mr. Gray why he had done so, he said it was upon the authority of Latham; now the truth is Linnæus described the Lesser Black-backed Gull, but did not describe the Herring Gull, but Latham described the Herring Gull, but did not describe the Lesser Black-backed Gull, and therefore cannot be quoted for the name of a bird he [did] not describe : I hope Mr. Gray will see the evil of this mistake."

Another early allusion to the Herring Gull in Yorkshire is found in Jesse's "Scenes of Country Life" (I844, p. 353), which is highly interesting, as being the first notice of this bird nesting in confinement. It relates to two Gulls of different species which, contrary to their habits in a wild state, interbred and nested in an enclosure at Wentworth House, Yorkshire, and runs as follows:- "The male was a Black-backed Gull, and the female a Blue-backed Gull, presumably the Herring Gull. One egg only was laid, on which the two birds took it in turn to sit. The young bird when hatched was covered with down, which changed to a spotted grey."

The Herring Gull is a common resident, nesting in large numbers on the cliffs from Saltburn to Robin Hood's Bay; a few pairs breed at Peak and Ravenscar, and a single pair has occupied a site in Burniston Bay, north of Scarborough, since I899. It is abundant on the Gristhorpe cliffs, between Scarborough and Filey, where a hundred and eighty eggs were taken on I3th May I899, and seventy-six in one day in May Igoo; on the famous range of chalk cliffs south of Filey it is not so plentiful as a breeding species, being driven away by constant persecution, though one or two pairs returned to nest in 1873 ; there was a nest at Bempton in 1876 , and odd pairs attempt to breed from year to year, but the " climmers" do not encourage this bird owing to the injury it does to their trade by carrying off the Guillemots' eggs ; it occasionally nests near the "Dor" and Danes' Dyke; a brood was reared there in Igoo, and eggs were taken in Igo2, I904, I905, and I906, whilst in the year I902 two nests were found on the Speeton range. The chief colonies in the north of the county are at Boulby, Staithes, Kettleness, and the 


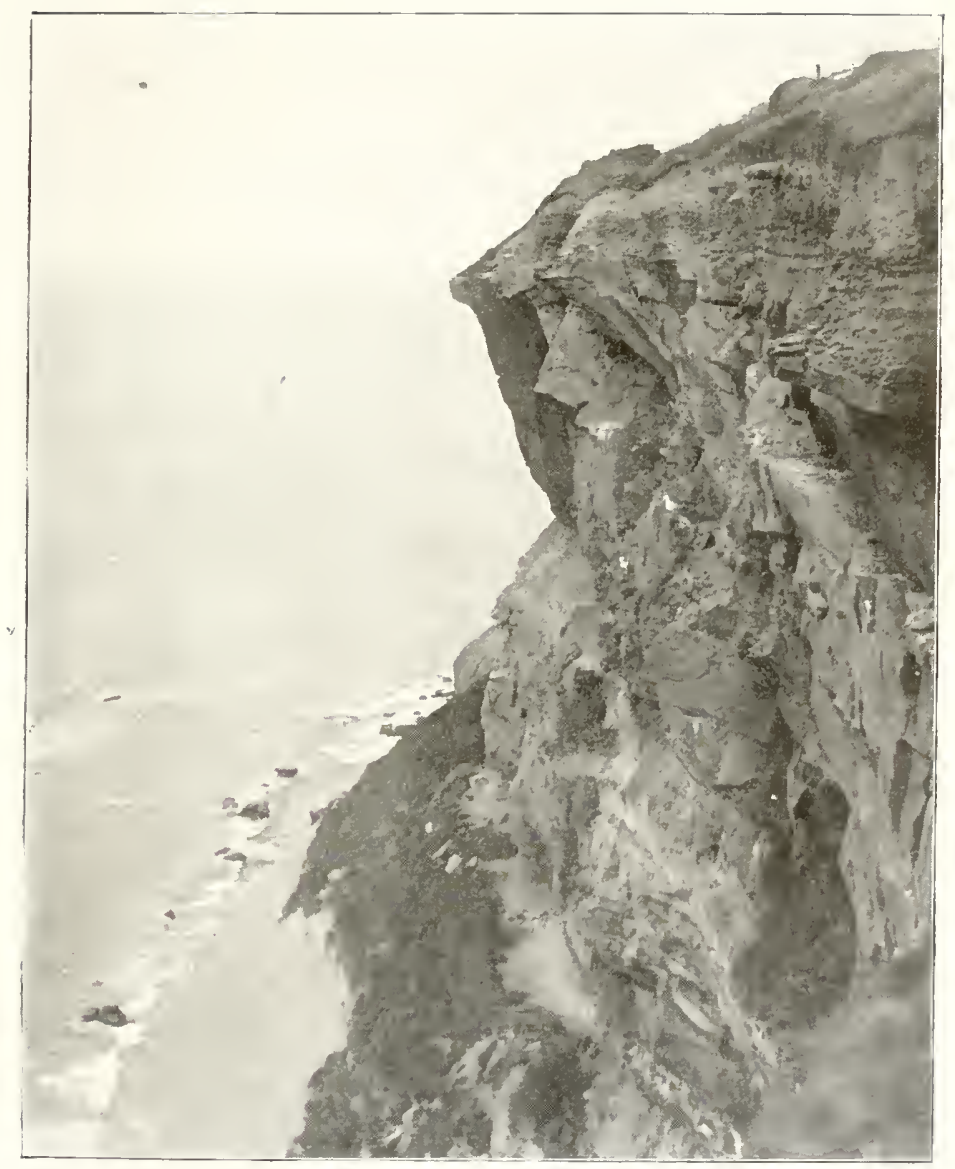

Cliffs near Whitby High Lights, haunt of Herring Gull.

R. Fortune.

See page 670. 

Whitby High Lights, where several hundred pairs breed in comparative security, although the birds nesting at and near Gin Hole (Staithes) were much harried by foxes between the years I895 and I900; their enemies had access to the ledges where the nests were placed, whence they carried off both eggs and young birds. I have found eggs partly buried in the potato plots at the top of the cliffs where the foxes had taken them, and this persecution caused the birds to remove their quarters nearer the west part of Boulby, at which place in 1902 they were more numerous than had ever before been known, whilst the "Gin Hole" locality was almost deserted. In Igoo two pairs appropriated sites at the highest part of the cliff, 660 feet, and have nested there since that year. At Kettleness the species is as abundant as ever, two or three hundred pairs occupying that station, at which upwards of a thousand eggs were gathered by Whitby fishermen in the season of I903; the Huntcliffe colony also maintains its standing of about twenty to thirty pairs.

The Herring Gull pairs very early in the year, in mild seasons so soon as the first week of January, and it resorts to the nesting cliffs towards the end of February or beginning of March. The young are on the wing in the first or second week of July, and they and their parents leave the cliffs about mid-August.

In the autumn a considerable addition is made to the ranks of the resident stock by immigrants from other parts, and in strong north and north-east gales they are observed passing up the coast in continuous flocks, sometimes for days together ; a similar movement is noticed at Spurn and Flamborough, the direction of flight being usually from east to west. A large proportion of immature birds remain throughout the summer in the estuaries of the Tees and the Humber.

The Herring Gull is occasionally met with in localities far removed from its accustomed haunts, having been obtained in the centre of the county, and in the dales of the north-west; possibly these are storm-driven birds or else are in transit from one coast to the other. In the neighbourhood of the coast line it visits the tillage land, often consorting with Rooks,

vol. II. 
following the farmers and taking toll of the worms and grubs unearthed by the ploughshare; while in the "Carrs " of East Yorkshire, in wet seasons when much land is flooded, it is frequently observed feeding on worms which have been drowned by the flood water.

A pair of Herring Gulls, kept in a garden at Redcar, nested in the spring of I905; the female laid one egg, which she diligently sat for a month, but it proved to be infertile.

Although this Gull is an omnivorous feeder, it is often reduced to great straits in winter weather; during the hard and protracted frost in I 895 I procured one which disgorged a starfish; and in February I906, I watched two or three of these birds fighting for possession" of a thirteen-rayed starfish, which was eventually eaten by the conquerer in the fight. Mr. W. Eagle Clarke, when staying on the Eddystone Lighthouse in October Ig0r, noticed this species feeding on seaweed.

The disparity in size between different examples of the Herring Gull seems almost calculated to make a specific distinction between the extremes; an immature bird shot on Ist November I900, at Redcar, measured 27 inches in total length, the wing from carpal joint 18 inches, expanse of wings 52 inches, tarsus 3 inches, middle-toe 3 inches; at tirst glance it looked like an immature Great Black-back, the bill measuring $2 \frac{3}{8}$ inches, and being quite as massive as in that species, but on examination of the back several blue feathers were found amongst the mottled grey plumage, thus leaving no other conclusion than that it was an abnormally large specimen of L.argentatus, and perhaps a third year's bird.

Of Yorkshire varieties there is but one instance on record, viz., a white immature example, shot at Filey on 26th September I884, by Mr. J. Fountain; the plumage, instead of being speckled grey, as usual, was pure white.

The only local name known to me is Blue-backed Gull, which is used in the Cleveland district. 


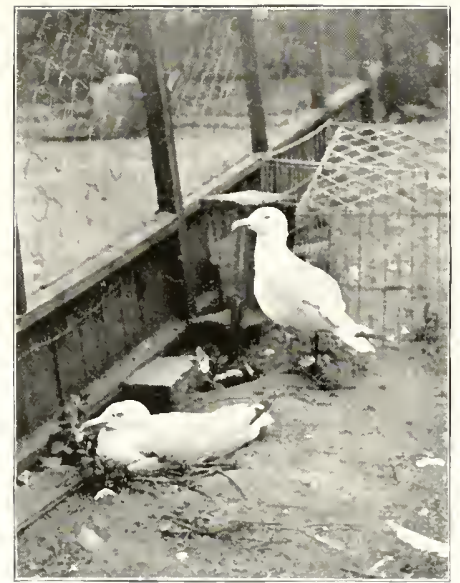

Herring Gulls Nesting in Captivity at Redcar.

T. 11. Falleat.

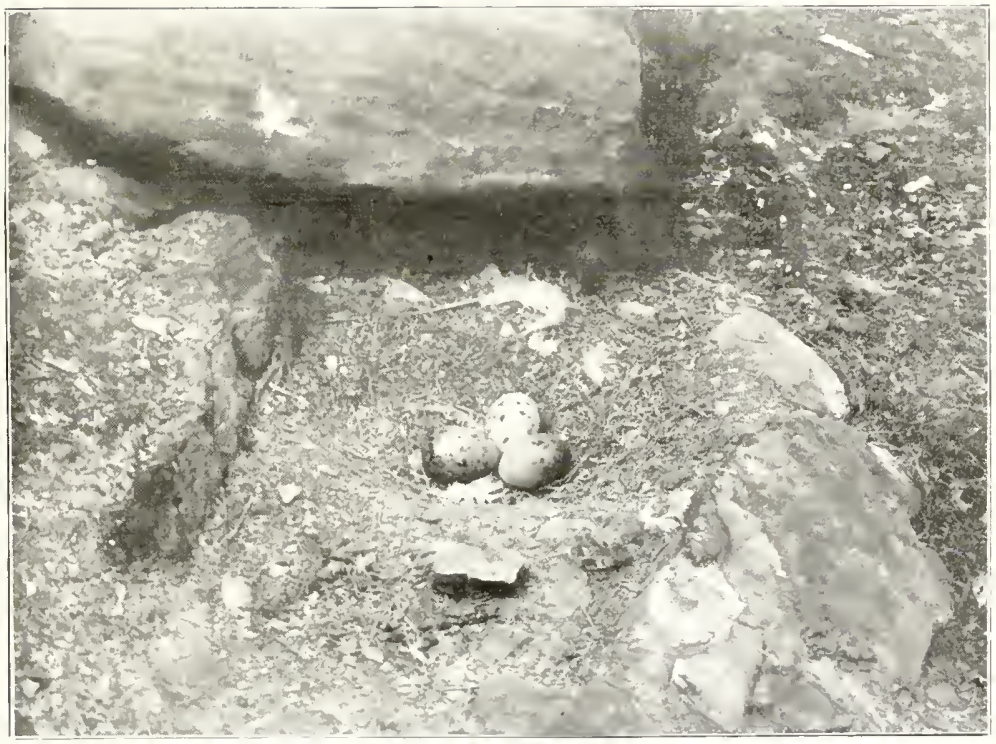

Nest of Herring Gull at Kettleness.

T. H. Nelson. 



\section{LESSER BLACK-BACKED GULL.}

Larus fuscus (L.).

Resident in limited numbers, also winter visitant, common from autumn to spring. Breeds sparingly in one or two localities. Immature birds remain off the coast during the whole of the year.

Probably the earliest published notice of this bird in Yorkshire is contained in the list of birds in the Rev. J. Graves's "History of Cleveland" (I808).

Thomas Allis, in $\mathrm{I} 844$, wrote :-

Larus fuscus.-Lesser Black-backed Gull-Met with rarely near Leeds; young birds not infrequently obtained about Sheffield; F. O. Morris reports it as common on the coast; A. Strickland remarks that "It is not an uncommon bird on this coast, but it does not breed on any part of the coast here, though in many places it breeds in company with the Herring Gull "

This Gull is not so common on the Yorkshire coast as the preceding species, but is fairly numerous in autumn and winter when the young and old birds leave their nesting quarters and assemble on the fishing grounds. In the Humber district it used to be considered rare, though it has greatly increased in numbers of late years. On the coast of the North Riding it occurs most abundantly in spring when on migration to its breeding stations further to the northward, and it is not so frequently met with in winter. The strange movements of large bodies of Gulls, referred to in the Common and Herring Gulls, are to be remarked of this species also ; on the north Yorkshire seaboard both the adult and immature birds are often noticed during autumn and winter in north and north-east gales, for days together, passing in immense numbers to the north-west, and sometimes associated with Herring Gulls; such a passage took place on 2oth-23rd October I884, at Redcar, and another on the I5th of the same month in I887. At Flamborough and Spurn, with south. west gales, they fly in a southerly direction; many were observed in September I880, and from 25th to 28th September I884; an estimate formed of the numbers passing a given 
point reached the total of 280 in an hour, and this movement lasted for ten hours a day for the space of four days.

As spring approaches, and the nesting season draws near, many adult birds are daily seen in April and May, going northwest en route for their breeding places on the Farne Isles, and if north-west winds should prevail at this period they fly along the margin of the sand-hills, where their yellow bills and black and white plumage are conspicuously thrown up against the blue of the sky.

Although generally considered as a winter visitant only, the Lesser Black-backed Gull was reported as having nested on the Yorkshire coast, between Scarborough and Filey, so long ago as 1876 , though the recorder was very doubtful as to the authenticity of the report (Tuck, Zool. I876, p. 4960); in the summer of I884 Mr. Thomas Carter saw a pair of these birds near Filey, and the year following had what were alleged to be genuine eggs brought to him by a cliff-climber, who averred that he had seen the bird sitting on the nest. Mr. Carter appears to have had no doubt as to their genuineness, although he did not see the birds nor the nest whence the eggs were said to have been taken; the statement of the climber was not considered to be satisfactory, and, after careful consideration, I have come to the conclusion that the evidence produced in support of the supposed occurrence is incomplete. I am quite aware that this species is frequently seen passing along the coast near Filey from the end of April throughout summer, but the birds do not go into the cliffs in a manner which suggests they are nesting, their movements having more the appearance of a migration. At Bempton, on 28th June I902, I saw fifteen old birds pass along the cliff sides, going south; and on I8th July Igo4, six adults flew past in the same direction. Therefore, until further proof is adduced, the Filey breeding record remains unproven (op. cit. I 884 , pp. 438, 485; and I885, pp. $26,27,346,388$ ).

On the northern portion of the coast, however, I have abundant proof that this Gull nests sparingly in one or two localities near Whitby, where there are also large colonies 


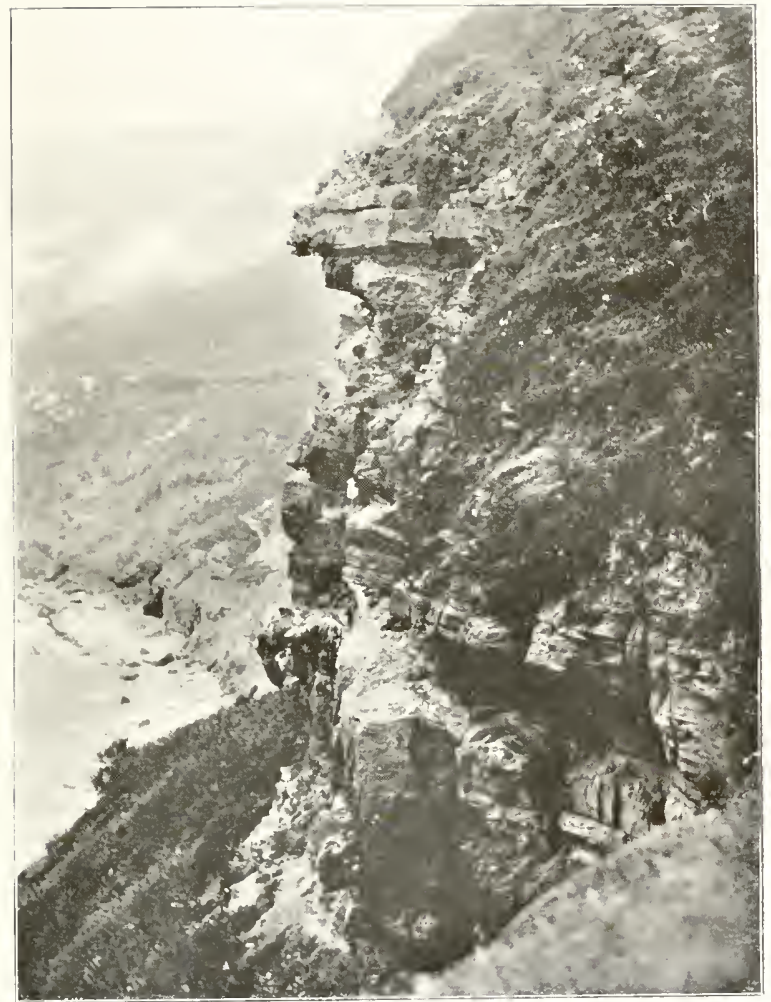

Kettleness; the nesting place of Herring and Lesser Black-backed Gulls.

T. H. Nison.

The bird in the centre of the picture is a Lesser Black-back. Si'e page 6s.3. 

of Herring Gulls. On the occasion of my first visit to these cliffs in 1878 , whilst the coast railway was in process of construction, two pairs of Lesser Black-backs were seen, and on every visit since then one or more pairs were to be noticed, generally on an inaccessible part of the rocks; in 1892 three pairs were observed, one of them undoubtedly nesting, and subsequently, having first located the nest, containing three eggs, I succeeded in taking a photograph which is here reproduced; both birds were present, the female was seen on the nest, and the male was perched on a boulder close at hand; two other pairs of birds had nests, but they were out of reach, though I was successful in photographing one of the birds on a ledge. In July I903, I saw a pair of these Gulls at a nest in which the young were hatched and fully a week old; and on 6th June I904, I saw two pairs on the nesting station. At Boulby, north of Staithes, a pair of adults may usually be seen in the breeding season, but as the ledges are very difficult of access, I have not as yet been able to satisfy myself that it breeds there.

Inland the Lesser Black-backed Gull has occurred in the centre of the county, as also in the remote dales of the North and West Ridings, but not so frequently as the Herring Gull, and, unlike that species, it is not often observed on the ploughed lands.

A case of interbreeding with the Herring Gull is recorded in Jesse's " Scenes of Country Life," particulars of which will be found under the heading of the latter species.

The local names are:-Lesser Saddle-back, and Blackback, in general use. 


\section{GREAT BLACK-BACKED GULL.}

Larus marinus (L.).

Winter visitant, fairly common, arrives on the coast in autumn and departs again in spring.

Probably the first Yorkshire mention of this fine bird is that by Thomas Allis, written in I844:-

Larus marinus.-Great Black-backed Gull-Occurs at times about Huddersfield and Barnsley; it is common on the coast.

This, the largest of the British Gulls,. is a winter visitant to Yorkshire, making its appearance after the nesting season, accompanied by the young birds, and departing for its breeding quarters again in spring. Some of the immature birds remain throughout the year.

It is fairly abundant on the coast and in the Humber and Tees areas, both in the immature and mature stages, and is known as one of the most voracious feeders amongst the frequenters of the shore. One, procured on the sands at Redcar in my presence, had made its last meal of a Redshank, that had been swallowed whole; another, at the Teesmouth, disgorged no fewer than six full-sized herrings, two being quite fresh; yet another, an immature bird killed at Bridlington, in January I895, had in its stomach a Little Auk, which was so slightly damaged that it was preserved by a taxidermist (Nat. I895, p. I2I).

Like the two preceding species, this one is noticed in stormy weather passing along the coast in those strange movements of Gulls which are so little understood; sometimes for several days together they may be noticed in small bodies, composed of both young and adults, their powerful pinions enabling them to overcome the force of the fiercest gales. On 23rd October I88I, and for several days previously, with strong easterly gales, there was a great passage of mature birds at Redcar, as many as a hundred going by to the northwest in the course of one day; a more extensive migration than had been known for many years (Third Migration Report, 


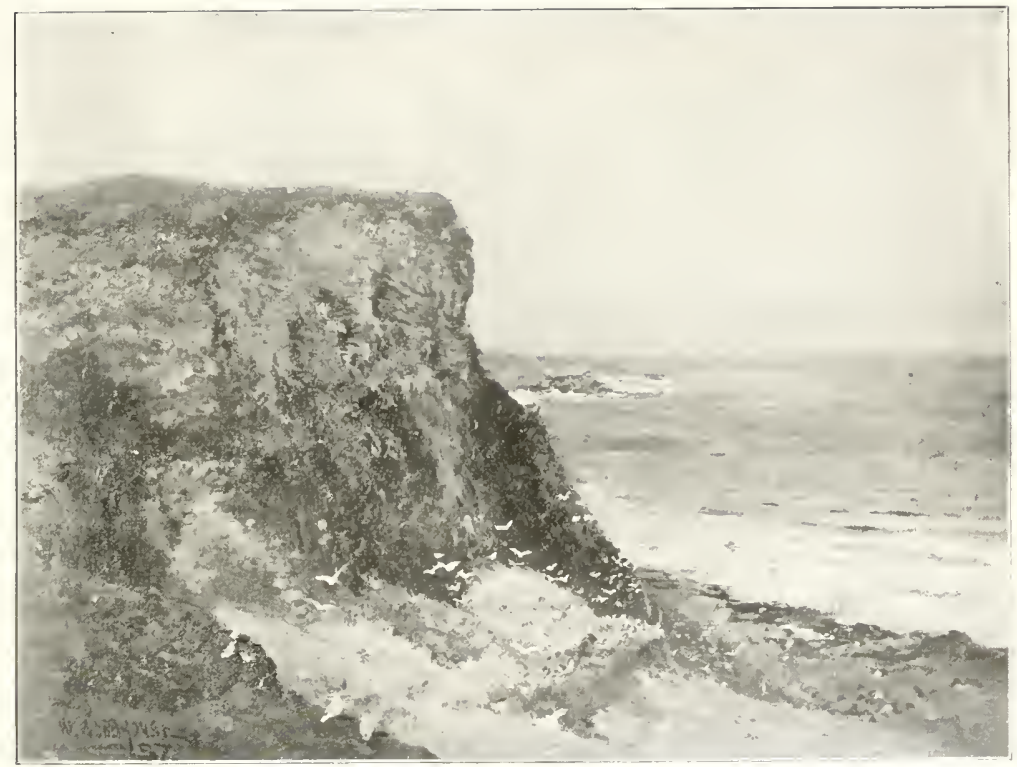

Kettleness; the nesting place of the Herring and Black-backed Gulls.

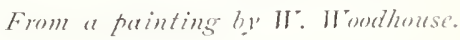

See page 68: 

p. 36). Another strong migration took place on $x 7$ th October I 898 , with a north-east gale. In spring also this gull is noticed moving northward at the same time as the Lesser Black-back is observed on passage towards the nesting grounds, although, as is well known, there is no breeding station of this bird on the east coast. The late J. Cordeaux's remarks as to its former nesting at Flamborough (Zool. I864, p. 9247) are not supported by any evidence that I am aware of.

The Great Black-back is not so common as some others of its genus away from the coast, but has been met with in the south and centre of the West Riding, chiefly on sheets of fresh water, and occasionally occurs in the valleys of the Aire, Nidd, Ure, Swale, and Tees.

Individuals vary greatly in size; I obtained an adult female on I2th November I875, which measured thirty-one inches from bill to tail, and whose wings extended to the width of six feet. George Mussell, the Middlesbrough taxidermist, is of opinion that, as this bird advances in age, the pink tinge of the legs and feet becomes fainter until those parts are almost colourless; an example examined on 6th January I902, had the legs and feet nearly white, while the spots on the head and neck were very faint; this, according to the above-mentioned theory, indicates great age.

Local names :-Black-back, in general use; Black and White Gull ; Saddleback, at Redcar ; Black-backed Hannock, at Bridlington, and Wagel Gull, applied to the immature bird.

\section{GLAUCOUS GULL.}

Larus glaucus (Faber).

Winter visitant on the coast; immature birds are met with every season, but not numerously, except in very severe weather; mature specimens are rarer.

The first allusion to this bird in the county is found in Thomas Allis's Report of I844, thus :- 
Larus glaucus.-Glaucous Gull-F. O. Morris reports one shot at Rossington Warren some years ago; R. Leyland says the Gulls and Terns may be sometimes seen to alight about Halifax, but their visits are so rare and so short as to be unworthy of notice; A. Strickland observes, "Mature specimens of this bird were, as far as I can ascertain, quite unknown on this coast until the severe winter of 1830 , when considerable numbers were to be seen on the coast, and many were procured; I am not aware that they have been seen since, but the young birds, called here the Cream-coloured Gull, are not infrequent in winter, and a few are generally killed every year."

This northern Gull, the "Burgomaster" of the Danes, is a winter visitant to the Yorkshire seaboard, occurring not infrequently in the immature plumage, from October to March, at most of the coast stations between the Tees and the Humber; in some years it appears in considerable numbers, as in $\mathbf{I} 830$, according to Allis, and in I875 (Tuck, Field, Ist January I876).

Adult examples are rarer, though not uncommonly met with a few miles out at sea, in severe winters. I have information of upwards of thirty occurrences, some of the data being as follows :-

On the Yorkshire coast, several in 1830 and 1875 .

Kilnsea, Spurn, one on 13 th November 1888.

Bridlington, two in $1846-47$, one in 1866 , one in $187 \mathrm{I}$. Flamborough, two in 1873 , two in 1877 , one in 1887 .

Filey, two in 1874 , one in 1875 .

Scarborough, one in 1853 , one on rgth January 1867 ; one, September I887; some, autumn 1889 .

Whitby, one before I880.

Redcar, one on I9th December 1878 (in Mr. E. B. Emerson's collection); one on 8th January I902 (in my collection); one on 8th April I903, seen on the beach in front of my house. I have seen two other specimens at Redcar, but no particulars respecting them are forthcoming.

Being a true sea-bird it is of very rare occurrence away from the coast; one is said to have been taken at Rossington Warren many years ago (fide Allis), and, so far as records show, this seems to be the only instance of its appearance inland.

This species is, like its compeers, of a ravenous nature, 


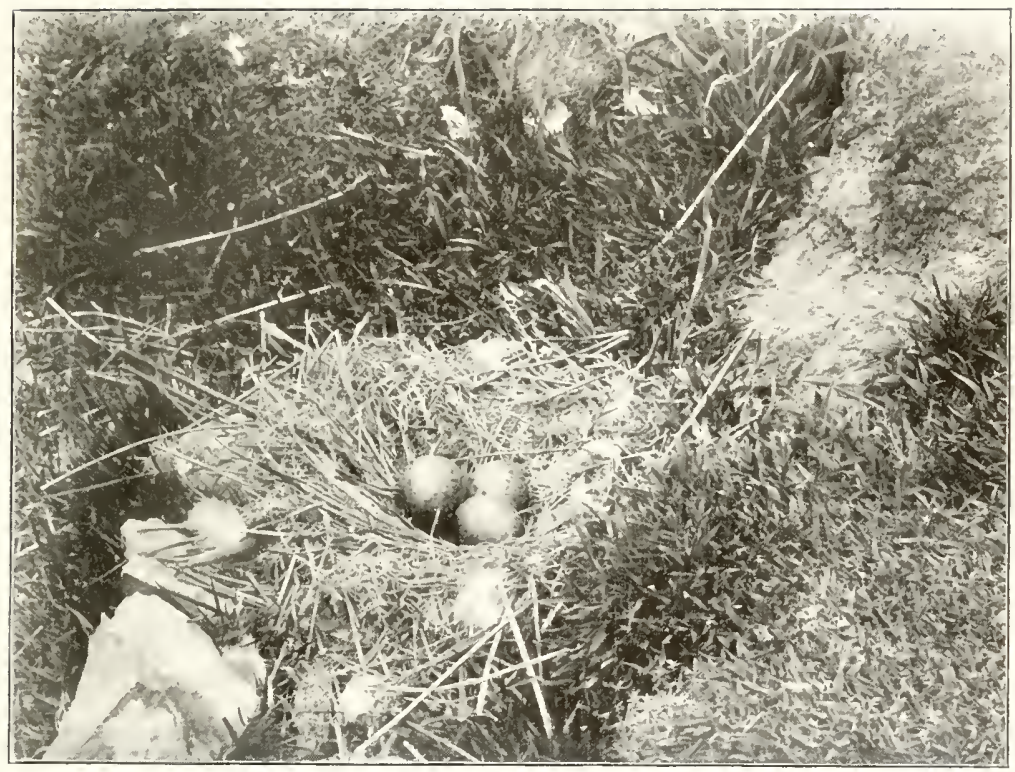

Nest of Lesser Black-backed Gull at Kettleness.

T. H. Nilson.

Sie' page 683. 

and has been known to attack and kill wounded birds left floating at its mercy on the waves; in January I895, one was seen to pounce down upon and devour a Little Auk, which had been shot from Filey Brigg.

Local names :--Iceland Gull ; Cream-coloured Gull, applied to immature birds. Mallemoke, or Mollemawk, sometimes thus called by sailors or fishermen, doubtless taken from Norwegians, and used in error for Fulmar (Hogg, Zool. I845, p. II85).

\section{ICELAND GULL.}

Larus leucopterus (Faber).

Occasional visitant to the coast in winter, when immature birds are met with at irregular intervals ; the adult is extremely rare.

The Iceland Gull is an inhabitant of the Arctic regions, and an occasional winter visitant to Yorkshire, though, doubtless, it is of more frequent occurrence than the few records imply.

The earliest published record of its connection with the county is found in Yarrell's "British Birds" (I843, Vol. iii. p. 46I), where an adult specimen is reported as taken in Yorkshire. This is also noted in Thomas Allis's Report, of 1844 , as follows :-

Larus icelandicus.-Iceland Gull-W. Yarrell in his "British Birds" reports an adult specimen taken in Yorkshire; the young birds are occasionally killed on the east coast in winter, but the mature ones are very uncommon.

Adult examples are extremely rare, there being only four captures recorded or communicated. The first is that mentioned by Yarrell in I843, as taken on the Yorkshire coast, particulars of which are, unfortunately, not now procurable; three others passed through the hands of $\mathrm{Mr}$. Machen of Bridlington, one of which was procured in March, before the passing of the Sea-Birds Protection Act; a male was obtained on 28th February I887, by W. Machen, 
and another in January 1896 ; while a fifth occurrence was noted by the late J. Cordeaux, who stated that he saw one at Flamborough on 8th May I894 (" Birds of Humber District," I899, p. 36).

The instances in which the immature birds have been chronicled are :-

In 1846-47, one at Bridlington (Zool. I847, p. I692).

Scarborough, on 8 th December 1854 , one taken alive in the harbour (op. cit. I855, p. 4560).

One at Redcar in the winter of I854-55 (Nat. I854-5, p. I44).

Yorkshire coast, one in possession of J. Malcolm, Esq. (Morris, "British Birds," I857, vi. p. I77).

Scarborough, one, I5th January I867 (Zool. I867, p. 637).

Flamborough, one on I2th October I867 (tom. cit. p. IOIO).

Bridlington, a male on I5th December I870 (op. cit. I87 I, p. 2488).

Same place, one at Ellotson's on I8th February I87I, killed a few days previously by a ploughman (tom. cit. p. 2527).

Easington, near Spurn, on 23rd January I883 (P. Loten, in litt.).

Whitby, on 2nd January I885, in the local collection at the Museum (Stephenson MS.).

Bridlington, two in 1885 (Machen, oral communication).

Scarborough, one on 8th November I892 (Field, I2th November I892).

Flamborough, one on 2nd January I893; several on I8th November I893 (Bailey MS.) ; one on 8th May I894 ("Birds of the Humber District," p. 36).

Scarborough, one at Scalby Ness on Ist January 1899 (W. J. Clarke MS.).

Teesmouth, one on Ist February I902, in the possession of Mr. J. Watson, Coatham.

Mr. W. Eagle Clarke is of opinion that the reported Iceland Gulls, Spurn, December I882 (Zool. I884, p. I80), belong to the larger species, the Glaucous Gull, with which this bird is frequently confused, both being known to professional gunners and fishermen as Iceland Gulls, or, in the immature stage, Cream-coloured Gull. 


\section{KITTIWAKE.}

\section{Rissa tridactyla (L.).}

Resident, breeding on the cliffs at Bempton and Speeton. A great increase of numbers takes place in autumn.

Pennant was the first to notice the Kittiwake in Yorkshire, and thus alluded to its occupation of the Flamborough Cliffs"It inhabits the romantic cliffs of Flamborough Head, where it is called Petrell" ("British Zoology," Vol. iv. I770, p. 26; and in his "Tour in Scotland" (I77I, p. I5), he again referred to it at Flamborough (see Introduction).

Thomas Allis, in I844, wrote as follows :-

Larus tridactylus.-Kittiwake Gull-Common on the coast; it occurs near Huddersfield, also about Sheffeld, and is occasionally seen near York. A. Strickland says "They breed in very great abundance on the rocks [cliffs] at Flamborough, but leave the country soon after, and are never seen here in winter."*

This graceful Gull is resident in Yorkshire, nesting in considerable numbers on the cliffs of the Flamborough range at Bempton and Speeton. In the first half of the past century it was extremely abundant there-Charles Waterton, in I834, found the nests so numerous as totally to defy any attempt to count them-but, unfortunately, a demand arose for the beautiful feathers forming its plumage, and thousands were slaughtered to meet the exigencies of fashion; it has been asserted that a single gunner made from $£$ I 5 to $£$ I 8 per week, during the season, for feathers, whilst in one year four thousand birds passed through his hands, being sent to London plumassiers. The time chosen for shooting was just as the birds were building their nests, the lining for which is generally composed of grass or roots collected on the cliff tops, or in the fields adjacent. I have seen the birds busily engaged plucking the grass on the edges of the cliffs, and the veteran climber, Edward Hodgson of Buckton, can remember when a

* Strickland was in error in defining the position of this bird, and especially so when he stated they are " never seen here in winter." 
whole field was cleared by the Kittiwakes of " twitch," which had been worked out of the land, between Saturday and Monday. The question formerly used to be asked, "Has thou been up at Cliff ; is Kitts carrying ?" by men who wished to know if it was worth while going out to the slaughter. Excursionists and gunners from inland towns were also guilty of wanton cruelty in shooting the poor birds while nesting, the young being left to perish on the cliffs, and there was a danger of their extermination, until the passing of the Seabirds Preservation Act of I869 put an end to the butchery. Now the numbers of nesting birds are gradually increasing, although, where one nest may at present be seen, there used formerly to be half-a-dozen, and the eggs were then sold at the rate of four or five for a penny.

The Kittiwake arrives at the breeding quarters at Bempton and Speeton at dates varying from the I2th of March, which is the earliest I have note of, up to the third week of April. The method of climbing for Seabirds' eggs, described under the heading of the Guillemot, is applicable to this species also. The first clutches consist of three in number, and are laid about the last week in May; if these are taken the bird lays again, but, as a rule, produces two only as the second clutch. W. Wilkinson, the Bempton cliff-climber, has frequently taken eight eggs from one nest : first three, second and third clutches of two each, and for the last laying one only; he has very rarely known nine laid by one bird, and, in the instances where this has occurred, the second set has consisted of three. The intervals between the laying of the clutches is practically the same as in the case of the Guillemot, about fourteen days, or, if the eggs are incubated, the time is extended to eighteen or twenty days. Occasionally varieties are found of a pale green colour, entirely spotless; a clutch of this type was brought up from Bempton cliffs in June I902, while I was present. In the event of the bird being obliged to produce a second clutch the first egg is at once sat on, consequently it may thus happen that eggs from the same nest are in different stages of incubation, and in July I904, I noticed young in variant degrees of growth in one nest. If the nest 
should be destroyed, or knocked off the ledge, as sometimes occurs in the climber's efforts to reach the eggs, and there is not sufficient time to construct another nest, the bird may lay again on the bare rock. The young, "pen-feathered," have been seen as early as the 3rd of July.

In autumn vast numbers of old and young birds, many of them migrants, assemble round the Flamborough Headland, and at other parts of the coast, attracted by the shoals of young herrings on which they feed; at these times one of the most interesting sights for an ornithologist may be witnessed at sea on a calm day in late autumn. One or two light-winged forms will be observed gracefully gliding in mid-air above the sea, when, its attention arrested perhaps by a shoal of sprats, one suddenly swoops down and snatches a fish from below the surface. Instantly there is commotion; with screams and swoops the others dash down to take their share of the prey; then more silvery wings are seen glancing in the sunlight, hurrying in from all quarters of the compass, and in the course of two or three minutes there is a crowd of shrieking, excited birds wheeling around where, ertswhile, the only sound to be heard was the lazy dip of the oars gently propelling the boat onwards. Unfortunately, this habit of the Kittiwake was taken advantage of by shooters, who used to throw a dead bird in the air in order to attract any living ones which were passing by, and as they were shot others came to the scene, and so the slaughter went on.

In 1877 Kittiwakes were very numerous off Redcar, as also in $1882-3$; 1884 ; in 1892 (all along the seaboard) ; and also in 1893 . The migratory movements noted in connection with other species of Gulls may be observed in this also, and in north and north-east gales great flocks pass along shore to the north-west, whilst in east or south-east winds a southward passage takes place. On Ist November I888, many thousands were going south; in October I892, there was a great flight to the north-west; while in October I896, many were going south off Flamborough, and later, with a change of wind, they were observed to be moving northward.

In mid-February I892, I noticed a vast assemblage of 
these birds about a mile out at sea off Redcar, the weather being calm and hazy; on procuring a boat to ascertain the cause of this great congregation of Gulls, many were found to be floating on the sea, dipping their bills into the water, while others were flying overhead, every few moments dashing down to pick up some object from the surface; two or three specimens were procured for examination, when it was discovered that their mouths were full of small crustaceans, with which the sea was literally alive.*

The Flamborough fishermen have told me that, when they are shooting their long lines, Kittiwakes sometimes seize the bait, and are dragged under water, striking examples of " the biter being bit." I have a note referring to an instance of one coming so close to a Redcar fishing-coble that one of the men caught the bird by one wing as it hovered near.

Inland the Kittiwake is only an occasional straggler, but has been reported from various localities in the West Riding; it has occurred rarely in some of the remote dales, and one was noted in April I880, at Skipton, which flew against a chimney pot and broke its wing. In the East Riding it is very seldom observed away from the coast, and then only occasionally on flooded lands.

Yorkshire examples of variation in plumage are rare; one was taken near Flamborough Headland on 23rd October I886, the plumage of which was entirely white, with the exception of a little fawn colour on the wing coverts, with a deeper fawn where the black should be on the primaries. Another white specimen was obtained, also at Flamborough, by Thomas Leng, four or five miles south of the Headland, on 15 th November 1887 ; it was nearly pure white, the outer margins of the primaries and the tips of the tail feathers being light drab colour. This bird was preserved by Mr. M. Bailey.

The local names are various. The usual English appellation becomes Kitti-ake at Flamborough and Bempton, in the

* Examples of these crustaceans were afterwards subinitted to the Rev. Canon A. M. Norman, who determined them as Euthemisto compressa, a species new to British seas. (See Naturalist, June I892. pp. I75-176.) 
same district being shortened to Kit, Kitty, or Kittie. Petrel is also an old name used at Flamborough and referred to by Pennant in 1770 , while old residents in Flamborough and Bempton can remember when this term was in actual use. Annett is a name used in Graves's "Cleveland " (I808); and Pet-maw is a Redcar term. In the Humber district one of its names is Mackerel Gull, so called by the fishermen because of the young birds just appearing when these fish are approach. ing the coast. Tarrock is a name applied to the young.

\section{IVORY GULL.}

\section{Pagophila eburnea (Phipps).}

Accidental visitaut from Arctic regions, of extremely rare occurrence.

The Ivory Gull is an inhabitant of the far northern regions, and a rare accidental visitant to the Yorkshire coast.

The first mention of it, as a county species, is contained in Allis's Report on the Birds of Yorkshire, thus :-

Larus eburneus. - Ivory Gull-A specimen was shot near Scarborough many years ago, by the late Charles Watson of York; he was no ornithologist, but from the account he gave me of the bird, which he said was pure white all over, there can, I think, be no doubt about the species; I believe the bird was not preserved.

There are but seven instances of the occurrence of this bird reported; the particulars of which are as follows:-

At Scarborough, one shot "many years ago," by Mr. C. Watson of York, is mentioned in Allis's Report.

An adult male example is in the possession of Mr. T. M. Edwards, who obtained it in Filey Bay, in August 1875 (Tuck, Zool. I875, p. 4689; and I876, p. 4960).

A specimen in the second year's plumage was observed on 2nd November I879, at East Scar, Redcar, while feeding on a stranded fish. It was first fired at by a fisherman, who missed it; the bird then flew away, but returned to the feed, and was killed. It is now in the collection of Mr. E. B. Emerson of Tollesby Hall (op. cit. r88r, p. 25). 
At Filey, an adult male was obtained in the autumn of I880 (J. Backhouse, in litt. and tom. cit. p. I08).

Another at the same place on 26th September I884, was reported by Mr. J. Fountain (fide Thomas Boynton).

An example was seen at Flamborough on 5th April I904, and ultimately came into the possession of Mr. W. Hewett.

One was reported at Whitby by the late J. Kitching, as I am informed by Mr. Thomas Stephenson, who says he has no reason to doubt the authenticity of Kitching's statement.

Mr. W. Backhouse, writing in the Zoologist (I846, p. I263), stated that a specimen of this bird, from the Teesmouth, is in the collection of Mr. Edward Backhouse, junr., but, in all probability, the locality was on the north side of the river, as I learn that was the place where many of Mr. Backhouse's birds were procured.

\section{GREAT SKUA.}

\section{Megalestris catarrhactes (L.).}

Bird of passage off the coast ; most frequently observed in autumn.

The earliest allusion to the Great Skua in Yorkshire is by Allis's correspondent, Arthur Strickland, thus :-

Larus catarractes.-Common Skua-Arthur Strickland remarks that after the breeding season this bird occurs occasionally on the coast, but is never numerous.

This noble looking bird, the largest of the British Skuas, breeds abundantly in Iceland and the Faroe Isles, and there are also small colonies in the Shetlands. It is a somewhat rare autumn visitant to the Yorkshire seaboard on its southward migration after the nesting season, and probably also occurs annually on the spring passage northward, but has escaped detection at that period, except on the two occasions in March which are here mentioned.

The Great Skua generally carries on its piratical operations where the Gulls and Terns are congregated to prey on the herring shoals, but is not often met with close inshore, being 
consequently considered much scarcer than really is the case, for it is a bird well known to the deep-sea fishermen, whose appellation for it is "Morrel Hen" ; and on more than one occasion I have had ocular proof that the bird was recognisable by my boatman at a considerable distance when I was unable to distinguish it from $S$. pomatorhinus.

Although usually noticed during its passage southward on the autumn migration, it has twice occurred in early spring, and on both occasions at Flamborough ; the first on Ist March I868, and the second in late February or early March I885. It is, perhaps, more frequently seen between Flamborough and Scarborough than at any other part of the coast line, being attracted to the vicinity of the Headland by the swarms of Gulls which assemble there in autumn.

The occurrences on the coast, as at present recorded or communicated, are :-

Scarborough, one, December I853 (Zool. I854, p. 433I).

Filey, one, August I864 (op. cit. I864, p. 9247).

Flamborough, immature female, 8th September I864, procured by Matthew Bailey (op. cit. I864, p. 9365).

Scarborough, one, 27th October I866 (Nat. I89o, p. 210). Sold at Stevens's sale rooms.

Flamborough, one, Ist March I868. In Mr. J. H. Gurney's collection.

Scarborough, two in autumn I880 ; in Mr. J. A. Wheldon's collection (Wheldon MS.).

Whitby, one in the Local Museum (Stephenson MS.).

Flamborough, one, in late February or early March I 885 , at North Landing (Nat. I884-5, p. 267).

Redcar, one, I4th October I886. Obtained by Mr. E. B. Emerson, while he and I were off at sea. In his collection.

Flamborough, one, autumn I887 (Bailey MS.).

Scarborough, one, 3rd October I889 (Zool. I89o, pp.2I-Ioo).

Whitby, two in the harbour in I890, reported by J. A. Wilson (Stephenson MS.).

Bridlington, one, I2th October I894. In Mr. T. Boynton's collection.

Scarborough, one, November I894 (Nat. I895, pp. 238, 308).

VOL. II. 
Redcar, an immature example, I2th October I896. In my collection.

Staithes, one from fishing grounds. In C. Milburn's possession.

Robin Hood's Bay, one, summer of I904.

Bridlington, one, autumn of I904. In the Hull Museum.

Inland this species has been reported at Nun Monckton several years ago; at Pateley Bridge, one, obtained in I864, is now in the Bewerley Hall collection, and on Tollerton Ings, near York, one occurred on I8th October I879 (Backhouse, Zool. I880, p. 2I).

Its vernacular names are :-Morrel Hen at Redcar; Murrel Hen at Flamborough and northward to Scarborough. According to Mr. Harper (op. cit. I890, pp. 2I, Ioo), this is a corruption of Merle Hen. Tod-bird and Bo'sun are in use at Bridlington and Flamborough.

\section{POMATORHINE SKUA. \\ Stercorarius pomatorhinus (Temminck).*}

Bird of passage off the coast in autumn; chiefly in immature plumage, and uncertain as to numbers. Large flocks have occurred at irregular intervals.

This fine Skua nests in northern Siberia and Greenland, migrating in winter southward to Africa.

There does not appear to have been any published reference to it, as a county species, before the date of Allis's Report, thus :-

Lestris pomarinus.-Pomarine Skua-Shot near Scarborough, sometimes in considerable numbers, in the immature plumage: one snch specimen has been shot near York; A. Strickland says that "At the same season as the last, young birds of this species are some years by no means uncommon, but very uncertain in their visits,

* Lestris pomarimus (Temminck), specific name amended to pomatorhinus by Mr. Sclater (Ibis. 1862, p. 2972. 
and some seasons are not seen at all, but it must be observed that the young birds of the next species are often mistaken for it, and are not easily discriminated. I have not seen a mature bird on this coast."

In considering the status of this bird in Yorkshire it will be found that, until the year 1879 , it was deemed to be an uncertain and rather scarce autumn or winter visitant to the coast, and, as a rule, only immature examples were met with, the adults being almost unknown, or very rare; and the locality most favoured by its presence was the famous Headland of Flamborough; true it is that Allis, in his Report on the Birds of Yorkshire (I844), mentioned that in some years considerable numbers occur near Scarborough, and his friend, Arthur Strickland, remarked that young birds are in some years not uncommon, but he had never seen a mature specimen on this coast. Several immature birds are reported from Flamborough in the "sixties"; others in 1874 , together with two adults; and one adult in the autumn of 1875 is recorded. On the Cleveland coast J. Hogg referred to it as a rare winter visitant before $\mathrm{I} 845$; while later I have notes of two immature birds-one in January 1876 , and another in October I877. Thus matters stood until October in the year 1879, when there occurred on the east coast of Britain one of those extraordinary visitations, or irruptions, which tend to disarrange the preconceived theories formed respecting the movements of birds. It was my good fortune to be an eye-witness in Yorkshire of this most remarkable migration of Skuas, and to be able to give at first hand an account of it, without which a history of the Birds of Yorkshire would be incomplete.

In the early part of October, in the year mentioned, great numbers of Skuas were noticed in the Tees Bay, and on the 8th, when off at sea, I procured an adult and two immature Pomatorhines, at the same time seeing some fifty others in small parties of four or five, all flying to the northwest. This in itself was so unusual an occurrence as to excite great interest amongst local naturalists. On the following day seven more Pomatorhines were obtained, and about a hundred others, in small flocks, were noted going in the same direction 
as those previously observed; while, during the succeeding four days, I observed one while punting in the Tees, others being seen and some killed by various gunners. Then came the memorable "Skua " gale on the I4th of October, which created an amount of interest and speculation amongst ornithologists equalled only by the famous irruption of Pallas's Sand-Grouse in I888. About II a.m. on the day named the wind suddenly flew round to the north, changing to north-east, and blew with great violence, being accompanied by torrents of rain. I had gone to the Teesmouth at the outbreak of the storm, and soon after noon the first flight of Pomatorhine Skuas appeared, coming from the eastward; more flights followed, their numbers increasing as the day wore on, and scarcely had one party gone by before another hove in sight; they flew in flocks of from seven to ten in number, skirting the shore, and on arriving at the Teesmouth many of them alighted on the sands, apparently exhausted by battling against the storm. They allowed a close approach as they sat on the beach, only taking flight when an intruder came within a few yards' distance ; possibly they were ignorant of the effects of a gun, and had not had any experience of their arch-enemy, man. Thus they continued to pass for several hours, until by dark some thousands must have gone by; then the approach of night prevented further observations. On the sand-hills, on both sides of Redcar, many gunners were out, taking toll of the passing birds, but, as they afforded little sport, the shooters abstained from firing at them after obtaining a few specimens. The majority of the Skuas constituting these flocks were adults, their white breasts and long twisted tail feathers rendering them very conspicuous, and easily distinguishable from the immature dark-breasted birds ; a considerable number of Buffon's and a few Richardson's Skuas accompanied them. In endeavouring to form an approximate idea of their numbers, after careful consideration and consultation with those of my acquaintance who were witnesses of the great flight, it was calculated that a total of between five and six thousand birds passed Redcar. On the day following they continued to fly by during the 
morning; on the r6th the wind slackened, and none were observable; but the gale freshened on the $I 7$ th, and I saw about fifty in small bands of seven or eight together, whilst on the 28 th two adults were seen.

As remarked in previous chapters, when treating of the migratory movements of Gulls in a north-east gale, these Skuas all flew in a north-westerly direction. At other stations on the coast the flght was observed; at Scarborough thirty specimens were brought to the late Alfred Roberts, who stated that many more were obtained, and in thirty years' experience as a taxidermist he had never had a bird of this species before. At Filey, Flamborough, and Bridlington also, heavy toll was levied on the migrating bands. Many were driven inland by the force of the gale, and were reported from parts of the county far removed from the coast line, and, doubtless, numbers were not identified. As to the causes which led to this historic irruption of Skuas, the late E. T. Booth of Brighton was of opinion that it was not an unusual occurrence, except that the storm drove the birds ashore as they were passing far out at sea in the course of their normal migration, and so they came under the notice of observers. Another theory was that the Skuas merely followed the Gulls, which in turn followed the herring shoals that were very abundant that year ; but the facts as stated, with regard to my observations at Redcar, lead me to differ from this view. The birds noticed on the 8th and gth October were evidently on migration, not stopping to pursue the Terns and Gulls as is their ordinary custom; they were in small parties, and the very fact of so many as fifty being seen in one day, and a hundred on the following day, was so unusual that we must look to some other cause for elucidation of the mystery (cf. Zool. I880, pp. I8, I9, 5II; and Field, I897, Ist November to 2oth December, and I88o, 3rd and $I 7$ th January).

In the year following another great migration occurred during a terrific storm from the north-east on 28th October; most of the Skuas then seen were adults, and during the height of the storm several hundreds passed Redcar, flying close to the Esplanade, and struggling to make headway 
against the elements; many were obliged to rest on the sands, or were driven inland. It was impossible to face the mingled rain, sleet, and sand, and therefore no captures were made (cf. Zool. I880, P. 5II ; and Field, 6th November I880).

In the year I88I, on I4th October, yet another flight of these Skuas was observed during a north-west gale; but on this occasion they came down wind, and flew high over the town into the country. The year I886 was also known as a "Skua year," large numbers being reported on the fishing grounds; on I4th October the fishermen said they had not seen so many since 1879 ; a storm arose on the $I 5$ th and I saw several small flocks pass by over the rocks (Nat. I887, p. 82). In the next year, 1887 , they were very abundant off Flamborough, where some hundreds were noted in flocks of eight to ten, going south. Off Redcar both adult and immature birds were seen from I3th August to I8th October, on which latter date I noticed thirty or forty flying to the north-west. On 3oth September I889, six Pomatorhine Skuas flew past, all mature birds, their white breasts and long tail feathers being plainly discernible from my window (op. cit. I889, pp. 82-86). At intervals since the year named the species has occurred on the Cleveland coast, but not in great quantity; it was fairly abundant off Scarborough in I889 and I892, and on 26th October I90r, an immense congregation of Pomatorhine and Richardson's Skuas, which at first were mistaken for ducks resting on the water, was observed some miles off Bridlington; immature birds were also abundant off the coast in October I903; a few were obtained off Redcar, and thirty-five specimens were brought in to Scarborough for preservation. It is evident, therefore, from the foregoing facts, that the bird is a fairly regular visitant in autumn; its migration is generally carried on in mid-October, and, although it may not always be found close inshore, it is not uncommon on the fishing grounds in the offing. It probably occurs on the northward passage in spring also, but has hitherto escaped notice.

This Skua has been recorded at considerable distances from the sea; at Skipwith Common an adult male was found 


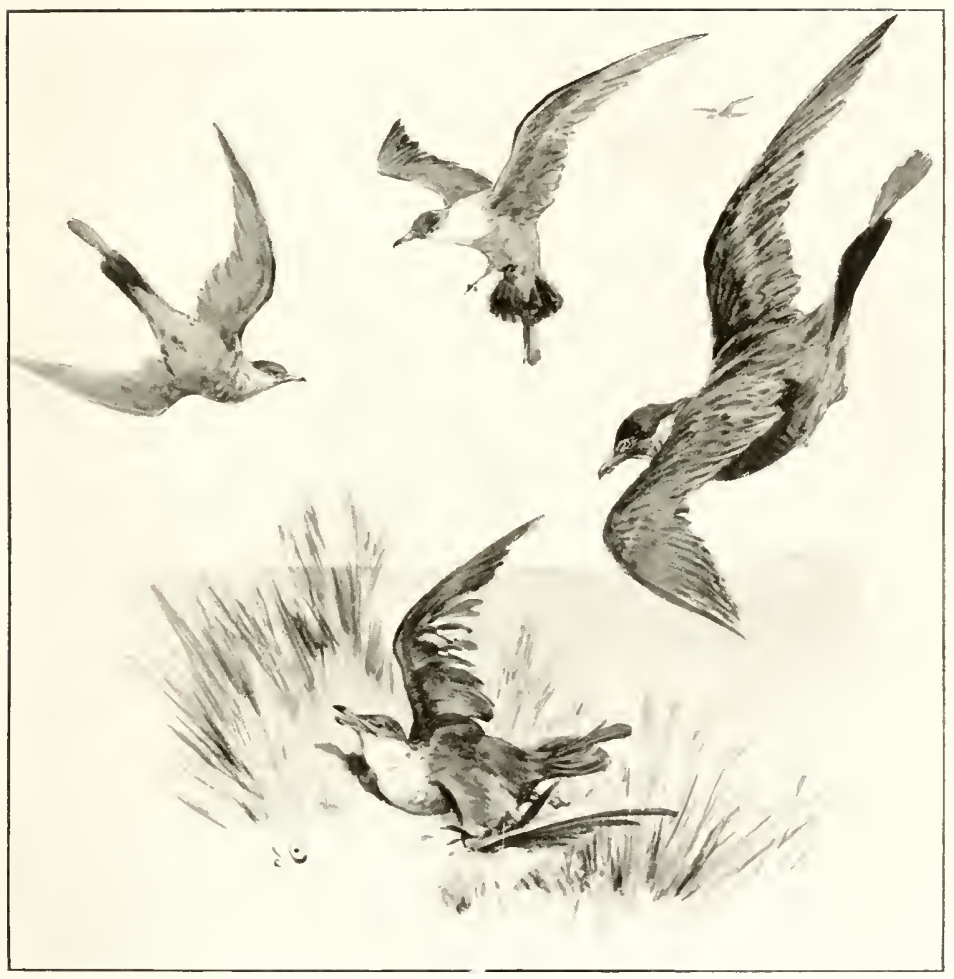

Pomatorhine Skuas, Redcar, 1879.

From a drazing bu John Charlton.

"The Wounded Friend."

See page 701. 

dead in October I858; near Leeds and York it has also been reported; one was noted at Carperby in Wensleydale on 2nd September I892; and after the storm of October I879, it was observed at Pocklington, Thirsk, Towton, and Newton Kyme; while on I2th September I886, five were seen flying over Deighton Manor, near Northallerton, about twenty-five miles from the coast.

In reference to the habits of this species, the late Altred Roberts observed (MS.), that, in October I879, he saw several at Scarborough pursuing the smaller Buffon's Skuas, snipping off their elongated tail feathers so as to impede their flight in the scrample for food, and also acting in like manner to members of their own species ; in many examples he examined he noticed that, although in every other respect they were in the full mature garb, the long obtuse projecting feathers had been cut off. This defect was noticeable in some of the specimens I examined, although all those which I have preserved possess perfect feathers. I was also much struck by the peculias appearance of the tail in flight; when a bird was taking a straight course the feathers were closed like a fan, and had a strange and unnatural look when viewed from underneath, appearing like a cross, - - - and seeming to be much longer than really was the case. In several instances when a Skua was killed its companions came to the dead bird, and, in their manœuvres while swooping round, continually opened and shut their tails, much in the same manner as Terns do when fishing over a shoal of sprats. Another peculiar feature in connection with the adult Skuas in the I879 invasion, which has not previously been commented upon, was that the webs of the feet were in many cases torn and mutilated, more or less, as though they had been roughly cut or torn asunder down the centre. Can it be possible that, in the northern regions whence they came, their feet had become frozen to the ice, and, in endeavouring to release themselves, they had torn away the webs?

The piratical nature of the Skuas has earned for them the unenviable notoriety they obtain amongst coast shooters. Mr. M. Bailey records an instance of one which clung to a 
wounded Kittiwake until it fell a victim to its own rapacity; and an adult melanic example I obtained on I4th October I879, disgorged a perfectly fresh Grey Plover. When one of these Skuas is wounded it fights with claws and bill like a Hawk or Owl, and sportsmen have been severely scratched when handling a bird with ungloved hands.

The dark form of Richardson's Skua is almcst as plentiful as the light-breasted, but this variety had not been met with in the Pomatorhine until I879, the first recorded examples being two which I obtained at Redcar on I4th and I 5 th October; both these birds are of a very dark shade of brown, almost black, with the bills, legs, and perfect obtuse feathers in the tails, as in the adults; one of these specimens is in the collection of Mr. E. B. Emerson of Tollesby Hall, and the other is in my own possession (Zool. I880, pp. I8, 5II; and Field, Ist November to 20th December I879, and I7th January I880). A third melanic example was noted at Redcar on $4^{\text {th }}$ October I884 (Zool. I884, p. 469), while another Yorkshire variety was recorded from Filey in I887, having white shoulders, and a few white feathers in the wing coverts; it is now in the collection of Mr. J. Whitaker

The Redcar Skuas in 1879 exhibited great variation of plumage; I examined upwards of fifty specimens, finding every gradation of colour, from the ordinary immature example to the fully adult, in both the light and dark forms.

The vernacular names are not differentiated from those of S. crepidatus except by the prefix " big " or "great."

\section{RICHARDSON'S SKUA.}

Stercorarius crepidatus (Gmelin).

Bird of passage on the coast, fairly numerous in most seasons. Has been occasionally taken inland.

The earliest local allusion to this bird was made by Montagu, before I802, when he stated that "It has been met with as far south as Yorkshire" ("Orn. Dict." I802). 
Thomas Allis, in 1844, wrote :-

Larus richardsonii.-Richardson's Skua-A specimen is reported by Saml. Gibson to have been picked up in Halifax about seven years ago ; it is occasionally met with on the coast. A. Strickland remarks : "Considerable numbers of this bird occasionally visit us after the breeding time, mostly young birds."

Richardson's Skua is the commonest of the four members of this family occurring on our coast, and is a regular autumn bird of passage, arriving about the early part of August, at which period both young and old are frequently to be met with. The earliest date of its appearance at Spurn is Ist August I880, when several were seen going southward; on the Cleveland coast a flock of about a hundred was observed on I2th July I88I, flying high towards the northwest, at 8-30 p.m.; and on 27th July I904, I saw two adults of the white-breasted form harassing the Black-headed Gulls which frequented the vicinity of Redcar Pier.

From the middle of August to the end of September, and into October, this Skua is very abundant at sea, pursuing the Gulls and Terns on whose industry it subsists, whilst in exceptional cases it has been known to remain as late as December. It doubtless occurs on the passage northward in spring, but has, so far, escaped observation at that period.

In 1879 , the year of the great invasion of Skuas, this species was very numerous in August and September, many mature specimens being observed with their larger relatives, S. pomatorhinus. Sometimes Richardson's Skua is noticed in flocks, and I believe this congregating of birds of this family was not generally known before I879, although I saw two flocks, each containing twenty birds, on 8th October I877; since that time large bodies have often been observed; in October I886, several parties passed Redcar during a southeast gale, and in September I887 a flock of thirty flew high overhead to the north-west, making a continuous screaming call. At Flamborough the species was abundant in $\mathbf{I 8 6 5}$ and 1879 , and was noted in autumn I887, passing the Headland, going southward, flock after flock, some extending for a mile in length; many were also noticed in September I895, 
passing continuously (M. Bailey, oral communication). The years I88I, I885, I886, I887, and I89I were great "Skua years" in the Teesmouth area; and, at Flamborough and Spurn, in addition to the years named, I8g6 was remarkable for the abundance of these birds, which were noticed in great numbers following the hosts of Kittiwakes that were passing south. On I6th October I90r, an immense assemblage of Richardson's and Pomatorhine Skuas was seen resting on the sea off Bridlington ; the observer at first thought they were ducks, but on a near approach discovered them to be the species mentioned.

Richardson's Skua has been met with in various inland localities, in the neighbourhood of fresh water, and sometimes on tracts of open moorland. A specimen, formerly in the collection of the late J. C. Garth of Knaresborough, labelled "Hopperton, near York, 6th November I863," is wrongly named, and is an immature example of Buffon's Skua.

The majority of those found on the Yorkshire coast are immature birds, though adults are not uncommon, and I have frequently noticed them hunting in couples, in some cases both the dark and light forms taking part in a chase; their tactics are similar to those of greyhounds coursing a hare, when one temporarily abandons the pursuit the other takes it up until the object of their piratical attentions is compelled to disgorge its food; on I2th September I89I, I saw fully forty Skuas working amongst the Terns in this manner, and despoiling them of their prey. A rather peculiar circumstance connected with the predaceous nature of this species came under my notice some years ago. I captured an immature bird off Redcar, and kept it alive for some time; on the sixth day it disgorged a long piece of cork, about four inches in length, shaped to resemble a fish, with two large eel-hooks fixed in the broad end; there was part of a fine line attached, and the bird must have swallowed the cork, mistaking it for a fish, and broken the line in its endeavours to escape; how it managed to disgorge the cork with the hooks in the end it is difficult to understand, for it would swallow the supposed fish head first; the hooks then, being point upwards, would 
stick in the bird's throat. This bird's greedy nature is often taken advantage of, to lure it to its own destruction, by coast shooters, who throw up a dead Gull or Tern to attract the Skua, which darts to the place, expecting to find a meal for itself, only to be met by a charge of shot. In September I89I a couple of Skuas came off the sea in the Tees Bay, attracted by a winged Knot that had fallen on the sands near me; while on another occasion one came to a wounded Tern, ignoring the presence of the shooter, and flying so near to him that he could have touched it with a walking stick.

An immature specimen in my collection, obtained at Redcar, has unusually large white patches on the carpal joints.

Vernacular names:-Allan or Chaser at Redcar; and, in common with others of this genus, it receives the cognomen of Morrel Hen at Flamborough.

\section{LONG-TAILED OR BUFFON'S SKUA.}

Stercorarius parasiticus (L.).

Bird of passage, irregularly observed in autumn ; adult examples are extremely rare.

The Long-tailed Skua breeds in northern Norway, Lapland, and within the Arctic circle, migrating, like the others of its genus, southward in winter.

The first published notice of this bird in the county is, probably, that contained in the Zoologist for I849 (pp. 2569, 2592), where three were recorded by E. T. Higgins as taken on the Yorkshire coast.

Thomas Allis, in 1844 , mentioned it in a negative manner, thus :-

Larus parasiticus.-Parasitic Gull-A. Strickland says, "I have not met with this bird here, but the young birds are very difficult to discriminate from the last."

On the Yorkshire seaboard Buffon's Skua is a rather rare bird of passage in autumn, and does not appear to have been 
noticed at the date of Allis's Report in I844. Previous to the great irruption of Skuas in October I879, the instances of its occurrence are limited to some five or six examples obtained at Redcar and Flamborough, and the mature birds were amongst the desiderata of most collectors. During the invasion of Skuas in the year mentioned no fewer than fifteen adults were captured at Redcar, and several others were seen (Zool. I880, pp. I8, I9, 365); at Scarborough eight adults were taken to the late Alfred Roberts; whilst specimens were also procured at Whitby, York, and Thirsk. Never before nor since have such extraordinary numbers of these birds been known on the eastern seaboard of Britain, and its causes have yet to be ascertained (see Pomatorhine Skua). As a rule its visits to Yorkshire take place in autumn only; the earliest example noted was taken alive at Redcar on 20 th June I849, a most unusual date for the occurrence of any bird of this family so far south; whilst the latest record is 6 th November. It has not yet been recorded on the spring passage northward, though, doubtless, it occurs at that period.

For purposes of reference a list of Yorkshire occurrences is appended :-

Yorkshire coast, I849. Three on the coast; one of these was taken alive by some fishermen near Redcar, on 2oth June I849, and was kept for some time at Thirsk in the possession of a man named Robinson. It died, and was preserved by Graham of York; he sold it to Mr. Rudstone Read, who presented it to the Yorkshire Philosophical Society (Zool. I849, pp. 2569, 2592).

Hopperton, near York. One immature, 6th November I853. Formerly in the late J. C. Garth's collection at Knaresborough. (This specimen is labelled "Richardson's Skua," but, on examination, I found it to be $S$. parasiticus.)

Flamborough, one immature male, 7 th September I864. Reported by Matthew Bailey (op. cit. I864, p. 9365; and "Birds of Humber," p. 209), though the recorder's description, viz., "white shafts of primaries," indicates Richardson's Skua. 
Same place, a male in second year's plumage, 23rd August I865 (Zool. I866, p. 28).

Same place, one adult, I2th October I867. Seen by Matthew Bailey (op. cit. I867, p. I009).

Same place, one, August I870 (Bailey MS.).

Redcar, one immature, 7 th October 1879 . Obtained off Redcar. In my collection.

Same place, fifteen adult, I4th-I5th October I879. Taken near Redcar. Two of these are in my collection, and another pair in Mr. E. B. Emerson's collection (op. cit. I88o, pp. I8, I9, 365; and Field, Ist November to 2oth December I879).

Scarborough, five males and three females, chiefly in mature plumage, October I879 (tom. cit. p. 357).

York, one, I8th October I879; found half starved, and captured alive on Strensall Common (tom. cit. p. 2I).

Slingsby, near Thirsk, one, Igth October I879; found dead.

Whitby, one adult, October I879. In the Whitby Museum.

Teesmouth, one immature, 5th October I88I.

Redcar, one adult, Ist September I883. Obtained off Redcar. In the collection of Dr. Kershaw, Trefrie, Aberdovey.

Scarborough, one adult, October I889, at Scalby Ness (op. cit. I89o, p. 2I).

Redcar, one immature, 9th September I889; procured by Dr. Kershaw ; in his collection (Nat. I890, p. 99).

Same place, one adult, Ioth October I89o ; picked up on the beach.

Same place, one immature, 2Ist September I892.

Bridlington, one immature, I5th October I895.

Redcar, one immature, 25th September I897; in Mr. L. Ingham's possession.

Bridlington, one adult, I6th October I9or.

Redcar, one immature, 3rd October I902. I picked it up on the beach. A very dark specimen, approaching the melanic variety of $S$. crepidatus, but, unfortunately, it was too far advanced in decomposition for preservation.

Robin Hood's Bay, an immature male, early in October Ig02; found dead. I examined this specimen, in the posses- 
sion of Mr. J. A. Wilson, Whitby; it is similar in plumage to that last described.

The projecting tail-feathers in the adult specimens extend in some instances to seven or eight inches beyond the tail; in two examples I obtained on I5th October I879, these feathers reached to eight and a quarter inches in length. Some peculiar observations were made in the year named by the late Alfred Roberts at Scarborough, who noticed the Pomatorhines and Buffon's chasing each other indiscriminately, and nipping off the projecting tail feathers, probably for the purpose of impeding their flight in the scramble for morsels of food (W. Eagle Clarke, Zool. I88o, p. 357).

\section{RAZORBILL.}

Alca torda (L.).

Resident, breeding in large numbers on the cliffs at Flamborough, Bempton, and Speeton. Departs with its young to the open sea in late July or August. In winter storms many are washed ashore.

The earliest mention of this bird in Yorkshire occurs in Willughby's "Ornithology," where it is stated that from the Sea-cliffs about Scarborough were sent "The Alke of Hoierus, known here by the name of Auks " (Will. "Orn." 1678. pp. 3-323).

Thomas Allis, in 1844, wrote of it thus :-

Alca torda.-The Razorbill-Common on the coast.

The Razorbill is a common resident, breeding on the cliffs of the Flamborough range which extend from the Headland of that name to Speeton, a distance of five or six miles; its numbers are considerably less than those of the Guillemot, the proportion being probably about as one to one hundred, and it occupies different sites to those frequented by the last named species. The Razorbill usually arrives at the breeding station in March, but has occasionally been seen there in February, on the 2Ist of which month in I884 Mr. 


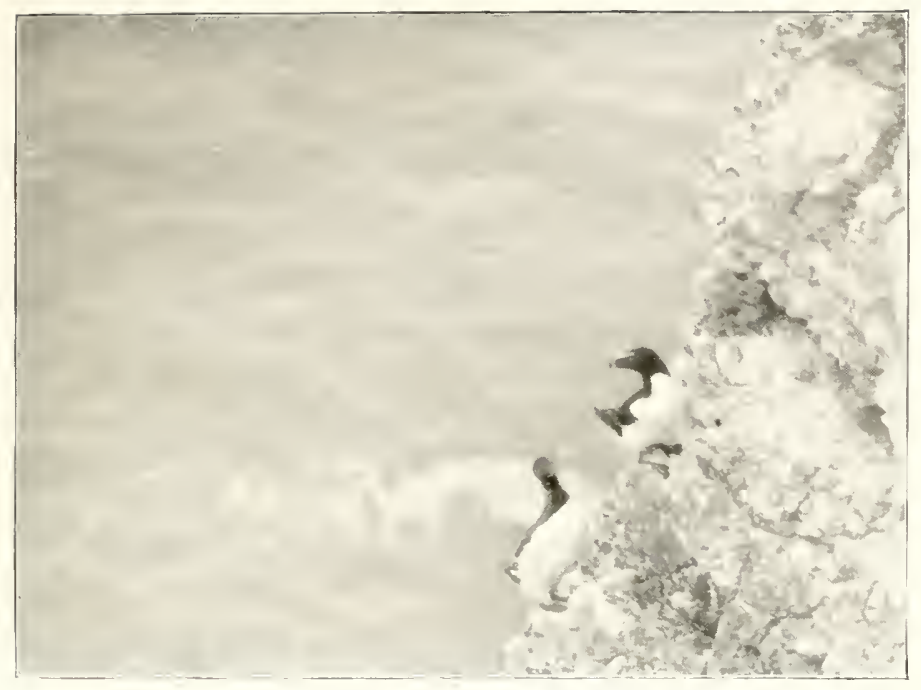

Ringed Guillemot and Razorbill at Staple Neuk.

R. Fortune,

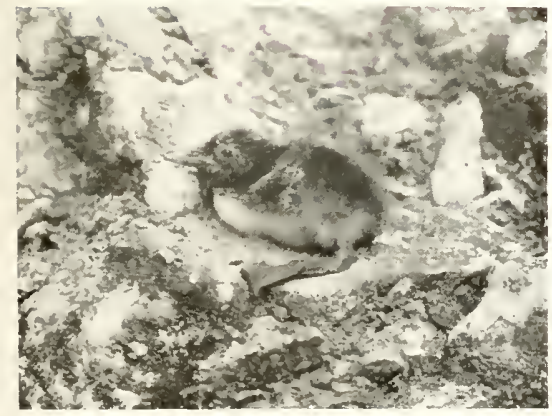

Razor-Bill newly hatched

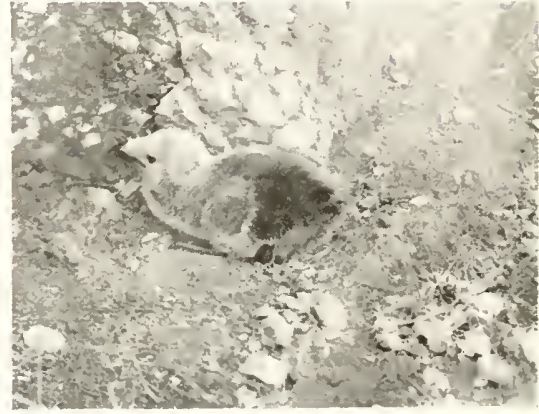

Young Razor-Bill. 

Matthew Bailey noted some thousands in the cliffs, and remarked to me that he had never before known them to be so early; though a still earlier date is the IIth of the same month, I90I, when several were seen at Buckton.

By mid-August both old and young have left the breeding quarters for the open sea, where they remain until the following spring; large numbers of young Razorbills were noticed off the Humber on 22nd August I88I, and on the 4th of that month in I884, I saw two young in down off Redcar, probably birds from the Farne Isles on their way southward.

This species is more a wanderer than a regular migrant, though there is a partial migration in autumn, small parties being often observed in October flying to the south-east and passing for several days continuously; doubtless these are individuals from more northerly latitudes taking the place of our Yorkshire birds, which in their turn retire further south. In winter storms the Razorbill is frequently driven ashore by stress of weather, and found cast up on the beach, in every month of the year between October and June; at rare intervals storm-driven birds are reported in inland localities far removed from the seaboard; on the high moorland near Malham Tarn one was picked up in March I894.

Although the Razorbill and the Guillemot resemble each other in many of their habits, the former begins laying a few days before the other; the earliest eggs the present climbers have known were taken on 6th May. The situations the bird selects are generally in holes or crevices, and not on the open ledges, more being found at the Buckton portion of the cliffs than further eastward. If the first egg is taken a second is produced, and frequently a third in the event of the second being stolen, the intervals between the layings being the same as in the case of the Guillemot, i.e., fourteen days if the egg is fresh, but, if it is slightly incubated, the next egg may be delayed for several days longer; while, if much incubated, the time may be prolonged to twenty-four days. Like the Guillemot, the Razorbill produces a distinct type of egg, year after year, on its particular breeding place. In June I906, I obtained an egg from a "climmer," who asserted that 
he had found similarly marked specimens on the same spot for fourteen years in succession. Incubation lasts about thirty days, and young birds appear on the ledges by the middle of June, an exceptionally early date being the 5 th of that month.

The method of climbing for sea-birds' eggs is fully dscribed under the heading of the Guillemot, p. 7 Io et seq., and, as it is applicable to this bird also, there is no need for further explanation. The manner in which the young are conveyed down to the sea is also similar to that adopted by the Guillemot.

The Yorkshire cliffs are justly celebrated for the wonderful beauty of their Razorbills' eggs; Henry Marr of Bempton took a perfectly black specimen several years ago off the "Dor" ; some of a deep chocolate hue are in the collections of Yorkshire naturalists; especially fine examples are ticked with minute black spots; others have deep black blotches on a brown ground; a peculiar variety is heavily marked all over with very large lilac coloured blotches, on top of which are smaller deep black blotches, the ground colour being creamy white; spotless examples of a pale green colour are known, and perfectly white eggs have been taken, one so recently as June Ig04. The thieving Jackdaw plays sad havoc with the Razorbills' eggs ; one of the best specimens John Hodgson, the Bempton "climmer," has seen was deep chocolate brown, and, as he showed me the half-eaten remains, he vowed vengeance against " those rascally Jacks."

The Razorbill is not subject to great variation in plumage, though examples have occurred at long intervals. Mr. J. H. Gurney has one in his collection, taken at Flamborough in January 1875 , in ordinary winter dress, with bill, legs, and feet yellow, but the dark portions of the plumage somewhat paler than in normal specimens. An immature bird with fawncoloured back is mentioned by the Rev. J. G. Tuck (Zool. I876, p. 4758), and one with white wings was observed at Buckton Hill on I $7^{\text {th }}$ March I902.

The vernacular names now in use are:-Auk, at Flamborough and Bempton; Sea-Auk, at Scarborough; and Bogey, at Redcar. 


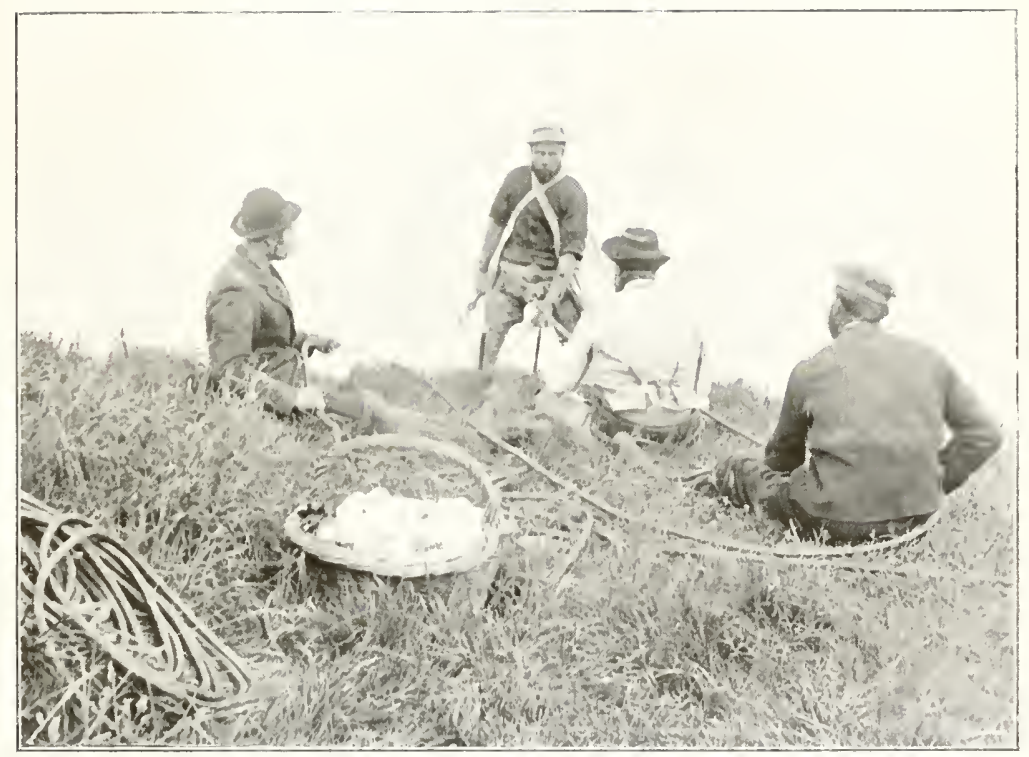

The Climmer going over the cope of the cliff, and laying the rope over the pulley.

T. H. Velson.

See page tio. 



\section{COMMON GUILLEMOT.}

Lomvia troile (L.).

Resident, breeding in vast numbers on the cliffs of the Flamborough and Bempton range; arrives there in March and April, and leaves with its young in August. Many remain off the coast throughout winter.

The first notice of the Guillemot in Yorkshire was by Willughby, who stated that "In Yorkshire, about Scarborough it is called a Skout.... moreover this bird frequents and builds on .... the cliffs about Scarborough in the summer months .... Mr. Johnson [of Brignall] hath observed these birds to vary somewhat in colour, some having black backs, some brown or gray; perchance these may be Hens, those Cocks" (Will. "Orn." I678, pp. 324-5).

Thomas Allis, in 1844, referred to it thus:-

Uria troile.-Common Guillemot-Common on the coast. A. Strickland says they breed in countless numbers on the Flamborough cliffs.

The most remarkable and interesting feature of the stupendous range of cliffs extending from the Headland of Flamborough westward to Speeton, a distance of five or six miles, and varying in height from 250 feet to $35^{\circ}$ feet, is the great " loomery ' or breeding station of the Guillemot, a species that is found there in the nesting season in such vast quantities as to be practically innumerable.

It may be termed a resident of Yorkshire, spending most of the year on the open sea off the coast, and returning for short visits to the cliffs about Christmas or early in January, and, in some seasons, not till February; in Igor it did not put in an appearance until the IIth of the latter month. These visits become more frequent, and of longer duration, as spring advances, generally taking place at high water and in calm weather, when, at times, the birds congregate as thickly on some of the ledges as in summer, but are quiet and undemonstrative. On I2th March I900 there were thousands at Buckton Cliffs, where they were clustering like bees on the breeding ledges, and were in full summer plumage.

VOL. II. 
Towards the end of April they take up their quarters for the season, the first eggs being laid in May; the earliest that the cliff-climbers have known were seen on the 6 th. Some years ago they were common by the second week, though the usual period is about the third week in the month.

By the middle or end of August most of the Guillemots have left the cliffs and dispersed over the sea along the coast, where they are found in more or less abundance during the remainder of the year. Although this species is more a wanderer than a migrant, there can be no doubt that a partial migration takes place, many of our Yorkshire birds probably going further south, whilst their places are taken by others from northern stations. On 22nd August I88I, great numbers of young Guillemots were noticed off the Humber; and, when at sea off Redcar in the autumn, I have frequently seen flocks passing for days continuously, to the south-east, in small parties of from three or four to twenty. In winter storms many are cast ashore, and occasionally they are driven inland, being reported from localities far removed from salt water. In the "Correspondence of Dr. Richardson of North Bierley" (p. 2I2), is an interesting remark, contained in a letter to Dr. Sherard, and dated " 7 th January I724-25," as follows :- "About the middle of last March was brought me Lommia hoieri, called at Flamborough Head (about two miles from Burlington), Whillocks, where they breed in great quantities. This bird was found alive [on a moor] four miles from hence, and fifty miles from the sea: it was brought hither alive, very brisk, and in good feather."

The practice of climbing, or " climming " as the local term goes, for sea-fowl' eggs, as carried out on the Yorkshire cliffs, has often been described, though not always with strict accuracy; some particulars of this interesting and daring pursuit, which I have many times taken part in, may be acceptable, and, with the aid of illustrations, I hope to make it perfectly clear. The right of gathering the eggs belongs to the farmers tenanting the adjacent lands, and this privilege is conceded to the men who work for them when egging is out of season. "Climming" is a very ancient institution, having been 


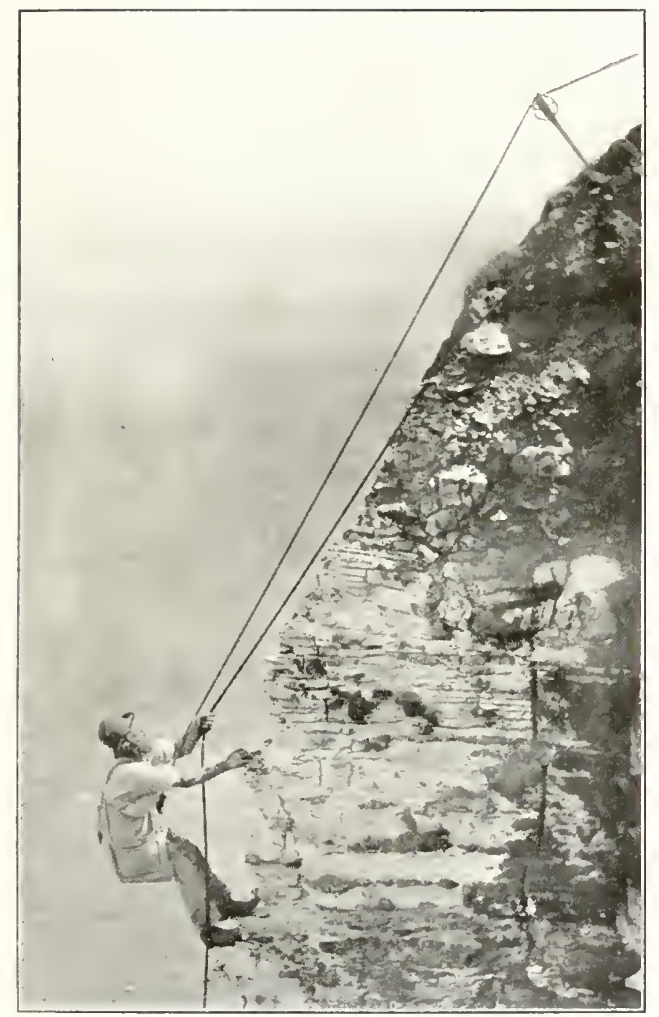

A dangerous corner.

T. H. Nolson.

Se'er perge ;io. 

in vogue for upwards of two hundred years, while one family at Buckton can boast of four generations who have followed this profession, viz. :-William Hodgson; his son Grindale, who died at the age of eighty about the year I864; Edward, son of the last named, who climbed for upwards of thirty years; and, lastly, John, son of Edward, who has been a "climmer" since about the year I885. Seventy to eighty years ago, that is, about 1825 to 1830 , there were four gangs, led respectively by Aaron Leppington of Buckton; old George Londesborough, or " Lowney," of Bempton; Grindale Hodgson, and - Fox. Old Ned Hodgson can recollect when, some fifty years ago, only two gangs of climbers went out at the Bempton, Buckton, and Speeton cliffs, who divided the ground between them; one of these was captained by George Londesborough, and the other by Grindale Hodgson. The gangs consisted of two men only, one to climb and the other to manage the ropes; as a boy, Ned Hodgson used to be taken to help his father in coiling up the ropes and to assist in hauling up, while sometimes the men's wives were requisitioned to give a helping hand. A few years later three in a gang went out, but dangerous places were not " clumb." The cliffs at or near to Flamborough were worked by the fishermen, and, at the period referred to, the bircs bred abundantly from the Headland westward, while in little bays, now entirely deserted, there was then a large avian population, as is exemplified by a spot near Thornwick called "Chatter Trove," from the noise the birds are said to have made. Many other portions of these cliffs have appellations derived from some incident connected with the bird-life, and handed down from father to son, e.g., "Bird's Shoot," "Hateley (Hartley) Shoot," "White-wings," where for some years, up to I897, a white-winged Guillemot used to fly out; "White Breadloaf," so called from a man asking Ned Hodgson's help, who replied, "Whatever's on that spot you shall have"; the eggs were given to the man, who purchased with the proceeds of their sale the first loaf of white bread he had eaten for months; "Broken Head"; "Fox's Broken Arm," where accidents occurred; "Jubilee Corner," first 
climbed in the late Queen's Jubilee year; while the name of "Seven Score Place" perpetuates the memory of the largest number of eggs taken at one climb by George Londesborough.

Then ensued the time when the poor birds were ruthlessly shot down in the breeding season by tourists and gunners, who often did not trouble to pick up the dead or wounded, while the young were left to perish on the ledges; at this time, Hodgson declares, climbing did not pay, and was almost discontinued for some years. It was chiefly owing to the indignation aroused by this wanton destruction that the "Sea-birds Preservation Act" was passed, and, as the birds afterwards increased under protection, the egg gathering was resumed. On the Bempton, Buckton, and Speeton cliffs there are now four gangs of "climmers," each having an apportioned part, beyond which they must not trespass; four men constitute the gang, viz., the "climmer," and three top men. The ground from Danes' Dyke for about a mile and a half westward to Bartlett $\mathrm{Nab}$ (excepting one field at Bempton Lane-end), is climbed by Henry Marr's party (until I902 the leadership of this gang was shared by the late George Wilkinson). The second portion is worked by William Wilkinson and his mates, who climb as far as Buckton Lordship, about half a mile, and they also have the Bempton Lane-end field; then William Chandler has Mainprize cliff, and a small part beyond; whilst the Hodgsons climb the Buckton end to Raincliff, comprising a stretch of about threequarters of a mile in length.

Within the past two or three years a few Guillemots have taken up their quarters on the Gristhorpe Cliff, near Scarborough, but are not sufficiently numerous to repay the labour of climbing. At Flamborough, where the birds had become scarce, the fishermen climbed irregularly and intermittently until the year I903, when a gang led by E. Major commenced to climb more methodically.

The ropes used are of strong stout hemp, 300 feet in length, and are renewed about every second year. In wet weather little climbing can be done as the ropes become slippery, or "greasy" as it is called, and difficult to work. 


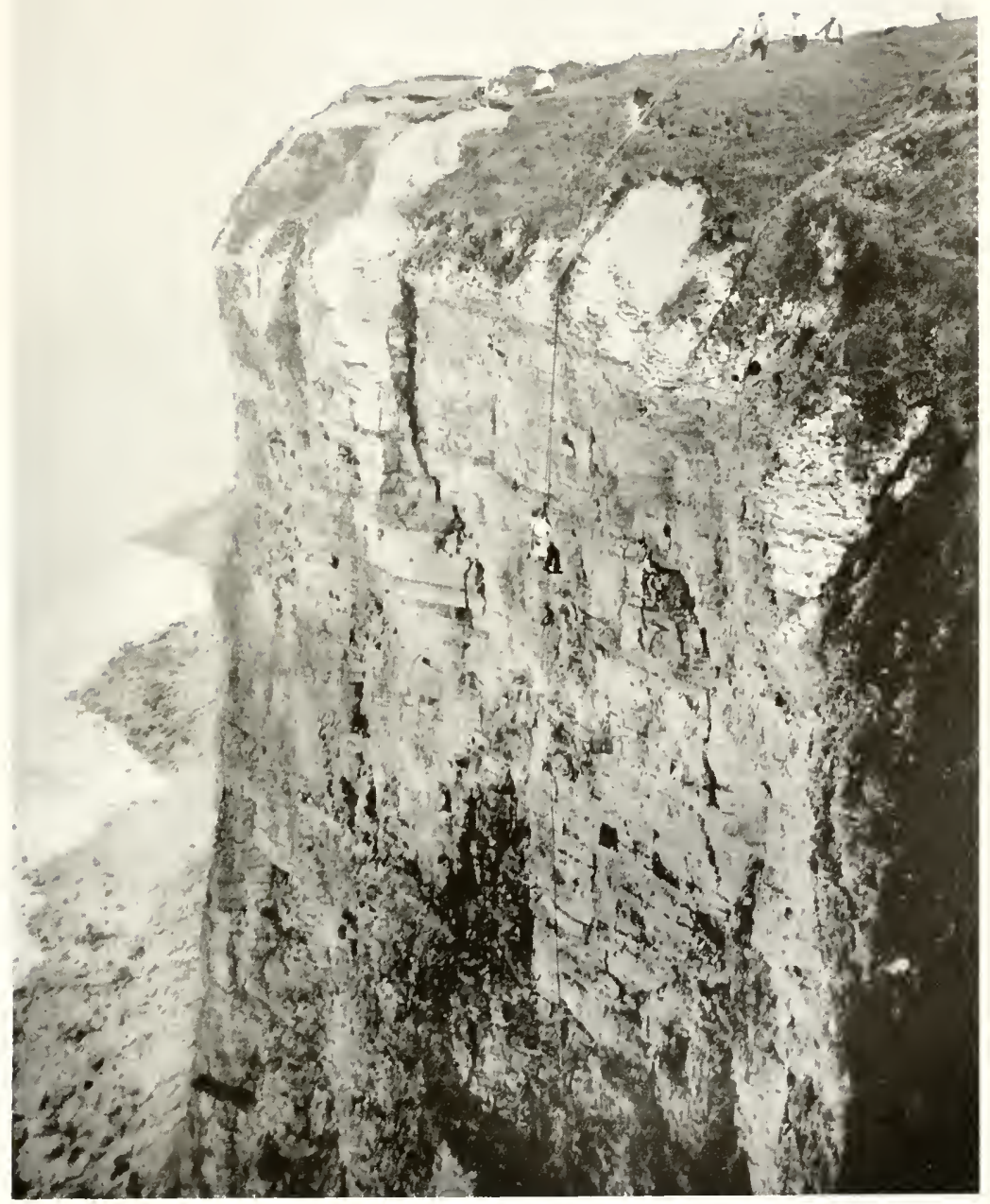

J. Hndgson seeking Razorbills' eggs. 

We will in imagination accompany a party of " climmers" on a fine morning, and, having arrived " at cliff," find all in readiness for the descent. The "climmer" dons what are locally called the "breeches," an arrangement consisting of two broad loops of flat rope with a belt attached, which is securely buckled around his waist, and to the front of the belt is fastened the "body" or "waist" rope. His hat is thickly padded to protect his head from falling stones, and on the arm which uses the guide-rope he wears a leather sheave, termed a "hand-leather"; his boots have toe-plates with edges turned down like a horse's shoe to enable him to walk on the slippery ledges; over each shoulder is slung a stout canvas bag; and a long stick, with a hook fixed at one end, for the purpose of raking eggs out of crevices and crannies, completes his outfit. A hand, or guide rope is made fast to an iron stake driven firmly into the ground, and the slack is thrown over the cliff. One of the men, the "lowerer," then sits on the edge of the cliff, with his feet planted in two holes purposely made to prevent his slipping; he wears a leather belt, or saddle, round which the waist rope is passed and held with both hands resting on his thighs ; both men gather bunches of grass in order to protect their hands from being blistered or scored by the ropes when running freely, and to enable them to secure a better grip when hauling. The "climmer" now takes the guide-rope in his right hand, and in the other an iron stake having a running pulley at the top; walking backward he fixes the stake on the extreme edge (or, when the cliff is much broken, two pulleys are used), and lays the waist rope over the wheel; this prevents it chafing on the sharp rock edges; the lowerer then slacks away, and the adventurous "climmer" swiftly descends on the face of the cliff, by a succession of backward jumps, keeping his feet to the rock and inclining his body outward. He sometimes in this manner descends a hundred feet without stopping. On arriving at a ledge where eggs are visible he rapidly transfers them to the bags he carries, then kicks himself free from the ledge, throwing his weight on the rope, and so is lowered to other places, where he repeats 
the operation, clearing off all the eggs he can find. The expedients a practised " climmer" resorts to in negotiating dangerous places and corners are very ingenious; sometimes he creeps along a ledge for some distance, and, to save the trouble of returning by the same way, swings off again into mid-air ; in order to get round a projecting corner he throws the slack of the waist-rope round and then launches himself off, so swinging to the spot he desires to reach. In some parts of the cliff iron pegs are driven into the rock, round which the " climmer" winds the hand-rope to assist him in his work, and at Jubilee corner, where the crag overhangs considerably, three wire ropes are permanently fastened, by means of which the inner shelves, otherwise inaccessible, are reached. I have seen William Wilkinson, at a depth of more than two hundred feet, stop and fasten the rope to a holdfast in the cliff side, and from there lower himself to the recesses of a cave almost within stone's throw of the beach; indeed, the gymnastic performances of an expert egg-gatherer are as clever as those of many a first-class trapeze artist. A regular code of signals is arranged, by which the man below can telegraph his wishes to the top-man, thus:- a single tug at the waist-rope signifies that the "climmer" is ready to ascend ; the laconic command " Up" is uttered, and all three of the top party, seated in a row behind each other, their feet firmly planted in holes, haul up their comrade from below. Two tugs mean "more hand or guide rope wanted " ; three tugs, "less hand rope" ; and these orders are executed accordingly; but by long experience the men have become so much accustomed to each other's ways that the lowerer seems to know intuitively what his mate wants, and instinctively holds or lowers, while the unsophisticated bystander naturally is lost in wonderment at the facility with which he seems to anticipate the other's wishes. When the "climmer" gives the signal to haul up he keeps kicking himself clear of the rock until he reaches a part where he can ease the labours of his companions by walking on the face of the cliff, reminding one of a fly on a window pane, and on reaching the top he picks up the iron stake at the edge, and so to the grassy flat where his spoils 


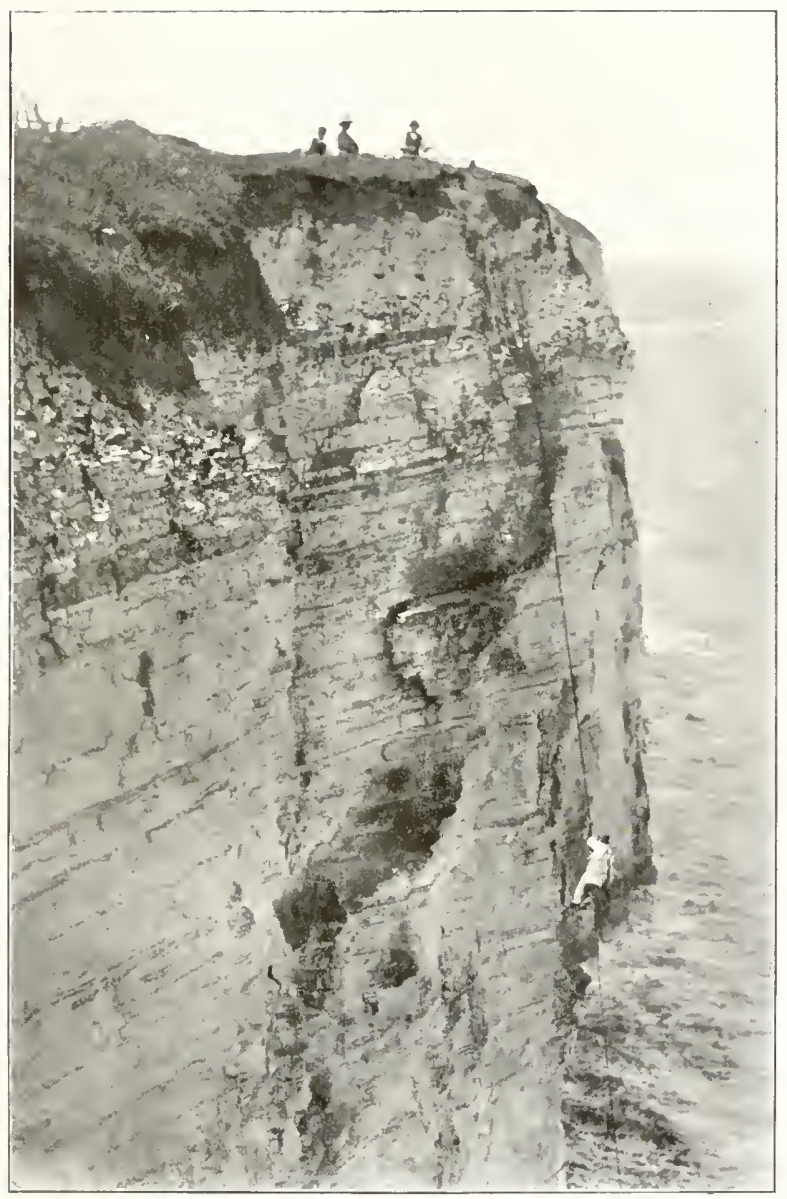

The Climmer at work

T. H. Nison.

Sie prege 7 io. 

are emptied into large market baskets. The other men meanwhile coil up the ropes and prepare for a move to the next spot. The day's work commences at seven o'clock, and, on an average, about thirty descents are made; at the end of the day the eggs are all pooled and shared out, each man taking six or eight, the "climmer" as his perquisite being entitled to first pick each time. The Flamborough gang usually lower a young man instead of a "grown-up." The work is so arranged that the whole ground shall be cleared bi-weekly, each portion being climbed every third day, thus ensuring a constant supply of fresh eggs; in wet weather it so happens, however, that it is impossible to work, in this case the eggs become partly incubated and are spoilt for edible purposes; they are therefore gathered and blown for specimens, and the birds are thereby induced to lay again. When any portion of the cliffs is "clumb out," and becomes "poor," it is fallowed for two years or until it recovers, and is then again visited. In fine weather the Guillemots often drop their eggs in the sea, and it is no uncommon occurrence for specimens to be found in crab-pots and trawling nets. Egg-climbing in the "sixties" and "seventies" commenced on I2th May, but is now a week or ten days later; it ends the first week in July, or in a backward season it may be extended for a few days; I have known it prolonged until the I3th, but in the year I904 a movement was started to induce the men to cease operations on Ist July. The average daily take of each gang is from 300 to 400 , the grand total approximating 130,000 . As many as I,400 eggs have been collected by one party in a single day; old Londesborough on one occasion took I,700 after stormy weather had prevented him getting down the cliffs for several days, and a few years ago George Wilkinson and Henry Marr gathered 600 from two spots between six and eight o'clock. The first laying is, as a rule, the most productive, after which there is a slack time; then ensues the midsummer "shut" or "flush," and after another slack interval, there is a third "flush"; the numbers then gradually decrease again towards the end of June. It may be here observed that there are many dangerous 
parts which are never climbed, and in these places the birds hatch out their first eggs without interference, and so a constant supply of young blood is ensured. The climbers say the Guillemot does not lay until the second year, their reasons for this assertion being based on the observations made with reference to fallowed spots which, if rested for one year, do not improve, but in two years the young birds have matured, and add their eggs to the general stock.

Accidents during the pursuit of egg-climbing rarely occur : one or two instances are known of the men having been damaged by pieces of falling rock, and this happened to Fox, whose arm was broken; also to old Londesborough and William Wilkinson, each of whom had an arm severely torn. A few years ago I was present when two of the men narrowly escaped shocking deaths; I had requested the "climmer" to procure me some Kittiwake's eggs, and he commenced his descent at a place where there were no foot holes for the lowerer, who, to my horror, began to slide towards the edge, being dragged by the weight of the man below; the other two top men were some distance away; I was on a point of the cliff a hundred yards off, and it seemed as though nothing could avert a frightful catastrophe, when, fortunately, Mr. John Morley, a Scarborough naturalist, who chanced to be near, rushed to the rescue and clasped the man by the shoulders, holding him until assistance arrived. The "climmer" has since told me he knew perfectly well what had happened " top o' cliff," and he had just reached a ledge where he could stand when the sickening sensation of falling stopped. Visitors are sometimes allowed to make the descent of the cliffs, and, if space had permitted, many amusing stories might be related in connection with their experiences. I have been told by a quondam climber that, when he was assisting his father, who used to climb at Flamborough, in the "seventies," soon after the Franco-German war, they received a visit from three foreign gentlemen staying at the Thornwick Hotel, the youngest of whom requested to be allowed to take some eggs; he was accordingly lowered, and succeeded in bringing up five specimens, with 


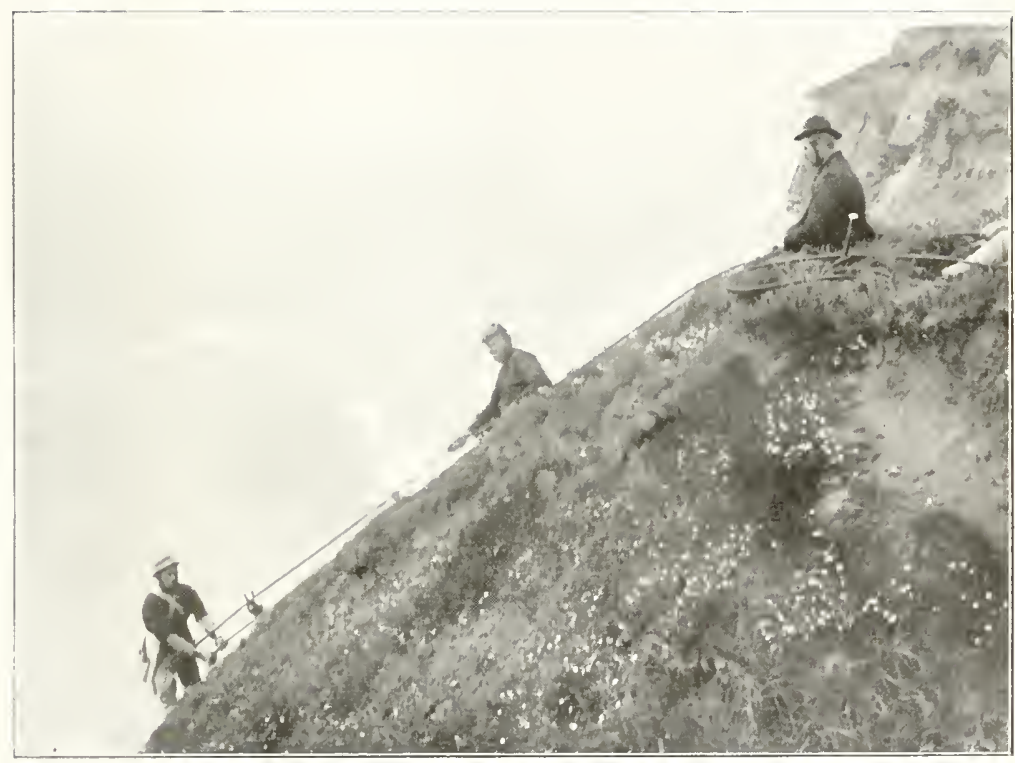

The Climmer ascending.

T. H. Velson.

See page ino. 

which he appeared to be highly delighted. The strangers visited the climbers each day for a week, helping them in their work, and it was not until they had departed that it was discovered the young visitor who had gone "ower cliff " was the Prince Imperial of France.

If the first egg is taken a second is produced, and, frequently but not invariably, a third, the intervals between the first and second layings being, on an average, fourteen days if the egg is fresh, but, in the event of it being slightly incubated, the time is extended to eighteen or twenty days, and, if much incubated, to twenty-four days. In the case of a female becoming "clocky" over both the first and second egg it is probable that she does not lay a third that season. I have been informed by an old Flamborough climber that he once found in a sitting bird an egg ready for extrusion and three others in a well developed state.

Notwithstanding the enormous quantities of eggs taken annually the climbers declare that there is no diminution in the number of birds, and my observations certainly lead me to believe this to be the case. In I834, when Charles Waterton visited Flamborough, the common eggs were sold at sixpence per score; the price is now twelve to sixteen for a shilling, and these are eaten by the villagers, or are sent to one of the large Yorkshire towns for use in the manufacture of patent leather, while the well marked specimens are set aside for collectors. Flamborough, or strictly speaking, Bempton, eggs are celebrated amongst oologists for their remarkable beauty and variety, though some twenty-five years ago, when collectors were few, common eggs were sold at three a penny, and twopence was considered a good price for a special example. The competition for good specimens is now very keen, prices having accordingly advanced until as much as $5 /-, 7 / 6$, and even half a sovereign is now paid for "real fancy eggs," as the men call them.*

There is an endless variety of colouring and marking in

"For another account of the "climmers" and their methods, see "The Birds of Bempton Cliffs," by E. W. Wade, Trans. Hull Sci. and Field Nat. Club, Vol. III. pt. 1, for 1903. 
the Yorkshire Guillemots' eggs, ranging through all shades of white, yellow, ochreous, green, blue, pink, red, chocolate brown, purple, and black; streaked, spotted, blotched, pencilled, and veined in a bewildering manner with black, brown, purple, lilac, or red; some present a perfect network of markings like delicate tracery, others seem as though one end had been dipped in an ink pot, some are spotless white, pale blue, or green, while occasionally examples have letters, numerals, or grotesque representations of animals figured on them. After one of IVilliam Wilkinson's descents he took out of his bag a nicely marked egg, and, on my inquiring the price, he turned it over, and, looking at it quizzically, replied, "Why the price, threepence, is on it"; pointing at the same time to a distinct figure 3 on the broad end. In the year I880 Henry Marr secured a perfectly black egg off Staple Neuk.

It is usually considered that the first eggs in a season are the most richly marked, though this is not the invariable rule, sometimes the second "flush" contains the best, and occasionally the third; experienced climbers assert that the same individual Guillemot produces a similarly marked type of egg year after year on the same ledge. Old George Londesborough took a particularly fine red egg from the same spot for fifteen years in succession; and William Wilkinson and Edward Hodgson have found certain peculiarly marked ones for eight, twelve, and even sixteen consecutive summers, and generally two in each season. I have seen several specimens from the sixteen years' resident: two were taken in I900, three in I90I, three in I903, and two in I904, all similarly marked, the pencilled variety on a white ground; a set of three, all of a pale uniform blue, were gathered from one spot in I900; and of another set of two the first was taken on 28th May I897, and the second on the same date in the year following. In June I902, I secured two eggs, of exactly similar colouring and markings, which W. Wilkinson had found, one on top of the other, but the first laid had fallen into a hollow of the rock, thus preventing the parent incubating it, and she had then laid the second one above it. 


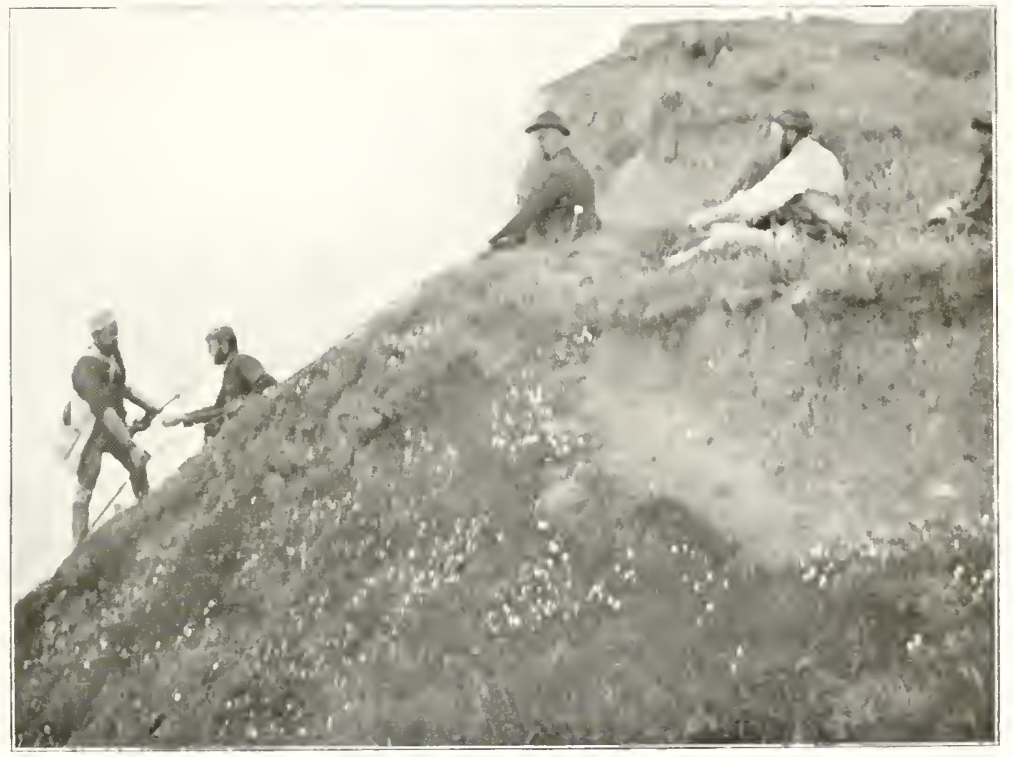

The Climmer ascending, having taken up the pulley.

T. H. I 1 / $/ 5 m$.

See page 710. 

Some remarkably fine series of Guillemots' eggs are in the collections of Yorkshire naturalists. The average weight of a Guillemot is $21 \mathrm{tb}$; of an egg 40z.; monstrosities and doubleyolked examples are met with from time to time, as also abnormally small specimens; a very long example measures $4 \frac{1}{2}$ inches by $I \frac{13}{16}$ inches; the largest I have note of measures 4 inches by $2 \frac{3}{10}$ inches, and weighed $5 \frac{1}{2} \mathrm{oz}$.; the heaviest egg noted scaled 6oz., and the smallest measures I.5 inches by $I$ inch. The proponderance of ground colour is in favour of the green and blue types; for several days in different years I have endeavoured to count the numbers showing these colours and have compared them with all others, with the result that rather more than two-thirds shewed a decided blue or green ground colouration, and the remaining one-third white, brown, and other varieties.

The position assumed by the sitting Guillemot is either a recumbent or an upright one, with the egg or young across the webs of the feet: I have several times observed the parent pulling the egg on to her feet and tucking it into place with her bill, and on one occasion, when a bird was disturbed by the climber, and her egg had commenced to roll towards the edge of the cliff where it had been laid, I distinctly saw the owner run to it, take it up in her bill, and deposit it in a safe position before she flew off.

Incubation lasts from twenty-eight to thirty days, and the young have been noticed as early as the 22nd of June, though it is usually mid-July before many are seen, and by the end of that month they take to the water. While feeding their young the Guillemots journey long distances in search of food ; some go as far as the Lincolnshire coast; some northward to Scarborough, while others may be observed, in small parties, or in long lines, passing to and from the herring grounds far out at sea. The water in the vicinity of the cliffs is also thickly dotted over with the black and white forms of the busy fishers, whose arrivals are welcomed by their mates on the cliffs with much bowing and chattering, the whole combining to make a wonderful scene of animation, which Mr. W. Woodhouse has depicted in two oil paintings. 
The method by which the young reach the water from their lofty nurseries is a problem regarding which there is considerable diversity of opinion, though the evidence of the Flamborough fishermen, who are most capable of forming a correct idea, and who have assured me they have seen the operation hundreds of times, is to the effect that the chicks are conveyed on their parents' backs, the latter launching themselves off the ledges and often reaching the sea a quarter of a mile from the shore.* Mr. M. Bailey told me he has frequently seen the young brought down "to water" in the manner described; and Mr. F. Boyes was once witness of the act of an old Guillemot carrying down its little one, which it did almost perpendicularly, and with very quick beating of its wings. His attention was attracted by the squeaking, or rather whistling, of the youngster, as if it were much afraid; he could not see the chick, but as soon as the old bird reached the sea it dived, leaving the young one on the surface. As the birds dropped within twenty yards of the boat there could be no mistake as to what took place ( $Z$ ool. I875, p. 4342). I once watched a number of Guillemots disporting themselves like children in the water at Staple Neuk. They climbed up a sloping boulder, jumped from the top into the sea, dived and played for a few seconds, then swam round and once more climbed up the rock, repeating the performance continually; on another occasion, in July I904, I witnessed, from the cliff tops, a fight between two Guillemots, one of which adopted the tactics of a submarine, coming up underneath and evidently torpedoing its adversary, which, after repeated attacks of this nature, eventually fled out to sea. As is well known, the predatory propensities of the Jackdaws at Bempton cliffs are accountable for the destruction of many Guillemots' eggs, and a case of retributive justice came under the notice of George Londesborough and the late George Wilkinson, who saw an enraged Guillemot lay hold of a thieving Daw and carry it out to sea three times,

* Charles Waterton was informed of this fact so long ago as 1834 . and his observations on the subject are worthy of consideration (" Essays on Natural History," p. 4II). 


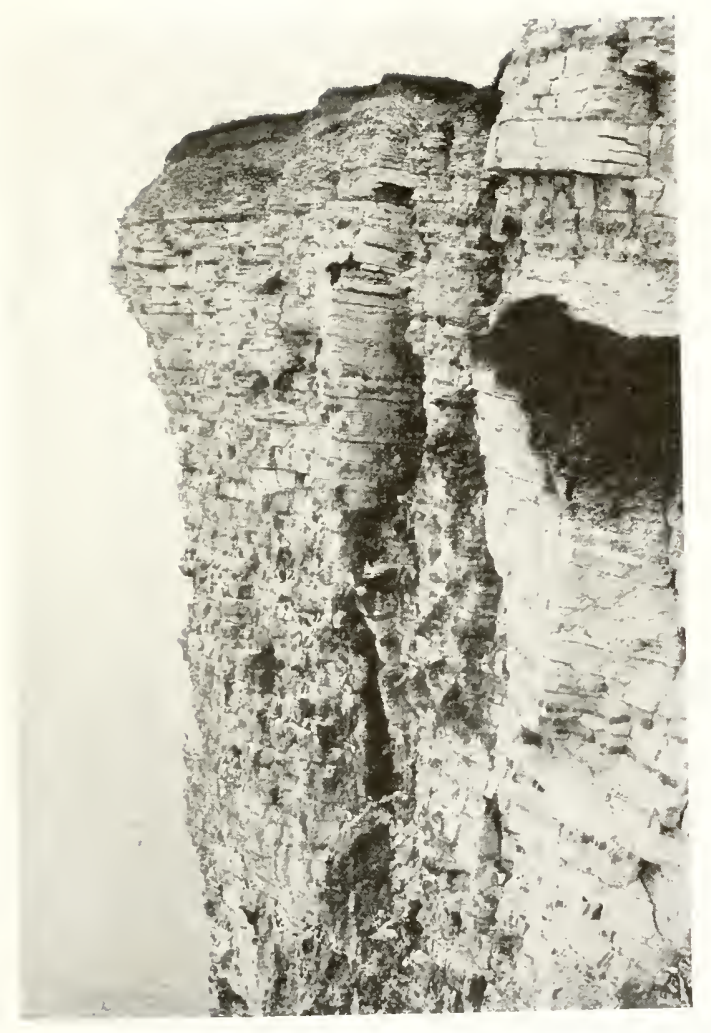

Cliffs near Hateley Corner.

E. II. Hade.

Ser page 71.3 

the robber returning to the cliffs after each ducking. The average duration of time a Guillemot remains under water when seeking food is, according to my experience, about twenty-five seconds.

Examples of variation in plumage are perhaps more commonly met with in Yorkshire than elsewhere. Of these may be mentioned several entirely white, others of a cream or sandy hue, two with white wings, and others partially pied. In June I902 I saw a bird at Bempton with a white head and a narrow collar of black round the throat; while a perfectly black, or melanic, example was reported in I897. Mr. J. Whitaker of Rainworth Lodge also possesses several Yorkshire varieties. A well-known Flamborough fisherman, the late Tom Leng, in the year I885, secured three peculiarly plumaged birds within a week; one entirely white, another cream-coloured, and the third with white wings; two other pure white ones were also obtained by him on other occasions. All these specimens passed through the hands of Mr. M. Bailey, to whom I am indebted for this information. One white example, a female, with yellow eyes, was purchased by Mr. J. H. Gurney.

Of the Bridled, or Ringed, Guillemot, Thomas Allis wrote in I844, as follows:-

Uria lacrymans.-Bridled Guillemot-A. Strickland remarks that "It is highly probable some of these species have, from the earliest times, frequented the cliffs here (Flamborough) for breeding, before it was distinctly noticed as a species, but they seem by no means abundant here, though I have known several specimens obtained; the egg. I have every reason to believe, is very distinct from that of the common species; I have no doubt that it will prove a perfect distinct species, though many still hesitate to consider it such."

It is scarcely necessary to remark that this is not now deemed worthy of even sub-specific rank, but is merely classed as a variety of the common form.*

It occurs on the Yorkshire cliffs, though not commonly,

* At the Farne Isles, in the year 1889, I noticed a Ringed and a Common Guillemot paired, both birds taking it in turn to sit on the egg, a green coloured one. 
indeed it is considered rare as compared with the ordinary form ; I have generally seen one or two amongst the thousands of the common kind in my visits to Bempton, and in June Igo6 I procured five eggs, all of which were of the commonest green or light ground, spotted and streaked with black. At various places on the coast the Ringed variety of the Guillemot has been recorded from time to time, and in the Cleveland area I have met with it repeatedly. In January I887, I saw one Common and three of the Ringed form swimming together inside the rocks off Redcar. Mr. J. H. Gurney possesses a very small example, obtained at Bridlington on Ioth March I860.

The local names are :-Skout or Scout, pronounced Scoot, which has been in use from time immemorial in the Flamborough and Bempton districts; Foolish Guillemot was a term used in the Allan MS. (I79r); Wullock is the Redcar name; at Whitby it is called Noddy, and Murre is another Yorkshire name; the nestling is called Kell-bird or Willock, derived from its cry, abbreviated to Wilk at Flamborough. This latter name was rendered by Dr. Richardson (I724) as Whillock. The Ringed variety is Silver-eyed, or Ring-eyed, Scoot.

\section{BRUNNICH'S GUILLEMOT.}

Uria bruennichi (E. Sabine).

Accidental winter visitant from the Arctic regions.

Although for some years included in the British list, this northern Guillemot, which is a rare visitant to these Islands, had not been chronicled from Yorkshire, * until the winter of 1894, when the memorable incursion of Little Auks and other northern sea-fowl took place. On $7^{\text {th }}$ December in that year a Guillemot, obtained in the North

- I am aware that one or two examples had been previously obtained at Bridlington, one of which occurred in December 1893. 


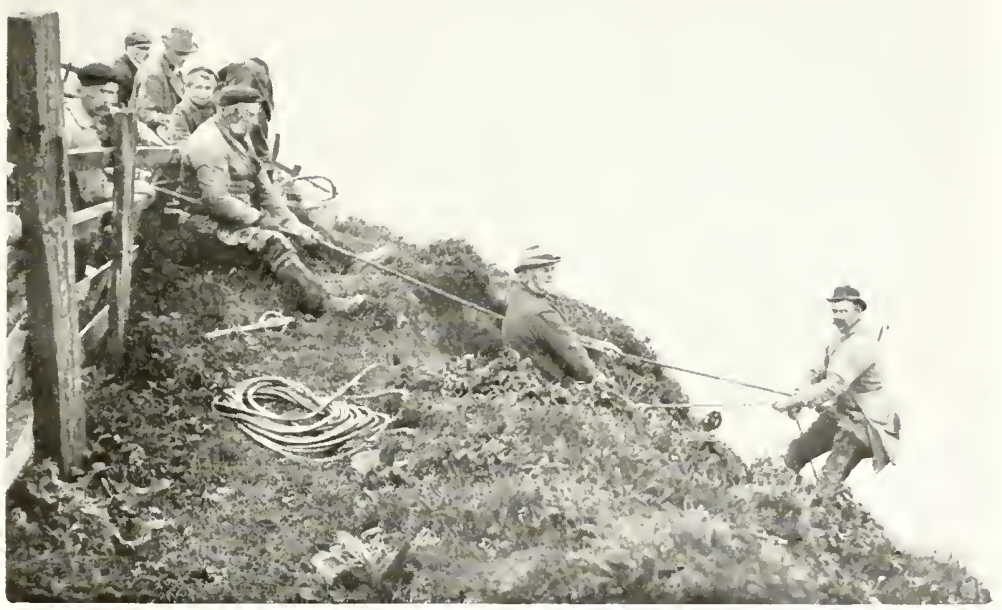

J. Kodgson descending the cliff.

E. II: Wide.

See page 715. 

Bay near the Pier at Scarborough, was taken to Mr. W. J. Clarke, taxidermist, of that town. It proved by dissection to be a male : total length I 8 inches, expanse of wings $24 \frac{1}{2}$ inches, wing from carpal joint to tip slightly more than 8 inches. Mr. Clarke at once noticed that it varied from the ordinary British type, and forwarded the specimen to Mr. J. E. Harting, who pronounced it to be $U$. bruennichi, and afterwards exhibited it at a meeting of the Linnean Society in January I895 (Proc. Linn. Soc., 17 th January I895).

In the January following, as I learn from Mr. Brown of Filey, several were picked up on the beach at that place. One of these, which was a male, measured I $9 \frac{3}{4}$ inches in length ; from the carpal joint to the end of the longest primary, $8 \frac{1}{4}$ inches; total expanse of wings, $28 \frac{1}{2}$ inches. The tarsi and toes were light yellowish olive, webs dirty brown. The second was a female, and measured in total length 183 inches; wing, $7 \frac{3}{4}$ inches; total expanse, 26 inches (Harting, Field, 9th February I895; and Zool. I895, pp. 70-7I). Another example, procured near Flamborough Head in November x899, is now in the collection of Sir Oswald Mosley of Rolleston Hall, Derby.

The latest occurrence was on 28th October 1902, when Mr. Joseph Morley of Scarborough wrote informing me that he had shot a Brunnich's Guillemot at sea, about two miles from the Castle Foot.

The figures of this species in winter plumage, depicted in Lord Lilford's work on "British Birds" (part 32), were drawn from the specimens obtained in Yorkshire in the winter of I894-95.

It is possible, indeed very probable, that this bird is often overlooked, or confused with the Common Guillemot, from which it differs in having much blacker plumage, lighter coloured legs, and a stouter bill with a white line on the upper mandible. 


\section{BLACK GUILLEMOT.}

\section{Uria grylle $(L$.$) .$}

Winter visitant of rare occurrence ; has occasionally been observed in spring and summer. Formerly bred at Flamborough.

The earliest mention of this, as a Yorkshire bird, was made by Pennant, who visited Flamborough Head on 3rd July I769, and remarked of the birds seen there, "Multitudes swarmed in the air, and almost stunned us with the variety of their croaks and screams; I observed among them .... a few black guillemots very shy and wild ("A Tour in Scotland," I77I, pp. I4-I5).

Thomas Allis, I844, reported thus :-

Uria grylle.-Black Guillemot-Obtained on the coast, but not a plentiful species. A. Strickland remarks, "About thirty years ago I killed a specimen of this bird, out of a small flock, in full plumage, at the height of the breeding season, near the rocks of Flamborough; this specimen I still have preserved; if they were then breeding at the cliffs, or ever did so, I cannot say; but it is the only instance I ever heard of their being seen there at that time of the year, but young birds, or others in immature plumage, are not infrequently met with in winter about here."

According to the account given by Pennant in $I 769$ (quoted above), the Black Guillemot was at that period included in the list of birds resorting to Flamborough Head in the nesting season; and Strickland's remarks, embodied in Allis's Report (I844), lead us to infer that it might have continued to breed there up to the early part of the last century ; additional evidence in support of this supposition has been unexpectedly supplied by Professor A. Newton, who has obligingly permitted me to examine an unmistakeable egg of this species from Charles Waterton's collection, labelled " I834," and taken at Flamborough. That portion of the coast affords suitable sites for its nesting places, but personal research on my part has failed to elicit reliable information as to the discovery of eggs within recent years, and, although adult examples of the bird have been seen near the Headland 


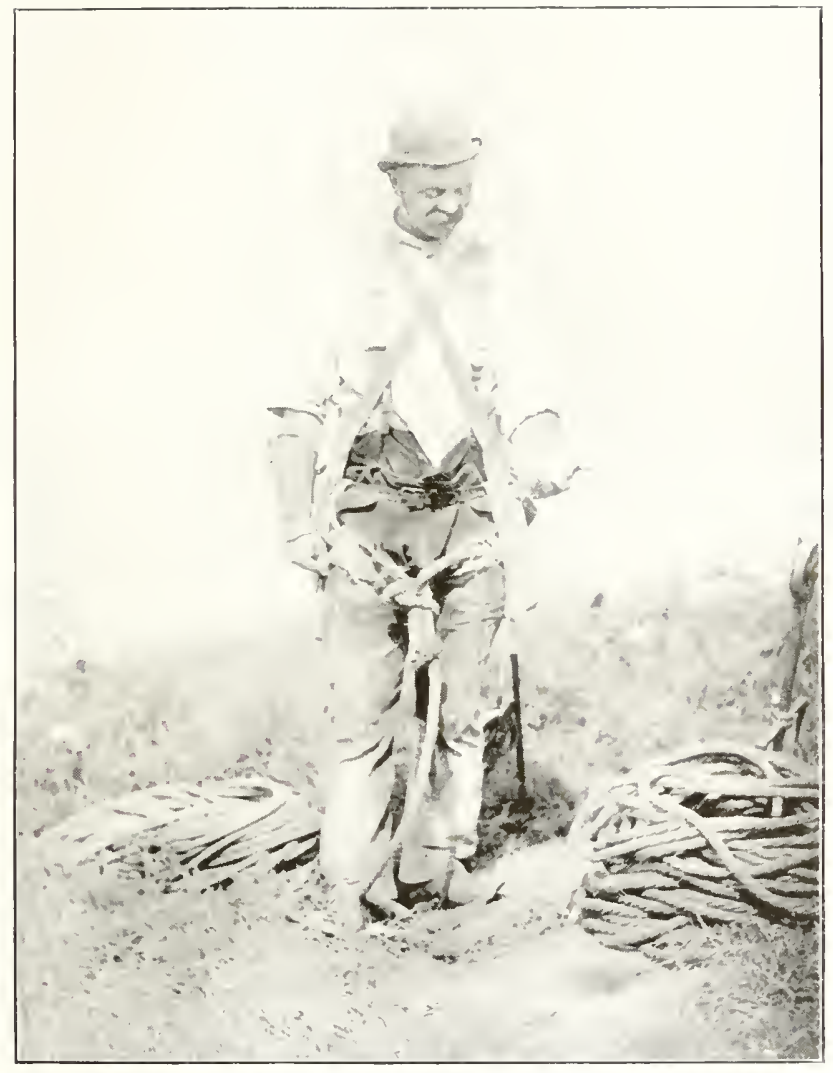

The Climmer with his outfit.

T. H. Virtsun.

Sé page is. 

during the summer,* and I have examined one obtained there, as also an immature specimen killed early in August I903, none of the present cliff-climbers or other residents of the district have any recollection of the Black Guillemot breeding there, and it must now be counted amongst those species, which-like the Cormorant and the Shag-have ceased to inhabit the Flamborough range.

This is not at any time an abundant species, being generally known as a rather rare autumn or winter visitant to the coast line, and chiefly in immature plumage. It occurs sparingly at most of the coast stations between Bridlington and the Teesmouth, at dates varying from September to January, and, on one occasion at least, a young bird has been shot in August at Flamborough.

In the adult plumage it is very rare; one was stormdriven and captured alive at Redcar on 6th March I883; at Whitby another was reported on 3oth August I888; a pair in the York Museum were procured at Flamborough; I have seen one taken at that place in Igoo, and also one obtained in Bridlington Bay, and now in the possession of Mr. T. Machen.

\section{PUFFIN.}

Fratercula arctica (L.).

Resident, nesting in large numbers on the Flamborough cliffs; the latest of the rock-breeding fowl to arrive ; departs in mid-August, the majority retiring far out to sea.

The first record of the Puffin, as a Yorkshire bird, is found in Willughby's "Ornithology," where it is described thus :"The Bird called Coulterneb at the Farne Isles .... at Scarborough, Mullet ... . They breed yearly in great numbers ... . by the sea-side about Scarborough. . . . Mr. Fr. Jessop sent us one killed in the fresh waters not far from

* Nat. 1896, p. 302 ; 1897, p. 238.

VOL. II. 
Sheffield in Yorkshire, much less than this we have described, which yet, I think, differed only in age, for all marks agreed." (Will. "Orn." I676, p. 325.)

Thomas Allis, in I844, referred to it as follows :-

Fratercula arctica.-The Puffin-Common at Flamborough.

This grotesque looking bird is resident in Yorkshire, breeding in very large numbers on the Flamborough range of cliffs between the Headland and Raincliff, one of its two nesting stations on the east coast of England, and the only one on the mainland; this is, doubtless, the situation Willughby referred to in his mention of the bird breeding "near Scarborough."

It arrives at the summer quarters about mid-April, generally later than the other fowl; nidification commences in May, and the solitary egg is deposited in a hole or crevice of the rocks, in a deserted rabbit burrow, or one scooped out by the bird itself where the soil is sufficiently friable for that purpose. If robbed of its first egg while fresh the Puffin lays again after a lapse of fourteen days, but if the egg should be much incubated it is doubtful whether a second is produced. The Yorkshire climbers do not as a rule take many Puffins' eggs, as they are difficult of access, and not greatly in demand by collectors, unless exceptional in the way of being heavily spotted or marked; occasionally specimens with zones or bands of markings are brought up; one with a broad zone of spots was found in June I904. It may here be mentioned that the Puffin, when sitting on the rocks, does not invariably rest on the tarsus, but more often assumes an erect attitude, standing on its feet. The young is at first covered with blackish down on the back, the breast being light-coloured.

The old birds often take long journeys to sea in search of food, and are found many miles away from their homes, to which they return in straggling parties as night approaches. By the middle of August the young are on the water, and, at the end of the month, both they and their parents have laft the neighbourhood, and gone out to sea, and southward, for the majority are partly migratory, few being seen near 


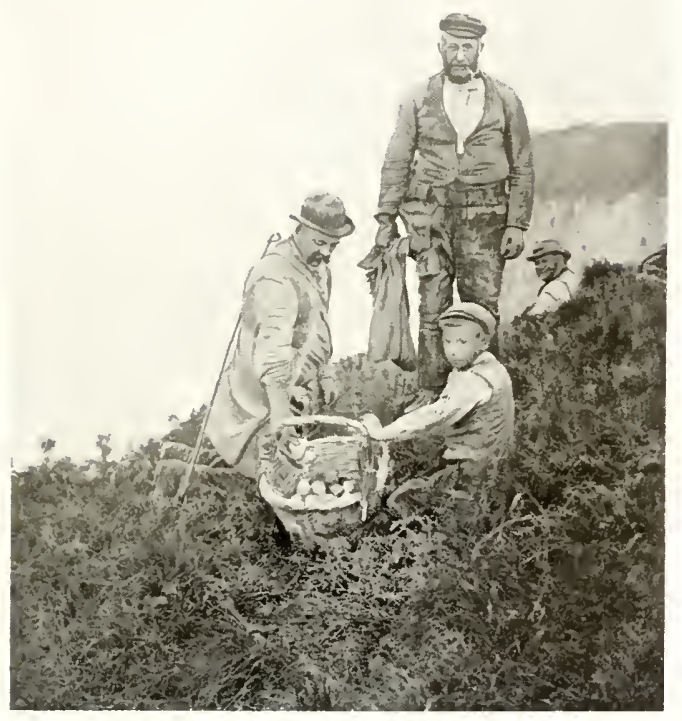

After the ascent.

E. II. H'ude.

See page 717. 

the coast in winter. In the spring it approaches nearer to the shore, and during the prevalence of sea-storm, many are driven by stress of weather on to the beach in a starved and dying condition. I have seen individuals on the sands both in winter and spring, though very seldom during the former season; in November I878 several were picked up, and in the following March, during stormy weather, upwards of thirty were taken to a local bird-stuffer. In April and May I887 numbers were found dead; one on the I4th of the latter month had not resumed the horny plates on the bill indicative of the breeding garb; in February I89o many perished of starvation, while in April I89I I noticed winterplumaged birds.

Occasionally the Puffin strays up the Humber in autumn and winter, but I have not observed it in the Tees estuary. In various inland localities, remote from tidal waters, stragglers, piobablystorm-driven, have been reported; amongst the places where it has been noted being Thirsk, Wetherby, Pocklington, Ackworth, Skelmanthorpe, Barnsley, Penistone, and at Ardsley one was killed against the telegraph wires in I87I.

White and pied varieties are not unknown in Yorkshire. One almost entirely white, except for a few cinnamon-coloured feathers on the back, was found at Marske, and is now in the collection of Mr. E. B. Emerson of Tollesby Hall. A pure white specimen, and also a white one with normal wings, both obtained at Flamborough, are in the possession of Mr. J. Whitaker of Rainworth Lodge. Another white bird was reported at Bempton in I902, and Mr. A. S. Hutchinson of Derby informs me he had one, sent from Scarborough in I896, which had only one or two black feathers on the back, all the rest of the plumage being white.

Its local names are not numerous; the term Mullet was stated by Willughby to be applied to it at Scarborough; it is generally known as Parrot or Sea Parrot; Flamborough Head Pilot is applied to it in the district indicated by this name, and Tommy Noddy was mentioned by J. Hogg to have been in use in the Teesmouth area in I845, though I have never heard it. 


\section{LITTLE AUK.}

Mergulus alle (L.).

Winter visitant, not uncommon in some years, though irregular in its appearance; occasionally driven inland during stormy weather.

An early allusion, perhaps the earliest, to this species was made in a statement of the Rer. W'. Dalton of Copgrove, near Knaresborough, to the effect that the Little Auk had been found near his house (Montagu's "Orn. Dict." I8I3, p. 5 of Newman's I866 reprint).

Thomas Allis, I844, wrote :-

Mergulus alle.-Little Auk-Hugh Reid says that about three years ago a large flight of these birds crossed the country near Doncaster; that many were picked up dead, and many caught alive in an exhausted state; several of the specimens are now in his own collection; a fine specimen was picked up alive near Hebden Bridge on 25th October I834; and about the same time another at Luddenden, about four miles off, both now in S. Gibson's collection. Arthur Strickland observes, "Except a few birds out of plumage in winter time, it is seldom found on this coast." This bird differs from the rest of the tribe, being at times found far inland; and some years ago I have known several killed in the water at Foss Island, near York.

Strickland's observations, quoted by Allis, may have been correct in his day, but do not, at the present time, accurately represent the status of the Little Auk, which may be described as an erratic winter visitant on the coast from the Arctic regions, being not uncommon in some seasons, in others rare or altogether absent, while at long intervals extraordinarily large numbers of these little Arctic visitors are reported. In the year I84I, when the flight, mentioned by Hugh Reid, took place near Doncaster, many were noted in October at Redcar (Zool. I845, p. II83; and Yarrell's "British Birds "), as also in the autumn of 1863 . In 1878 a sudden north-west gale, with snow, sprang up on I2th November, and, from that date to the 2 Ist, examples of this bird were washed up on the shore; many were found at Lowthorpe in I879; in November r884 they were again abundant, and in January and February of I89o numbers were reported 


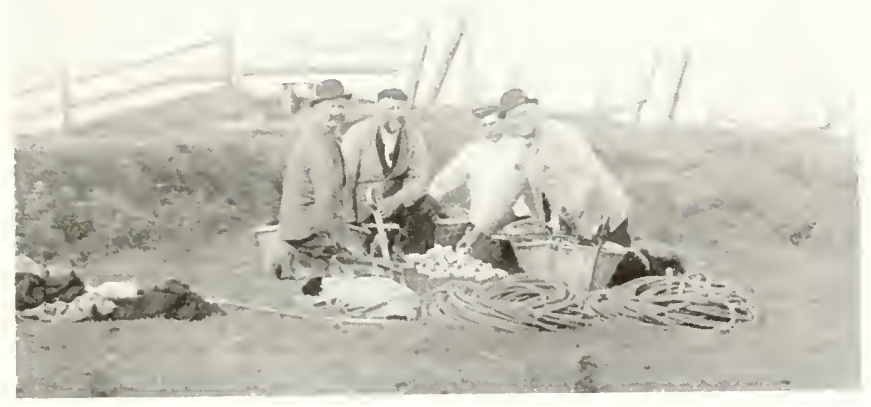

Sharing the spoil.

E. W: Made.

Seepage 717 

at sea, while several were washed ashore at Redcar and Scarborough. In the early months of I894 a few were seen at various places on the coast from the Tees to Holderness, but in the winter following there occurred the most remarkable invasion of these northern sea-fowl which has been recorded within the memory of living man. The weather during the latter part of $x 894$, and in the opening days of January I895, was of a very stormy character, with on-shore gales, and during the first fortnight of the new year immense companies of Little Auks passed along the coast, many being shot, while more were driven in by stress of weather and cast up on the sands in a dead, or exhausted and dying, condition. The gales and rough seas continued, with scarcely any intermission, until the middle of February; consequently the poor little ocean wanderers, being unable to procure food, perished wholesale, and some hundreds were taken to the bird-stuffers ; on 2Ist January I picked up seven examples on the sands in the course of a mile's walk. Similar reports were received from other places on the coast; at Whitby, Scarborough, Filey, and Bridlington the taxidermists had a busy time; at Beverley no fewer than eighty-four specimens were brought in in one day, and it was estimated that many thousands were observed close in shore between Scarborough and Spurn.

Individuals were reported in places far removed from salt water; one was caught alive on a pond at Hutton Rudby; three were found at Thirsk; others at Swainby, Leeming Lane, Leeds, Bradford, and even in the high dales, and on the moors of the north-west, instances were recorded of the capture of these "rare sea birds" (Field, 9th February I895; Nat. I895, pp. 94, Io6, II 7 ; and Zool. I895, p. 68). In the year I897 another visitation took place, but not in such quantities as that of two years previously, yet many occurred at all the coast stations.

On I3th November I899 a flock of about sixty was seen off Redcar; in I900, in the last week of February, during a north-east gale that lasted for a week, some fifty examples were cast on shore, several of which had partially black throats, and in Holderness eighteen were picked up in one day; at 
Scarborough upwards of one hundred and fifty were taken to the taxidermists; many were also reported at Spurn. Out of nineteen dissected at Scarborough eleven were females, two males, and the remaining six were too much decomposed for accurate examination. In February Igor I noticed considerable numbers swimming at sea off Redcar, some shewing the head only, and apparently in search of food, diving close under the surface and appearing almost like fishes, though others loomed as large as Razorbills at two hundred yards' distance.

The instances of the occurrence of this species in inland localities are too numerous for recapitulation; suffice it to state that there are few districts from which it has not been reported at some time or other, and one of the very few records of its appearance in summer was near Tadcaster, where one was found dead in a grass field on $x 6$ th July $188_{5}$

Vernacular names:-Rotche and Iceland Auk, in general use, and Dwarf Auk in the Flamborough district.

\section{GREAT NORTHERN DIVER.}

Colymbus glacialis (L.).

Winter visitant, regular, but not common, on the coast ; also occurs inland, though rarely. Arrives in September, leaves in April or May

Probably the earliest evidence of the connection of this bird with Yorkshire is that in Willughby's "Ornithology," under the title of "The Greatest Speckled Diver or LoonColymbus maximus caudatus. I have seen four of them . . . . One in Yorkshire at Dr. Henley's, shot near Cawood."

And under the title of "Gesner's Greatest Doucker," the following appears:-Mr. Johnson [of Brignall, near Greta Bridge], in his papers sent us, writes that he hath seen a bird of this kind, without any spots on its Back or wings, but yet thinks it not to differ specifically but accidentally." (Will. “Orn." I678, pp. 34I-2.) 


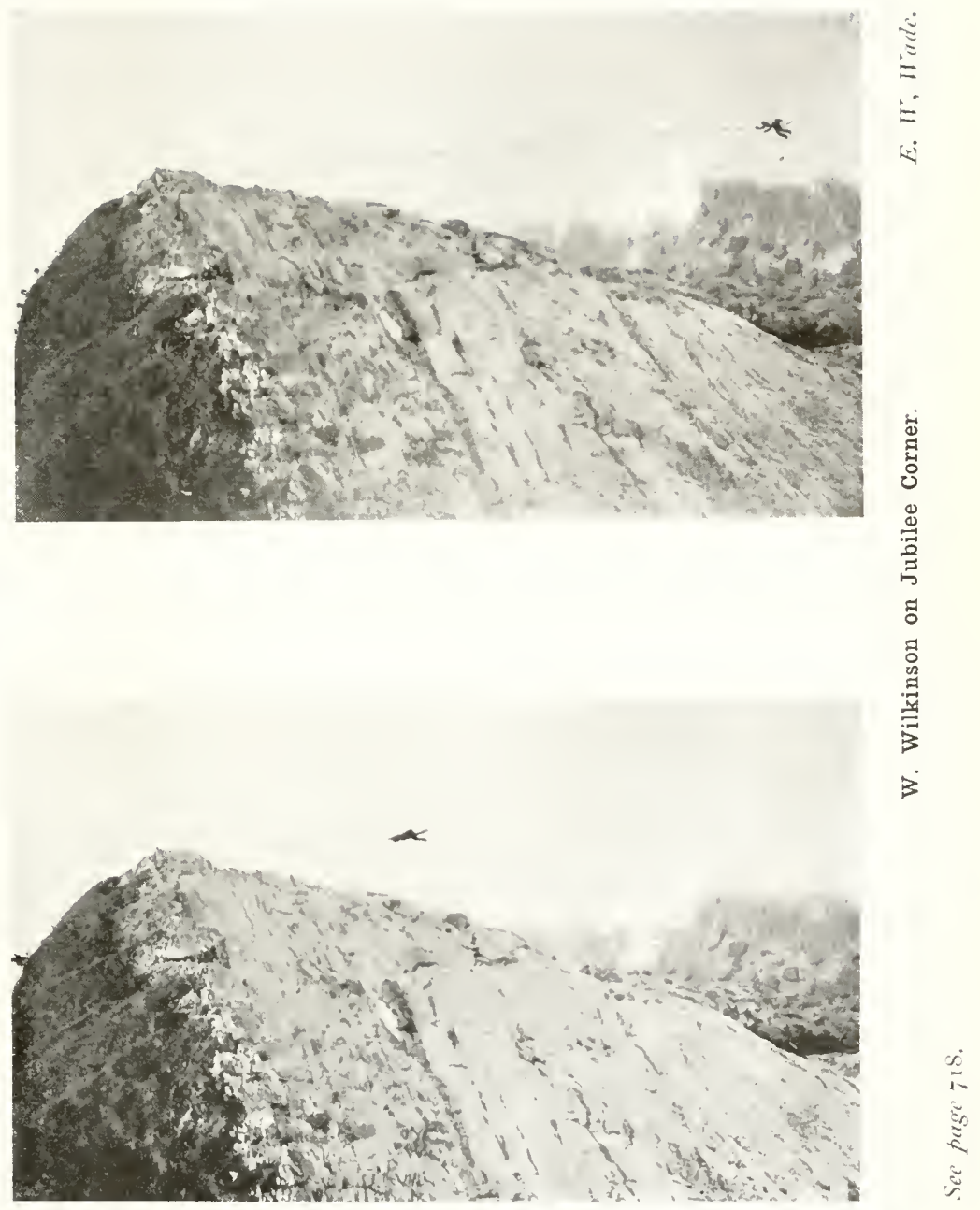



Thomas Allis, in I844, wrote :-

Colymbus glacialis.-Great Northern Diver-Dr. Farrar, F. O. Morris, and H. Reid all report a splendid specimen which was taken alive in an exhausted state at Cannon Hall, and is in the possession of S. Stanhope, Esq., of that place: my friend, Bartholomew Smith of Thirsk, informs me that a specimen was taken at Gormire; it has been obtained in beautiful plumage off Whitby, and I have had a young specimen from near Sutton-on-Derwent. A. Strickland remarks : "The Northern Diver, Black-throated Diver, and Red-throated Diver are all northern birds which are only known on this coast in autumn or winter, when out of mature plumage, but may frequently be met with at those times on various parts of the coast; the Red-throated or the Speckled Diver is the most frequent, but the Black-throated, which is the least common, seems to be a more inland bird, and in the severe winter of 1830 many were killed, and some toward the spring assuming the mature colours."

A truly pelagic bird, this fine species is a not uncommon autumn and winter visitant on the coast, appearing sometimes as early as August, though not as a rule until September or October, and remaining until the following spring. In the Humber district, according to the late J. Cordeaux, it is occasionally found in summer, but at the Teesmouth $I$ have only once noted it at that season, viz., in July I877. In the fall of the year individuals in the immature dress are annually met with, though it is seldom obtained in the adult stage.

On inland lakes and reservoirs the Great Northern Diver is of rare occurrence, and, in addition to the examples cited by Allis, it has been recorded at Newton Kyme, where the late Rev. J. W. Chaloner saw three on the Wharfe in $18 \mathrm{I} 8$ or I8I9; one was captured alive in central Ryedale in 1852 , and another at Masham "many years ago." It has occurred on the river Hull near Beverley, and on Howden Mere; at Goole; at Cold Hiendley Reservoir in December 1875; at Banks Hall, near Staincross ; on Blackstone Edge Reservoir ; Slingsby; Birdforth, near Thirsk, where one was killed on the ice during a storm in January I887; on Fewston Reservoir in I888; near Wakefield in March I888, and October I89o, on the last occasion a male, in partial summer plumage, being obtained.

Generally speaking this bird is of solitary habits, but 
occasionally two are seen together, as on $4^{\text {th }}$ December 1877 , at West Scar Head, Redcar; again on I6th March 1892 , I watched through a telescope a couple feeding near the shore; and in November I893 two were near my boat inside the Redcar rocks. The marvellous rapidity with which this bird can swim and dive under water has frequently been commented upon; I have known one remain under the surface, after diving, and not re-appear until it had traversed a distance of at least half a mile, whilst in swimming it can easily outdistance a pair-oared boat. A specimen that I had alive for some time, when placed in the water, gave utterance to a mournful, not unmusical, cry.

The average weight of a Northern Diver is stated to be between nine and ten pounds; the heaviest I have note of is a female example, obtained at the Teesmouth in November I886, which weighed twelve pounds.

Local names:-Loon or Leaan, in general use; Herring Loon on the Humber; Big Northern Diver at Redcar; and Penwings is an old Redcar name, probably a corruption of Penguin.

\section{WHITE-BILLED NORTHERN DIVER.}

Colymbus adamsi (G. R. Gray).

Accidental visitant from northern America.

The only claim of this bird to be admitted to the Yorkshire list rests on the occurrence of an example recorded by the late J. Cordeaux ("Birds of the Humber District," I899, p. 38), as having been obtained in January I897, at Filey, which came into the possession of the late D. Brown of that place. I have been unable, however, to obtain any further information regarding this specimen. 


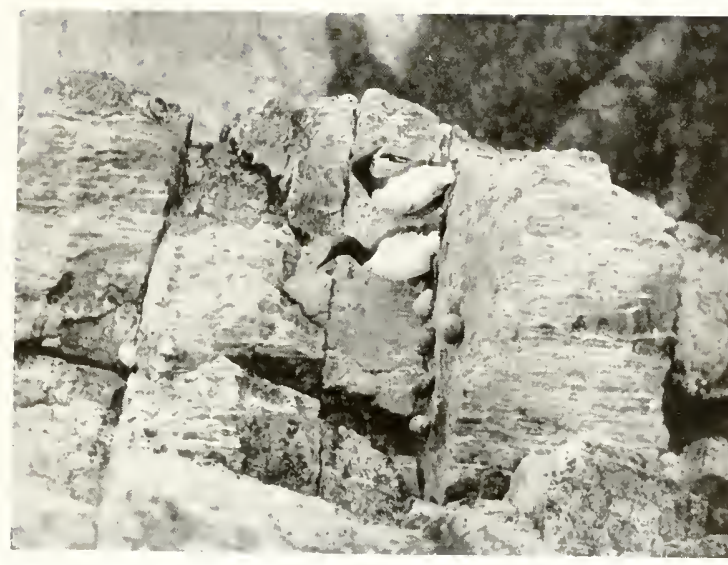

$\tilde{\Xi}$
$\vdots$
$\vdots$
$=$

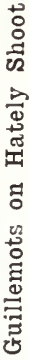

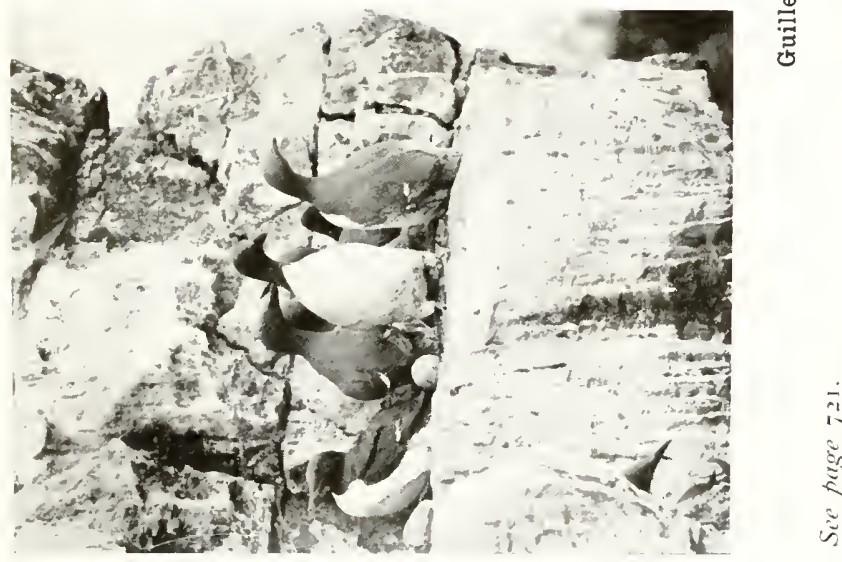





\section{BLACK-THROATED DIVER.}

\section{Colymbus arcticus (L.).}

Winter visitant, uncommon; rarer on the coast than $C$. glacialis, but more frequently observed inland.

The earliest known occurrence of this species in the county is, apparently, that included in Hogg's "Birds of S.E. Durham and N.W. Cleveland," where it is stated that one was shot on the coast in January I830 ( $\mathrm{Zool}$. I845, p. II 8 I).

Thomas Allis's Report contains the following, written in $1844:-$

Colymbus arcticus.-Black-throated Diver-Hugh Reid says one was shot near Doncaster in most perfect plumage, and is now in the possession of the Rev. J. R. Miller of Walkingham; and that another equally fine specimen, killed there, remains in his own possession; it is rare near Hebden Bridge ; a young bird was shot at Elland, near Halifax, 17 th November 1832 ; and I have had two or three immature birds, without the black throat, from the neighbourhood of Sutton-onDerwent; it is very rare near Huddersfield, but a few stray specimens have been taken.

This handsome bird is a winter visitant on the coast, but later in its arrival, and less numerous, than the preceding species. Like the Great Northern Diver, it is very seldom met with in the adult stage; a female, in the late W. W. Boulton's collection, was procured on the river Hull, near Beverley; and another, taken in the Humber on I6th February I87o, is in the collection of Capt. Seddon; one was noted at Bridlington in February 1876 ; one at Filey on Ioth December I875; and my collection contains a male example, in almost full breeding plumage, captured within twenty yards of the shore opposite Redcar, on Ist December I89o. Immature specimens have been reported from most stations on the coast line at irregular intervals, and it was especially abundant in 1876 . I have obtained two at Redcar : one on 2Ist November 1878 , and the other on 3rd February I893; whilst I have examined three others which occurred there.

The Black-throated Diver, although rarer than $C$. glacialis 
on the coast, appears to be more frequently found on inland waters, and, in addition to those mentioned by Allis, and in the text, it has been recorded from Halifax-one on Pelton Reservoir, in December I874, and a second in January I886, both of which are in the Halifax Museum;-trom Sowerby Bridge; Hambleton; Wakefield, and near Bingley (in the winter of I887-88). The latest occurrence on the River Hull was on 28th February I905.

\section{RED-THROATED DIVER.}

Colymbus septentrionalis (L.).

Winter visitant, common, and regular in appearance; immature birds sometimes remain off the coast all the year round. Occurs on inland waters, but not numerously.

The reference to the Speckled Diver in the Allan MS. (I79I), is probably meant for this species, which is described as "Common in winter in our seas and rivers-called by the fishermen Sprat Loon, being often seen in vast numbers among the shoals of sprats." Though, in his description of its plumage and eggs, that writer seems to have confused the bird with its larger congener, the Great Northern Diver (Fox's "Synopsis," p. 93).

Thomas Allis, in I844, referred to this bird as follows:-

Colymbus septentrionalis.-Red-throated Diver-One specimen is reported by Dr. Farrar as shot at Woolley Park, the seat of Godfrey Wentworth, Esq., in July 1833, which is now in his possession; he met with a young bird which fell exhausted at Bankes Hall, near Barnsley, and another that was shot at Staincross; the young birds have been taken several times near Sheffield in winter; it is rare at Hebden Bridge, and also at Doncaster; several have been shot near Huddersfield; IV. Eddison has one specimen, now in the Huddersfield Museum; it is rare about Leeds, but one was at Harehills Lane in January 1829 ; another in the river Aire in 1838 ; the immature bird is not infrequently obtained in winter near York; in full plumage it is very rare.

This, the smallest of the Colymbidx, is also the most 

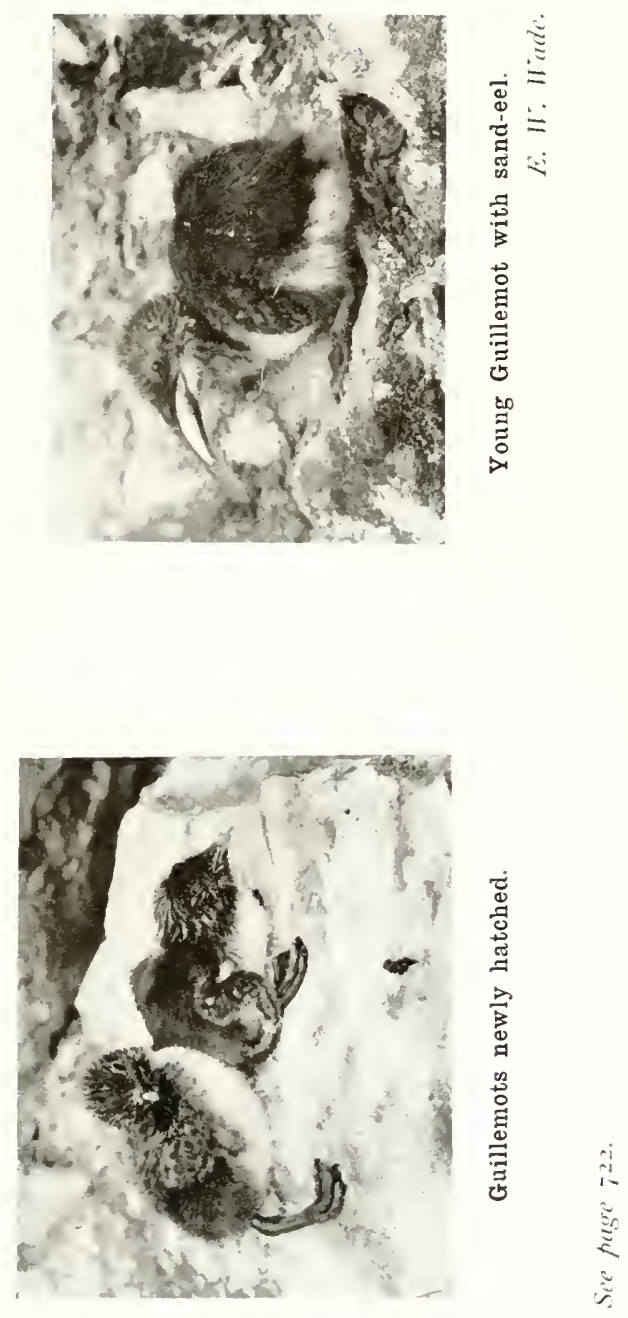

numerous, and is never altogether absent from the neighbourhood of the coast-line, as a few individuals, probably immature and non-breeding birds, may be observed at sea throughout the spring and summer months. It is a regular and common autumn or winter migrant to the seaboard and estuaries, immature birds arriving in early September and October, sometimes in great numbers; on 2oth September I883, I saw at least fifty at sea, flying to the south-east in advance of an approaching storm, and during that autumn it was unusually abundant.

This bird occurs with tolerable frequency on inland waters, and has been reported from the river Hull at Beverley, Scampston Lake, the Derwent at East Cottingwith, Gormire Lake, and Semerwater, the Wharfe at Newton Kyme, Malham Tarn, and the reservoirs and large sheets of water supplying the populous West Riding manufacturing towns. It has also figured in the list of casualties at our coast beacons, an immature female, now in the York Museum, being picked up below the Spurn Lighthouse in October I90o.

The red gular patch, indicative of the adult bird, is assumed early in spring; on 28th March 1875 , I obtained an example in full nuptial garb, and on Ist April I89I, distinctly saw three others near the rocks. This plumage is retained until late in autumn; specimens have been seen and procured in August, September, and October, whilst in 1887 one with partly red throat was killed as late as $9^{\text {th }}$ November.

Divers are occasionally taken in the nets of the herring fishermen, and one, captured on a fishing line at Redcar in January I884, was brought to me alive and uninjured. From personal observation I have found that the Red-throated Diver, when pursuing its prey, remains under water for a length of time varying from forty-five to seventy seconds, and it often approaches very near to the shore; I have seen one within two yards of where I was standing on the beach. The rapacious appetite of this bird was exemplified in the case of an individual killed at the Teesmouth in December Igor, which disgorged eight sand eels, three of them being eight inches in length, and only two partly digested. 
Birds of the Colymbidæ family are not subject to great variation; the only Yorkshire example reported being of this species, and pure white in plumage, with pale yellow legs, feet, and bill; it is in the collection of Mr. J. Whitaker, who informs me it was shot at Spurn.

The vernacular names are:-Sprat Loon and Speckled Loon, used in the Humber district, which in the Yorkshire dialect is rendered Leään at Flamborough, Scarborough, Whitby, and Redcar. To the river Tees fowlers it is known as Sparling Whew; in the East Riding it receives the cognomen of Guinea-bird Diver, from its speckled back being similar to that of a Guinea-fowl, and at Bridlington it is sometimes called by the peculiar name of Sheep's-head-andpluck, as indicating its resemblance to that portion of a sheep's anatomy.

\section{GREAT CRESTED GREBE.}

Podicipes cristatus (L.).

Resident, breeding irregularly and in limited numbers on protected sheets of water in various localities. Also winter visitant, both inland and on the coast, though not common.

The first mention of this as a county species is, apparently, that referred to by the celebrated John Ray, who stated that one was sent by Mr. Jessop out of Yorkshire (Ray's "Synopsis," I7I3, p. I25).

Thomas Allis, I844, wrote:-

Podiceps cristatus.-Great Crested Grebe-Has been obtained once or twice near Sheffield. F. O. Morris reports it to breed near Hornsea ; in the winter plumage it is not infrequent near Sutton-on-Derwent; in the male summer plumage it is very rare in this district. A. Strickland states that it breeds at Hornsea Mere, and probably used to be abundant in the Carrs.

Notwithstanding the persecution to which it has been subjected, this singular looking and beautiful bird is still resident in Yorkshire, though very local and few in numbers, 


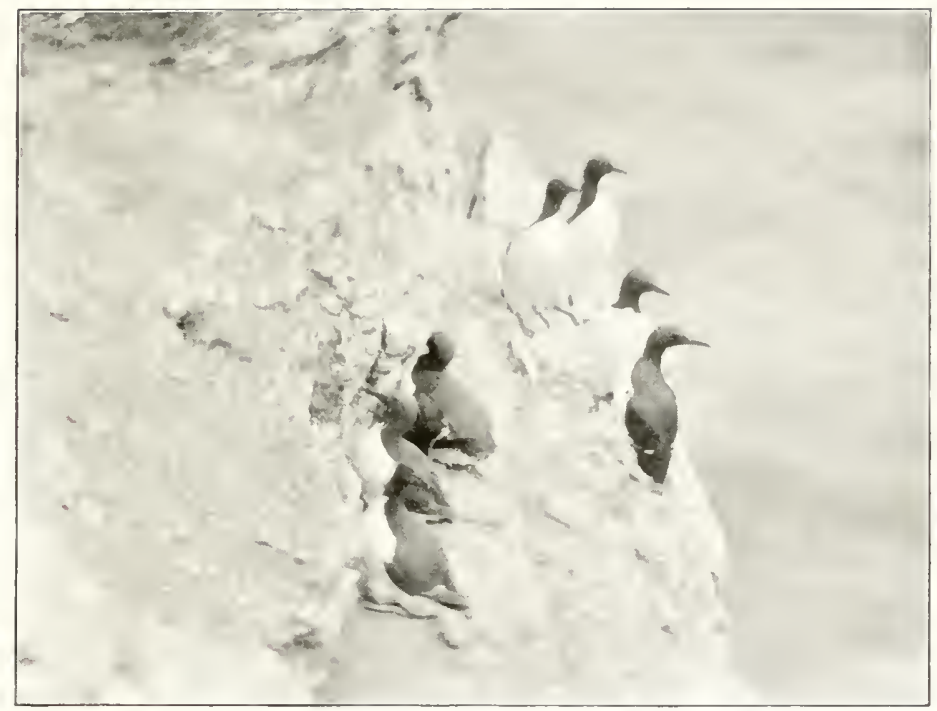

Guillemots on Staple Neuk.

R. Fortune.

Sé page 722. 

being restricted to sheets of inland waters where it is protected from molestation, and where it finds the seclusion necessary for its nidification, one of which is Hornsea Mere in Holderness ; in 1888 no fewer than six nests were observed there.

It occasionally occurs in summer plumage on the river Hull, near Beverley, though its numbers are decreasing in the East Riding; it was, in olden days, one of the inhabitants of the famous Potteric Carr, near Doncaster, before the levels of Hatfield were drained and reclaimed ; one or two pairs usually breed on the lake at Castle Howard ; there are generally two, and sometimes three, pairs on Hemsworth Dam; whilst Mr. Rosse Butterfield tells me he discovered nesting birds on four different sheets of water in the Wakefield district. It has nested on the lakes at Sandbeck Park, and Woodhouse ponds near Kineton Park; on Ryhill and Worsborough Reservoirs, near Barnsley, and in one or two localities near Sheffield; I saw two pairs on the lakes at Harewood and Allerton Parks in the spring of I902, and it nests on a preserved lake in Nidderdale. At the Swinsty and Fewston Reservoirs the first example was noted in I894; in I902 two pairs nested, but, unfortunately, one of the old birds was killed in the early part of I904, though there were still two pairs on the water, and it is to be hoped that strict protection will in future be afforded to the survivors. It is a casual visitor to Malham Tarn, where a fine adult male was observed in I 890 , and another on 7 th June I895, but there is no evidence of its nesting there.

In autumn the Hornsea birds leave the mere and retire to the sea or the Humber; at this period the species is more generally distributed, and may be met with both on inland waters and on the coast, its numbers being augmented by immigrants from more northern latitudes. In very hard winters, when its inland haunts are frozen up, it is more frequently found on the tidal waters, and has been reported from most of the coast stations, though usually considered a rare bird. J. Hogg, writing in 1845 , mentioned that it frequented the Tees in severe weather in his day; one was captured there on Igth December I876; and I have seen and 
obtained specimens, since that year, both in the estuary and off Redcar. During the stormy weather of January I89I, when the Red-necked species was so abundant, I noticed several Great Crested Grebes, one of which was procured at sea, while another was caught asleep on the sands early one morning; and on I7th January I9or, three of these birds were swimming within a few yards of the shore in front of my house. The examples obtained off the Cleveland coast are usually in immature or winter plumage; I have only two records of specimens in the breeding dress, viz., in spring of the years I 882 and I900.

The following particulars of the bill and legs of a bird, examined in January I904, may be of interest, as these parts are not usually described by authors of works on British Birds. Bill, pink flesh colour, with top of upper mandible of a dark horn hue, and lighter towards the point. Legs, on the outside dark brownish black, other parts yellowish white, with dark purple spots and blotches.

The only vernacular name we have note of is Tippet Grebe, used in the Tees (Hogg, I845), and at Hornsea Mere.

\section{RED-NECKED GREBE.}

\section{Podicipes griseigena (Bodd.)}

Winter visitant, of uncommon occurrence, and irregular as to numbers. Occasionally observed on inland waters.

The first allusion to the Red-necked Grebe in Yorkshire occurs in Fothergill's Wensleydale list of I823, where it is enumerated amongst the birds observed in that district.

Thomas Allis, I844, wrote:-

Podiceps rubricollis.-Red-necked Grebe-One or two shot near Doncaster every winter; it is very rare near Barnsley; a specimen was shot on Worsborough Reservoir in 1830; many have been shot or taken near Huddersfield, but they are among the rare birds of 

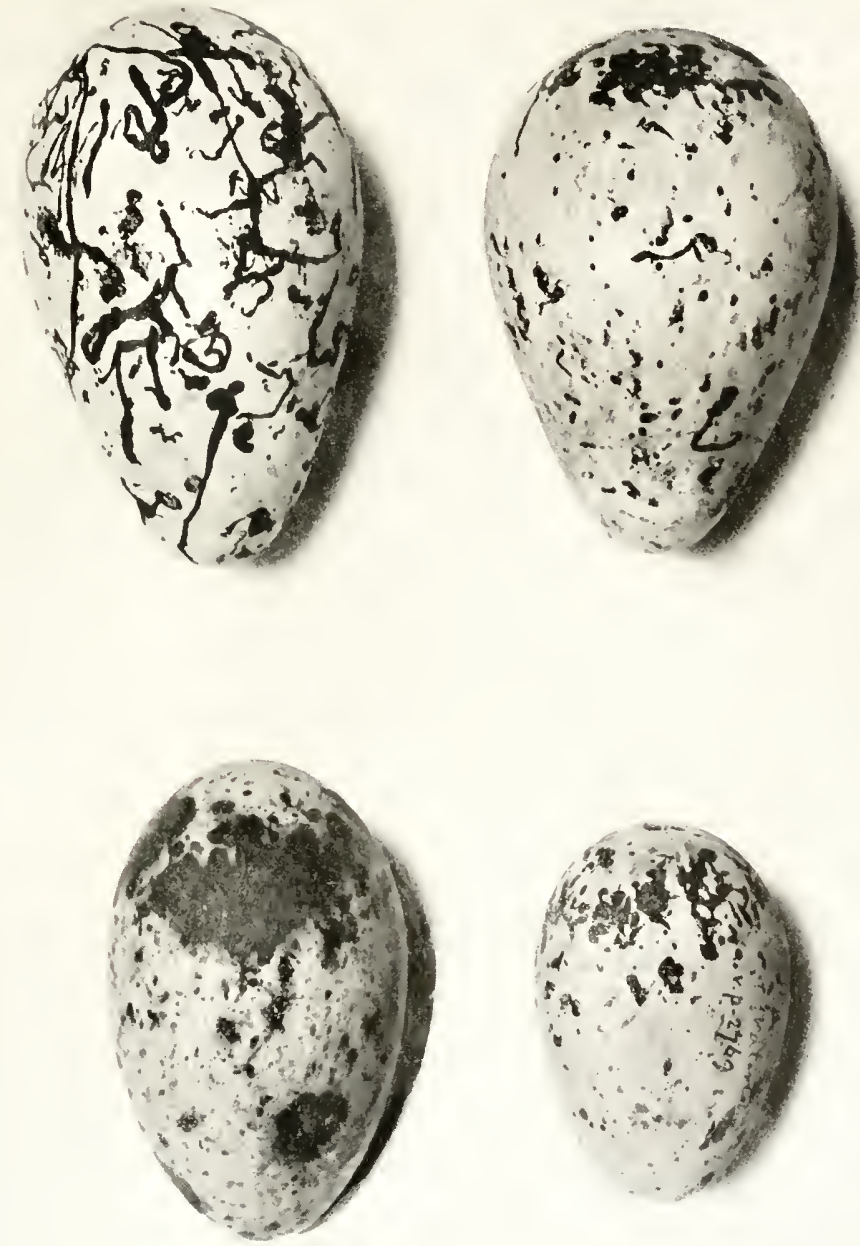

Eggs of Guillemots, Razorbill, and Black Guillemot, shewing comparative sizes. T. II. Velson.

1. Typical egg of Common Guillemot. 2. Typical esg of Ringed Guillemot. 3. Typical egg of Razorbill,

4. Egg of Black Guillemot taken at Flamborough. From the collection of the late Charles Watertun. See page 726 . 

the district ; it is rare near Leeds; a specimen was shot at Ripponden in 1800 ; it is met with near York occasionally, in immature and winter plumage; I once had a male nearly arrived at its full summer plumage; a specimen in full plumage was shot in the Ouse a few years ago, close to the City, and is in "the Museum at York; it is rare at Hebden Bridge; it is occasionally met with in winter in Bridlington [Bay], but it is by no means common.

This bird is a winter visitant to the coast-line from September to March, of very irregular and uncertain appearance, in some years being altogether absent, whilst in very severe seasons it has been observed in considerable numbers. In the winter of I855 five specimens were taken to a Scarborough taxidermist; several occurred in Holderness in the winter of I884-85, and since that date it has occasionally been obtained in the neighbourhood of the Humber. Odd individuals have also been met with at intervals at Bridlington, Flamborough, Whitby, and in the Teesmouth area, where I have notes of its occurrence on six occasions between I875 and I890. In the early part of the year I89I, however, it appeared in such surprising numbers as to excite the attention of ornithologists on the whole length of the seaboard, that year having since been known as the "Grebe year." On Igth January I was off at sea and obtained three of these Grebes, the first I had had an opportunity of observing, whilst, at the same time, twelve others were seen, but I could not follow them owing to cold snow showers and darkness coming on; two Redcar boatmen, who were about a mile distant from my craft, told me they had seen at least twenty more. During the following week, the weather being stormy, the fishermen reported astonishing quantities of Grebes at sea between Huntcliffe and Teesmouth; on the 27 th another example was procured, and several more seen, and, from that time until Ist April, these birds were noticed in the vicinity of the rocks, some being shot, while others were driven ashore and taken alive on the sands. Twenty-eight specimens were killed in the Scarborough neighbourhood, seven at Filey, and it was also reported as unusually abundant off the Headland of Flamborough (Zool. I89I, pp. I93-253; and Nat. I89I, p. I23). 
The extraordinary superabundance of this species was, in all probability, to be accounted for by the intensely cold weather, then prevailing, having frozen up their continental haunts, thus driving them to our shores; still it is difficult to understand why, in other years of equal severity, it has not been noticed in like quantities. In the year I893 it was again numerous off Flamborough; and in February I895 several occurred off Redcar and the Teesmouth, though not in such numbers as in I89I.

The examples which have been procured are generally in the winter or immature stage, but, on rare occasions it has been reported in adult summer dress; one was noted at Bridlington in September I852; another at Flamborough in the same month in I875; and one at Scarborough on Igth October I 899 .

The Red-necked Grebe has been observed on inland waters in many parts of the county; it is mentioned in Hatfield's "Historical Notices of Doncaster" (I866), as occurring on the Carrs; also in Fothergill's Wensleydale list of I823, and Barker's "Wensleydale" (I854). On various open sheets of water in the West Riding it has been obtained; it was mentioned by Allis in his Report; at Acaster and York it was noted in I850; at Newmiller Dam in I858, and at Kirkthorpe in 1860 ; one was killed near Danby in 1870 ; an example was captured in a farmyard at Owldray, near Helmsley, in I880; and another in a stackyard at Skeffling in November I895; near Beverley one was shot on a flooded field in I872, and in I89I one was killed at Waghen. The York Museum contains several specimens which have been taken in the county, one being an immature bird picked up dead near the city.

This species is occasionally immolated by flying against the telegraph wires, one such instance being recorded at Horsforth in 1865 , and a second at Scarborough in January I89I.

The only local name of which I am cognizant is Greve, used at Redcar. 


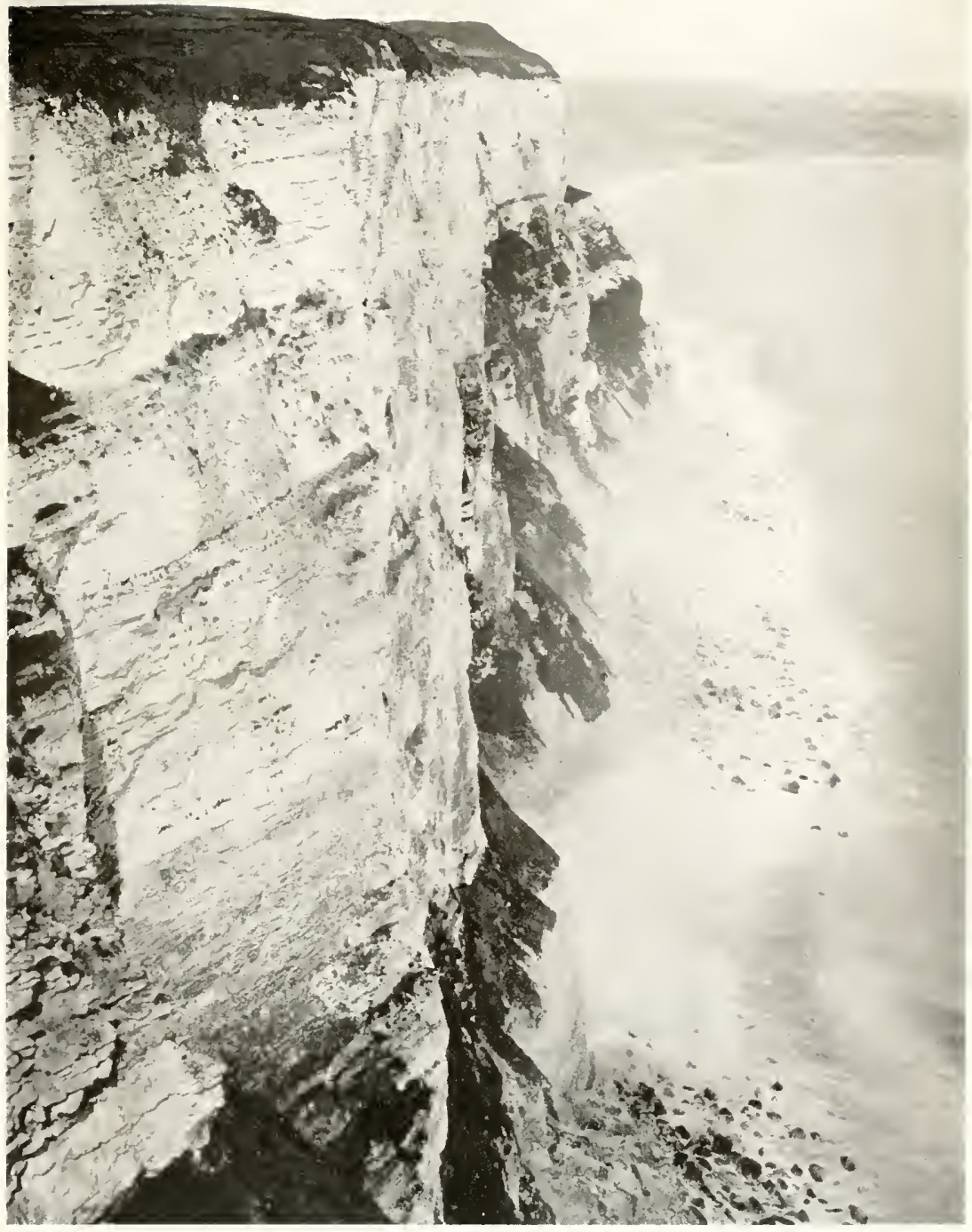

Bempton and Speeton Cliffs, looking west.

Nesting places of the Puffin are on the grassy slopes midway down the cliffs. 



\section{SCLAVONIAN GREBE.}

Podicipes auritus (L.).

Winter visitant, not uncommon on the coast. Occasionally met with on inland waters.

Fothergill's Wensleydale list, in Whitaker's "Richmondshire" (I823), contains what is probably the first Yorkshire mention of this Grebe, it being noted amongst the birds of that district, under the name of "Dusky Grebe."

Thomas Allis, in 1844 , thus referred to it :-

Podiceps cormutus.-Sclavonian Grebe-One shot at Barmby-onDun several years ago, according to F. O. Morris. I had myself a beautiful male specimen in summer plumage, but it is very rare in this neighbourhood in that state; not infrequently met with in winter and immature plumage.

Like its preceding congener, this bird is a winter visitant, usually appearing in September or October, and remaining until March, though instances are known when it has occurred in August; one, obtained on the 3 rd of that month, in the year 1876 , is now in the Hull Museum. Although never very numerous, it is the commonest of the Grebes except the Dabchick, and occurs annually on the coast, chiefly in the neighbourhood of the river estuaries or amongst the half-tide rocks in shallow water; I have several times watched birds of this species fishing close inshore near the Redcar "scars," and in I90I procured one, in a channel at the Teesmouth, which had been feeding on sprats, one fish hanging out of its bill when the bird was brought ashore. Several were killed in the Tees estuary in the winter of $1874-75$, and also in $1896-97$, when it was more than usually abundant, and it was reported in some numbers from Scarborough during the same season. An adult female was shot off Flamborough on 29th October I874, while Allis referred to an example in summer plumage in his possession, but, as a rule, the bird is met with in the dusky or winter dress. It takes its departure in March or April, an unusually late lingerer being reported in May I883, when one was observed on a pond near Barnsley.

VOL. II. 
On inland streams and lakes this Grebe has often been noted ; it is recorded from near Beverley; Scampston ; Selby ; Malton; the Derwent at East Cottingwith, where in some seasons it is not uncommon; in Wensleydale on the Ure; at Thirsk; near Waekfield, in which locality it was, for several years before 1876 , a regular visitor to the reservoir ; Waterton mentioned it at Walton Park; and it has also been reported from Halifax, Fewston, Bolton Bridge in Craven, and in Ribblesdale.

The local names formerly applied to it were Horned Grebe and Dusky Grebe; in the Humber it is called Small Diver.

\section{EARED GREBE.}

Podicipes nigricollis (C. L. Brchm).

Occasional visitant, of rare occurrence.

The first published Yorkshire notice of the Eared Grebe appears to have been made by J. Hogg, who remarked that one was reported to have been taken at the Teesmouth in January I823 ( $Z$ ool. I845, p. II 82 ).

Thomas Allis, in I844, wrote :-

Podiceps auritus.-Eared Grebe-A few stray specimens have been found about Huddersfield; it is rare about Hebden Bridge; it has been obtained near York in full plumage, but is very rare ; it is occasionally met with in immature and winter dress. A. Strickland says, " It is probable that the breeding places of these two birds, cornutus and auritus, are very distant from this country, as the mature birds are of the rarest occurrence, at the same time the young or immature bird of both these species, under the common name of Dusky Grebe, is often met with in winter; to distinguish these two species in this state can only be done by minute attention to the form of the bills."

Though it has been captured in spring and summer, when in full breeding plumage, there is no evidence that the Eared Grebe has ever bred in Yorkshire, and it is to be ranked as a casual visitant, chiefly in winter, from the Continent of 


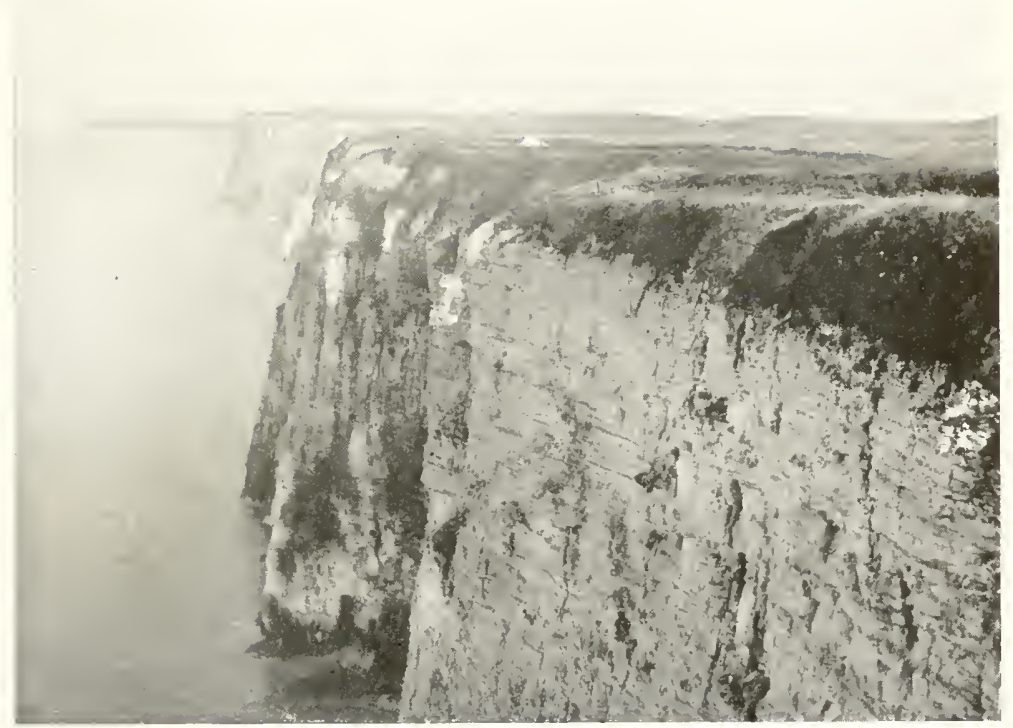

Bempton Cliffs, looking east.

The nesting holes of the Puffin are on the grassy slopes midway down the cliffs. Se' page' 72S. 

Europe; though it is probably of more frequent occurrence than the records imply, as, off the coast of Northumberland and in the Firth of Forth, it is a regular winter visitor.

In addition to the example recorded by Hogg and those mentioned in Allis's Report, of which no further particulars are now available, the instances of this bird's occurrence may be set forth as follows :-

One, near the lighthouse at the Teesmouth, I2th April I846 ( Nat. I856, p. 308).

One, near York, I8th December $x 849$; exhibited by $D$. Graham at a meeting of the Yorkshire Naturalists' Club, on I6th January 1850 .

An adult male, in splendid plumage, at Bubwith, near Selby, in the year I854; formerly in the late W. W. Boulton's collection, now in the possession of Mr. T. Boynton (Boynton MS.).

One, at Scarborough, in February I855 (Roberts, Zool. I855, p. 4660).

One, at Thornes on the Calder, in February I86I (Talbot, "Birds of Wakefield," p. 3I).

A female example, on the Humber near Hull, 2oth February I864; formerly in the late W. W. Boulton's collection, now in that of Mr. T. Boynton (Zool. I864, p. 9048).

One, near Ripon, in the possession of Mr. Parkin (H. H. Slater MS.).

A female specimen, at Spurn, 20th December I872 (Zool. I873, p. 34I3).

One, at the Teesmouth, in the winter of $1874-75$; in my collection.

One, at Easington, near Spurn, Igth December I882 (Loten MS.).

One, at the same place, 3rd September I887, shot by Mr. IV. Eagle Clarke; formerly in the collection of Mr. J. Backhouse, now in the York Museum.

One, in the collection at Thicket Priory; obtained near that place by Capt. Dunnington-Jefferson.

A pair of adults, in perfect breeding plumage; taken alive in Whitby harbour, Ioth March I888, by John Harland. 
Acquired by Mr. Thomas Stephenson; afterwards in the possession of Mr. J. Braim, and now in the Halifax Museum.

A female specimen, with eggs in an advanced state, at Scarborough, I6th December I889; in the possession of Mr. Head (Zool. I89o, p. 77).

One, near York, 23rd October I89o (Nat. I89I, p. 6).

One, off Scarborough, 2oth January I892; in the Scarborough Museum (Zool. I892, p. I44).

A female example, at Easington, 23rd August I896 (Cordeaux, Nat. I897, p. I4).

One, found on the beach at Redcar, Ioth February 1897 ; in my collection.

An adult female, at Scarborough, I2th January IgoI (W. J. Clarke MS.).

One, at Hinderwell, in January Igor; preserved by Mr. John Morley, Scarborough.

One, on a pond at Great Ayton in Cleveland, in the spring of $\operatorname{Ig02}$ (F. Atkinson MS.).

And, finally, a specimen in the possession of Mr. Thomas Machen, procured in Bridlington Bay in the winter of I903.

The only name, other than its ordinary appellation, is Black-necked Grebe.

\section{LITTLE GREBE.}

Podicipes fluviatilis (Tunstall).

Resident, generally distributed, and not uncommon. Also winter visitant, arriving in September and October.

Probably the first reference to this, as a Yorkshire bird, is in the Allan MS. (I79I) in connection with the Tunstall or Wycliffe Museum, thus:- "Little Grebe, Didapper, Dipper, Dabchick, Small Ducker. Frequents same places as other Grebes, even more common. Makes a large nest floating in the water, and lays 5 or 6 eggs. Always covers them when it leaves the nest. They eat fish, insects, and plants. Is an excellent diver" (Fox's "Synopsis," p. 9I). 

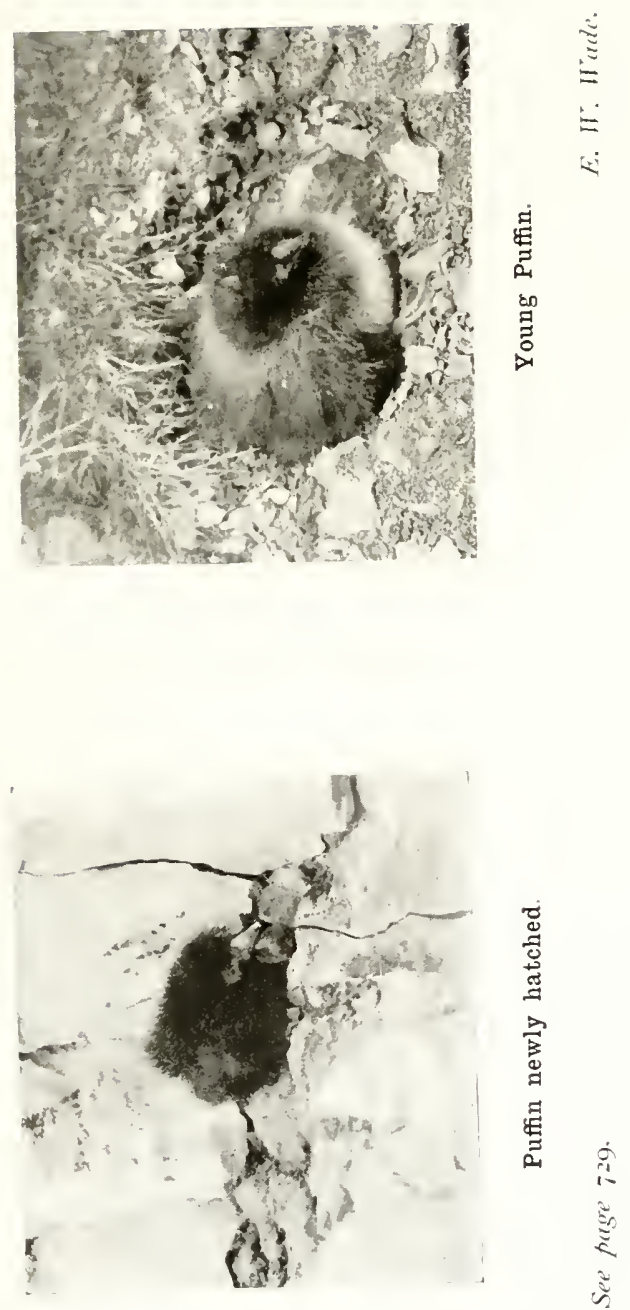

Thomas Allis, in I844, wrote :-

Podiceps minor.-Little Grebe-Common near Hebden Bridge and Doncaster; occasionally met with near Halifax; uncommon in the vicinity of Sheffield; not uncommon about Barnsley and Huddersfield, where it stays through the year; not infrequent near Leeds and York. A. Strickland says, "It is by no means uncommon in this county, and probably breeds in various parts of it, and it is often found ia winter."

The Little Grebe, or Dabchick, is resident, and the most numerous of the genus, being found in the breeding season in most parts of the county where there are secluded ponds, lakes, and streams which afford the concealment requisite for its nest; it is known to breed at Malham Tarn at an elevation of 1,250 feet. An early allusion to its haunts in Wensleydale was made by W. G. Barker, who stated that "near East Witton, on the banks of the Yore, is a fish-pond where Dabchicks are plentiful" ("Loudon's Magazine," I832). From twelve to thirty of these birds have been observed on Hemsworth Dam in spring, before the reeds grew up; in the East Riding many nest annually on the Driffield streams, and in South Holderness it was formerly plentiful enough to have a local name.

In the autumn, from September to November, there is an influx of immigrants on the coast, sometimes in considerable numbers, and examples have been killed by striking against the Lighthouses on dark nights; on I6th October IS9I, during a south-west gale, one took refuge in Redcar Station, where it was captured by the Company's policeman, who brought it to me; I have occasionally observed specimens in the Tees estuary, and, on 8th November I905, I saw a party of seven on the sea off Redcar; the species has also been noticed on migration in the Beverley district. There is but one example in breeding plumage reported on the coast; this was caught near Redcar Pier in June.

An interesting account of the nidification habits of the Little Grebe is related by Mr. J. W. Dent of Ribston Hall, near Harrogate, who, in the spring of 1896 , noted a pair on a pond near his house, which had a late brood in September, 
whilst in I 897 he found eggs as early as 3 rd March. The birds, owing to disturbance, built no fewer than nine nests, four of which contained eggs. Mr. Riley Fortune tells me he has found several nests near Harrogate built on branches of trees which hung down to the water.

Local names:-Dabchick (general), Didapper, Dipper, Small Ducker (Allan MS., I79I) ; Tom Pudding (North and West Ridings) ; Dobber (Zool. I848, p. 2290) ; Tom Puffer and Tom Puffin, or Tom Poofin (North and East Ridings); Dipper Duck (Central Ryedale), Peep o' Day (East Cottingwith;.

\section{STORM PETREL.}

Procellaria pelagica (L.).

Winter visitant, not infrequent on the coast in stormy weather; sometimes found inland after very severe gales.

The first published allusion to this bird in Yorkshire occurs in the Rev. John Graves's "History of Cleveland" (I808), where it is enumerated in the list of birds.

Thomas Allis, in his Report, made in I844, wrote:-

Thalassidroma pelagica.-Storm Petrel-J. Heppenstall informs me that one was found swimming in the river in a populous part of Sheffield; it flew up and settled on a house, where it was shot. It is rare at Leeds; rarely seen about Hebden Bridge; one specimen was shot at Keighley about four years since ; it is met with about Huddersfield. A. Strickland has known considerable flights of this bird occasionally, on the east coast, where many specimens have been procured, but these visits are very uncertain, and seem entirely the effect of accidental causes.

This little wanderer is an autumn or winter visitant, not uncommon in some years, but, being essentially a rover of the deep sea, it is not often observed close to land, unless in wild and stormy weather, when it is compelled to fly before the gale and seek refuge from the storms which rage with terrible frequency on our eastern seaboard. Arthur Strick- 


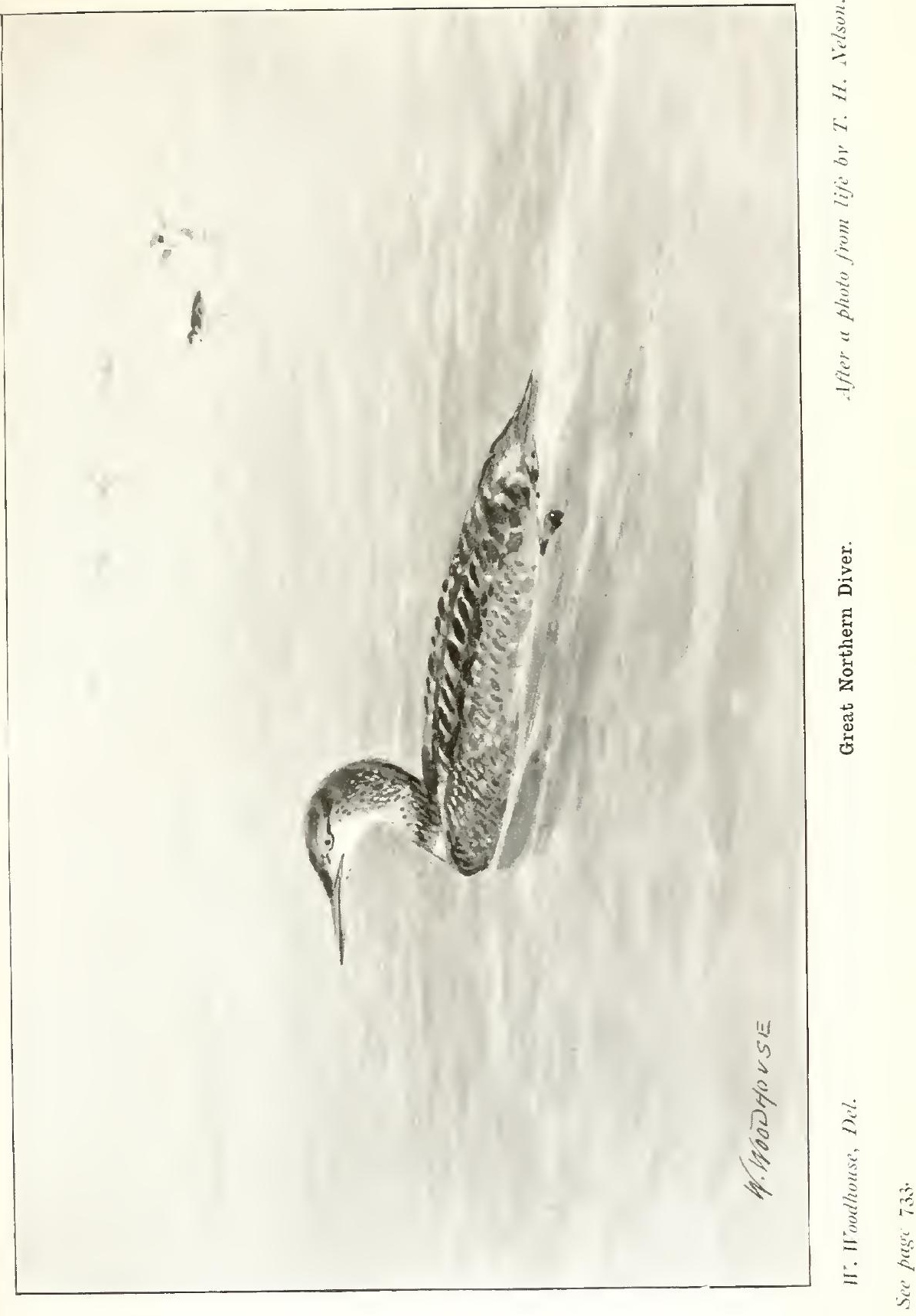


land informed Allis that considerable flights occurred before 5844 , and, in October and November I867, a number of these Petrels appeared in Bridlington Bay, where eight or nine were killed; they exhibited no fear of the presence of man, and one was knocked down by a short gaff. Off the Redcar coast some were seen in November and December I877; as also at Redcar, Spurn, and other stations on 28 th October I880, and the I4th of the same month in the year following, during heavy northerly gales; on the latter date one was blown against a bathing van and captured alive; I kept it for some days, when it readily fed on oil which it took from the surface of water in a saucer, skimming to and fro like a Swallow. In the great hurricane from the north-north-east, on I8th November I893, five or six of these birds were stormdriven and picked up dead or exhausted on the sands.

Although not usually observed before the month of October, it occasionally occurs at an earlier date; I saw one at sea on 23rd September I883; two were noted on 2oth August I889, off Spurn, near a fishing boat, fluttering and beating for food as the men hauled their crab-pots; and at Masham one was seen on the river Ure on 2Ist August I880.

It sometimes comes within the influence of the Lighthouse rays, and the Migration Reports contain references to its immolation against the lanterns on dark and stormy nights; several struck the Spurn Light on I4th October I88I, and also on I6th-I7th Nevomber I898, whilst between the IIth and I2th November I906, no fewer than five were thus killed at the same station.

In districts remote from the coast this little bird has many times been found after stormy weather at sea, in north or east gales, blown in from the North Sea, and, in westerly gales, from the Irish Sea. One was found so long ago as I8I3 at Knaresborough; it has also occurred in the recesses of the West Riding dales, and on the moorlands of the north and north-west, though the instances of these occurrences are too numerous to be given in detail; it is probable that, owing to its small size, it has often passed unnoticed.

The specimen from which Bewick drew his figure of this 
bird was sent to him by Col. Dalton, who found it dead at Tanfield (Bewick, "British Birds," Ist Ed. ii. pp. 249-25I). Local names:-Storm Finch (Tunstall, I784); Stormy Sea-runner, Cleveland (Hogg, I845).

\section{LEACH'S FORK-TAILED PETREL.}

\section{Oceanodroma leucorrhoa (Vieillot).}

Casual visitant on the coast in winter, of rather rare occurrence ; after severe gales it is sometimes found dead in inland localities.

The first Yorkshire reference to this bird was made by Thomas Allis, in "Loudon's Magazine" for 1832, where several examples were recorded, and these were also mentioned in his Report on the Birds of Yorkshire, written in I844:-

Thalassidroma leachii.-Fork-tailed Petrel-H. Reid informs me that one was shot by a boatman on the river Don near Sprotborough, in 1837. which is now in the excellent collection of George Foljambe, Esq. ; one was found dead in the streets of Halifax, I6th December 1831 ; another was found dead on Sutton Common, near Doncaster ; three or four were found some winters ago near York, at which time they had been met with over most of the midland counties; very rare near Leeds; a specimen was found at Halifax a few years ago; this, as well as several of the tribe, is often attracted by the light at night, where they remain till exhausted.

When winter gales sweep across the North Sea, the Forktailed Petrel, though an ocean-loving bird, is compelled to seek shelter near the land, being sometimes driven by the fury of the storm on to the beach, or even into country districts far removed from the seaboard. An opinion has been expressed that, as it is a western species, it is blown across from the Western Sea, though I have met with it more often in north-east gales than at other times. The earliest date on which it has appeared, so far as I am aware, is I $7^{\text {th }}$ September in the year 1903, when a female bird, now in my possession, was shot at the Teesmouth. 


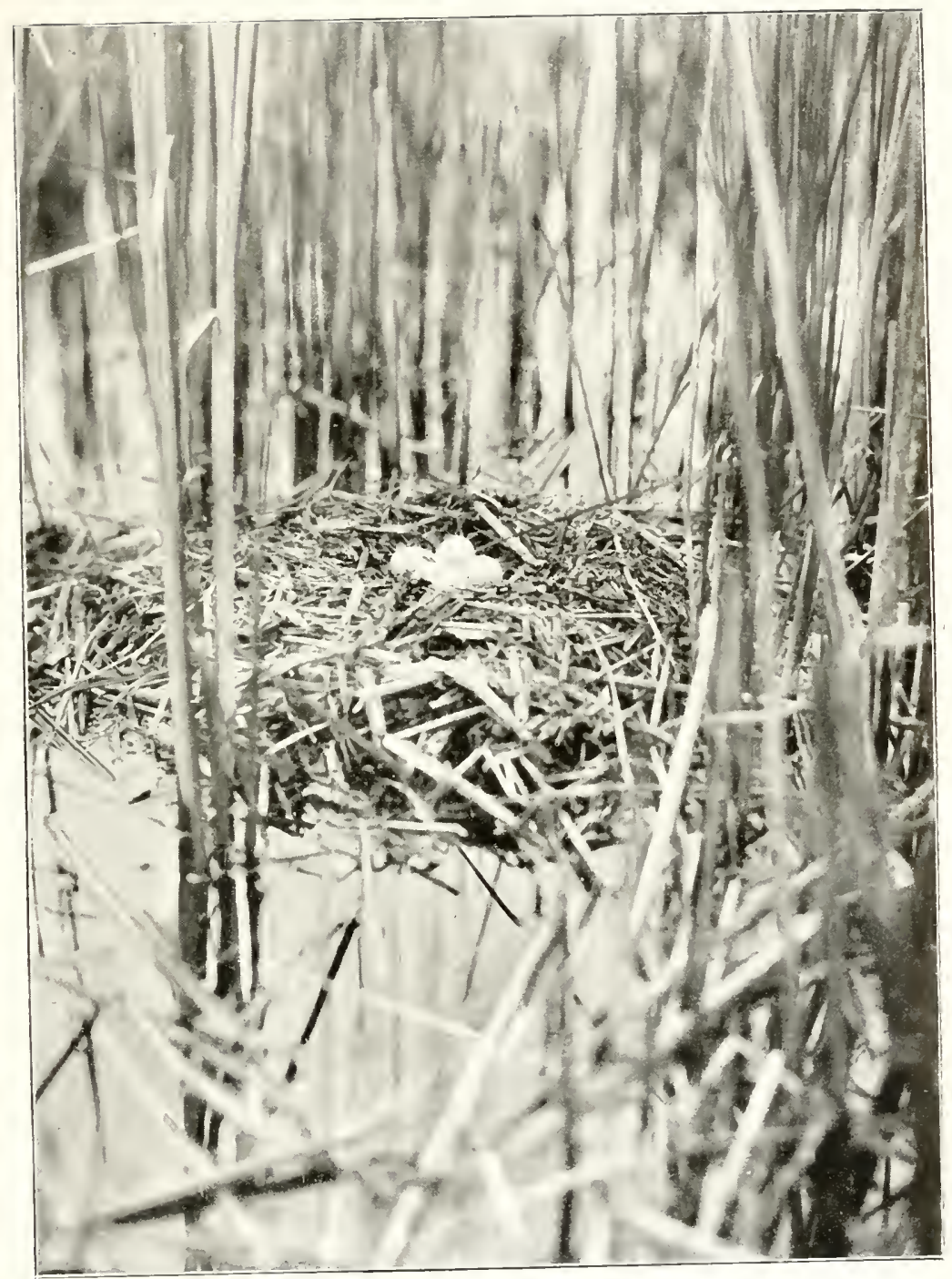

Nest of Great Crested Grebe, Hornsea Mere R. Fortune. 

It is an autumn or winter visitant, in very limited numbers, and not at all regular in its appearance. Thomas Allis, in "Loudon's Magazine" for I832, recorded that, in the winter of I83I-32, several examples occurred far inland, driven in by stormy weather, and in his Report on the Birds of Yorkshire, quoted above, he mentioned others near York, though at most of the Yorkshire coast stations it was considered a very rare species until the year I88I, when some were taken in October and November ; while in Cleveland I had known of but one instance before IS9I; in that year it was reported as being unusually plentiful on several parts of the west coast, and doubtless, the Cleveland specimen, which was brought into the kitchen at Easby Hall by a cat, had been blown across from the Irish Sea. During the prevalence of a hurricane from north-north-east, on I8th October I893, several individuals were storm-driven, and cast on the beach, where they became "sand-warped," and, in some instances, were blown up to the foot of the sand-hills; at Redcar six were picked up under these conditions. Other occurrences at Redcar were in Igoo, when one was immolated against the telegraph wires; on I2th November IgoI, one was shot during a gale from east-north-east, and came into my possession ; another, also in my collection, was, as stated above, captured in Igo3, and, in the first week of October I905, a specimen was picked up below the telegraph wires between Redcar and Marske. A female example, in the Hull Museum, was found at Flamborough in December I883.

Inland it has occurred at several places, in addition to those mentioned in Allis's Report and in the text, and for convenience of reference a list is here appended :-

One or two near Hull.

One near Thirsk.

Near Beverley, one taken alive, autumn I854 (Zool. I865, pp. 9493-4).

One at Kirkhammerton, before I857 (Morris, "British Birds," vi. p. 248).

Leeds, one, purchased in the market about I863 ("Yorkshire Post," 6th February I875). 
An example in the York Museum, labelled "Bolton Park, I872."

Hornby Park, one, found dead some years ago (W. Wade Dalton MS., I880).

Riplingham, near Beverley, one picked up; now in the collection of Mr. John Stephenson (Nat. I882, p. I00).

Western Ainsty, one, picked up dead at Newton Kyme (op. cit. I8gi, p. IIo).

(The example reported at Southowram, near Halitax, I3th November I874, is evidently to be referred to Wilson's Petrel, which see.)

\section{WILSON'S PETREL. \\ Oceanites oceanicus $(K u h l)$.}

Accidental visitant from the Atlantic, of extremely rare occurrence.

This long-legged Petrel is common on the west coast of North America, and ranges southward to the Cape of Good Hope, the South Atlantic, and the South Pacific; it has been found breeding on Kerguelen Island.

Yorkshire can lay claim to a single example of this bird which was killed, or found dead, at Southowram, near Halifax, on I3th November I874, and is now in the possession of Mr. Christopher Ward of Wray, near Lancaster, to whom it was taken in the flesh, while quite fresh (Ward MS.).

\section{GREAT SHEARWATER.}

Puffinus gravis (O'Reilly).

Autumn and winter visitant of uncertain occurrence, generally speaking rare, but appears to be more frequent off Flamborough Head than elsewhere.

This bird extends its range northward to the shores of Iceland, Greenland, and North America, and probably 


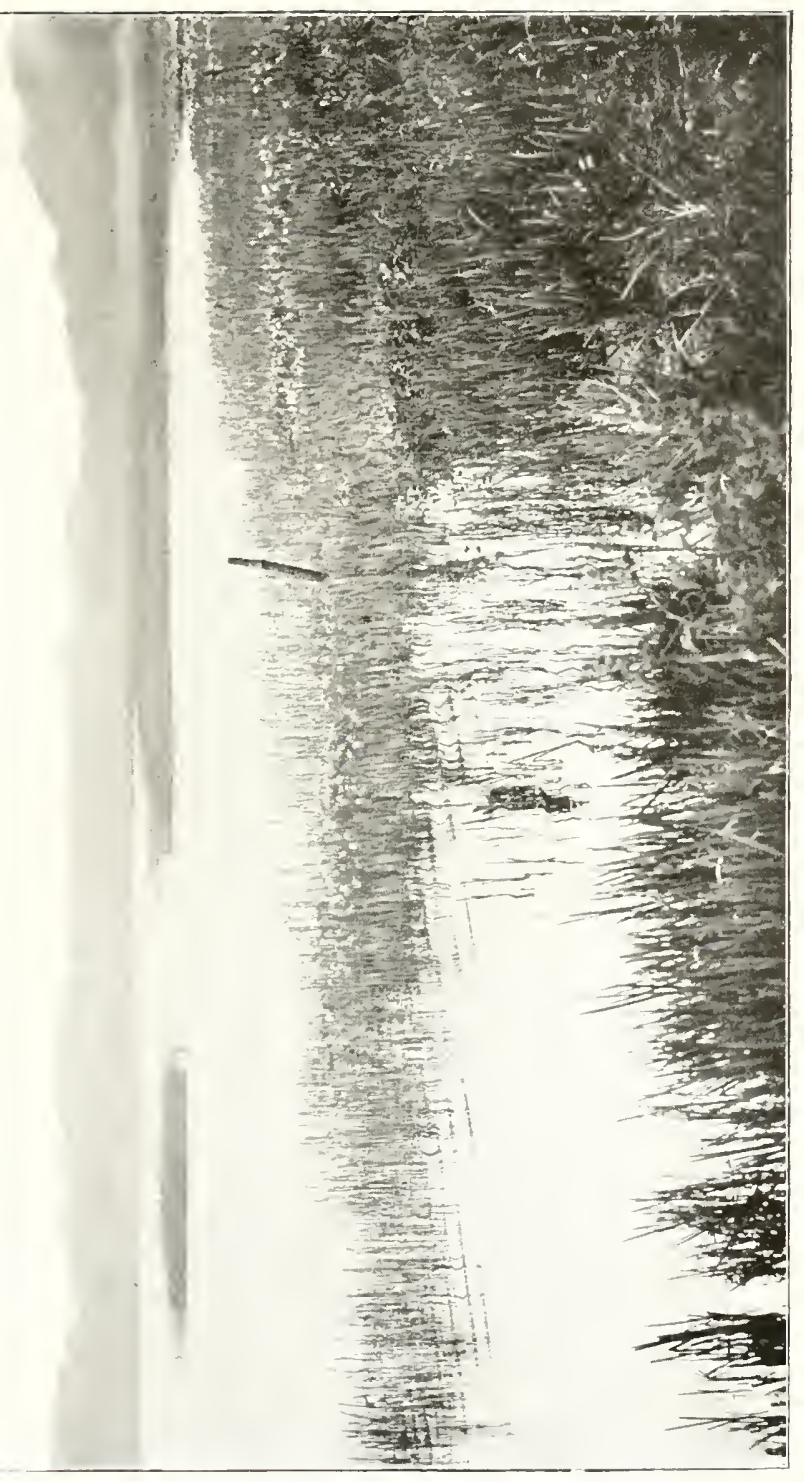



resorts to the Southern Ocean for breeding purposes, although as yet nothing authentic is known of its nesting haunts.

Thomas Allis's Report on the Birds of Yorkshire, written in 1844 , contains the following allusion to this species, but, in the light of more recent knowledge, it is doubtful if the specimens mentioned were to be referred to the Great Shearwater or to $P$. griseus :-

Puffinus major.-Greater Shearwater-I am informed by my friend James $\mathrm{H}$. Tuke that a specimen of this bird has been procured at Robin Hood's Bay; another specimen was shot at Bridlington about two weeks ago, and it was procured by Mr. from near Warwick. A. Strickland remarks, 'The two specimens from which this bird was first constituted a British bird were both killed on different parts of this coast, and are still in my collection; I have since heard of another killed near Whitby; it is now ascertained that this is not the same as the Cinerius Shearwater, as was supposed by Mr. Gould, but a distinct species, this bird frequenting the northern regions, and the latter in the Mediterranean and a more southern range."

The early Yorkshire records appertaining to the Shearwater are now known to be inextricably entangled with those of its congener, the Sooty Shearwater, which was supposed to be a dark, or immature, form of this bird, and thus it is extremely difficult to give correct details of occurrences without examination of the specimens.

The Great Shearwater is an autumn and winter visitant to the Yorkshire seaboard, but is not of frequent or regular occurrence. As in the case of some of the rarer Gulls, Skuas, and Petrels, it is met with most frequently in the neighbourhood of the Headland of Flamborough, being attracted to that locality by the shoals of fish which are found there in the herring season, and an instance is known of one being taken on a hook attached to a fishing line. It was unusually abundant in September I88I ; and in August I876 several "Big Shearwaters" were reported to me by the Redcar fishermen.

For purposes of reference a list of occurrences is here appended, though it must be borne in mind that, in considering it, the instances are not all authenticated, and the reader is requested to peruse the history of the next species, $P$. griseus 
Robin Hood's Bay, one, before I844 (Allis's Report, fide J. H. Tuke).

Bridlington, one, in I844 (Allis). The above two specimens and a third, are also referred to by A. Strickland in Allis's Report.

Robin Hood's Bay, one, taken alive in a fishing-net, 1848 (Milner, Zool. I848, p. 2027).

Leeds, one, 6th October I854; taken in Leeds. Purchased by the Leeds Philosophical Society (35th Report, I854-55).

Flamborough, one, I8th July I866, shot by Thomas Leng. Formerly in the Sunderlandwick collection, now in that formed by the late Sir Hy. Boynton at Burton Agnes.

Same place, one obtained, others seen, autumn 1873 (Gurney, Zool. I874, p. 3882).

Same place, one adult, captured by Matthew Bailey on Ioth January I874 (Bailey MS. In the collection of Mr. J. H. Gurney, who described the specimen; tom. cit. p. 3882).

Same place, one, 2oth September I88I (Tuck, op. cit. I88I, p. 472).

Bridlington, an adult female, in winter plumage, shot

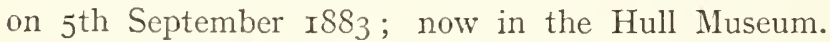

Rishworth Moor, Ripponden, Halifax, one, in I885.

Scarborough, one, caught on a fishing line, on $4^{\text {th }}$ December I889 (R. P. Harper, op. cit. I8go, p. 2I; with the remark that this is the first specimen the recorder had seen at Scarborough in the course of a long residence).

Flamborough, several, September I893 (Bailey, Nat. I893, p. 323).

Scarborough, one, December I894 (W. J. Clarke MS.).

Bridlington, one adult, November I895 (Howarth, op. cit. I8g6, p. I00).

Same place, one, November I898. In the collection of Sir Oswald Mosley of Rolleston Hall, Burton-on-Trent.

Scarborough, a female, obtained by Mr. Joseph Morley, in the autumn of Ig04. In my collection.

The following, recorded as Great Shearwaters, have proved on investigation to be referable to $P$. griseus :-

Teesmouth, one, August I828 (P.Z.S. I832, ii. p. I28). 


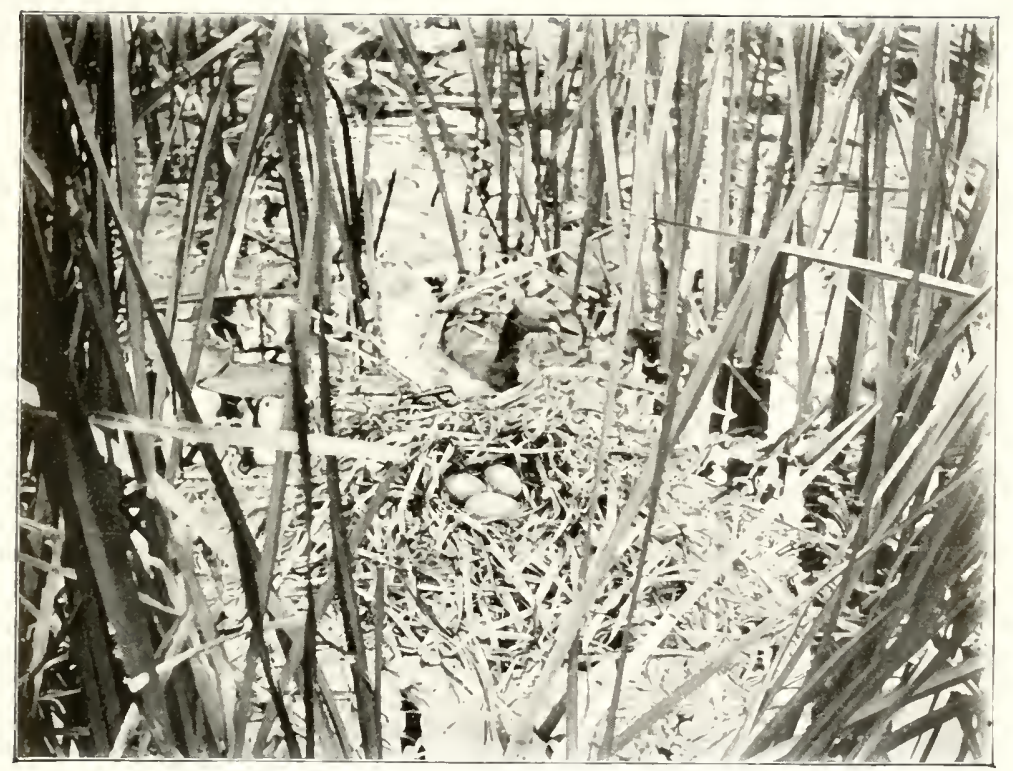

Little Grebe swimming to its nest.

T. A. Metrulfi.

Ser page $7+7$. 

Flamborough, a male, r3th September I865 (Boulton, Zool. I866, pp. 29-30).

Bridlington and Flamborough, two at the former place and one at the latter, 6 th to Igth September I866 (op. cit. I867, p. 543).

Flamborough, one, 15th October I869 (Field, 3oth October I869).

Bridlington, one shot, others seen, I876 (Zool. I876, p. 5II6).

From other sources, three "immature Great Shearwaters," reported in the same year.

At Redcar several Big Shearwaters were announced by the Redcar fishermen to be out in the offing, in the autumn of 1876 , and I recorded them as Great Shearwaters, but, in all probability, they were referable to the next species.

\section{SOOTY SHEARIVATER.}

Puffinus griseus (Gmelin).

Autumn and winter visitant, of fairly regular occurrence, but uncertain as to numbers.

The Sooty Shearwater is found in the North Atlantic, and breeds in the Chatham group of islands off the coast of New Zealand.

The earliest known British example of this bird is that originally recorded as a Great Shearwater, which was shot by the late George Marwood, then of Busby Hall, in Cleveland, near the mouth of the Tees, on a very stormy day in the middle of August I828. It was seen early in the morning sitting on the water like a duck, and was killed as it was rising; its manner of flight was consequently not noticed. It afterwards passed into the possession of Arthur Strickland of Boynton, near Bridlington, the friend and correspondent of Thomas Allis, and was exhibited by its possessor at a meeting 
of the Zoological Society on I2th July I832 (P.Z.S. I832, ii. p. I28; Zool. I883, p. I2I. See also Allis's Report under heading of Great Shearwater). Strickland's collection was afterwards acquired by the Yorkshire Philosophical Society, and the specimen in question is now in their Museum at York.

Until comparatively recently there was considerable confusion existing between this and the preceding species, of which it was considered to be the immature form; there is therefore great difficulty, without examination of specimens, in disentangling the earlier records and assigning each to its proper species; the lapse of time has also tended to prevent correct identification.

This bird is now known to be a fairly regular visitant to the Yorkshire coast in autumn and winter, but, like its congeners, prefers the open sea to the propinquity of the land. The famous Headland of Flamborough is the locality most favoured by its visits, and at sea off that point it has occurred in some seasons in large numbers. Mr. Matthew Bailey, in the course of conversation with me at various times, has told me that in autumn he has seen scores, and even hundreds, in flocks off the Headland in a single day. In one day, in the autumn of 1887 , he secured three in the course of a few minutes, and, if he had wished, could have killed a score. In the year mentioned several specimens, two of which were old birds, were brought in to Flamborough and Filey. In the autumns of I895 and I904 also, the species was abundant off Flamborough and Bridlington, where several examples were captured, and from twenty to thirty others reported as seen by the fishermen and boatmen. I have met with it on one occasion only on the Cleveland coast, on $I$ th September I883, a fine calm day; it was resting on the water, and at first I thought it was a Skua, but discovered my error on handling the bird, which fought and scratched with its claws as savagely as the Pomatorhine Skuas did in I879.

The history of the Sooty Shearwater in Yorkshire must be read in conjunction with that of its congener, $P$. gravis; a list of Yorkshire examples is here appended, and if errors have unfortunately crept in, the fault must be attributed to 


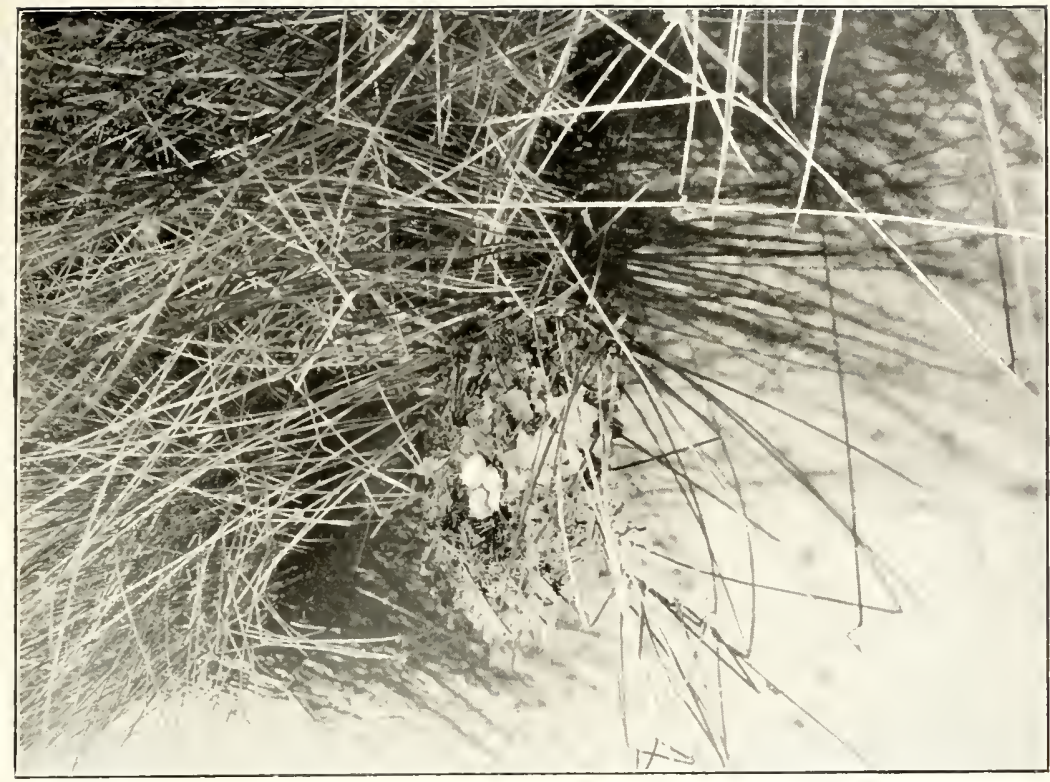

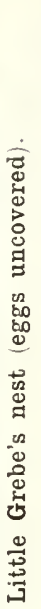

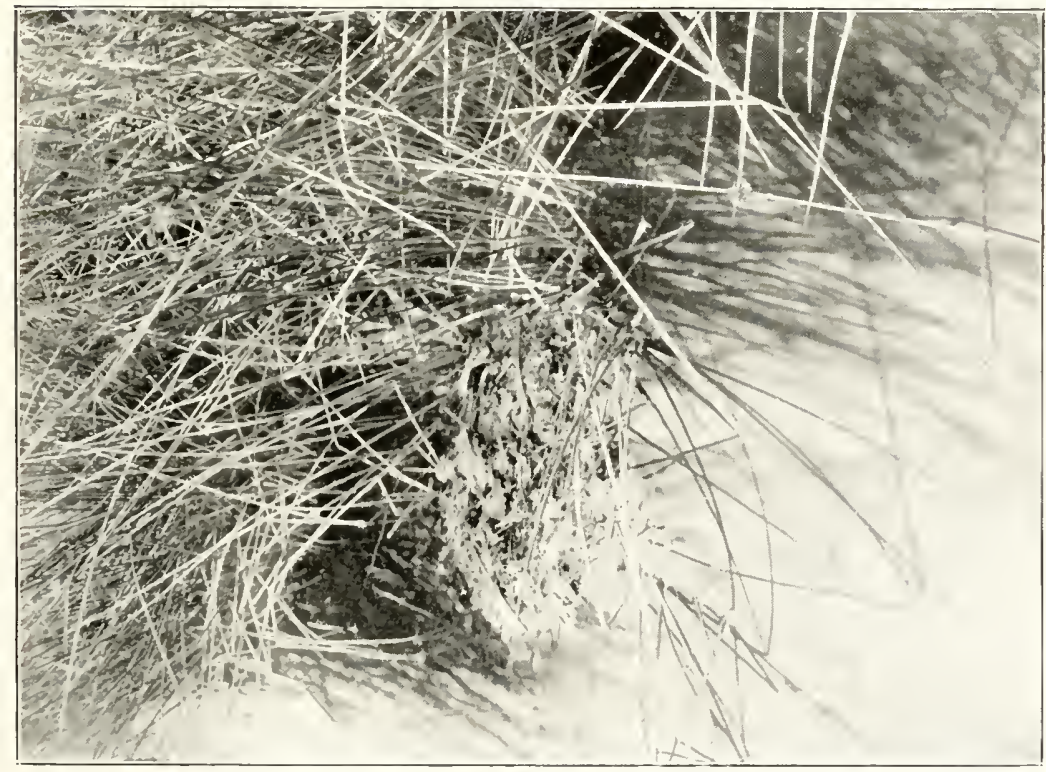

$<$

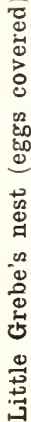

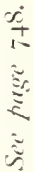



the difficulty of tracing specimens, some of which have been altogether lost sight of.

* Tees Bay, one shot in August I828, at the Teesmouth (mentioned at the commencement of this chapter).

* Flamborough, a male, I3th September I865 (Boulton, Zool. I866, pp. 29, 30).

* Bridlington and Flamborough, two at the former place and one at the latter, 6th to Igth September I866 (op. cit. I867, p. 543).

* Flamborough, one, I5th October I869 (Boyes, Field, 3oth October I869).

Whitby, one, September I870. In the local Museum (T. Stephenson MS.; W. Eagle Clarke, Zool. I884, p. I80).

Bridlington, one obtained by Mr. J. Elton, I872. Presented to the Oxford Museum (H. A. Macpherson, op. cit. I883, p. I2I).

* Same place, one killed, others seen, 1876 (op. cit. I876, p. 5II6); and from other sources, three immature Great Shearwaters, but probably referable to this species, were reported in the same year.

Scarborough, one I879; in the possession of Sir W. Fielden, who shot it (Harting's "Handbook," 2nd Ed. p. 488).

Filey, one is recorded in the same year as in the possession of Sir W. Fielden, doubtless the same specimen (Harper, Zool. I887, p. 430).

Flamborough, one, October I88I; in Mr. J. Whitaker's collection.

Redcar, one, I7th September I883; in my collection. Exhibited by Mr. T. Southwell before the Norfolk and Norwich Naturalists' Society, and by Mr. Howard Saunders at the Zoological Society meeting (P.Z.S. I884, p. I50; Zool. I884, pp. I57, I80 ; Yarrell's "British Birds," 4th Ed. pp. I7, I8).

Redcar, one, in Admiral Oxley's collection at Ripon (Ex. litt. J. H. Gurney, 27th June I887). (But I did not see this when looking over the collection.)

Flamborough, two, September I883. Examined by Mr. W. Eagle Clarke (Zool. I884, p. I80). 
Same place, two adult, male and female, 23rd August r887. Preserved by E. Allen, York. Now in the York Museum (Backhouse, Nat. I887, p. 29I).

Filey, four, 26th August I887. Preserved by Helstrip of York (Backhouse, tom. cit. p. 354). Two of these specimens were utilized by Lord Lilford for the figures of this species in his work on "British Birds," Vol. vi. Plate 59.

Flamborough, one, 27th August 1887. Preserved by J. Morley, Scarborough (Harper, Zool. I887, p. 430).

Same place, five captured in the neighbourhood, October 1887. Three were killed in one day by Mr. Matthew Bailey. All five specimens were examined by Mr. F. Boyes (Bailey MS.). One of the birds Mr. Bailey procured is in Mr. J. Whitaker's collection; another in that of Sir Vauncey Crewe at Calke Abbey, Derby; and the third in the Rev. J. G. Tuck's collection.

Scarborough, two, 25th October I888 (op. cit. IS89, p. I50).

Same place, one, 28th October I889.

Flamborough, one, on the same date (op. cit. I8go, p. 2I).

Same place, two, Ist October I895, shot by G. Emmerson. Twenty to thirty others seen (Bailey, Nat. I895, p. 3I2; Cordeaux, op. cit. I896, p. 7).

Bridlington, one adult, November 1895. Preserved by A. S. Hutchinson of Derby (tom. cit. p. Ioo).

Same place, two, December I895. Preserved by E. Allen, York, and presented by him to the Leeds Museum.

Same place, one, November I898. In the collection of Sir Oswald Mosley, Rolleston Hall, Burton-on-Trent.

Scarborough, two, male and female, apparently adults (W. J. Clarke, Zool. Igor, p. 477).

Same place, two, in October I904; others reported off Flamborough and Bridlington. The Scarborough specimens came into the possession of Mr. W. J. Clarke of that town, and were afterwards purchased by Mr. C. J. Carroll, Rocklow, Ireland.

This bird is called the Black Shearwater by Flamborough fishermen. 


\section{MANX SHEARIVATER.}

\section{Puffinus anglorum (Temminck)}

Bird of passage, sometimes in considerable numbers in autumn. Occasionally occurs inland.

As a Yorkshire bird, the earliest reference to the Manx Shearwater may be found in Allis's Report of I844, thus :-

Puffinus anglonm.-Manx Shearwater-A. Strickland says it is seldom found on the east coast, but occasionally met with, generally in the autumn.

The Manx Shearwater is a bird of passage, usually occurring on the fishing grounds, or off the Headland of Flamborough in autumn, but occasionally earlier in the year, whence it would appear that the individuals seen in the summer are non-breeding birds, as the Yorkshire coast is far removed from their nearest nesting station. In August, September, and October it is often noticed by the deep-sea fishermen when hauling the herring nets; at these times it also approaches the shore, being then brought under the observation of naturalists.

In the "sixties" it was considered to be a rare bird off Flamborough, as stated by the late W. W. Boulton (Zool. I864, pp. 929I-9330), who expressed his surprise at meeting with eight specimens off Filey. In I876 it was common off the East Riding and Cleveland coasts ; several were obtained near Bridlington; in the Teesmouth area I saw a flock of ten on the 7 th July, and one in August, whilst the Redcar and Staithes fishermen assured me it was very numerous in the offing. In I887 it was plentiful off Flamborough from August until October; several were seen in late spring off Redcar; in August and September of the same year three were procured, and numerous others reported (Nat. I889, p. 83); it was also very abundant along the coast from Flamborough Head to the Tees Bay in the years I885 and I904. A most unusual date on which to observe this bird in Yorkshire is I8th January in the year I888, when one was seen off Redcar,

VOL. II. 
where it remained on the water for some time near a fishing boat.

The Manx Shearwater has been known to fall a victim to the attractions of the lanterns of our sea-marks; one struck the Spurn Light on 5 th August $I 88_{3}$, and another was picked up there on zrd September I888.

In many inland localities it has been reported, being probably storm-driven from its accustomed haunts, but the communicated and recorded instances are so voluminous that a recapitulation of them would prove tedious, and is unnecessary.

\section{LEVANTINE SHEARWATER. \\ Puffinus yelkouanus (Acerbi).}

Accidental visitant from the Mediterranean, of very rare occurrence.

This is the Mediterranean representative of our well-known Manx Shearvater, and is the "Âme damnée" of Turkish superstition, which is to the effect that the souls of the wicked pass into the bodies of these birds, and are doomed, for their sins, to wander for all eternity over the waters. I have seen immense flocks, which are amongst the most noticeable features of the Bosphorus, passing and re-passing all day long, between the Sea of Marmora and Kavak, at the entrance to the Black Sea, as many as fifteen flocks being within the range of vision at one time.

It was only within comparatively recent years discovered to be a visitant to the Yorkshire coast, and is, so far as at present known, of rare occurrence there in autumn and winter ; but it is quite possible it may have been overlooked, and may be of more frequent appearance than is supposed ; an examination of specimens of aileged immature or dark-breasted Manx Shearwaters might lead to the identification of more examples of this species.

The first specimen known to me is one in my own possession, 
obtained near Redcar in the autumn of 1877 , which is probably the first Yorkshire example of this bird.

One, in the collection formed by the late Sir Henry Boynton at Burton Agnes, is labelled "Manx Shearwater, immature; shot by M. Bailey, Flamborough." I have seen this individual, and, on asking Mr. Bailey as to its occurrence, he replied that he could not remember the exact date, but he thought it was about 1880 .

Another, killed at Flamborough on I6th August I8go, by Thomas Leng, was preserved by Mr. John Morley; the sex was not ascertained. This specimen is now in the York Museum.

At Scarborough, an adult female was procured near the Castle Foot on 4th February I899; it was taken in the flesh to Mr. W. J. Clarke, and by him forwarded to Dr. R. Bowdler Sharpe, who identified it (Zool. Igoo, p. 52I).

An immature female occurred in the South Bay, Scarborough, on I3th September I900, and was identified by Mr. Howard Saunders. This specimen is now in the collection of Mr. Riley Fortune, where I have seen it (W. J. Clarke, tom. cit. p. 52 I ; Fortune, Nat. I900, p. 352).

In the autumn of 1900 another specimen was obtained near Scarborough, and was afterwards sold to a collector in the south of England.

An adult male, which was captured at the same place on Ist September I902, was forwarded to me for identification ; it afterwards passed into the collection of Sir Vauncey Crewe.

The latest occurrences took place in the autumn of Igo4, when three examples were reported between Scarborough and the Headland of Flamborough. One of these, an adult female, was purchased by the Hon. N. C. Rothschild; and an adult male is in my collection.

A specimen in Admiral Oxley's collection at Ripon, labelled "Manx Shearwater," may have been obtained in the Redcar district. Admiral Oxley's father, the late Charles Oxley, lived at Redcar for many years, and most of his birds were collected in that neighbourhood. 


\section{2 \\ BULWER'S PETREL.}

Bulweria bulweri (Jardine \& Selby).

Accidental visitant from the Atlantic, of extremely rare occurrence.

This small Petrel nests on the Canary Isles and Maderia, and is found as far south as Japan.

Thomas Allis, in I844, wrote:-

Thalassidroma bulwerii.-Bulwer's Petrel-This bird has lately been met with in the neighbourhood of Ripon, as I learn from W. Stubbs, a bird-stuffer of that city.

The first authentic record of the appearance of this species in Europe relates to a Yorkshire example picked up dead on the banks of the Ure at Tanfield on 8th May I837, and formerly in the collection of Col. Dalton (Yarrell, "British Birds," I 843 , iii. p. 5I4).

From I843 until I903 this bird remained unique as a British specimen. It was long lost sight of, and in order, if possible, to rescue it from oblivion, Mr. W. Eagle Clarke set to work to investigate its history, fortunately with success, and the specimen is now deposited in the York Museum. It was exhibited at a meeting of the Zoological Society on I5th November I887, by Professor Newton, who remarked that "Some doubt having, it seems, been expressed as to the occurrence of Bulwer's Petrel in this country, which was announced by Gould in the concluding part of his 'Birds of Europe,' published on Ist August I837, Mr. Wm. Eagle Clarke, Curator of the Nuseum of the Phil. and Lit. Society at Leeds, determined to investigate the facts, and as his search for the specimen in question has been successful, I have great pleasure in exhibiting it to you, on his behalf, to-night. I have the greater pleasure in doing this, as but for his perseverance and that of a local naturalist, Mr. James Carter of Burton House, Masham, the specimen would probably have been for ever lost sight of, whereas we may now hope that it will find a permanently safe abode. Gould's statement was that the specimen, having been found dead on the banks of 
the Ure, near Tanfield in Yorkshire, on 8th May I837, was brought to Capt. Dalton of Slenningford, near Ripon, a gentleman, as I learn, who had succeeded to a collection of stuffed birds begun by his father. The father was Col. Dalton, who, curiously enough, had sent Bewick the specimen of the Common Stormy Petrel (also found dead in that neighbourhood) from which the figure and description in his well-known work was taken ('British Birds,' Ist Ed. ii. pp. 249-25I). At the end of last May Mr. W. Eagle Clarke applied to Mr. Carter, and the first result of the latter's inquiry was to find that the Dalton collection had been dispersed by sale just a week before. Fortunately all the cases of stuffed birds had been bought by persons living in Ripon, and, having obtained their names from the auctioneer, Mr. Carter, after many failures and some loss of time, discovered in the possession of Mr. Jacobs, the head-master of the Choir School in that city, the case and the specimen before you, labelled Procellaria bulwerii, which he had bought with others at the Dalton sale. Beyond this fact, however, there was no note or anything to identify the specimen with the object of the search. Mr. Carter thereupon undertook to inquire of the surviving members and connections of the Dalton family, and, fortunately, again, one of the latter, being Mr. George Clarke of Tanfield House, Bedale, a son-in-law of Capt. Dalton, was found, who not only remembered the specimen perfectly well, having seen it 'scores of times,' but produced an old manuscript note he had made on the margin of a 'Bewick' (in which he had been accustomed to record ornithological observations), to the effect that this bird was ' found dead on the bridge at Tanfield,' and had been given to his father-in-law, who had it 'preserved by the late John Stubbs of Ripon, fishing-tackle maker and bird-stuffer.' Mr. George Clarke also remembered the owner having several times refused the offer of twenty guineas for the specimen, which, it appears, had been put away in a lumber room and wholly forgotten. I think, therefore, that no doubt can be entertained of our having before us the remains of the very bird which was found dead at Tanfield, as recorded by Gould, and that we are much indebted to the 
gentlemen concerned in hunting out this specimen, which had so long disappeared" (P.Z.S. I887, pp. 562-3; see also Nat. I888, p. I56).

This specimen was used by the late Lord Lilford for the illustration of this species in his splendid work on "British Birds."

An alleged occurrence of Bulwer's Petrel at Scarborough in spring I849 (Higgins, fide Graham, Zool. I849, p. 2569). is unsatisfactory, from the lack of details necessary to substantiate its accuracy.

\section{FULMAR.}

Fulmarus glacialis (L.).

Casual visitant in autumn and winter, rather rare inshore, but in some seasons plentiful on the fishing grounds. Has been occasionally met with in summer.

Probably the earliest notice relating to the Yorkshire status of this bird is contained in Allis's Report, I844, thus :-

Procellaria glacialis.-Fulmar Petrel-Reported by F. O. Morris as uncommon; by W. Eddison to have been takeu near Huddersfield; by $\mathrm{A}$. Strickland to be rare on the east coast.

To the Yorkshire deep-sea fishermen the Mollemoke, as it is called by them, is well known in the autumn herring season, when numbers of these birds beset the boats of the smacksmen to take their share of the fish when the nets are being hauled in; so voracious are they at these times as to often allow themselves to be taken by hand on the decks of the smacks.

In November I868 it was particularly numerous in the offing, as reported by the fishermen (Zool. I869, pp. I5I8-I9), and off Flamborough in 1872 many were captured on the fishing grounds and brought in by the boatmen. On the coast, that is, near the shore, it is a casual visitant, chiefly in autumn and winter, and generally after storms at sea, when it is driven in by stress of weather, and found dead or in an exhausted state; an opinion has been expressed that these are weak 
or diseased birds, the healthy ones keeping further out to sea, but this can hardly be so in every case, though I have no doubt that those seen on the beach in summer are suffering from some fatal disease. After the "Skua Gale" on I4th-I5th October I879, several Fulmars were observed on various parts of the coast ; eleven were reported from Flamborough, and examples were picked up at Redcar and Teesmouth; the autumn of r887 was also noticeable for the comparative abundance of this bird after a storm on 28 th October. It has been met with at most of the coast stations, though the instances of its occurrence are too numerous for mention in detail; Flamborough, Scarborough, and Redcar are the localities whence it has been most frequently recorded.

As stated above, the autumn and winter are the periods when the Fulmar is usually met with, though in the year I 869 one was found at Saltburn in the month of June, and I have on four occasions seen examples in summer :-on Ist July I888 a specimen was washed ashore on Coatham sands; on the 3Ist of the same month in I89I another occurred at Redcar; on 25th May I902 I found a splendid adult specimen on the beach east of Redcar, but, unfortunately, my taxidermist was unable to preserve it, and on 22nd June I903 a very fine adult was picked up.

Mr. J. H. Gurney commented in the Naturalist (I879, p. 74) on the number of Yorkshire specimens he has examined (he had eleven in October I879), and on the discrepancy in their weights and the size of their bills; the heaviest scaling $260 z$., whilst the smallest weighed only I $40 z$.

The white-breasted and the dark northern forms are both met with, and I have had specimens of each kind on the Cleveland coast. A Fulmar, taken on a hook at Filey on 26 th October I868, was found to have swallowed a Redwing (Zool. I868, p. I483). The example recorded from Flamborough, in October of the same year, was figured by Gould in his work on British Birds.

The only vernacular name is Mollemoke or Mollemawk, which is probably derived from the Norwegian sailors, with whom Yorkshire fishermen formerly frequently associated. 



\section{APPENDIX.}

\section{IVILD BIRDS' PROTECTION.}

The Orders under the IVild Birds Protection Acts, at present in force in the County, are as follows :-

\section{For the North Riding.}

The time during which the taking and killing of Wild Birds is prohibited is extended, so as to be from the Ist day of March to the 3ist day of August in any year, both days inclusive, except with respect to the following Birds :-

Mallard, Golden Plover, Snipe, Teal, Widgeon, Wild Duck, and Woodcock.

The time during which the taking and killing of the Birds, so excepted, is prohibited, is extended so as to be from the Ist day of March to the IIth day of August in any year, both days inclusive.

\section{For the EAST Riding.}

(a) The period during which the killing or taking of Wild Birds is $p$ ohibited by the Act of I 880 shall be extended throughout the Administrative County of the East Riding of Yorkshire, except as regards the Mallard (Wild Duck), Golden Plover, Snipe, and Woodcock so as to be between the last day of February and the Ist day of September in each year.

(b) As regards the Mallard (Wild Duck), Golden Plover, Snipe, and Woodcock, the close time shall be altered so as to be between the last day of February and the rath day of August in each year.

Certain Birds protected during the whole of the year.

During the period between the 3Ist day of August in any year and the Ist day of March following, the killing or taking of the following species of Wild Birds is prohibited 
throughout the administrative County of the East Riding of Yorkshire :-

Bittern, Little Bittern, Black-headed Bunting, Cirl Bunting, Corn Bunting, Reed Bunting, Snow Bunting, Yellow Bunting (Yellow Hammer), Buzzard, Honey Buzzard, Dipper or Water Ouzel, Dotterel, Eagle, Peregrine Falcon, Goldfinch, Great Crested Grebe, Blackheaded Gull, Kittiwake Gull, Kestrel or Windhover, Kingfisher, Limnet, Nightingale, Nightjar (Goat Sucker, Night Hawk, or Fern Owl), Nuthatch, Osprey, Long-eared Owl, Short-eared Owl, Tawny or Brown Owl, White or Barn Owl, Raven, Lesser Redpole, Mealy Redpole, Swallow, Swift, Tern (all species) Green Woodpecker. Great Spotted Woodpecker, Lesser Spotted Woodpecker.

\section{All Birds protected within cerlain Areas.}

During that period of the year to which the protection afforded by the Wild Birds' Protection Act, I880, as extended, so far as certain of the birds are concerned by Clause I. of this Order does not apply, the killing or taking of Wild Birds is prohibited.

(a) On or from the piers or seashore of Bridlington.

(b) On or from the sands or seashore between the south landing in the parish of Flamborough and the Skipsea Watch House, in the parish of Skipsea.

All Birds protected on Sundays within certain Areas.

V. During the period between the 3rst day of August in any year and the Ist day of March following, the killing or taking of Wild Birds on Sundays is prohibited throughout the undermentioned Urban and Rural Districts, including the foreshore within the East Riding of Yorkshire, the estuary of the Humber, and the tidal portion of the River Hull :-

URBAN Districts.-Beverley (except in the parish of St. Martin), Bridlington, Cottingham. Driffield, Filey, Hedon, Hessle, Hornsea, Norton, Pocklington, and Withernsea.

Rural Districts.-Beverley, Bridlington, Driffield, Escrick, Howden, Norton, Patrington, Pocklington, Riccall, Sculcoates, Sherburn, and Skirlaugh. 
EGGS.

Certain Eggs protected throughout the East Riding.

The taking or destroying of the Eggs of the following species of Wild Birds is prohibited within the Administrative County of the East Riding of Yorkshire for a period of five years from the date of this Order :-

Bittern, Blackhead Bunting, Cirl Bunting, Corn Bunting, Reed Bunting, Snow Bunting, Yellow Bunting (Yellow Hammer), Common Buzzard, Honey Buzzard, Curlew, Stone Curlew, Dipper or Water Ouzel, Dotterel, Dunlin (Ox Bird, Purre), Peregrine Falcon, Pied Flycatcher, Goldfinch, Great Crested Grebe, Little Grebe, Blackheaded Gull, Hen Harrier, Marsh Harrier, Montagu's Harrier, Heron, Hobby, Kestrel, Kingfisher, Merlin, Nightjar (Fern Owl, Goat Sucker, Night Hawk), Nightingale, Nuthatch, Owl (all species), Ringed Plover, Raven, Redpoll, Redshank, Snipe, Swallow, Swift, Tern (all species), Bearded Tit (Reedling or Reed Pheasant), Turtle Dove, Grey IVagtail, White Wagtail, Yellow Wagtail, Reed Warbler, Land Rail, Water Rail, Wild Duck, Woodcock, Green Woodpecker, Great Spotted Woodpecker, Lesser Spotted Woodpecker, Wryneck (Cuckoo's Mate or Snakebird).

\section{EGGS.}

\section{All Eggs protected within certain areas.}

The taking or destroying of Wild Birds' Eggs is prohibited for a period of five years from the date of this Order :-

(I) On the Promontory of Spurn, including Kilnsea Warren south of the line taken by the road leading from the Village of Kilnsea towards the site of the old Village of Kilnsea.

(2) On Hornsea Mere and the lands immediately adjoining, the boundary of which area (outlined in pink on an Ordnance map sealed with the Seal of the Secretary of State, dated the 29th January, I906, and deposited with the Clerk of the County Council) commences at a point on the Hornsea and Seaton Road 7 chains east of Mill Lane, and proceeds in a south-ea,terly direction along the road past the north-east side of 'Great Wassand' for a distance of about 5 I chains, 
thence along a footpath on the south side of the Mere to Lelly Lane, thence north-easterly for $\mathbf{I}_{\mathbf{4}}^{\mathbf{1}}$ chains along the north side of Lelly Lane, thence in a north-westerly direction along the boundary fence dividing property belonging to Mr. William Bethell and Mr. Constable to the Mere, thence along the edge of the water of the Mere to and along a stream passing the west front of Ventnor House, to the Hornsea and Seaton Road, and then along the south side of the said roal to the abovementioned point 7 chains east of Mill Lane.

For the WEST Riding.

(a) Birds protected from the last day of February to the I2th day of August in any year ;-

American Quail.

Auk.

Avocet.

Bonxie.

Colin.

Cornish Chough.

Coulterneb.

Curlew.

Divers :

Great Northern Diver.

Red Throated Diver.

Dunbird.

Fulmar.

Gadwall.

Gannet.

Godwit :

Bartailed Godwit.

Blacktailed Godwit.

Golden Plover.

Goosander.

Grebes :

Rednecked Grebe

Slavonian Grebe.

Eared Grebe.

Greenshank.

Guillemot.

Gull (except Blackbacked Gull).

Common Gull.

Herring Gull.

Kentish Plover.
Lapwing.

Loon.

Mallard.

Marrot.

Merganser.

Nurre.

Oyster Catcher.

Peewit.

Petrel.

Phalarope.

Grey Phalarope.

Relnecked Phalarope.

Plover.

Ploverspage.

Pochard.

Puffin.

Quail.

Razorbill.

Scout.

Sealark.

Seamew.

Sea Parrot.

Sea Swallow.

Shearwater.

Sheldrake.

Shoveler.

Skua.

Smew.

Snipes :

Great Snipe. 
Snipes (continued) :

Common Snipe.

Jack Snipe.

Solan Goose.

Spoonbill.

Stonehatch.

Teal.

Tystey.

Whaup.
Whimbrel.

Widgeon.

Wild Ducks :

Eider.

Pintail.

Scoter.

Tufted Duck.

IVillock.

Woodcock.

(b) Birds protected all the year round.

Bee Eater.

Bittern.

Little Bittern.

Bullfinch.

Buntings :

Blackheaded Bunting.

Cirl Bunting.

Corn Bunting.

Reed Bunting.

Snow Bunting.

Yellow Bunting.

Yellow Hammer.

Buzzards :

Common Buzzard.

Honey Buzzard.

Rough Legged Buzzard.

Chaffinch.

Chiffchaff.

Corncrake (Landrail).

Crossbill.

Cuckoo.

Dipper or Water Ouzel.

Diver (Black-throated).

Dotterel.

Dunlin :

Purre, Ox Bird.

Eagles :

Golden Eagle.

Sea Eagle.

Falcon.

Flycatchers :

Pied Flycatcher.

Spotted Flycatcher.

Goldfinch.
Grebes :

Great Crested Grebe.

Littlle Grebe (Dabchick).

Gull (Blackheaded).

Harriers :

Marsh Harrier.

Hen Harrier.

Montagu's Harrier.

Heron (Common).

Hobby.

Hoopoe.

Kestrel.

Kingfisher.

Kite.

Kittiwake.

Larks :

Skylark.

Woodlark.

Linnet.

Martins :

House Martin.

Sand Martin.

Merlin.

Nightingale.

Nightjar.

Goat Sucker.

Night Hawk or Fern Owl.

Nuthatch.

Oriole (Golden).

Osprey.

Owls.

Long-eared Owl.

Short-eared Owl.

Tawny or Brown Owl. 
Owls (continued) :

White or Barn Owl.

Pallas's Sandgrouse.

Peregrine Falcon.

Pipits :

Alpine Pipit (Water Pipit).

Neadow Pipit.

Richard's Pipit.

Rock Pipit.

Tree Pipit.

Raven.

Redpolls :

Lesser Redpoll.

Mealy Redpoll.

Redshank.

Redstart.

Ring Ouzel.

Robin.

Roller.

Ruff or Reeve.

Sanderling.

Sandpipers :

Common Sandpiper (Summer

Snipe).

Green Sandpiper.

Shrikes :

Great Grey Shrike.

Lesser Grey Shrike.

Redbacked Shrike (Butcher

Bird).

Woodchat Shrike.

Siskin.

Sparrows :

Hedge Sparrow.

Tree Sparrow.

Spotted Crake.

Stint.

Stonechat.

Stone Curlew or Thick Knee.

Swallow.

Swift.

Song Thrush.

Terns :

Arctic Tern (Tarrock).

Black Tern.

Common Tern.
Terns (continued) :

Lesser Tern.

Roseate Tern.

Sandwich Tern.

Tits :

Bearded Tit (Reedling or Reed

Blue Tit.

Pheasant).

Coal Tit.

Crested Tit.

Great Tit.

Long-tailed Tit.

Marsh Tit.

Treecreeper.

Turtle Dove.

Twite.

Wagtails :

Grey Wagtail.

Pied Wagtail.

White Wagtail.

Yellow Wagtail.

Warblers :

Aquatic Warbler.

Blackcap Warbler.

Dartford Warbler.

Garden Warbler.

Grasshopper Warbler.

Marsh Warbler.

Reed Warbler.

Sedge Warbler.

Willow Warbler.

Wood Warbler.

Water Rail.

Wheatear.

Whinchat.

Whitethroat.

Lesser Whitethroat.

Woodpeckers :

Green Woodpecker.

Great Spotted Woodpecker.

Lesser Spotted Woodpecker.

Wrens:

Common Wren.

Fire-crested Wren.

Golden Crested Wren.

Wryneck :

Cuckoo's Mate or Snakebird 
All other Birds not included in the above Schedules, other than the Honse Sparrow, are protected between the last day of February and the I2th day of August in each year, except as against the owners and occupiers of land, or persons authorised by them.

\section{EGGS.}

Any person will be liable to the penalties in the Acts mentioned who takes or destroys the Eggs of any of the Wild Birds mentioned in the above Schedules; except the eggs of the Plover (Green Plover, Lapwing, or Peewit), which may be taken before the I5th day of April in any year. 


\section{EXTRACTS FROM ANCIENT RECORDS.}

A LTHOUgh Yorkshire does not possess evidence so definite or so complete as that which exists for some other counties, there are
records extant which in some degree serve to throw light on the fauna which once inhabited the district. A brief summary of the birds mentioned in three of the principal documents will not be devoid of interest, and therefore, with the permission of the authors of the "Vertebrate Fauna of Yorkshire," I reproduce their account.

In 1466, as Leland writes in his "Collectanea," a great feast was given in the archiepiscopal palace at Cawood, on the occasion of the "intronization" of "George Nevell, Archbishop of York, and Chaumcelour of Englande, in the vj. yere of the raigne of Kyng Elwarde the fourth" ; the goodly provision made for which included :-

Swannes, CCCC.; Geese, Mn.; .... Plovers, iiii.C.; Quayles, C. dosen. ; Of the Fowles called Rees, CC. dosen. ; In Peacockes, Ciiii. : Mallardes and Teales, iiii.M.; In Cranes, CC.iiii. ; . . Pigeons, iiii.M. : In Bittors, CC.iiii.; Heronshawes, iiii.C.; Fessanntes, CC.; Partriges, v.C. ; Woodcockes, iiii.C. ; Curlewes, C. ; Egrittes, M.

The document next in point of age dates 1512 , and is entitled" The Regulations and Establishment of the Household of Henry Algernon Percy, the Fifth Earl of Northumberland, at his castles of Wresill and Lekinfield in Yorkshire. Begun Anno domini M.D.XII." This valuable book, usually called the "Northumberland Household Book," well shows the almost regal state maintained by the Percys, and no doubt other great nobles, in the time of Henry the Eighth.*

Therein we find that while "chekyns" cost a halfpenny each and "hennys" $2 d$. each, it was "thought good that no pluvers be bought at noo Season bot oonely in Chrystynmas and princypall Feestes and my Lorde to be servyde therewith and his Boordend and non other and to be boght for $\mathrm{j} d$. a pece or $\mathrm{j} d$. ob. at moste." Then it was thought good that " my Lordes Swannys" be taken and none bought "seynge that my Lorde hath Swannys inew of hys owne." Other birds were to be bought for "my Lordes owne Mces," and the prices are duly set forth. "Cranys" were to be at "xvjd. a pece," "Hearonsewys" at " xijd.," "Mallardes" at "ij $d$. ." "Teyles" at " $\mathrm{j} d$. " " bot if so be that other Wyldefowll cannot be gottyn," "Woodcockes" at " $\mathrm{j} d$. a pece or jd. ob. at moste," "Wypes " at " jd.," " Seegulles " " so they

* See the Naturalist, 1906, Pp. 52-56. 
be good and in season and at $\mathrm{j} d$. a pece or $\mathrm{j} d$. ob. at the moste," " Styntes " so they be after vj a jd.," "Quaylles" at "ijd.," " Snypes " " after iii a jd.," "Pertryges" at "ij $d$. a pece yff they be goode," "Redeshankes" after " $\mathrm{j} d$. ob. the pece," "Bytters" at " xij $d$. a pece so they be good," "Fesauntes " at " xijd.," " Reys " at “ ijd.," "Sholardes " at "vjd.," “ Kyyrlewes " at " xij $d$.," "Pacokes" at " xij $d$. a pece and noo Payhennys to be bought," "Seepyes" have no price allotted, "Wegions " were to be at jd. ob.," "Knottes " at " jd.," " Dottrells " " when thay ar in Season and to be at $\mathrm{j} d$. a pece," "Bustardes" with no price affixed, "Ternes" " after iiij a j $d ., "$ " Great Byrdes after iiij a jd.," " Smale Byrdes " “" after xij a jd.," and “ Larkys ” “ after xij for ijd." There is an interesting memorandum that " it is thought good that all manner of Wyldfewyll be bought at the first hand where they be gotten and a Caytor to be apoynted for the same For it is thought that the pulters of Hemmyngburghe and Clyf hathe great advantage or my Lorde Yerely of Sellynge of Cunys and Wyldefewyll." Copies of warrants too long to be quoted are given, one for "Twentie Signettes To be takenne of the breide of my Swannys within my Carre of Arromme within my Lordeschip of Lekinfield" for the Christmas feast of 1514 .

In the year i 526 another member of the great family of the Neviles, Sir John Nevile of Chevet, near Wakefield, High Sheriff of Yorkshire, gave a banquet to celebrate his daughter's marriage. Some of the charges are thus given :- "Swans, I $5 s$. ; nine Cranes, $r l$. Ios. ; twelve Peacocks, I6s.; thirty dozen Mallards and Teal, 3l. I Is. 8d.; two dozen Heron-sewes, I $l .4 s$. ; twelve bitterns, r6s.; eighteen Pheasants, Il. $4 s$. ; forty Partridges, 6s. $8 d$.; eighteen Curlews, Il. $4 s$. ; three dozen Plovers, 5s. ; five dozen Stints, 9s."

In I530, another daughter was married, and the expenses are returned pretty much as before. The prices were:-for Swans, 6 s. each ; Cranes, 3s. 4d. each; Heronsewes, 12d.; Bytters, $14 d$.

In I 528, Sir John acted as Sheriff, and returned his charges as follows :-

At the Lammas Assizes twelve Shovelards were priced at I2s.; item, ten Bytters, I $3 s .4 d$. ; item, eighty Partridges, 1l. $6 \mathrm{s.} 8 \mathrm{~d}$. ; item, twelve Ffesants, I $l$. ; item, twenty Curlews, Il. $6 s .8 d$.; item, Curlew Knaves, thirty-two, Il. I2s.; six dozen Plovers, I 2s.; item, thirty dozen Pigeons, 7s. 6d.," etc., showing a slight advance on the prices of 1526 . 


\section{LITERATURE CONSULTED.}

The Ornithology of Francis Willughby. Ed. by Joln Ray, I678. Ray's Synopsis Methodica Avium. (Posthumous), I 7 I 3. Philosophical Transactions. Vol. 28. Dr. Richardson, I7I3.

Philosophical Transactions. Vol. 6o. G. Edwards, I757.

A Natural History of Uncommon Birds. 4 Vols. G. Edwards, $17+3-1756$.

Gleanings of Natural History. 3 Parts. G. Edwards, I;60.

Birds of Great Britain. 8 Vols. W. Lewin, 1795.

Montagu's Ornithological Dictionary, I 8 I 3 .

Synopsis of Newcastle Museum, late the Allan, formerly the Tunstall

Museum. Ed. by G. Townshend Fox, I827. (The major

portion of this collection is now in the Middlesbrough Museum.)

Extracts from the Correspondence of Dr. Richardson of North

Bierley, 1835 .

Memorials of Ray. Ed. by Lankester, I 846 .

Correspondence of John Ray. Ed. by Lankester, I 848.

British Birds. 3 Vols. IV. Yarrell, 1843.

British Birds. $4^{\text {th }}$ Ed. 4 Vols. By Prof. Newton and Howard Saunders, I 87 I-I 885 .

Essays on Natural History. By Charles Waterton, I871.

Handbook of British Birds. J. E. Harting. 2nd Ed., Igor.

British Birds, 4 Vols. H. Seebohm, I 883.

The Book of Duck Decoys. Sir R. Payne-Gallwey, I 886.

Birds of the Humber District. J. Cordeaux, I872.

List of British Birds belonging to the Humber District. J. Cordeaux, I 889 .

Birds of Europe. 8 Vols. I8TI-I88I, and Supplement, I895-I896. H. E. Dresser.

Handbook of the Vertebrate Fauna of Yorkshire. IT. Eagle Clarke and W. Denison Roebuck (Birds by W. E. Clarke), I88I.

Ackworth Birds. W. B. Arundel, I 898 .

Manual of British Birds. 2nd Ed. Howard Saunders, I899.

Of published records all available sources of information, whether natural history journals and publications, or the appendices to topographical works, have been carefully examined.

The principal district-lists which have been contributed to the natural history periodicals include Leyland's list of Halifax birds (London's Mag. N.H., I828), Williamson's notes on Scarborough 
birds (Proc. Zool. Soc., I 830 ), Denny's list of animals occurring near Leeds (Ann. and Mag. N.H., I 840), Hogg's Catalogue of Birds observed in south-eastern Durham and north-western Cleveland (Zool. 1845), and Talbot's Birds of Wakefield (Nat. I 876 ).

The chief lists which have appeared in, or as appendices to, topographical works are to be found in Miller's "History of Doncaster" (1804), Graves's “ History of Cleveland" (I808), Young's "History of Whitby" ( 817 ), Whitaker's "History of Richmondshire" (1823), Hinderwell's " History of Scarborough" (1832), Lankester's " Account of Askern" (I842), Barker's "Three Days of Wensleydale" (I 854), Hobkirk's "History and Natural History of Huddersfield" (I859, 2nd Ed. I 868), Hobson's “ Life of Charles Waterton" ( I 866), Roberts'"Topography and Natural History of Lofthouse" (1882-5), Swains son's “Folk-lore and Provincial Names" (1886), Atkinson's "Forty Years in a Moorland Parish" (I89I), and Backhouse's “Upper Teesdale" ( 1896$)$.

In addition to these lists, there are innumerable records in the periodicals and in natural history and topographical works generally, chiefly in the pages of the " Zoologist," the " Ibis," the " Field," "Land and Water," "Loudon's Magazine of Natural History," the various publications bearing the name of "Naturalist," which have appeared under the editorship of Messrs. Wood, Morris, Hobkirk, Porritt, Eagle Clarke, Roebuck, Sheppard, Woodhead, and others, and in the earlier volumes of the "Annals and Magazine of Natural History," and of the "Proceedings of the Zoological Society."

The late John Cordeaux's "Birds of the Humber District " (I 872) and "List of Brit. Birds belonging to the Humber District" (I 899), are valuable contributions - not only to the Yorkshire and Lincolnshire fauna-but to British ornithology generally; and lastly-but in point of value first and most important-is Mr. W. Eagle Clarke's bird portion of the "Handbook of the Vertebrate Fauna of Yorkshire," which was published in $\mathbf{I} 88 \mathrm{I}$, and contains in a condensed form the results of previous research in Yorkshire ornithology. The Reports of the British Association Migration Committee (1880-1887), to which I furnished information from the Teesmouth area, have been treely quoted in connection with the interesting subject of migration.

I have also had the advantage of consulting the MS. Report of Thomas Allis on "The Birds of Yorkshire" (1 844 ). This list, which includes 258 species, has been of much assistance from the evidence it contains as to the faunistic position of various species at that and earlier dates, besides the numerous records of occurrences. 



\section{INDEX OF BIRDS.}

'Aberdevine' (Siskin), I 74

[Acadian Owl], 305

Accentor, Alpine, roo

Hedge, 97

Accentor collaris, I0o modularis, 97

Accipiter nisus, 343

Acredula caudata, 106

Acroccphalus phragmitis, 91

streperus, 89

turdoides, 9 I

Egialitis cantiana, 576

- curonica, 575

- hiaticula, 573

Agelaus pheeniceus], 221

[Alauda arborea, 257

- arvensis, 255

Alca torda, 708

Alcedo ispida, 278

'Alder Finch,' 174

'Alke' (Razorbill), 708

'Allan' (Richardson's Skua), 705 Big, 702

Alpine Accentor, Ioo

$[760$

Âme damnée (Levantine Shearwater)

American Bittern, 403

- [Kestrel], 372

[Passenger Pigeon], 498

[Purple Martin], I6I

[Saw-Whet Ow1], 305, 306

[Scaup], 465

Teal, 456

Wigeon, 461

Ammer, Yellow, 204

Ampelis garrulus, 145

Anas albifrons, 419
Anas anser, 417, 419

- boscas, 434

- ferus, 417, 419

paludosus, 419

- - segctum, 419 strepera, 450

[Andalucian Hemipode], 353

'Annett' (Kittiwake), 693

[Anous stolidus], 655

Anser albifrons, $4 \mathrm{II}$

- arvensis, 415, 420

brachyrhyncus, 415

- cincreus, 408

erythropus, 4I 3

- paludosus, 415,420

- segetum, 4I 3

Anthus campestris, 134

- obscurus, 134

_-_ pratensis, 132

- rupestris, I 36

trivialis, 130

Aquila chrysatus, 33I

Arctic Tern, 658

Ardea alba, 392

- cinerea, 393

- garzetta, 393

- purpurea, 39I

ralloides, 395

Ardetta minuta, 396

Asiatic Houbara, 559

'A silus' (Wood Warbler), 87

Asio accipitrimus, 296

_- otus, 295

Astur palumbarius, 339

Athene noctua, 305

'Auk' (Razorbill), 708, 7ro 
Auk, 'Dwarf,' 732

_- 'Iceland,' 732

- Little, 730

—— 'Sea,' 7 10

Avocet, 588

\section{B}

Baillon's Crake, 539

'Bald Buzzard' (Osprey), 374

- Coot, 547

- headed Coot, 547

'Bank Lark' (Tree Pipit), I 3 I

(Meadow Pipit), I 33

__ Martin' (Sand Martin), I63 Swallow' (Sand Martin), 163

_- Wren' (Willow Warbler), 86

[Barbary Partridge], 53 I [I30

'Barley-seed Bird' (Yellow Wagtail),

Barn Owl, 292

'Barn Swallow' (Swallow), I 58

Barred Warbler, 74

Bar-tailed Godwit, 639

'Bastard Plover' (Lapwing), 582-5

'Beam Bird' (Spotted Flycatcher), 148, 149

(Garden Warbler), 73

Bean Goose, 4I3, 416

Bearded Reedling, IO 4

- Titmouse, 104

'Beccafigo' (Garden Warbler), 73

'Bee-Bird' (Spotted Flycatcher), I 49

Bee-eater, 283

-_- [Blue-tailed], 284

'Beech Owl ' (Tawny Owl), 303

'Bell Wigeon' (Scaup), 470

'Bent Linnet' (Linnet), I 86

Bernacle Goose, 423

Bernicla lrenta, 425

- [canadensis], 427

-_ leucopsis, 423

- ruficollis, 423

'Bessy' (Yellow Bunting), 204

'Bessie Ducker '(Pied Wagtail), 123

'Betty' (Sedge Warbler), 93

Bewick's Swan, 429

' Big Allan ' (Pomatorhine Skua),696
'Big Black and White Duck' (Velvet Scoter), 482

Bunting ' (Corn Bunting), 203

- - - (Pomatorhine Skua), 702

'Bighead' (Greenfinch), 163

- (Pochard), 465

'Big Northern Diver' (Great Northern Diver), 734

'Big Peggy' (Whitethroat), 66

- - Whitethroat, $66 \quad[654$ Sea Swallow (Sandwich Tern), Shearwater(GreatShearwater), 753,755

'Bilcock' (Water Rail), 543

- (Moorhen), 545

'Biltor '(-), 545

'Billy' (Hedge Accentor), 100

- - Hedge Sparrow,' Ioo

-Biter' (Great Titmouse), 109

_- (Blue Titmonse), 1 I 4

Bluecap (Blne Titmouse), I I4

Birds assisted on Migration, 78

Bittern, American, 403

——Common, 399

-_ Little, 396

'Bitter')

'Bittor' (Common Bittern),

'Bittoun' f 399, 402

'Bittour'

'Black and White Gull' (Great Black-backed Gull), 685

—_ — Wagtail' (Pied Wagtail), I 23

'Black Back' (Great Black-backed Gull), 685

-_ Lesser (Lesser Blackbacked Gull), 683

'Black-backed Gull ' (Great Blackbacked Gull), 685

-_ _-(Lesser Black-backed Gull) Hannock (Great Black-backed Gull), 685

Black-bellied Dipper, I03

Blackbird, 14

- Moor, $2 \mathrm{I}$

Mountain, 2 I 
Blackcap, 7o

'Black-Cap' (Black-headed Gull), 674

__ (Great Titmouse), 109 (Coal Titmouse), i Io

(Marsh Titmouse), I 2

(Stonechat), 32

(Reed Bunting), 2 Io

Little, I Io

'Black-capped Billy' (Great Titmouse), Iog

- Peggy' (Blackcap),' 7 I $[674$

'Black-cap Gull ' (Black-headed Gull)

_- Mew' (Black-headed Gull),670-4

Titmouse (Marsh Titmouse), I I 2

Black-Cock (Black Grouse), 509

'Black Diver ' (Common Scoter), 477

'Black Duck' (Common Scoter),479

Blackgame, 509

'Black Goose' (Brent), 427

Black-Grouse, 505

Guillemot, 726

'Black-headed Bully'(Bullfinch), 194

'Black-headed Bunting' (Reed Bunting), 210

Black-headed Gull, 670

- Mediterranean, 675

Blackey, Water, I03

- Blackie' (Blackbird), 17

__ Collared, 2 I

Fell, 2 I

Moor, 2 I

'Black Martin' (Swift), 266

'Black Neb' (Hooded Crow), 249

'Black-nebbed Crow' (Carrion Crow), 243

Black-necked Grebe, 746

- Black Ouzel' (Blackbird), 17

'Black Pheasant' (Carrion Crow), 243

'Black Pocker' (Tufted Duck), 467

'Black Poker Duck' (Scaup), 470

Black Redstart, 36

'Black Scaup' (Scaup), 469

'Black Scoter' (Stoter), 479

'Black Shearwater' (Sooty Shearwater). 758

Black Stork, 40 j
Black-tailed Godwit, 64 I

Black Tern, 648

- White-winged, 650

Black-throated Diver, 735

[—- Wheatear], 26

'Black-toppin' Duck' (Tufted Duck)

'Black Uzzle' (Blackbird), I 7

Black-winged Stilt, 590

'Blakeling' (Yellow Bunting), 204

'Blue-back' (Fieldfare), I 2

'Blue-backed Crow' (Hooded Crow) 249

- Falcon' (Peregrine), $36 \mathrm{r}$

__ Gull' (Herring Gull), 680

'Blue Bonnet ' (Blue Titmouse), I I 4

'Blue Cap' (Blue Titmouse), Ir4

'Blue Hawk' (Hen Harrier), $32 \mathrm{I}$

_- _- (Sparrow Hawk), 344

Blue-headed Wagtail, I 26

'Blue Jay' (Jay), 227

'Blue-pen' (Cuckoo), 292

Blıe-Rock (Stock Dove), 493

- (Rock-Dove), 495

'Blue-rump' (Fieldfare), I 2

'Blue-tail' (Fieldfare), I 2

[Blue-tailed Bee-eater], 284

Bluethroat, Red-spotted-, 39

White-spotted-, 38

Blue Titmouse, I I 2

'Blue WVing ' (Jay), 227

'Bluey' (Blue Titmouse), I I 4

'Bogey' (Razorbill), 7 IO

Bohemian Waxwing, I4 8

'Bo'sun' (Great Skua), 696

Botaurus lentiginosus, 403 stellaris, 399

'Bottle Bump' (Bittern), 402

'Bottle Jug' (Long-tailed Titmouse), 107

'Bottle Tit' (Longtailed Titmouse), 107

Bramble Finch (Brambling), I 84

Brambling, I 82

'Branlin' 2 I 2

'Brancher' (Young Rook), 254

'Brand-tail' (Redstart), 36 
Brent Goose, 425

Bridled Guillemot, 723

Broad-billed Sandpiper, 607

'Brook-Ouzel' (Water Rail). 543 Runner' (Water Rail), 543

Brown Hawk (Kestrel), 352

Brown-headed Gull (Black-headed Gull), 67I

'Brownie' (Linnet), 186

Brown Linnet (Linnet), I86

'Brown Owl ' or 'Hoolet ' (Tawny Owl), 302, 303

Brown Tern (Common Tern), $6_{5} 6$

Brunnich's Guillemot, 724

Bubo ignavus, 3 I 2

Buffel-headed Duck, 47 I

Buffon's Skua, 705

Bullfinch, I 93

- Northern or Russian, 194

_- Grosbeak (Bullfinch), I9.4

'Bullflinch' (Bullfinch), I94

'Bullspink' (Chaffinch), 182

'Bully Black-liead' (Bullfinch), 194

- Bullspink' (Bullfinch), 194

'Bully' (Bullfinch), I94

'Bully' (Chaffinch), I 82

Bulwerta bulweri, 762

Bulwer's Petrel, 762

'Bulking Lark' (Tree Pipit), I 3 I

Bunting (Corn Bunting), 203

—_ Big (Corn Bunting), $2 \mathrm{O}_{3}$

_- Black-headed (Reed Bunting). 209

Cirl, 204

Common, 202, 203

Corn, 2OI, $2 \mathrm{O}_{3}$

Lapland, $20 \mathrm{I}$

[Little], 208

Mountain, 2 I 5

Ortolan, 206

- Reed, 208

- Rustic, 207

- Siberian Meadow, 206

Snow, 212

Tawny, 215
Bunting [White-throated], 2 I5

—_ Yellow, 203

'Burgomaster' (Glaucous Gull), 686

'Burrow Chat ' (Wheatear), 25

'Burrow Duck' (Sheld-Duck), 434

'Burrow Pigeon' (Stock-Dove), 493

'Bush Chat' (Whinchat), 28

Bustard, Asiatic Ruffed, 559

- Great, 548

- Little, 557

_- McQueen's, 359

— Ruffed, 559

—— Thick-kneed, 561, 564

Butcher-bird (Great Grey Shrike), 140

-_- (Red-backed Shrike), 144

- Greater, I 38

Buteo lagopus, 328

- vulgaris, 325

'Butter-Bump' (Bittern), 402

'Butther-Bump' (Bittern), 402

Buzzard,' 'Bald, 374

—- Common, 325

- Honey, 350

- Moor, 315-317

- Rough-legged, $32 \mathrm{~S}$

'Byttor' (Bittern), 402

C

[Caccabis petrosa], $53 \mathrm{I}$

- rufa, 527

'Cad Crow' (Carrion Crow), 243

Calcarius lapponicus, 2 Io

Caludris arenaria, 620

[Canada Goose], 427

Capercaillie, 503

Caprimulgus europaus, 265

'Captain' (Goldfinch), I 72

'Car Crow' (Carrion Crow), 243

Carduelis elegans, I69

- spinus, 172

Carr Lag Goose, 419

' Carrion Craw' (Carrion Crow), 243

Carrion Crow, 240

'Carr Sparrow' (Reed Bunting), 2 Io

- Swallow' (Black-headed Gull), 674 
Caspian Tern, 652

'Caw Daw' (Jackdaw), 234

Certhia familiaris, 120

Chaffinch, I80

'Chaffy' (Chaffinch), I8z

Charadrius pluvialis, 577

'Charlie Cock' (Mistle Thruslı) 3

'Chaser' (Richardson's Skua), 705

- Big, 605

Chat,' 'Burrow-, 28

'Bush-, 28

Desert-, 25

' Grass-, 28

' 'Hay-, $2 \mathrm{~S}$

' 'Sedge-, 33

' "Wall-, 149

Whin-, 26

'Chatty' (Wheatear), 25

Chelidon urbica, 158

[Chenalopex agyptica], 427

Chen hyperboreus, 422

'Chep Starling ' (Starling), 220

'Chetstone' (Wheatear), 25

'Cherry Finch' (Hawfinch), I68

'Cheverel' or 'Chevil' (Goldfinch), I 7 I

'Chevy Linnet '(Lesser Redpoll), 190

'Chickstone' (Stonechat), 32

Chiffchaff, 8 I

Chimney Swallow, ${ }_{5} 8$

'Chippet Linnet' (Lesser Redpoll), 190

'Chit Lark' (Meadow Pipit), I33

'Chitty' (Wren), I 20

'Chitty Prat' (Sedge Warbler), 93

'Chivey' (Lesser Redpoll), I90

'Chivey Linnet ' (Lesser Redpoll), 190 Chough, 223

'Chub Lark' (Corn Bunting), 203

'Chucker' (Fieldfare), I 2

'Churcock' (Mistle Thrush), 3

'Church Owl' (Barn Owl), 292, 295

'Clurn Owl' (Nightjar), 268

Ciconia alba, 403

—_ nigra, 405

Cincius aquaticus, ror

_- _- melanogaster, $30 \mathrm{I}$

vOL. II.
Cinclus melanogaster, 103$]$ [334

Cinereous Eagle (White-tailed Eagle

Circus aruginosus, 315

- cineraceus, $32 \mathrm{I}$

_- cyaneus, 3 I8

Cirl Bunting, 204

Clangula glaucion, 470

- albeola, $47 \mathrm{I}$

'Clatter-Dove' (Ring-Dove), 490

'Cliff-Pigeon' (Rock-Dove), 495

'Coal Hood' (Bullfinch), 194

'_- Hoodie' (Blackcap), 71

Coal Titmouse, rog

Coatham Crow (Hooded Crow), 249

Coccothraustes vulgaris, 165

Cock, Black- (see 'Black-Cock')

- Gor- (see ' Gor-Cock)

—- Heath- (see 'Heath-Cock)

-_ Moor- (see 'Moor-Cock)

- Red- (see 'Red-Cock')

[Colin, Virginian], 533

'Collared Blackie' (Ring Ouzel), 2 I

Collared Pratincole, $56_{5}$

'Collier' (House Sparrow), I77

- (Swift), 264

Columba livia, 494

- anas, 490

- palumbiss, 487

Colymbus adamsi, 734

- arcticus, 735

- glacialis, 732

- maximus caudatus, 732 - septentrionalis, 736

Common Bittern, 399

- Bunting, 202, 203

- Buzzard, 325

- Cormorant, 375

- Crane, 547

Grossbill, I97

- Curlew, 643

Guillemot, $7 \mathbf{1}$

- Gull, 675

- Heron, 384

- Pochard, 462

Quail, 53 I

Sandpiper, 620 
Common Scoter, 477

- - Sheld-Duck, 432

—_ Skua (Great Skua), 694

- Snipe, 602

Teal, 454

Tern, 655

Continental Long-tailed Titmouse,

Coot, 545

- Bald or Bald-headed, 547

'Cooshat' (Ring-Dove). 490

'Cooshout' (Ring-Dove), 490

Coracias garrulus, $28 \mathrm{I}$

'Corbie' (Raven), 240

'- Craw' (Carrion Crow), 243

Cormorant, Common, 375

- Crested, 380

- Great, 375

Green, 380

Corn Bunting, 203

- Crake, 534. 535

'D Drake' (Corn Crake), 535

‘__ Rake' (Corn Crake), 535

'Corvorant' (Cormorant), 375

Corves corax, 235

- Cornix, 244

- corone, 240

-— frugilegus, 249

- monedula, 232

Cosmonetta hestrionica, 474

Cotile riparia, I6I

Coturnix communis, $53 \mathrm{I}$

'Coulterneb' (Puffin), 727

Courser, Cream-coloured, 566

'Cow-bird' (Yellow Wagtail), I 30

'Cowscot' (Ring-Dove), 490

'Crag Ouzel ' (Ring Ouzel), 2 I

Crake, Baillon's, 539

- Corn, 534. 535

- Grass, 535

— Hay, 535

- L Little, 538

- Spotted, 536

- Water, I03

'Crake' (Corn Crake), 536

'Cracker' (Corn Crake), 536

'Creek' (Corn Crake). 536
Crane, Conmon, 547

-_ Lang, 379

'Craw' (Carrion Crow), 243 (Rook), 254

Cream-coloured Courser, 566

—— Gull (Iceland Gull), 688

- - (Glaucous Gull), 68 ;

Creeper, 120

- Tree, 120

'Creepy-tree' (Creeper), I 2 I

'Crested Cormorant,' 380

Crested Titmouse, I I 4

Crex pratensis, 534

Crossbill, Common, 197

—_ European White-winged, 20 I

Parrot, 200

- Two-barred, $20 \mathrm{I}$

'Croupy Craw' (Raven), 240

'Crow' (Rookj, $25+$

-C Carrion, 240

Crow, Hooded, 244

- Black-nebbed, 243

Blue-backed, 249

- Cad, 243

- Car, 243

- Coathan. 249

- Corbic, 243

- Croupy, 240

- Daup, 243

- Denmark, 249

- Dutch, 249

- Dun, 249

- Flesh, $2+3$

- Ger, 243

- Gor, 243

- Grey, 249

- Grey-backed, 249

- Ket, 243

Moor, 249

Night, 268

Northern, 249

- Norway, 249

[249

- Royston (see 'Royston Crow')。

- Scare, 648-9

- Sea, 244

- Water, 103 
Crow, Woodcock, 249

Cuckoo, 287

'Cuckoo's Maiden,' (Wryneck), 27 I

_- Mate' (Wryneck), 27 I

-_ Messenger' (Wryneck), 271

Cuculus canorus, 287

'Cuddy' (Tree Sparrow), 180

- (Hedge Accentor), I00 [100 Whooper' (Hedge Accentor),

Cuneate-tailed Gull, 665

Curlew, Common, 643

_ Half' (see 'Half Curlew')

— Jack' (Whimbrel), 648

_- Knave' (Whimbrel), 646, 648

— Pygmy, 615

Curlew Sandpiper, 6 I 5

Curlew, Stone, 561

[64I

- Whelp' (Bar-tailed Godwit),

Cursorius gallicus, 566

'Cushat' (Ring-Dove), 490

'Cushard' (Ring-Dove), 490

'Cut-Bill ' (Green Woodpecker), 274

Cyanecula leucocyana, 38

- - suecica. 39

Cygnus bewicki, 429

- ferus, 428

- immutabilis, 431

- mansuetus, 431

-D musicus, 428

- olor, 430

Cypselus apus, $26 \mathrm{I}$

- melba, 264

Dabchick, 746, 748

Dafila acuta, 453

'Daker Hen' (Corn Crake), 535

[Dartford Warbler], 97

'Daup ' (Carrion Crow), 243

'Daup Crow' (Carrion Crow). 243

'Daupee' (Carrion Crow). 243

- Daw' (Jackdaw), 234 ' Red-legged, 224

Decoys, 437

Dendrocopus major, 274 .

- minor, 276

__ [villosus], 276

'Denmark Crow' (Hooded Crow), 249
Desert Chat, 25

Wheatear, 25

'Devil-bird' (Swift), 264

—_-bitch' (Swift), 264

—_-screamer' (Swift), 264

- - -screw' (Swift), 264

—— -shrieker' (Swift), 264

_- -squeaker' (Swift), 264

'Develin' (Swift), 264

'Develling' (Swift), 264

'Dibbling' (Swift), 264

'Dicky Develling' (Swift), 264

- Dunnock'(HedgeAccentor), 100

'Didapper' (Little Grebe), 746, 748

'Dipper' (Little Grebe), 746, 748

'Dipper Duck' (Little Grebe), 748

Dipper, I I I

- Black-bellied-, 103

'Ditch Lark' (Meadow Pipit), I 32

Diver,' 'Black, 477

- Black-throated, 735

- Dun, 484

- Great Northern, 732

__ 'Guinea-bird, 738

-m 'Lough, 485-486

- 'Red-throated, 736

- 'Small, 744

- White-bellied Northern, 734

'Dob' (Carrion Crow), 243

' Doup' (Carrion Crow), 243

- Dowp' (Carrion Crow), 243

'Dowk' (Carrion Crow), 243

'Dobber' (Little Grebe). 748

'Dor-hawk' (Nightjar), 269

Dotterel. 567

'Dotterel' (Turnstone), 586

- Land (Dotterel). 573

- Moor (Dotterel), 573

- Sand, 575

- Spring (Dotterel), 573

Ring or Ring-necked (Ringed Plover), 575

'Doucker' or 'Greatest Doucker'

(Great Northern Diver), 732

'Douk' (Dipper), 103

Dove,' 'Clatter. 
Dove, Ring, 487

—— Rock, 494

-_' 'Ring, 'Rock, 'Rocket (see local names of Stock-Dove), 493 ' 'Stog (see 'Stog-Dove), 490

- Stock, 490

- Stock, 487

Turtle, 495

Rufous Turtle, 498

$[632$

' Drain Swallow' (Green Sandpiper),

Drake,' 'Corn, 536

- 'Dress, 536

- 'Grass, 535

- 'Gress, 535

— hen,' 535

- - 'Land, 535

'Meadow, 535

'Draker-hen' (Corn Crake), 535

'Dress Drake' (Corn Crake), 536

Duck, Big Black and White, 482

- Bimaculated, 46 I

— Black, 479

- 'Black Poker, 470

- 'Black Toppin, 467

- Buffel-headed, 471

- Burrow, 434

- Common Sheld, 432

- ' Dipper, 748

- Eider, 475

-_ Ferruginous, 465

- Grey, 437

-_- Golden-eye, 470

__ ' Gors or ' Gurs, 536

- Harlequin, 474

- Hawk (Peregrine Falcon), $36 \mathrm{I}$

- Hawk (Marsh Harrier), 317

- Long-tailed, 472

- 'Mussell, 479

- Pintail, 453

- 'Pheasant, 454

—_ [Ruddy Sheld], 434

—_ 'Sawbill, 484-5

_- Scaup, 468

- Sly, 434

-_ Steller's Western, 476

- Tufted, 466
Duck, Velvet, 482

- 'Whew, 46 I

_- White-eyed, 465

- W Wild, 434

Ducker,' 'Small, 746-8

'Dunbird' (Pochard), 465

'Dunpocker' (Pochard), $46_{5}$

'Dun Crow' (Hooded Crow), 249

'Dutch Crow' (Hooded Crow), 249

'Dun Diver' (Goosander), 484 (Red-breasted Merganser), 485

Dunlin, 608

- (Knot), 620

'Dunnock' (Hedge Accentor), IOO

- 'Dicky (Hedge Accentor), 100

'Dusky Grebe' (Sclavonian Grebe), 743,744

- - Redshank, 635

'Dwaft Auk' (Little Auk), 732

__ Gull' (Little Gull), 670

'Eagle Fisher' (Osprey), 374

-C Cinereous, 334

- Golden, 33 I

- Owl, 3 I 2

— White-tailed, 334

Eared Grebe, 744

'Eaves ' or 'Easin Swallow' (House Martin), I6 I

[Ectopistes migratorius], 498

Egret, Little, 393

'Egritte' (Lapwing), 581

[Egyptian Goose], 427

Eider Duck, 475

- K King-, 476

- Steller's, 476

[Elanoides furcatus], 347

'Elk' (Whooper Swan), 429

Emberiza cioides, 206

- cioides castaneiceps, 207

- cirlus, 204

citrinella, 203

hortulana, 206

milaria, 201

-_ [pusilla], 207

rustica, 207

schœniclus, 208 
'Emmet Hunter' (Wryneck), 27 I

Evithacus rubecula, 4I

Endromias morinellus, 567

'Eutic' (Whinchat), 26

' Eve-chur ' or ' Jar ' (Nightjar), 269

Falco asalon, 365

- candicans, 352

cenchris, 372

[furcatus], 349

grcenlandicus, 353

- islandus, 355

- peregrinus, 357

- rufipes, 368

- [sparverius], 372

subbrteo, 362

tivinunculus, 370

vespertinus, 367

Falcon, Blue-backed, 36I

- Greenland, 352

'Grey, 357

Gyr, 353, 354, 356

Iceland, 355

- Peregrine, 357

Red-footed, 367

'Stone, 367

[Swallow-tailed], 349

'Fanny Redtail ' (Redstart), 36

'Featherpoke' (Chiffchaff), 83

- (Willow Warbler), 86

(Greenfinch), I65

(Long-tailed Titmouse), 107

'Ground, 86

'Feathersack' (Long-tailed Titmouse), 107

'Feldy'

'Felfer'

'Felfor'

'Fellfer'

'Fellfor'

(Fieldfare), I 2

'Felfit'

'Feltyfare '

'Fentyfare ")

'Felfer' (Redwing), 9

'Fell Blackie' (Ring Ouzel), 2 I

'Fern Owl ' (Nightjar), 268

'Ferny Hoolet ' (Tawny Owl), 303
Ferruginous Duck, 465

Fieldfare, 9

'Fig-eater' (Garden Warbler), 73

Finch, 'Alder, I74

-_ 'Bramble, I 84

'Cherry, I68

- Lesser Mountain, 2 I 2

- Mountain, I 84

'Storm, 750

'Thistle, I 72

'Twate, I92

'Twite, 192

Fire-crested Wren, 79

'Fire - crown' (Golden - crested Wren), 78

'Firetail' (Redstart), 36

'Fisher' (Kingfisher), 281

'Flambro' Head Pilot ' (Puffin), 729

[Flamingo], 408

'Flasher' or 'Flesher ' (Red-backed Shrike), 144

'Flaxfinch' (Chaffinch), I80, I 82

'Fleck Linnet' (Chaffinch), I 82

'Fleingall' (Kestrel), 372

'Flesh Crow' (Carrion Crow), 243

'Flirt-tail' (Redstart), 36

'Flusher' (Red-backed Shrike), I 40-4

Flycatcher, Grey, 149

—— Pied, 149

- Red-breasted, ${ }_{5} 5$

- Spotted, I48

'Foolish Guillemot' (Common

Guillemot), 724

'Fork-tail' (Kite), 347

Fork-tailed Petrel, 750

— Swallow' (Swallow), i 58

Fratercula arctica, 727

'French Linnet' (Chaffinch), I 82

- (Lesser Redpoll), 190

- or 'Lenny' (Brambling), I8 4

'Frenchman' (Black Tern), 649

- (Red-legged Partridge), $53^{\circ}$

French Partridge (Red-legged Par-

tridge), 530

_- Sparrow' (Snow Bunting), 215

Fringilla calebs, 180 
Fringilla montifringilla, 182

Fulica atra, 545

Fuligula cristata, 466

- ferina, 462

- marila, 468

- nyroca, 465

Full Snipe (Common Snipe), 605

Fulmar, 764

Fulmarus glacialis, 764

' Gabble-ratch' (Nightjar), 268, 269

' Gabriel-ratch ' (Nightjar), 268, 269

'Gabriel's-hounds' (Grey Lag Geese), 4II, 4I 5, 427

-_ (Brent Geese), 427

Gadwall, $45^{\circ}$

Gallinago colestis, 602

- major, 6or

Gallinula chloropus, 544

- - hypoleucos, 626

- minuta, 538

-

Gallinule,' 'Little, 539

-_- 'Olivaceous, 539

- - [Purple], 545 'Spotted, 537

Gannet, 38r

'Gant' (Gannet), 384

_- 'Mackerel (Gannet), 384

Garden Warbler, 72

Garganey, 457

Garrulus glandarius, 225

[249

' Garton Greyback' (Hooded Crow),

'Gawk' (Cuckoo), 292

Gecinus viridis, 272

' Ger Crow' (Carrion Crow), 243

'Gid' (Jack Snipe), 605

Glareola pratincola, 565

Glaucous Gull, 685

'Glead' or 'Gled' (Common Buzzard), 328

'Glead ' or 'Gled ' (Kite), 347

Glossy Ibis, 406

- Greedy Glead ' (Kite), 347

Goatsucker, 266, 268

' Godwin,' ' Goodwin ' (Godwit), 64 I

Godwit, Bar-tailed, 639
Godwit, Black-tailed, 64I

Goldcrest, 76-78

Golden-crested Wren, 75

- Kinglet, 78

Golden Eagle, 33 I

Golden-eye, 470

- (Scaup), 470

Oriole, 136

—— Plover, 577

Thrush' (Mistle Thrush), 3

Goldfinch, 169

'Goldie'

'Goldspink'

'Gowdspink'

'Gold Linnet'

(Goldfinch), 172

'Gowd Linnet'

'Gold Lenny' '

'Goldfinch'

'Goldie '

'Goldspink' (Yellow Bunting)

'Gowdspink' 204

'Goldring '

'Gold Lénny')

'Gold-tip' (Sparrowhawk), 344

Goosander, 482

Goose, Bean, 4I3

- Bernacle, 423

'Black, 437

Brent, 425

[Canada], 427

Carr Lag, 419

[Egyptian], 427

Grey Lag, 408

'Laughing, 4I 2

Lesser White-fronted, 4I 3

Long-billed, 419

Pink-footed, 4I 5

Red-breasted, 423

'Road, 'Rood, ' 'Rhode,'Rock, (Brent Goose), 'Rott, 'Rat 425,427

'Scotch, 427

Snow, 422

Solan, 384

White-fronted, 4I I

Yellow-billed Bean, 420 
'Gor-cock' (Red Grouse), 5 Io, 522

'Gor Crow' (Carrion Crow), 243

'Gors-duck' (Corn Crake), 536

' Goss ' or 'Gorse Linnet ' (Linnet).

Goshawk, 339, 357 [1 86

'Go-west' (Long-tailed Duck), 474

'Gowk' (Cuckoo), 292

'Grass-chat' (Whinchat), 28

'Grass Crake')

- Drake' Qualie'

'Gress Drake'

(Corn Crake), $535-6$

'Gurs Duck' J

Grasshopper Warbler, 93

'Grass Warbler' (Chiffchaff), 83 (Willow Warbler), 86

Wren' (Chiffchaff), 83 (Willow Warbler), 86

'Grass Whew' (Wigeon), 46I

Great Black-backed Gull, 684

-_ [Black Woodpecker], 278

_- Blue Hawk' (Peregrine), 36I

Bustard, 548

Crested Grebe, 738

Grey Shrike, I 38

Northern Diver, 732

$[73$

Pettychaps' (Garden Warbler),

- Plover (Stone Curlew), 564

[Reed Warbler], 9I

Shearwater, 752

Skua, 694

Snipe, 60I

Spotted Woodpecker, 274

Titmouse, 108

White Heron, 392

'Greater Billy Bluecap ' (Great Titmouse), 109

- Butcher Bird (Great Grey Shrike), 138

- Pettychaps' (W'hitethroat), 66

- Tit' (Great 'Titmouse), 109

'Greatest Doucker' (Great Northern Diver), 732

-_ Speckled Diver' (Great Northern Diver), 732

Grebe, Black-necked, 746
Grebe, 'Dusky, 743-744

- Eared, 744

_- Great Crested, 738

-_' ' Horned, 744

- Little, 746

--_ Red-necked, 740

Sclavonian, 743

" 'Tippet, 740

Green Cormorant, 380

Greenfinch, I 63

'Green Grosbeak' (Greenfinch), I 63-5

___ Linnet' (Greenfinch), I 65

_- Lenny' (Greenfinch), I 65

'Greeny' (Greenfinch), I65

Greenland Falcon, 352

Mealy Redpoll, I 89

Green Plover, 584

- Sandpiper, 63 I

Greenshank, 637

Green-winged Teal, 456

- Woodpecker, 272

'Greve' (Grebe), 742

'Grey-back' (Hooded Crow), 249

- - backed Crow; 249

Crow, 249

'Grey-bird' (Sedge Warbler), 93

Grey Duck or Grey Drake (Mallard), 437

__ Falcon' (Peregrine Falcon), 357

- Flycatcher (Spotted Flycatcher), I 49

Grey-headed Yellow Wagtail, I 27

Grey-hen (Black Grouse), 509

_- Kate' or 'Grey Pate' (Goldfinch), 172

Lag Goose, 408, 416

Linnet' (Linnet), I 86

Linnet' or 'Grey Lenny'

(Twite), I92

-_ Phalarope, 59 I

- Plover, 579

- Plover' (Knot), 620

Wagtail, I 25

Grosbeak (Hawfinch), 168

Green, I 63-I 65

Pine, I95 
'Ground Featherpoke' (Willow Warbler), 86

- Wren' (Willow Warbler), 86 Wren' (Chiffchaff), 83

Lark' (Common Bunting), 203 Lark' (Mleadow Pipit), I 33

Laverick' (Meadow Pipit), I 33

Grouse, Black, 505

Pallas's Sand, 498

__ Red, 5 Io

Grus communis, 547

Guillemot, Black, 726

—— Bridled, 723

- Brunnich's, 724

Common, 7 I I

___ 'Foolish, 724

_- Ringed, 723

_- Thick-billed, 724

'Guinea-bird Diver' (Red-throated Diver), 738

Gull [American Laughing], 674

- - -billed Tern, 651

__ 'Black-cap, 674

- Black-headed, 670

- Black and White, 685

- Blue-backed, 680

- Brown-headed, 67 I

- Common, 675

- Cream-coloured,

-.C Cuneate-tailed, $66_{5}$

' 'Dwarf, 670

- Glaucous, 685

- Great Black-backed, $68_{4}$

_- Great Saddle-back, 684

- Herring, 677

_- Iceland, 687

—— Iceland (Glaucous Gull), 687

__ Ivory, 693

—_ Fittiwake, 689

-_ [Laughing], 674

- Lesser Black-backed, 681

- Little, 667

_.' ' Mackerel, $693 \quad[675$

_- Mediterranean Black-headed,

—— Parasitic, 705

-'Peewit, 674
Gull,' 'Pigeon, 674

—— Ross's, $66_{5}$

Rosy, 665

- Sabine's, 662

' 'Tumbler' or 'Tumbling,'6,4

' 'Wagel, 685

Wedge-tailed, 665

'Gypey,' 'Gyp,' 'Gipey ' (Starling), 220

' Gyp Starling,' ' Gyp Starnil ' (Starling), 220

Hamatopus ostralegus, 586

'Hair-tail' (Garden Warbler), 73

[Hairy Woodpecker], 276

'Half-Curlew' (Whimbrell, 6.8

Haliatus albicilla, 334

Harelda glacialis, 472

Harlequin Duck, 474

Harrier, Marsh, 3 I 5

_- Montagu's, 32 I

- Hen, 3 I 5

- Ringtail, $32 \mathrm{I}$

Hawfinch, 165

Hawk, 'Blue, 321

- 'Brown, 372

—_ 'Dor, 269

_- 'Duck, 36I, 3 I 7

- Gos, 339, 375

' Great Blue, 361

'Hover, 372

' Jack, 372

__ Little, 367

'Little Blue, 367

'Little Blue Pigeon, 367

_L Little Red, 372

_- Marsh, 3 I 7

_- 'Moor, 317

'Nouse, 372, 297, 30r

'Mullet, 374

'Night, 268

- [Owl], 30I

'Perry, 36r

' Pigeon, 344

' Red, 372

' Rock, 367

Sparrow, 343 
Hawk, 'Stand, 372

- 'Standing, 372

- 'Stone, 367

- 'Vanner, 372

——'Yellow, 372

'Hay-bird' (Whinchat), $2 S$

__ (Wood Warbler), 88

- Hay-chat' (Whinchat), 28

'Hay-Crake' (Corn Crake), 535

'Hayhoe')

'Heffald' (Green Woodpecker),

'Hefful' $\}$ 272, 274

'Heath-Cock' (Blackgame), 509

'Heath-Throstle' (Ring Ouzel), I 8, 2 I

'Heather-Bleater' (Common Snipe), 605

—— Lintie' (Meadow Pipit), 133

Hedge Accentor, 97

'Hedge Chanter'

_- Creeper'

- Sparrow' (HedgeAccentor),

'_ Warbler' 100

'Hernshaw'

'Heronshaw'

(Common

'Heronsew' Heron), 390 and other variants

Heron, Common, 384

—_ Purple, 39I

- Great IVhite, 392

- Night, 395

Squacco, 395

Heronshew, Speckled, 402

Herring Gull, 677

- Loon' (Great Northern Diver)

- Spink' (Goldcrest), 79

Himantopus candidus, 590

Hirundo rustica, 153

'Hissing Owl' (Barn Owl), 295

Hobby, 362

'Hollin-Cock' (Mistle Thrush), 3

Honey Buzzard, 350

Hooded Crow, 244

- Merganser, 486

'Hoodie' (Hooded Crow), 249
'Hoolet,' 'Howlet,' ) (Tawny

'Hoot Owl,' 'Hullot,') Owl), 303

'Hoolet, 'Brown, 302, 303

-... Ferny, 303

_-_White, 295

Hooper, 428

Hoopoe, 285

Horned Ow1 (Long-eared Owl), 296

_- Grebe (Sclavonian), 744

'Horner' (Goosander), 484

Houbara, Asiatic, 559

House Martin, 158

- Sparrow, 175

Swallow' (House Martin), 16I

'Hover Hawk' (Kestrel), 372

'Humming-bird' (Goldcrest), 79

Hybrids, 437, 454, 46I, 509, 520, $524,527,678$

Hydrochelidon hybrida, 65 I

- leucoptera, 650

- nigra, 648

Hypolais icterina, 88

Ibis, Glossy, 406

'Iceland Auk' (Little Ank), 732

- Falcon, 355

_- Gull, 687

_- Gull' (Glaucous Gull), 68;

Icterine Warbler, 88

Ivory Gull, 693

'Ivy Owl' (Tawny Owl), 303

Iynx torquilla, 269

'Jack' (Jackdaw), 234

'Jack Curlew' (Thimbrel), 646

Jackdaw, 232

'Jack Hawk' (Kestrel), 372

- Plover' (Dunlin), 61 2

- - -saw' (Goosander), 484

- Snipe, 605

'Jacky' (Jackdaw), 234

Blue Cap' (Blue Titmouse), I I 4

' Jacob' (Starling), 220

'Jar-Owl' (Nightjar), 269

Jay, 225

'Jay Piet,'

'Jenny Jay,', (Jay), 227

'Jinny Jay,' 
' Jenner-hen'

'Jenny Wa-ren,

'Jenny Wren'

(Wren), 120

'Jenny Howlet' (Barn Owl), 295 (Tawny Owl), 303

'Jenny Redtail ' (Redstart), 36 'Wrentail' (Redstart), 36

' Jenny Wren' (Blue Titmouse), I I4

'Jeremy Joy' (Mistle 'Thrush), 3

'Jim-Jan' (Chiffchaff), 83

- Jinny Hullut ' (Tawny Ow1), 303

- Jewlatt' (Tawny Owl), 303

' Jinny Wren' (Gold-crest), 79

' Jinties' (Crecper), I 21

' Judcock' (Jack Snipe), 605 (Dunlin), 612

'Kelne' (Stone Curlew), 564

'Kell-bird' (Young of Guillemot), 724

Kentish Plover, 576

Iíestrel, 370

[American], 372

Lesser, 372

'Ket-Crow' (Carrion Crow), 243

King Eider, 476

King fisher, 278

'King Harry' King Harry Redcap ' $\}^{\text {(Goldfinc }}$

Kite, 344

'Kite' (Common Buzzard), 328

-_ [Swallow-tailed], 347

Kittiwake Gull, 689

'Kit,' 'Kitty,' $\}$ (Kittiwake), 692-3

'Kitty' (Wren), I 20

Knot, 6I 8

Lagopus scoticus, 5 IO

Land Dotterel (Dotterel), 573

- Drake' (Corn Crake), 535 Maul' (Black-headed Gull), 674

Land Rail, 534, 535

'Lang Crane' (Cormorant), 379

Lamius collurio, Ito

- excubitor, 138

__neridionalis, I 39

- minor, I40
Lanius pomeranus, 144

Lapland Bunting, 210

Lapwing, $58 \mathrm{I}$

Lark,' 'Bank-, I31-1 33

' 'Bulking*, I 31

' 'Chit-, 133

' 'Chub-, 203

' Ditch-, I 32

' 'Ground-, 203

Lesser-crested-, I 30-13 I

' 'Rock-, I 36

' 'Sand-, 575, I36

' Scribbling-, 204

' 'Sea-, 575

Shore-, 259

' 'Tree-, I3 I

Wood-, 257

' Wood-(Tree Pipit), 13 I

' 'Writing-, 204

'Lark,'

'Laverack' $\}$ (Skylark), 257

' Laverock,'

Lans argentatus, 677

- [atricilla], 674

- canus, 675

- catarractes, 694

eburneus, 693

fuscus, 681

- glaucus, 685

- leucopterus, 687

marimus, 684

- melanocephalus, 675

- minutus, 667

niger, 648

- parasiticus, 705

—_ richardsonii, 703

- ridibundus, 670

tridactylus, 689

'Laughing Goose' (White-fronted

Goose), 412

[Laughing Gull], 674

'Laverack,' 257

Laverick,' ' Ground-, I 33

'Leaän' (Great Northern Diver), 734

(Red-tliroated Diver), 738

Leach's Fork-tailed Petrel, 750 
'Least Willow Wren' (Chiffchaff), 83

'Lemon-bird' (Linnet), I 86

'Lennert' (Linnet), I 86

Lenny, ' Gold, 172

- 'Over-sea, I 84

—_ 'White, 215

' Yellow, 204

Lesser Black-backed Gull, 68 I

Crested Lark(Tree Pipit), I 30 - I

Grey Shrike, I fo

Kestrel, 372

Mountain Finch' (Snow Bunting), 212

Pettychaps' (Chiffchaff), 83

Pettychaps' (Lesser Whitethroat), 68

_- Redpoll, I 89

[Ringed Plover], 575

Saddle-back' (Lesser Blackbacked Gull), 683

-_ Spotted Woodpecker, 276

\section{Tern, 66o}

White-fronted Goose, 4 I 3

Whitethroat, 67

Lestris pomarinus, 696

Levantine Shearwater, 760

Ligurinus chloris, I 63

'Liltie-Cock' or 'Lintie-Cock' (Cormorant), 379

Limicola platyrrhyncha, 607

Limosa agocephala, 64I

- lapponica, 639

' Ling-bird' (Meadow Pipit), I33

' Ling-tit' (Meadow Pipit), I 33

'Ling-Linnet' (Twite), 193

Linnet, I 85

- 'Bent, i 86

-_ Brown, I 86

'Chevy, I9o

' Chippet, I90

'Chivey, I90

'Fleck, 182

'French, 184

Gold, I 72

' Goss, I 86

' Grey, I 86
Linnet, ' Ling, 193

'Mountain, 192

_- 'Over-sea, 2 I 5

_- ' Red, I 86

' Robin, I 86

—_ ' Rose, I90

—_ Song, i 86

__ "Thorn, I 86

'Thorny, 193

- 'Whin, 186

- 'White, 180-182

Linota cannabina, 185

- - exilipes, 188

- flavirostris, 190

_- hornemanni, 189

- linaria, I 86

rufescens, I 89

Lintie,' 'Heather, 133

'Lintie-Cock,' 379

Little Auk, 730

'Little Billy-Bluecap' (Blue Titmouse), I 14

Little Bittern, 396

'Little Blackcap' (Coal Titmouse), I Io

—_ Blue Hawk' (Merlin), 367

___ Blue Pigeon Hawk' (Merlin) , 367

- [Bunting], 208

- Bustard, 557

-Crake, 538

- Egret, 393

- Gallinule' (Little Crake), 539

Grebe, 746

- Gull, 667

- Hawk' (Merlin), 367

Owl, 306

Peewit ' (Twite), 193

- Red Hawk' (Kestrel), 372

- [Screech Owl], 3 I 2

Snipe' (Dunlin), 612

Stint, 6I 2

Tern, 660

- Woodpecker' (Lesser Spotted Woodpecker), 277

- Woodpecker' (Creeper), I 2 I

- Wren'(Golden-CrestedWren) 79

Locustella navia, 93 
Lomvia troile, 7 I I

Long-billed Goose, 419

- - -eared Owl, 295 -horned Ullat' (Long-eared Owl), 296

_- Neb' (Common Snipe), 605

—— -Neck' (Common Heron), 390

- - -tailed Duck, 472

—— -tailed Mag' (Magpie), 231

- - -tailed Nan' (Magpie), 23 I

-_- -tailed Pie' (Long-tailed Titmouse), 107

—— -tailed Skua(Buffon'sSkua), 705 -tailed Titmouse, Io6 -tailed Tom' (Long-tailed Titmouse), 107

Tongue' (Wryneck), 27 I

'Longwings' (Swift), 264

'Loon' (Great Northern Diver), $[732-734$

- - (Red-throated Diver), 738

' 'Herring, 734

' 'Speckled, 738

' 'Sprat, 738

'Lough Diver' (Smew), 485, 486

Loxia bifasciata, $20 \mathrm{I}$

- curvirostra, 197

- pityopsittacus, 200

'Luteola' (Wood Warbler), 87

Machetes pugnax, 622

'Mackerel Gant' (Gannet), 384

_- Gull' (Kittiwake), 693

Macrorhamphus griseus, 638

MacQueen's Bustard, 559

Magpie, 228

' Mag,' 'Maggie,')

'Miggy,' $\}$ (Magpie), 23 I

Mallard, 434

Mallemoke' (Fulmar), 763

-_ (Glaucous Gull), 687

Manx Shearwater, 759

Mareca americana, 46I

- penelope, 458

Marsh Harrier, 315

- Hawk' (Marsh Harrier), 3 I 7

Titmouse, III
Martin, I6I

- - [American Purple], I6I

-_ 'Bank, I63

'Black, 266

- House, 158

—— 'Pit, 163

- Sand, 16 I

'Mattagasse,' I 38

Maul,' 'Land, 674

'Mavis' (Song Thrush), 6

Maw,' 'Pet, 677

'Meadow Drake' (Corn Crake), 535

—_ Pipit, 132

'Mealymouth' (Lesser Whitethroat), 68

-_- (Willow Warbler), 86

Mealy Redpole, 186

- Redpole, Greenland, 189

- Redpole, Northern, I88

Mediterranean Black-headedGull,675

Megalestris catarrhactes, $69+$

Merganser, Hooded, 486

- Red-breasted, 484

Mergulus alle, 730

Nergus albellus, 485

- cuculatus, 486

-- merganser, 482

- serrator, 484

'Merle Hen' (Great Skua), 696

Merlin, 365

Merops apiaster, 283

- [phillipensis], 284

Mew,' 'Black-cap, 670-674 ' 'Sea-, 677

'Midden Daup' (Carrion Crow), 243

Migration, Birds assisted on, 78

—_ Fieldfare, I I

Golden-crested Wren, 76

Hedge Accentor, 98

Lapwing, 583

Redbreast, 43

Redwing, 7

Redstart, 34

Remarks on (Introduction).

Rook, 25 I

Skylark, 256 
Migration, Song Thrush, 5

- Starling, 217
- Swallow, I 55
—— Wheatear, 23
- White Wagtail, I24

'Miller's Thumb' (Chiffchaff), 83

- - (Willow Warbler), 86 - (Wood Warbler), 88

- - (Long-tailed Titmouse), 107

'Mealy Miller's Thumb' (Longtailed Titmouse), I07

Milvus ictinus, 344

"Mire Drum" (Bittern), 402

Mistle Thrush, I

'Mock Nightingale' (Whitetliroat), 66 —_ _ (Sedge Warbler), 93

'Mollemawk' (Fulmar), 764

- (Glaucous Gull), 685

Montagu's Harrier, 32 I

Monticola saxatilis, 2 I

'Moor Blackbird ' (Ring Ouzel), 2 I

—_ Blackie' (Ring Ouzel), 2 I

'Thrush' (Ring Ouzel), 2 I

Buzzard' (Marsh Harrier), 3 I 5-7

-bird ' (Red Grouse), 522

-Cock' (Black Grouse), 505

(Red Grouse), 510,522

Crow' (Hooded Crow), 249

Dotterel' (Dotterel), 573

-fowl' (Red Grouse), 5 IO

Game' (Red Grouse), 522

Hawk' (Marsh Harrier), 317

Hen' (Black Grouse), 505

- (Red Grouse), 522

Pout ' (Red Grouse), 522

Moorhen, 544

'Moor Tit' (Meadow Pipit), I 33

- - (Stonechat), 32

—— Red-breasted, 32

Titling ' (Stonechat), 32

'Morrel Hen' (Great Skua), 695-6 (Richardson's Skua), 705

'Moss Hen ' (Red Grouse), 522

Owl' (Short-eared Owl), 301

Motacilla alba, 123
Motacilla borealis, 127

- flava, I 26

- lugubris, $12 \mathrm{I}$

- melanope, 125

- raii, 128

Mottled Owl, 312

'Mouse Hawk' (Kestrel), 372

-_ - (Short-eared Owl), 297,301

'Moun tain Blackbird'(RingOuzel), 2 I

_- Bunting' (Snow Bunting), 215

—— Finch ' (Brambling), I 84

- - - Great Pied, 2 I 2

-_ Lesser, 212

- Linnet' (Twite), 192

- Sparrow' (Tree Sparrow), i 80

'Muggie' or 'Meggie' (Whitethroat), 66

'Mullet' (Puffin), 727, 729

'Mullet Hawk' (Osprey), 374

'Murre' (Guillemot), 724

'Murrel Hen ' (Great Skua), 696

Muscicapa atricapilla, I 49

- - grisola, 148

- parva, I 52

'Musket' (Sparrowhawk), 344

'MrusselCracker'(OysterCatcher), 588

- Duck' (Common Scoter), 479

-— - (Scaup), 470

Mute Swan, 430

' Nanny Redtail' (Redstart), 36

'Nanpie' (Magpie), 231

'Nan-piannot' (Magpie), 232

Nanpie,' ' Sea-(Oyster Catcher), 588

Netta rufina, 462

Nettion carolinensis, 456

- crecca, 454

'Nettle Creeper' (Whitethroat), 66

-_ - (Garden Warbler), 73

Monger' (Whitethroat), 66

-_ (Reed Bunting), 2 Io

- Wren' (Whitethroat), 66

'Nickle' (Green Woodpecker), 274

- Night-Churr ' (Nightjar), 269

—- Crow' (Night jar), 268

—- -Hawk' (Nightjar), 268

—- Heron, 395 
Nightingale, 47

—_'Mock (Whitethroat), 66

- Sedge Warbler, 93)

Nightjar, 265

'Nightsinger' (Sedge Warbler), 93

'Night Raven' (Bittern), 402

'Noddy' (Common Guillemot), 724

[Noddy Tern], 655

Norfolk Plover, 561, 564

'Norman Thrush ' (Mistle Thrush), 3

Northern Bullfinch, 194

-_- Crow' (Hooded Crow), 249

-n Diver, Great, 732

_-_ W- White-billed, 734

-_ Mealy Redpoll, i 88

'Norway Crow' (Hooded Crow), 249

Nucifraga caryocatactes, 224

Numenius arquata, 643

- phopus, 646

Nutcracker, 224

- Siberian, 224

Nuthatch, I 5

'Nut-jobber' (Nuthatch), 115 , I I $7-8$

Nyctala [acadica], 305

- tengmalmi, 303

Nyctca scandiaca, 309

Nycticorax europoess, 396

— griseus, 395

Oceanites oceanicus, 752

Oceanodroma leucorrhoa, 750

Edemia fusca, 480

- nigra, $47 \mathrm{~T}$

-_- [perspicillata], 482

Edicnemus scolopax, 56r

Olivaceous Gallinule, 539

Oriole, Golden, ${ }_{3} 6$

Oriolus galbula, 136

Orphean Warbler, 68

Ortolan Bunting, 206

[Orty.x virginianus]. 533

Osprey, 373

Otis Macqueeni, 549

-

— tetrax. 357

Otocorys alpestris, 259

' Ouzell ' (Blackbird), I7
'Ouizle' (Blackbird), 17

Ouzel, 'Brook, 543

'Crag,

Ring, 17

'Rock, 2 I

'Water, Ior

'White-breasted, I03

'Over-sea Bird' (Snow Bunting), 215

—— Linnet' (Snow Bunting), 285

Lenny' (Brambling), 184

Owl [Acadian] or [American Sawwhet], 305

Barn, 292

'Beech, 303

Brown, 302-303

'Church,

'Churn,

Eagle, 312

' Fern, 268

Hawk, 3 or

'Hissing, 295

Horned, 296

'Ivy, 303

Little, 306

[Little Screech], 3 I 2

Long-eared, 295

'Moss, 301

Mottled, 312

[Saw-whet,] 303

Scops, 30I

Screaming, 295

'Screech, 295

'Short-eared, 296

Snowy, 309

[Sparrow], 306

Tawny, 30I

Tengmalm's, 303

White, 295

Wood, 274

'Woodcock, 297-30r

'Yellow, 295

'Oxeye' (Great Titmouse), 109

Oyster Catcher, 586

Pagophila eburnea, 693

Pallas's Sandgrouse, 498

Pandon halicetus, 373 
Panurus biarmicus, 107

- Parasitic Gull ' (Buffon's Skua), jo5

Parrot Crossbill, 200

' Parrot 'or'Sea-Parrot' (Puffin), 729

'Partrick' or 'Partrig' (Partridge). Partridge, 524

- [Barbary]. 531

- French, 530

- Red-legged, 527

Parus ater, 109

- - coruleus, II 2

— cristatus, IIt

- major, 108

- palustris, I I I

Passer domesticus, $17 \hat{j}$

—— minor, 159

montanus, 178

Pastor, Rose-coloured, 221

Pastor roscus, 221

'Pearker' (Young Rook), 254

Pectoral Sandpiper, 607

'Peep-o'-day' (Little Grebe), 748

Peewit, 584

Gull ' (Black-headed Gull), 67+ 'Little, 193

'Peggy' (Blackcap), $;$ I

(Chiffchaff), 83

(Garden Warbler), 73

(Willow Warbler), 86

(Wren), 120

(Whitethroat), 66

Chatter' (Whitethroat), 66

Whitethroat,' 66

(Willow Warbler), 86

Dishwash' (Pied Wagtail), 123

'Pendle Whew' (Wigeon), 46I

'Penwings ' (Great Northern Diver), Perdix cinerea, 524

Peregrine Falcon, 357

Pernis apivorous, 350

- Perry Hawk' (Peregrine), 36 I

'Pet-Naw' (Common Gull), 677 (Kittiwake), 693

'Petrel' (Kittiwake). 689, 693

- Bulwer's, 762

Fulmar, 764
Petrel, Leaclı's Fork-tailed, 750

Storm, 748

Wilson's, 752

'Pettychaps' or 'Great Pettycliaps '

(Garden Warbler), 72, 73

' 'Lesser(LesserWhitetliroat),68 (Chiffchaff), 83

Phalacrocorax carbo, 375 graculus, 379

Phalarope, Grey, 59 I

- - Red-necked, 593

'Phalaroe' (Phalarope), 593

Phalaropus fulicarius, 59 I

- hyperborcus, 593

Phasianus colchicus, 523

— torquatus, 523

Pheasant, 523

—_ 'Black, 243

-- Duck' (Pintail). 454

-...' 'Sea, 454

Philomela luscinia, 47

[Phanicopterus roseus], 408

Phylloscopus borcalis, 86

- - brehmi, 83

- rufus, $8 \mathrm{I}$

— sibilatrix, 86

- superciliosus, so

- trochilus, 83

Pica rustica, 228

'Pickie' (Mistle Thrush), 3

[Picus martius], 278

'Pie,' 'Pianate,'

'Pyenate,' 'Pinot,

'Pienet,' 'Pynot,"

'Piannot,' 'Pianet,' (Magpie), 231.

'Pyannot,' 'Pyet,' 232

'Pied Margaret,'

'Pie-nanny,'

Pied Flycatclier, 149

_- Wagtail, 121

Pigeon [American Passenger], 498

—_- 'Burrow, 493

' Cliff, 495

—CGull' (Black-headed Gull), 674

Hawk' (Sparrowhawk), 344

Plover' (Grey Plover), 58 ז 
Pigeon, 'Ring (see Ring Pigeon)

__ 'Rock (Rock-Dove), 495

_- - (Stock-Dove), 493

- 'Sea, $58 \mathrm{I}$

Wild, 490

-_. Wood, 488

'Pinçon' (see Chaffinch)

Pine Grosbeak, 195

Pinicola enencleator, 195

'Pink' (Chaffinch), I 82

- - footed Goose, 415

Pintail, 453

Pipit, Meadow, I32

—_ Rock, I 34

__ 'Sea-beach, I 36

- Tawny, 134

- Tree, 130

'Pit Martin' (Sand Martin), I63

Platalea lencorodia, 406

Plectrophanes nivalis, 212

Plegadis falcinellus, 406

- Ploughman's Bird ' (Redbreast),47

Plover,' 'Bastard, 582-58j

- Golden, 577, 581

Great, 564

- Green, 584

Grey, 579

' Jack, 612

- Kentish, 576

Knot (Knot), 620

—- [Lesser Ringed], 575

Norfolk, 564

- Pigeon, 58I

_- Ringed, 573

-.. 'Sand, $58 \mathrm{I}$

- 'Silver, $58 \mathrm{I}$

_- Turnstone (Turnstone), 586 'Whistling, 564

Pochard, Common, 462

- Red-breasted, 462

-_ 'Silver, 470

Pocker,' 'Black, 467

Podicipes auritus, 743

—_ cristatus, 738

- fuviatilis, 746

- griseigena, 740
Podicipes nigricollis, 744

'Poker ' or 'Pokker '(Pochard), 465

[Polish Swan], 43I

Pomatorhine Skua, 696

'Pool Snipe' (Redshank), 635

'Popinjay '(Green Woodpecker), 274

[Poryphyrio caruleus], 545

Porzana bailloni, 539

—_ maruetta, 536

- parva, 538

Pratincola rubetra, 26

- rubicola, 28

Pratincole, Collared, 565

Procellaria lencorrhoa, 750

- pelagica, 748

[Progne purpurea], I6 I

Puffin, 727

—. 'Tom, 748

Puffinus anglorum, 759

- - gravis, 752

—_ griseus, 755

__ yelkonanus, 760

[Purple Gallinule], 545

- Heron, 39I

[Martin], I6I

Sandpiper, 617

'Purre' (Dunlin), 6r 2

Pygmy Curlew, 615

Pyrrhocorax graculus, 223

Pyrrhula europcea, 193

-_ major, I94

Quail, Common, 53 I

Quake,' 'Grass, 536

Querquedula circia, 457

' Rafter ' or ' Rafter-bird ' (Spotted Flycatcher), I 49

Rail, Land, 534, 535

- Spotted, 537

Water, 540

'Rain-bird,' )

'Rain-fowl,' (Green Woodpecker).

'Rain-pie,' 274

Rake,' 'Corn, 535

Rallus aquaticus, 540

- Dusillus, 538

'Ralphieand Dykie' (Cormorant), 379 
'Rat-bird,' 'Rat-hen'(WaterRail), 543

'Rat,' or 'Rott Goose' (Brent Goose), 427

'Rattle Thrush' (Mistle Thrush), 3 Raven, 235

(Carrion Crow), 243

Crow' (Carrion Crow), 243

'Night, 402

Ray's Wagtail, I 30

Razorbill, 708

Recurvirostra avocetta, 588

Red-backed Shrike, I40

Redbreast, 4I

Red-breasted Flycatcher, I52

- - Goose, 423

-_ - Merganser, 484

- - Moor Tit' (Stonechat), 32

- - Snipe, 638

'Redcap' (Goldfinch), I 72

—— (Lesser Redpoll), 190

'Red-Cock' (Red Grouse), 5 10, 522

Red-crested Pochard, 462

'Reddy,' 'Red-legs' (Redshank), 635

Reeve, 622

Red-footed Falcon, 367

Red-game, 510,522

Red Grouse, 5 Io

'Red Hawk' (Kestrel), 372

'Red-head' (Pochard), 465

'Red-headed Sparrow' (Tree Sparrow), 178

'Red-legged Daw' (Chough), 224

Red-legged Partridge, 527

'Red Linnet' (Lesser Redpoll), I9o

-_- (Linnet), I 86

- Lenn' (Linnet), 186

-necked Grebe, 740

- Phalarope, 593

Redpoll, Mealy, I 86

- Greenland Mealy, 189

Lesser, I 89

Northern Mealy, i 88

'Red Sandpiper' (Knot), 620

Redshank, 633

- Dusky, 635

- Spotted, 635

VOL. II.
Red-spotted Bluethroat, 39

Redstart, 33

- Black, 36

'Redster,'

'Redstare,' , (Redstart), 36

'Red-rump,'

'Red-tail,'

Red-throated Diver, 636

Redwing, 6

'Redwing Felfer' (Redwing).9

_- Throlly' (Redwing), 9

[Red-winged Starling], 22 I

Reed Bunting, 208

Reedling, Bearded, I04

'Reed Sparrow' (Reed Bunting), 2 ro

Reed Warbler, 89

'Ree,' 'Reeve,' Rey,' 6zz

Regulus cristatus, 75

- ignicapillus, 79

Regulus, Fire-crested, 79

- Golden-crested, 75

'Rhode Goose' (Brent Goose), 425

Rhodostethia rosea, 665

[Richards' Pipit], I 34

Richardson's Skua, 702

Ring, or Ringed Dotterel, 573

Ring-Dove, 487

- - (Stock-Dove), 493

Ringed Guillemot, 723

—- Plover, 573

'Ring-eyed Scout' (Ringed Guille mot), 724

'Ring-neck' (Ringed Plover), 575

Ring Ouzel, I7

- Pigeon' (Ring-Dove), 487, 490

- Sparrow' (Reed Bunting), 210

' Ringtail ' (Hen Harrier), 319, 321

'Ring Uzzle' (Ring Ouzle), 2 I

- Whistle' (Ring Ouzel), 2 I

Rissa tridactyla, 689

' River Swallow ' (Sand Martin), 163

Robin, 47

_- Linnet ' (Linnet), 186

- - Redbreast,' 47

Rock-Dove, 494

(Stock-Dove), 493 
'Rocket Dove' (Stock-Dove), 493

'Rhode-,' 'Road-,' 'Rock-,' 'Rood-,' or 'Rott-Goose' (Brent Goose), 427

'Rock Hawk' (Merlin), 367

—_ Ouzel' (Ring Ouzel), 2 I

_- Pigeon' (Rock-Dove), 495

—— (Stock-Dove), 493

—_ Lark' (Rock Pipit), I 36 Pipit, I 34

- Sparrow' (Tree Sparrow), I 80

Rock Thrush, 2I

Roller, 28I

Rook, 249

Rose-coloured Pastor, 221

Roseate Tern, 654

'Rose Linnet ' (Lesser Redpoll), I90

Ross's Gull, 665

Rosy Gull, 665

'Rotche' (Little Auk), 732

Rough-legged Buzzard, 328

' Royston Crow ' (Hooded Crow), 249

'Ruddock' (Redbreast), 47

[Ruddy Sheld-Duck], 434

Ruff or Reeve, 622

Ruffed Bustard, 559

Rufous Turtle Dove, 498

'Runner' (Water Rail), 543

'Runt ' (Wren), 120

Russian Bullfinch, 194

Rustic Bunting, 207

Ruticilla phonicurus, 33

titys, 36

Sabine's Gull, 662

Snipe, 606

'Saddle-back' (Great Black-backed Gull), 687

- 'Lesser (Lesser Black-backed Gull), 683

'Sand Dotterel' (Ringed Plover), 575 Sanderling, 620

Sand-Grouse, Pallas's, 498

'Sand Lark' (Ringed Plover), 575 (Rock Pipit), 136

Nartin, I6r

Plover' (Grey Plover), 58I
'Sand Runner' (Ringed Plover), 575

_- - (Sanderling), 622

Sandpiper, Broad-billed, 607

- Common, 626

- Curlew, 615

- Green, 631

- Pectoral, 607

- Purple, 6i 7

' ' Red, 620

- Spotted, 628

Wood, 629

$[628$

'Sand-Snipe' (Common Sandpiper).

- - -Swallow' or 'Sandy' (Sand Martin), 163

Sandwich Tern, 652

Sardinian Starling, 220

'Sawbill ' or 'Sawbill Duck' (Goosander), 484

- - - (Merganser), 485

'Saw-whet' or 'Saw-whetter' (Great Titmouse), 109

[Saw-whet Owl], 305

Saxicola deserti, 25

- ananthe, 22

- [stapazina], 26

'Scare Crow' (Black Tern), 648-49

Scaup, 468

- [American], 465

'Black, 469

Sclavonian Grebe, 743

'Scobby' or 'Scobbie' (Chaffinch), I 82

Scolopax gallinula, 605

- - vusticola, 595

- - sabini, 605

'Scoot,' 'Scout,' or 'Skout' (Guillemot), 7 II, 724

_- ' Ring-eyed (Ringed Guillemot), 724

_- _ - 'Silver-eyed (Ringed Guillemot), 724

Scops asio, 312

- gill, 310

Scops Owl, 3 10

'Scotch Goose' (Brent), 427

Scoter,' ' Black, 479

Common, 479 
Scoter [Surf], 482

- Velvet, 480

"Screaming Owl ' or ' Screech Owl ' (Barn Owl), 295

'Screecher' (Swift), 264

'Screw' (Swift), 264

'Scribbler' (Yellow Bunting), 204

'Scribbling Lark' (Yellow Bunting),

'Sea-Auk' (Razorbill), 7 ro [204

'Sea-beach Pipit' (Rock Pipit), I 36

- - Crow' (Hooded Crow), 244

-_ (Black-headed Gull), 674

-_ - (Common Gull), 677

Lark' (Ringed Plover), 575

(Shore Lark), 251

Mew' (Common Gull), 677

Nanpie' (Oyster Catcher), 588

Parrot' (Puffin), 729

- Plieasant' (Pintail), 454

- - (Long-tailed Duck), 474 -Pie' (Oyster Catcher), 587-8

- Pigeon' (Grey Plover), 58I

- Swallow' (Arctic Tern), 659

-_-(Common Tern), 657 'Big, 654

'Seave-cap' (Reed Bunting), 2 ro

'Seed-bird ' (Pied Vagtail), 1 21-1 23

' Seg-bird,'

'Sedge-bird,' (Sedge Warbler),

$\left.\begin{array}{l}\text { - } \\ - \text {-chat,' } \\ -\end{array}\right\}$. 93

Sedge Warbler, 9 I

Serin, I 74

Serinus hortulanus, 174

$[64 \mathrm{I}$

'Set Hammer' (Bar-tailed Godwit),

Shag, 379

'Sharpie' (Black-headed Grull), 674

Shearwater, Big, 753, 755

- Black (Sooty), $75^{8}$

- Great, 752

- Levantine, 760

- Manx, 759

- Sooty, 755

'Sheelfa,'

'Sheelie,' $\}$ (Chaffinch), I 82
'Sheep's Head and Pluck' (Redthroated Diver), $73^{8}$

Sheld-Duck, Common, 432

- [Ruddy], 434

Sheldrake,' 'Swallow-tailed, 474

'Shell' (Sheld-duck), 434

'Shepster,'

'Sheep-stare,'

'Shepstare,'

'Shipster,'

'Shep-starling,' (Starling), 220

'Sheep-starling,'

'Shep,' 'Sheppy,'

'Shepstey,' 'Ship,'

' 'Ship-starling,'

'Shercock' (Mistle Thrush), 3

'Sholard' or 'Shovelarde' (Spoonbill),

Shore Lark, 259

Short-eared Owl, 296

Shoveler, $45 \mathrm{I}$

Shrike, Great Grey, 138

—_ Lesser Grey, 140

— Red-backed, r 40

— Woodchat, 144

'Shuffle-wings' (Hedge'Accentor), I00

Siberian Meadow Bunting, 206

Siberian Nutcracker, 214

- Sibilous Brakehopper (Grasshopper Warbler), 96

'Silk-tail ' (Waxwing), I 46, I 48

'Silver-eyed Scoot' (Ringed Guillemot), 724

'Silver Plover' (Grey Plover), $58 \mathbf{I}$

-_ Pochard' (Scaup), 470

Siskin, I 72

Sitta cesia, I I 5

'Skell' or 'Skell-duck' (Sheld(luck), 434

'Skout' 724

Skua, Arctic, 702

- Buffon's, 705

- Common, 694

- Great, 694

—— Long-tailed, 705

- Pomatorhine, 696

— Richardson's, 702 
'Sky' (Skylark), 257

Skylark, 255

'Slab' (Wryneck), 271

[1 2

'Slate-backed Throstle ' (Fieldfare),

'Sleightholme Throstle" (Snow Bunting), 2I 5

'Sly-Duck' (Sheld-duck), 434

'Small Diver' (Sclavonian Grebe), 744

__ Ducker' (Little Grebe), 746-8 Spotted Water-hen' (Spotted Crake), 537

'Small-straw' or 'Straw-small' (Whitethroat), 66

- Lesser Whitethroat), 68

- (Blackcap), 7 I

-_ Garden Warbler), 73

—- (Wood Warbler), 88

—— (Sedge Warbler), 93

Smew, 485

Snipe, Common, 6oz

- Full, $60_{5}$

- Jack, 605

'Little, 612

' 'Pool, 635

- - Red-breasted, 638

- Sabine's, 605

-' 'Sand, 628

- Solitary, 6or

' 'Summer, 628

Snow Bunting, 212

'Snow Flake' or 'Snow Fleck' (Snow Bunting), 2 I 5

Snow Goose, 422

Snowy Owl, 309

Solan Goose, 384

Solitary Snipe (Great Snipe), 6oI

Somatcria mollissima, 475

- - spectabilis, 476

- - stelleri, 476

'Song Lark' (Skylark), 257

—— Linnet' (Linnet), 186

Song Thrush, 3

Sooty Shearwater, 755

[Sooty Tern], 655

'Spadge,' 'Spadger,' 'Spuggy,'

(House Sparrow), I 77
Sparling Fowl' (Goosander), 484. - Whew' (Red-throated Diver). Sparrowhawk, 343

[Sparrow Owl], 306

Sparrow,' 'Carr, 210

——'French, 215

- Hedge, 100

House, 175

'Mountain, I80

__' 'Red-headed, I78

' Reed, 2 IO

' Ring, 2 Io

' Rock, 180

'Tile, 177

Tree, 178

' Water, 210

' Willow, 93

Spatula clypeata, 45 I

'Speckled Diver' (Red-throated Diver), 736

- Heronshew' (Bittern), 402

- Loon ' (Red throated Diver), 738

'Spink,' 'Spinky,' (Chaffinch), 180-2

'Spink' (Yellow Bunting), 204

Spoonbill, 206

'Spoonbill' (Shoveler), 452

Spotted Crake, 536

Spotted Flycatcher, 148

- - Gallinule (Spotted Crake), 537

- Rail' (Spotted Crake), 537

- Redshank, 635

Sandpiper, 628

'Sprat Loon' (Red-throated Diver). $73^{6,738}$

'Spring Dotterel' (Dotterel), 573

_- Wagtail' (Yellow Wagtail), 130

Squacco Heron, 395

Squatarola helvetica, 579

'Stanchel,'

'Stannel,'

'Stand Hawk,' >(Kestrel), 372

'Standing Hawk,'

'Stannel Hawk,' J

'Stannin Hawk' (Sparrowhawk), 344

Starling, 215

Rose-coloured, 22 I 
Starling [Red-winged], 22 I

Sardinian, 220

'Stare,' 'Starnil ' (Starling), 220

Stangall (Kestrel), 372

Steller's Eider, 476

Stercorarius crepidatiss, 702

- parasiticus, 705 pomatorhinus, 696

Sterna anglica, 651

- cantiaca, 652

caspia, 652

dougalli, 654

fuliginosa, 655

hirundo, 655

macrura, 658

minuta, 660

- portlandica, 659

Stilt, Black-winged, 590

Stint, Little, 6r 2

- Temminck's, 6i4

'Stint,' 'Tommy Stint' (Dunlin), 609,612

$[622$

'Stint,' 'White Stint ' (Sanderling),

Stock-Dove, 490

-_ - (Ring-Dove), 490

'Stockie' (Stock-Dove), 493

'Stoggie' (Stock-Dove), 493

'Stog-Dove' (Ring-Dove), 490

'Stoggie' (Ring-Dove), 490

Stonechat, 28

'Stonechack.'

'Stone-chacker,'

'Stone-chatter,'

'Stone-check,'

'Stone-clink,'

'Stone-smich,'

'Stone-smick,'

'Stone-smith,'

(Stonechat), 32

'Stonechat' (Whinchat), 28

'Stonechat' (Wheatear), 25

'Stone-chopper' (Wheatear), 25

'Stoney-crop' (Wheatear), 25

Stone Curlew, 561, 564

'Stone Falcon' (Merlin), 367

'Stone Hawk' (Merlin), 367

Stork, Black, 405
Stork, White, 403

'Storm-Cock,' 'Stormy' (Mistle

Thrush), 3

'Storm Finch' (Storm Petrel), 750

Storm Petrel, 748

$[750$

' Stormy Sea-runner ' (Storm Petrel)

'Straw-small ' (Blackcap), 7 I

Strepsilas interpres, 585

[Strix acadica], 306

- aluco, $30 \mathrm{I}$

- flammea, 292

- - passerina, 307

'Stump-tail' (Wren), I 20

Sturmes vulgaris, 2 I 5

- unicolor, 220

'Stynt' (Dunlin), 608

Sula bassana, $38 \mathrm{I}$

'Summer Snipe' (Common Sand. piper), 628

- Teal' (Garganey), 457

[Surf Scoter], 482

[Surnia funevea], $30 \mathrm{I}$

- nyctea, 3 Iо

Swallow, 153

- (House Martin), I6I

- 'Bank, I 53

- 'Barn, I 58

- 'Big Sea, 654

—_ 'Carr, 674

— 'Chimney, 674

- 'Drain, 632

___ 'Eaves, or 'Easin, I6I

__ 'Fork-tailed, I 58

__ 'River, 163

- 'Sand, I63

_- 'Sea, 657

_- 'Tile, 264

' Window, I6I

[Swallow-tailed Falcon]. 349

[Swallow-tailed Kite,] 347

'Swallow-tailed Sheldrake' (Long tailed Duck), 474

Swan, Bewick's, 429

- - Mute, 430

-— [Polish], 43I

- Whooper, 428 
'Swat' (Redshank), 635

'Swinepipe' (Redwing), 9

Swift, $26 \mathrm{r}$

_- White-bellied, 264

Sylvia, atricapilla, 70

- cinerea, 65

- curruca, 67

- hortensis, 72

- nisoria, 74

- orphea, 68 [undata], 97

Syrrhaptes paradoxus, 498

[Tadorna casarca], 434

- cornuta, 432

- vulpanser, 432

'Tarrock' (Kittiwake), 693

'Tawny Bunting' (Snow Bunting),

- Owl, 301

[2I5

- - Pipit, I 34

Teal, American, 456

- Common, 454

- Garganey, 457

- Green-winged, 456

- 'Summer, 457

'Tell-pie,'

$\left.\begin{array}{l}\text { - Tell-piet,' } \\ \text { - Tell-pienot,' }\end{array}\right\}$ (Magpie), 232

Temminck's Stint, 6i4

Tengmalm's $\mathrm{Owl}, 303$

Tern, Arctic, 658

- Black, 648

Brown,

- Caspian, 652

- Common, 655

- Gull-billed, 65 I

— Little, 660

- [Noddy], 655

- Roseate, 654

- Sandwich, 652

- [Sooty], 655

- Whiskered, $65 \mathrm{I}$

White-winged Black, 650

Tetrao tetrix, 505

\section{—urvellus, 503}

Tewit,' 'Tewhit' (Lapwing), 585
'Tewet,' 'Tuet,

'Tuit,' 'Teewit,' (Lapwing), 585

'Tewfit,' 'Teäfit,'

'Thickbill' (Bullfincl), 194

Thick-billed Guillemot (Brunnich's Guillemot), 724

'Thick-knee' or 'Thick-kneed Bnstard,' 561, 564

'Thistle-finch' (Goldfinch), I 72

'Thorn Linnet' (Linnet), I86

'Thorny Linnet' (Twite), 193

' Thorn Warbler' (Sedge Warbler), 93

'Thrattle' (Redshank), 635

'Throstle' (Song Thrush), 6

_ 'Heath (see 'Heath Throstle) 'Slate-backed, I2 'Wood, 3

'Throlly' (Song Thrush), 6

'Throttler' (Red-backed Shrike), 144

'Thrush' (Song Thrush), 3

—— 'Golden, 3

- Mistle, I

- 'Noor, $2 \mathrm{I}$

_- 'Norman, 3

'Rattle, 3

- Rock, 2I

_- Song, 3

- White's, I2 "Wind, 6

'Thrushie' (Song Thrush), 6

'Tile Sparrow' (House Sparrow), I 77 Swallow' (Swift), 264

'Tillie Littie' (Common Sandpiper), $[628$

Tippet Grebe (Great Crested Grebe), Tinnuculus cenchris, 373

$\left[73^{8}\right.$

Tit,' 'Bottle, ro7

'Titinaup' (Blue Titmouse), I I4

'Titlark' (Corn Bunting), 203

- (Neadow Pipit), I 32, 133

(Rock Pipit), I 36

- (Tree Pipit), I3I

Tit,' 'Ling, I 33

—_ 'Moor, I 33

- ' Red-breasted Moor, I 32

'Titling ' (Meadow Pipit), I 33 
Titling,' 'Moor, 32

Titmouse, Bearded, 104

_- Blackcap, II 2

Blue, I 2

Coal, 109

Crested, I 14

Great, 108

Long-tailed, 106

- Continental, 107

Marsh, II I

'Titty' (Meadow Pipit), I 33

'Toad Snatcher' (Reed Bunting), 210

' Tod Bird ' (Great Skua), 696

'Tom Piper' (Fieldfare), I 2

- (Long-tailed Titmouse), I07

'Tom Poofer,'

—_ Pudding,' Puffin,'

'Tommy,' 'Tommy Tit,' 'Tom Tit ' (Wren), 120

'Tommy Noddy' (Puffin), 729

'Tommy Stint' (Dunlin), 608

'Tom Tit' (Blue Titmouse), II4 (Coal Titmouse), I IO

(Great Titmouse), I09 (Marsh Titmouse), I1 2

'Tom Tit's Nest' (Chiffchaff's), 83 —- - - (Willow Warbler's), 86

'Tongue-bird' (Wryneck), 271

Totanus, calidris, 633

- canescens, 637

- flavipes, 632

- fuscus, 635

glareola, 629

hypoleucus, 626

macuslarius, 628 ochropus, 63I

'Tot-o'er-seas' (Golden-crested Wren), 79 $[274$

'Tree Climber ' (Green Woodpecker)

Tree Creeper, 12 I

'Tree Lark' (Tree Pipit), I 3 I

Tree Pipit, I 30

Tree Sparrow, 178

'Tricker' (Wren), I20
Tringa alpina, 608

- canutus, 618

- maculata, 607

minor, 626

minuta, 612

temmincki, 6I 4

striata, 617

subarquata, 6I5

Troglodytes paroulus, I I 8

Tufted Duck, 466

'Tumbler' or 'Tumbling Gull ' (Black-headed Gull), 674

'Tunny' (Black-headed Gull), 674

Turdus iliacus, 6

- merula, I 4

- musicus, 3

- pilaris, 9

- torquatus, I7

- varius, 12

- viscivorus, I

[Turnix sylvatica], 533

Turnstone, 585

'Turnstone Plover' (Turnstone), 586

Turtle-Dove, 495

— Rufous, or Oriental, 498

Turtur communis, 495

- orientalis, 498

'Twate' (Twite), 192

Twite, 190

"Twite-finch' or 'Twate-finch"

(Twite), 192

'TwitteringWren' (WoodWarbler), 88

'Twitty Blue' (Blue Titmouse), 114

Two-barred Crossbill, 201

'Ullat' (Tawny Owl), 303

- (Barn Owl), 295

' Ullot' (Barn Qwl), 295

Upupa epops, 285

Uria bruennichi, 724

- grylle, 726

- lachrymans, 723

'Utic' or 'Yewtic' (Whinchat), 28

Uzzle,' 'Black, I 7

- "Ring, 21

Vanellus vulgaris, $58 \mathrm{I}$

'Vanner Hawk' (Kestrel), 372 
'Velvet Duck' (Velvet Scoter), 482 - Scoter, 480

[Virginian Colin], 533

'Wall-bird' (Spotted Flycatcher), I 49

'Wall-chat' (Spotted Flycatcher), I 49

- (Wheatear), 25

'Wally' (Wheatear), 25

'Wagel Gull' (Great Black-backed Gull), 685

Wagtail, Blue-headed, I 26

- Grey, I25

- Grey-headed Yellow, 127

—_ Pied, I 2 I

- 'Spring, I 30

- White, 123

'Winter, 126

—— Yellow, I 26, I 28

' Waggy Wagtail' (Grey Wagtail), I 26

Warbler, Barred, 74

- Blue-throated, 38, 39

-_ [Dartford], 97

-... Garden, 72

- Grasshopper, 93

- [Great Reed], 9 I

- Hedge, Ioo

- Icterine, 88

_- Orphean, 68

- Reed, 89

- Sedge, 9 I

__ [Siberian Willow], 86

_- 'Thorn, 93

- Willow, 83

_ Wood, 86

-_Yellow, 88

—_ Yellow-browed, 80

'Washtail' (Grey Wagtail), 126

' Water Blackey'

- Crake'

- Crow'

—— Drill'

Waterhen, 544, 545

(Dipper), 103

Water Ouzel, IOI

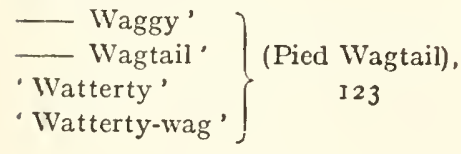

'WaterWagtail'(YellowWagtail), 130

- Sparrow' (Reed Bunting), 210

Waxwing, or Waxen Chatterer, I 45-8

- Bohemian, I48

Wedge-tailed Gull, 665

'Weetie' (Chaffinch), I 82

'Wet-bird' (Chaffinch), 182 [249

'WetwangGreyback' (Hooded Crow).

'Weirangle')

'Worrier' (Red-backed Shrike),

'Wurger' $\}$ I44

'Whaup' (Curlew), 645

'Wheat Bird' (Green Sandipiper), 632

Wheatear, 22

- [Black-throated], 26

- Desert, 25

'Wheel-bird' (Nightjar), 269

'Whew'

'Whewer'

Whew,' 'Grass, 46I

-_' Pendle, 46I ' 'Sparling, 738

'Whillock,' 724

Whimbrel, 646

'Whinchacker' (Whinchat), 28

Whinchat, 26

'Whinchat' (Stonechat), 32

'Whin Linnet' (Linnet), I 86

'Whip' (Swift), 264

Whiskered Tern, $65 \mathrm{I}$

'Whistling Plover'(Stone Curlew), 564

'Whistling Swan' (Whooper), 429

White-bellied Swift, 264

White-billed Northern Diver, 734

' White-breasted Ouzel' (Dipper), I03

'White-cap' (Redstart), 36

'White-eyed Duck' (Ferruginous

Duck), 465

White-fronted Goose, 4 II

'White-headed Harpy' (Marsh Harrier), 317

'White Hoolet' (Barn Owl), 295

- Lenny' (Snow Bunting), 215 Linnet' (Chaffinch), I 80, I 82 Nun' (Smew), 485, 486 
'White Owl' (Barn Owl), 295

—_ Rump' (Green Sandpiper), 632 -rump' (Wheatear), 25

Spotted Bluethroat, 38

Stint' (Sanderling), 622

- Stork, 403

___ -straw' (LesserWhitethroat), 68

—_ -tailed Eagle, 334

Whitethroat, 65

- Lesser, 67

[White-throated Bunting], 2 I 5

'White-throated Fauvet' (Whitethroat), 66

White Wagtail, 123

White-winged Black Tern, $65^{\circ}$

White's Thrush, 12

Whooper Swan, 428

Wigeon, 458

- American, 461

'Bell, 470

Wild Duck, 434

'Wild Pigeon' (Ring-Dove), 490

- Willock' (Guillemot), 724

'Wilk' (Guillemot), 724

Willow IVarbler, 83

\section{[Siberian], 86}

Wren' (Willow Warbler), 86 ' 'Least (Chaffinch), 83

Sparrow' (Willow Warbler), 86 -_ (Reed Bunting), 2 Io

- IVren' (Sedge Warbler), 93

Chit' (Sedge Warbler), 93

Sparrow' (Sedge WVarbler), 93

'Willy Fisher' (Dipper), Io3

'Willy Wagtail ' (Pied Wagtail), I 23

Wilson's Petrel, 752

' Windlestraw' (Sedge Warbler), 93

—_ or 'Winnel Straw' (Whitethroat), 66

' Wind-fanner' (Kestrel), 372

- -hover' (Kestrel), 372

_- Thrush' (Redwing), 6, 9

'Window Swallow' (House Martin), $16 \mathrm{I}$

- Winter Wagtail' (Grey Wagtail), I 26

' Wintie' (Chaffinch), I 82
'Wood-awl' ' -borer' (Green Wood-

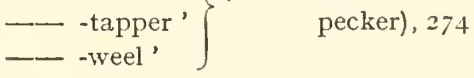

Woodchat Shrike, 144

Woodcock, 595

'WoodcockCrow',(Hooded Crow), 249 Owl' (Short-eared Owl), 297,30I Pilot' (Golden-crested Wren), 76,79

'Wood-cracker' (Nuthatch), I 18

'Woodie' (Ring-Dove), 490

Vood Lark, 257

-_ (Tree Pipit), I 3 I

' Wood Owl' or 'Ullot' (Tawny Owl), 303

Woodpecker [Great Black], 278

- Great Spotted, 274

- Green, 273

-... [Hairy], 276 Lesser Spotted, 276

'Wood Pigeon' (Ring-Dove), 488

_-_ - (Stock-Dove), 493

Wood Sandpiper, 629

' Wood Throstle' (Mistle Thrush), 3

Wood Warbler, 86

Wood Wren (Wood Warbler), 88

Wren, i I 8

—_ 'Bank, 86

Fire-crested, 79

Golden-crested, 75

'Grass, 83

'Ground, 86

' Jenny, II4

' Jinny, 79

'Little, 79

'Twittering, 88

' Willow, 93

- ' 'Yellow, 86

' Wrenny' (Redstart), 36

Redtail' (Redstart), 36

' Writhe Neck' (Wryneck), 27 I

' Writing Lark' (Yellow Bunting), 204

Wryneck, 269

'Wullock,' 724

'Wype' (Lapwing), 582, 585 
Xema sabini, 622

'Yaffle' or 'Yaffler' (Green Wroodpecker), 274

'Yeldrock' (Yellow Bunting), 204

Yellow Ammer, or Hammer (Yellow Bunting), 204

Yellow Bunting, 203

'Yellow Yowley' (Yellow Bunting).

'Yellow-backed Hawk' (Kestrel), 372

Yellow-billed Bean Goose, 420

Yellow-browed Warbler, 8o

' Yellow Owl' (Barn Owl). 295

[Yellowshank], 632

'Yellow Warbler' (WVood Warbler),

Yellow Wagtail, I2S

- - (Grey Wagtail), I 26

_- Water Waggy' (Yellow Wagtail), 130
'I'ellow Water Waggy' (Grey Wagtail), I 26

Wren' (Willow Warbler), 86 (Wood Warbler), 88

'Yellow Yowley'

___ Youldring' Yowring ' Lenny'

'Yolering.' (Yellow

'Yoldring" $\quad$ Bunting), 204

'Youldring'

'Yowlring'

'Yowley'

'Youldie'

Yoolat (Tawny Owl), 303

'Yewtic,' 28

'Yony Crony' (Heron), 390

[Zonatrichia albicollis], 2 I 5 


\section{INDEX OF PERSONAL AND PLACE NAMES.}

Aberdeen 314

Aberdeen, Countess of $33 \mathrm{I}$

Aberdovey 707

Abberford 49, 56

Acaster 661, 742

Acaster Malbis 324

Acklam I47

Acklam-in-Cleveland 283

Ackworth 9, 30, 50, 53, 67, 82,83, $85,89,95$, I I6, I 27 , I 43,169 , 187, I98, 270, 277, 279, 346, 369, 406, 4I2, 425, 464, 466, 469, 496, 529, 532, 536, 574, $581,593,634,638,642,649$, 669,729

Ackworth Moor 53

Acomb 667

Addingham 143

Addleston 652

Adel 24, 95

Adel Moor 29, 191, 455

Agar, Wm. Keld, 283

Agars, Robert, 550, 551, 552, 553

Aike 393, 591

Aike Carr, Beverley, 394, 590

Ainley Wood 54

Aire xx., 487

Airedale 52, I42, I73, 596

Aire Valley SI, 95, I24, 166, 179 , I $85,187,191,236,279,672$, 685

Airmyn 54I

Alie, T., 405

Albert Park 280
Aldbrough 30, 144, I 7 I, 204, 223, 377

Aldwarke Bridge 538

Allan, Ed., 308

Allan, George, 270, 423, 473, 479

Allan MS. 30, 172, 209, 261, 296, $365,482,540,568,573,579$,

$637,736,746$

Allan Museum 674

Allen, E., 444. 758

Allerston Marishes $55^{8}$

Allerthorpe Common 277

Allerton 469,500

Allerton-Mauleverer Lake 546

Allerton Park II 6, 236, 454

Allis, Thomas (numerous)-I to 764

Allison, G., 336

Almondbury 29,69, 70, 95, 145,346

Almondbury Bank, Huddersfield 99

Alston 512

Altham, Thomas, 102,163

Anderson, J. E., 572

Anderson, J. H., 318, 568

Anderson, Sir Charles, 549, 550, $554,55^{\circ}$

Annals of Natural History 3 I 3

Annual Register $246,5^{8} 3$

Anston Stones 53

Apperley Bridge 53

Appersett Bottoms 537

Appleby $55^{8}$

Appletrewick 634

Archer, late H. T., 283 
Ardsley 729

Ardsley Reservoir 50I

Ardwick-le-Street 22I

Argyll, Duke of, 2 I 6

Arkengarthdale 147, 155, 162, 167, 191, 216, 237, 266, 300, $326,354,366,389,455,507$, $518,572,610,673,676$

Armistead, J. J., 398

Armitage Bridge 79

Armitage, Rev. G. D., 225, 358, $549,556,563$

Armitage, W., 556

Arncliffe 507, 596

Arncliffe Woods 277

Arthington 19, 513, 642

Arundel, Miajor, 346,369, 385,406, $466,467,536$

Ashby 4.49

Ash Head Noor 327

Aske 351

Askern 89, I66, 221

Askham Bog xxiii., $S_{1}, 83,95$, 320,400

Askrigg 237, 348, 381, 538

Aspden 636

Aswarbey 306

Atkinson 236, 566

Atkinson, F., 24, 746

Atkinson, John, 149

Atkinson, Canon J., 6, 13 , I4, 16, $20,34, \mathrm{I} 64, \mathrm{I} 82,184,206,224$, $247,366,406,49 \mathrm{I}, 508,532$, 604,606

Audas, T., 300, 502, 564

Audubon 258, 3 I 2

Audubon's "Birds of America" 306

Austwick 291

Austwick Moors 54I

Aysgarth 85

Ayton 199

Ayton Moor 305

Azerley Hall 386

Backhouse, Edward, Junr., 694

Backhouse, James, 2, I3, 54, I I 7 ,

ᄂ 209, 258, 308, 320, $33635 \mathrm{I}$,
Backhouse, James (continued)$372,388,400,403,451,498$, $499,504,505,540,546,576$, $611,694,696,745,75^{8}$

Backhouse, W., 450, 636, 654, 694 Badcock 4I

Bagby 59, 641

Bagshaw, George, 440

Bailey, H., 36

Bailey, Matthew, 143, 151, 200, 207, 2II, 224, 246, 304, 324, $336,337,338,340,361,377$, $410,424,455,458,473,500$, $576,590,663,668,669,688$, 692, 695, 701, 704, 706, 707, $709,722,723,754,756,758$, 761

Bainbridge 320

Baisdale 527

Baker, J., 487, 652

Baldersby 272

Baldersby Park 58, I 84

Balne Moor 532

Banks Hall, Staincross, 733

Bannister, A., 333

Barchard 379

Barden 365,366

Barden and Hauxwell Moor 507

Barden Fell 242

Barden Moor 323

Barker 388, 464, 481, 661, 742

Barker, W. G., 747

Barkley, R., 308

Barkley, Samuel, 308

Barlow Moor 309

Barmston xxvi., 6, 404, 442, 443, Barnard 527

Barnard Castle I 50, 366, 472, 473 Barnsley xxi., xxii., 29, 50, 51, 67, $70,81,87,92,94$, I I6, I19, $141,150,151,154,161,166$, $198,221,228,229,266,317$, $320,337,345,358,362,363$. $365,371,393,404,467,48 \mathrm{I}$, $486,516,534,596,614,625$. $634,659,729,739,743$ 
Barnsley Naturalists' Society 265

Barrett 449

Barrow-in-Furness, Bishop of, 570

Barry, Joshua, 39r

Bartlett 417, 418, 432

Basedale Moor 522

Bashall 279

Bashall Hall 102, 454, 673

Bashall Lane 163

Batley Wood 277

Battersby 500

Battersby-in-Cleveland 160

Bawtry $186,222,404,547$

Bayford, E. G., 265

Baynes MS. 365

Bean 463

Beaumont, Alfred, 190, 349

Beaumont, T. W., 404

Beaver Dam 501

Beckwithshaw 493

Bedale 68, 90, 95, 117, 167, 179, 19I, 192, 205, 206, 280, 313, $326,366,458,469,530,54 \mathrm{I}$, $545,546,671,763$

Bedale Wood 336

Bedlington (Northumberland) $47 \sigma$, 565

Bedlington, Thomas, 2I

Beech Lawn, Wakefield, 515

Bell, Alwin S., I 45, 300, $482,553,556$

Bell Bros. 285

Bell, John, Esq., MI.P., 28z

Bell, Sir Hugh, 285

Bell, Sir I. L., 530

Bell, R. J., 477

Bellerby Moor 507

Belle Vue Museum I 3

Bempton xxix. 30,66, 93, II 4 , I79, 185, 233, 238, 241, 329, $358,359,368,377,494,568$, $678,682,689,690,710,713$, $714,719,722,723,724,729$

Bempton Cliffs 368

Beningborough, 55, 332

Bennison, W., 321, 345

Ben Rhydding 166
Bentham 15I, 283, 300,

Berkeley Castle 449

Berkenhout, Dr. John, 307

Berwick 76

Bessingby 225, 408, 474, 629

Bessingby Beck $47 \mathrm{I}$

Beswick Rush 387, 388

Bethell, William, 387,772

Beverley xxvi., 2, 9, 18, 21, 27, 30, $46,50,62,63,67,71,72,73,80$, 90, 95, 99, IOI, I04, I13, II9, 126, 129, I41, $147,157,160$, $163,164,166,170,173,174$, 177. 179, 18I, 186, 187, 199, 200, 203, 218, 222, 226, 229, $233,234,242,247,251,252$, 262, 267, 273, 275, 277, 282, 283, 304, 306, 308, 317, 324, $327,337,350,363,364,368$, $374,379,385,387,393,394$, 397, 40I, 412, 422, 427, 430, $433,442,443,444,45 \mathrm{I}, 452$, $453,457,465,466,469,47 \mathrm{I}$, $483,485,486,492,493,496$, 497, 501, 502, 528, 529, 531, 533. 537, 54I, 542, 544, 556, $558,562,564,590,591,601$ 。 $602,603,606,613,616,625$, $627,629,630,632,634,636$, $638,642,649,676,731,733$. 735, 737, 739, 742, 747, 75I, 752,770

Beverley Minster 35, 234, 237. 378,442

Bewerley 151, 192

Bewerley Hall 239, 696

Bewick 206, 380, 674, 749, 750, 763

Bewick's "British Birds" 335

Bickley 305, 324

Bishop Auckland 397, 565, 590

Bielby Field, Everingham, 395

Bilham 363

Bilsdale 34, 160, 218, 236, 509, 597

Bilsdale Noors 20

Bilton 249,563, 625 


\section{I2 INDEX OF PERSONAL AND PLACE NAMES.}

Bilton Banks, Harrogate, 109

Bingley 37, I 37, I 73, 279, 282, 672

Bingley Noor 519

Bingley Spring Wood 53

Binnie, F., 326

Birchworth Reservoir 592

Bird 276

Birdforth 733

Birdsall 396, 442

Birdsall Decoy 446

"Birds of Europe" I 84

" Birds of Great Britain " 394, 567

"Birds of the Humber District"

, 336, 341, 350, 354, 523, 533 , 6I 5, 619, 622, 650, 688, 734

"Birds of Norfolk" 335

"Birds of Northumberland and Durham " xxxviii., 282, 284 , $316,318,335,350,461,498$

Birk Brow 508

Birkdale Tarn xx.

Birmingham 145, 207 ,

Birstwith I98

Bishop Auckland 356

Bishop's Wood 236, 273, 325

Bishop Wood, Selby, 363

Bishop Thornton 387, 529

Blackburn 548

Black Hambleton 358

Blackley 66I

Blackmore Museum 557

Blackstone Edge $32 \mathrm{I}$

Blackstone Edge Reservoir 733

Blakeborough, R., 268

Blankney 39, 3I7, 324, 340, 347 . 365,369

Blenkhorn, C., 535

Blow, Rev. WV., 558

Bluberhouse 507, 516, 520, 527 , $588,606,659$

Bluberhouse Moor I 83

Bluecoat Boys' School, York, I 43,449

Boat Bottom I 37

Blyth, Edward, 4, 21, 27, 32, 34, $43,76,82,85$, I $31,181,267$
Bolckow, Vaughan \& Co. 285

Boltby 282,330

Bolterstone 520

Bolton 64, 158,365

Bolton Abbey 123, 166, 242, 273 , 337,374

Bolton Bridge 744

Bolton-by-Bowland 116, 166, 226, 548

Bolton Gill 320

Bolton Hall 262

Bolton, Lord, 507

Bolton-on-Dearne 205, 526

Bolton Park 389, 752

Bolton, Thos., $59 \mathrm{I}$

Bolton Woods 73, II7, I5I, 349

Bond, F., 527

Bonny Grove 530

Booth Deane 6 Io

Booth, E. T., 699

Booth, Haworth, 405

Booth, H. B., 289

Booth, Mark, I05, 614, 637

Boroughbridge $49,50,114,15 \mathrm{I}$, $38 \mathrm{I}, 386,586$

Borrow 552

Borrow Greens Wood, Easby in Cleveland I 50

Boston Spa 56, 71, 95, 166, 289. $530,532,54 \mathrm{I}$,

Boulby xxviii., xxix., I35, I60, I62, 238, 376, 678,679, 683

Boulton, WV. W., 30, 35, IOI, I 37 , $177,200,282,304,308,324$, $333,350,361,363,368,396$, $397,465,496,556,557,558$, $562,576,592,602,615,624$, $637,662,735,745,755,757$, 759

Bower, J., 339

Bowes 515, 522

Bowes Moor 237, 366, 508

Bowland 87, 242, 320, 507, 519. 546

Bowland, Forest of, xxi., 72, 92, 596,634 
Boyes, F., 43, 62, 63, 74, 78, 80, 104, 109, II3, I4I, 175, I77, 199, 234, 238, 258, 259, 265. $271,276,283,317,324,337$, $350,363,364,388,397,398$, $40 \mathrm{I}, 42 \mathrm{O}, 43 \mathrm{O}, 437,45 \mathrm{O}, 45 \mathrm{I}$, $457,486,489,49 \mathrm{I}, 492,5 \mathrm{II}$, $524,532,533,535,536,544$, 579, 59I, 594, 606, 6I2, 6I5, $629,630,661,722,757,758$, Boynton 64, 138, 222, 337, 550, 755

Boynton Hall 554

Boynton, Sir Griffith, $55^{\circ}$

Boynton, Sir Henry, 6, 277, 304. $308,324,363,391,396,405$, 413, 576, 607,663, 754, 761

Boynton Park $3+4$

Boynton, Thomas, 134, 222, 225 , 282, 304, 308, 381, 397, 408, $465,475,549,550,554,556$, $557,55^{8}, 576,616,629,637$. $662,664,668,669,694,695$. 745

Boynton Woods 199, 225

Bradfield 3I 7

Bradfield Moors 506

Bradford xxi., 5, 23, 50, 53, 115 , $164,288,313,334,354,476$, 541, 731

Bradford Corporation 323

Bradford-on-Tees 157

Bradley 53

Brady, W. E., 265

Braim, John, 7I, I51, 322, 533 , $562,594,746$

Braithwaite, C., 208

Bramham 56, 387, 529

Bramham Park 54, 198

Bramham Woods 226

Bransdale 329, 411,509

Brayshaw Hill 532

Brayton Bridge 406

Bree, Dr. C. R., 351

Bretton Park 478

Bretton Park. Barnsley, 404
Bretton Park, Huddersfield, 405 Bridlington 30,64, 90, I0.4, I34, I35. I 38, 147, 170, 199, 201 , $213,218,225,282,304,308$, 3 II, 323, 337, 34I, 346, 35I, $354,363,365,368,378,397$, $404,408,412,417,424,443$, $458,460,465,469,471,476$, $480,483,486,513,532,548$, $549,554,557,564,565,573$, $576,590,594,595,608,6$ I5, $616,619,621,628,630,642$, $647,662,663,664,665,668$, $669,684,686,687,688,695$. $696,699,700,704,707,724$, $727,73 \mathrm{I}, 735,74 \mathrm{I}, 742,754$, $755,756,757,758,759,770$ Bridlington Bay xxxi., xxxii., xxxiii., 286, 38 I, 478

Bridlington Quay 476, 550

Brierley Common 123

Briggs, J. J., 534

Briggs, Riley, 446

Brighan, James, 371, 403

Brigham 592

Brignall, Greta Bridge, 65, II 5 , I2 I, 125, I46, I75, 212, 215 , $287,292,362,373,392,400$, $425,457,468,472,473,477$. $480,485,494,593,598,609$, $646,648,656,658,711,732$

Brimham I 5 I

Brimham Rocks 532

British Association xxxiii., 4, I 8 , $31,34,43,71,77,98,126$, I29, I 3 I, I 33, I 38, 244, 262, $275,288,343,37 \mathrm{I}, 392,393$. $414,417,420,489,490,542$, $598,619,644$

"British Birds" I 83, 282, 283. 30I, 309, 3I 3, 450, 483, 5 I9, 549, 594, 596, 608, 624, 688, $750,751,763$

British Museum (Nat. Hist.) 195 , 223, 487

British Ornithologist's Club I27,208 
British Orn. Union xxxvii.

"British Zoology" 73, I78, 312, 357, 379, 394, 689

Broadfield 5 I 5

Brock-o'-dale 53, 369

Brokesly, Rev. Francis, 444

Brompton 323, 526

Brook, George, 324, 359

Brooksbank, Najor, 358

Broomhall 424, 596

Broomhead 515, 516, 520

Brotten 563

Brough 59, 424, 509, 528

Brough-on-Humber 167

Brown 195, 725

Brown, D., 500, 734

Brown, John, 570

Brown, Sir Thomas, 477

Browsholme 386, 387

Browsholme Tarn 673

Bubwith 745

Buckden 33, 65

Buckley, T. E., 606, 6I6

Buckton xxix., 358, 689, 709, 713,7 I 4

Buckton Cliffs xxx., 7 I I

Buckton Hill 7 IO

Bulby 400,402

Bunker, Thomas, 191, 300, 340, $398,541,672$

Burlington 7 I 2

Burnham, R. T., I 3

Burniston 500

Burniston Bay 678

Burnsall 387

Burnsall Moor 374

Burnt Wood 52

Burntwood Hall 337

Burton Agnes 6, $138,277,304$, $308,347,391,396,405,412$, $413,501,576,594,607,629$, $663,754,761$,

Burton Agnes Museum 324, 636

Burton Bushes 62

Burton Constable 234

Burton Head xxiv.
Burton-on-Trent 754,758

Burton Pidsea 558

Bury 306

Bury, Dr. John, 555

Bury St. Edmunds 665

Busby $3^{8} 3$

Busby Hall 755

Bushy Cliff 52

Butterfield, R., 288, 290, 334, 739

Butterfield, E. P., 23, 24, 27, 85 ,

I I 5. I 20, I 37, I67, I 1 I, 282,

Buxton, Hugh, 563

[323

Buzzard Scar 326

Byers Green 284

Caistor 216

Caldbergh 5 I9

Calder I 23, 487, 576, 745

Calder Valley 464

Calke Abbey, Derby, I 53, 403. 758

Calverley Church 234

Calvert, F., 529

Calvert, S., 365

Cambridge 196, 553, 652

Cambridgeshire $6 \mathrm{I}$

Camden 409

Cam Fell 6I8

Campsall 6I, 204, 225, 258

Campsall Hall I 56

Cannon Hall, Barnsley, I5 I, 5 I6

Cannon Hall Park 270

Cantley 538

Cardigan, Earl of, 312

Carlton 365

Carnaby 405

Carperby 90, I43, I $51,205,299$. $389,533,701$

Carperby Moor 507

Carlisle 512, 570, 670

Carr End 348, 381, 538

Carr Hill 500

Carroll, C. J., 758

Carter, James, 107, I12, I13, 124,

$137,155,184,192,205,224$,

247, 302, 308, 313, 317, 327 ,

$343,410,497,500,597,604$,

$628,762,763$ 
Carter, Thomas, 377, 682

Casson, Rev. H. C., 6I

Castle Cliff 238

Castle Holmes, Scarborough, I45

Castle Howard 60, 90, I I 7, I 50 , $167,235,236,435,467,546$, 739

Castle Sayle Hill 54, 365

Castle Yard, York, I 70

Catterick xxiii., 258, 636

Cattersty 336, 433

Cattle, Mrs., 55

Cawthorne 51, 385, 399, 406, 455 , $475,523,525,531,547,595$, $622,643,732$

Cayton Bay 37, 577

Caywood 54

Central Plain, York, 54, 72, 275. 497, 546

Chalk Wolds 50

Challand, George, 539

Chaloner, J., 105

Chaloner, Rev. J. WV., 56, 114, 137 , $483,486,532,733$

Champley, Robert, 314, 463

Chandler, William, 714

Chantrey 600

Chapeltown I8I

Chapman, E., 320, 572, 614

Charlesworth, J. C. D., 408, 666

Chase, R. W., 145, 207

Chatsworth 337

Chaytor, A. W., 520

Chaytor, Lady, 519

Cherry Burton 64, 374, 526

Chester Museum 345, 394, 477, 625

Chevet $385,399,407,430,435$. 455, 523, 525, 547, 609, 643, 646

Chilton, late R. F., 540

Cholmley, Sir George, 388

Church Fenton 529

Christie, A., 345

Christy, R. M., 227

[53

Cinderfield Dyke Wood, in Bradley VOL. II.
Clarke, WV. J., 211, 337, 381, 473 , $577,595,650,665,688,725$, $746,754,758,76 \mathrm{I}$

Clarke, IV. Eagle, xxxiii., xlv., I I, $13,29,35,37,38,39,40,45$. $48,59,71,74,78,87,88,89$, 99. IOI, I $27,140,143,152$, 205, 206, 207, 208, 259, 265, $27 \mathrm{I}, 301,302,304,305,320$, $32 \mathrm{I}, 325,333,35^{8}, 360,39 \mathrm{I}$, $398,403,405,406,460,471$, $475,478,487,498,501,512$, $532,549,552,560,575,588$, $595,606,608,630,632,637$, $638,644,659,671,676,680$, $688,708,745,757,762,763$

Clark-Kennedy, late Capt., 408

Clapham 29, 48r, 504

Clapham, A., 309, $317,322,323$, $335,340,344,347,349,356$, $357,369,37 \mathrm{I}$

Clarke, George, 763

Clayton West 143

Clay Wheel Dam, Wadsley Bridge, 393

Cleveland, Duke of, 512

Cleveland, Florence, 253

Cleveland Golf Club 433, 435, 575

Cleveland Hills xxiv., 50, 191, 280, $359,366,578,602$

"Cleveland, History of " I

Cleveland Moors I 8, 159, 331, 508

Cliffe 5 I I

Cliffe Castle 46

Cliffe Wood 51, 141, 242, 267

Clifton 80

Clifton Castle 247, 313

Clifton, Lord, 20I, 431, 510

Clifton, York, 55

Clitheroe 107, 326, 386

Clough Hey Reservoir 672

Clubley, John, 323, 558, 560, 59 I

Clubly, G. E., 74, 337, 338

Coates 590

Coatham $424,442,469,497,530$. 688,765 
Coatham Decoy $436,446,465$

Coatham Marsh xxviii., 222, 447 , $452,459,462,465,466,467$, $542,570,630$

Coatham Piè 378,380

Cobcar Wood 5 I

Cockett Wood, Upper Ribblesdale, 387

Cockroft, Dr., 52 I

Cold Hiendley 6 I4

Cold Hiendley Reservoir, Wakefield, $397,401,464,586,619$. 733

Colemire Wood, Swainby, 200

Cole, Rev. E. Maule, 501

Collta 397

Colne 616

Colne Bridge 161, 365

Colsterdale 507

Commondale 508

Coniston 364

Coniston Moor 563

Constable, Henry Strickland, 388, 463,772

Cooke, Lieut.-Gen. A. C., 55 I

Cooke, Rev. R. B., 467, 552

Cook, W., 238, 508, 524, 600

Copgrove 117, 151, 730

Cordeaux, J., 10, 19, 26, 30, 40, $44,60,74,80,86,88,110$, 127, I31, 135, I37, I 39, I42, 145, 188, 195, $211,215,247$, $259,263,267,285,289,297$, $310,314,321,324,336,337$, $341,350,354,357,358,363$, $368,381,472,474,481,501$, $523,529,542,548,549,560$, $580,595,607,608,616,618$, $619,621,625,630,636,650$, 659, 661, 685, 688, 733, 734, 746,758

Corner, Edward, 396

Cotherstone $48 \mathrm{I}$

Cottingham $157,222,397,434$, 533. 770

Cottingham Common 396
Cottingley Wood 85

Cottingwith 464,485

Cottonian MS. xxvii., xxviii,, 408 , $656,677,588$

Coucher, "Book of Sallay" 64

Coupe, Pearce, 364, 559

"Courant" 332

Court Moor, Kildale, 333

Coverdale 519, 520

Cover Head 237

Cowcliffe 314

Cowick 6I, 201

Cowling-in-Craven 29I

Cowthorpe 95

Coxley Valley 52

Coxwold I 50, 597

Crabtree, A., I 3, I 27, 128, 202, $258,321,374,474,638$

Cranswick 548

Crag Bank, Kildale, 388

Crossthwaite 31

Crathorne-in-Cleveland 338

Craven xx., 29, 33, 64, 89, 228, $242,253,291,360,366,464$, 596,744

Crawforth 405

Crawshaw, Samuel, 400, 402

Crewe, Sir Vauncey, I 53, 340, 403. $758,76 \mathrm{I}$

Creyke II 7

Crimwith Moors 520

Croft-on-Tees 149

Crompton, R. S., 386

Cronkley Scar 237, 336

Cropton 528

Crosby, T., 339

Crosscliffe, 322

Cross Fell 20, 263. 572

Cross Keys 552

Crossland Moor, Huddersfield, I9I, 563

Crowe, Captain, 336

Crowe, R., 364

Crowle 445,452

Cumberland \&Westmorland Antiq. \& Archaeol. Soc. Trans. 670 
Cumberland, Earl of, 510

\section{Cummins $33 \mathrm{I}$}

Cunningham, late James, I 3, I27, 308,638

Cusworth 339

Curzon 477

Dallas, W. S., 373

Dalton 53, I33, 465, 555

Dalton Holme 630

Dalton, Col. Wade, 282, 326, 507 , $750,762,763$

Dalton, Rev. James, I 5 I

Dalton, Rev. W., 730

Dalton, IV. Wade, 752

Danby 16, 20, 34, 78, 83, I 51 , $165,167,236,247,271,301$, $327,364,365,406,454,491$, $508,532,604,606,74^{2}$

Danby Beacon 319

Danby Lodge 335

Danby Moor 319, 366

Dane's Dyke 238, 359, 377, 678. 714

Danford, C. G., I 45

Daniel 520

Dark Lane 5 I

Darley 74, 405, 501

Darley Abbey 456

Darley, J., 222

Darlington 348

Darlington, Lord, 182

Dawnay, Hon. Francis H., 58, 59

Dawnay, Hon. Guy, 184

Dawnay, Hon. Payan, 54, 55

Dawnay, Hon. W., 403

Dawson, G. P., 446

Day House 5 I

Dean Hall Wood 270

Dearne Valley $5 \mathrm{I}$

Dee Side 34 I

Deepdale 123

Deighton 218, 288, 427,530,625

Deighton Manor 414, 654, 701

Denby 592

Denny, Henry, I41, 270, 282, 313, $319,331,365,651$
Denny's Leeds Catalogue 221, 350, $386,450,453$

Dent, J. W., 571,747

Dent Vicarage 235

Dentdale 319, 3.4I

Derby 79, 265, 393, 397, 403, 456, $725,729,758$

Derbyshire 153, 510, 5 II

Derwent xxir., xxv., 425, 452, $458,465,471,474,485,487$, $545,737,744$

Derwent River, 412, 414

Devonshire, Duke of, 337

Dimlington Height xxi.

Dixon 97, 354

Dixon, Charles, 224

Dixon, John, 365

Dob Park Wood, Fewston, 386

Dobree, N. F., 451, 562, 660

Dodsley's "Annual Register " 331

Dodwoth Bottom 5 I

Don xxii., xxiii.

Don, Banks of, 8 I

Doncaster xxiii., 48, 50, 61, 89, 95 , 97. I I6, I 37, I $47,163,166$, 196, 198, 201, 204, 205, 220, $225,227,258,266,270,292$, $316,319,322,339,363,368$, $369,394,397,400,401,402$, $412,414,427,435,438,439$, $44 \mathrm{I}, 450,453,456,474,48 \mathrm{I}$, $486,496,527,536,538,546$, $556,56 \mathrm{r}, 583,589,596,622$, $624,634,641,642,730,739$, 742

Doncaster Decoy 462, 467, 471

Doncaste= Mills 440

Donovan, Rev. A., 377

Dormer, Mrs., 389

"Dotterel" Inn 569

Douthwaite Dale 327

Dove Valley 5 I

Dowker, James, 555, 556

Downe, Lady, 336, 340

Downe, Lord, 201, 508

Downs 242 
Dowson, C., 336

Dresser, H. E., 25, 140, 184, 220 , 312,356

Dresser's “ Birds of Europe " 366

Driffield 90, 333, 404, 443, 444, $450,474,501,548,649,747,770$

Dropping Well, Knaresborough,

Dublin $66_{5}$

$[103$

Dublin Museum 624

Dudley 489, 522, 527, 530, 600

Duff 476

Duff, Joseph, 356, 397, 565, 590

Duff, Theo., 356

Duncombe, Capt., 342

Duncombe Park I50

Dungeon Wood, Huddersfield, 225

Dunnington, near York, 222

Durham xxxii., xxxiii., xxxviii., xxxix., xl., xlii., 135, 207, 244 , 284, 335, 407, 423, 452, 455, $457,504,540,54 \mathrm{I}$

Dutch River 445

Dymond, J., 337

Easby, 277

Easby Hall 525, 75 I

Easby-in-Cleveland 150, 154, 199 , $271,533,537,600$

Easington 25, 40,46,80,88, 127, I 39, I42, I45, I73, I86, I 87 , 188, 201, 207, 214, 222, 247, $267,271,293,303,310,314$, $337,338,339,341,365,397$, 405, 406, 458, 499, 545, 559, 569, 608, 629, 630, 688, 745, 746

Easington Church 405

Easington Lane End I 21

Easingwold 55, 56

East 649

East Cottingwith 412, 425, 430, $433,437,451,452,453,458$, $474,485,619,625,636,637$, 737,744

Eastholme Bridge 143

East Scarr 592

East Scar, Redcar, 693
Easterside 263

East Witton $7+7$

East Witton Moors 507

Eavestone 95, 216, 236, 279, 514

Ecclesfield 193, 240

Eccup 23, 277

Eccup Reservoir 467

Eden $x x$.

Eddison, W., 572

Eddystone Lighthouse 438,680

Edgerton 222

Edinburgh University 326

Edlington 345

Edlington Woods xxiii., 6 I

Edwards, G., 178, 591, 592

Edwards, T. M., 693

“Eggs and Nests" 224

Egton 304, 311

Egton Bridge 46, 321, 345, 369

Egton Moor 301, 32 I

Elland IVoods 54

Ellerton 237, 327

Ellerton Moor 354

Elley, S., 288

Elliot 316

Ellis, Henry, 445

Ellotson, T., 363,607

Elton, J., 757

Emerson, E. B., 199, 200, 218 , $288,338,427,508,520,530$, $56 \mathrm{I}, 600,606,630,654,686$. $693,695,702,707,729$

Emerson, J. J., 1 54, 525

Emmerson, George, 664, $75^{8}$

Emmet, J., 5.II

Endcliff Woods 79, 258

Escrick 233, 277, 308, 323, 342, $388,442,453,485,770$

Escrick Park Decoy 445

Esholt Woods, Airedale, 52

Eshton Hall 387

Esk xxiv., 280

Eskdale 230

Esk Hall 396

Esk Valley 68, 92, I 50, 27 I, 46j $49 \mathrm{r}, 597$ 
" Essays on Natural History " 294

Eston 262,284

Ethersley Wood 5 I

Etton 50I

Evans, Col, John, 456

Everingham I44, 388, 395

Everingliam Park 59, 363

Faith 448

Falsgrave 176

Farndale 33 I

Farndale Hear 329

Farne Islands $x x x ., 77,475,654$, $655,656,709,727$

Farnley Hall, Otley, 222

Farnley Pool, Otley, 392

Farrar, Dr., 135, 141, 350, 362, $374,393,407,504,506$

Farsley 5

Faversham, Lord, 4 II

Fawkes, Rev. F., 392

Fellbeck 29, 270

Fells, Langden, 366

Fells, Slaidburn, 326

Fells, Swaledale, 359

Fen Bog, 205, 460

Fenton, Wm., 441

Fern Hill, Warley, 127

Ferriby xxv.

Fewster, Tom, 333

Fewston 19, I19, I5 I, I60, 166, 170, 187, 198, 218, 270, 277. 279, 317, 37I, 386, 507, 54I, $410,634,659,676,744$

Fewston Reservoir 426, 47 I, 478, $546,574,584,638,733,739$

Feversham, Earl of, 1 55, 349

"Field" (see "The Field")

Fielden, H. IV., 8, 555

Fielden, Sir W., 757

Fife 404

Filey xxix., I6, 24, 37, 60, 104, $195,259,283,320,358,377$, $406,424,473,474,475,477$, $486,500,528,552,564,608$, $617,647,653,662,664,665$, $669,678,682,686,694,695$,
Filey (continued)-

699, 702, 725, 731, 734, 735, $741,756,757,758,759,765$, 770

Filey Bay 693

Filey Brigg xxix., 238, 339, 356, 398,687

Filey Road 529

Filey Rocks 310

Firth, Jos., 314

Firth 408

Fisher, Theo., 40

Fitzhardinge, Lord, 449

Fitzwilliam, Earl, 467

Fixby 314

Flamborough xxv., xxix., xxx., xxxii., xxxiii., $4,7,8,11$, $18,23,24,30,34,35,36$, $37,66,77,80,86,95$, I I 3 , I I 8 , I 26, I 39,143, I 5 I, I 52, I 54 , I60, I62, I70, I73, I74, I79, 180, I 85 , I 88, I90, I92, 199, $200,201,207,210,211,213$, $217,218,224,233,234,238$, $24 \mathrm{I}, 245,246,259,263,27 \mathrm{I}$, $282,286,289,293,298,304$, $308,310,313,324,329,336$, $337,338,340,346,352,354$, $358,359,361,364,377,378$, $379,380,381,382,384,411$, $412,424,453,455,458,473$, $475,480,483,484,488,49 \mathrm{I}$, $492,493,494,497,500,528$, $548,550,557,574,576,579$, $597,598,599,617,618,627$, $632,649,653,661,663,665$, $668,669,677,679,681,685$, 686, 688, 689, 691, 692, 694, 695, 697, 699, 703, 706, 708, $7 \mathrm{II}, 712,713,714,719,722$, $723,725,726,727,728,729$. $741,742,743,75 \mathrm{I}, 753,754$, $755,756,757,758,759,761$, $764,765,770$

Flamborough Lighthouse 54, 544, 590 
Flanshaw 143

Flasby 364,387

Flasby Hall 36.4

Fletcher, T., 397

Flixton $55^{\circ}$

Flixton Wold 553

Flotmanby ${ }^{2} 4$

Foggit 373

Foljambe, H. S., 306, 310,368

Foljambe, F. J. Saville, 666

Folkton 554

Forbes 389

Ford 2 I 6

Forest Moors 337

Forster, IV. F., 64, 201, 341, 352, $576,590,642$

Fortune, R., 24, 30, 109, 130 , I49, 201, 205, 258, 305, 324, $497,501,539,572,576,604$, $608,664,673,748,761$

Forth, Firth of, 745

Fossgate, York, 220

Foster 147, 504

Foster, John, 520

Foster, R., 474

Foster, Wm., 504

Foston 552

Foston Trout Club 55I

Fothergill, late Charles, 81,83 , 278,3 I $, 348,378,38 \mathrm{r}, 403$, $404,425,426,428,45 I, 464$, $466,470,48 \mathrm{I}, 547,63 \mathrm{I}, 638$, $641,740,742,743$

Fothergill, William, 8 I, 83, 348, 538

Foulds 354

Fountain, J., 377, 680, 694

Fountaine, Rev. M., 449

Foxholes 549, 554

Fox's "Synopsis" 209, 261, 297. $334,363,380,423,473,479$, 482,5 II, 540, 549, 554, 568, $573,575,580,609,713,718$, 736,746

Fraisthorpe 30, 594

Frank, W. M., 342

Frankland, Sir Thomas, 507
Frickley Hall 6I

Friend's "Natural History Journal" 320

Frohawk 219

Fryer, J. H., 127

Fryup 283, 363, 495, 508

Gallwey, Sir Ralph Payne, 59, 6 I 2 Galway, Lord, 440

Ganton $5^{6} 3$

Ganton Wolds 568

Garforth 323

Gargrave 387

Garsdale 507

Garth, J. C., 20I, 234, 345, 385 , $539,575,594,704,706$

Garwood, C. R., 667

Garwood, Rev. W., 667

Gätke, H., xxxii., 275, 298

Gatherley Moor 330

Gaunt, Leonard, 5, 532

"Gentleman's Magazine" 344, 526

Gibbon, Wm., 207

Gibbons, Thos., 78

Gibbs, G. S., 339

Giggleswick 252

Gill, E. L., 7 I

Gill, Leonard, 649

Gill's "Vallis Eboracensis" 56

Gilling $19^{8}$

Gilling Castle 45

Gin Hole, Staithes, 679

Gisburn I24, I 5 I, 387

Glaisdale 283, 304, 3 I I, 329, 345 . $349,369,508,533$

Glassholme Reservoir $46_{4}$

"Gleanings in Craven " 64

"Gleanings of Natural History" I78, $59 \mathrm{I}$

Gmelin, J. F., 655

Goathland $30,289,357,389$

Goit Stock Valley 85

Goldsborough 387, 501

Goodmanham 558, 559

Goole 30, 50, 61, 89, 95, 162, I66, $300,398,442,444,445,48$ I, 540, $541,574,642,672,733,762$ 
Goole Moor 454

Goole New Decoy 445

Goole Old Decoy 445

Goosnargh 319

Gordale Scar 236, 326

Gormire 546

Gormire Lake 737

Gough, Roger, 440, 464

Gould 394, 418, 419, 420, 487 . $533,567,600,666,763,765$

Gouthwaite Hall 387

Growerdale 236

Graham, David, 69, I34, 304, 333, $336,337,339,340,349,356$, $373,396,404,628,633,665$. $666,667,706,745,764$

Graham, Sir Reginald, 254

Granby, Marquess of, 440

Grassington 29, 64, 198, 673

Graves, F., I 3 I

Graves, Rev. George, 506

Graves, Rev. John, 1, 91, 173, 316,432

Graves, Rev. J., "History of Cleveland " 70 , I08, III, I20, I6I, 228, 238, 257, 270, 274. $301,335,343,370,534,544$, $545,675,68 \mathrm{r}, 748$

Gray 238

Greame, Rev. Lloyd, 340

Great Ayton, 186, 404, 746

Great Whernside 239, 325

Greatham 428

Green Hammerton 372, 539

Greenhough I 7 I

Greenland 666

Greenwich xix.

Greetland 3 I 3

Greta Bridge 65, I I5, I 21,125 , $146,212,215,242,287,292$, $362,373,392,400,457,472$, $477,480,494,593,609,646$, $648,656,658,670,732$

Grey, Earl de, 518, 526

Grey, John, 323, 335, 358, 628

Greygreth 347
Grimshaw, Percy, 5 I 4

Grimston Park, Tadcaster, I 37

Grindale Field 554

Grindleton 366

Grinkle 84, 90, 191, 193, 198, $238,320,508,524,597,600$

Grinkle Park I 7

Grinkle Woods 106, 226, 277 , 327,389

Gristhorpe 482

Gristhorpe Cliff 714

Grosmont 282, 329

Grosvenor Museum, Chester, 394

Guernsey 77

Guisborough 143, 206, 236, 239 , $32 \mathrm{I}, 323,335,355,483,500$, 508,600

Gunnergate II 3, 142, 402, 530

Gunter, Col., 56

Gunter, Sir R., 386

Gurney, J. H., xxxviii., 26, 35,41, 74. IOI, I04, I53, 196, 220, 323, 333, 394, 395, 458, 462, $474,48 \mathrm{r}, 563,565,589,628$, $662,663,669,695,710,723$, 724, 754, 757

Guyscliffe 29, I 5 I

Gyngell, Walter, 66, I42, I 98, 264

Hackfall I 5 I, 236

Hackness 30, 145, 246, 293, 322 , $330,333,351,369$

Hagg Wood 386

Halifax xxi., 29, 54, 67, 70, 92, 95. I06, I27, I28, I 5 I, I 54 , $158,166,173,190,19 \mathrm{I}, 222$, $226,265,282,302,307,3$ [ 3 , $316,319,345,346,349,357$, $363,365,366,381,432,454$. $486,497,525,541,570,59 \mathrm{I}$, 600,6 Iо, 6r5, 619, 638, 736, 752

Halifax Museum I3, 222, 638, 736,746

"Halifax Naturalist" I3, 258. $308,321,374$

Hall 369 
Hall, Dr., I4I

Hall, General, 5 I 6

Hall, James, 393, 394, 556, 590

Hall, Miss, 59I

Hambleton IO3, I $50,303,319$, $524,592,594$

Hambleton Hills xxiv., 272, $38 \mathrm{I}$, 492,5 II, 522, 563, 569, 58I, 597

Hamer 137

Hancock, John, xxxviii, 80, I52, $282,284,316,318,350,353$, $355,463,465,470,476,565$, 572

Handale Woods 305

"Handbook of British Birds" 368

"Handbook of Vertebrate Fauna of Yorkshire" 531, 632

"Handbook of Yorkshire Vertebrata" 97

Hann, Thomas, 284

Hannaford, S., 303

Hanson, C. C., 313, 314, 365, 605

Hardrow Scarr 349

Harefield I 5 I

Harewood 17, I I6, I 5 I, 26I, 350, 387,392

Harewood Bridge 398

Harewood, Earl of, $387,429,567$

Harewood Lake 546

Harewood Park 429, 739

Harland, John, 404, 745

Harland, Wm., 325, 363

Harlow Moor 258

Harlsey Hall 403

Harmby 388,521

Harome 93, 349

Harper I43, 289, 394, 757, $75^{\mathrm{S}}$ Harper, R. P., 305, 321, 405, 754

Harrison, Charles, 345

Harrison, John, 236, 239, 324 , $325,327,34 \mathrm{I}, 372,373,38 \mathrm{I}$, $403,431,449,474,594$

Harrogate $17,24,30,46,50,56$, $57,84,90,95$, I09, I I6, I 24 , I $30,149, I 5 I, I 55, I 59, I 60$,
Harrogate (continued)-

163, I66, I84, I93, 20I, 205, $220,234,258,262,270,273$, $275,305,313,324,340,370$, 493, 496, 497, 513, 519, 539, $563,583,586,593,608,624$, $625,634,644,645,747,748$ Harrogate Irrigation Farm 536 Harrop Hall, Slaidburn, 386, 387 Harswell Rectory 59, 290

Hartforth Hall, Richmond, I03

Harting, J. E., 24, 74, 9 I, I 54 , $225,278,368,370,37 \mathrm{I}, 393$, $420,427,464,482,528,549$, $551,552,725,757$

Hartley, J. E., I 78

Harvie-Brown 216

Harwood Dale 333

Harwood, L., 75

Hatfield 30, I76, 224, 282, 410, 4 I $4,435,44 \mathrm{I}, 456,463,464$, $529,540,624,739,742$

Hatfield, Chas. W., 400, 469

Hatfield Chase xxiii., 32 I, 344, 400, 438

Hatfield Levels 435, 438, 44I, 442,456

Hatfield Moor 624, 642

Hatfield's "Doncaster" 402

Hauxwell Hall, Bedale, 326

Haverah Park 336

Haw Park 52, 386

Hawes 3, 31, 348, 38 I, 51 5, 535, 537

Hawke, Lord, 386

Hawkridge, Patrick, 282, 3I3, 3 I 8 , $336,363,558$

Hawksworth Cover 3 I 2

Hawksworth, Peter, 565

Hawnby I I 7,345

Haworth 366

Haworth-Booth, Col. B. B., 9 I, I 5 I, I66, 503, 558, 628

Hawsker 16, 305

Hawsker Bot roms 238

Haxby I 50, I73, 6I 4

Hay, R., 282 
Hayburn Wyke 395, 529

Hayden, Rev. F. W., 54

Haydyn, Rev. J. A., 235

Hayton 602

Haywold 556

Hazlewood 49, 56

Head 498, 746

Headingley 29, 493

Healagh 534

Healey, Captain, 449

Healey Vicarage, Masham, I 56

Heaton, Gerald, 398

Hebden, E. H., 549, 552

Hebden Bridge 19, 29, 15I, 166, I 8 I $, 320,325,366,374$

Hebden Valley 506

Hebrides 192, 420

Heckmondwike I8I

Hedon $167,17 \mathrm{I}, 239,560,770$

Heligoland xxxii., 275

Helmsley 3I, I I 7 , I 50 , I 56, I 67 , $236,349,372,388,470,58 \mathrm{I}$, 597,742

Helpholme 450

Helstrip 364,758

Hemsworth 95, 335, 385

Hemsworth Dam 454, 536, 649, 739,747

Henderson's Folk-lore 157

Henley, Dr., 732

Heppenstall, John, 20, 222, 270 , $362,368,596$

Herries, Lord, 59

Heslington I $5 \mathrm{I}$

Heslington Hall 266

Hessle 770

Hewetson, H. B., 26, 80, I 45, I 88 , 206, 3I0, 34I, 374, 434

Hewett, IV., 80, 143, 341, 694

Hewitson 362, 45I, 463

Heworth 252, 29 I

Heysham, Dr., 570

Heysham, T. C., $57^{\circ}$

Hick, Rev. T. MI., 284

Hicks, Robert, 403

Hiendley 546
Hiendley Reservoir 469, 48 I

Higgins, E. T., 276, 628, 705, 764

High Bentham 284 [5 6

High Force, Teesdale, I 73, 280,

High Gardham 502

High Stake 572

Highcliff 236

Highfields 326

Hikeley, J., 423

Hildenley 549

Hill 456, 626

Hill, Colonel, 430

Hill, Lord, 456

Hill, R., 346

Hill, Squire, 333

Hill, T., 442

Hillingdon, Lord, 342

Hinderwell 238, 258, 746

"History of Cleveland" I, 9I, 432

Hoare, Francis, 333, 450, 469

Hob Green, Ripon, I 37

Hobkirk, 53, 222, 465, 653

Hobson, Dr., 307, 312,355

Hodder xx., 386

Hodder Valley 279, 292, 464

Hodgson,Edward, 358, 689, 7 1 3, 720

Hodgson, Grindale, 7 I 3

Hodgson, John, 233, 710, 7I 3

Hodgson, William, 7 33

Hodroyd 440

Hogg, John, 8, 31, 71, I36, I73, $239,270,316,355,357,362$, $380,407,412,414,423,424$, $563,589,628,66 \mathrm{I}, 697,735$, 739,744

Holden Clough 507

Holderness xix., xxv., xxvi., xxxi., 6 , I0, I5, 34, 45, 50, 6I, 64, 68, $76,95,119, \mathrm{I} 3 \mathrm{I}, \mathrm{I} 34, \mathrm{I} 38, \mathrm{I} 43$, I47, I 48, I 5 I, I7 I, I 76, I 79 , $183,204,209,2$ I 3,2 I, 229 , $233,246,247,252,265,27$ I, $273,285,305,320,324,339$, $377,380,437,442,450,455$, $458,502,536,537,539,546$, $558,568,583,599,603,607$, 


\section{INDEX OF PERSONAL AND PLACE NAMES.}

Holderness (continused)$611,624,628,631,634,67$, $731,739,741,747$

Holdsworth 532

Hole Bottom, Nidderdale, 143

Holgate 54

Hollym 500, 502, 625

Holme xxvi., 267

Holme Decoy 444

Holme Moss xxi.

Holme-on-Spalding-Moor 388, 442, 5 I I , 562, 567

Holmes, B., $55^{8}$

Holmfirth 20, 506

Holmpton 305, 539

Holmfirth Reservoir 70

Holtby I I 4

Holy Island 329, 572

Honley 270

Hood Hill 236

Hook 61

Hooton Pagnall Common 61

Hopperton 704, 706

Horbury 190, 592

Horbury Mill Dam 408

Horbury Reservoir 6I 4

Hornby $258,449,453,636$

Hornby Castle xxiii,, 247, 313 . $442,46 \mathrm{I}, 526,530,630,65 \mathrm{I}$

Hornby Castle Decoy 450, 452, 544 Hornby Decoy 408, 456, 464, 475

Hornby Grange 5 I 5

Hornby Park 752

Horner 666

Hornsea 50, 1 36, 160, 265, 316 , $379,388,405,500,541,739,770$

Hornsea Mere xxvi., 90, 105, 238 , $350,388,391,393,436,451$. $463,467,471,474,546,607$, $611,649,657,671,739,771$,

Horrocks, T., 5 I 2

Hors Dam, Kirkheaton, 539

Horsecar Wood 345

Horsfall, F. W., 430, 509

Horsfall, H., 107

Horsfall, M. A., 515
Horsfall, W. Christy, 52, 346, 487

Horsforth, 52, 346, 487, 742

Horton 288, 3I 3, 520

Hotham 387

Hotham, Lord, 496, 59 I

Houghton, Great, 52

House 559

Hovingham, $31,33,83,84,107$. I I $7,150,251,530,638$

Howard, R. J., 548

Howardian Hills xxiv.

Howarth 754

Howdah Wood 320

Howden 403, 444, 528, 770

Howden, Lord, 666

Howden Mere 733

Howe 527

Huby 56

Huddersfield xxi., 5, I3, 29, 50, $53,70,79,82,99,123,124,133$. I 4 I, I45, I 5 I, I 54, I 57, I 6I, 166, 177, 19I, 192, 198, 205. $206,213,222,225,228,265$, $266,270,277,279,29 \mathrm{I}, 302$. $314,319,320,324,345,346$, $349,352,359,365,378,397$, $405,426,465,489,502,507$, $529,533,539,563,570,592$, 6 I $_{5}, 616,653,66 \mathrm{I}$

Huddleston, John, 548

Hudson, Rev. C., 34I

Hudson, Harrington, 225

Hudson, Robert, 44I

Hudswell Scar 237

Hull 46, 74, 90, 91, 95, 137, I43. $152,157,199,215,222,223$, $245,252,255,329,333,387$. $405,434,442,444,456,469$, $577,582,595,608,609,615$, $639,645,646,649,745$

Hull, River, I04, 320, 363, 379, 393, 398, 429, 430, 443, 45 I, $453,457,465,466,469,470$, $483,485,536,542,624,627$. $629,630,638,733,735,737$, 739, 770 
Hull Museum 222, $311,317,320$, $346,364,369,405,422,45 \mathrm{I}$, 457, 475, 501, 590, 613, 615. 629, $696,743,751,754$

Hull Museum Guide I 37

Humber xxy., xxvii., xxxi., xxxiv., $23,35,50,61,122,124,126$, I $28,133,135,155,184,203$, $213,229,24 \mathrm{I}, 245,259,367$, $368,371,378,382,414,418$, $420,421,422,424,426,428$, $430,433,444,445,450,45 \mathrm{I}$, $453,459,460,464,466,469$. $470,471,473,478,483,486$, $528,563,573,574,575,580$, $581,585,586,587,589,607$, $611,612,616,619,625,634$, $637,640,641,643,647,656$, 660, 679, 681, 684, 686, 709, 7 I2, 733, 735, 739, 741, 745, 770

Hummersea 314,376

Humphrey, John, 538

Hunmanby 137, 195, 304, 332, $374,528,550,553,554,569,632$

Hunslet 398

Huntcliffe xxviii., 239, 358, 375 . $478,677,679$

Hunter 515

Husband 54I

Hutchinson, A. S., 79, 265, 393. $397,520,729,75^{8}$

Hutchinson, Massey, 368

Hutton 387, 508, 600

Hutton Cranswick 387

Hutton Rudby 338, 73 I

Hutton, Timothy, 237

I'anson 452

I'anson, Colonel, 527

"Ibis" see "The Ibis"

Ilkley xxi., 29, 225, 283, 314, 366, $458,485,634$

Ilkley Moors 95, 96, 366

Illingworth, WV., 190

Inchbald, late P., 71, I60, 346 365
Ingbirchworth 29, 574

Ingham, L., 707

Ingilby, Sir WV. A., 336

Ingleborough 222, 504

Ingleby I 50, 489, 514, 597, 600

Ingleby Greenhow, Cleveland, 124

Ingleby-in-Cleveland 327

Ingleby MS. 236

Ingleby Manor 530

Ingleton 239

Ingmanthorpe 387,529

Ingmire Hall, Sedbergh, 389

Inverary 216

Irby, Col., 195

Ireland $75^{8}$

Irish Sea xx., 749

Irton 305,523

Isle, Lord de L', 489, 508, 522, $527,530,600$

Jackson, J., 406

Jacobs 763

Jalland, G. W., 4r, 74, 569, 595. 637

Jalland, J. W., 215

Jefferson, Capt. Dunnington, 388 , $45^{8}, 487,564,624,745$

Jeffreys, Dr. Gwyn, 427

Jesse 678,683

Jessop, Francis, 72, 75, 185, 191, $295,424,477,505,596,727,73^{8}$

Johnson, Ralph, 65, 94, I I5, I2 I, I 25,128, I 30, I 32, I 46,175 , $212,215,242,244,287,292$, $362,373,392,400,425,457$. $468,472,473,477,480,485$. 494, 539, 593, 598, 609, 646, $656,658,711,732,754$

Johnstone, Sir John, 333

Jones 104, 323, 357, 548, 630

Jonas Wood 52

Iieadby Canal 444

Kedleston 477

Keighley xxi., 20, 29, 46, I I5. I91, 280, 302, 499, 532, 570

Keighley Moor Dam 672

Keighley Museum 532 
Keld 216, 237, 280, 327, 455

Kelfield 198

Kell, A. R., 363

Kells Springs, Slingsby, 403

Kemp 333

Kendal 648

Kent, Richard, 440

Keresforth Woods 5 I

Kerr, H., 99

Kershaw, Dr., 707

Kettering 364

Kettleness 380, 493, 500, 529, 678,679

Kettleness Point 376

Kettlewell 333

Kexby 378

Kexwith 507

Kildale 282, 333, 388, 508, 597

Kildale Hall 282

Kilham 318, 501, 554, 568

Killerby $105,614,632,637$

Killingbeck $52,258,365$

Killinghall 163,474

Killingnab Scar 357

Kilner Bank 124

Kilnsea 19, 25, 30, 41, 71, 74, 138, 139, I $86,187,192,195,217$, $259,289,315,320,329,337$, $338,364,381,453,474,492$, $558,560,569,591,608,613$, $630,636,686,771$

Kilnsea Warren 89, 323

Kilnsey 325

Kilnsey Crag, Wharfedale, I60, 263

Kineton Park 739

King and Queen Rocks $23 S$

King's Mill, Huddersfield, I 57

Kipling Cotes 496, 570

Kirkburton $187,265,485$

Kirby Hill 386

Kirby 666,667

Kirby Malzeard 308

Kirby Underdale 1 I 7

Kirbymoorside 230

Kirk, H., 339
Kirkby-in-Cleveland I60, 288

Kirkby Misperton 396

Kirkdale Cave 223, 235, 427

Kirkham Abbey 107

Kirkhammerton $75 \mathrm{I}$

Kirkheaton 190, 365, 539

Kirkleatham I 12, I I 3, I 77,446 , $448,500,533$

Kirkleatham Hospital 105

Kirkless 365

Kirkless Hall 276

Kirkstall Abbey 3 I 2

Kirkthorpe 592, 742

Kitching, G., I96

Kitching, J., $211,324,339,346$, $351,356,380,391,460,462$, $54 \mathrm{I}, 694$

Kitroyd Jump 5 I

Kiveton Park 303, 452

Knapton 30, 90, 162, I 70, 320 , $363,532,597,629,663$

Knapton Hall 293

Knapton Wolds 568

Knaresborough $46,47,57,58,82$, 89,95 , II6, I $51,166,169,198$, $201,232,234,249,535,539$, $575,594,659,704,706,730,749$ Knaresborough Dropping Well 103 Knavesmire 219

Knubley, Rev. E. P., 49, 192, 50 I

Laidlaw, T., 89

Lakin, Thomas, 395

Lambert, T. M., 451

Lambert, W., 657

Lammas Assizes 523, 643, 646

Lancaster xxii., 752

Lancaster's "Askern" 225, 282

"Land and Water" 45, 3 Io, 456

Landesburg I 78

Langden 366

Langden Fell 319

Langdon 242

Langsett 265

Langstrothdale 279

Langtoft 552,562

Langwith 258 
Langwith Moor 266

Lartington 508

Latham, Dr., 49, 56, 146,158 , I 59, I 89, $276,423,566$

Laughton-en-le-Morthen 336, 526

Lawson, M., 365

Lawson, Major, I 35

Lawton, F., 268

Lawton, M., 222

Lazenby, H., 2

Lea 549

Leach, Dr., 350

Leadbitter 144

Lealholm 363

Leckby Carr II 7

Lee, Robert, I I 5, 282, 320, 321 , $347,362,364,371,373,451,527$

Leeds xxi., 7, 20, 23, 27, 29, 37, $50,52,78,82,90,92$, II 6 , I 24 , I4I, I46, I49, I66, I69, I 76, I 77, I8I, 206, $213,258,261$, 277, 279, 3I2, 3I4, 319, 33I, $355,365,371,391,398,426$, $450,455,461,486,487,496$, $501,513,532,593,614,626$, $666,672,701,73 \mathrm{I}, 75 \mathrm{I}, 754$

Leeds, Duke of, 3 I $3,408,449$, $630,65 \mathrm{I}$

Leeds Museum 69, 99, 335, 404, $408,594,633,758$

Leeds Naturalists' Club 455, 47 I

Leeds Phil. Soc. 754

Leeman, Frank, I 3

Leeming Lane $73 \mathrm{I}$

Lekinfield Castle 385, 399, 407. $455,458,525,531,549,567,586$

Leland 525, 531, 595, 622, 643, 776

Leng, Thomas, 336, 354, 384, $663,692,723,754,761$

Leppington, Aaron, 713

Leven $55^{8}$

Levisham 34 I

Lewin, W., I I4

Lewis 298

Lewisham 190

Leyburn 299, 366, 507
Leyburn Shawl 3I

Leyland, R., I65, 276, 28I, 307, $316,319,365,506,601,610$, 6 I 5,617

Lilford, Lord, I\$9, 195, 278, 408, $462,539,550,608,665,725$, 758,764

Lindholme 176

Lindley Wood 364

Lingdale Noor 3 I

Linnreus 5 I I

Linnean Society $348,368,538,725$

Linton-upon-Ouse $29,35,88$, I79, I 80, I 8 I, 34 I

Lipscombe, Wm., 5 I 5

Lister, J., 266

Lister, Dr. Martin, 17, 19, 42, 97, I45, I 53, 20I, 4IO, 4I6, 605

Lister, Thomas, 5 I, I 23, I 3 I, 320 , $365,48 \mathrm{I}, 534$

Lister, Wm., 22I, 283, 300, 304, 3 I I, 345, 349, 369

Littlebeck 196

Littlethorpe 64, 641, 642

Liverpool 78

Liversedge 29, 95, 279

Liverton 406

Liverton Wood 389

Livesey, late R., 508

Lloyd 322

Locker Tarn 455, 546, 673

Lockton Moors 340,356

Lockwood 53

Lof thouse 3, 52, 91, 92, $151,205$. 339

Loftus 424, 509, 529, 532

Loftus Fox Cover 49

Loftus-in-Cleveland $16,31,37,72$, I02, I 50, I67, I70, 224, 239. 259, 280, 305, 314, 329, 346, $363,374,376,414$

Londesborough, Earl of, 38, 39, 314, 3I7, 369

Londesborough, George, 238, 494, $713,717,718,720,722$

Long, Josepl, 502 


\section{INDEX OF PERSONAL AND PLACE NAMES.}

Long Pain, Bedale Wood, 336

Lorrimer 356

Loten, Philip W., 3, 41, 46, 88, I 39 , $200,207,305,321,337,405$, $406,499,501,503,558,608$, $617,629,630,671,688,745$

Loudon's Magazine of Nat. Hist. $67,107,146,325,345,747$, 750,751

Low Mills 54I

Low Row 216

Lower Wensleydale 597

Lower Wharfe 72,574

Lower Wharfedale $87,89,170$, 483,632

Low thorpe 179, 237, 304, 338, $39 \mathrm{I}, 45 \mathrm{I}, 454,49 \mathrm{I}, 492,496$, $501,550,562,632,730$

Lubbock's "Fauna of Norfolk" $3+2$

Lucas, Joseph, 52, I 43

Luddenden 258

Luddenden Dean I $3_{3}$

Lumb, G., 91, 225

Lune $\mathrm{xx} ., 150,379$

Lunedale 546, 610

Lunn Wood 345

Lydekker. R., 223, 427

Machen, H., 282

Machen, Thos., $138,337,346,364$, 368, 472, 564, 595, 687, 727, 746

Machen, W., 687

Maclean, K., 24, 105, I94, 222 , $223,305,314,320,336,365$

Macpherson, Rev. H. A., 432, 57 , 625,757

Maddox, John, 439

"Magazine of Natural History" 393

Maharajah Dhuleep Singh 529

Major, E., 714

Major, Wm., 663

Malcolm, J., 688

Nalham 29, 68, 87, 103, 216, 279 , 300,410

Malham Cove 160, 263
Nalham Ings 563

Malham Tarn xx., 454, 460, 464, $467,471,483,543,546,634$, 709, 737, 739, 747

Mallinson, J. W., 333, 334

Maltby 258

Malton, 46, 60, 90, 96, 138, 186, $272,340,388,396,446,454$, $469,485,486,491,493,557$. $574,634,744$

Manchester Museum 319

Mansfield 368, 663

"Manual of British Birds" 303

Mappleton $379,405,500$

Nar Lodge, N.B., 3I 3

Marble Mills $57 \mathrm{I}$

Marfield Pond 452

Market Weighton 30, 63, 157 . $170,173,187,199,226,229$, $267,271,273,345,363,405$, $42 \mathrm{I}, 444,496,501,51 \mathrm{I}, 558$, 562

Market Weighton Wolds 59

Marr, Henry, 238, 494, $710,717$. 720

Marr, Richard, 238

Marsden 291, 452

Marshall 3, 265, 669

Narshall, Benjamin, 439

Marske-by-the-Sea xxviii., I27, 335, 364, 430, 433, 500, 559, $729,75 \mathrm{I}$

Marston Moor 355

Martin 396

Marton-in-Cleveland I 59, 204, 277 3II, 497

Marton Hall 19, 34 $\mathrm{I}$

Marwood, George, 755

Marwood, Rev. G. J., 383

Nasham 16, 66, 70, 84, 85, 99, I03, I07, III, II, I 24, I 38 , I49, I 50, I $51,156,168, I 84$, 205, 224, 277, 299, 302, 303, $308,313,327,343,366,372$, $389,407,408,410,430,452$, $455,464,467,47 \mathrm{I}, 478,485$, 
Nasham (continued) $492,497,500,526,530,539$, $545,584,597,604,627,632$. $634,673,733,749,762$

Masham, Lord, 389

Matthewman's Selby List 450

Maude, Moorsom, 387

Mausoleum, Castle Howard, 236

May Moss 316

Meanwood Road, Leeds, I 70

Meaux xxvi., 442, 624

Neaux Decoy 40I, 443, 444

Meersbrook Park 183

Meltham 324, 507

Merton Farm 325

Metcalf, John, 249

Metcalf, Thos, 305

Metcalfe, Mrs., 554

Metcalfe, T. T. S., 537

Mickle Fell xix., 23, 546, 572

Micklefield I76

Mickleton 398

Mickley 247

Middledale 554

Middleham 388, 520, $52 \mathrm{I}$

Middlesbrough xxvii., 2I, 90, 96, 99, I07, II $3,147,184,222$, $280,283,284,320,364,45 \mathrm{I}$, $530,594,685$

Middlesbrough Museum 346

Middlesbrough Park 275

Middleton-in-Teesdale 64, I62, 280, $316,319,327,358,622$

Middieton, Lord, 446

Midgeley $58 \mathrm{I}$

Migration Committee (British Association) $15,18,24,31,71$, $77,98,126,129,131,138,245$. $256,262,288,343,37 \mathrm{I}, 489$, $542,598,644$

Migration Reports (British Association) $\mathrm{I}, 4,7,34,4 \mathrm{O}, 4 \mathrm{I}, 43,68$, $73,82,87,92,96,108$, II 3 . I19, I $21, I 22, I 33,143,152$, $164,167,171,179,181,186$, $194,209,213,217,223,226$,
Migration Reports (British Association) continued-

$232,241,246,251,262,275$. 289, 293, 434, 488, 492, 594, 599, 615, 616, 619, 630, 656, $657,660,684,749$

Milbank, Sir Frederick, 5 I 6

Milburn, C. E., 19, 37, 66, 90, 97, 127,696

Milford-cum-Kirby 666, 667

Miller 6I, 278, 31 5

Millington 503

Mills 530

Milne-Redhead 86

Milner 754

Milner, Henry, 45I, 666, 667

Niiner, John, 554

Milner, Sir Wm., 69, 306, 316, $404,408,463,467,565,594$, $628,665,666,667$

Misson 633

Mitchell, F. S., 326, 390, 548

Mitford, Admiral, I 37, 304, 332, 406

Moiser, Cyril, 664

Mollicar Wood, Huddersfield, 53

Montagu, F., 64

Montagu's "Ornithological Dictionary" $73,87,121,130,702$, 730

Moore, James, I 5 I

Moorsholm-in-Cleveland 406, 532

"Moorland Parish" 236, 533

More, A. G., I73, 300, 330, 362, $464,528,589,624,642,648$

More, A. J., IO5

Moreby II $6,437,454$

Moreby Park, York, 388

Norecambe I5 t

Morley, J., 265, 300, 305, 32I, $463,630,758$

Morley, John, I 52, 493, 718,746 , $76 \mathrm{I}$

Morley, Joseph, 354, 398, 725, 754

Morrell's "Selby " 384

Morris 282, 283, 450, 549, 688, $75 \mathrm{I}$ 
Morris, Rev. F. O., 60, I02, I63, 309, 3I3, 3I9, 39I, 404, 435. $483,533,547,555,594,608$, 624

Morris, Dr. Beverley R., 62, 304, 316,405

Morris, Richard, 368, 47 I

Morris, Wm., I 24, I42, I 74, I 86, $219,320,365,366,379,389$

Morris's "Naturalist " 20, 2 I, 52 , $53,8 \mathrm{I}, 102,14 \mathrm{I}, \mathrm{I} 43,222,322$, $326,339,366$

Mortimer, R., 562

Mosley, Sir Oswald, 725, 754, 758

Mosley, S. L., 53, I 33, 192, 206, $225,230,265,324,365,405$. 539, 6IO, 6I 5

Mosley Wood, Horsforth, 52

Mowbray, Vale of, 527

Mowbraydale 340

Moyle, Walter, 75, I09, I IO, I78

Muker 327, 610

Mulgrave 324, 389, 498, 524, 529, 597

Mulgrave Castle 325,342

Mulgrave Woods I 50, 277, 327

Murdock, G. W., 283

Murray, Dr., 46I, 557

Murton 345

Mussell, George, 147, 275, 283, $284,320,321,346,364,424$, $45 \mathrm{I}, 453,484,594,685$

Needle Eye Wood 5 I

Nelson, T. H., I 28

Netherton 5

Nevell, Archbishop, 394, 523, 525, $531,577,582,643$

Nevell, George, 385, 399, 595, 776

Neville, Elizabeth, 400

Neville, Sir John, 385, 399, 407. $430,435,455,523,525,547$, $577,608,643,646$

Newbald Lodge Farm 502

Newbould 520

Newburgh Priory 546

Newburn 284
Newby, C., 323

Newby Wiske 389,541

Newcastle-on-Tyne 258, 393, 559, 572

Newcastle Museum 80, 206, 247. 355, 559, 649

Newcomen, G. H. T., 446, 448

New Forest 507

New Hall 5I, 393

Newham 530

Newholme 346

Newman 276

Newman, Colonel, 339, 730

Newmiller Dam 742

New Park Spring 52

Newsome 65, 279

New Spring Wood 228

Newstead 345

Newstead, Robert, 394

Newton 388

Newton, A., 74

Newton Dale 236

Newton Fell 672

Newton House, Whitby, 356

Newton-le-Clay 50 I

Newton Kyme 56, I I4, I I6, I 37 . $205,270,454,483,486,532$, $624,625,701,733,737,752$

Newton-on-Derwent 471

Newton, Professor, 94, 144, 207. 208, 294, 307, 313, 342, 348, $549,553,554,652,726,762$

New Zealand Decoy 445

Nicholson, Bishop, 670, 671

Nichtgaleriding 64

Nidd, River, xx., 57, 58, 72, I29, $410,412,467,486,546$

Nidderdale 4, 27, 29, 33, 87, 95 , I 43. I 5I, I 55, I 59, I 60, I62, I66, I9I, I98, 236, 239, 267 , $270,273,467,513,535,596$, 610, 739

Nidd Valley 68, I16, 170, 179 , $216,277,279,317,426,454$. 464, 541, 574, 685

Noble, Heatley, 342 
Norfolk xxxiii., xxxiv., xxxviii., xxxix., xl., 45, 104, 25 I, 312, $335,367,368,558$

Norfolk and Norwich Soc., Trans. of, xxxviii., 41, 757

Norland 205

Norland Moor 308, 638

Normanby-in-Cleveland 50,305,355

Normanby House, Cleveland, 59

Normanby, Marquis of, 325

Norris, John, 393

Northallerton 31, I I7, I 50, 177. 179, 181, 191, 192, 216, 218, $280,323,403,414,427,515$, $526,527,541,625,632,634$, $637,654,701$

North Bierley 75, 106, 109, 178, $510,596,712$

North Burton 222, $55^{8}$

North Cave 60, 528

North Cliffe 63

North Dalton 549, 555, 556

North Duffield 67I

North Grimston 446

North Landing,Flamborough,xxx., 695

North Stainley 68, 70, 166, 524, 535

Northumberland xxxiii., xxxviii., $335,476,565,745$

Northumberland, Earl of, 385,548

Northumberland Household Book $40,399,434,455,458,523$, $525,531,547,567,577,582$, $586,595,602,618,622,633$. $643,645,655$

Norton Conyers 254

Norton 770

Norwich xxxviii., 101, 342

Norwich Museum 333

Norwood, Thos., 557

Nostell 469

Nostell Priory 386

"Notes and Queries" 177, 254

Nottinghamshire xxiii., 50, 54, 633

Notton Wood 69

Nova Scotia Wood, Skelton, 54 VOL. II.
Nunappleton 218, 665, 666

Nunburnholme 102, 166, 435

Nun Monckton 696

Nuttall 294

Oakdale 3 I 7

Oglethorpe Whin Cover I70

Okeley 336

Oliver's Mount, Scarborough, 60, 142,305

Ord's "History ot Cleveland " 282

Ormesby 500, 530, 60I

Osbaldeston 554

Osberton 306, 310, 666

Oscar Wood $5 \mathrm{I}$

Osgodby 227, 442

Osgodby Decoy 446, 449

Osmondthorpe 37

Osmotherly

Oswaldkirk 339, 513, 583

Other, Capt., 320

Otley 50, I6I, I66, 222, 266, 268, $278,392,529$

Otley Moors 300

Otley Road 29

Otterington $53^{\circ}$

Oughtybridge 265

Ouse 433, 444, 528, 6I 5

Ousefleet 528

Ousefleet Grange 340

Ovenden I $51,363,532$

Ovenden Moor 6I7

Overton, Rev. J., 55

Overton Wood 55

Owen, Joseph, 3 I 2

Owldray 742

Owston Hall 6I

Oxenhope 20, 673

Oxford Museum 757

Oxley, Admiral C. C., 27 I. 319, $335,340,345,355,365,375$. $398,408,642,757,76 \mathrm{I}$

Oxnop Scar 237

Page, A., 225

Page, G., 320, 335

Palmer, J. E., 539, 584

Pannal 5 
Pannant 323

Parke 487

Parker 386

Parkin, G., 496, 524, 745

Parrington, Thomas, 59

Pateley Bridge 17, 95, 162, 192, 198, 236, 239, 366, 464, 469, 507, 519, 520, 574, 696

Pateley Moor 570

Paterson, A., 369

Patrington $3,46,50,61,148$, I6I, I64, I76, 329, 330, 770

Paull 394, 469

Payne, Dr. H., I 49

Payne-Gallwey, Sir R., 445, 446, 449, 45I, 460, 46I

Peak 238, 377

Peake, Rev. E., 92

Peake, Rev. Ed., 341, 347, 360, $504,541,632$

Peake's Scar 236

Pearey 508

Pease, Claude, 329, 430

Pease, Sir A. E., 25, 75, 483, 500, $508,528,530$

Peasholme, Scarborough, 405

Pelton Reservoir, Halifax, 736

Pennant's " British Zoology " I46, 307

Pennant, Thomas, xxix., xliv., $47,61,73,148,155,178,240$, $312,357,375,377,379,394$, $623,639,677,689,726$

Penistone $265,320,345,366,506$, 6 I 8,729

Penyghent 2, 570

Penny Spring Wood 69

Percy, Earl, 399, 407, 455, 4.58, $523,525,531,567,577,586$, 618,633

Petch, G., 237, 532

Petch, T., 144, 209, 377

Petre, Rt. Hon. E. R., 368

Peven 337

Phillips, J. H., 569

[59I

Philosophical Transactions 75, 118,
Pickering xxiv., xxv., xxviii., 3 I 95, 179, 236, 252, 266, 272, $319,340,356,500,528,558$. $562,594,601$

Pierce Bridge 242

$[634$

Pilmoor xxiii., 192, 454, 546, 625, Pilmoor Farm, Hunmanby, 374 Pinchinthorpe 530

Piper's Wood 387

Pittlebeck 324

Plompton 2OI

Pocklington $13,30,90,101,102$, II7, I43, I 5 I, I66, I 7O, I73, $187,258,273,308,317,321$, $395,398,454,496,529,539$, 70I, 729, 770

Pollard's Woods, Leeds 78

Pontefract 124, I54, I66, 246, $385,45^{8}$

Pool, T. W., 608

Portland, Duchess of, 276

Posting Inn, Northallerton, 216

Potter II9, I43, 662

Potterick Carr 438, 624, 739

Potts, late Thomas, 394

Powell, Rev. T., I 56

Pratt, J. F., $5^{8}$

Preston 319

Preston, Captain, 387

Preston, Major, 388

Priestley 265

Priestman 104

Pringles 335

Prodham 333

Pryme, Rev. Abraham de la, xxvi., 442, 657

Plumpton II6, 524

Public Pasture I67

Pulfin 629

Pulleine, J., 34I

Punchard Head 673

Pye 338

Pyman, W., 509, 664, 669

P.Z.S. 498, 533. 538, 562, 599, $614,620,668,754,756,757$, 764 
Quarry Bank, Helmsley, 349

Radcliffe, Sir Joseph, Bart., 393

Raikes' IVood $\sigma_{5}$

Raincliffe $377,380,728$

Raincliffe Wood 60

Raine, Thomas, 460

Rainworth Lodge 368, 398, 472, $474,628,663,723,729$

Raithwaite Hall 664

Rampton I 30

Ramsden 442

Randy Mere, Groathland, 389

Ranson, J., S3, 88, 99, I So, 204, 229, 34I

Rash Gill 324

Raven Hill 239

Raven's Cliff 236

Raven's Crag 237, 239

Raven's Gill 236, 239

Raven's (or Jackdaw's) Well 236

Raven's Roe 239

Raven's Scar 237, 239

Ravenscar 678

Rawcliffe 6r

Raw, Robert, 319, 365

Rawson (F.G.S.) MS. 173, 265,363

Rawson, H. E., 664

Raw, W. H., 301, 319, 363, 508

Ray, John, 18, 42, 65, 75, 94, 97 . $101,115,12 \mathrm{I}, 132,138,145$, $153,175,185,202,242,287$, $410,4 I 5,416,424,472,598$

Rayner Stones 5 I 6

Read, IV. H. Rudston, 61, 706

Redcar (numerous)

Redcliff 22, 27, 32, 34

Red Crag, Richmond, 326

Redhead, R. Milne, 548

Redhouse Wood 345

Reid, Hugh, 201, 220, 222, 292, 345, 363, 397, 40I, 453, 426, $481,536,538,557,589,624$, 641,642

Reighton 30, 550, 564, 569

Reighton Hall I45

Reighton, Vicar of, $55 \mathrm{t}$
Rennie's Field Naturalist 22, 27 , $32,34,43,75,82,85$, I 3I, I8I, $216,267,318,568$

Report on the Birds of Yorkshire I

Reynard 404

Reynolds 63

Ribble xx., 279, 483

Ribble Valley 464

Ribblesdale 64, 143, 19I, 198, 24I, 242. $360,370,412,541,572$, 596, 610, 618, 641, 744

Ribblesdale, Lord, 387, 519

Ribblesdale, Upper, 387

Ribston 486

Ribston Hall 747

Ribston Park II6, 166

Rishworth Moor 754

Riccall 404, 474, 770

Riccall Common xxiii., 454, 624 , $634,67 \mathrm{I}$

Riccaldale 388

Richardson, Dr. R., 75, I06, I09, II7, I1 $8,178,283,324$, $364,457,510,596,712$

Richardson, Thos., 304

Richardson 559

Richmond 20, 3I, 102, 103, II7, $141,143,167,187,198,205$. $233,247,282,326,339,352$, $366,408,485,507,511,518$, 520

Richmond Park, Sheffield, 54, 99

Rickaby, Miss Charlotte, 550

Rievaulx II7, 236

Rivelin, River, IOI

Rivelin Valley 97, 397

Rillington 307

Rimington-Vilson, R. H., 516 , 518,520

Rimswell 13

Ripley 58, 109, I 16, 166, 222, 233. 278,387

Ripley Castle 336

Riplingham 752

Ripon 30, 50, 58, 68, 70, 81, 90, 95. I37, I51, 166, I70, 191, 
Ripon (continued) -

$198,236,251,254,266,319$, $335,340,345,346,355,366$, $370,408,496,519,524,526$, $570,597,634,745,757,76 \mathrm{I}$, 763

Ripon, Marquis of, 5 I 8

Ripon Nuseum 458

Ripon Park 604

Ripponden 265, 292, 754

Roberts, Alfred, 38, Ior, 123 , I $37,143,144,222,238,258$, $280,296,305,308,314,316$, $320,324,332,333,336,340$, 346, 365, 369, 381, 397, 406, $463,474,48 \mathrm{I}, 532,54 \mathrm{I}, 558$, $592,594,629,632,699,701$, $706,708,745$

Roberts, George, 3, 52, 91, 226, 339,653

Roberts, W., I44

Robin Hood's Bay 21, 354, 424, $678,696,707,754$

Robinson 706

Robinson, H. P., 405

Robinson, John, 57 I

Robinson, Thos., 665

Robinson, Wm., 60

Roche Abbey 50, 54, 107, 258

Roche Court 537

Rocklow, Ireland, 758

Rodd's "Birds of Cornwall " $1>8$

Roe Beck 354

Roebuck 48

Roebuck, IV. D., 552

Rolleston Hall, Derby, 725

Rolleston Hall, Hull, 223, 754, 758

Romanby 191, 192

Rombalds Moor 3 I 4

Rooke, Dr., 35 I

Rowleston Hall 405

Rowley, G. D., 463

Rowlstone 628

Rossington xxiii.

Rossington Warren 686

Rossington Wood, Doncaster, 363
Rotherham 50, 54

Rothschild, Hon. N. C., 761

Rothschild, Hon. Walter, 664.

Rothwell 392

Roulston 503

Roulston Scar 236

Roundhay Park, Leeds, 95. 3 I 4

Rounton Grange 530

Routh Head 5 Is

Royal Scottish Museum 74, So, 88, I89, 195, 258, 514, 608

Rudding Park 87, I16, I66

Ruddock 345

Rudd, T. S., 465, 607

Rudston 393, 408, 558, 559

Rudstone-on-the-Wolds 550

Rufforth Moor 557

Runswick Bay 669

Russell, Thomas, 52

Ruswarp 319, 565

Ruswarp Dam, Whitby, 39I, 397

Ruswarp Fields 2 I I

Rutherford Bridge 389

Rutson 389

Rye xxy.

Ryedale 33, 263, 433, 464, 597, 604,733

Rye Valley if 7

Ryhill Reservoir 739

Rylston Fell 320

Ryshworth and Edwarde's Moors 5 I 6

St. Quintin, Mrs., 552

St. Quintin, Sir Wm., 550

St. Quintin, W. H., I09, 277, 287. $307,338,361,364,388,391$, 4 II, 4I2, 4I4, 429, 437, 454 . 460, 496, 501, 532, 54I, 549, $550,55 \mathrm{I}, 552,562$

St. Quintin, Wm. Thos., 552

Salisbury 537, 557

Saltaire 29

Saltburn xxviii., II7, I35, I60, I62, $233,239,263,286,288$, $375,402,493,563,573,64 \mathrm{I}$, $674,677,678,765$ 


\section{INDEX OF PERSONAL AND PLACE NAMES. $\$_{35}$}

Salterhebble 54I

Salt Scar $378,475,617,619$

Saltwick 402

Sandal 398

Sandbeck Park 739

Sandhutton 170

Sandsend 239

Saunders, Howard, 303, 394, 496, $525,608,633,659,667,757$, 761

Saunders' "Manual " xxxvii., 372, $432,456,498,674,675$

Savage 369

Savage, Anthony, 408

Savile, Henry, 5 I 6

Saxby 24

Saxton 665

Sayer, Arthur, 572

Scalby 30, 337, 574, 555

Scalby Beck 280, 397, 398

Scalby Mills 650

Scalby Ness 381,688

Scampston 90, 102, 109, I66, 170, $173,181,199,233,237,267$, $273,277,361,364,388,411$, $412,414,429,452,460,464$, $470,496,528,532,54 \mathrm{I}, 549$. $562,594,616,625,631,634$, 744

Scampston Lake 737

Scampston Park II7, 226, 229 , 307

Scarborough (numerous)

Scarborough Castle 2 I 6

Scarborough Mere 397

Scarborough Museum 247, 282, $332,336,354,363,396,404$, $555,556,557,632,650,663$, 746

Scarborough Philosophical Socy. 27 I

Scargill 366

Scarrow Fell Moor 64I

Scarthingwell 105, 386

Scarth Nick 266, 338

Scarsdale, Lord, 477
Science and Art Museum, Dublin, 624

Scorborough xxvi., $387,393,394$, $442,443,444,45 \mathrm{I}, 556,557$, 590,624

Scollit 327

Scout Nab 377

Scrafton Lodge, Coverdale, 520

Scriven Park 57

Scugdale 366

Scugdale-in-Cleveland 290

Sculcoates 770

Sea Birds Preservation Act xxx., 687,690

Seamer 28I, 308, 3I7, 340, 346, $352,528,636$

Seamer Carr 198

Seamer Moor 324, 329, 331, 336

Seaton Carew 262

Seaton Snook 208, 284, 285

Sealey 196

Sedbergh 17, 31, 46, 82, 85, 87, 88,95, IO3, I24, I3I, I4I, I50, I60, 167. I74, I86, 191, $219,233,266,27 \mathrm{I}, 273,277$. $303,326,365,366,379,389$, $454,507,546,597,634,644$

Seddon, Captain, 735

Seebohm, Henry, 4O, I 47, $18_{3}$, 207,3 OI, 366, 498, 596

Selby $30,46,50,76,95,100$, 166, 198, 227, 236, 273, 319, $325,341,363,368,406,412$, $445,532,562,582,624,661$, $67 \mathrm{I}, 744,745$

Selby Abbey $384,430,524$

Sellaby i 82

Semerwater xx., 464, 673, 737

Sessay 597

Sessay Wood 55

Settle 24, 29, 95, $163,181,242$, $502,504,520,627,632$

Sewerby I47, 564

Sewerby Hall xxxi., 340

Sharp, H., 422, 636

Sharp, Sir Cuthbert, 468 
Sharpe, Dr. R. Bowdler, 76I

Shaw Gill 348

Sheffield xxi., 29, 50, 54, 67, 70 . $72,79,8 \mathrm{I}, 83,89,92,95,98$, 99. IOI, II6, I 25, I 47, I 5 I, I66, I83, I85, I9I, I93, I96, 198, 224, 240, 270, 266, 279, $283,302,316,319,362,366$, $426,430,496,505,506,520$, $529,532,570,574,596,6 \cap 1$, $610,634,661,728,739$

Sheffield Museum 368

Sherard, Dr., 75, 109, 178, 712

Sherborn 770

Sherburn-in-Elmet I 69

Sherburn Wolds 568

Sheffield "Daily Telegraph" 3 I 7 . 339

Shetland Isles xxxiv.

Shipley 53, 464, 476

Shipton 55

Sidney, late Hon. H., 600

Silsden 142

Sinclair, Jack, 236

Simonstone 348

Sims, Dr., 348

Simpson, Martin, I 3, 304

Simpson 326

Skeffling I42, I 88,742

Skelmanthorpe $23,29,47,95$, I 5 I, 268,279

Skinningrove 222, 336, 433

Skelton 48, 50, 54, II 7, 486

Skelton, George 446, 449

Skelton-in-Cleveland 282

Skelton Springs 54, 55

Skelton, T. Gilbert, 449

Skerne 333,450

Skewkirk 56

Skipton I43, I48, I $87,239,300$, $310,320,525,535,672,673,692$

Skipton Bridge 254

Skipton Castle 505, 510

Skipton-in-Craven 95, 478, 497

Skipton-on-Swale 430

Skipsea 404, 669, 770
Skipsea Watch House 770

Skipwith 452, 496

Skipwith Common, 454, 460, 589 .

$624,634,645,669,671,673,700$

Skipwith Manor 323

Skirlaugh 74,770

Slaidburn 326, 386

Slaithwaite 572

Slater 192

Slater, Rev. H. H., 74, 19I, 201 , $512,539,745$

Sledmere 199, 551, 552, 553

Sleights I40, I 5 I

Sleights Moor 304

Sleights, Snowden, $437,497,636$

Slenningford $76_{3}$

Slingsby $302,37 \mathrm{I}, 403.425,500$

$574,707,733$

Sloane, Sir Hans, 510, 596

Smeaton, John, 438, 44 I

Smith, Rev. H., 466, 592, 595

Smith, Matthew, 312

Smith, S., 608

Smith, S. H., I 86

Smorfitt 501

Smurthwaite, H., 20, I02, I fr. 326,366

Snailsworth 239

Snaith 201, 532

Sneaton Thorpe I6

Snilesworth Moor 321

Snook 262

Snowdon, Dr., 338

Southampton 394

South Bay, Scarborough, 761

South Cave 60, 527

South Dalton Park 496

South Gare Breakwater 502, 6 I 7

South Kensington 195, 487

South Konsington Museum 276

South Kirby 337

Southowram 752

Southwell, Thomas, xxxviii., 342, $432,65 \mathrm{I}, 757$

South Woods 569

Sowerby Bridge 474, 610 
Spalding Moor 267,444

Speeton xix., 30, 238, 336, 354, $35^{8}, 568,678,689,690,708$. 711,714

Speeton Cliffs $336,528,713$

Spofforth 67

“Sporting Magazine" 549, 550

Sproatley 95, 258

Spurn (numerous)

Spurn Lighthouse 41, 139, 298, $35 \mathrm{I}, 434,534,587,618,627$, 660,737

Stainborough Park, Barnsley, I 6 Stainborough Woods I51, 596

Staincross 407,733

Stainer Wood 368

Staingate 335

Stainland 365

Stainsacre 346,437

Stainton Moor 507

Staithes 31, I02, I35, 167, 233 , 259, 280, 346, 376, 629, 66r, $678,679,683,696,759$

Stamford Bridge 102

Stanbury 291

Standedge 6 Io

Standen, R., 319, 320

Stanhope, IV. Spencer, 506, 516

Stanley 52

Stape Moor 237

Stapleton 369

Stapleton Estate 53

Starbottom 333

Staveley $30,47,49,58,90,166$, I 70, $425,502,529,667$

Staveley Bridge 502

Staxton Wold 565

Steels, George, IOI, 143, 308, 321 , 395. 398

Stephenson 698

Stephenson, John, 304, 556. 590,

Stephenson, T., 100, II 5, 140, 2 I I, 283, 304, 305, 3II, 324. 335. $34 \mathrm{I}, 345,349,356,388,39 \mathrm{I}$, $396,397,460,462,508,541$, $565,654,694,695,746,757$
Stephenson and Wilson 196

Sterland"s "Birds of Sherwood Forest " 336

Stevens 71, 347, 351, 695

Stevens, J. C., 3 I9

Stevenson 294, 335

Stevenson's "Birds of Norfolk" 312

Steward, Dr., 90, 508

Stillingfleet 60

Stockton 244, 468, 484, 590

Stockton-on-Tees $265,320,323,339$

Stockton-on-the-Forest I98, 323 , 499

Stockburn, R. N., 364

Stockfield $33 \mathrm{r}$

Stockeld Park 56

Stocksmoor 228

Stokesley 99, 252, 333, 522, 636

Stokesley Moor 522

Stonegate Ghyll 335

Stonehouse, Rev. WV. B., 445

Stone House, Dent, 57 .

Storey, IVm, I60, 317, 37, 386 . 47 I, 507

Storthes Hall, Wakefield, 95, 108, 352

Storthwaite 353

Stork Hill, Beverley, 387

Stourton, Hon. Chas., 567

Strangwayes, R., 205

Strathmore, Lord, 5 I 5

Strickland 270, 401, 413, 420, $421,475,491,559,610,625$, $726,730,756$

Strickland, Arthur xliv., 222, 333. $380,393,404,410,412,417$. $443,460,531,549,555,557$. $558,56 \mathrm{r}, 567,568,569,589$. $618,646,649,694,697,754$, 755

Strickland, Mrs., 569

Strickland, Sir C. IV., 337, 549. $55^{\circ}$

Strickland, Sir George 388, 550

Strickland, Sir IVm., 550, 553, 554 


\section{INDEX OF PERSONAL AND PLACE NAMES.}

Strensall 186,5 I 2.546

Strensall Common xxiii., I7, I6r, I9I, 290, 300, 37I, 427, 430, $454,509,545,601,671,707$

Stuart 143, 234, 310, 337, 564, 630

Stubbs, John, 763

Studley I5I, 272, 277

Studley Park I 6,166

Studley Royal 518

Summer Lodge Tarn 673

Summerfield, Rev. R. A., 535

Summerside 2 I 6

Sunderlandwick $324,636,754$

Sunk Island 442, 625,636

Sunk Island Decoy 444

Sunny Bank 5 I

Sutton 486

Sutton-on-Derwent $353,388,429$, 433,467

Swailes 80

Swailes, G. C., I74

Swailes, Johnson, 457, 502

Swainby I 50, I67, I99, 200, 288 , $299,329,338,383,597,73 \mathrm{I}$

Swainby-in-Cleveland $56 \mathrm{I}$

Swainby Moor 155, 329, 331, 338, $383,520,570,606$

Swale $x x ., 129,237,408,651$

Swaledale $33,68,82$, I 62, I67, 179, 19I, 192, $216,239,266$, $280,302,324,326,330,354$, $359,366,455,464,507,513$, $572,597,610,673$

Swale Valley 360,685

Swanland 387

Swarth Fell, Ribblesdale, I9I

Swillington 450

Swillington Hall 142

Swinefleet 89

Swinnergill, 237, 326

Swinsty 634

Swinsty Reservoir 47I, 574, 627, 739

Swinton, Lake, 594

Swinton Park, Masham, 1 37, 273 , 389,530
Sykes, Bowland, 320

Sykes, George, 5 I 6

Sykes Moor 519

Sykes, Sir Tatton, 199, 553

Tadcaster 92, 137, 326, 534, 593 , $665,666,667,732$

Talbot, William, I 2, I9, 52, 96 , I $37,143,162,270,316,363$, $408,452,47 \mathrm{I}, 48 \mathrm{I}, 496,535$, $546,576,601,614,616,745$

Talbot's "Birds of Wakefield" 397

Tanfield $750,762,763$

Taunton 3, 669

Taylor 397

Taylor, Jonathan, 349

Tegetmeier, IV. B., 219, 509

Temple Newsam 452

Temple Thorpe 39 I

Tenbury 504

Tennant, J., I42, 222, 289, 325 , 345,398

Tees (numerous)

Tees Bay 469, 476, 484, 654, 662, $663,697,705,757,759$

Tees Breakwater 10, 32, 34, 78, 214, 297, 299, 338, 476, 497, $526,537,575,597,598,606$

Teesdale 27, 31, 72, 82, I55, I 59, I62, I67, I 73, I79, I 80, I9I, 199, 237, 266, 273, 336, 366, $398,433,464,505,511,515$, 546,644

Tees Marshes 217, 246, 407, 459, 635

Tees Lighthouse I94

Tees Light Vessel 434

Teesmouth (numerous)

Tees Valley xxiii., xxiv., 272, 685

Thackerey Beck, Bluberhouse, 588

Thackley 476

"The Field" (numerous)

"The Ibis" I05, I66, I73, I 82 , I $84,207,208,223,225,300$, $330,362,427,464,528,642$, 648

"The Naturalist" (numerous) 
Thainston-on-Don $38 \mathrm{r}$

Thicket Priory 427, 458, 464, 471, $474,487,545,564,624,637$, 745

Thirkleby 347

Thirkleby Park 59, 442, 451, 460, $46 \mathrm{I}, 464,467$

Thirkleby Park Decoy 447, 449

Thirsk 3I, 50, 56, 58, 59, 79, 82, II 5 , II $, 167, I 79, I 84, I 87$, $218,268,280,282,320,330$, $333,347,362,364,37 \mathrm{I}, 373$, $425,427,461,527,530,625$, $634,638,641,701,706,707$ $729,731,733,744,75 \mathrm{I}$

Thompson 353

Thompson, Edward, 310, 398

Thompson, E. V., 398

Thompson, R., 386

Thompson, W'm., 355

Thompson, W. H., 553

Thoresby 146

Thorleby Springs 364

Thorne 222, 442, 445, 624

Thorne Waste xxiii., 20, 30, 162, I9I, 300, 452, 454, 509, 610, $634,644,672$

Thorne Waste Decoy 444

Thornhill $5 \mathrm{I}$

Thornes 745

Thornsetts Moors 317

Thornthwaite 267

Thornton 333, 454, 54I, $58 \mathrm{I}$

Thornton, Colonel, 358

Thornton Bridge 670, 671

Thornton Rust 198, 389, 614

Thornwick 7I3

Thorp Arch 56, 319, 320

Thorpe 408

Throxenby Mere 60

Thwaite, John, 5 I 5

Thwing 364

Tickhill 222

Tindall, E., 162, 238, 363, 369, $396,404,532,629,650,655$, 663
Tinkler, J. E., 326, 354, 408, 572 , 676

Tivy Dale 5 I

Todd, Wm., 224

Todmorden 19

Tod Point 124, 262, 447

Tollerton 56

Tollerton Ings 696

Tollesby 59, 427

Tollesby Hall 693, 702, 729

Tong Park Reservoir 476

Toothill 564

Tostock Rectory 665

Townend, J. S., 393

Townhead 601

Towton $70 \mathrm{I}$

Tranby Park, Hull, 333, 450

Travis, Rev. W. T., I09

Trefrie, Aberdovey, 707

Trent xxiii., 433, 528, 589

Tristram, Canon H. B., 207

Trowler's Gill 236

Tuck, Rev. Julian G., 38, 104, 665, 674, 682, 686, 693, 710, 754,758

Tuke, J. H., 754

Tunstall, Marmaduke, 3, IO, I4, I $7,26,33,49,56$, II 2, I I 7 , I $22, I 46,154,157,160,163$, 169, I 80, I82, 193, 194, 197, $203,213,235,252,269,270$, $272,285,286,288,290,29 \mathrm{I}$, $334,378,380,400,402,423$. $487,489,505,510,520,521$, $532,536,549,550,561,601$, 645,660

Tunstall Museum 30, 46, I 72, 209, $296,365,482,540,568,573$, $575,580,609,637,674$

Turton, Captain, 26I

Turton, E. R., 282, 286, 496

Tuton, IV. J., 13

Tyne $\mathrm{xx}$.

Ugthorpe 31, 320

Ulladale Force 302

Ulleskelf $36 j$ 
Ulrome 549,576

Upgang 30

Upper Nidderdale 501

Upper Poppleton 356

Upper Ribblesdale 454

Upper Teesdale $359,455,481,504$. $507,519,610,625,634$

Upper Wharfedale $29,65,95,228$, Upsall 286, 496

Upsall Castle 261, 282, 333

Upton Beacon 53

Ure xx., I $29,151,247,429,744$, $749,762,763$

Ure Valley 685

Vale of Pickering 272

Vale of York 272

Vane, Hon. Fred, I8z

Vansittart, H., 447, 448

Varley, James, 53, 69, 79, 99, I4I, $145,206,222,320,326,346$

Vaughan, Thomas, 320

Vavasour, Sir Walter, 49, 56

Ventriss 305

Vermuyden, C., 438, 44I

Vermuyden River 509

"Vertebrate Fauna of Yorkshire"

Victoria Cave, Settle, 504

Vigors, A. N., 309

Waddington 366

Wadsley Bridge 393

Wadwith Wood 369

Waghen 742

Waite, E. R., 205, 320, 324, 326, $34 \mathrm{I}, 425,495,633$

Wakefield (numerous)

Walden Head 237

Waupley 19I, 327, 508

Waupley Moors 3I, 3I6

Wales, North, 347

Walker, J. C., 34I

Walkington 64

Walsingham, Lord, 451, 507, 516, $518,520,527,588,606,659$

Walton Hall 52, 105, 173, 228, $236,270,294,325,374,378$, 386,469
Walton Park xxii., 229, 274, 389, 410, 48 I, 649, 744

Walton, W., 316, 319, 327, 345, 622

Wansford 404, 550

Wanesford, Sir Christopher, 670

Waplington 101, 199, 622

Ward, A., 460

Ward, C., 388, 752

Ward, J., 91, 205

Warley 127

Warley Clough, Halifax, 222, 59t

Warner, C. J. Lee, 302

Warrenby 447

Warter Priory 166, 529

Warwick, Earl, 385, 595

Wash xxxy.

Washburndale II, 364, 507, 584

Washburn Valley $29,91,95,116$, 166, 170, 216, 277, 467, 596

Wassand $316,317,388,463$

Waterton, Charles (numerous)

Wath-upon-Dearne 149

Watson, Cuthbert, 406, 693

Watson, Harold, 93

Watson, J., 688

Watson, T., 365

Wattam, W. E. L., 6is

Watton xxvi., 442, 444, 624

Watton Beck 398

Watton Decoy 443

Wear xx.

Weaverthorpe 562

Webb, J. S., 125

Webster 397

Wedgewood 346

Weeton 5 I 3

Wetherby $56,67,69,95,222,31 \mathrm{I}$, $320,331,365,566,592,729$

Wetherby Grange 56, 386

Wetherill IoI

Wetwang 501

Welbeck Wath 65

Welbury 625

Wellburn, T., 503

Wellburn, W., 39r 
Welwick $\mathrm{IO}_{4}$

Wilstrop 432

Winestead I 9

Wemmergill 5 I6

Wemmergill Moors 316,318, 356

Wenlock, Lord, 404, 445, 672

Wensley 538

Wensleydale $31,33,67,82,90$, 96 , I I 7,143, I 47 , I 50, I 59 , $198,205,230,237,266,272$, $277,292,299,320,327,348$, $389,401,412,427,429,433$, $455,458,464,466,467,48 \mathrm{I}$, $507,513,514,519,520,521$, $533,546,569,572,610,614$, $625,641,661,673,701,740$, $742,743,744,747$

Wentworth Castle I6

Wentworth Park 467

West 525

West Burton 230

West, E., $38 \mathrm{~s}$

West, L., 59, 424, 509, 528

West Scar 6I7

West Scar Head, Redcar, 734

West Hartlepool 262

Western Ainsty $205,275,320,365$, $400,414,425,501,532,535$, $624,638,752$

Westmorland I5 1, 237, 326, 327 , $355,507,528$

Westerdale $342,54 \mathrm{I}$

Wharfe xx., 123, 283, 333, 410, $467,483,546,733,737$

Wharfe and Nidd Valleys Sz

Wharfe, Banks of, 29

Wharfedale $19,33,52,64,122$, I 5 I, I60, I 66, I67, 263, 302, $323,330,507,535,541,584$, 596

Wharfedale, Upper, I9I, I98, 325 Wharfe Valley II6, I79, 216, 426, Wharncliffe Chase xxii. $\quad[464$ Wharncliffe Wood 350

Wharton, W. H., M.F.H., 282

Wheatley Wood 496
Wheeldale 34I

Wheldon, J. A., 695

Whernside 519,520

Whichcote, Sir Thomas, 306

Whitaker's "Craven" 64

Whitaker, J., 305, 308, 368, 426, $43 \mathrm{I}, 45 \mathrm{I}, 472,474,505,5 \mathrm{IO}$, $538,575,628,663,702,723$, $738,743,757,758$

Whitaker's " Richmondshire" 378

Whitby (numerous)

Whitby High Lights 679

Whitby Museum 211, 271, 304, $391,397,411,565,688,695$, 707,757

Whitby Museum, Curator of, I 3

White, Colonel, 560

White, Gilbert, 94

White Mare Cliff 236

Whitwell, T., 299, 338, 383, 4II,

Whixley 575

Widdas, G. A., I03, 334

Winson, Thomas, 40

Wike 35

Wighill Ings 624, 625

Wighill Park 529

Wilberfoss 408, 539, 594

Wild Birds Protection Acts 302, $596,661,769$

Wiley, WVm., 550

Wilfholme 457

Wilkinson, George, 714, 717,722

Wilkinson, W., 690, 716, 718, 720

Williamson's Scarborough Catalogue 242, 247

VVilliamson, Prof. W. C., 538, 562, $6 \mathrm{I}_{4}, 620,668$

Willis, R. A., 652

Willoughby, H. 396

Willughby, Francis, 72, 86, 94, I $25.148,183,19 I, 272,400$, $426,473,510,593,594,596$, $609,646,648$

Willughby's “ Ornithology" 28 I2I, I 28, I $30,140,212,215$, $265,287,295,362,373,392$, 
Willughby's "Ornithology" (cont.) $423,425,457,468,472,477$, $480,485,494,605,656,658$, $708,711,727,732$

Wilsden 20, 24, 29, 67, 85, 92, $163,191,275,277,279,323$. $334,497,529,638$

Wilson 5 I 5

Wilson, J., 78

Wilson, J. A., 695, 708

Wilson, J. H., 305, 325

Wilson, Sir M. W., 387

Wilson, WV., 364

Wilstrop 95, I 79, 205, 236, 239 , $28 \mathrm{I}, 324,325,327,34 \mathrm{I}, 345$, $387,403,412,454,474,634$

Wilstrop Hall 372

Wilsdell 570

Wilton I $7,262,597$

Wilton Beacon xxv.

Windermere $66_{4}$

Windy Hill Farm 559

Winestead 388

Winsetts, Easington, I 42

Winston 601

Winterburn 634

Wintringham 528

Wiske, River, I 50

Witherby, H. F., 560

Withernsea 92, 405, 500, 594. $625,669,770$

Wolls xxv., xxvi., I23, I62, 213 , $273,275,287,4 \mathrm{I} 4,4 \mathrm{I} 8,42 \mathrm{O}$, $42 \mathrm{I}, 422,490,49 \mathrm{I}, 528,550$, $551,552,553,555,561,562$, $569,578,597,616$

Wolley, John, 555

Wombwell Wood 506

Wood I4I, 397

Wood, Neville, 52, I 54, 204, 225. Wood's (Neville) " Naturalist " $6 \mathrm{I}$, 97. I 19, I 56, 163, I 86,282 , $313,319,336,353,363,393$, 622

Woodall, Henry, 549, 555

Woodall, J. W., 549, 554
Woodend 79

Woodcock, Michael, 335

Woodhall $56,55 \mathrm{I}$

Woodhall Bridge 497

Woodhouse 560,739

Woodhouse, W., $72 \mathrm{I}$

Woodlands 227

Woodruffe-Peacock, A., 335

Woodsome 205

Woofell 57 I

Wooley Park, Wilstrop, 387

Worksop 666

Worsborough i 76

Worsberough Reservoir 467, 739

Wray, Canon, 558

Wray, Mrs. $55^{8}$

Wray 752

Wressill and Lekinfield Castles 255

Wressill Castle 385, 399, 407, 455 . $458,525,531,549,567,586$

Wright, G., 220

Wycliffe-on-Tees $3,17,49,96$, II 7, I 46, I 54, I 82, I97, 213 , 235. 269, 270, 285, 288, 378, $400,423,482,487,505,532$, $536,550,561,579$

Wycliffe Museum 296, 365, 746

Wykeham 336, 340, 497

Yarm 17, $167,208,278$

Yarrell, W., I 44, 278, 307, 394, $418,419,420,456,470,477$, $496,515,519,615,674$

Yarrell's "British Birds" 69, 73, 94. I 30, I $46,172,294,3$ I 3 , $348,393,477,509,520,527$, $538,605,687,730,757,762$

Yeadon Moor Reservoir 6I4

Yearby 4

Yearby Bank 448

Yore 538, 747

Yoredale 610, 627, 673

York (numerons)

York \& Dist. Field Naturalists' Society 364

York, Archbishop of, 385, 399. $400,455,547,595,776$ 
INDEX OF PERSONAL AND PLACE NAMES. $\$_{43}$

York Blue Coat Boys School 220

"York Herald " 289

York Museum 13, 41, 75, 104, I $37,208,222,351,364,365$, $372,373,391,393,395,408$, $430,45 \mathrm{I}, 47 \mathrm{I}, 48 \mathrm{I}, 49 \mathrm{~S}, 54 \mathrm{O}$, $548,557,558,559,590,602$, $625,665,669,727,737,742$, $745,752,758,761,762$

Yorke, J., 507

York Nurseries II 7

Yorkshire Philosophical Society $405,627,666,706,756$

Yorkshire Coalfield 50, $5 \mathrm{I}$

Yorkshire Magazine 249

Yorkshire Naturalists' Club 337, $403,437,661,745$
Yorkshire Naturalists' Union, 3, 321,333

"Yorkshire Post" 339, 75 I

"Yorkshire Weekly Post" 46

Youlton 529

Young, A., 3I7, 324, 340, 347, $36_{5}, 369$

Young, D., 39, 305, 528

Young, Jolnn, 38, 317 ,

Young, J. J. Baldwin, 54, 99

Ioung's "Whitby" 230

Zetland, Marquis of, 352

Zimmerman 300

Zoological Society 25, 74, I53. 195, 207, 208, 309, 417, 462, 756. 757,762

"Zoologist" (numerous) 





e

$\mapsto$

$\infty$

$\pi$

? 
(1)

(1)

(1)

(1) 